Cover: Valley of Ten Thousand Smokes, original painting by Amy Komar, artist, 10" x 10", acrylic on paper. 


\section{Alaska Volcanoes Guidebook for Teachers}

By Jennifer N. Adleman

General Information Product 99

U.S. Department of the Interior U.S. Geological Survey 


\section{U.S. Department of the Interior \\ KEN SALAZAR, Secretary}

\section{U.S. Geological Survey \\ Marcia K. McNutt, Director}

U.S. Geological Survey, Reston, Virginia 2011

For more information on the USGS-the Federal source for science about the Earth, its natural and living resources, natural hazards, and the environment, visit http://www.usgs.gov or call 1-888-ASK-USGS.

For an overview of USGS information products, including maps, imagery, and publications, visit http://www.usgs.gov/pubprod

To order this and other USGS information products, visit http://store.usgs.gov

Suggested citation:

Adleman, J.N., 2011, Alaska volcanoes guidebook for teachers: U.S. Geological Survey General Information Product 99, $348 \mathrm{p}$.

Library of Congress Cataloging-in-Publication Data

Adleman, Jennifer Nicole.

Alaska volcanoes guidebook for teachers / by Jennifer N. Adleman.

p. cm.

Includes bibliographical references and index.

ISBN 978-1-4113-3047-4

1. Volcanoes--Alaska--Study and teaching. 2. Volcanoes--Alaska--Guidebooks. I. Geological Survey (U.S.)

II. Title.

QE524.2.U6A45 2011

551.2109798--dc22 


\section{Credits}

The author wishes to acknowledge the time, forethought, and enthusiasm of the students, educators, and scientists who helped develop and provided support this guidebook.

\section{Educators}

Anchorage School District (ASD)

Teachers who participated in professional development courses and the generation of activities in this guidebook:

Kevin Lynch, West High School

Konrad Mittelstad, Hanshew Middle School

Heather Nissen, Central Middle School of Science

Jessie Salaway, SAVE High School

Jane Yokoyama, Begich Middle School

Staff reviewers:

Texas Gail Raymond, K-12 Science Coordinator

Trisha Herminghaus, Elementary Support Teacher

Joanna Hubbard, Elementary Science Support Teacher

Judy Onslow, Secondary Science Support Teacher

Additional educators who participated in the development of this guidebook:

Caitlain Bergin

Nicole Fitzgerald

Shannon Herda

Alaska Pacific University

Ted Munsch, Professor of Education, Masters of Arts in Teaching Director National Park Service

\section{Scientists}

Elizabeth Wasserman, Park Ranger, Lake Clark National Park and Preserve

U.S. Geological Survey (USGS)

Carolyn Driedger, Cascades Volcano Observatory

Tina Neal, Alaska Volcano Observatory

Melissa Pfeffer, Alaska Volcano Observatory

Evan Thoms, Alaska Volcano Observatory

Chris Waythomas, Alaska Volcano Observatory

Rick Wessels, Alaska Volcano Observatory

Bill Evans, Water Resources Discipline and National Research Program

Cindy Werner, Volcano Gas Emission Program / Cascades Volcano Observatory

Alaska Division of Geological and Geophysical Surveys (ADGGS)

Cheryl Cameron, Alaska Volcano Observatory

University of Alaska Fairbanks Geophysical Institute (UAFGI)

Pavel Izbekov, Alaska Volcano Observatory

Jeff Freymueller, Alaska Volcano Observatory

Natalia Ruppert, Alaska Earthquake Information Center

Lea Burris, Alaska Earthquake Information Center 


\section{Contents}

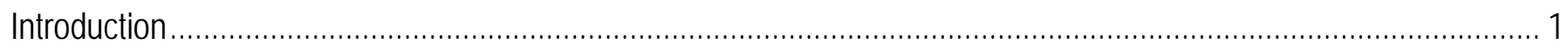

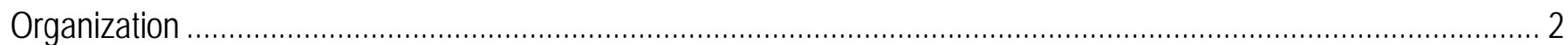

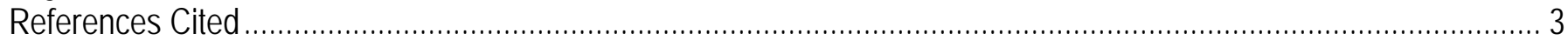

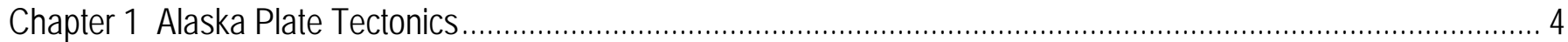

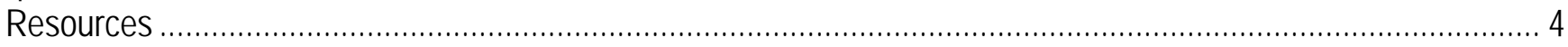

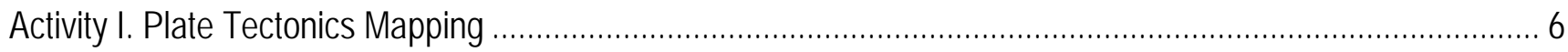

Activity II. Earthquake Mapping.................................................................................................. 20

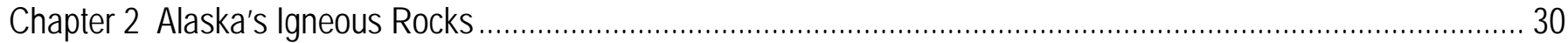

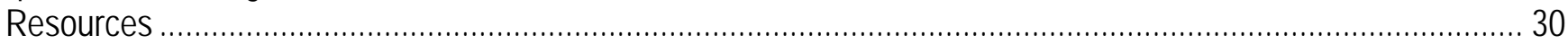

Activity I. Igneous Rock Identification...................................................................................................... 33

Activity II. Igneous Rocks - Coming to a Location Near You!...................................................................... 41

Activity III. Comparison of Hawaiian, Cascade, and Alaskan Volcanic Rocks.................................................. 48

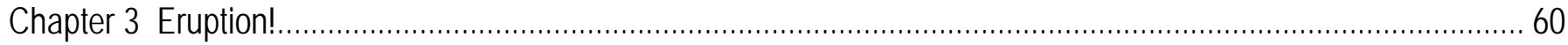

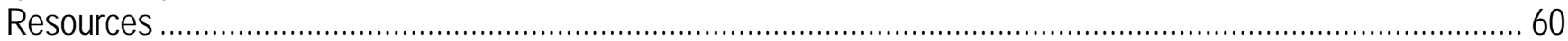

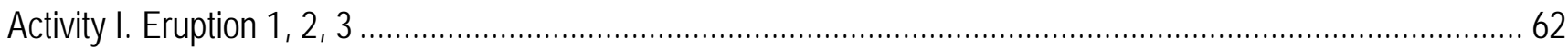

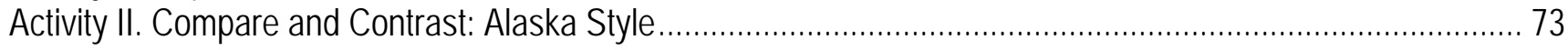

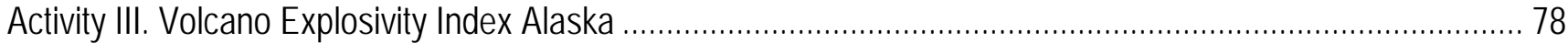

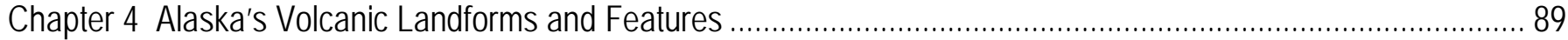

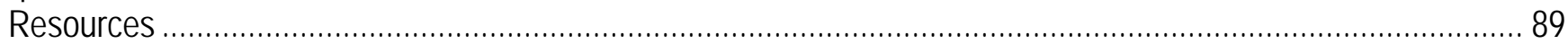

Activity I. Volcanic Landforms and Features Information Search ............................................................. 90

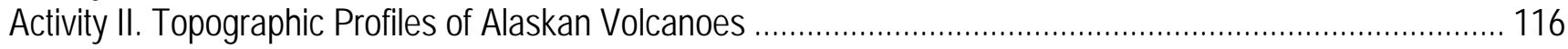

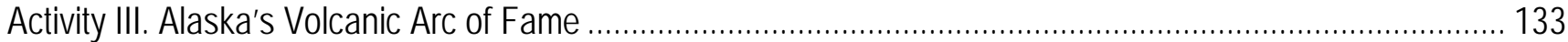

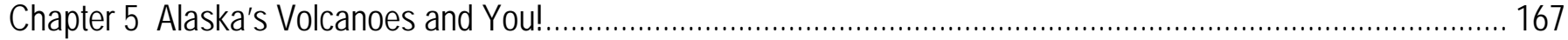

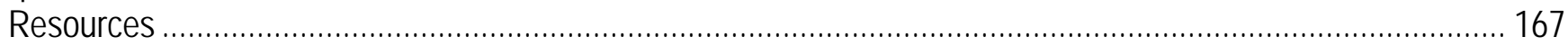

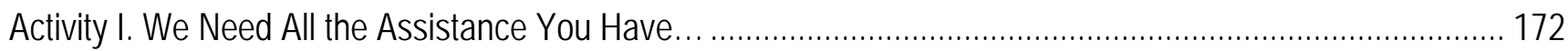

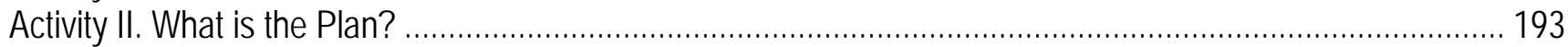

Activity III. Volcanic Ash Fall in Your Community............................................................................ 198

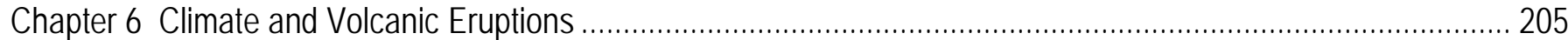

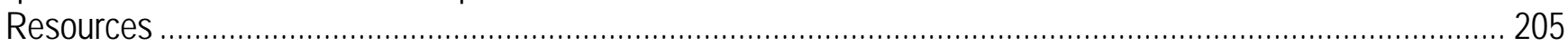

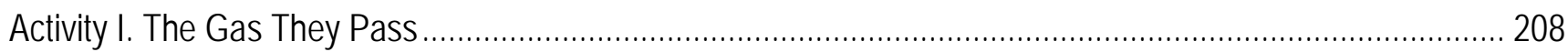

Activity II. What Goes Up Must Come Down....................................................................................... 218

Activity III. Globally Averaged Temperature and Volcanic Eruptions ……………...................................... 226

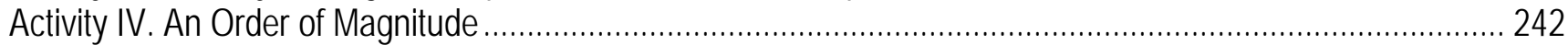

Chapter 7 Volcanic Monitoring, Research, and Careers .................................................................................. 250

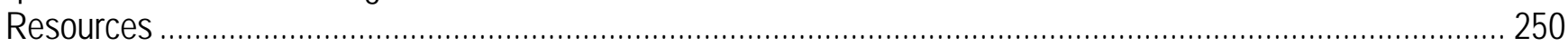

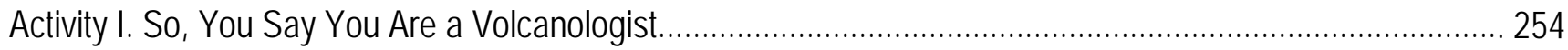

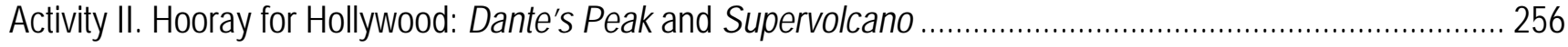

Activity III. A Day in the Life of a Volcano Observatory ........................................................................ 286

Activity IV. Activities to Consider Before, During, and After a Volcanic Eruption.............................................. 344 


\section{Conversion Factors}

Inch/Pound to SI

\begin{tabular}{|c|c|c|}
\hline Multiply & By & To obtain \\
\hline inch (in.) & 2.54 & centimeter (cm) \\
\hline inch (in.) & 25.4 & millimeter (mm) \\
\hline foot $(\mathrm{ft})$ & 0.3048 & meter $(\mathrm{m})$ \\
\hline mile (mi) & 1.609 & kilometer (km) \\
\hline mile per hour (mi/h) & 1.609 & kilometer per hour (km/h) \\
\hline \multicolumn{3}{|l|}{ SI to Inch/Pound } \\
\hline Multiply & By & To obtain \\
\hline centimeter (cm) & 0.3937 & inch (in.) \\
\hline centimeter per year (cm/yr) & 0.3937 & inch (in/yr) \\
\hline cubic kilometer $\left(\mathrm{km}^{3}\right)$ & 0.2399 & cubic mile $\left(\mathrm{mi}^{3}\right)$ \\
\hline kilometer (km) & 0.6214 & mile (mi) \\
\hline kilometer (km) & 0.5400 & mile, nautical (nmi) \\
\hline kilometer per hour (km/h) & 0.6214 & mile per hour (mi/h) \\
\hline liter (L) & 0.2642 & gallon (gal) \\
\hline liter (L) & 61.02 & cubic inch $\left(\mathrm{in}^{3}\right)$ \\
\hline millimeter (mm) & 0.03937 & inch (in.) \\
\hline millimeter per year (mm/yr) & 0.03937 & inch per year (in/yr) \\
\hline meter (m) & 3.281 & foot $(\mathrm{ft})$ \\
\hline square kilometer $\left(\mathrm{km}^{2}\right)$ & 0.3861 & square mile $\left(\mathrm{mi}^{2}\right)$ \\
\hline
\end{tabular}

Temperature in degrees Celsius $\left({ }^{\circ} \mathrm{C}\right)$ may be converted to degrees Fahrenheit $\left({ }^{\circ} \mathrm{F}\right)$ as follows:

${ }^{\circ} \mathrm{F}=\left(1.8 x^{\circ} \mathrm{C}\right)+32$.

Temperature in degrees Fahrenheit $\left({ }^{\circ} \mathrm{F}\right)$ may be converted to degrees Celsius $\left({ }^{\circ} \mathrm{C}\right)$ as follows:

${ }^{\circ} \mathrm{C}=\left({ }^{\circ} \mathrm{F}-32\right) / 1.8$. 


\title{
Alaska Volcanoes Guidebook for Teachers
}

\author{
By Jennifer N. Adleman¹
}

\section{Introduction}

Alaska’s volcanoes, like its abundant glaciers, charismatic wildlife, and wild expanses inspire and ignite scientific curiosity and generate an ever-growing source of questions for students in Alaska and throughout the world. Alaska is home to more than 140 volcanoes, which have been active over the last 2 million years. About 90 of these volcanoes have been active within the last 10,000 years and more than 50 of these have been active since about 1700. The volcanoes in Alaska make up well over threequarters of volcanoes in the United States that have erupted in the last 200 years. In fact, Alaska's volcanoes erupt so frequently that it is almost guaranteed that an Alaskan will experience a volcanic eruption in his or her lifetime, and it is likely they will experience more than one. It is hard to imagine a better place for students to explore active volcanism and to understand volcanic hazards, phenomena, and global impacts.

Previously developed teachers' guidebooks with an emphasis on the volcanoes in Hawaii Volcanoes National Park (Mattox, 1994) and Mount Rainier National Park in the Cascade Range (Driedger and others, 2005) provide place-based resources and activities for use in other volcanic regions in the United States. Along the lines of this tradition, this guidebook serves to provide locally relevant and useful resources and activities for the exploration of numerous and truly unique volcanic landscapes in Alaska. This guidebook provides supplemental teaching materials to be used by Alaskan students who will be inspired to become educated and prepared for inevitable future volcanic activity in Alaska. The lessons and activities in this guidebook are meant to supplement and enhance existing science content already being taught in grade levels 6-12. Correlations with Alaska State Science Standards and Grade Level Expectations adopted by the Alaska State Department of Education and Early Development (2006) for grades six through eleven are listed at the beginning of each activity. A complete explanation, including the format of the Alaska State Science Standards and Grade Level Expectations, is available at the beginning of each grade link at http://www.eed.state.ak.us/tls/assessment/GLEHome.html.

\footnotetext{
${ }^{1}$ Currently with Alaska Division of Economic Development, 550 W 7th Ave, Ste 1770 Anchorage, AK 99501-3569
} 


\section{Organization}

\section{Chapters}

This guidebook consists of seven topical chapters placed in recommended order of use. Each chapter begins with a list of recommended resources followed by three or four activities associated with the chapter topic. These activities are sequentially arranged to provide appropriate background materials and experiences that allow students an opportunity to build upon their understanding of the content as they explore new information. Most of the activities include worksheets for distribution and use in your classroom, or that can act as a guide from which to generate class discussion. All of the figures used in the activities are available on an accompanying digital presentation for classroom use.

Educators can use this guidebook to augment existing curriculum focused on Earth science processes, including those with an emphasis on natural hazards, earthquakes, volcanoes, and plate tectonics. These inquiry-based, hands-on, and place-based activities allow educators to use appropriately Alaska's dynamic environment to illustrate scientific concepts and content emphasized in the State's secondary-level science standards. The final activity prioritizes materials from the guidebook and recommends additional dynamic internet resources available in the event of heightened volcanic activity or volcanic eruption(s) in Alaska.

\section{Activities}

Each activity includes all or some of these sections:

- Activity title

- Grade level

- Setting

- Time (estimate)

- Vocabulary (where appropriate)

- Correlations to Alaska State Science Standards (where appropriate)

- Overview of the goals of the exercise

- Background

- Objectives (for students)

- Materials

- $\quad$ Procedures (for teachers and students)

- Extension (extra activities)

- References (where appropriate)

- Glossary (where appropriate)

- Student worksheets (where appropriate)

- Worksheet keys (where appropriate) 


\section{References Cited}

Alaska State Department of Education and Early Development, 2006, Standards and grade level expectations, March 2006: State of Alaska website, accessed October 2009 at http://www.eed.state.ak.us/tls/assessment/GLEHome.html.

Driedger, C.L., Doherty, Anne, and Dixon, Cheryll, 2005, Living with a volcano in your backyard-An educator's guide with emphasis on Mount Rainier: U.S. Geological Survey General Interest Product 19; produced in cooperation with the National Park Service, available at http://vulcan.wr.usgs.gov/Outreach/Publications/GIP19/.

Mattox, S.R., 1994, A teachers' guide to the geology of Hawaiian Volcanoes National Park: Hawaii Natural History Association. 


\section{Chapter 1 \\ Alaska Plate Tectonics}

\section{Resources}

- U.S. Geological Survey

- Fuis, G.S., and Wald, L.A., 2003, Why do earthquakes occur in southern Alaska?: U.S. Geological Survey Fact Sheet 014-03, 4 p. (Also available at http://pubs.usgs.gov/fs/2003/fs014-03/alaska.html.)

- Haeussler, P.J., and Plafker, G., 1995, Earthquakes in Alaska: U.S. Geological Survey Open-File Report, 95-624, 1 sheet. (Available at

o PDF Poster http://geopubs.wr.usgs.gov/open-file/of95-624/of95-624L.pdf

o PDF page-size http://geopubs.wr.usgs.gov/open-file/of95-624/of95-624.pdf

- Kious, W.J., and Tilling, R.I., 1996, This dynamic Earth-The story of plate tectonics [online edition]: Reston, Va., U.S. Geological Survey website. (Available at http://pubs.usgs.gov/gip/dynamic/dynamic.html and o Some unanswered questions-What drives the plates? http://pubs.usgs.gov/gip/dynamic/unanswered.html\#anchor19928310.)

- Robertson, E.C., [n.d.], The interior of the Earth: Reston, Va., U.S. Geological Survey Generail Information Product. (Available at http://pubs.usgs.gov/gip/interior/.)

- Shedlock, K.M., and Pakiser, L.C., 1994, Earthquakes: Reston, Va., U.S. Geological Survey General Information Product. (Available at http://pubs.usgs.gov/gip/earthq1/.)

- Simkin, T., and others, 2006, This dynamic planet-World map of volcanoes, earthquakes, impact craters, and plate tectonics ( $3^{\text {rd }}$ ed.): U.S. Geological Survey Geologic Investigations Map I-2800. (Available at http://www.minerals.si.edu/tdpmap/ and

o Printable $8.5 \times 11$-inch pages http://www.minerals.si.edu/tdpmap/printable.htm.)

- Winkler, G.R, 2000, A geologic guide to Wrangell-Saint Elias National Park and Preserve, Alaska-A tectonic collage of northbound terranes: U.S. Geological Survey Professional Paper 1616, p. 69-76. (Also available at

o Website Introductory Page http://pubs.usgs.gov/pp/p1616/ and

o PDF http://pubs.usgs.gov/pp/p1616/P1616.pdf [129 MB].)

- U.S. Geological Survey, Earthquake Hazards Program

o Wald, D., and Dewey, J.W., 2005, Did you feel it? -Citizens contribute to earthquake science: U.S. Geological Survey Fact Sheet 2005-3016, 4 p. (Also available at http://pubs.usgs.gov/fs/2005/3016/ and http://pubs.usgs.gov/fs/2005/3016/pdf/FS-2005-3016.pdf.)

o Wald, D., Wald L., Dewey, J., Quitoriano, V., and Adams, E., 2001, Did you feel it?-Community-made earthquake shaking maps: U.S. Geological Survey Fact Sheet 030-01, 2 p. (Also available at http://pubs.usgs.gov/fs/fs030-01/ and http://pubs.usgs.gov/fs/fs030-01/fs030-01.pdf.) 
o Wald, D., Wald, L., Woden, B., and Goltz, J., 2003, ShakeMap-A tool for earthquake response: U.S. Geological Survey Fact Sheet 87-03, 4 p. (Also available at http://pubs.usgs.gov/fs/fs-087-03/FS-087-03-508.pdf.)

o U.S. Geological Survey, 2009, Earthquake Hazards program-Alaska Earthquake Information: U.S. Geological Survey website. (Available at http://earthquake.usgs.gov/earthquakes/states/index.php?regionID=3.)

- Alaska Earthquake Information Center (AEIC), 2010, Maps: Alaska Earthquake Information center website, accessed May 27, 2010, at

- AEIC Maps http://www.aeic.alaska.edu/html_docs/maps.html and

- AEIC Frequently Asked Questions http://www.aeic.alaska.edu/html_docs/faq.html.

- Lillie, R.J., 2005, Parks and plates-The geology of our National parks, monuments, and seashores: New York, W.W. Norton and Comdishy, 298 p.

- Chapter 1: Plate tectonics, p. 5-21.

- Chapter 5: Subduction zones, southern Alaska subduction zone, p. 119-120.

- Chapter 11: Accreted terranes, Alaska-A glimpse of continental growth in action, p. 241-245.

- Nye, C.J., McGimsey, R.G., and Power, J., 1998, Volcanoes of Alaska: Alaska Division of Geological \& Geophysical Surveys Information Circular 38, 1 sheet [2 sides], accessed May 27, 2010, at

- Front http://www.dggs.dnr.state.ak.us/webpubs/dggs/ic/oversized/ic038ed1998_sh001.P $\underline{\mathrm{DF}}$ and

- Back http://www.dggs.dnr.state.ak.us/webpubs/dggs/ic/oversized/ic038ed1998_sh002.P $\underline{\mathrm{DF}}$

\section{Activities}

These activities include material associated with the concept of plate tectonics on a global scale and related plate boundaries using the depth and location of associated earthquakes. Through progression within the activities and from one activity to the next, these concepts will be locally applied to the types of plate boundaries and associated earthquakes and volcanic processes in Alaska. The materials included in these activities will serve as base upon which the associated concepts of subduction and volcanism will be built upon in subsequent chapters.

Activity I. Plate Tectonics Mapping

Activity II. Earthquake Mapping 


\section{Activity I. Plate Tectonics Mapping}

An activity or discussion illustrating the layers of the Earth and the process of mantle convection would serve as an appropriate introduction prior to this activity. In addition to the resources listed above, an excellent exercise for convection can be found in B.A. Ford's Project Earth Science-Geology published by NSTA Press in 1996 (activity 6, p. 71-79).

Grade Level 6-11

Setting Classroom

Time 45-90 minutes

Vocabulary (see Glossary)

convergence, divergence, hot spot, subduction zone, tectonic plate, trench, velocity

Correlations to Alaska State Department of Education (2006) Performance Standards (Grade Level Expectations)

D1-Concepts of Earth Science

SD[6-11] Students develop an understanding of the concepts, processes, theories, models, evidence, and systems of Earth and space science.

SD2[6-11] Students develop an understanding of the origins, ongoing processes, and forces that shape the structure, composition, and physical history of the Earth.

SD2.2[7] The student demonstrates an understanding of the forces that shape Earth by describing how the movement of the tectonic plates results in both slow changes (e.g., formation of mountains, ocean floors, and basins) and shortterm events (e.g., volcanic eruptions, seismic waves, and earthquakes) on the surface.

SD2.2[9-11] Students demonstrates an understanding of the forces that shape Earth by describing how the theory of Plate tectonics explains the dynamic nature of its surface

\section{Overview}

Plate boundaries have an overall effect on determining the landscape and dominant features local to a region, including volcanoes. In this activity, students will relate the physical features of Alaska's landscape with their associated tectonic plate boundaries, namely convergent zones. 


\section{Background}

Alaska is home to an arc of volcanoes, which serves as one surface manifestation of the subduction zone formed by the convergence of the North American and Pacific Plates. Alaska's varying geologic features, such as faults, folds, and mountains are also associated with ongoing dynamic processes at depth associated with convergence.

\section{Objectives}

The students will be able to identify and define convergent, divergent, and transform tectonic plate boundaries. The students will be able to describe how the velocity and direction of movement of different plates affects the type of boundary present and will be able to cite examples of this relationship to various landscape features in Alaska.

\section{Materials}

- the map, This Dynamic Planet by T. Simkin and others, 2006-you can enlarge the version provided, or use a poster version of your own.

- scissors

— black felt, thick-tip pens or markers

- Plate Tectonics Q \& A worksheet

\section{Procedure}

\section{A. Teacher preparations before class}

1. Study or prepare the map pieces on the page size map provided (Dynamic Planet Map Pieces) first before cutting the poster size map to use for the activity in the classroom. It is recommended to have an additional poster size version of the map available in the classroom for students to view and reference during, or only after, they do the activity. Two maps displayed in the classroom are preferred, because there is relevant material on both sides. Another option is to enlarge and use the Dynamic Planet Map Pieces on the page provided for the class to view after the activity is completed.

2. Use the poster size map, This Dynamic Planet. With scissors, trim off the white edges (leaving latitude and longitude degrees) and the legend below the map. Save the legend. Cut strips off the left and right sides of the map at $100^{\circ} \mathrm{E}$ longitude (some areas of the world are duplicated on both sides of the map).

3. Cut the poster size map into pieces along the plate boundaries. Make a smooth cut approximately on the plate boundary. You may use a simpler plate map to help you decide where the plates begin and end. Remember use the Dynamic Planet Map Pieces provided for guidance. 
After cutting, you should have the following 17 pieces:

- 1. African Plate (includes Nubia and Somalia Plates)

- 2. - 3. Antarctic Plate (2 sections)

- 4. Arabian Plate

- 5. - 6. Australia Plate (2 sections)

- 7. Caribbean Plate

- 8. Cocos Plate

- 9. - 10. Eurasia Plate (2 sections)

- 11. Indian Plate

- 12. Nazca Plate

- 13. North American Plate

- 14. Pacific Plate

- 15. Philippine Plate

- 16. Scotia Plate

- 17. South American Plate

4. Find the arrows on most of the plates and the white numbers on many of the midocean ridges that indicate the directions and velocities of plate motion. Write the velocity of the plate motion next to the arrows using a black felt marker or pen so that the numbers are bigger and more visible. The length of the arrows indicate the relative rate of plate motion (short arrows $=$ slower velocities, long arrows $=$ faster velocities). The velocities are given in $\mathrm{mm} / \mathrm{yr}$. If you are more familiar with plate motions given in $\mathrm{cm} / \mathrm{yr}$, you can write the velocities in $\mathrm{cm} / \mathrm{yr}$ by "moving the decimal point.” For example, for the Arabian Plate, the velocity is $26 \mathrm{~mm} / \mathrm{yr}$ or $2.6 \mathrm{~cm} / \mathrm{yr}$. Still further, you may want to convert it into in/yr.

5. Laminate the 17 plate pieces and cut off excess laminating material. Also, laminate the legend (the strip cut off the bottom of the map) and save for reference (optional).

\section{B. Students assemble the puzzle in class}

1. Give one piece of the puzzle (a plate or piece of a plate) to each student or group of students. Tell them that they will be responsible for their plate - placing it in the right position to form the world map and determining the motion of the plate with respect to surrounding plates. Instruct your students to assemble the map (like putting together a jigsaw puzzle) on the floor or on a large table.

An alternative procedure that works well and stimulates thinking and discovery:

- Give a piece of the puzzle to each student (or team of students). Tell them that these are pieces of a puzzle and that it comes from a world map.

- Their instructions are to put the puzzle together without talking. They can point to communicate, but they must put the puzzle together in silence.

- After the puzzle is completed, the students can be asked about what they think the pieces are and why. 
2. When the map puzzle is complete discuss with the class that the arrows and velocities (in $\mathrm{mm} / \mathrm{yr}, \mathrm{cm} / \mathrm{yr}$, or in/yr - which ever you chose) indicate direction and rate of the motion of the plates. Some plates do not include arrows. Find the highest (fastest) and lowest (slowest) plate velocities. Comment on the speed of the plates; for example, 35 $\mathrm{mm} / \mathrm{yr}$ or $3.5 \mathrm{~cm} / \mathrm{yr}$ is equivalent to $35 \mathrm{~km} / \mathrm{million}$ years, so the plates are not moving very fast-about the speed that a person's fingernails grow. Identify areas of the Earth that are associated with the fastest plate velocities. (With older students, you may want to tie in the concept of rates and vectors.)

3. Encourage students to spend some time looking at their plate and determining what characteristics it may have. For instance, does the entire plate consist of a buoyant continent or a heavy oceanic basin, or portions of both? This is important for students to consider when determining the type of action the boundary of their plate may make. Generally, continental crust is more buoyant (less dense) than the mantle, and therefore resists subduction, however, after it cools, the oceanic crust is actually denser than the mantle, which makes for easier subduction. Pay particular attention to this during your discussion concerning convergent zones, subduction, and mountain building.

4. Direct each student (or group of students) to determine how their plate moves with respect to the surrounding plates. Students should discuss with each other and agree with each other or note their differing interpretations. Ask a few students to explain what their plate's motion is and how it is interacting with adjacent plates.

5. Discuss with your students the locations that are associated with the different types of plate boundaries. For each of these examples, move the appropriate plates a small amount in the direction of the arrows to see what the plate interactions will be. Question or comment on the features that are associated with the plate boundariesearthquakes, mountain ranges, deep-sea trenches, volcanoes. For this and other parts of the activity, it is convenient for the class to stand around the map and to use a laser pointer or a meter stick (or a ski pole!) to point our individual plates or plate boundaries. The example summaries below are from:

- Braile, Larry, and Braile, Sheryl, 2006, Plate puzzle: West Lafayette, Ind., Purdue University, Department of Earth and Atmospheric Sciences website. (Available at http://web.ics.purdue.edu/ braile/edumod/platepuzz/platepuzz.htm.)

- Kious, W.J., and Tilling, R.I., 1996, This dynamic Earth-The story of plate tectonics [online edition]: Reston, Va., U.S. Geological Survey website. (Available at http://pubs.usgs.gov/gip/dynamic/dynamic.html.) 


\section{Plate Movements}

Convergence: The South American Plate and the Nazca Plate, the western Pacific, Indian, and Eurasia (1) Plates. Note that convergence occurs when two plates are moving in almost directions toward each other (for example, South America Plate and Nazca Plate), or when two plates are moving in nearly the same direction but the plate that is "following" is moving faster (for example, the Pacific Plate and the Philippine Plate).

These two types of motions that result in convergence could be modeled with two parallel lines of students representing the edges of two plates. In the first type of convergence, the students face each other and walk slowly forward until collision. In the second type of convergence, the students face the same direction and walk slowly forward, with the second line of students walking faster until colliding with the first line.

Divergence: The Mid Atlantic Ridge. Point out that Iceland straddles two sides of the East Pacific Rise, thus is on two separate divergent plates, the North American and Eurasian Plates.

Transform: The San Andreas fault in California, the Alpine fault in New Zealand, and the transform faults along the southern boundary of the Nazca Plate.

Combination of movements: Sometimes the plate motions and interactions are more complicated. For example, for the North American and Pacific Plates, the Pacific Plate is moving approximately northwest and the North American Plate is moving approximately southwest. The combination of these motions and the irregularly shaped plate boundaries results in convergence along the Aleutian Islands, divergence at the Juan de Fuca Ridge and predominately transforms motions along the San Andreas Fault and within the Gulf of California.

Hot Spots: Note the Hawaiian Islands in the middle of the Pacific Plate. Although the islands are not near a plate boundary, they are very active seismically and volcanically. The ages of the volcanic rocks in the Hawaiian Islands, the chain of seamounts to the west-northwest, and the Emperor seamounts located farther west and north, all increase toward the west and north. These observations indicate that the Hawaiian Island chain is the track of a mantle hotspot, currently located beneath the southeastern part of the Island of Hawai $i$ (the "Big Island"). The volcanic islands and seamounts at the northern end of the Emperor Seamounts, near the Aleutian Trench, are more than 65 million years old. At the "bend" in the seamount chains, which connects the Emperor and Hawaiian chains, the volcanic rocks are about 42 million years old. At Kauai, the westernmost of the main Hawaiian Islands, the volcanic rocks are about 5 million years old. The Big Island (Hawai i) is less than 1 million years old and eruptions are occurring today. 
To model the hotspot, place the flashlight under the north end of the Emperor Seamount chain and cause the plate to move northwest and then west-northwest (at the "bend") until the flashlight is at the current position of the hotspot under Hawai i.

\section{For discussion:}

- What direction has the plate been moving (with respect to the mantle hotspot)?

- Where will the future volcanic chain of islands and seamounts be?

- How fast is the plate moving at Hawai ì?

- Does the velocity measurement (near the arrow) agree with the velocity estimated from the volcanic ages (divide the distance in $\mathrm{km}$ from Hawai $\mathrm{i}$ to the "bend" by 42 million years, then convert to $\mathrm{mm} / \mathrm{yr}$ or $\mathrm{cm} / \mathrm{yr}$ )?

Note Mention to students that scientific understanding of ongoing and dynamic processes below the Earth's surface is an ongoing process in itself. There has been research that indicates that the bend of the Hawaiian-Emperor hotspot track mentioned above may have been formed by a fast change in position of the Hawaiian hotspot (Tarduno and others, 2003)!

\section{Exploring plate boundaries in Alaska}

1. Convergence in the form of a subduction zone plays a major role in Alaskan volcanism. Be sure to stress the presence of a subduction zone along southern Alaska and note that it, like other convergent boundaries, experiences a great deal of volcanism due to the melting of rock above the subducting plates.

2. Point out that the map shows (and you can demonstrate by moving pieces) that the Pacific Plate is moving towards Alaska causing convergence and as it subducts it will melt and generate the volcanism witnessed in Alaska. You can also mention the existence of both continental and ocean crust playing key roles at this subduction zone as illustrated in the following figure provided by the Alaska Earthquake Information Center (AEIC).

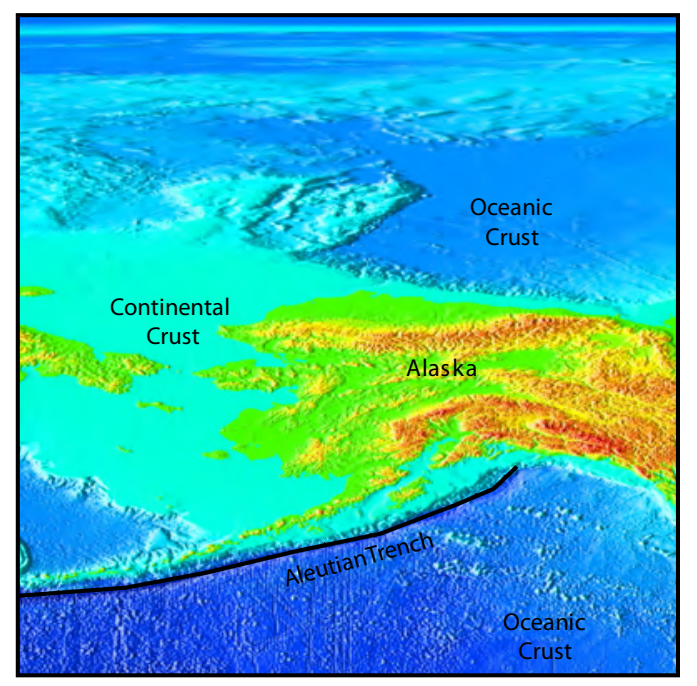


3. Ask students if there are any other instances in the world where a convergent boundary is in an area of great volcanism. Emphasize the volcanism and subduction of Kamchatka, Russia, and Japan. Discuss and outline the "Ring of Fire."

4. Focus for a bit more on Alaska. According to the Alaska Earthquake Information Center website, Alaska is the most tectonically active region in the United States experiencing more than half of all earthquakes recorded in North America annually. At the northwest corner of North America, Alaska is situated at the receiving end of the Pacific Plate, which slides laterally past southeast Alaska and collides directly with the North American Plate across southcentral Alaska and along the length of Aleutian Arc. The accumulation of tectonic stresses at depth along the plate boundaries and the translation of those stresses into the shallower crust of southern Alaska are the driving forces behind the high level of earthquake activity that occurs in the state.

5. You may wish to use additional maps to illustrate specific tectonic features in Alaska. Here are some resources:

- Alaska Earthquake Information Center (AEIC), 2010, Maps: Alaska Earthquake Information center website, accessed May 27, 2010, at http://www.aeic.alaska.edu/html_docs/maps.html.

- Haeussler, P.J., and Plafker, G., 1995, Earthquakes in Alaska: U.S. Geological Survey Open-File Report, 95-624, 1 sheet. (Also available at

- PDF Poster http://geopubs.wr.usgs.gov/open-file/of95-624/of95-624L.pdf and

- PDF page-size http://geopubs.wr.usgs.gov/open-file/of95-624/of95-624.pdf.)

As illustrated on the USGS and AEIC Earthquakes in Alaska map, earthquake risk is high in much of the southern half of Alaska, but the risk is not the same everywhere. This map shows the overall geologic setting that produces earthquakes in Alaska. The Pacific Plate (darker blue) is sliding northwestward past southeastern Alaska and then dives beneath the North American Plate (light blue, green, and brown) in southern Alaska, the Alaska Peninsula, and the Aleutian Islands. Most earthquakes are produced where these two plates come into contact and slide past each other. Major earthquakes also occur throughout much of interior Alaska and result from a collision of a piece of crust with the southern border. A more detailed tectonic map of southern Alaska is on p. 70 of:

- Winkler, G.R, 2000, A geologic guide to Wrangell-Saint Elias National Park and Preserve, Alaska-A tectonic collage of northbound terranes: U.S. Geological Survey Professional Paper 1616, 166 p. (Also available at http://pubs.usgs.gov/pp/p1616/P1616.pdf [129 MB].) 


\section{Plate tectonics $Q \& A$ worksheet}

1. Direct the students to fill out the Plate tectonics $Q \& A$ worksheet or use the questions selectively to generate class discussion.

\section{Extensions}

1. Education Multimedia Isolation Visualization Center, 2008, Animation clips related to plate tectonics: Santa Barbara, Calif., University of California website, accessed June 1, 2010, at http://emvc.geol.ucsb.edu/downloads.php.

2. Incorporate discussion on the Denali Fault earthquake of 2002. Fuis, G.S., and Wald, L.A., 2003, Rupture in south-central Alaska-The Denali Fault earthquake of 2002, U.S. Geological Survey Fact Sheet 014-03, 4 p. (Also available at http://pubs.usgs.gov/fs/2003/fs014-03/index.html.)

\section{Modified from}

Braile, Larry, and Braile, Sheryl, 2006, Plate puzzle: West Lafayette, Ind., Purdue University, Department of Earth and Atmospheric Sciences, accessed June 1, 2010, at http://web.ics.purdue.edu/ braile/edumod/platepuzz/platepuzz.htm.

\section{References Cited}

Alaska Earthquake Information Center (AEIC), 2010, The tectonic setting of Alaska and how it causes earthquake in our state: Alaska Earthquake Information center website, accessed June 1, 2010, at http://www.aeic.alaska.edu/vltpage2.html.

Alaska State Department of Education and Early Development, 2006, Standards and grade level expectations, March 2006: State of Alaska website, accessed October 2009 at http://www.eed.state.ak.us/tls/assessment/GLEHome.html.

Simkin, T., and others, 2006, This dynamic planet-World map of volcanoes, earthquakes, impact craters, and plate tectonics: U.S. Geological Survey Geologic Investigations Map I-2800 1 sheet [2 sides]. (Also available at http://pubs.usgs.gov/imap/2800/.)

Tarduno, J.A., and others, 2003, The Emperor Seamounts—Southward motion of the Hawaiian hotspot plume in Earth's mantle: Science, v. 301, no. 5636, p. 1064-1069.

\section{Glossary}

Convergence-The act of two tectonic plates coming together, including subduction.

Divergence-The act of two tectonic plates moving away from each other.

Hot spot-An area where magma from deep within the mantle melts through the crust above it.

Subduction Zone-The zone of convergence of two tectonic plates, one of which usually overrides the subducting plate leading to localized volcanism.

Tectonic Plate-A segment of the Earth's crust that moves relative to other segments and is characterized by volcanic and seismic activity around its margins. 
Trench-A long narrow valley on an ocean or sea floor that occurs where two plates converge or subduct.

Velocity-The time rate of change of position of a body in a specified direction.

\section{Sources of Glossary Definitions}

Kious, W.J., and Tilling, R.I., 1996, This dynamic Earth—The story of plate tectonics [online edition]: Reston, Va., U.S. Geological Survey website. (Available at http://pubs.usgs.gov/gip/dynamic/dynamic.html.)

Stein, Jess, ed., 1982, The Random House College Dictionary Revised Edition: New York, Random House, Inc. 
Dynamic Planet Map Pieces

Simkin, T., and others, 2006, This dynamic planet—World map of volcanoes, earthquakes, impact craters, and plate tectonics: U.S. Geological Survey Geologic Investigations Map I-2800.

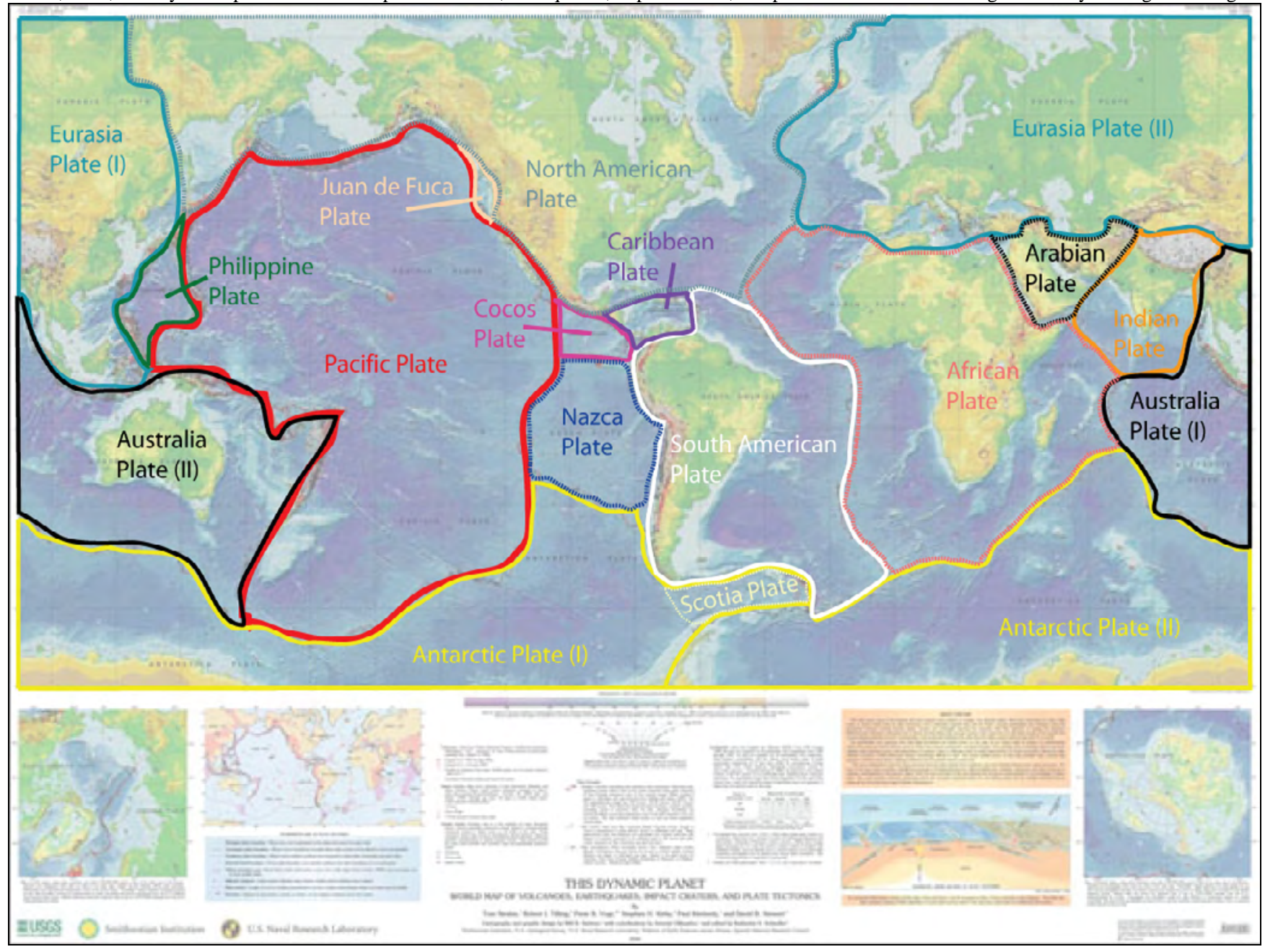


Name

Date

Period

\section{Plate Tectonics Q\&A}

1. What type of boundary exists in southern Alaska between the Pacific and North American Plates?

2. Why is the boundary between the Pacific and North American Plates different in Alaska than it is in California? Why might that give us a clue as to why Alaska has so many volcanoes?

3. What happens when the plates move apart at the mid-ocean ridges? Note Iceland, an area of active volcanism, located along the Mid-Atlantic Ridge.

4. What direction do you think that the Pacific Plate is moving? How do you know?

5. How does the plate boundary between the Pacific and North American Plates account for or contribute to volcanism in Alaska? Draw a figure that shows this relationship.

6. Can all of the current and historical activity (last 250 years) at Alaska's volcanoes be accounted for due to subduction and the generation of the Aleutian Arc? Are there volcanoes in Alaska that do not lie on the Aleutian Arc? How might they have formed?

7. What is the cause of the Himalayan Mountains? Why is this zone of convergence unique on the Earth today? Are there Alaskan analogs to this kind of plate boundary? 


\section{Plate Tectonics Q\&A Key}

1. What type of boundary exists in Southern Alaska between the Pacific and North American Plates?

Subduction, a combination of ocean-ocean and continental-oceanic collision/convergence

2. Why is the boundary between the Pacific and North American Plates different in Alaska than it is in California? Why might that give us a clue as to why Alaska has so many volcanoes?

The direction of Pacific Plate movement is toward the northwest relative to the North American Plate. In Alaska, subduction is the dominant boundary process; however, along California's southern and central coast, the relative plate motion is transform, with the Pacific Plate scraping along the edge of the North American Plate. Without a subducting slab to contribute to the generation of molten material, there is no source for the production of volcanism. Subduction off the coast of northern California, Oregon, and Washington, is the primary source of magma for the Cascade volcanoes.

3. What happens when the plates move apart at the mid-ocean ridges? Note Iceland, an area of active volcanism, located along the Mid-Atlantic Ridge.

Although the predominant plate motion is divergence, separate ridge segments are offset by transform faults. The Mid-Atlantic Ridge shows a number of great examples of divergence.

4. What direction do you think that the Pacific Plate is moving? How do you know?

The Pacific Plate is moving northwestward (white arrows point in that direction). In addition, the map shows a northwestward appearance of the Hawaiian Islands, which are produced as a mostly stationary hot spot form volcanic features on the overriding plate over time as it moves. Alternately, there is scientific discussion concerning the movement of the hotspot that may be associated with the current thinking concerning a change in direction of the movement of the Pacific Plate (see section in the activity on "hot spots"). 
5. How does the plate boundary between the Pacific and North American Plates account for or contribute to volcanism in Alaska? Draw one or more figures that illustrate these relations.

Subduction processes during plate convergence result in the formation of volcanoes. When the convergence is under the ocean, over millions of years, the erupted lava and volcanic debris pile up on the ocean floor until a submarine volcano rises above sea level to form an island volcano. Such volcanoes typically are strung out in chains called island arcs, such as the Aleutian Arc (and associated Aleutian Trench). As the name implies, volcanic island arcs, which closely parallel the trenches, generally are curved. The trenches are the key to understanding how island arcs such as the Marianas and the Aleutian Islands have formed and why they experience numerous strong earthquakes. Magmas that form island arcs are produced by the partial melting of the descending plate and (or) the overlying oceanic lithosphere. The descending plate also provides a source of stress as the two plates interact, leading to frequent moderate to strong earthquakes. Associated figures are provided below.

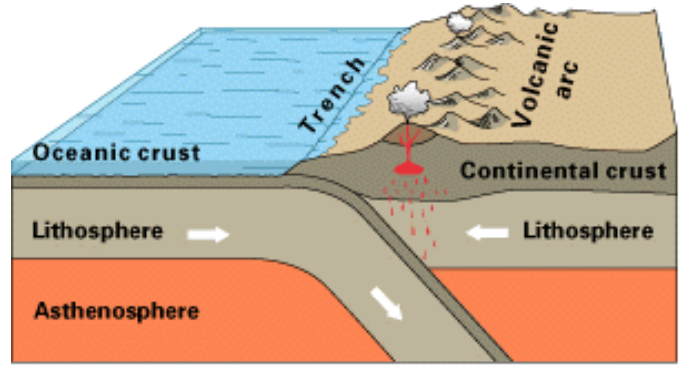

Oceanic-continental convergence

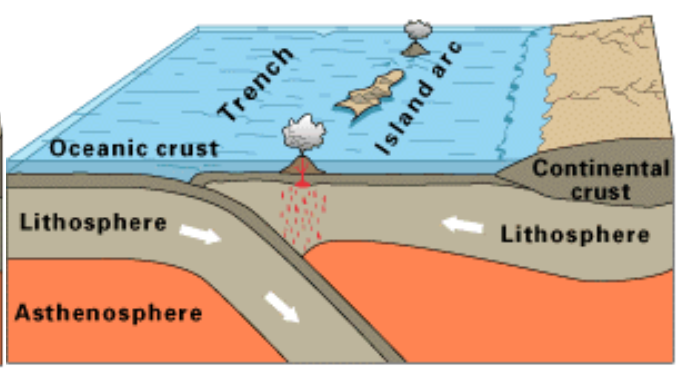

Oceanic-oceanic convergence

From Kious and Tilling, 1996 http://pubs.usgs.gov/gip/dynamic/understanding.html

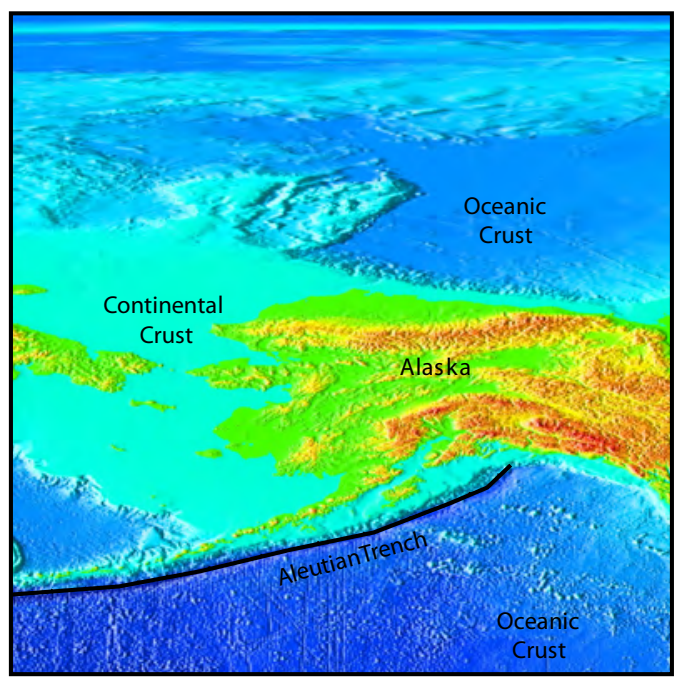

From Alaska Earthquake Information Center 
6. Can all of the current and historic activity (last 250 years) at Alaska's volcanoes be accounted for due to subduction and the generation of the Aleutian Arc? Are there volcanoes in Alaska that do not lie on the Aleutian Arc? How might they have formed?

For the most part the process of subduction contributes to the historic activity of Alaska's volcanoes. This includes Mt. Wrangell and mud volcanoes near the difficult but accomplished subduction of the Yakutat block (or terrane) which was carried to the region on the Pacific Plate.

7. What is the cause of the Himalayan Mountains? Why is this zone of convergence unique on the Earth today? Are there Alaskan analogs to this kind of plate boundary?

Continent to continent collision or convergence is the type of plate motion that continues to cause rise of the Himalayas. Rocks within the Indian and Asian continents are of similar rock density. Because the one plate does not subduct beneath the other, pressure of the colliding plates is relieved by upward thrusting, and formation of the Himalayas. Mt. Everest, in the Himalayas, is the world's tallest peak on land at 29,035 $\mathrm{ft}(\sim 8,850 \mathrm{~m})$ high. The same mechanism applies to the development of the St. Elias Range in Alaska. The St. Elias Range is rising rapidly today because of the collision of the Yakutat block (or terrane), which does not easily subduct and thus causes mountain building. 


\section{Activity II. Earthquake Mapping}

Grade Level 6-11

Setting Classroom

Time 50 minutes

Vocabulary (see Glossary)

latitude, longitude, plate boundary, seismicity, subduction zone, tectonic

Correlations to Alaska State Department of Education (2006) Performance Standards (Grade Level Expectations)

D1-Concepts of Earth Science

SD[6-11] Students develop an understanding of the concepts, processes, theories, models, evidence, and systems of Earth and space science.

SD2[6-11] Students develop an understanding of the origins, ongoing processes, and forces that shape the structure, composition, and physical history of the Earth.

SD2.2[7] The student demonstrates an understanding of the forces that shape Earth by describing how the movement of the tectonic plates results in both slow changes (e.g., formation of mountains, ocean floors, and basins) and short -term events (e.g., volcanic eruptions, seismic waves, and earthquakes) on the surface.

SD2.2[9-11] Students demonstrate an understanding of the forces that shape Earth by describing how the theory of Plate tectonics explains the dynamic nature of its surface

\section{Overview}

In addition to the observations of sea floor spreading stripes due to magnetic pole reversals, the history of determining the location of plate boundaries involves determining the location and depth of earthquakes. The location of earthquakes tends to correspond to the location of plate boundaries and the depth of earthquakes corresponds to the type of process occurring at the plate boundary. In this activity, students will build an interactive map of earthquakes to illustrate the relation between the location and depth of earthquake occurrences, and associated plate tectonic boundaries worldwide and specifically, in Alaska.

\section{Background}

Generally, the depth of an earthquake is related to the type of tectonic boundary in which it occurs. Relatively shallow earthquakes occur at divergent and transform boundaries and hotspots. Closely spaced earthquakes with a range of depths that deepen in the direction of plate movement can reflect a subducting plate at a convergent boundary. Plotting the location and depth of earthquakes in a latitude and longitude area can illustrate a rough outline of the plate boundaries of the Earth and the type of plate boundary in which they occur. You can see this relation using the following figures modified from Lillie, 2005. 


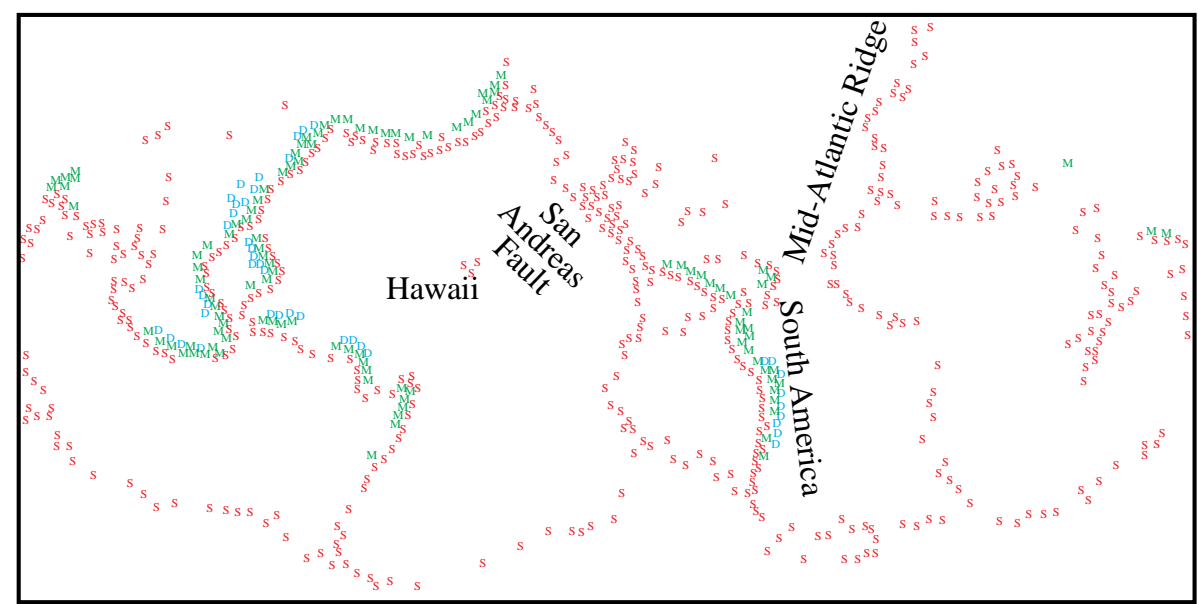

$\mathrm{S}=$ Shallow $(<40$ miles $) \quad \mathrm{M}=$ Intermediate $(40-200$ miles $) \quad \mathrm{D}=$ Deep $(>200$ miles $)$

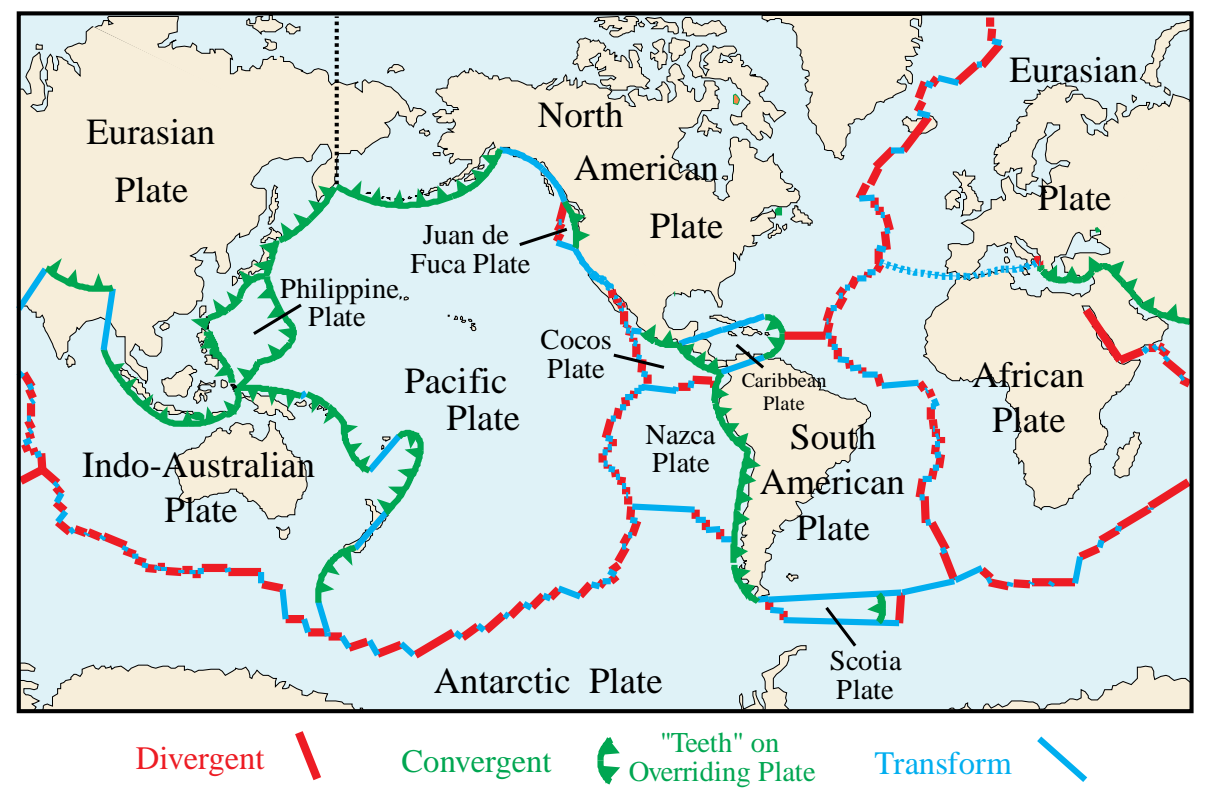

Modified from Lillie, 2005

The subducting part of the Pacific Plate generates a significant number of earthquakes. As the Pacific Plate deepens under the North American Plate, the depth of earthquakes generated by this subduction also deepens. The depth where the crust is no longer brittle enough to produce earthquakes is the maximum depth where earthquakes can be used to identify a subducting plate. The Pacific Plate is subducting under the North American Plate at an angle that shallows westward, so the region of earthquakes associated with the subducting plate also shallows westward. This phenomenon in Alaska can be illustrated by using the next set of figures from the Alaska Earthquake Information Center. 


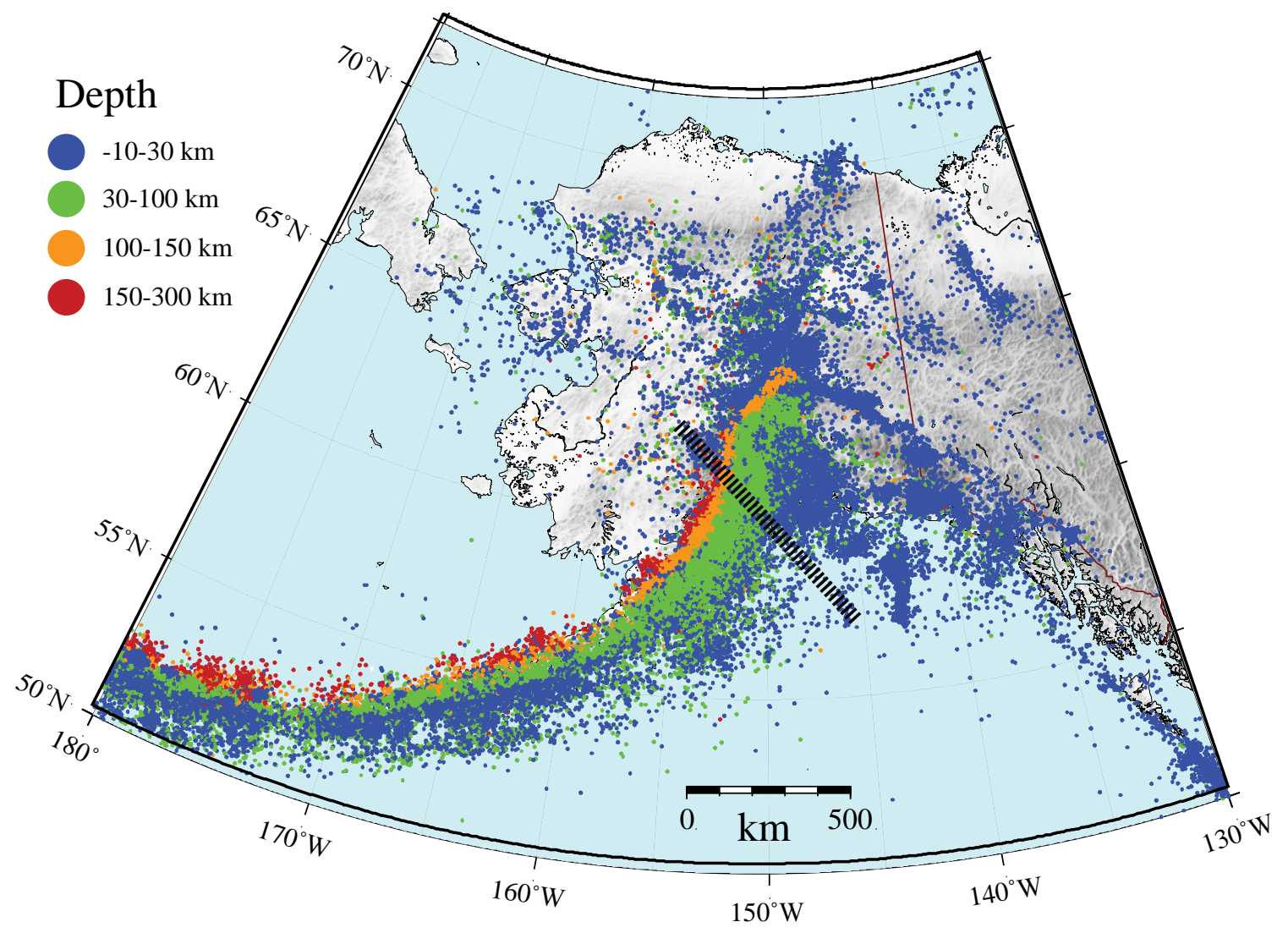

NW

SE

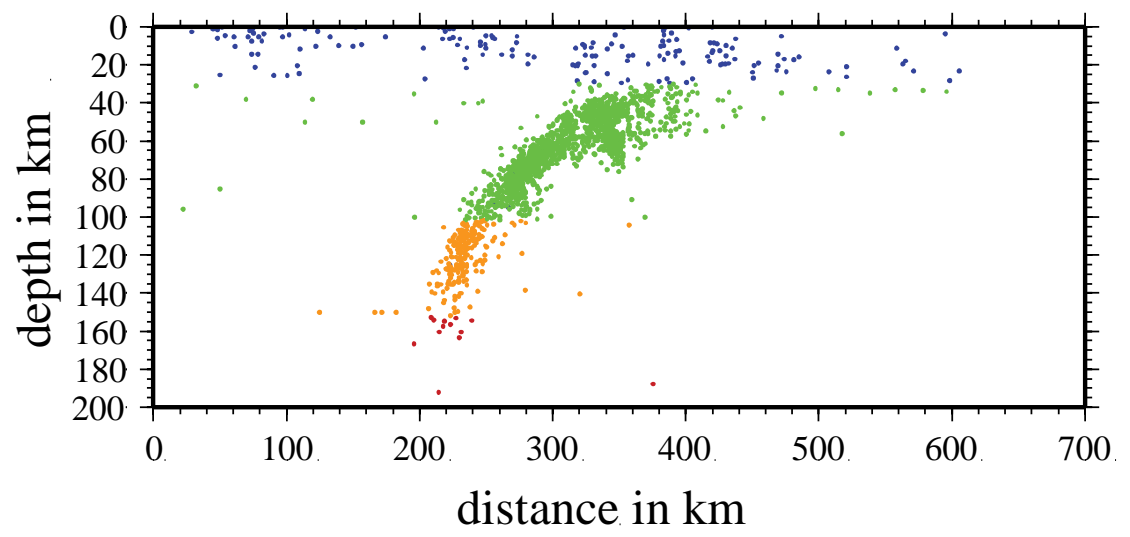

The above figures show earthquakes in Alaska greater than or equal to M2 (magnitude 2) recorded between 1970 and 2008. The cross section above is taken across the subduction zone in south-central Alaska and is represented by the dashed line in the top figure. The colors of earthquake locations represent the depth of the earthquakes as noted on the map. Figure modified courtesy of Lea Burris, Alaska Earthquake Information Center (AEIC). 


\section{Objective}

The students will be able to illustrate the connection between plate boundaries, tectonic activity, and the depth and location of earthquakes (also known as seismic events) with an emphasis in Alaska.

\section{Materials}

_ provided continent outline maps (world and Alaska)

_ blank, transparent overhead sheets (transparencies)

_ fine tipped markers that will work on overheads (transparencies)

- clear tape

_ overhead projector and screen or wall on which to project

- Incorporated Research Institutions for Seismology (IRIS) list of global earthquakes from last 30 days available at http://www.iris.edu/seismon/last30.html

_ Alaska Earthquake Information Center (AEIC) list of Alaskan earthquakes for a few days previous available at http://Earthquake.usgs.gov/eqcenter/recenteqsus/Maps/special/Alaska.php

\section{Procedure}

\section{A. Building an illustrative tectonic map of the world}

1. To build an illustrative tectonic map of the world, instruct each group of students to plot a different set of earthquakes from the IRIS list of global earthquakes from the last 30 days, which have been downloaded or provided.

2. Direct students to lay an overhead sheet carefully over the world map given using the lines of latitude and longitude for guidance.

3. Further, instruct students to align the two sheets carefully and then clip or tape together so they will not move.

4. Assign each group some of the earthquakes and a few volcanoes to map on their sheet. For this part of the exercise, students plot shallowest earthquakes and a single color should be used by all groups to identify that these are the shallowest earthquakes plotted. Many sources are available online for location maps of volcanoes. One source is the:

- Smithsonian Institution [n.d.], Global volcanism program-Find a Volcano by Region: Smithsonian Institution web page, accessed June 1, 2010, at http://www.volcano.si.edu/world/find_regions.cfm. 
5. After the groups have finished this exercise, instruct the students to layer the mapped overhead sheets (making sure that the orientation is the same for each layer) on top of each other in a single pile on one desk and view from above. Students also can be instructed to pile overhead sheets on top of the overhead projector for display on a screen or wall) and watch as the plotted earthquakes begin to outline the plate boundaries (as seen in the figure in the Background section).

6. If a rough outline of the plate boundaries cannot be seen, assign the students an additional set of deeper earthquakes to plot in another color and stack up their results again. Repeat until the outlines of the plates are apparent.

\section{B. Building an illustrative tectonic map of Alaska}

1. To build an illustrative tectonic map of Alaska given, instruct each group of students to plot a different set of earthquakes from the list downloaded or provided.

2. Direct the students to lay an overhead sheet carefully over the map of Alaska and use the lines of latitude and longitude as guides.

3. Further, instruct students to align the two sheets carefully and then clip or tape together so they will not move.

4. Assign each group some of the earthquakes and a few volcanoes to map on their sheet. It is best if you assign earthquakes in depth ranges to different groups of students. For instance a shallow set, an intermediate set, and a deep set. The students should plot these sets with a different color representing each set. Many online sources are available for location maps of volcanoes. Sources include:

- Alaska Volcano Observatory, [n.d.], Regional map of Alaskan volcanoes: Alaska Volcano Observatory webpage. (Available at http://www.avo.alaska.edu/volcanoes/.)

- Nye, C.J., McGimsey, R.G., and Power, J., 1998, Volcanoes of Alaska: Alaska Division of Geological and Geophysical Surveys Information Circular 38, 1 sheet [2 sides], accessed May 27, 2010, at

- PDF Front http://www.dggs.dnr.state.ak.us/webpubs/dggs/ic/oversized/ic038ed1998_sh0 01.PDF and

- PDF Back

http://www.dggs.dnr.state.ak.us/webpubs/dggs/ic/oversized/ic038ed1998_sh0 02.PDF

- Schaefer, J., and Nye, C.J., 2002, Historically active volcanoes of the Aleutian Arc: Alaska Division of Geological and Geophysical Surveys Miscellaneous Publication MP 0123, 1 sheet, accessed June 1, 2010, at http://www.avo.alaska.edu/pdfs/mp123.pdf.

- Smithsonian Institution, [n.d.], Global volcanism program—Volcanoes of Alaska map: Smithsonian Institution web page, accessed June 1, 2010, at http://www.volcano.si.edu/world/region.cfm?rnum=11. 
5. After the groups have finished, instruct the students to layer the mapped overhead sheets (making sure that the orientation is the same for each layer) on top of each other in a single pile on one desk and view from above. Students also can be instructed to pile sheets on top of the overhead projector for display on a screen or wall) and watch as the plotted earthquakes begin to outline the subduction zone at this convergent plate boundary.

6. The compilation of the plots should illustrate a progression of shallow to deep earthquakes at the Pacific Plate and North American Plate subduction zone.

7. If a rough outline of the subduction zone cannot be seen, assign the students an additional set of deeper earthquakes to plot in another color and stack up their results again. Repeat until the outlines of the subduction zone is apparent.

\section{Discussion}

1. Conduct a class discussion about why earthquakes occur along tectonic plate boundaries, worldwide, and in Alaska.

2. Use the figures from the Background section (available in the companion digital presentation) to illustrate the coherence with which thousands of plotted earthquakes image the plate boundaries worldwide and the subduction zone of southern Alaska.

3. Elaborate on the Pacific Plate and North American Plate subduction zone cross section including the angle of subduction and its relation to earthquake depth. You may ask students to draw or describe an additional cross section west of the cross section shown in the figure.

\section{Extensions}

1. Have students plot earthquakes from the same general location vs. depth and summarize the connections between earthquake depth and plate boundary type.

2. Saltus, R.W., and Barnett, A., 2000, Eastern Aleutian volcanic arc digital model-ver. 1.0: U.S. Geological Survey Open-File Report 00-365. (Available at http://pubs.usgs.gov/of/2000/ofr-00-0365/report.htm.)

3. UNAVCO, 2010, Jules Verne Voyager Jr. Map Tool: UNAVCO web page, accessed June 1, 2010, at http://jules.unavco.org/VoyagerJr/Earth.

4. Van Wagner, Lois, 1991, The great continental drift mystery: Yale—New Haven Teachers Institute, Global Change, Volume VI, accessed May 27, 2010 at http://www.yale.edu/ynhti/curriculum/units/1991/6/91.06.05.x.html. 


\section{References Cited}

Alaska Earthquake Information Center (AEIC), 2010, Patterns of regional seismicity and major earthquakes: Alaska Earthquake Information center website, accessed May 27, 2010, at http://www.aeic.alaska.edu/vltpage3.html.

Alaska State Department of Education and Early Development, 2006, Standards and grade level expectations, March 2006: State of Alaska website, accessed October 2009 at http://www.eed.state.ak.us/tls/assessment/GLEHome.html.

Lillie, R.J., 2005, Parks and plates-The geology of our National parks, monuments and seashores: New York, W.W. Norton and Comdishy, 298 p.

- Chapter 1: Plate tectonics, p. 5-21; figure 1.1, p. 6; figure 1.9, p. 10.

- Chapter 5: Subduction zones, southern Alaska subduction zone, p. 119-120.

- Chapter 11: Accreted terranes, Alaska: A glimpse of continental growth in action, p. 241-245.

\section{Modified from}

Atwater, Tanya, 2008, World tectonics map exercise-World earthquake and volcanoes map exercise: Santa Barbara, University of California website, accessed June 1, 2010, at http://emvc.geol.ucsb.edu/download/worldtectonicsmap.php.

Driedger, C.L., Doherty, Anne, and Dixon, Cheryll, 2005, Living with a volcano in your backyard-An educator's guide with emphasis on Mount Rainier: U.S. Geological Survey General Interest Product 19; produced in cooperation with the National Park Service, available at

- Chapter 1: What the past tells us-Surrounded by volcanoes: http://vulcan.wr.usgs.gov/Outreach/Publications/GIP19/framework.html and

- http://vulcan.wr.usgs.gov/Outreach/Publications/GIP19/chapter_one_surrounded_b y_volcanoes.pdf $(6.9 \mathrm{MB})$

\section{Glossary}

Latitude-The angular distance of a point on the earth's surface north or south or the equator, measured along a meridian.

Longitude-The angular distance between the meridian of a given place and the prime meridian of Greenwich, England, measured east or west to a maximum value of 180 degrees.

Plate boundary-An area on the margins of tectonic plates where seismic, volcanic, and tectonic activity takes place because of the relative motion of the plates.

Seismicity-The distribution and frequency of seismic events such as earthquakes or fault movement.

Subduction Zone-The zone of convergence of two tectonic plates, one of which usually overrides the subducting plate. 
Tectonic-Refers to earthquakes generated by faulting rather than by volcanic activity. Latitude: an imaginary line joining points on Earth's surface that are all of equal distance north or south of the equator.

\section{Sources of Glossary Definitions}

Bates, R.K., and Jackson, J.A., eds., 1987, Glossary of Geology ( ${ }^{\text {rd }}$ ed.): Falls Church, Va., American Geological Institute, 571 p.

Kious, W.J., and Tilling, R.I., 1996. This dynamic Earth—The story of plate tectonics: U.S. Geological Survey General Information Product. (Also available at http://pubs.usgs.gov/gip/dynamic/dynamic.html.) 


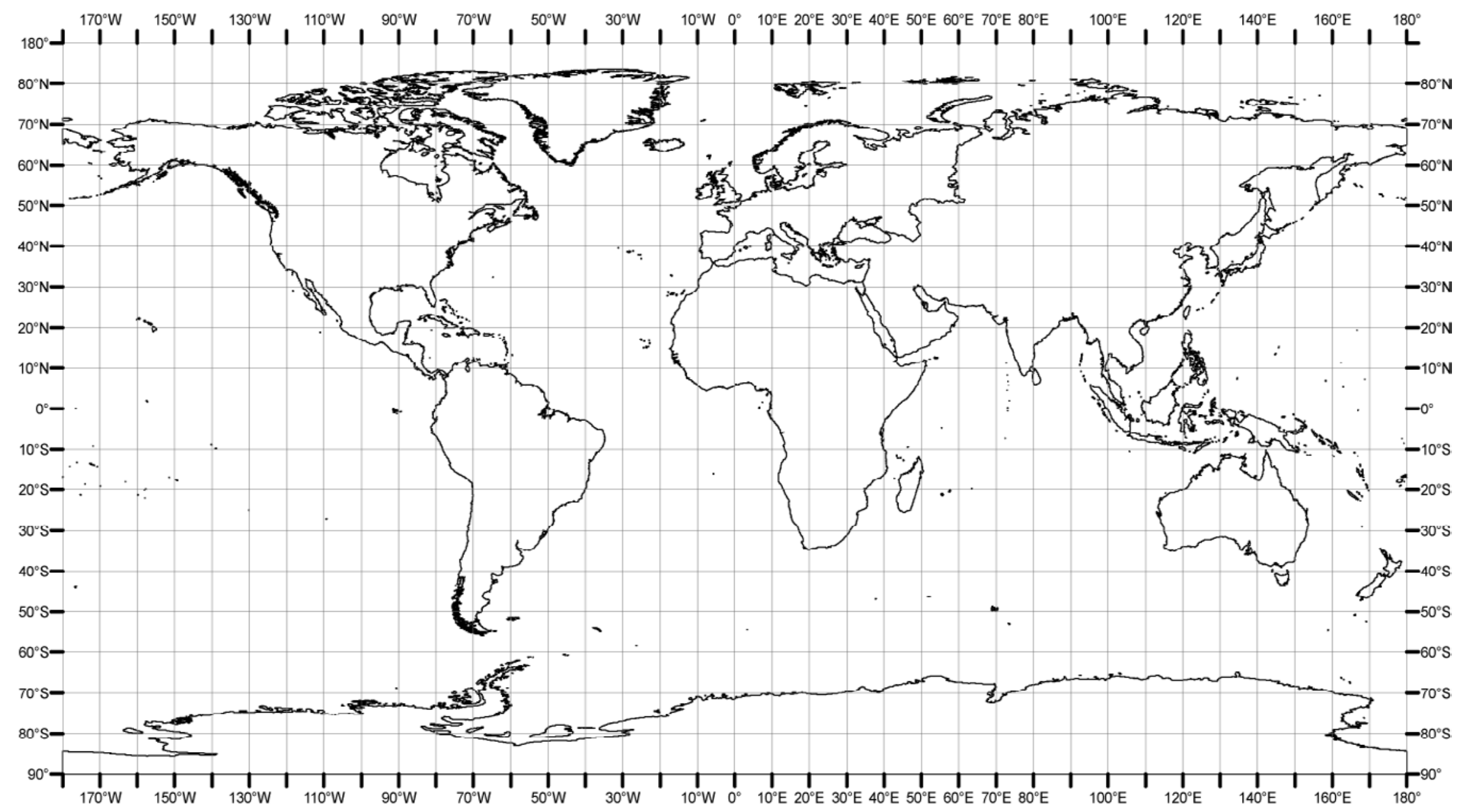




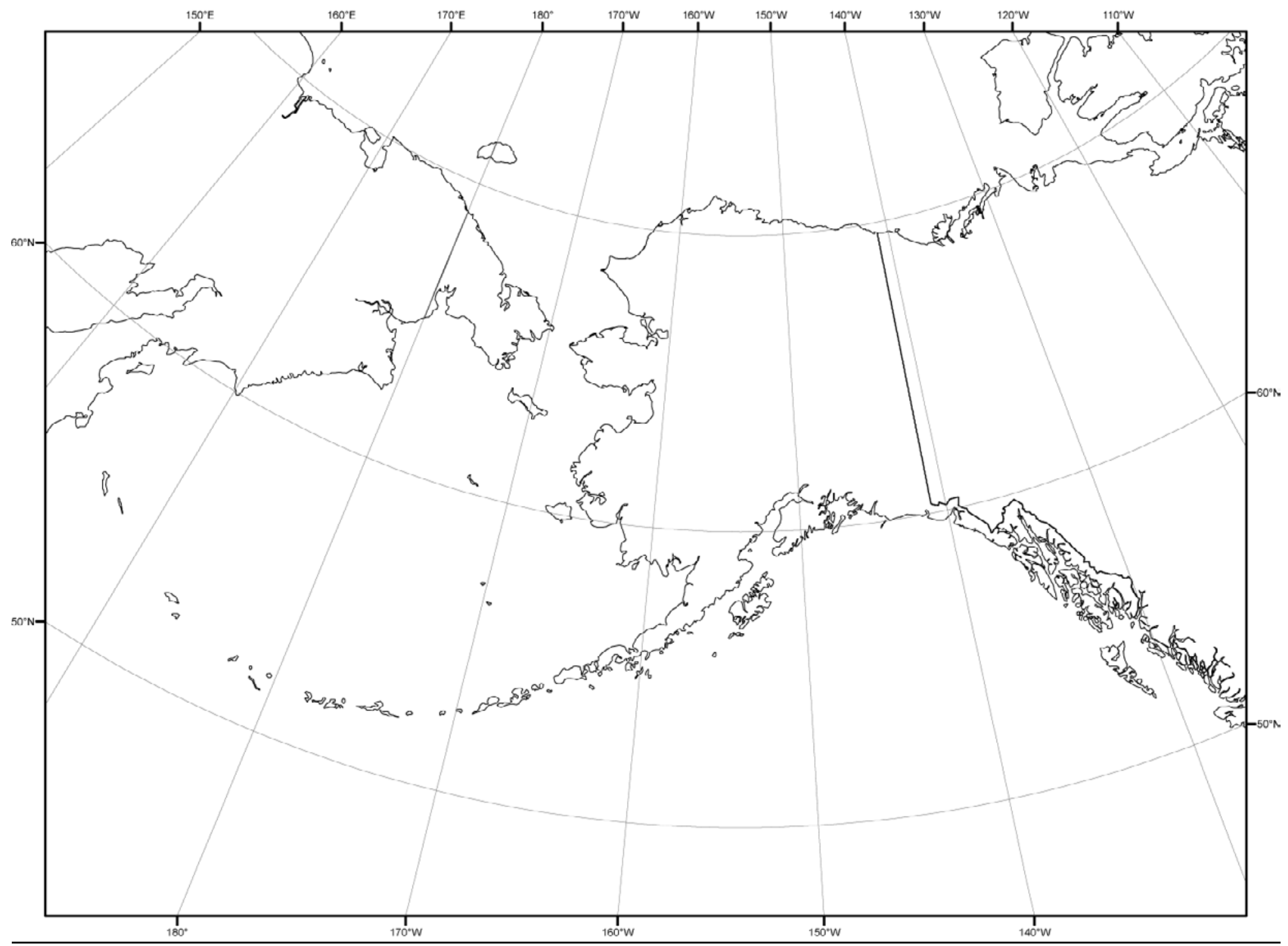




\section{Chapter 2 \\ Alaska's Igneous Rocks}

\section{Resources}

- Alaska Department of Natural Resources, 2010, Division of Geological and Geophysical Surveys, Alaska Geologic Materials Center website, accessed May 27, 2010, at http://www.dggs.dnr.state.ak.us/?link=gmc_overview\&menu_link=gmc.

- Alaska Resource Education: Alaska Resource Education website, accessed February 22, 2011, at http://www.akresource.org/.

- Barton, K.E., Howell, D.G., and Vigil, J.F., 2003, The North America tapestry of time and terrain: U.S. Geological Survey Geologic Investigations Series I-2781, 1 sheet. (Also available at http://pubs.usgs.gov/imap/i2781/.)

- Danaher, Hugh, 2006, Mineral identification project website, accessed May 27, 2010, at http://www.fremontica.com/minerals/.

- Digital Library for Earth System Education, [n.d.], Find a resource-Bowens reaction series: Digital Library for Earth System Education website, accessed June 10, 2010, at http://www.dlese.org/library/query.do?q=Bowens\%20reaction\%20series\&s=0.

- $\quad$ Edwards, L.E., and Pojeta, J., Jr., 1997, Fossils, rocks, and time: U.S. Geological Survey website. (Available at http://pubs.usgs.gov/gip/fossils/contents.html.)

- Garden Buildings Direct, 2010, Rocks and minerals: Garden Buildings Direct website, accessed June 4, 2010, at http://www.gardenbuildingsdirect.co.uk/Article/rocks-andminerals.

- Illinois State Museum, 2003, Geology online-GeoGallery: Illinois State Museum Society database, accessed May 27, 2010 at http://geologyonline.museum.state.il.us/geogallery/.

- Knecht, Elizebeth, designer, Pearson, R.W., and Hermans, Majorie, eds., 1998, Alaska in maps-A thematic atlas: Alaska Geographic Society, 100 p.

Lillie, R.J., 2005, Parks and plates-The geology of our National parks, monuments, and seashores: New York, W.W. Norton and Comdishy, 298 p.

- Chapter 2: Geologic features and processes, p. 34-39.

- National Aeronautics and Space Administration, [n.d.], In Situ Resource Utilizaiton (ISRU) element at Marshall Space Flight Center: National Aeronautics and Space Administration web page, accessed June 10, 2010, at http://isru.msfc.nasa.gov/igneousrocks.html.

- Newman, W.L., 1997, Geologic time-Online edition: U.S. Geological Survey. (Available at http://pubs.usgs.gov/gip/geotime/.) Schmincke, H.-U., 2004, Volcanism: New York, Springer-Verlag, 324 p.

- Chapter 3: Magmas, p. 21-34.

- Smithsonian Institution, [n.d.], The dynamic Earth: Smithsonian National Museum of Natural History website, accessed June 10, 2010, at http://www.mnh.si.edu/earth/main_frames.html. 
- Smithsonian Institution, 2010, Minerals, crystals, and gems-Stepping-stones to inquiry-Create a classroom exihibit—Rocks and minerals: Smithsonian Institution website, accessed June 10, 2010, at http://www.smithsonianeducation.org/educators/lesson_plans/minerals/lesson1_main.ht ml.

- U.S. Geological Survey, [n.d.], The living rock—The Earth's continental crust (movie file). This 1-hour video provides a global tour of geologic processes through the eyes of several USGS scientists. (Media file available at mms://video.wr.usgs.gov/movies/living_rock.wmv.)

- U.S. Geological Survey, 2004, Geologic maps: U.S. Geological Survey website. (Available at http://geomaps.wr.usgs.gov/parks/gmap/index.html.)

- U.S. Geological Survey, 2004, Rocks and minerals: U.S. Geological Survey website. (Available at http://geomaps.wr.usgs.gov/parks/rxmin/.)

- U.S. Geological Survey, 2005, Geologic maps and mapping: U.S. Geological Survey website. (Available at http://ngmdb.usgs.gov/ncgmp/ncgmpgeomaps/.)

- U.S. Geological Survey, 2008, Digital geologic map products for Alaska: U.S. Geological Survey web site. (Available at http://minerals.usgs.gov/alaska/prodxdgt.html.)

- U.S. Geological Survey Geologic Names Committee, 2007, Divisions of geologic time-Major chronostratigraphic and geochronologic units: U.S. Geological Survey Fact Sheet 2007-3015, 2 p. (Also available at http://pubs.usgs.gov/fs/2007/3015/; PDF http://pubs.usgs.gov/fs/2007/3015/fs2007-3015.pdf.)

- University of North Carolina, [n.d.], Atlas of igneous and metamorphic rocks, minerals, and textures: University of North Carolina Geology Department website, accessed June 10, 2010, at http://www.geolab.unc.edu/Petunia/IgMetAtlas/mainmenu.html.

- Weathers, Judy, Galloway, John, and Frank, Dave, 2001, Minerals in our environment: U.S. Geological Survey Open-File Report 00-144, 1 sheet. (Also available at http://geopubs.wr.usgs.gov/open-file/of00-144/.)

- Werdon, M.B., Szumigala, D.J., and Davidson, G., 2000, Generalized geologic map of Alaska: Alaska Department of Natural Resources, Division of Geological and Geophysical Surveys, 1 sheet, accessed May 27, 2010, at http://www.dggs.dnr.state.ak.us/download/akgeomap.pdf. 


\section{Activities}

The activities in this chapter will allow students to become familiar with igneous rocks in terms of identification, location, and association with landscape features including volcanoes. Students will learn about the importance, value, and usage of geological maps with an emphasis on their local region. Students also will become familiar with geochemistry, the various recipes, or compositions of various igneous rock types, and the volcanic forms commonly associated with these compositions in three volcanic regions in the United States, including Alaska. Students will build on their knowledge of plate tectonics and the local plate tectonic boundaries in Alaska.

Activity I. Igneous Rock Identification

Activity II. Igneous Rocks_-Coming to a Location Near You!

Activity III. Comparison of Hawaiian, Cascade, and Alaskan Volcanic Rocks 


\section{Activity I. Igneous Rock Identification}

Grade Level 6-11

Setting Classroom or computer lab

Time 45-90 minutes

Vocabulary (see Glossary)

igneous, mafic, magma, plutonic, silicic, volcanic rock

Correlations to Alaska State Department of Education (2006) Science Performance Standards (Grade Level Expectations)

D1 - Concepts of Earth Science

SD1[6-11] Students develop an understanding of Earth’s geochemical cycles.

\section{Overview}

In this activity, students will investigate how to identify and classify assorted Alaskan igneous rocks using various properties. These properties also are used to determine the mechanism and location of formation for these igneous rocks including their relations to Alaskan volcanism.

\section{Background}

Igneous rocks are formed by solidification of magma, which generally consists of silicate melt (molten rock mainly consisting of silica [Si]), mineral crystals, and dissolved gasses. Magma is generated deep beneath the Earth's surface. As it moves toward the surface, it may be forced out and erupt. Gas-rich magma erupts violently (explosively) as volcanic bombs and ash, whereas gas-poor magma erupts in a less dramatic manner as lava flows. When volcanic bombs, ash, and lavas cool, they form volcanic igneous rocks. Not all magma reaches the surface, however. Sometimes magma remains below the surface and crystallizes completely to form plutonic igneous rocks. The cooling history has an important role in the classification of igneous rocks.

One way scientists classify rocks is by determining the origin of the rock (whether it formed above or below the surface). Plutonic rocks cool and crystallize slowly below the Earth's surface allowing crystals more time to develop and results in a rock with large mineral grains typically visible to the unaided eye (known as coarse-grained) with no glass remaining between crystals (the glass represents the solidified melt in the magma). Volcanic rocks cool rapidly at the surface, so magma does not have enough time to crystallize completely. In addition, crystals forming in magma that reached the surface (then called lava) have less time to develop. The result is a rock with fewer and smaller mineral grains (fine-grained), and large amounts of glass between crystals. Another way scientists classify igneous rocks is to determine whether a rock is fine-grained or coarsegrained; this is called texture. The third characteristic that scientists use to classify igneous rocks is chemical composition. Magma that is high in silica (Si) generally forms lightcolored rocks, called silicic. Magma that is low in silica generally forms dark-colored rocks, called mafic. These are generalities, however, so keep in mind other factors that affect rock color (for example, bubbles that are left behind by escaped gasses.) 


\section{Objectives}

The students will be able to classify igneous rocks according to origin, texture, and color. The students will be able to describe how igneous rocks form.

\section{Materials}

- igneous rock samples (samples [number] correspond to samples in Alaska Resource Education kit*) with as many of the following as possible:

- Granite (31-8)

- Pumice (27-7)

- Scoria

- Obsidian (28-9)

- Basalt (29-11)

- Rhyolite

- Gabbro (30-10)

- Andesite

- Dacite

_ magnifiers or hand lenses

— general rock identification book (a few for the class, or one for each group or student)

and (or)

- use the online virtual rock kit of the

School of Ocean and Earth Science, 2006, Igneous rocks: Southampton, U.K., University of Southampton website, accessed June 10, 2010, at http://www.soes.soton.ac.uk/resources/collection/minerals/igne-1/index.htm.

and

— index cards

- Classification of Igneous Rocks worksheet

* Kits are available from the Alaska Resource Education for educators in Alaska. This kit includes a collection of rock and mineral samples. Kits can be requested from the Alaska Resource Education website http://www.akresource.org/.

\section{Procedure}

\section{A. Student designed classification system}

1. Divide students into small groups. Give each student a tray of igneous rocks (see list of suggested rocks in Materials) or use the recommended virtual rock collection. Ask students to look at the rocks and determine some way to classify their rocks. Once the groups have separated their rocks, ask the class what characteristics they selected to help them classify the rocks. Write these characteristics on the board. Have students classify their rocks again using a different system than they used the first time. When they are finished, ask them again what characteristics they selected and add them to the board. 
2. Discuss how scientists classify igneous rocks. Discuss origin (plutonic or volcanic), texture (fine-grained or coarse-grained), and color (mafic or silicic). Relate this vocabulary to the characteristics that the students defined when making their own classifications.

3. Using handbooks and rock identification guides, have students fill out the following list of igneous rock identification information on an index card for each unlabeled rock. Have students use the terms that were used in the discussion concerning how scientists classify igneous rocks.

- Name: Scientific (likely the last thing to fill in).

- Grain size/texture: Dominant crystal size: small (need a magnifier), medium (can just make out with unaided eye), large (easily seen with unaided eye) a mix of two or three sizes, somewhere in between, are all the crystals equal in size.

- Color: Dark, medium, light, black, grey, pink, white, and so on.

- Composition: Mafic, silicic, also note if this could be due to bubbles left behind in the rock from gases which escaped during cooling.

- Origin: Extrusive or intrusive, volcanic, or plutonic.

- Cool Alaska Fact: Associated mineral and rock type, locale, and origin of name, found in Alaska.

- Picture: Have students draw a picture of their rock on the back of their paper.

\section{B. Classifying Igneous Rocks worksheet}

1. Have students fill in the chart on the Classifying Igneous Rocks worksheet and answer the questions using their note cards for assistance.

\section{Extensions}

1. Have students put their note cards together to create an identification booklet. Have them include additional pages that may include a glossary, a figure showing the rock cycle, and so on.

2. Obtain additional specimens of igneous rocks have your students try to identify them using the technique in number 1 . Ask students to determine if their system used for classifying igneous rocks works well, or not, and to explain the issues.

3. Have students create a newspaper article of a rock obituary that outlines an igneous rock's life story.

4. Use Smithsonian Education-Minerals, Crystals, and Gems-Stepping-Stones to Inquiry, Lesson Plan 1: Create a Classroom Exhibit: Rocks and Minerals website. (Available at http://www.smithsonianeducation.org/educators/lesson_plans/minerals/lesson1_main.ht $\underline{\mathrm{ml}}$.) 
5. Have students also use the Atlas of Igneous and Metamorphic Rocks, Minerals, and Textures website to learn more about volcanic and plutonic textures and common minerals in igneous rocks. (Available at http://www.geolab.unc.edu/Petunia/IgMetAtlas/mainmenu.html.)

6. Have the students review the Smithsonian Institution's The Dynamic Earth website. (Available at http://www.mnh.si.edu/earth/main_frames.html.)

7. Have students identify the majority of minerals that their igneous rocks are made of. Are there some repeat performers? The most common minerals in igneous rocks may form sequentially as cooling progresses following the Bowens Reaction. Material on the Bowens Reaction Series includes:

- Digital Library for Earth System Education (DLESE)

- Bowens reaction series available at http://www.dlese.org/library/query.do?q=Bowens\%20reaction\%20series\&s=0; and

- Igneous minerals available at http://www.dlese.org/library/query.do?q=igneous\%20minerals\&s=0.

8. Students can learn about the International Union on Geological Sciences (IGUS) Classification of Igneous Rock.

- In Situ Resource Utilization (ISRU) Element at Marshall space Flight Center Lunar Regolith Simulant Development and Characterization NASA Simulant Development: Igneous Rocks website available at http://isru.msfc.nasa.gov/igneous-rocks.html.

\section{Reference Cited}

Alaska State Department of Education and Early Development, 2006, Standards and grade level expectations, March 2006: State of Alaska website, accessed October 2009 at http://www.eed.state.ak.us/tls/assessment/GLEHome.html.

\section{Glossary}

Igneous-A rock or mineral that solidified from magma; also applied to processes leading to, related to, or resulting from the formation of such rocks.

Mafic-An igneous rock composed mostly of one or more dark-colored minerals

Magma-Naturally occurring mobile rock material generated within the Earth and capable of intrusion, extrusion, from which igneous rocks are derived through solidification and other processes.

Plutonic-Igneous rocks formed at depth.

Silicic-Silica (Si)-rich igneous rocks or magma, typically two-thirds or 65 percent of the composition is $\mathrm{Si}$. 
Volcanic rock-A fine-grained or glassy igneous rock resulting from volcanic action at or near the Earth's surface; either ejected explosively or extruded as lava.

\section{Source of Glossary Definitions}

Bates, R.K., and Jackson, J.A., eds., 1987, Glossary of Geology (3 ${ }^{\text {rd }}$ ed.): Falls Church, Va., American Geological Institute, 571 p. 
Name

Date

Period

\section{Classifying Igneous Rocks}

\begin{tabular}{|c|l|l|l|}
\hline Igneous Rocks & Rate of Cooling & Texture & Origin \\
\hline Granite & & & \\
\hline Pumice & & & \\
\hline Scoria & & & \\
\hline Obsidian & & & \\
\hline Basalt & & & \\
\hline Rhyolite & & & \\
\hline Gabbro & & & \\
\hline Andesite & & & \\
\hline Dacite & & & \\
\hline
\end{tabular}

1. What are three ways that scientists use to classify igneous rocks?

2. Describe how cooling rate affects the size of mineral grains in an igneous rock.

3. Compare and contrast volcanic igneous rocks with plutonic igneous rocks. 
Classifying Igneous Rocks Answer Key

\begin{tabular}{|c|c|c|c|c|}
\hline Igneous Rocks & $\begin{array}{l}\text { Rate of } \\
\text { Cooling }\end{array}$ & Texture & Origin & $\begin{array}{c}\text { Mineral } \\
\text { Composition }\end{array}$ \\
\hline Granite & Slow & Coarse-grained & Plutonic & Silicic \\
\hline Pumice & Very rapid & Fine-grained & Volcanic & Silicic \\
\hline Scoria & Rapid & Fine-grained & Volcanic & Mafic \\
\hline Obsidian & Rapid & $\begin{array}{l}\text { Fine-grained; } \\
\text { glassy }\end{array}$ & Volcanic & Silicic \\
\hline Basalt & Rapid & Fine-grained & Volcanic & Mafic \\
\hline Rhyolite & Rapid & Fine-grained & Volcanic & Silicic \\
\hline Gabbro & Slow & Coarse-grained & Plutonic & Mafic \\
\hline Andesite & Rapid & $\begin{array}{l}\text { Fine to medium } \\
\text { grained }\end{array}$ & Volcanic & Intermediate \\
\hline Dacite & Rapid & $\begin{array}{l}\text { Fine to medium } \\
\text { grained }\end{array}$ & Volcanic & Intermediate \\
\hline
\end{tabular}

1. What are three ways that scientists use to classify igneous rocks?

Scientists use origin, texture, and composition to classify rocks. They look at the texture of the rock to see if it is fine-grained or coarse-grained. The texture of the rock determines its origin - if it cooled below the surface or above the surface. The mineral composition (the types of minerals in the rock and their proportions) tells if it is mafic or silicic (low in silica or high in silica). 
2. Describe how the location of magma and its respective cooling rate affects the size of mineral grains in an igneous rock.

If magma cools below the surface of the earth, it takes longer to solidify. The longer it takes to cool, the more time crystals have to develop and the larger they will become. All of the melt crystallizes, so no glass remains in the rock. If magma cools above the surface, it will solidify faster and melt crystallizes to glass. The mineral crystals will have less time to develop and will be smaller with glass present between crystals.

3. Compare and contrast volcanic igneous rocks with plutonic igneous rocks.

Extrusive igneous rocks form from lava that has cooled on the surface of the earth. They are volcanic and have small mineral grains. Intrusive igneous rocks form from magma that has cooled below the surface. They are plutonic and have larger mineral grains than extrusive igneous rocks.

Volcanic igneous rocks form from magma that has cooled on the surface of the earth. Often they have small mineral grains. Plutonic igneous rocks form from magma that has crystallized below the surface. They have larger mineral grains than volcanic igneous rocks. 


\section{Activity II. Igneous Rocks_Coming to a Location Near You!}

Grade Level 6-11

Setting Classroom

Time 50 minutes

Vocabulary (see Glossary)

bedrock, geologic features, stratigraphic column (geologic column)

Correlations to Alaska State Department of Education (2006) Science Performance Standards (Grade Level Expectations)

D1 - Concepts of Earth Science

SD1[6-11] Students develop an understanding of Earth's geochemical cycles.

SD1.1[8] The student demonstrates an understanding of geochemical cycles by making connections between components of the locally observable geologic environment and the rock cycle.

SD2[6-11] Students develop and understanding of the Earth origins, ongoing processes, and forces that shape the structure composition, and physical history of the Earth.

SD2.1[8] The student demonstrates an understanding of the forces that shape Earth by interpreting topographical maps to identify features (that is, rivers, lakes, mountains, valleys, islands, permafrost, and tundra).

\section{Overview}

Students will use a series of maps to identify igneous rock outcrops, young volcanic or plutonic features, and (or) nearby old volcanic features close (or relatively nearby).

\section{Background}

Maps of bedrock geology illustrate the types of rocks that exist in a given area. Even if there are no currently active volcanoes outside the classroom, students likely will be able to associate regional features with bedrock types using a geologic map. Students also are likely to identify igneous intrusions or volcanic rocks associated with volcanic activity that may have occurred thousands of years ago.

\section{Objectives}

The students will identify local igneous rocks and their associated landforms using an Alaska statewide and (or) regional bedrock geologic map.

\section{Materials}

- Geologic Map of Your Area worksheet

— string, yarn, or twine, and

- pins with heads, or

- drawing compass, and

- pencil 
Geologic Maps-enough copies so that each group has one map. Suggested maps are:

- Werdon, M.B., Szumigala, D.J., and Davidson, G., 2000, Generalized geologic map of Alaska: Alaska Department of Geological and Geophysical Surveys (included in activity)

PDF http://www.dggs.dnr.state.ak.us/download/akgeomap.pdf and (or)

- A map of your area from

Alaska Department of Natural Resources, [n.d.], Alaska geologic map index search-

Text search interface: Alaska Department of Natural Resources web page, accessed June 10, 2010, at http://maps.akgeology.info/STSE/tsi.jsp.

Go to the "Geology" section and check "Bedrock geology" and then "Search" (lower left)

- The purple areas in the completed search have corresponding bedrock geologic maps listed below the map. Click on the Online links (second column from left) for the map of interest. This will bring you to the Alaska Division of Geologic and Geophysical Surveys (ADGGS) website where you can download the PDF of the map, generally by choosing the "Sheet" link(s) and (or)

- Geologic Maps from

U.S. Geological Survey, 2008, Alaska Mineral Resources—Digital geologic map products for Alaska: U.S. Geological Survey web page. (Available at http://minerals.usgs.gov/alaska/prodxdgt.html.

- For those titled "Geologic Maps of..." click on the title and on the next screen, the SIM or Plate link to the right is to a PDF file of the map.

- For those titled "Digital Data for..." click on the title and on the next screen, scroll down to the table of "PDF files of the geologic map and text" the links there go to PDF files of the map and (or)

- Geologic maps accessible from the Alaska Volcano Observatory website http://www.avo.alaska.edu/downloads/classresults.php?pregen=map.

Additional maps of volcanoes in Alaska include:

- Nye, C.J., and others, 1998, Volcanoes of Alaska: Alaska Division of Geological and Geophysical Surveys Information Circular IC 0038, 1 sheet [2 sides], accessed June 1, 2010, at

- Front PDF (6.4 MB) http://www.dggs.dnr.state.ak.us/webpubs/dggs/ic/oversized/ic038ed1998_sh001.PDF and

- Back PDF (6.6 MB) http://www.dggs.dnr.state.ak.us/webpubs/dggs/ic/oversized/ic038ed1998_sh002.PDF.

- Smithsonian Institution, [n.d.], Global volcanism program - Volcanoes of Alaska, Map: Smithsonian Institution web page, accessed June 1, 2010, at http://www.volcano.si.edu/world/region.cfm?rnum=11. 


\section{Procedure}

\section{A. Students read a geologic map of their area}

1. Illustrate for the students how to use the map explanation, scale, and other information that is included on the map (such as the stratigraphic column, list of formations, inset maps, and so on).

2. Instruct students to locate their community and place a pin in its exact center. This could be challenging. Students may need to use additional state maps with communities labeled for reference.

3. Direct students to draw in pencil a light circle on the map using a piece of string or a drawing compass to draw an arc around the pin. For large-scale maps, direct students to draw a small circle around their area, for small-scale maps, have students draw a bigger circle.

4. Ask students to figure out and record the scale of their circled region-diameter, radius, and (or) area.

5. Inside the circle, students can identify and record requested information on the Geologic Map of Your Area worksheet:

- All the symbols inside the circle;

- The age and rock types of the various rocks; and

- Associate various rock types on the map with surface features (mountains, fjords, mines, gravel pits, volcanoes, valleys, and so on.), using local knowledge of the students.

6. Assign students to answer the questions on the Geologic Map of Your Area worksheet. The questions will require the use of a volcanic map of Alaska.

\section{Modified from}

Maine Geological Survey, 2005, Activities and resources for Earth Science teachers, Activity \#10-Bedrock geologic map of Maine: Maine Department of Conservation website, accessed May 27, 2010, at

http://maine.gov/doc/nrimc/mgs/education/lessons/act10.htm.

\section{Reference Cited}

Alaska State Department of Education and Early Development, 2006, Standards and grade level expectations, March 2006: State of Alaska website, accessed October 2009 at http://www.eed.state.ak.us/tls/assessment/GLEHome.html. 
Glossary

Bedrock - A general term for the rock, solid, that underlies soil or other unconsolidated, superficial material.

Geologic features - The rocks, minerals, and physical structure of a specific area.

Stratigraphic column (geologic column) - A composite diagram that shows in a single column the subdivisions of part or all of geological time or the sequence of stratigraphic units of a given locality or region (with the oldest units at the bottom and the newest at the top) to indicate their relations to the subdivisions of geologic time and their relative positions to each other.

\section{Source of Glossary Definitions}

Bates, R.K., and Jackson, J.A., eds., 1987, Glossary of Geology (3 ${ }^{\text {rd }}$ ed.): Falls Church, Va., American Geological Institute, 571 p. 


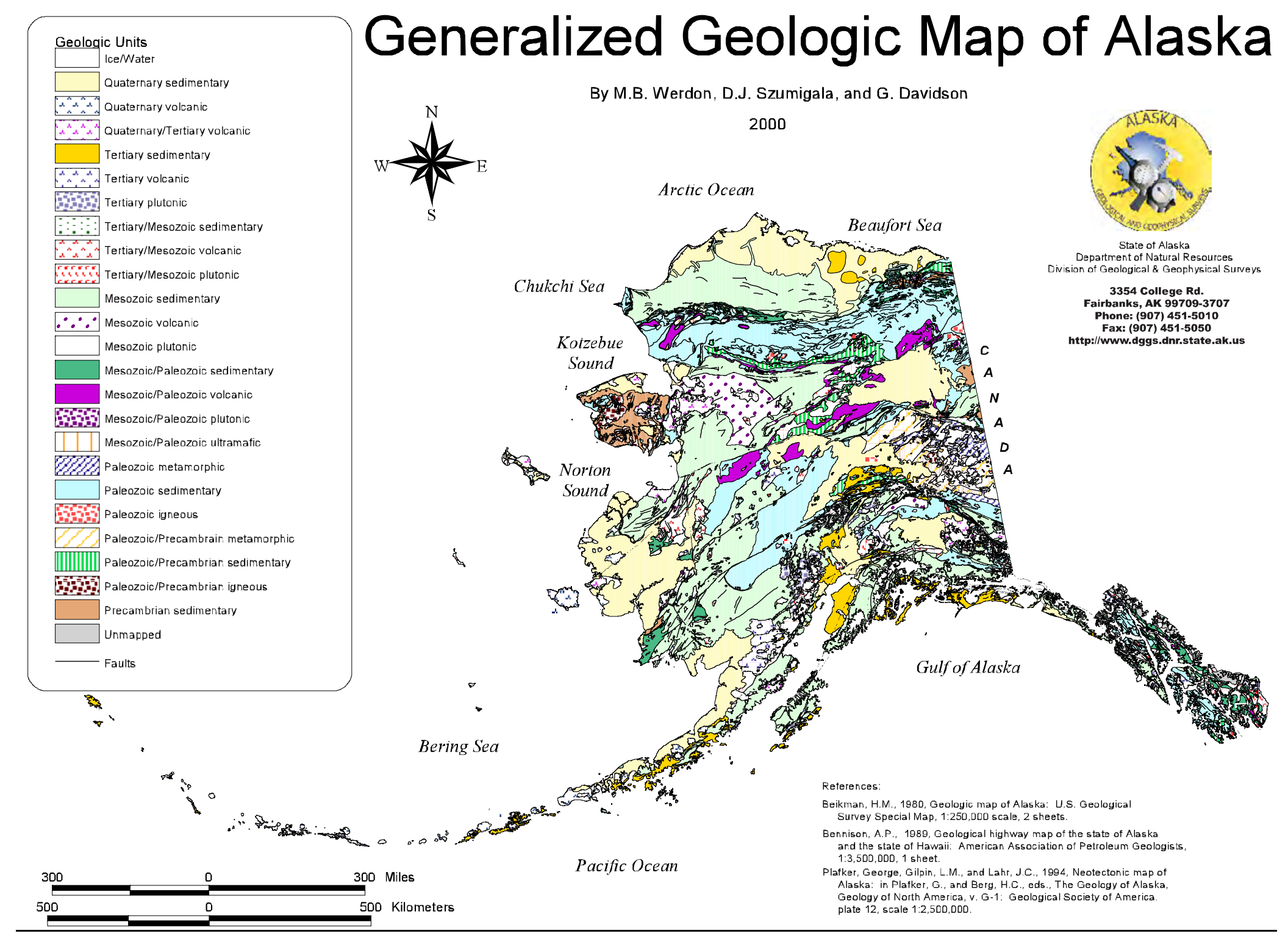


Name

Date

Period

\section{Geologic Map of Your Area}

1. Familiarize yourself with the explanation, scale, and other information that is included on the map such as the stratigraphic column, list of formations, inset figures, and so on.

2. Locate your community on the map and place a pin in the exact center. This could be challenging! You may need to use additional state maps with communities labeled for reference.

3. Use a piece of string or a drawing compass and pencil to draw an arc around the pin, leaving a circle lightly in pencil on the map. The circle should encompass a familiar region around your community.

4. Figure out and record the scale of your circled region-diameter, radius, and area. Remember to label your units!

Diameter

Radius

Area

5. In the table below, identify and record the information inside the circle. Continue on the back of this worksheet if you need more room.

\begin{tabular}{|c|c|c|c|c|}
\hline $\begin{array}{c}\text { Rock Unit } \\
\text { Symbol }\end{array}$ & $\begin{array}{c}\text { Rock Unit } \\
\text { Name }\end{array}$ & $\begin{array}{c}\text { Rock } \\
\text { Unit } \\
\text { Age }\end{array}$ & $\begin{array}{c}\text { Amount } \\
\text { (percent) of } \\
\text { Unit in Circle }\end{array}$ & $\begin{array}{c}\text { Local Feature Associated } \\
\text { With This Unit } \\
\text { (mountain, volcano, mine, } \\
\text { valley, gravel pit, and so } \\
\text { on) }\end{array}$ \\
\hline & & & & \\
\hline & & & & \\
\hline & & & & \\
\hline & & & & \\
\hline & & & & \\
\hline
\end{tabular}


6. Write a short paragraph describing the major rock types and their likely relations to local features that are inside your circle.

7. Are there igneous, volcanic, and (or) plutonic rocks in your circle? If so, with what local features are they associated?

8. Do your igneous, volcanic, and (or) plutonic rocks correspond with areas of present or past volcanic activity? Look at maps of volcanic regions of Alaska for a comparison. 
Activity III. Comparison of Hawaiian, Cascade, and Alaskan Volcanic Rocks

Grade Level 7-11

Setting Classroom

Time 45-90 minutes

Vocabulary (see Glossary)

pyroclastic flow, viscosity, Volcano Explosivity Index (VEI)

Correlations to Alaska State Department of Education (2006) Science Performance Standards (Grade Level Expectations)

D1 - Concepts of Earth Science

SD1[6-11] Students develop an understanding of Earth's geochemical cycles.

SD1.1[8] The student demonstrates an understanding of geochemical cycles by making connections between components of the locally observable geologic environment and the rock cycle.

SD2[6-11] Students develop an understanding of the origins, ongoing processes, and forces that shape the structure, composition and physical history of the Earth.

\section{Overview}

Volcanic rocks from historically active volcanoes in the United States vary in composition - the amounts and relative proportions of minerals that make up the rock. In this activity, students will learn how these compositional variations often are related to the style of eruption and type of volcano seen on the landscape today. It is important to note to students that there are exceptions in almost every case.

\section{Background}

Silica (generally referred to as an oxide, $\mathrm{SiO}_{2}$ - silica dioxide) content determines the thickness of magma, which in turn affects its viscosity: resistance to flow. The higher the amount of $\mathrm{SiO}_{2}$ (the higher the viscosity) the more resistant to flow. The amount of water, as a dissolved gas, in magma also affects its viscosity. The difficulty with which gas can travel through magma depends in part on the viscosity; the higher the viscosity, the more difficult it is for gases to be released from the magma. Typically, magmas with higher amounts of $\mathrm{SiO}_{2}$ have volcanic eruptions that are more explosive.

\section{Objectives}

The students will be able to describe how composition and tectonic setting of a volcano generally affect the eruptive style and size of a volcanic eruption.

\section{Materials}

- Volcanic Compositions and Recent U.S. Volcanic Eruptions worksheets,

- computer with spreadsheet/graphing computer software program, or

- materials to generate bar graphs by hand (pens, pencils, paper). 


\section{Procedure}

\section{A. Research assignment}

1. Individually, or in groups, have students study the following eruptions of U.S. volcanoes and fill in the Recent U.S. Volcanic Eruptions worksheet.

- Mt. St Helens, Cascade Range, Washington, 1980-86

- Kilauea, Big Island of Hawai i, 1983-ongoing

- Okmok, Alaska Peninsula, 1997

- Novarupta, Alaska Peninsula, 1912

- Augustine, Cook Inlet, Alaska, 1986

Suggested resources include:

- Alaska Volcano Observatory, [n.d.], Regional map of Alaskan volcanoes: Alaska Volcano Observatory website. (Available at http://www.avo.alaska.edu/volcanoes/.)

- Miller, T.P., McGimsey, R.G., Richter, D.H., Riehle, J.R., Nye, C.J., Yount, M.E., and Dumoulin, J.A., 1998, Catalog of the historically active volcanoes of Alaska: U.S. Geological Survey Open-File Report 98-0582, 104 p. (Also available at http://www.avo.alaska.edu/downloads/classresults.php?citid=645.)

- Smithsonian Institution, [n.d.], Global volcanism program: Smithsonian Institution web pages, accessed May 27, 2010, at

- Volcanoes of the World http://www.volcano.si.edu/world/ and

- Large Holocene Eruptions http://www.volcano.si.edu/world/largeeruptions.cfm

- U.S. Geological Survey, 2009, Volcano Hazards Program, VHP photo glossaryVEI: U.S. Geological Survey web page. (Available at http://volcanoes.usgs.gov/images/pglossary/vei.php.)

- U.S. Geological Survey, 2010, Cascades Volcano Observatory (CVO): U.S. Geological Survey website. (Available at http://vulcan.wr.usgs.gov/.)

- U.S. Geological Survey, 2010, Hawaiian Volcano Observatory (HVO): U.S. Geological Survey website. (Available at http://hvo.wr.usgs.gov/.)

- U.S. Geological Survey, 2010, Volcano Hazards Program: U.S. Geological Survey website. (Available at http://volcanoes.usgs.gov/.)

\section{B. Graphing assignment}

1. Have the students use a spreadsheet/graphing computer software program or draw by hand a bar graph (space provided on Volcanic Compositions worksheet) of the compositions of five volcanic rocks and answer the Volcanic Compositions worksheet using the graph and eruption cards worksheet.

\section{Discussion}

1. Discuss trends on the graphs and the answers to the Volcanic Compositions worksheet with students. 


\section{Extensions}

1. Have students explore these and other on-line resources for additional research projects comparing and contrasting these volcanoes further.

- National Park Service, variously dated, Explore nature: National Park Service websites available at

- Explore Geology-Tour of park geology, search by state, http://www.nature.nps.gov/geology/parks/bystate.cfm.

- Geology Fieldnotes, Hawaii Volcanoes National Park, Hawaii, http://www.nature.nps.gov/geology/parks/havo/index.cfm.

- Geology Fieldnotes, Katmai National Park and Preserve, Alaska, http://www.nature.nps.gov/geology/parks/katm/index.cfm.

- Rozell, Ned, 2001, Okmok Volcano on the rise in the Aleutians, Alaska Science Forum, August 30, 2001: Geophysical Institute, University of Fairbanks, Article No. 1557, accessed May 27, 2010, at http://www.gi.alaska.edu/ScienceForum/ASF15/1557.html.

- U.S. Forest Service, 2010, Mount St. Helens National Volcano Monument: U.S. Forest Service website. (Available at http://www.fs.fed.us/gpnf/mshnvm/.)

- U.S. Geological Survey, variously dated, Geology of National Parks-3D and photographic tours featuring park geology and natural history: U.S. Geological Survey websites available at

- Hawaii Volcanoes National Park-A 3D photographic geology tour. (Available at http://3dparks.wr.usgs.gov/havo/index.html.) and

- Mount St. Helens National Volcanic Monument-A 3D photographic tour of park geology. (Available at http://3dparks.wr.usgs.gov/sthelens/.)

2. The cooling history and crystallization of plutonic and volcanic rocks can be explored. A comparison of igneous rocks of the same composition and their cooling histories can help students identify that cooling rate associated with cooling location, above or below the ground surface, leads to two different rock types for the same composition magma. Resources include:

- U.S. Geological Survey, 2009, Volcano Hazards Program, VHP photo glossaryVolcanic rocks-Types of Igneous Rocks: U.S. Geological Survey web page. (Available at http://volcanoes.usgs.gov/images/pglossary/VolRocks.php.)

3. Crystal growing experiments can further illustrate how cooling time relates to crystal size and growth. This may be shown by grown sugar crystals (rock candy) or through laboratory use of salol. Resources include:

- Digital Library for Earth System Education (DLESE), [n.d.],

- Crystal growing. (Available at http://www.dlese.org/library/query.do?q=crystal\%20growing\&s=0.) and

- Salol. (Available at http://www.dlese.org/library/query.do?q=salol\&s=0.) 


\section{Modified from}

Oregon State University, 2010, VolcanoWorld-Comparing the Chemical Composition of Hawaiian Basalt and Mount Saint Helens Dacite website, accessed May 27, 2010, at http://volcano.oregonstate.edu/vwdocs/vwlessons/activities/r_number8.html.

\section{References Cited}

Alaska State Department of Education and Early Development, 2006, Standards and grade level expectations, March 2006: State of Alaska website, accessed October 2009 at http://www.eed.state.ak.us/tls/assessment/GLEHome.html.

U.S. Geological Survey, 2009, Volcano Hazards Program, VHP Photo GlossaryVolcanic rocks-Types of Igneous Rocks: U.S. Geological Survey webpage. (Available at http://volcanoes.usgs.gov/images/pglossary/VolRocks.php.)

\section{Glossary}

Pyroclastic flow - A pyroclastic flow is a ground-hugging avalanche of hot ash, pumice, rock fragments, and volcanic gas that rushes down the side of a volcano as fast as 100 $\mathrm{km} / \mathrm{h}(\sim 62 \mathrm{mi} / \mathrm{h})$ or more. The temperature within a pyroclastic flow may be greater than $500^{\circ} \mathrm{C}\left(932^{\circ} \mathrm{F}\right)$, sufficient to burn and carbonize wood. Once deposited, the ash, pumice, and rock fragments may deform (flatten) and weld together because of the intense heat and the weight of the overlying material.

Viscosity - Viscosity is the property of a substance to offer internal resistance to flow, specifically the ratio of the shear stress to the rate of shear strain known as the coefficient of friction.

Volcano Explosivity Index (VEI) - Proposed in 1982 as a way to describe the relative size or magnitude of explosive volcanic eruptions. It is a 0 -to-8 index of increasing explosivity. Each increase in number represents an increase around a factor of ten. The VEI uses several factors to assign a number, including volume of erupted pyroclastic material (for example, ash fall, pyroclastic flows, and other ejecta), height of eruption column, duration in hours, and qualitative descriptive terms.

\section{Source of Glossary Definitions}

Bates, R.K., and Jackson, J.A., eds., 1987, Glossary of Geology ( $3^{\text {rd }}$ ed.): Falls Church, Va., American Geological Institute, 571 p.

U.S. Geological Survey, 2010, Volcano Hazards Program-USGS photo glossary of volcanic terms: U.S. Geological Survey website. (Available at http://volcanoes.usgs.gov/images/pglossary/index.php.) 


\section{Recent U.S. Volcanic Eruptions}

Study the following recent volcanic eruptions in the United States and complete the following volcanic eruption cards.

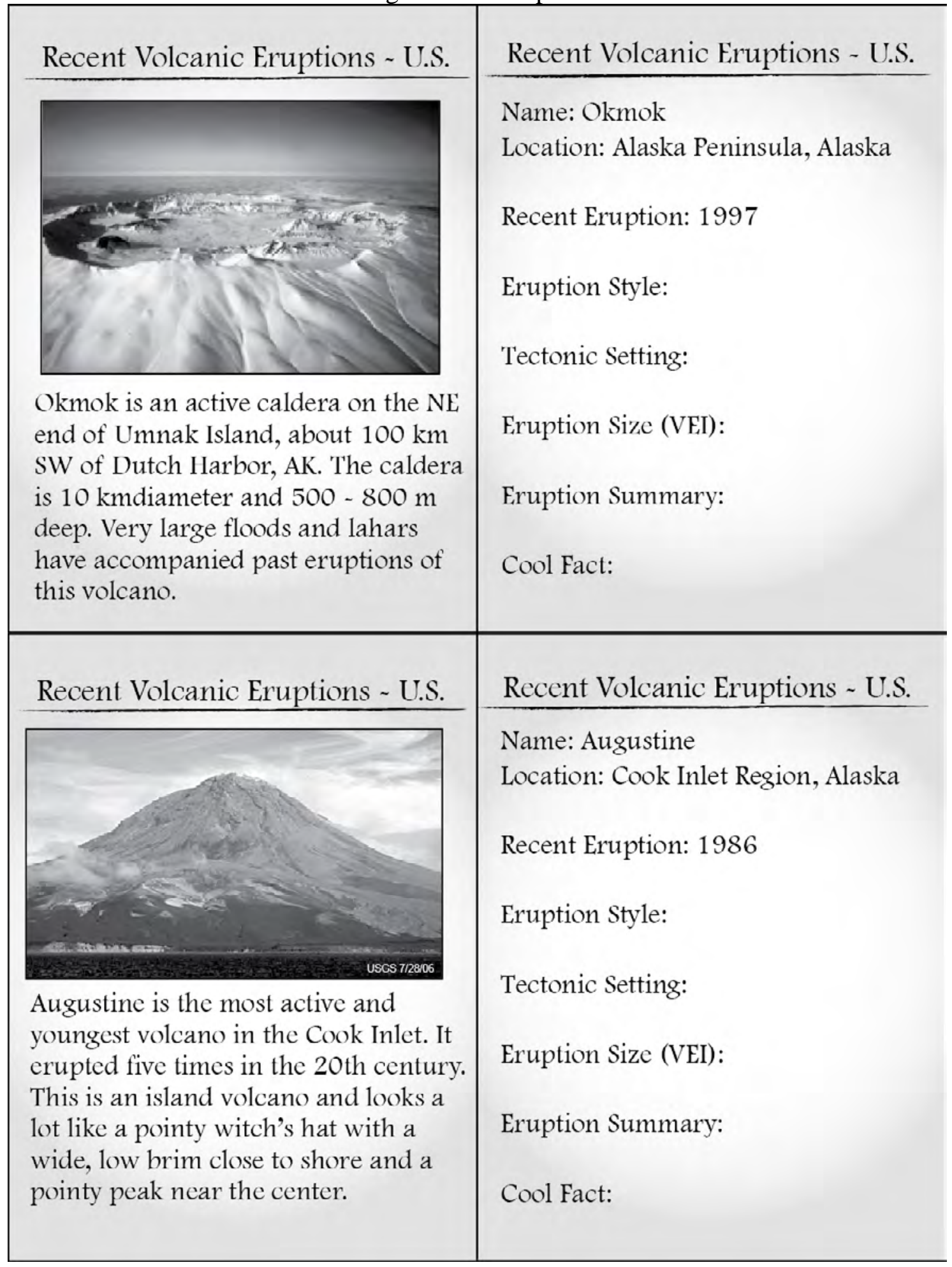




\begin{tabular}{|c|c|}
\hline Recent Volcanic Eruptions U.S. & Recent Volcanic Eruptions U.S. \\
\hline $\begin{array}{l}\text { Low fountaining from Pu'u 'O'o on } \\
\text { Kilauea volcano was common when } \\
\text { the still ongoing volcanic volcanic } \\
\text { eruption beagn there in } 1983 \text {. Kilauea } \\
\text { reminas one of the most active } \\
\text { volcanoes on earth. Scientists have } \\
\text { subdivided the multi decade long } \\
\text { eruption of Kilauea into "episodes". }\end{array}$ & $\begin{array}{l}\text { Name: Kilauea } \\
\text { Location: Big Island of Hawai i } \\
\text { Recent Eruption: 1983 present } \\
\text { Eruption Style: } \\
\text { Tectonic Setting: } \\
\text { Eruption Size (VEI): } \\
\text { Eruption Summary: } \\
\text { Cool Fact: }\end{array}$ \\
\hline $\begin{array}{l}\text { expedition into the Katmai valley on the } \\
\text { Alaska Peninsula discovered this newly } \\
\text { formed lava domethey named } \\
\text { Novarupta. This volcanic dome formed } \\
\text { during the } 1912 \text { eruption that created } \\
\text { the Valley of Ten Thousand Smokes. }\end{array}$ & $\begin{array}{l}\text { Recent Volcanic Eruptions U.S. } \\
\text { Name: Novarupta } \\
\text { Location: Alaska Peninsula, Alaska } \\
\text { Recent Eruption: } 1912 \\
\text { Eruption Style: } \\
\text { Tectonic Setting: } \\
\text { Eruption Size (VEI): } \\
\text { Eruption Summary: } \\
\text { Cool Fact: }\end{array}$ \\
\hline
\end{tabular}




\begin{tabular}{|l|l|l}
\hline Recent Volcanic Eruptions - U.S. & \begin{tabular}{l} 
Recent Volcanic Eruptions - U.S. \\
\hline
\end{tabular} & $\begin{array}{l}\text { Name: Mt. St. Helens } \\
\text { Location: Cascade Range, Washington } \\
\text { Recent Eruption: } 1980\end{array}$ \\
& Eruption Style: \\
& Tectonic Setting: \\
& Eruption Size (VEI): \\
\hline $\begin{array}{l}\text { The 1980 eruption of Mt. St. Helens } \\
\text { produced the largest landslide on Earth } \\
\text { in recorded history! Rocks, ash, volcanid } \\
\text { gas, and steam were blasted upward } \\
\text { and outward to the north. The volcano } \\
\text { continued to explode and form a } \\
\text { summit dome over the next } 6 \text { years. }\end{array}$ & $\begin{array}{l}\text { Eruption Summary: } \\
\text { Cool Fact: }\end{array}$ \\
\hline
\end{tabular}


Name

Date

Period

\section{Volcanic Compositions}

Using a spreadsheet/graphing computer software program or drawing by hand in the space provided below, plot the compositions (in weight percent of oxides [wt\%]) of the five volcanic rock types given as a bar graph and answer the questions using your graph.

\begin{tabular}{|c|c|c|c|c|c|}
\hline $\begin{array}{c}\text { wt\% } \\
\text { Oxides* }\end{array}$ & $\begin{array}{c}\text { Kilauea } \\
\text { (Hawaii) } \\
\text { Basalt } \\
\mathbf{1 9 8 3}\end{array}$ & $\begin{array}{c}\text { Okmok } \\
\text { (Alaska) } \\
\text { Basalt } \\
\mathbf{1 9 9 7}\end{array}$ & $\begin{array}{c}\text { Augustine } \\
\text { (Alaska) } \\
\text { Andesite } \\
\mathbf{1 9 8 6}\end{array}$ & $\begin{array}{c}\text { Mt. St. } \\
\text { Helens } \\
\text { (Washington) } \\
\text { Dacite 1980 }\end{array}$ & $\begin{array}{c}\text { Novarupta } \\
\text { (Alaska) } \\
\text { Rhyolite } \\
\mathbf{1 9 1 2}\end{array}$ \\
\hline $\mathbf{S i O}_{2}$ & 48.4 & 52.4 & 60.1 & 63.5 & 77.6 \\
\hline $\mathbf{A l}_{\mathbf{2}} \mathbf{O}_{3}$ & 13.2 & 15.8 & 16.7 & 17.6 & 12.4 \\
\hline $\mathbf{F e O}$ & 11.2 & 11.5 & 5.9 & 4.2 & 1.2 \\
\hline $\mathbf{M g O}$ & 9.7 & 4.9 & 4.6 & 2.0 & 0.1 \\
\hline $\mathbf{C a O}$ & 10.3 & 9.8 & 7.4 & 5.2 & 0.9 \\
\hline $\mathbf{N a}_{\mathbf{2}} \mathbf{O}$ & 2.4 & 3.1 & 3.7 & 4.6 & 4.2 \\
\hline $\mathbf{K}_{\mathbf{2}} \mathbf{O}$ & 0.6 & 0.8 & 0.9 & 1.3 & 3.3 \\
\hline $\mathbf{T i O}$ & 2.8 & 1.4 & 0.6 & 0.6 & 0.2 \\
\hline $\mathbf{O} \mathbf{O t h e r}_{2}$ & 1.4 & 0.3 & 0.1 & 1.0 & 0.1 \\
\hline
\end{tabular}

* $\mathrm{SiO}_{2}$ = silica dioxide; $\mathrm{Al}_{2} \mathrm{O}_{3}$ = aluminum oxide; $\mathrm{FeO}=$ total iron oxide; $\mathrm{MgO}$ = magnesium oxide;

$\mathrm{CaO}$ = calcium oxide; $\mathrm{Na}_{2} \mathrm{O}=$ sodium oxide; $\mathrm{K}_{2} \mathrm{O}$ = potassium oxide; $\mathrm{TiO}_{2}=$ titanium oxide; Other = other elements. Values are weight percent oxide. 
Date

Period

\section{Volcanic Compositions Questions}

Using your bar graph of the five given volcanic rock compositions and your volcanic eruption cards, answer the following questions.

1. Which rock has the greatest amount (weight percent) of silica?

2. Do you think the amount of silica within the magma, lava, or volcanic rock composition is related to the explosiveness of volcanic eruptions? If so, how?

3. Which rock type has the greatest amount of iron and magnesium?

4. How may the amount of iron and magnesium influence the color of the rock?

5. Of the three Alaskan volcanoes, which one has the greatest weight percent of silica?

6. Which volcano do you think has the most viscous lava?

7. Which volcano will erupt explosively due to the higher weight percent of silica in its lava? 


\section{Recent U.S. Volcanic Eruptions Key}

\begin{tabular}{|c|c|c|c|}
\hline Volcano/year & $\begin{array}{c}\text { Eruption } \\
\text { Style }\end{array}$ & $\begin{array}{c}\text { Tectonic } \\
\text { Setting }\end{array}$ & $\begin{array}{c}\text { Eruption } \\
\text { Size (VEI) }\end{array}$ \\
\hline $\begin{array}{c}\text { Okmok (Alaska) } \\
\mathbf{1 9 9 7}\end{array}$ & $\begin{array}{c}\text { Explosive with } \\
\text { lava flows }\end{array}$ & $\begin{array}{c}\text { Subduction } \\
\text { Zone }\end{array}$ & 3 \\
\hline $\begin{array}{c}\text { Augustine } \\
\text { (Alaska) } \\
\mathbf{1 9 8 6}\end{array}$ & $\begin{array}{c}\text { Explosive with } \\
\text { pyroclastic flows }\end{array}$ & $\begin{array}{c}\text { Subduction } \\
\text { Zone }\end{array}$ & 1 \\
\hline $\begin{array}{c}\text { Kilauea (Hawaii) } \\
\text { 1983-ongoing }\end{array}$ & $\begin{array}{c}\text { Explosive with } \\
\text { lava flow }\end{array}$ & Hot Spot & 6 \\
\hline $\begin{array}{c}\text { Novarupta } \\
\text { (Alaska) } \\
\mathbf{1 9 1 2}\end{array}$ & $\begin{array}{c}\text { Explosive with } \\
\text { pyroclastic flows } \\
\begin{array}{c}\text { Mt St Helens } \\
\text { (Washington) } \\
\mathbf{1 9 8 0 - 8 6}\end{array}\end{array}$ & $\begin{array}{c}\text { Explosive with } \\
\text { pyroclastic flows } \\
\text { and flank failure }\end{array}$ & $\begin{array}{c}\text { Subduction } \\
\text { Zone }\end{array}$ \\
\hline
\end{tabular}




\section{Volcanic Compositions Key}

\section{Composition of Alaskan, Hawaiian, and Cascades Volcanic Rocks}

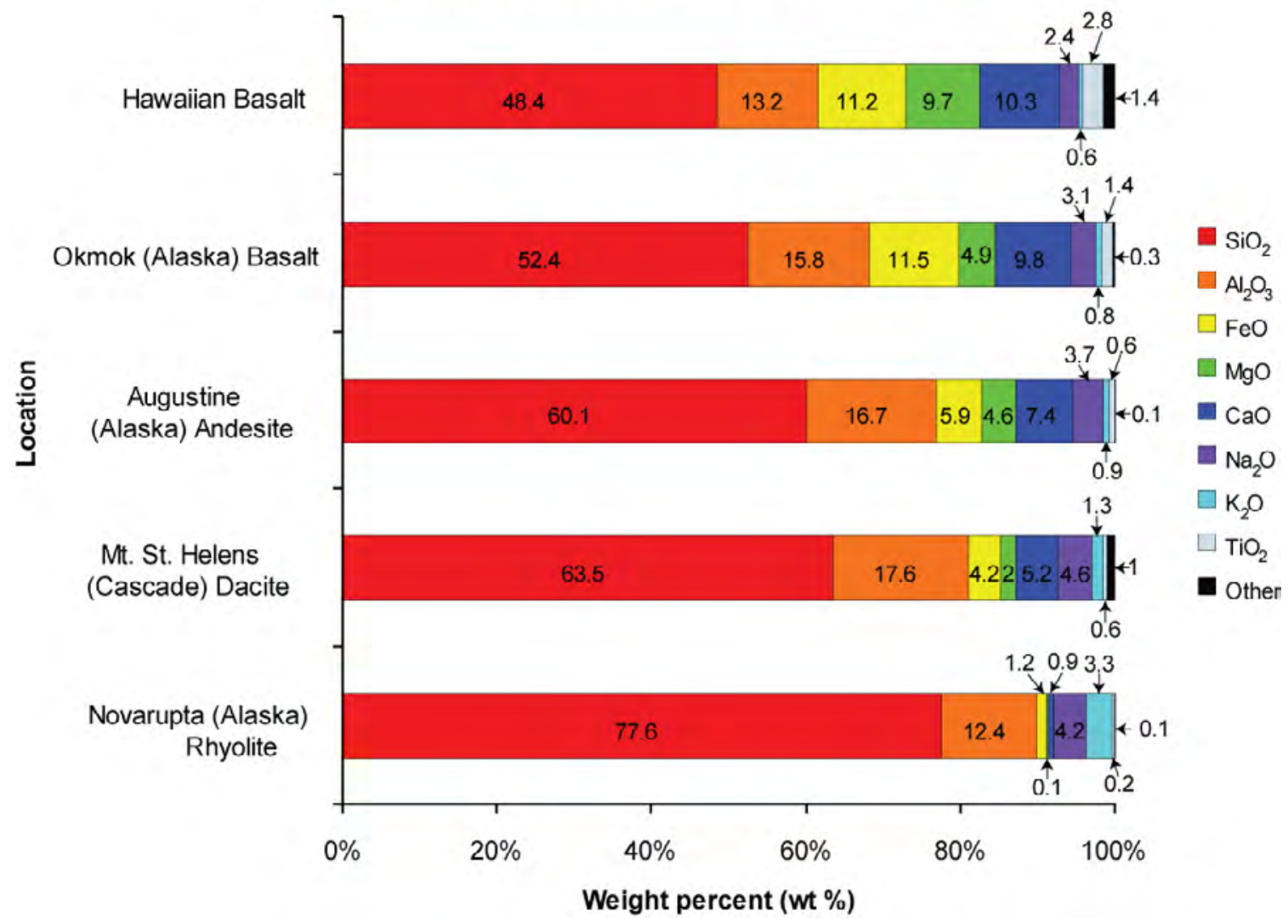

$\mathrm{SiO}_{2}$, silica; $\mathrm{Al}_{2} \mathrm{O}_{3}$, aluminum oxide; $\mathrm{FeO}$, total iron oxide; $\mathrm{MgO}$, magnesium oxide; $\mathrm{CaO}$, calcium oxide; $\mathrm{Na}_{2} \mathrm{O}$, sodium oxide; $\mathrm{K}_{2} \mathrm{O}$, potassium oxide; $\mathrm{TiO}_{2}$, titanium oxide; Other, other elements. Values are weight percent oxide. 


\section{Volcanic Compositions Questions Key}

1. Which rock has the greatest amount of silica?

The Novarupta (Alaska) rhyolite has the greatest amount of silica with 77.6 weight percent (wt\%) $\mathrm{SiO}_{2}$.

2. Do you think the amount of silica within the magma, lava, or volcanic rock composition is related to the explosiveness of volcanic eruptions? If so, how?

It may be (it is!). The Novarupta eruption was gigantic!

3. Which rock type has the greatest amount of iron and magnesium?

The Hawaiian basalt has the greatest amount of iron (FeO at $11.2 \mathrm{wt} \%)$ and magnesium ( $\mathrm{MgO}$ at $9.7 \mathrm{wt} \%$ ).

4. How may the amount of iron and magnesium influence the color of the rock?

Iron and magnesium are metallic and dark, in large enough quantities; they may contribute to the dark color of the rock.

5. Of the three Alaskan volcanoes, which one has the greatest percentage of silica?

The Novarupta (Alaska) rhyolite has the greatest amount of silica with $77.6 \mathrm{wt} \%$ $\mathrm{SiO}_{2}$.

6. Which volcano do you think has the most viscous lava?

The Novarupta (Alaska) rhyolite has the greatest amount of silica with 77.6 wt\% $\mathrm{SiO}_{2}$ and must be the most viscous.

7. Which volcano will erupt explosively due to the higher percentage of silica in its lava?

The Novarupta (Alaska) Volcano. 


\section{Chapter 3 Eruption!}

\section{Resources}

- Brantley, S.R., 1999, Volcanoes of the United States: U.S. Geological Survey General Interest Publication, http://pubs.usgs.gov/gip/volcus/index.html.

- Hawaii Natural History Association, [n.d.], A teacher's guide to the geology of Hawaii Volcanoes National Park-Kinds of volcanic eruptions: Oregon State University website, accessed June 1, 2010, at http://volcano.oregonstate.edu/education/vwlessons/kinds/kinds.html

- Lillie, R.J., 2005, Parks and plates-The geology of our National parks, monuments, and seashores: New York, W.W. Norton and Comdishy, 298 p.

- Chapter 2: Geologic Features and Processes, p. 34-39.

- Shcmincke, H.-U., 2004, Volcanism: New York, Springer-Verlag, 324 p.

- Chapter 3: Magmas, p. 21-34.

- Smithsonian Institution, [n.d.], Global volcanism program: Smithsonian Institution web page, accessed June 1, 2010, at

- Large Holocene Eruptions http://www.volcano.si.edu/world/largeeruptions.cfm

- Tilling, R.I., 1997, Volcanoes-On-line edition: U.S. Geological Survey General Interest Publication. (Available at http://pubs.usgs.gov/gip/volc/.)

- U.S. Geological Survey, 1997 [2007], Volcanoes teacher’s guide: U.S. Geological Survey website. (Available at http://erg.usgs.gov/isb/pubs/teacherspackets/volcanoes/.

- WGBH Educational Foundation, 2010, Teacher's domain resource: WGBH Educational Foundation web pages, accessed June 1, 2010, at

- Volcanic Features http://www.teachersdomain.org/resources/ess05/sci/ess/earthsys/volcanfeatr/index .html and

- Volcanism http://www.teachersdomain.org/resources/ess05/sci/ess/earthsys/volcanintro/index .html. 


\section{Activities}

These activities allow students to build on their knowledge of igneous rocks and magmatic compositions and relate them to features and eruptive products formed at Alaskan volcanoes through multiple eruptions that sometimes occur at the same vent. Students will compare volcanic eruptions that occurred in Alaska to one another and (or) to volcanic eruptions that occurred elsewhere in the United States. Students will learn about a scale used to compare the size of one eruption to another and ultimately will learn about the largest volcanic eruption on Earth in the 20th century, which took place on the Alaska Peninsula in 1912. Specific volcanic products that may pose potential hazards to population locally and far away are presented in Chapter 5. Alaska's Volcanoes and You.

Activity I. Eruption 1, 2, 3...

Activity II. Compare and Contrast-Alaska Style

Activity III. Volcanic Explosivity Index, Alaska 
Activity I Eruption 1, 2, 3...

Grade Level 6-11

Setting Classroom

Time 50-90 minutes (with homework assignment of varying length at the beginning)

Vocabulary (see Glossary)

caldera, cinder cone, flood or plateau basalt, intracaldera, lava dome, maar, pyroclastic flow, resurgent dome, shield, stratovolcano (or composite cone)

Correlations to Alaska State Department of Education (2006) Performance Standards (Grade Level Expectations)

D1 - Concepts of Earth Science

SD[6-11] Students develop an understanding of the concepts, processes, theories, models, evidence, and systems of earth and space sciences.

SD2[6-11] Students develop an understanding of the origins, ongoing processes, and forces that shape the structure, composition, and physical history of the Earth

SD2.3[6] The student demonstrates an understanding of the forces that shape Earth by describing how the surface can change rapidly as a result of geological activities (i.e., earthquakes, tsunamis, volcanoes, floods, landslides, avalanches).

\section{Overview}

Several types of eruptive processes can occur at a single volcano over its long lifespan. Many of Alaska's volcanoes have had multiple eruptions of varying types over the course of their lengthy and active history. This variance in eruption style is reflected in the types of volcanic features and deposits that may still be visible at the volcano. By using common, everyday materials available in the classroom and at home, students will construct a volcano model. Using at least two different methods students will generate at least two consecutive and varying volcanic eruptions of their model volcano and recreate various eruptive types and products, which then can be related to those seen at Alaskan volcanoes. 


\section{Background}

Several types of eruptive processes generate various volcanic deposits and features. In many cases, a dominant eruption process leads a particular volcano to be labeled as a shield, caldera, stratovolcano or composite cone, cinder cone or dome. In many cases, however, individual volcanoes have had variation in eruption processes and products over time. A single volcano can produce a wide variety of features throughout its multieruption history. Resources concerning the various volcanic eruption processes include:

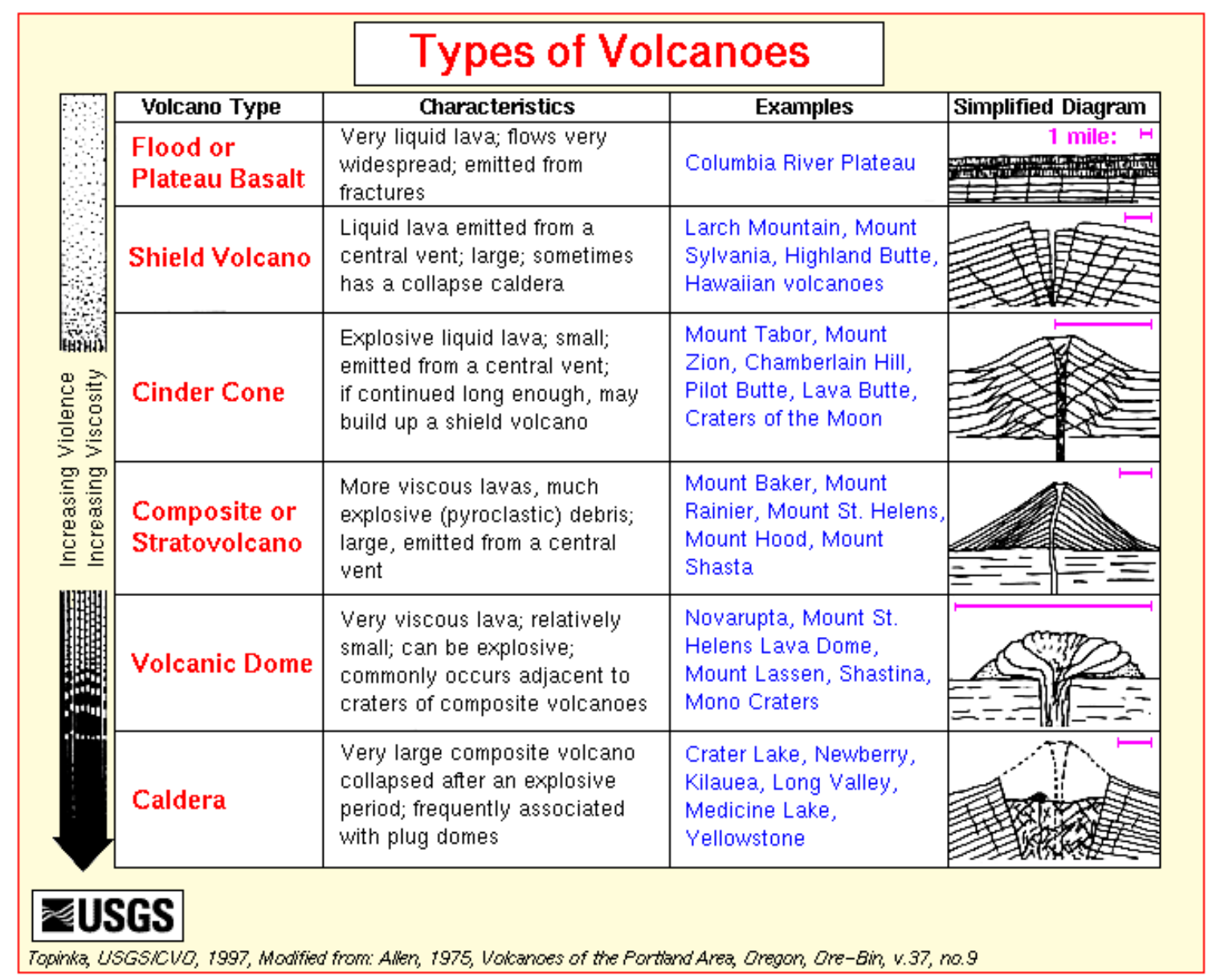

- http://vulcan.wr.usgs.gov/Glossary/VolcanoTypes/volcano_types.html and

- U.S. Geological Survey, 2008, Volcano types "Quick reference guide": U.S. Geological Survey web page. (Available at http://vulcan.wr.usgs.gov/Glossary/VolcanoTypes/volcano_types_quick_reference.html.) 
Some salient points that can provide a general view of Alaskan-style volcanism and dispel misperceptions about the nature of volcanic eruptions are:

- A wide range of activity can take place during volcanic eruptions, including explosive and non-explosive events that may occur during the entire period of eruption.

- Volcanoes can produce what may initially appear as processes leading up to an eruption ending without an eruption; in many cases this is due to magma moving underground but not erupting.

- Eruptions can be long or short; they may culminate in a single event or progress for months to years in several events.

- Eruptions are multifaceted-they consist of multiple processes occurring simultaneously, or one following the other, and this dynamic may change throughout the entire timeframe of an eruption.

- Volcanoes can erupt in different ways through time with varying degrees and timing of constructive and destructive processes shaping the volcanoes.

Over the long lifespan of many of Alaska's calderas, consecutive eruptions have generated complexes of closely spaced domes, cider cones, and lava flows, sometimes piled on top of one another. In some instances, an eruption leading to the formation of a caldera can happen before and after the formation of other significant volcanic products over millions of years. Example Alaskan calderas with intracaldera features include Aniakchak, Okmok, Kaguyak, and Veniaminof. For descriptions, see the AVO website http://www.avo.alaska.edu/volcanoes/.

Additionally, some volcanoes exhibit an eruptive type not classically recognized based solely on the type of igneous rocks ejected. For example, Wrangell, an andesitic volcano is a shield volcano, which is more commonly associated with basaltic compositions. Scientists believe this is because of the massive amount of lava ejected by Wrangell volcano, with lava flows as long as $58 \mathrm{~km}$ (36 mi), which occurred over a very short amount of time. Many stratovolcano or composite cones in Alaska also feature summit domes and craters, and cinder cones on their flanks. Each volcanic feature is connected to a particular, varying eruptive process, and magmatic composition.

\section{Objectives}

Students will learn about how one volcano can display different eruption styles and products through time. Students will understand different eruption processes at Alaskan volcanoes.

\section{Materials}

Students will need to combine several volcanic models and eruption processes using different household and classroom materials for this activity. Students can create their volcano model as a homework assignment and then conduct two or more eruptions (using different processes) of that model in the classroom. 
Suggestions for volcano models, eruption processes, and materials needed are available at these web sites:

- Hawai'i Space Grant College, 1996, Teacher pages: University of Hawaii, Hawai'i Institute of Geophysics and Planetology, accessed June 1, 2010, at

- Gelatin Volcanoes http://www.spacegrant.hawaii.edu/class_acts/GelVolTe.html and

- Cake Batter Lava http://www.spacegrant.hawaii.edu/class acts/CakeLavaTe.html.

- Montana Bureau of Mines and Geology, [n.d.], Let’s make a volcano: Montana Bureau of Mines and Geology web page, accessed June 1, 2010, at http://www.mbmg.mtech.edu/kids/make_a_volcano.htm.

- Oregon State University, [n.d.], VolcanoWorld-Volcano models: Oregon State University website, accessed June 1, 2010, at http://volcano.oregonstate.edu/education/models/index.html.

- Reeko’s Mad Scientist Lab, 2005, Build a real working volcano: Reeko’s Mad Scientist Lab web page, accessed June 1, 2010, at http://www.spartechsoftware.com/reeko/Experiments/volcano.htm.

- Rockhounding Arkansas, 1998, Make a volcano: Rockhounding Arkansas web page, accessed June 1, 2010, at http://rockhoundingar.com/pebblepups/volcano.html.

- U.S. Geological Survey, 1997, The mountain blows its top, Lesson 2, Activity 1, in Volcanoes! Creators and destroyers: U.S. Geological Survey web pages (Available at http://edc2.usgs.gov/pubslists/teachers-packets/volcanoes/pdf/Lesson2-all.pdf.)

- Wolff-Michael Roth, [n.d.], How to build your own volcano-Paper mâché volcano: University of Victoria, Lansdowne Professor, Applied Cognitive Science, Faculty of Education, accessed June 1, 2010, at http://www.educ.uvic.ca/faculty/mroth/438/VOLCANO/PAPER_MACHE.html.

The materials required will vary based on the eruption styles selected.

Procedure (see part E for an example)

A. Review or introduce materials on types of volcanoes

1. Using the background figure and resources, and additional materials available through your science curriculum, review the main types of volcanoes with your class. Note Activity I in Chapter 4 of this guidebook also covers this material.

\section{B. Planning and student homework assignment}

1. Divide your class into small groups who will work together on this homework assignment and follow-up classroom activity.

2. Have each group of students select an Alaskan volcano to model. In addition to other on-line, classroom, and library resources, students may use the AVO website (http://www.avo.alaska.edu/) or other source(s) of information on eruptive features and types of Alaskan volcanoes. Students can learn about the most recent and (or) most dominant (still visible) eruptive processes and products at their selected volcano. 
3. Assign students the task of building a model of their selected volcano as homework. It may be best to give students a weekend or multiple evenings to work on the model. Students may generate an initial, first eruption in the process of making their volcano. Students will then conduct two subsequent eruptions of their volcano in the classroom using two different processes and record their observations.

\section{Subsequent eruptions in the classroom}

1. Students may or may not have conducted an initial, first, eruption in the construction of their volcano model. Either way, direct students to bring their homework volcano models into the classroom and have them conduct at least two eruptions in the classroom using different processes to generate different volcanic products on top any existing erupted material they may have generated at home.

2. Students can record their observations and identify any preexisting and newly formed land features (cone, vent, dome, explosion, lava flow) on the Successive Volcanic Eruptions: Record Sheet worksheet.

3. If time allows, students may follow the same procedures, using yet another eruption mechanism. They record their observations and identify any preexisting and newly formed land features (cone, vent, dome, explosion, lava flow) on the Successive Volcanic Eruptions: Record Sheet worksheet.

\section{Sketches, investigations, and class discussion}

1. At the completion of all of the eruptions, students can draw a sketch illustrating and labeling all deposits and features that formed, were altered, or destroyed by all of their eruptions. Students can do this on the Successive Volcanic Eruption Sketch worksheet. If a digital camera is available, photographs of each eruption can be used for comparison purposes as well.

2. Make enough copies of each completed Successive Volcanic Eruption Sketch worksheet so that every group receives a sketch from every other group.

3. Students can try to determine the sequence of eruptive processes that produced the features illustrated in each group's sketch (or photograph), and then write down the eruptive order (using additional copies of the Successive Eruptions: Record Sheet worksheet) they suspect lead to the outcome volcano and its features. You may also do this as a class exercise and write their conclusions on the board. If available, students may also want to look at each other's post-eruptions models.

4. Students will then learn from the groups who generated each volcano model the order of eruption processes and product generation and (or) destruction. 


\section{E. Example}

1. Students may select Aniakchak volcano, a large caldera on the Alaska Peninsula that has several cinder cones, lava flows, and domes inside.

(http://www.avo.alaska.edu/volcanoes/volcinfo.php?volcname=Aniakchak). Also see this example used in the Example Successive Volcanic Eruptions Record Sheet.

- For their homework assignment, students may generate the caldera using a balloon and flour or sand model (one eruption) or paper mache.

- For their classroom eruption, students may inject jelly or warm wax into the caldera using a plastic tube and pastry bag (a second eruption).

- Also in the classroom, students may follow up with a tube and air compressor or pressurized air from a canister to generate an ash explosion leading to cone formation elsewhere in their caldera (a third eruption).

\section{Extensions}

1. Some volcanoes in Alaska are thought to be connected through an underground network of pipes, dikes, and (or) sills. One such connection is suspected in the eruption and formation of the Novarupta dome and the collapse of Mt Katmai on the Alaska Peninsula in 1912. Students can be challenged to construct two (or more) connected volcanic vents and to observe the consequences when each vent erupts separately or when a single vent erupts repeatedly.

2. Alaska Museum of Natural History, 2006, Volcano simulator: Alaska Museum of Natural History website, accessed June 1, 2010, at http://www.alaskamuseum.org/features/volcano/.

3. Camp, Vic, [n.d.], How volcanoes work-The eruption model-Dynamics of a Plinian eruption: San Diego State University, animation, accessed June 1, 2010, at http://www.geology.sdsu.edu/how_volcanoes_work/Eruption_model.html.

4. Driedger, C.L., Doherty, Anne, and Dixon, Cheryll, 2005, Living with a volcano in your backyard-An educator's guide with emphasis on Mount Rainier: U.S. Geological Survey General Interest Product 19; produced in cooperation with the National Park Service. (Available at http://vulcan.wr.usgs.gov/Outreach/Publications/GIP19/.)

- PlayDough Topo http://vulcan.wr.usgs.gov/Outreach/Publications/GIP19/chapter_three_playdough_topo.pdf.

- Lava Building Blocks http://vulcan.wr.usgs.gov/Outreach/Publications/GIP19/chapter_two_lava_blocks. pdf.

- Riding the Magma Elevator http://vulcan.wr.usgs.gov/Outreach/Publications/GIP19/chapter_one_magma_elev ator.pdf.

- Soda Bottle Volcano http://vulcan.wr.usgs.gov/Outreach/Publications/GIP19/chapter_one_soda_bottle_ volcano.pdf. 


\section{References Cited}

Alaska State Department of Education and Early Development, 2006, Standards and grade level expectations, March 2006: State of Alaska website, accessed October 2009 at http://www.eed.state.ak.us/tls/assessment/GLEHome.html.

Smithsonian Institution, [n.d.], Global volcanism program-Wrangell: Smithsonian Institution web page, accessed June 1, 2010, at http://www.volcano.si.edu/world/volcano.cfm?vnum=1105-02-.

\section{Glossary}

Caldera - A caldera is a large, usually circular depression at the summit of a volcano formed when magma is withdrawn or erupted from a shallow underground magma reservoir. The removal of large volumes of magma may result in loss of structural support for the overlying rock, thereby leading to collapse of the ground, and formation of a large depression. Calderas are different from craters, which are smaller, circular depressions created primarily by explosive excavation of rock during eruptions.

Cinder cone - A steep, conical hill of volcanic fragments that accumulate around and downwind from a vent. The rock fragments, often called cinders or scoria, are glassy and contain numerous gas bubbles "frozen” into place as magma exploded into the air and then cooled quickly. Cinder cones range in size from tens to hundreds of meters tall.

Flood or plateau basalt - Very liquid basaltic lava pours from long fissures and floods the surrounding countryside with lava flows forming broad plateaus.

Intracaldera - Within a caldera.

Lava dome - A roughly circular mound-shaped protrusion resulting from the slow eruption of felsic lava (usually rhyolite or dacite) from a volcano, or from multiple lava episodes of different magma types.

Maar - A low-relief broad volcanic crater formed by shallow explosive eruptions. The explosions are usually caused by the heating and boiling of groundwater when magma invades the groundwater table. Often fill with water to form a lake.

Pyroclastic flow -A ground-hugging avalanche of hot ash, pumice, rock fragments, and volcanic gas that rushes down the side of a volcano as fast as $100 \mathrm{~km} /$ hour ( 60 mi/hour) or more. The temperature within a pyroclastic flow may be greater than $500^{\circ} \mathrm{C}\left(900^{\circ} \mathrm{F}\right)$, sufficient to burn and carbonize wood. Once deposited, the ash, pumice, and rock fragments may deform (flatten) and weld together because of the intense heat and the weight of the overlying material. The emplaced flow is called a deposit.

Resurgent dome - Volcanic domes are rounded, steep-sided mounds built by very viscous magma, usually either dacite or rhyolite, if they are resurgent then they have appeared again after a previous growth or eruption. 
Shield volcano - A volcano characterized by low angle slopes.

Stratovolcano - A type of volcano (also called a composite cone), characterized by slope angles of as much as 35 degrees.

\section{Sources of Glossary Definitions}

Bates, R.K., and Jackson, J.A., eds., 1987, Glossary of Geology ( $3^{\text {rd }}$ ed.): Falls Church, Va., American Geological Institute, 571 p.

U.S. Geological Survey, 2008, Cascades Volcano Observatory—Volcano Types : U.S. Geological Survey web page. (Available at http://vulcan.wr.usgs.gov/Glossary/VolcanoTypes/volcano_types.html.

U.S. Geological Survey, 2010, Volcano Hazards Program-USGS photo glossary of volcanic terms: U.S. Geological Survey website. (Available at http://volcanoes.usgs.gov/images/pglossary/index.php.) 
Name

Date

Period

Successive Volcanic Eruptions: Record Sheet

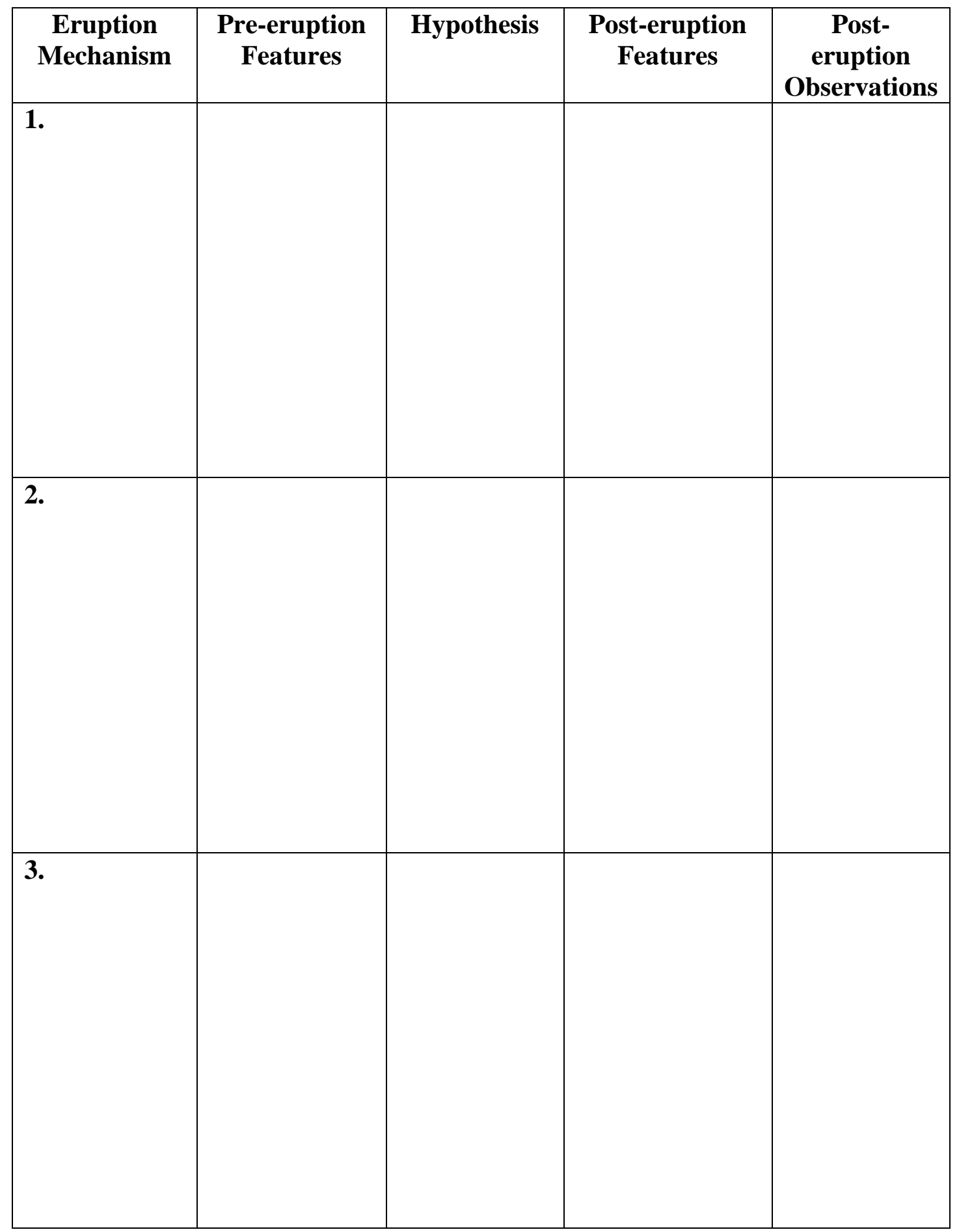


Name

Date

Period

\section{Successive Volcanic Eruption Sketch}

\section{Map View}

Cross Section View 


\section{Example Successive Volcanic Eruptions: Record Sheet Key}

For example, students may choose Aniakchak volcano, a large caldera on the Alaska Peninsula that has several cinder cones, lava flows, and domes inside. Also, see this example used in the Example Successive Volcanic Eruptions Record Sheet

- For their homework assignment, students may generate the caldera using a balloon and flour or sand model (one eruption) or paper mache.

- For their classroom eruption, students may inject jelly or warm wax into the caldera using a plastic tube and pastry bag (a second eruption).

- Also in the classroom, students may follow up with a tube and air compressor or pressurized air from a canister to generate an ash explosion leading to cone formation elsewhere in their caldera (a third eruption).

\begin{tabular}{|c|c|c|c|c|}
\hline $\begin{array}{c}\text { Eruption } \\
\text { Mechanism }\end{array}$ & $\begin{array}{l}\text { Pre-eruption } \\
\text { Features }\end{array}$ & Hypothesis & $\begin{array}{l}\text { Post-eruption } \\
\text { Features }\end{array}$ & $\begin{array}{c}\text { Post- } \\
\text { eruption } \\
\text { Observations }\end{array}$ \\
\hline $\begin{array}{l}\mathbf{1 .} \\
\text { stratovolcano } \\
\text { or composite } \\
\text { cone collapse }\end{array}$ & $\begin{array}{l}\text { stratovolcano } \\
\text { or composite } \\
\text { cone }\end{array}$ & $\begin{array}{l}\text { generation of } \\
\text { a caldera }\end{array}$ & caldera & $\begin{array}{l}\text { left behind a } \\
\text { spherical } \\
\text { ridge of } \\
\text { almost } \\
\text { uniform } \\
\text { height } \\
\text { defining the } \\
\text { caldera walls }\end{array}$ \\
\hline $\begin{array}{l}2 . \\
\text { eruption of } \\
\text { viscous lava }\end{array}$ & caldera & $\begin{array}{l}\text { dome } \\
\text { generation } \\
\text { through the } \\
\text { caldera floor }\end{array}$ & $\begin{array}{l}\text { caldera and } \\
\text { dome }\end{array}$ & $\begin{array}{l}\text { caldera rim } \\
\text { stayed the } \\
\text { same, dome } \\
\text { feature } \\
\text { dominates } \\
\text { caldera floor. } \\
\text { May have } \\
\text { some lava } \\
\text { flows or } \\
\text { spreading of } \\
\text { the dome. }\end{array}$ \\
\hline $\begin{array}{l}3 . \\
\text { high pressure } \\
\text { explosion }\end{array}$ & $\begin{array}{l}\text { caldera and } \\
\text { dome }\end{array}$ & $\begin{array}{l}\text { dome and } \\
\text { (or) rim of } \\
\text { caldera could } \\
\text { break apart, } \\
\text { vent or cone } \\
\text { could form } \\
\text { on caldera } \\
\text { floor }\end{array}$ & $\begin{array}{l}\text { caldera, dome } \\
\text { and vent or cone }\end{array}$ & $\begin{array}{l}\text { dome and (or) } \\
\text { rim of caldera } \\
\text { could break } \\
\text { apart, vent or } \\
\text { cone could } \\
\text { form on } \\
\text { caldera floor }\end{array}$ \\
\hline
\end{tabular}




\section{Activity II. Compare and Contrast: Alaska Style}

Grade Level 6-11

Setting Classroom

Time 50-90 minutes (may best be done as a homework assignment with class discussion)

Correlations to Alaska State Department of Education (2006) Performance Standards (Grade Level Expectations)

D1-Concepts of Earth Science

SD[6-11] Students develop an understanding of the concepts, processes, theories, models, evidence, and systems of earth and space sciences.

SD2[6-11] Students develop an understanding of the origins, ongoing processes, and forces that shape the structure, composition, and physical history of the Earth

\section{Vocabulary (see Glossary)}

tectonic setting, vent, viscosity, Volcanic Eruption Index (VEI)

\section{Overview}

Students can select two volcanic eruptions, and compare and contrast their occurrences. Students may select two eruptions at the same volcano in Alaska, or eruptions from one volcano in Alaska and another one elsewhere.

\section{Background}

Alaska is home to so many volcanoes that just about every eruption type is represented there. With so many Alaskan volcanoes to choose from, each student can research one that is unique. Several resources are available that describe many of the more popular Alaskan volcanoes and volcanic eruptions. Students may also choose to compare and Alaskan eruption with one outside of Alaska.

\section{Objectives}

By comparing and contrasting two volcanic eruptions, at least one of which took place in Alaska, students will gain an appreciation for the variances in eruption types, products, and hazards throughout the state and elsewhere. Student presentations on their research may be best suited for a poster, paper, oral presentation, or Compare and Contrast Volcanic Eruptions worksheet.

\section{Materials}

Students will need on-line access, and time to also use library and (or) textbook resources. Presentation materials will be dependent on the presentation type and can be limited to materials available on hand. The Compare and Contrast Volcanic Eruptions worksheet provided may act in place or to aid in the organization of a presentation. 


\section{Procedure}

\section{A. Research and Present}

1. Students can select two volcanoes, or two volcanic eruptions from a single volcano in Alaska, to compare and contrast in a poster, paper, oral presentation and (or) by completing the Compare and Contrast Volcanic Eruptions worksheet.

2. There are many obscure volcanoes and eruptions in Alaska with few resources available to complete this activity. Students can select from a list specific volcanoes and volcanic eruptions based on the amount of available materials for research. One suggested list includes:

- Akutan

- Aniakchak

- Augustine

- Bogoslof

- Cleveland

- Katmai:1912

- Novarupta:1912

- Okmok: 1997

- Pavlof

- Redoubt: 1989-1990, 2009

- Shishaldin

- Spurr: 1992 (Crater Peak), 1953

- Trident

\section{Extensions}

1. As a class, students can make a key of different kinds of volcanic features found through their research. Students can develop an identifying mark for each feature and draw them on a map of Alaska at the volcanoes where each feature is found. Depending on the volcanoes studied, students may see a large cluster of calderas on the Alaska Peninsula, stratovolcanoes (or composite cones) in the Cook Inlet region and Aleutians, and the large shield volcano, Wrangell, in the southeastern area of the state. Students could conduct further investigations to find out if their observations have relevance to tectonic regions, local faults or other structures, or if there is not a systematic occurrence of volcano features throughout the state.

2. Students may incorporate or focus on the use of the VEI in their comparisons. Some resources for this comparison are:

- Smithsonian Institution, [n.d.], Global volcanism program: Smithsonian Institution web pages, accessed June 1, 2010, at

- Large Holocene Eruptions http://www.volcano.si.edu/world/largeeruptions.cfm and

- Volcanic Explosivity Index (VEI) http://www.volcano.si.edu/world/eruptioncriteria.cfm\#VEI 
- U.S. Geological Survey, 2009, Volcano Hazards Program-VHP photo glossary-VEI: U.S. Geological Survey website. (Available at http://volcanoes.usgs.gov/images/pglossary/vei.php.)

\section{References Cited}

Alaska State Department of Education and Early Development, 2006, Standards and grade level expectations, March 2006: State of Alaska website, accessed October 2009 at http://www.eed.state.ak.us/tls/assessment/GLEHome.html.

Oregon State University, [n.d.], VolcanoWorld-Kinds of volcano eruptions: Oregon State University website, accessed June 1, 2010, at http://volcano.oregonstate.edu/education/vwlessons/kinds/kinds.html.

\section{Glossary}

Tectonic setting - The way in which plates move at their margins defines the tectonic setting or type of dynamic movement of tectonic plates, for a given region. Examples include divergence, convergence, and transform.

Vent - Vents are openings in the Earth's crust from which molten rock and volcanic gases escape onto the ground or into the atmosphere. Vents may consist of a single circular-shaped structure, a large elongate fissure and fracture, or a tiny ground crack. The release of volcanic gases and the eruption of molten rock will result in an assortment of constructional features ranging from enormous shield volcanoes and calderas to fumaroles and small rootless hornitos.

Viscosity - The property of a substance to offer internal resistance to flow; specifically the ratio of the shear stress to the rate of shear strain, which is known as the coefficient of friction.

Volcano Explosivity Index (VEI) - Proposed in 1982 as a way to describe the relative size or magnitude of explosive volcanic eruptions. It is a 0-to-8 index of increasing explosivity. Each increase in number represents an increase around a factor of ten. The VEI uses several factors to assign a number, including volume of erupted pyroclastic material (for example, ash fall, pyroclastic flows, and other ejecta), height of eruption column, duration in hours, and qualitative descriptive terms.

\section{Sources of Glossary Definitions}

Bates, R.K., and Jackson, J.A., eds., 1987, Glossary of Geology ( $3^{\text {rd }}$ ed.): Falls Church, Va., American Geological Institute, 571 p.

U.S. Geological Survey, 2010, Volcano Hazards Program-USGS photo glossary of volcanic terms: U.S. Geological Survey website. (Available at http://volcanoes.usgs.gov/images/pglossary/index.php 
Name

Date

Period

\section{Compare and Contrast Volcanic Eruptions}

Fill in two different volcanic eruptions (they may be from the same volcano) and compare and contrast the various volcanic features. You may add more features in the space available in the table on the second page.

\begin{tabular}{|c|c|c|}
\hline Feature & $\begin{array}{c}\text { Volcanic Eruption I } \\
\text { name, location } \\
\text { \& eruption date: }\end{array}$ & $\begin{array}{c}\text { Volcanic Eruption II } \\
\text { name, location } \\
\text { \& eruption date: }\end{array}$ \\
\hline $\begin{array}{c}\text { Vent type } \\
\text { features } \\
\text { Volcanic }\end{array}$ & & \\
\hline $\begin{array}{c}\text { Eruption } \\
\text { length }\end{array}$ & & \\
\hline $\begin{array}{c}\text { Placement of } \\
\text { vent }\end{array}$ & & \\
\hline $\begin{array}{c}\text { Hazards } \\
\text { material } \\
\text { erupted }\end{array}$ & & \\
\hline $\begin{array}{c}\text { Destruction } \\
\text { frequency, } \\
\text { measured }\end{array}$ & & \\
\hline $\begin{array}{c}\text { Volume of } \\
\text { Rock type }\end{array}$ & & \\
\hline $\begin{array}{c}\text { Gas type(s) } \\
\text { Earthquake }\end{array}$ & & \\
\hline
\end{tabular}




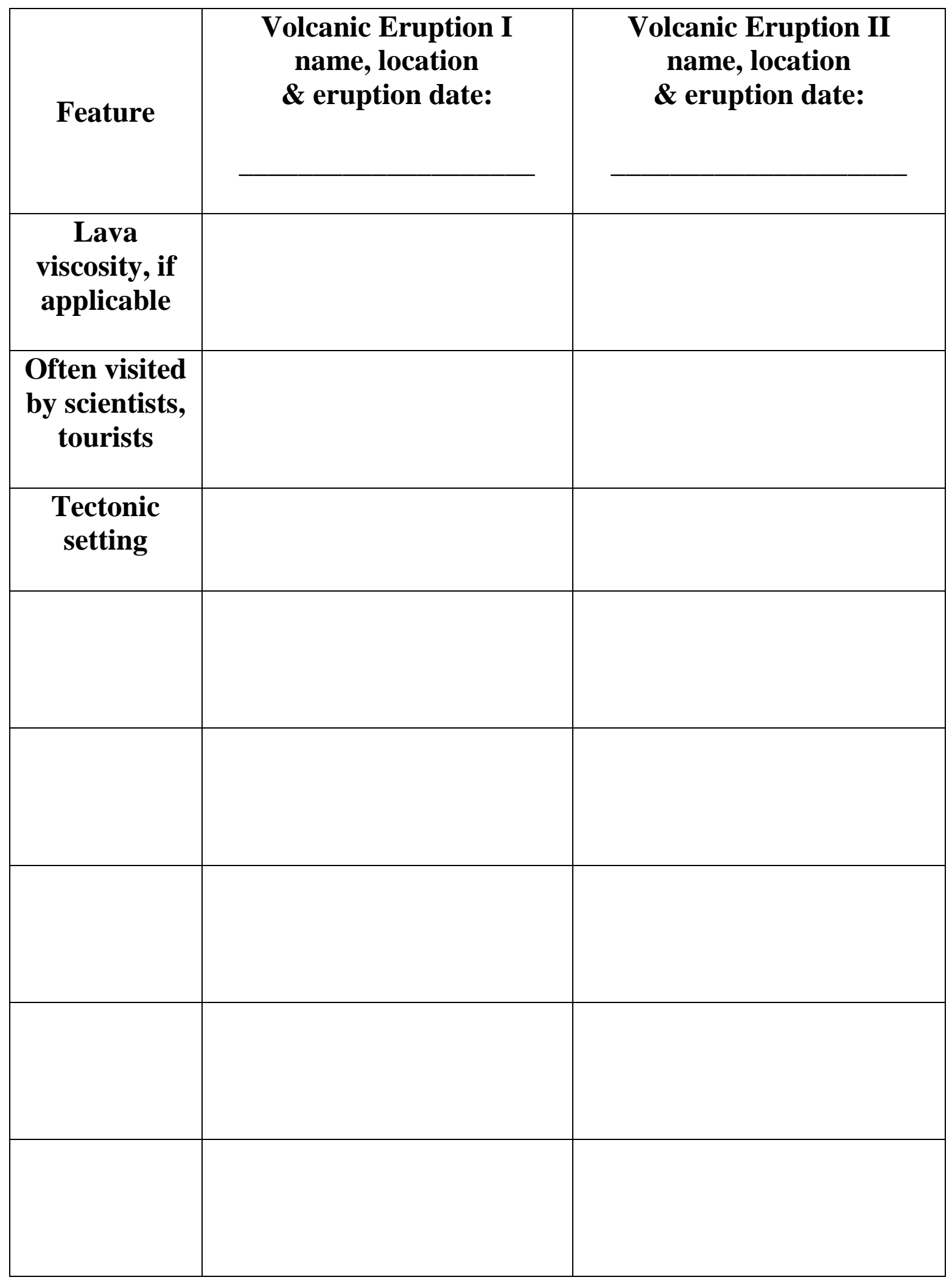




\section{Activity III. Volcanic Explosivity Index, Alaska}

Grade Level 6-11

Setting Classroom

Time 50 minutes

Correlations to Alaska State Department of Education (2006) Performance Standards (Grade Level Expectations)

D1-Concepts of Earth Science

SD[6-11] Students develop an understanding of the concepts, processes, theories, models, evidence, and systems of earth and space sciences.

SD2[6-11] Students develop an understanding of the origins, ongoing processes, and forces that shape the structure, composition, and physical history of the Earth

\section{Overview}

According to the Volcano Hazards Program USGS photo glossary of volcanic terms, in 1982, volcanologists proposed a scale from which to assign values associated to the "size" of a volcano eruption. This logarithmic scale is called the Volcanic Explosivity Index, or VEI, and has been applied to known volcanic eruptions worldwide. After students are introduced to this scale, they will apply it to a significant, recent volcanic eruption in Alaska - the June 6-9, 1912, eruption of Novaraupta volcano, the associated collapse event, which formed the Katmai caldera and the Valley of Ten Thousand Smokes in what is now Katmai National Park on the Alaska Peninsula.

\section{Background}

- Alaska Volcano Observatory, [n.d.], Statistics, description and links to images, maps, bibliography, reported activity, and webicorders and webcams where available:

Alaska Volcano Observatory web pages available at:

- Novarupta description and statistics http://www.avo.alaska.edu/volcanoes/volcinfo.php?volcname=Novarupta

- Katmai description and statistics http://www.avo.alaska.edu/volcanoes/volcinfo.php?volcname=Katmai Regional map and volcano list

o Alaska Peninsula http://www.avo.alaska.edu/volcanoes/alaska_peninsula.php

- U.S. Geological Survey

- Fierstein, Judy, and Hildreth, Wes, 2001, Preliminary volcano-hazard assessment for the Katmai volcanic cluster, Alaska: U.S. Geological Survey Open-File Report 00-0489, 50 p., 1 plate. (Also available at http://geopubs.wr.usgs.gov/openfile/of00-489/of00-489.pdf.)

- Fierstein, Judy, Hildreth, Wes, Hendley, J.W., II, and Stauffer, P.H., 1998, Can another great volcanic eruption happen in Alaska?: U.S. Geological Survey Fact Sheet 0075-98, 2 p. (Also available at http://pubs.usgs.gov/fs/fs075-98/ and http://pubs.usgs.gov/fs/fs075-98/fs075-98.pdf.) 
- U.S. Geological Survey, 1997, The Valley of Ten Thousand Smokes: U.S. Geological Survey Hawaiian Volcano Observatory Volcano Watch, June 20, 1997 web page. (Available at http://hvo.wr.usgs.gov/volcanowatch/1997/97_06_20.html.)

- U.S. Geological Survey, 2008, Annotated NASA image Katmai vicinity, Alaska—Katmai vicinity including the Valley of Ten Thousand Smokes, Alaska, August 1989: U.S. Geological Survey web page. (Available at http://vulcan.wr.usgs.gov/Photo/NASA/AnnotatedImages/nasa_katmai_vicinity_8 908.html.)

- U.S. Geological Survey, 2009, 1912 Eruption of Novarupta, Alaska: U.S. Geological Survey web page. (Available at http://vulcan.wr.usgs.gov/Volcanoes/Alaska/description_1912_eruption_novarupt a.html.)

- U.S. Geological Survey, 2009, Valley of Ten Thousand Smokes, Alaska: U.S. Geological Survey web page. (Available at http://vulcan.wr.usgs.gov/Volcanoes/Alaska/Maps/map_valley_10000_smokes.html.)

- Annenberg Media Multimedia Collection, 2010, Interactives-Volcanoes, judging hazards_-Katmai Video Clip (1:02 minutes; 6,272 KB), accessed June 1, 2010, at http://www.learner.org/interactives/volcanoes/movies/movies4.html.

- Smithsonian Institution, [n.d.], Global volcanism program: Smithsonian Institution web pages, accessed June 1, 2010, at

- Novarupta http://www.volcano.si.edu/world/volcano.cfm?vnum=1102-18- and

- Katmai http://www.volcano.si.edu/world/volcano.cfm?vnum=1102-17-.

- National Park Service

- Adleman, J.N., 2002 The great eruption of 1912, in Alaska Park ScienceConnections to natural and cultural resources in Alaska's National parks: U.S. Department of the Interior, National Park Service, Alaska Support Office, 39 p., accessed July 2, 2010, at http://www.arlis.org/docs/vol1/52558645/52558645v1no1.pdf.

- Clemens, Janet, and Norris, Frank, 1999, Building in an Ashen Land-Historic Resource Study of Katmai National Park and Preserve: Anchorage, Alaska, National Park Service, Alaska Support Office, accessed June 1, 2010, at http://www.nps.gov/history/history/online_books/katm//hrs/hrs.htm .

- National Park Service, 2004, Prehistory of Alaska—Katmai National Park and Preserve: National Park Service web pages, accessed June 1, 2010, at http://www.nps.gov/akso/akarc/cr_katm.htm.

- National Park Service, 2005, Geology field notes, Katmai National Park and Preserve, Alaska: National Park Service web pages, accessed June 1, 2010, at http://www.nature.nps.gov/geology/parks/katm/index.cfm.

- National Park Service, 2007, The Novarupta: National Park Service Park News, Issue number 1, 16 p. (Also available at http://www.nps.gov/katm/upload/Novarupta\%20Newspaper\%202007\%20WEB.pdf.) 
- National Park Service, 2009, Katmai National Park and Preserve, Valley of Ten Thousand Smokes tour: National Park Service website, accessed June 1, 2010, at http://www.nps.gov/katm/planyourvisit/valley-of-ten-thousand-smokes-tour.htm.

- National Park Service, 2010, Katmai National Park and Preserve, Alaska:

National Park Service website, accessed June 1, 2010 at http://www.nps.gov/katm.

- Norris, F.B., 1996, Isolated paradise-An administrative history of the Katmai and Aniakchak NPS Units, Alaska: Anchorage, Alaska, National Park Service, Alaska System Support Office, accessed June 1, 2010, at http://www.nps.gov/history/history/online_books/katm/adhi/. Schaaf, J.M., 2004, Witness-Firsthand accounts of the largest volcanic eruption in the twentieth century: Anchorage, Alaska, National Park Service, Lake ClarkKatmai Studies Center, unpaged, accessed June 1, 2010, at PDF http://www.nps.gov/history/history/online_books/katm/witness.pdf.

- National Aeronautics and Space Administration

- National Aeronautics and Space Administration, 2006, Goddard Space Flight Center-Historic volcanic eruption shrunk the mighty Nile River: NASA News and Media Releases, Feature November 21, 2006, accessed June 1, 2010 at http://www.nasa.gov/centers/goddard/news/topstory/2006/volcano_nile.html.

- National Aeronautics and Space Administration, 2006, NASA Science, Science News- Novarupta: Science-at-NASA feature October 3, 2006, accessed June 1, 2010, at http://science.nasa.gov/headlines/y2006/03oct_novarupta.htm?list120645.

- VolcanoWorld (Oregon State University)

- Oregon State University, [n.d.], VolcanoWorld—Katmai and Novarupta, Alaska Peninsula, Alaska: Oregon State University web page, accessed June 1, 2010, at http://volcano.oregonstate.edu/vwdocs/volc_images/north_america/alaska/katami. $\underline{\mathrm{html}}$

- University of Alaska Geophysical Institute

- Pullar, Gordan, 2004, Our history - The Katmai eruption, chap. 2, Afognak Village history: Native village of Afognak, accessed June 1, 2010, at http://www.afognak.org/education/history_chapter2.php.

- Rozell, Ned, 2001, Journey into the Valley of Ten Thousand Smokes, Alaska Science Forum, July 12, 2001: Geophysical Institute, University of Fairbanks, Article No. 1550, accessed June 1, 2010, at http://www.gi.alaska.edu/ScienceForum/ASF15/1550.html.

- Alaska Geographic

- Rennick, Penny, ed., 1989, Katmai Country: Alaska Geographic Society, v. 16, no. $1,96 \mathrm{p}$.

- Rennick, Penny, ed., 1991, Alaska’s Volcanoes: Alaska Geographic Society, v. 18, no. 2, 80 p. 
- National Geographic Magazine

- Griggs, R.F, 1917, The Valley of Ten Thousand Smokes-National Geographic Society Explorations in the Katmai District of Alaska: National Geographic Magazine, v. 81 no. 1, p. 13-68.

- Griggs, R.F., 1918, The Valley of Ten Thousand Smokes—An account of the discovery and exploration of the most wonderful volcanic region in the world: National Geographic Magazine, v. 33, no. 2, p. 115-169.

- Griggs, R.F., 1921, Our greatest national monument-The National Geographic Society completes its explorations in the Valley of Ten Thousand Smokes: National Geographic Magazine, v. 40, no. 3, p. 219-292.

- Griggs, R.F., 1922, The Valley of Ten Thousand Smokes: Washington, DC, National Geographic Society, 340 p., 3 sheets, scale unknown.

- Gruening, Ernest, 1963, Lonely wonders of Katmai: National Geographic Magazine, v. 123, no. 6, p. 800-831.

- Martin, G.C., 1913, The recent eruption of Katmai Volcano in Alaska-An account of one of the most tremendous volcanic explosions known in history: National Geographic Magazine, v. 24, p. 131-181.

- Robinson, G.D., 1948, Exploring Aleutian volcanoes: National Geographic Magazine, v. 94, no. 4, p. 509-528.

- Unknown, 1994, Monumental eruption echoes through time: National Geographic Magazine, v. 185, no. 6, following p. 138.

- Bodeau, Jean, 1992, Katmai National Park: Anchorage, Alaska, Alaska Natural History Association, 11 p.

- Erskine, H.D., 1976, Katmai's black-out, in Ashes and Water: Kodiak Historical Society, p. 1-9.

- Erskine, W.F., 1962, Katmai-A true narrative: London, Abelard-Schuman, 223 p.

- Fierstein, Judy, 1984, The Valley of Ten Thousand Smokes: Anchorage, Alaska, Alaska Natural History Association, 16 p.

- Lillie, R.J., 2005, Parks and plates-The geology of our National parks, monuments, and seashores: New York, W.W. Norton and Comdishy, 298 p.

- Chapter 5: Southern Alaska Subduction Zone, p. 120-121.

- Riehle, Jim, 2002, The geology of Katmai National Park and Preserve, Alaska: Publication Consultants, p. 112.

\section{Objectives}

Students will understand the Volcano Explosivity Index (VEI) scale used to determine the relative size of volcanic eruptions worldwide. By applying this scale to a significant volcanic eruption in Alaska students will be introduced to the largest volcanic eruption in the world in the Twentieth century and the significance Alaska's volcanism plays in global tectonics, economy, and hazards.

\section{Materials}

— Eruption Data: Novarupta 1912 worksheet 


\section{Procedure}

\section{Class brainstorming exercise and introduction to VEI}

1. Ask students to brainstorm about the various ways one could measure the "size" of a volcanic eruption. Record student answers. You may contribute key measurement techniques if students do not generate these answers. A robust list will include:

- Magma volume

- Tephra volume

- Amount of energy released

- Plume height

- Temperature of deposits

- Area covered by deposits

- "Reach" of deposits - as far as they got

- Amount of time materials was airborne

- Type of eruption

- Composition (rock type) of deposits

- Length, in time, of eruption

- Size and or number of associated earthquakes

- Number of people displaced, effected, harmed or killed

2. Introduce students to the Volcano Explosivity Index (VEI).

Several resources/examples are available to cover this materials:

- Lowenstern, J.B., and others, 2005, Steam explosions, earthquakes, and volcanic eruptions-What's in Yellowstone's future?: U.S. Geological Survey Fact Sheet 2005-3024, 6 p. (Also available at http://pubs.usgs.gov/fs/2005/3024/ and http://pubs.usgs.gov/fs/2005/3024/fs2005-3024.pdf.)

- Mattox, S.R., 1994, A teachers' guide to the geology of Hawaii Volcanoes National Park: Hawaii Natural History Association, 391 p.

- Activity 9.5: The Volcanic Explosivity Index (Grades 9-12) p. 159; 162.

- Newhall, C.G., and Self, Stephen, 1982, The Volcanic Explosivity Index (VEI) An estimate of explosive magnitude for historical volcanism: Journal of Geophysical Research, v. 87, no. C2, p. 1231-1238. (Also available at http://www.agu.org/journals/jc/v087/iC02/JC087iC02p01231/JC087iC02p01231. pdf.)

- Oregon State University, [n.d.], How BIG are volcanic eruptions?: Oregon State University web page, accessed June 1, 2010, at http://volcano.oregonstate.edu/education/eruption_scale.html.

- Smithsonian Institution, [n.d.], Global volcanism program-VEI (Volcanic Explosivity Index): Smithsonian Institution web page, accessed June 1, 2010, at http://www.volcano.si.edu/world/eruptioncriteria.cfm\#VEI.

- U.S. Geological Survey, 2009, Volcano Hazards Program, VHP photo glossaryVEI : U.S. Geological Survey web page. (Available at http://volcanoes.usgs.gov/images/pglossary/vei.php.) 


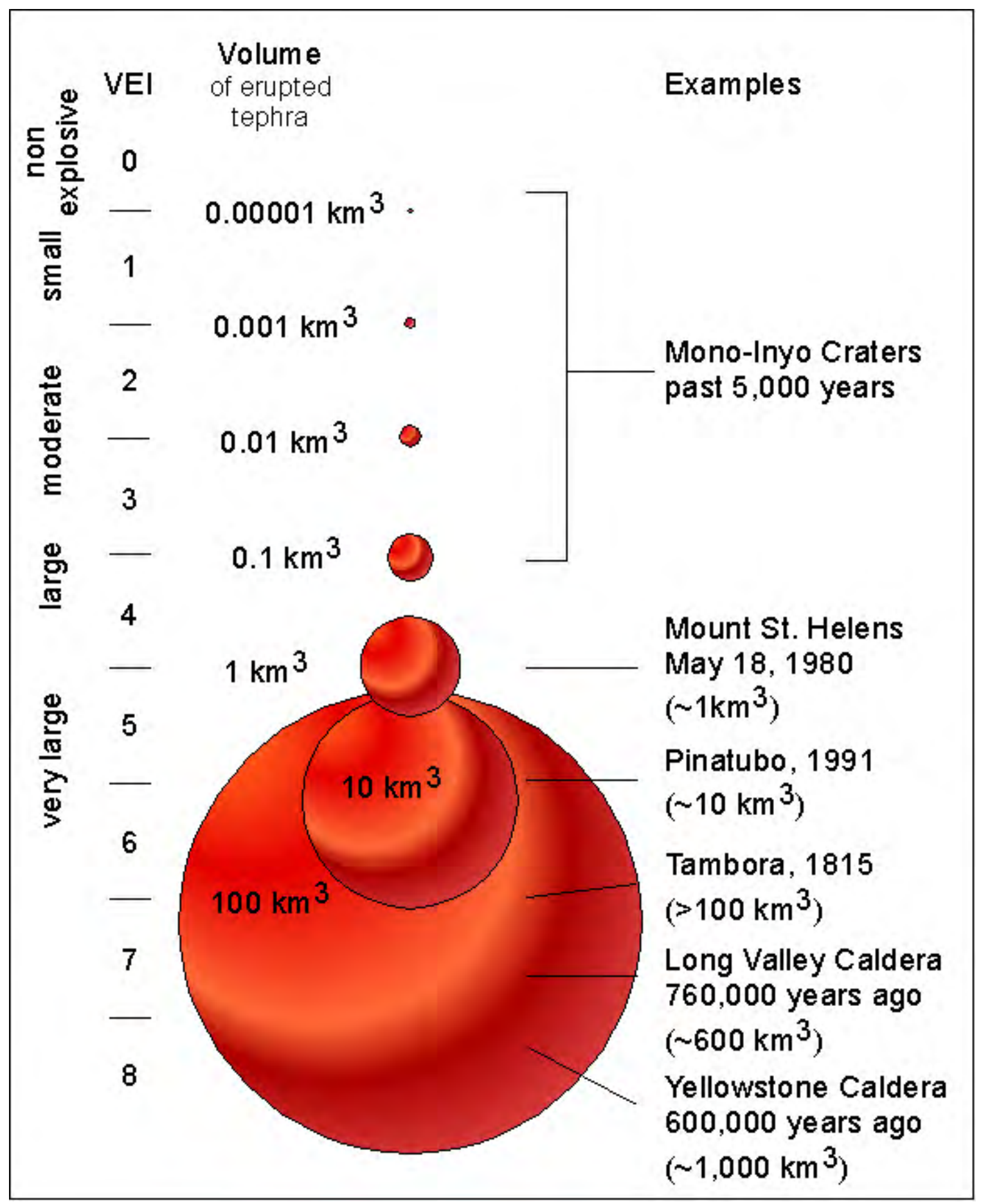


3. If needed, explain the principle of the logarithmic scale (as opposed to a linear scale). A logarithmic scale is a unit of measurement in which an increase or decrease of one unit represents a ten-fold change in the quantity measured. Several resources focus on earthquakes that can be used to illustrate a logarithmic scale.

- Braile, L.W., 2002 [2006], The AS-1 Seismograph-Magnitude determination: Explorations in Earth Science web page, accessed June 1, 2010, at http://web.ics.purdue.edu/ braile/edumod/as1mag/as1mag3.htm.

- Southern California Earthquake Center (SCEC), [n.d.], Investigating earthquakes through regional seismicity, sec. 3, Rating the size of earthquakes: Southern California Earthquake Center website, accessed June 1, 2010, at http://www.data.scec.org/Module/sec3pg16.html.

- U.S. Geological Survey, 2004, The severity of an earthquake: U.S. Geological Survey General Interest Publication. (Available at http://pubs.usgs.gov/gip/earthq4/severitygip.html.)

- Wald, Lisa, and Shindle, Wendy, 2001 [2004], Magnitude vs intensity—4-12: U.S. Geological Survey Earthquake Hazards Program web page. (Available at http://earthquake.usgs.gov/learning/teachers/Mag_vs_Int_Pkg.pdf.)

4. Ask students to identify very large volcanic eruptions — start worldwide. Students will likely come up with Vesuvius and additional volcanoes featured in documentaries they have seen. Some may come up with recent eruptions of Alaskan volcanoes such as Redoubt, Spurr, and Augustine. Tell your students that they will learn about the largest volcanic eruption of the 20th century — and that it occurred in Alaska. Ask if any students can name this volcano and the year of this eruption. Although students may name the volcano as Katmai, let students know that the largest volcanic eruption of the 20th century was the 1912 eruption of Novarupta on the Alaska Peninsula.

5. Students will work individually or in small groups to learn about the 1912 eruption of Novarupta. Using the resources listed in the Background section in Chapter 3 and other resources, students will complete a data table (Eruption Data: Novarupta 1912 worksheet provided). Using this data, students will assign a VEI to this eruption.

\section{Extensions}

1. Students can investigate how the Novarupta eruption affected Alaska and parts of western Canada and the lower-48 states in 1912 and for several subsequent years.

2. Students can make circle diagrams that illustrate the relative sizes of each VEI levels. Students could also collect, label and discuss containers that show the relative sizes of different eruptions (pill jar or pickle jar or soda bottle or bucket, and so on) 
3. Driedger, C.L., Doherty, Anne, and Dixon, Cheryll, 2005, Living with a volcano in your backyard—An educator's guide with emphasis on Mount Rainier: U.S.

Geological Survey General Interest Product 19; produced in cooperation with the National Park service. (Available at http://vulcan.wr.usgs.gov/Outreach/Publications/GIP19/.)

- Chapter 2: Tephra popcorn http://vulcan.wr.usgs.gov/Outreach/Publications/GIP19/chapter_two_tephra_popc orn.pdf.

4. NOVA Online, 2000, Deadly shadow of Vesuvius—Volcanic Explosivity Index (VEI) and activity http://www.pbs.org/wgbh/nova/vesuvius/deadliest3.html.

5. U.S. Geological Survey, 2008, Predict an eruption: U.S. Geological Survey webbased program. (Available at http://volcanoes.usgs.gov/edu/predict/.)

6. University Corporation for Atmospheric Research, 2005, Windows to the UniverseStudent Worksheet—Lesson: Reading graphs with a logarithmic scale: University Corporation for Atmospheric Research website, accessed June 1, 2010, at http://www.windows.ucar.edu/tour/link=/teacher_resources/graphs/worksheet_logarit hmic_scale.html.

7. Explore different types of natural disaster scales: Modified Mercalli Scale: DLESE Teaching Boxes Living in Earthquake Country (6-12) Lesson 5: A Whole Lot of Shakin’ Goin' On! Activity 2-Determining the Intensity http://www.teachingboxes.org/earthquakes/lessons/lesson5_activity2.jsp.

\section{References Cited}

Alaska State Department of Education and Early Development, 2006, Standards and grade level expectations, March 2006: State of Alaska website, accessed October 2009 at http://www.eed.state.ak.us/tls/assessment/GLEHome.html.

U.S. Geological Survey, 2009, Volcano Hazards Program, VHP photo glossary-VEI : U.S. Geological Survey web page. (Available at http://volcanoes.usgs.gov/images/pglossary/vei.php. 
Name

Date

Period

\section{Eruption Data: Novarupta 1912}

\begin{tabular}{|c|c|}
\hline Feature & Value \\
\hline Plume height & \\
\hline $\begin{array}{c}\text { Ash fall } \\
\text { (where and how much) }\end{array}$ & \\
\hline $\begin{array}{l}\text { Length of eruption } \\
\text { (duration in time) }\end{array}$ & \\
\hline $\begin{array}{l}\text { Geomorphic observations } \\
\text { (cones, domes, flows...) }\end{array}$ & \\
\hline $\begin{array}{l}\text { Earthquakes } \\
\text { (size, frequency, } \\
\text { number...) }\end{array}$ & \\
\hline $\begin{array}{c}\text { Airborne ash } \\
\text { (volumes, coverage, } \\
\text { distance traveled...) }\end{array}$ & \\
\hline $\begin{array}{c}\text { Total volume } \\
\text { (of features, total...) }\end{array}$ & \\
\hline $\begin{array}{c}\text { Phenomena reported } \\
\text { (human and animal } \\
\text { behaviors...) }\end{array}$ & \\
\hline $\begin{array}{l}\text { Volcanic deposit } \\
\text { temperatures }\end{array}$ & \\
\hline
\end{tabular}

VEI 


\section{Eruption Data: Novarupta 1912 Key}

\begin{tabular}{|c|c|}
\hline Feature & Value \\
\hline Plume height & $100,000 \mathrm{ft}$ \\
\hline Ash fall & $\begin{array}{l}1,000 \mathrm{~km} \text { east and } 100 \mathrm{~km} \text { west in } 24 \text { hours after onset } \\
\text { of eruption }\end{array}$ \\
\hline Length of eruption (time) & $\sim 60$ hours \\
\hline Geomorphic observations & $\begin{array}{l}11 \text { hours after onset, a } 2.5 \mathrm{~km} \text {-wide caldera formed from } \\
\text { summit collapse due to the absence of roughly } 5 \mathrm{~km}^{3} \text { of } \\
\text { magma had erupted thus far }\end{array}$ \\
\hline Earthquakes & $\begin{array}{l}\text { The caldera formation generated } 14 \text { earthquakes of } \\
\text { magnitudes } 6 \text { and } 7 \text {, and up to } 100 \text { greater than } \\
\text { magnitude } 5 \text {, some felt as far as } 200 \text { miles away }\end{array}$ \\
\hline Airborne ash & $\begin{array}{l}\text { Traveled 4,000 miles southeast reaching Virginia } 4 \\
\text { days after onset and more than } 25,000 \text { miles southeast } \\
\text { reaching Algeria } 11 \text { days after onset }\end{array}$ \\
\hline $\begin{array}{l}\text { Total volume of new } \\
\text { magma erupted }\end{array}$ & $\begin{array}{l}13 \mathrm{~km}^{3} \text { total : } 17 \mathrm{~km}^{3} \text { of fall deposit and } 11 \mathrm{~km}^{3} \text { of ash- } \\
\text { flow tuff (ignimbrite) }\end{array}$ \\
\hline Phenomena reported & $\begin{array}{l}\text { lightening, areas within } 200 \mathrm{mi} \text { including Kodiak and } \\
\text { Afognak Islands, were engulfed in dark, opaque ash fall, } \\
\text { explosions were heard as far as } 600 \mathrm{mi} \text { away in Juneau, } \\
\text { the average temperature of the Northern hemisphere was } \\
\text { lowered by } \sim 1^{\circ} \mathrm{C}\left(2^{\circ} \mathrm{F}\right) \text { for more than } 1 \text { year }\end{array}$ \\
\hline $\begin{array}{l}\text { Volcanic deposit } \\
\text { temperatures }\end{array}$ & $\begin{array}{l}\text { The ash flow deposit temperatures were } 800-1,000^{\circ} \mathrm{C} \\
\left(1,400-2,000^{\circ} \mathrm{F}\right)\end{array}$ \\
\hline
\end{tabular}

VEI 6 


\section{References Cited}

Alaska Volcano Observatory, [n.d.], Novarupta reported activity 1912: Alaska Volcano Observatory website. (Available at

http://www.avo.alaska.edu/volcanoes/volcact.php?volcname=Novarupta\&eruptionid=456,)

Fierstein, Judy, and Hildreth, Wes, 2001, Preliminary volcano-hazard assessment for the Katmai volcanic cluster, Alaska: U.S. Geological Survey Open-File Report 00-489, 50 p., 1 plate. (Also available at http://geopubs.wr.usgs.gov/open-file/of00-489/of00489.pdf $[29 \mathrm{MB}]$.

Fierstein, Judy, Hildreth, Wes, Hendley, J.W., II., and Stauffer, P.H., 1998, Can another great volcanic eruption happen in Alaska?: U.S. Geological Survey Fact Sheet 075-98, 2 p. (Also available at http://pubs.usgs.gov/fs/fs075-98/.) 


\section{Chapter 4 \\ Alaska's Volcanic Landforms and Features}

\section{Resources}

- Alaska Volcano Observatory website. (Available at http://www.avo.alaska.edu.)

- Brantley, S.R., 1999, Volcanoes of the United States: U.S. Geological Survey General Interest Publication. (Available at http://pubs.usgs.gov/gip/volcus/index.html.)

- $\quad$ Miller, T.P., McGimsey, R.G., Richter, D.H., Riehle, J.R., Nye, C.J., Yount, M.E., and Dumoulin, J.A., 1998, Catalog of the historically active volcanoes of Alaska: U.S. Geological Survey Open-File Report 98-0582, 104 p. (Also available at http://www.avo.alaska.edu/downloads/classresults.php?citid=645.)

- Nye, C.J., and others, 1998, Volcanoes of Alaska: Alaska Division of Geological and Geophysical Surveys Information Circular IC 0038, accessed June 1, 2010, at

- PDF Front (6.4 MB) http://www.dggs.dnr.state.ak.us/webpubs/dggs/ic/oversized/ic038_sh001.PDF and

- PDF Back (6.6 MB) http://www.dggs.dnr.state.ak.us/webpubs/dggs/ic/oversized/ic038_sh002.PDF.

- Smithsonian Institution, [n.d.], Global volcanism program-Augustine: Smithsonian Institution web page, accessed June 1, 2010, at http://www.volcano.si.edu/world/volcano.cfm?vnum=1103-01\&volpage $=$ photos \&phoyo $=026071$.

- Tilling, R.I., 1997, Volcanoes-On-line edition: U.S. Geological Survey General Interest Product. (Available at http://pubs.usgs.gov/gip/volc/.)

- U.S. Geological Survey, 1997 [2007], Volcanoes teacher's guide: U.S. Geological Survey website. (Available at http://erg.usgs.gov/isb/pubs/teacherspackets/volcanoes/.

- U.S. Geological Survey, 2010, Volcano Hazards Program-USGS photo glossary of volcanic terms: U.S. Geological Survey website. (Available at http://volcanoes.usgs.gov/images/pglossary/index.php.)

\section{Activities}

Through research, mapping projects, and classroom discussion these activities will provide students with an understanding of the various landforms associated with volcanoes in Alaska, the development and use of topographic profiles, and pertinent information including the names, locations, and types of most of the historically active volcanoes in the state. These activities build on the student's knowledge of igneous rock types, volcano types, and the subduction zone tectonics driving Alaska's volcanism.

Activity I. Volcanic Landforms and Features Information Search Activity II. Topographic Profiles of Alaskan Volcanoes Activity III. Alaska Volcanic Arc of Fame 


\section{Activity I. Volcanic Landforms and Features Information Search}

Grade Level 6-11

Setting Classroom

Time 45-90 minutes

Vocabulary (see Glossary)

andesite, basalt, caldera, cinder cone, cross section, debris-avalanche, fault zone, flood basalt, geyser, hummock, ignimbrite, intracaldera, lava dome, maar, map view, morphology, phreatic, phreatomagmatic, profile, pyroclastic flow, pyroclastic flow deposit, resurgent dome, rhyolite, shield volcano, stratovolcano or composite cone, truncated, tuya, viscosity, voluminous

\section{Correlations to Alaska State Department of Education (2006) Performance Standards (Grade Level Expectations) D1-Concepts of Earth Science \\ SD[6-11] Students develop an understanding of the concepts, processes, theories, models, evidence, and systems of earth and space sciences. \\ SD2[6-11] Students develop an understanding of the origins, ongoing processes, and forces that shape the structure, composition, and physical history of the Earth. \\ SD2.3[6] The student demonstrates an understanding of the forces that shape Earth by describing how the surface can change rapidly as a result of geological activities (i.e., earthquakes, tsunamis, volcanoes, floods, landslides, avalanches).}

\section{Overview}

These activities will provide students with an understanding of the various landforms associated with volcanoes in Alaska using photographic examples, worksheets, and student derived presentations, papers, and (or) posters.

\section{Background}

Alaskan volcanism produces several types of volcanoes and eruption products (discussed as landforms and features). This wide and varied volcanic history can lead to misconceptions about the shapes, features, and landforms of Alaska's volcanoes and the hazards they may pose. Students have already learned about the many types of volcanoes in Alaska, and that the same volcano can produce vastly different products. In this section students will be introduced to volcanic features not necessarily associated with an eruption, such as hot springs and fumaroles, and will learn about formations associated with long past volcanic activity, such as the Togiak Tuya-a basaltic lava flow that occurred underneath a glacier. 


\section{Objectives}

Students will be able to identify the most common types of volcanic landforms and features found in Alaska.

\section{Materials}

— drawing paper

- colored pens, pencils, crayons, and (or) thin markers

- Alaska's Volcanic Landforms and Features handout and (or) worksheet and (or) presentation

— Volcanic Landforms and Features worksheet

\section{Procedure}

\section{A. Classroom introduction}

1. Ask students to draw a volcano on paper and label as many parts as possible. You can ask your students to draw a volcano from the side (cross section, also known as profile view) and (or) from a bird's-eye or map view (view from above). Be careful not to lead the students in any other way; they can decide on their own how to orient the paper, what shapes, colors to use, and so on. This way, you will be able to identify students' knowledge of volcanoes.

2. After completion, discuss the drawings with your students. One good way to do this is to collect the drawings and display or pass out several of them for the class to observe. Below are a few example questions that may be used to instigate discussion. You can gear your discussion to reflect students' comments and preconceptions about the volcanoes.

- What do most of these drawings have in common?

- What differences do you notice between these drawings?

- Do all real volcanoes have to have the same appearance? Explain your answer.

- What characteristics make a volcano "look like a volcano"?

3. Review the main types of volcanoes and eruption types with your class. Note Activity I in Chapter 3 of this activity guidebook covers this material and activities in Chapter 5 discuss the potential hazards of some of these landforms and features.

\section{B. Alaska's volcanoes in photos}

1. Included as a handout (with and without captions) and as a digital presentation (also, with and without captions) is a collection of photographs of Alaskan landforms and features.

- You may distribute the uncaptioned handouts or show the uncaptioned photographs to the class and allow students the chance to name the feature, landform, and volcano in each of the photographs. The handouts have space Or provided for students to write in their answers.

- You can distribute the captioned handouts or review the captioned photographic presentation and introduce students to the feature, landform, and volcano in each of the photographs. 
In either case,

- Discuss with your class the most likely processes that formed each volcano and review the types of volcanoes and their Alaskan examples with your students.

2. Tell the students to draw another volcano and label as many parts as possible. Have the students compare this new drawing to their original one and to note what they have learned.

\section{Volcanic Landforms and Features worksheet}

1. Hand out the Volcanic Landforms and Features worksheet and have students answer the questions based on information they find on the internet or through resources available in the library and (or) the classroom. Several websites are available to lead students to answers for these questions. Two suggestions are:

- Nelson, Prof. S.A., 2008, EENS 204-Volcanic landforms, volcanoes, and plate tectonics: Tulane University website, accessed June 1, 2010, at http://www.tulane.edu/ sanelson/geol204/volclandforms.htm.

- U.S. Geological Survey, 2010, Volcano Hazards Program-USGS photo glossary of volcanic terms website. (Available at http://volcanoes.usgs.gov/images/pglossary/index.php.)

2. Discuss the answers with your students and ask them which volcanic landforms and features are likely to be found in Alaska, and why or why not. Dozens of volcanoes are in Alaska and every volcanic eruption type can be found if one looks hard enough. Generally, subduction, the dominant tectonic process, generates most of the volcanic activity in Alaska.

\section{Extensions}

1. Show a wafer, chocolate chip, chocolate kiss, and chocolate drop (or similar shaped food items) and ask students which food represents which type of volcano and why (from Lillie, R.J., 2005, p. 39).

Note Photographs for this extension are included in the accompanying digital presentation, Alaska's Volcanic Types-Food for Thought.

- Wafer - the broad flat shape of a shield volcano is like that of a wafer

- Chocolate kiss - a steep pointed stratovolcano is like a chocolate kiss. A white and dark chocolate swirl can illustrate lava flows along the flanks or varying lava types.

- Chocolate chip - like a cinder cone, a chocolate chip is dark and steep sided but much smaller than a shield or composite stratovolcano.

- Chocolate drop - is similar in shape to a lava dome with a rounded top.

- Ice cream cone - is similar in shape to a caldera with a flat bottom and steep sides walls

2. Have the students write an essay explaining what they now know about volcanoes and their landforms and features. Give students key words to use in their essays. 
3. Students research a specific volcano and make a chart with its associated landforms and features. Students can contrast and compare how many volcanoes have the various types of landforms or volcanic features (cones, domes, and so on) and why.

4. Have students create their own presentation, poster, or paper focused on various volcanic landforms and features.

\section{References Cited}

Alaska State Department of Education and Early Development, 2006, Standards and grade level expectations, March 2006: State of Alaska website, accessed October 2009 at http://www.eed.state.ak.us/tls/assessment/GLEHome.html.

Lillie, R.J., 2005, Parks and plates-The geology of our National parks, monuments, and seashores: New York, W.W. Norton and Comdishy, 298 p.

Motyka, R.J., Liss, S.A., Nye, C.J., and Moorman, M.A., 1994, Geothermal resources of the Aleutian arc: Alaska Division of Geological and Geophysical Surveys Professional Report 114, 17 p., 4 sheets, scale 1:1,000,000, accessed June 1, 2010, at http://www.dggs.dnr.state.ak.us./pubs/pubs?reqtype=citation\&ID=2314.

\section{Glossary}

Andesite - A gray to black volcanic rock with between about 52 and 63 weight percent silica $\left(\mathrm{SiO}_{2}\right)$.

Basalt - A hard black volcanic rock with less than about 52 weight percent silica $\left(\mathrm{SiO}_{2}\right)$.

Caldera - A caldera is a large, usually circular depression at the summit of a volcano formed when magma is withdrawn or erupted from a shallow underground magma reservoir. The removal of large volumes of magma may result in loss of structural support for the overlying rock, thereby leading to collapse of the ground and formation of a large depression. Calderas are different from craters, which are smaller, circular depressions created primarily by explosive excavation of rock during eruptions.

Cinder cone - A steep, conical hill of volcanic fragments that accumulate around and downwind from a vent.

Cross section - A diagram or drawing that shows features transected by a given plane, typically a vertical section drawn at right angles to the longer axis of a geologic feature.

Fault zone - Region of fractures in the Earth's crust along which one side moves with respect to the other.

Flood basalt - The result of a giant volcanic eruption or series of eruptions that coats large stretches of land or the ocean floor with basalt lava.

Geyser - Hot springs that episodically erupt fountains of scalding water and steam. 
Hummock - Rounded or conical mounds within a volcanic landslide or debris avalanche deposit; debris-avalanche -debris avalanches are moving masses of rock, soil, and snow that occur when the flank of a mountain or volcano collapses and slides down slope.

Ignimbrite - The rock formed by the widespread deposition and consolidation of volcanic ash flows.

Intracaldera - Within a caldera.

Lava dome - A roughly circular mound-shaped protrusion resulting from the slow eruption of felsic lava (usually rhyolite or dacite) from a volcano, or from multiple lava episodes of different magma types.

Maar - A low-relief, broad volcanic crater formed by shallow explosive eruptions. The explosions are usually caused by the heating and boiling of groundwater when magma invades the groundwater table. A maar will often fill with water to form a lake.

Map view - View of an area from overhead.

Morphology - The study of the shape of the Earth's surface and the external structure, form, and arrangement of rock in relation to the development of landforms.

Phreatic - A volcanic explosion of steam, mud, or other material that is not incandescent; the explosion is caused by the heating and consequent expansion of groundwater due to an underlying igneous heat source.

Phreatomagmatic - A volcanic explosion that extrudes steam and magmatic gases; the explosion is caused by the contact of magma with shallow or surface water.

Profile - The outline produced where the plane of a vertical section intersects the surface of the ground

Pyroclastic flow - A ground-hugging avalanche of hot ash, pumice, rock fragments, and volcanic gas that rushes down the side of a volcano as fast as $100 \mathrm{~km} /$ hour ( 60 mi/hour) or more. The temperature within a pyroclastic flow may be greater than $500^{\circ} \mathrm{C}\left(900^{\circ} \mathrm{F}\right)$, sufficient to burn and carbonize wood. Once deposited, the ash, pumice, and rock fragments may deform (flatten) and weld together because of the intense heat and the weight of the overlying material. The emplaced flow is called a pyroclastic flow deposit.

Resurgent dome - Volcanic domes are rounded, steep-sided mounds built by very viscous magma, usually either dacite or rhyolite. If domes are resurgent then they have appeared again after a previous growth or eruption.

Rhyolite - A light-colored rock with silica $\left(\mathrm{SiO}_{2}\right)$ content greater than about 68 weight percent. Sodium and potassium oxides can reach about 5 weight percent. 
Shield volcano - A volcano characterized by low angle slopes.

Stratovolcano - A type of volcano (also called a composite cone), characterized by slope angles of as much as 35 degrees.

Truncated - Stopped, prevented, or chopped off.

Tuya - A flat-topped and steep-sided volcano that has erupted into a lake thawed in a glacier by the volcano's heat.

Viscosity - The property of a substance to offer internal resistance to flow; specifically the ratio of the shear stress to the rate of shear strain known as the coefficient of friction.

Voluminous - Great in volume.

\section{Source of Glossary Definitions}

Bates, R.K., and Jackson, J.A., eds., 1987, Glossary of Geology ( $3^{\text {rd }}$ ed.): Falls Church, Va., American Geological Institute, 571 p.

U.S. Geological Survey, 2008, Cascades Volcano Observatory—Volcano Types : U.S. Geological Survey web page. (Available at http://vulcan.wr.usgs.gov/Glossary/VolcanoTypes/volcano_types.html.

U.S. Geological Survey, 2010, Volcano Hazards Program-USGS photo glossary of volcanic terms: U.S. Geological Survey website. (Available at http://volcanoes.usgs.gov/images/pglossary/index.php.) 


\section{Alaska's Volcanic Landforms and Features Handout}

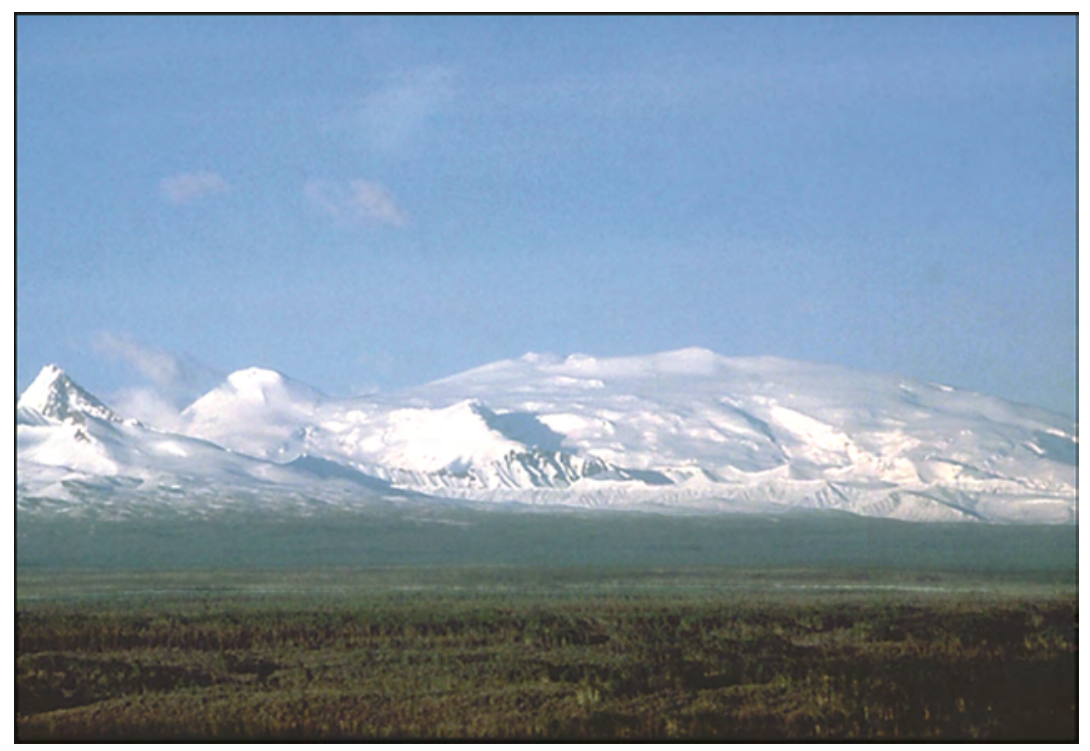

1. Mount Wrangell, a 4,317-m (14,163-ft) high andesite shield volcano on the right skyline, is the only volcano in the Wrangell Mountains with documented historical activity consisting of several minor, possibly phreatic eruptions in the early 1900s. Andesite is a gray to black volcanic rock with between about 52 and 63 weight percent silica $\left(\mathrm{SiO}_{2}\right)$. The shield shape is rare for an andesitic volcano and is due to a high volume of lava erupting from the volcano over a short amount of time. View is to the northeast. Photograph taken by B. Cella, National Park Service, 1987.

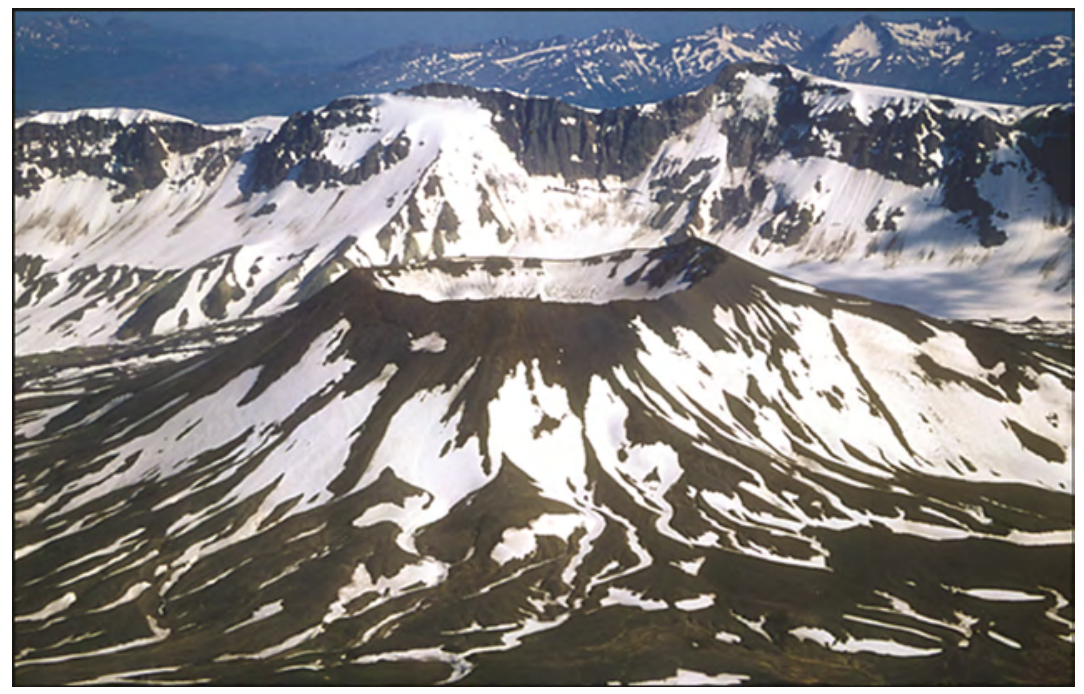

2. Vent Mountain in the foreground is a cinder cone inside Aniakchak Caldera. The caldera wall is in the background. Aniakchak Volcano is on the Alaska Peninsula. Photograph taken by R.G. McGimsey, U.S. Geological Survey, June 28, 1997. 


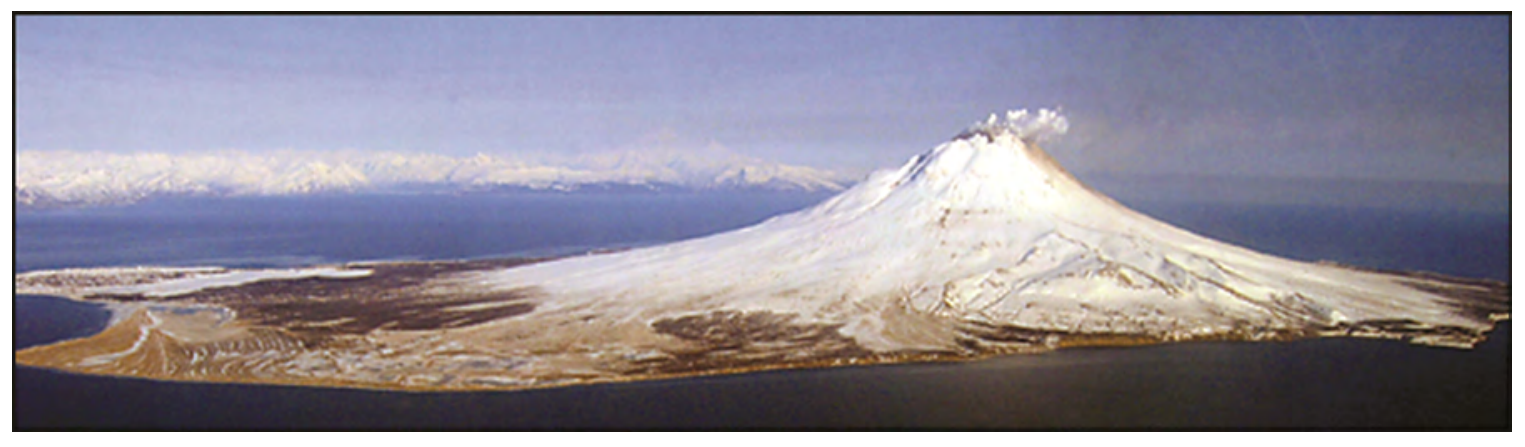

3. Augustine Volcano in the Cook Inlet is a stratovolcano (or composite cone). This photograph was taken looking northwest; volcanic ash covers the upper flanks of the summit. White steam is being emitted. Photograph was taken by J. Adleman, U.S. Geological Survey, February 24, 2006.

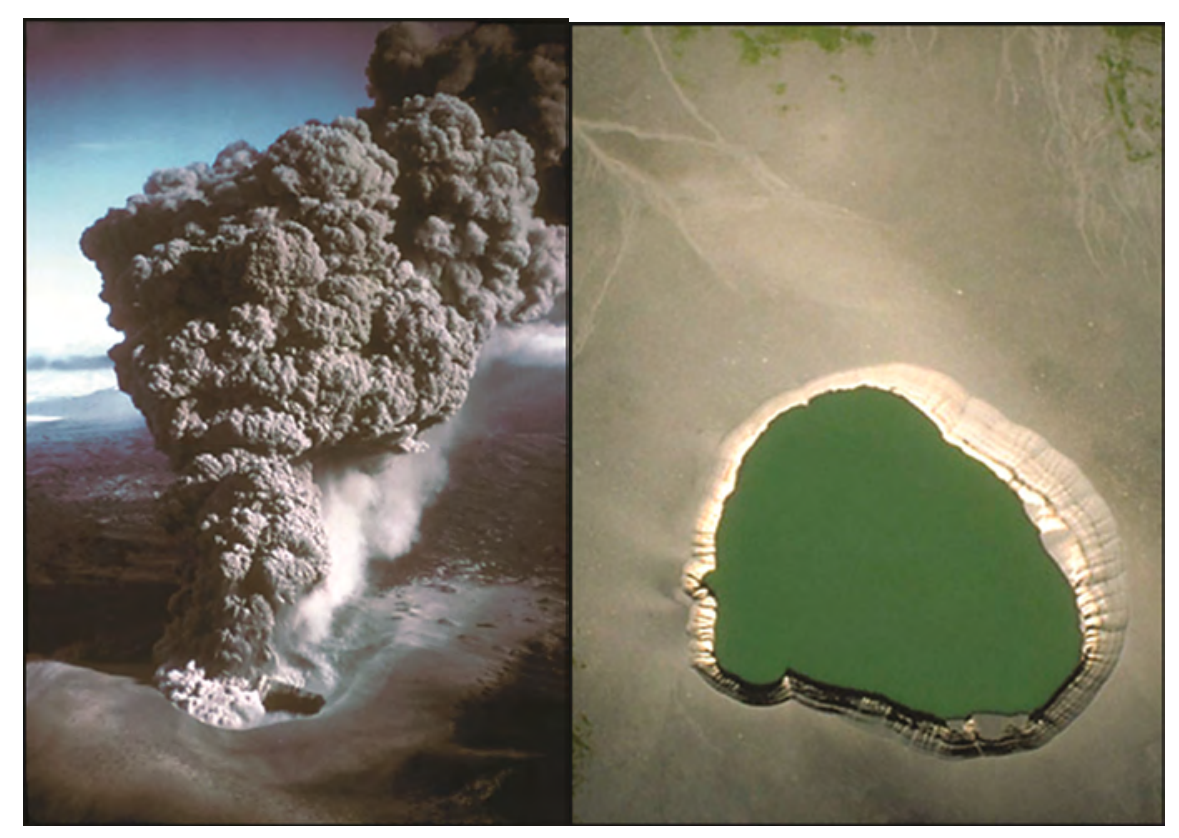

(A)

(B)

4. (A) Aerial view of a phreatomagmatic eruption of the East Maar of Ukinrek Maars. The Ukinrek Maars are on the south shore of Becharof Lake on the Alaska Peninsula; the maar craters formed during a 10-day eruption in March and April 1977.

Photograph was taken by Juergen Kienle, University of Alaska Geophysical Institute, April 6, 1977.

(B) Near-vertical view of the east Ukinrek Maar crater, $300 \mathrm{~m}$ (980 ft) across.

Photograph was taken by D. Dewhurst, U.S. Fish and Wildlife Service, July 8, 1990. 


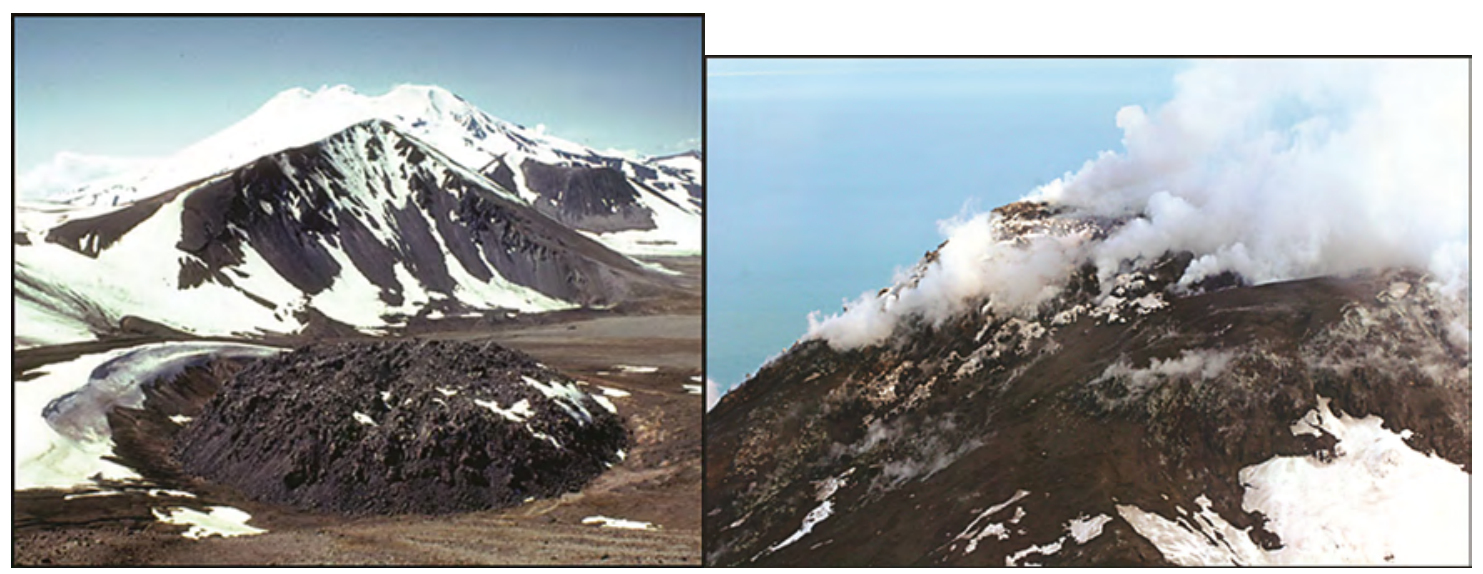

(A)

(B)

5. (A) Aerial view of 80-m (260-ft) high Novarupta, a blocky rhyolite (high silica) lava dome that marks the vent for the 1912 eruption that created the Valley of Ten Thousand Smokes in Katmai National Park and Preserve, Alaska. This eruption was the most voluminous on Earth in the 20th century, ejecting nearly $30 \mathrm{~km}^{3}\left(7 \mathrm{mi}^{3}\right)$ of material in 60 hours. Falling Mountain, a lava dome truncated by the 1912 eruption, is visible behind the Novarupta dome; snow-capped stratovolcano Mount Mageik can be seen at top of the photograph. Rhyolite is a light-colored rock with silica $\left(\mathrm{SiO}_{2}\right)$ content greater than about 68 weight percent. Photograph taken by T. Miller, U.S. Geological Survey, June 1979.

(B) Summit dome on Augustine Volcano, Cook Inlet, Alaska. Photograph taken by J. Adleman, U.S. Geological Survey, May 12, 2006. 


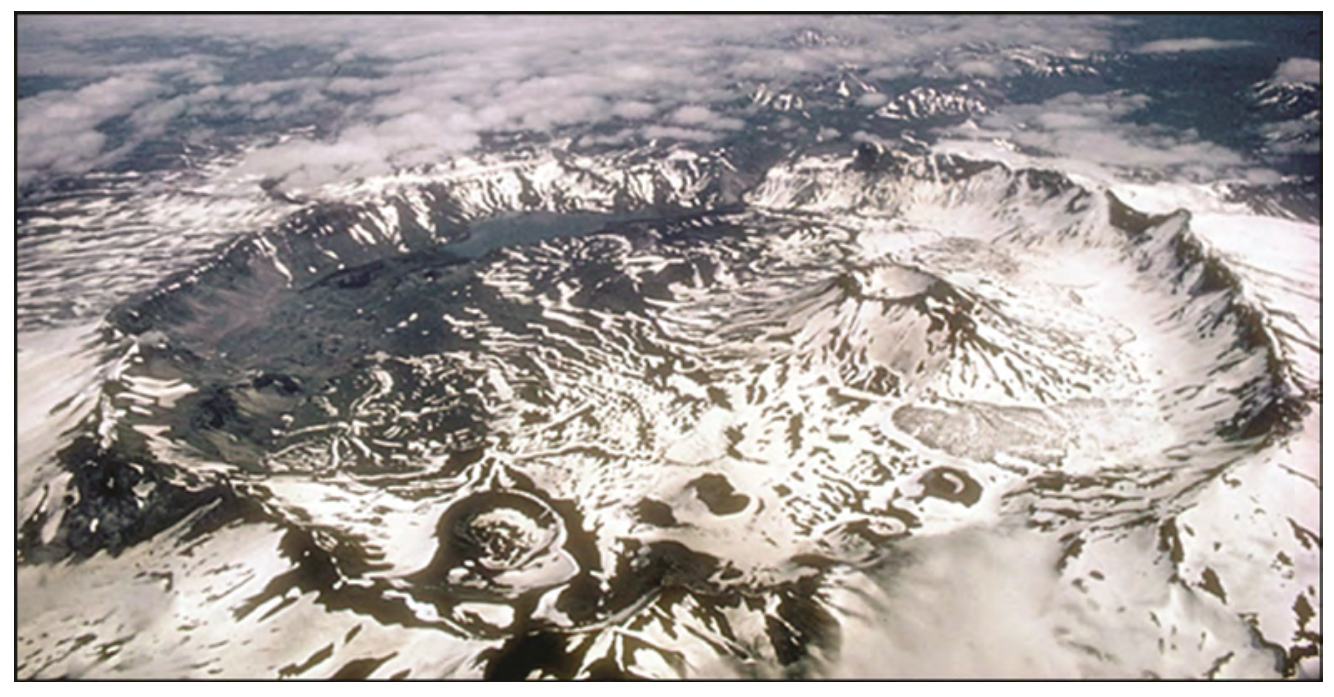

6. Aerial view, looking east, of Aniakchak caldera. Formed during a catastrophic ashflow producing eruption about 3,400 years ago, Aniakchak caldera is about $10 \mathrm{~km}$ (6 mi) across and averages $500 \mathrm{~m}(1,640 \mathrm{ft})$ in depth. Voluminous post-caldera eruptive activity has produced a wide variety of volcanic landforms and deposits within the caldera. The opening in the caldera is called the Gates and one of the largest floods on Earth in the past 10,000 years occurred when a proto-Surprise lake catastrophically emptied through this low point in the caldera rim. The volcano is located in Aniakchak National Park and Preserve on the Alaska Peninsula. Photograph taken by M. Williams, National Park Service, 1977.

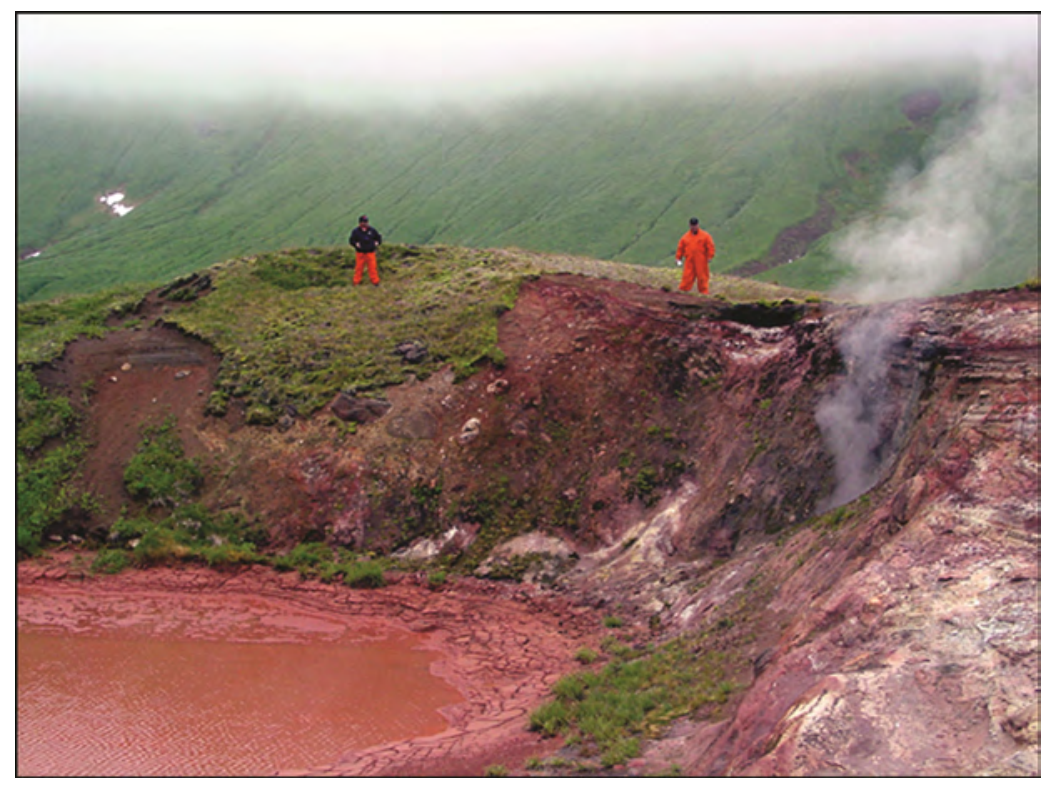

7. Large-pool thermal hot springs area southwest of Korovin Volcano and westnorthwest of Kluichef Volcano on Atka Island in the Aleutians. Photograph taken by R.G. McGimsey, U.S. Geological Survey, July 14, 2004. 


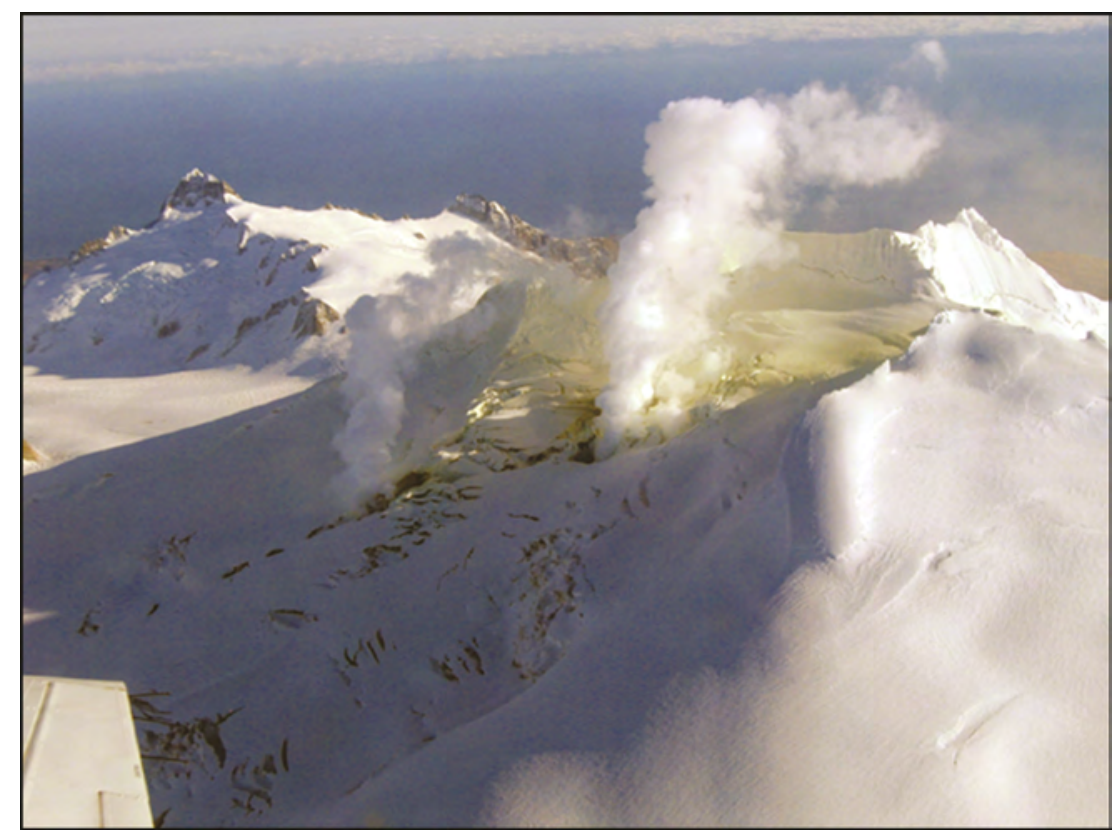

8. Fumarolic activity at the summit of Fourpeaked Volcano in Kamtai National Park and Preserve on the Alaska Peninsula. Photograph taken by J. Adleman, U.S. Geological Survey, November 4, 2006.

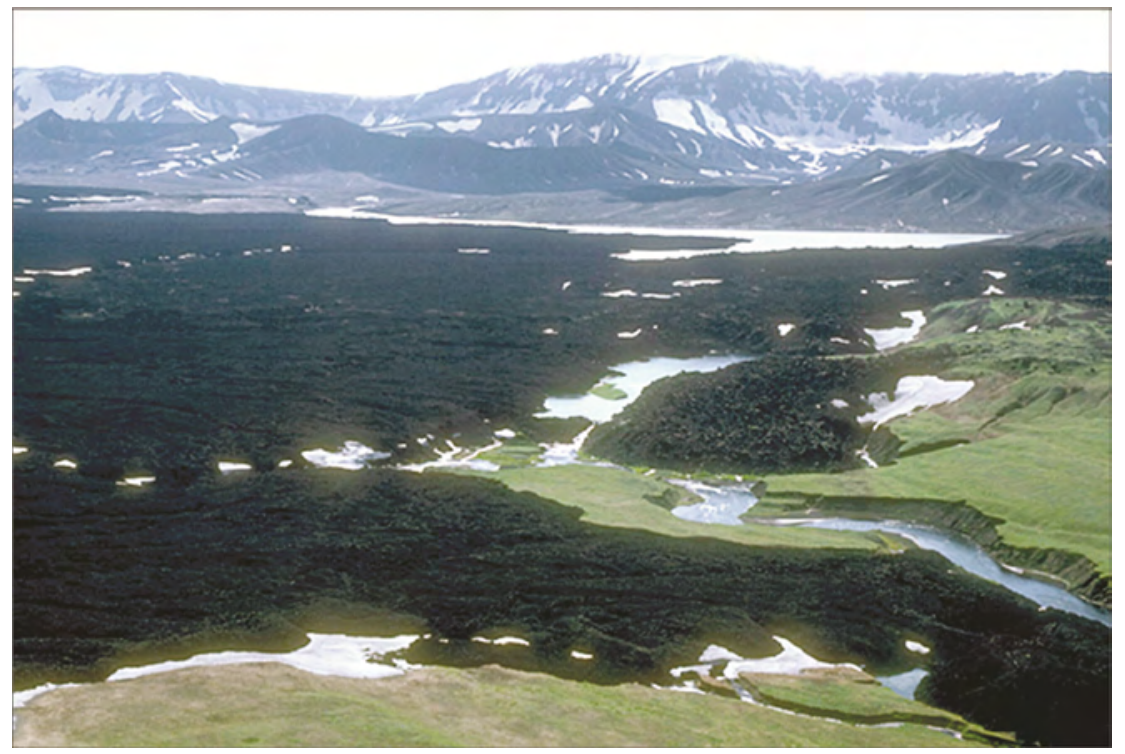

9. View of 1997 basaltic andesite lava flow inside Okmok caldera, a 9.3-km (5.8-mi) diameter circular crater that truncates the top of a large shield volcano on the northeastern part of Umnak Island in the eastern Aleutian Islands. The most recent caldera-forming eruption at Okmok occurred about 2,400 years ago. Since then, numerous intracaldera eruptions have occurred, including the eruption that extruded these blocky lava flows onto the caldera floor. Basaltic andesite is a hard, dark volcanic rock with approximately 52 weight percent silica $\left(\mathrm{SiO}_{2}\right)$. Photograph taken by C. Nye, Alaska Division of 
Geological and Geophysical Surveys, September 1980.

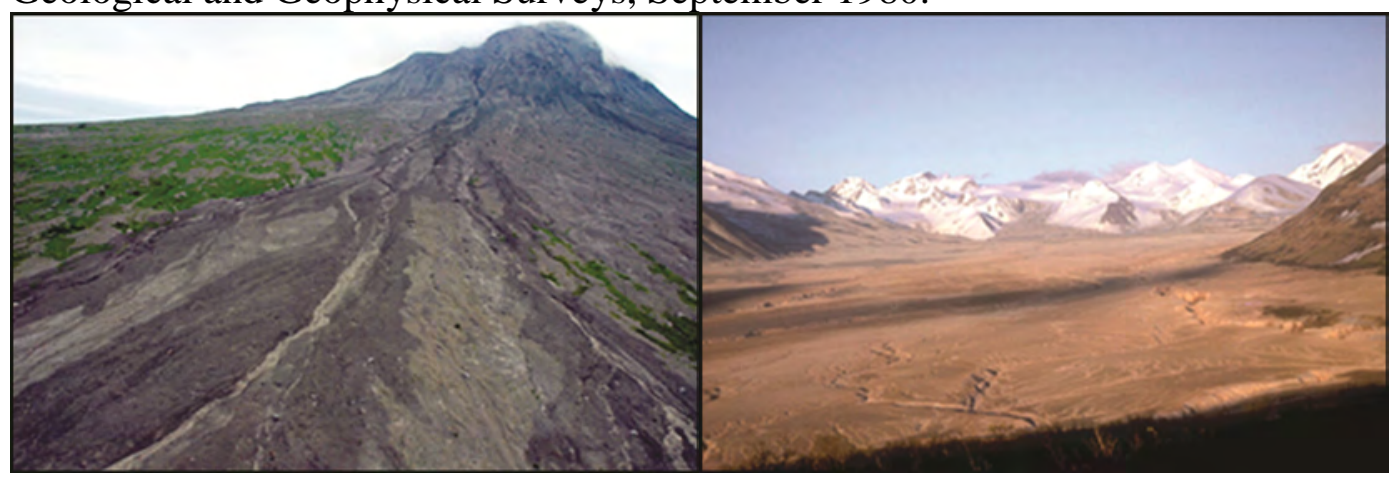

(A)

(B)

10. (A) Pyroclastic flow (deposits of volcanic ash, gas, and pumice flows) deposits on the southwestern flank of Augustine Volcano, Cook Inlet, Alaska. Photograph taken by M. Coombs, U.S. Geological Survey, August 14, 2006.

(B) View southeast looking up the Valley of Ten Thousand Smokes from the Overlook Cabin in Katmai National Park and Preserve, Alaska. The valley has been filled with as much as $200 \mathrm{~m}$ (660 ft) of pyroclastic flow deposits (ignimbrite) from the 1912 eruption of Novarupta volcano. The rim of the Katmai Caldera is on the skyline at left. Photograph taken by R.G. McGimsey, U.S. Geological Survey, June 8, 1991.

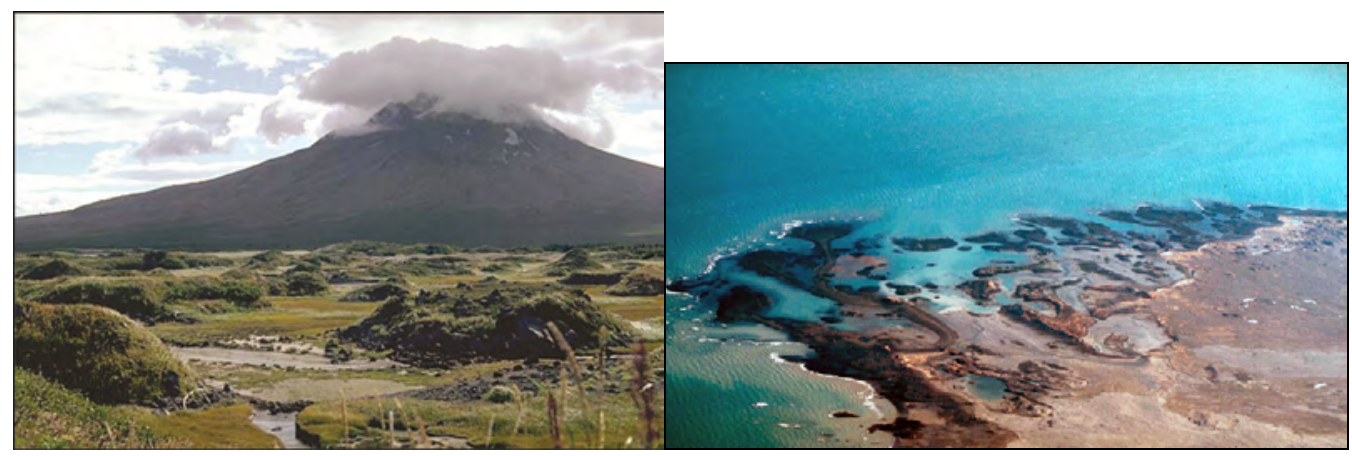

(A)

(B)

11. (A) Collapse of the summit and flank of a volcano can produce massive volcanic landslides. The resulting highly mobile debris avalanches rapidly sweep down the volcano and far beyond its flanks. These small hills in the foreground of Alaska's Augustine volcano show morphology common to debris-avalanche deposits. The hummocks consist of relatively intact segments of the volcanic edifice that were transported long distances without disaggregating (separating, crumbling). This debris avalanche traveled roughly $11 \mathrm{~km}$ ( $\sim 6.8 \mathrm{mi})$ from the summit about 450 years ago. Photograph and caption courtesy of Smithsonian Institution, dated 1987.

(B) Debris avalanche deposits from the 1883 eruption of Augustine Volcano entered Cook Inlet along the north shoreline of the island forming hummocky topography. 
Photograph by U.S. Geological Survey, April 27, 1986.

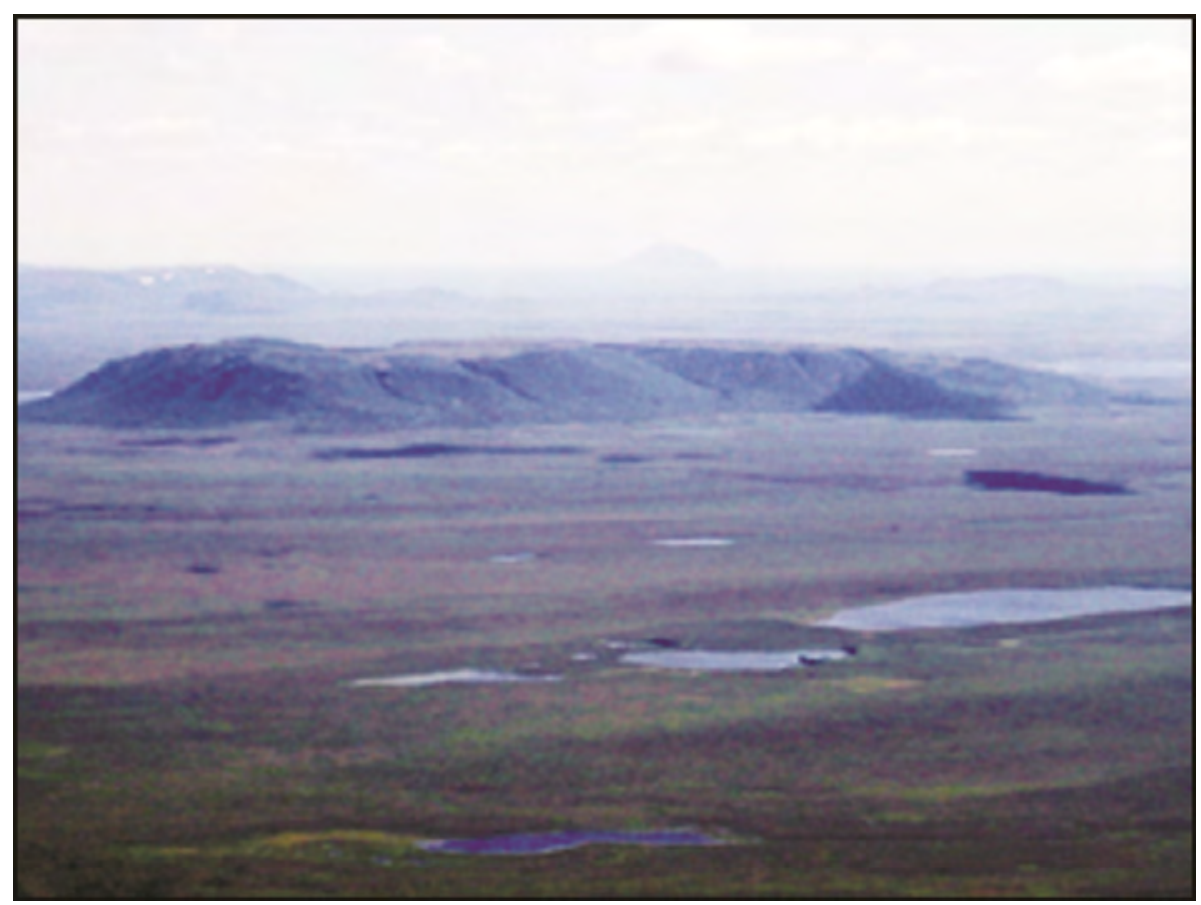

12. Togiak Tuya in the Ahklun Mountains. The Ahklun Mountains form the highest range in Alaska west of the Alaska Range and north of the Alaska Peninsula. A tuya is a table mountain that forms when a volcano erupts underneath a glacier. Photograph taken by Darrell S. Kaufman, Professor of Geology and Environmental Science, Department of Geology, Northern Arizona University, Flagstaff, Arizona, dated 2004. 


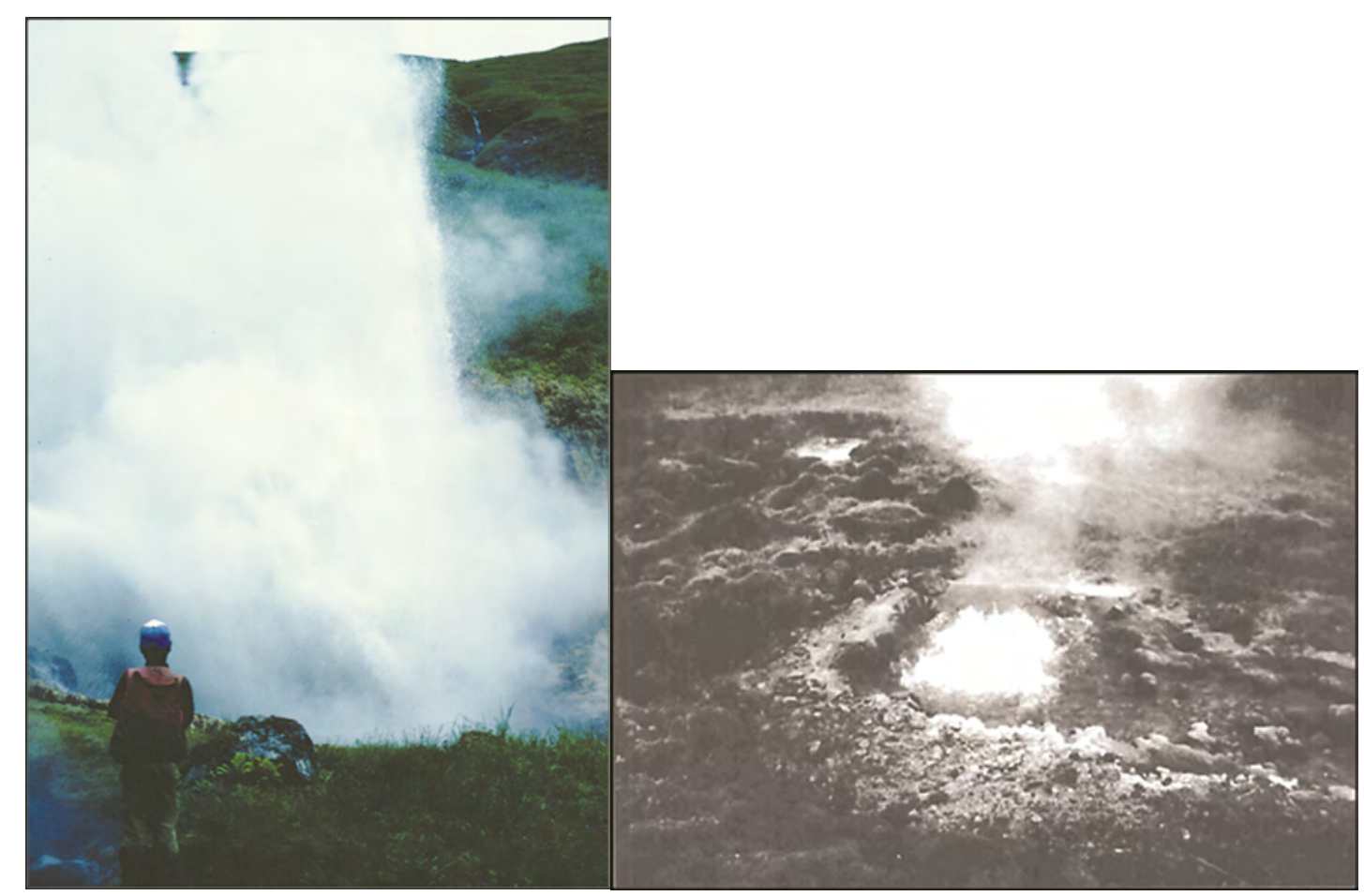

(A)

(B)

13. (A) “Old Faithful” (spring G8) of Geyser Bight geothermal area on Umnak Island, Alaska (shown here at maximum activity). An eruption cycle of 12 minutes was noted when venting of steam was observed $(1870,1948,1980$, and 1988). This activity likely continues when people are not able to see it. This area contains one of the hottest and most extensive areas of geothermal activity in Alaska. This is the only area in Alaska where sustained geyser activity has been documented: geothermal activity was observed at five springs during 1988 (Motkya and others, 1994). Photograph taken by Shirley Liss, Alaska Department of Natural Resources, Division of Geological and Geophysical Surveys, 1988.

(B) Geyser Bight geothermal resource area. Photograph taken by Dave Szumigala, Alaska Department of Natural Resources, Division of Geological and Geophysical Surveys, 1985. 
Name Date Period

\section{Alaska's Volcanic Landforms and Features Worksheet}

Label each image with the type of volcanic feature or landform illustrated. If possible, identify the volcano, its location, and any other information about it.

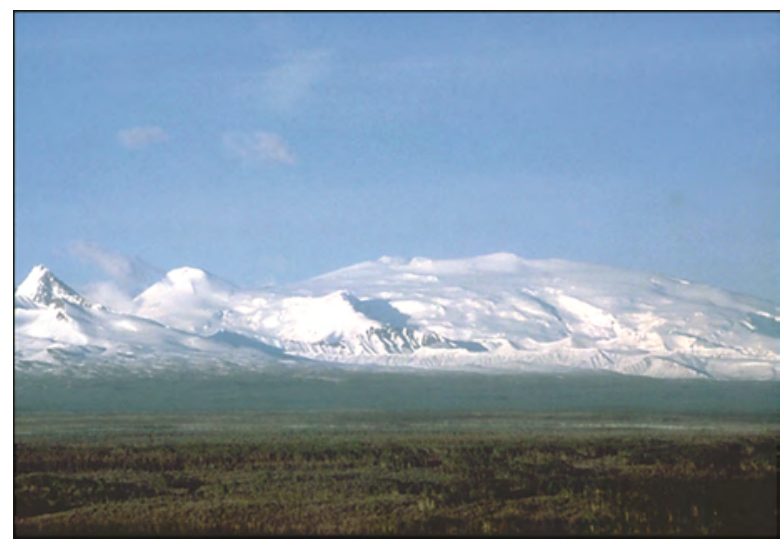

1.

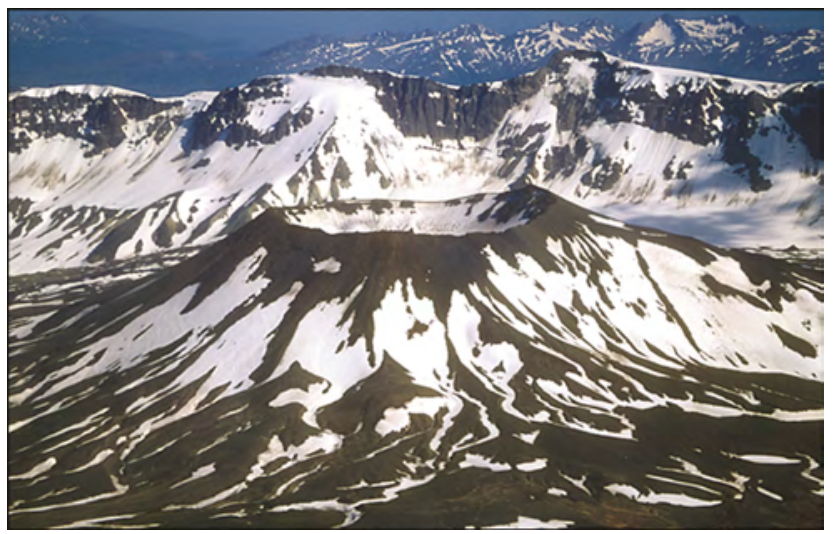

2. 


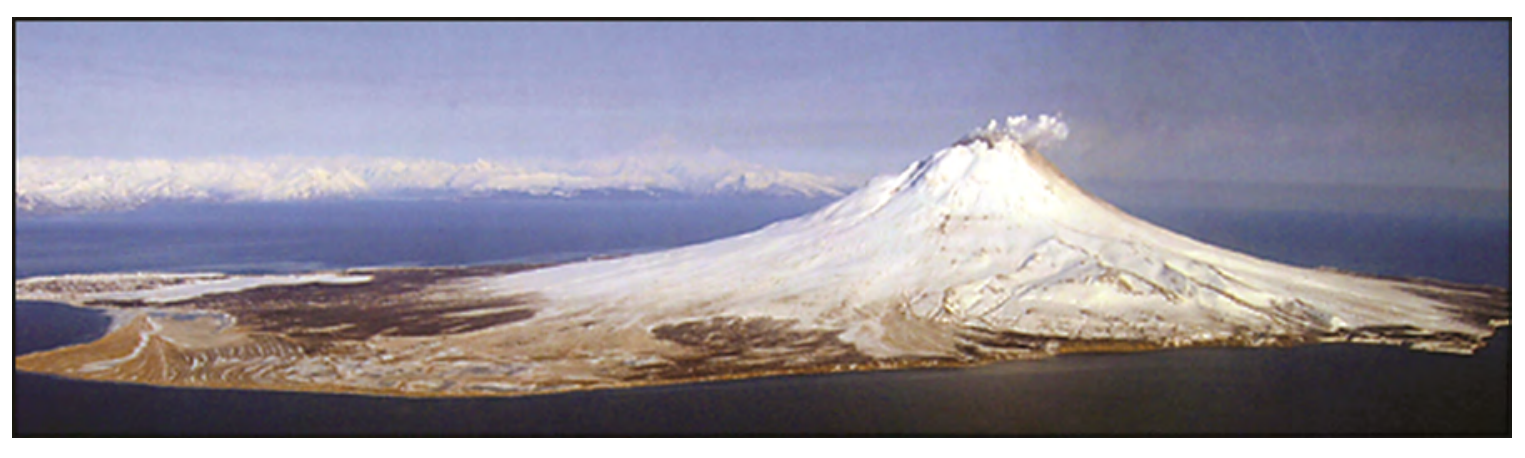

3.

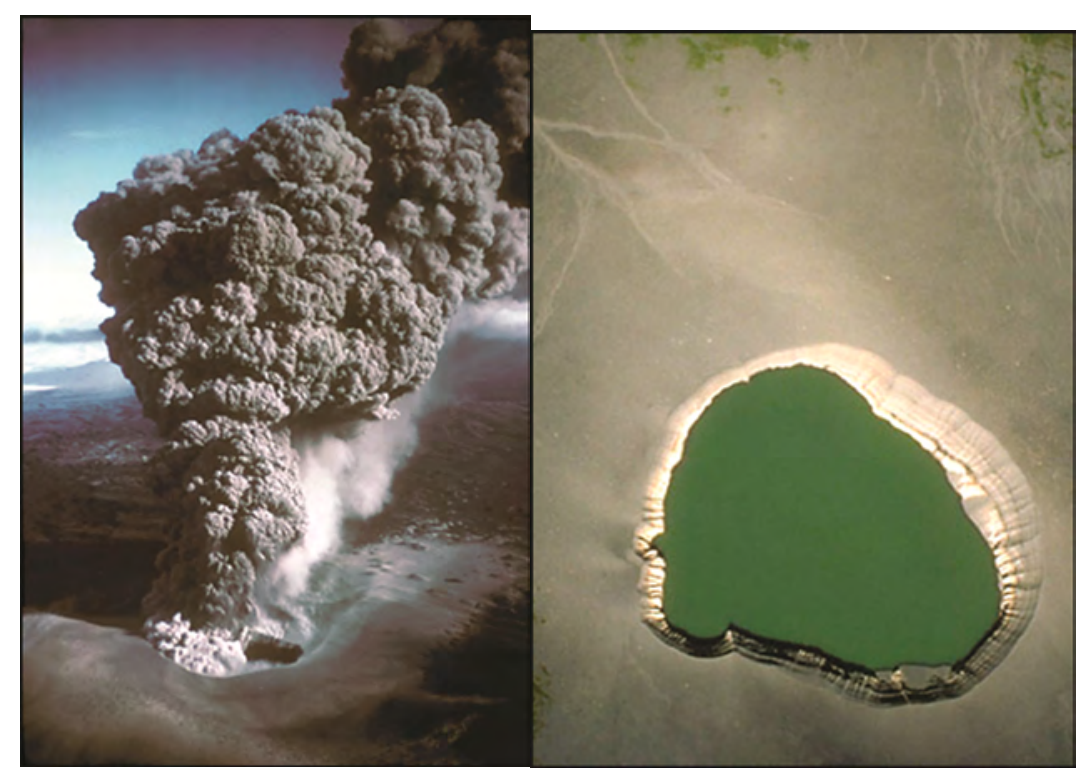

(A)

(B)

4. (A)

(B) 


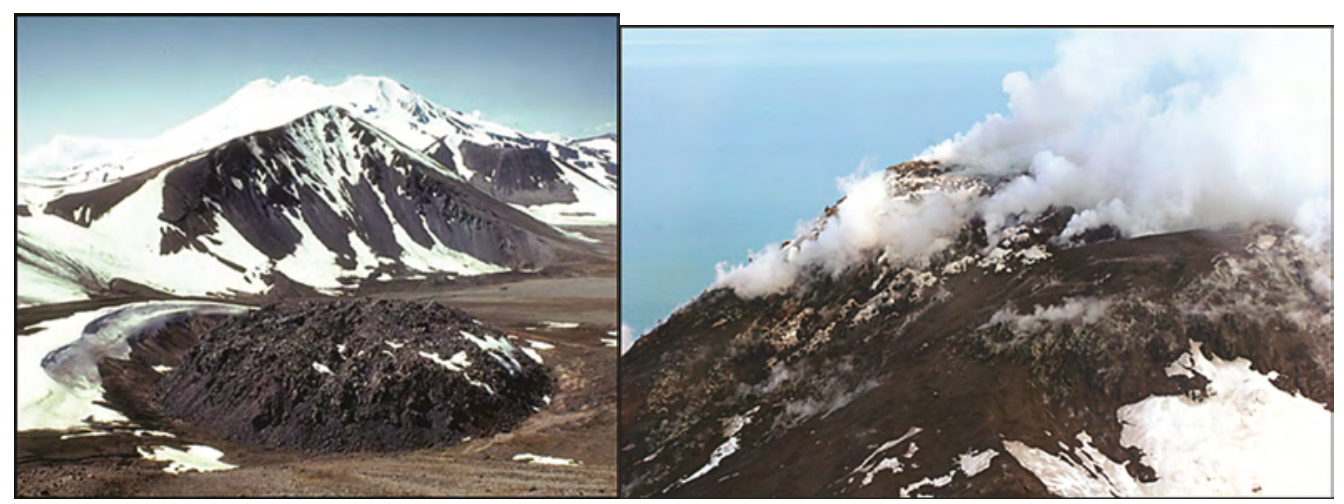

(A)

(B)

5. (A)

(B)

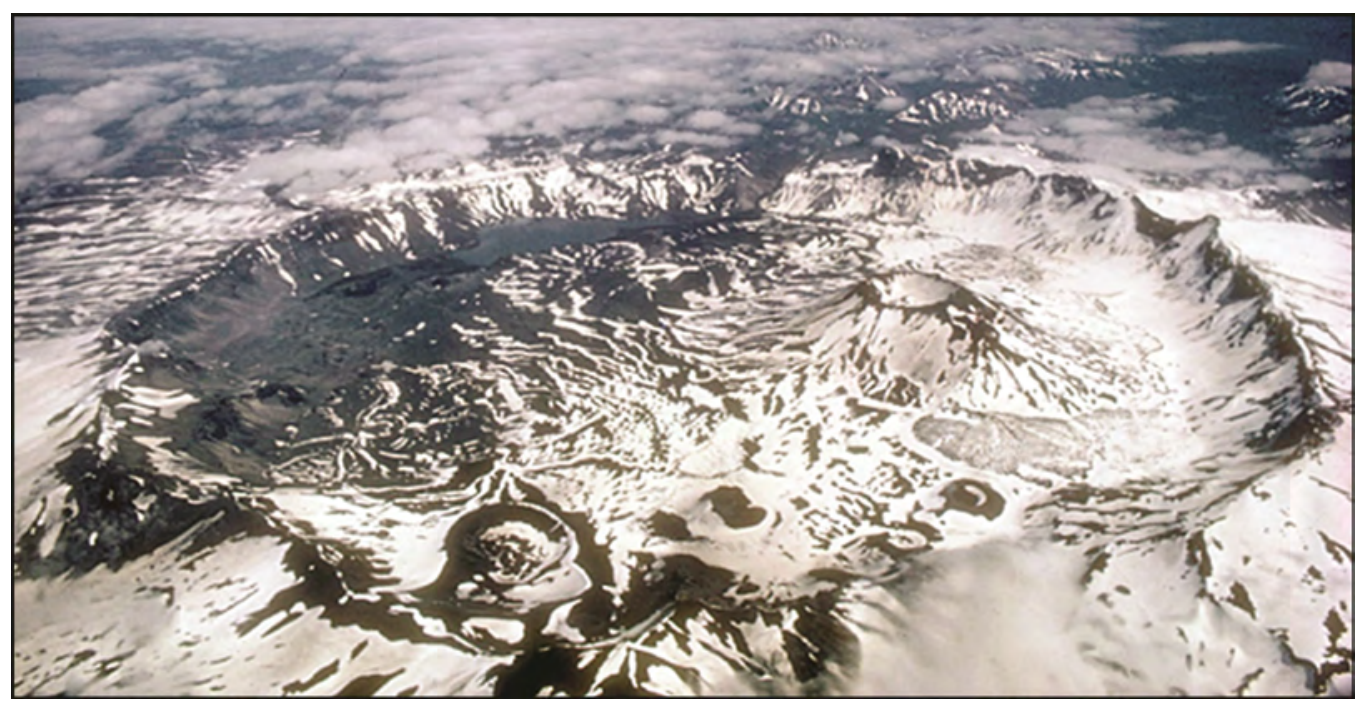

6. 


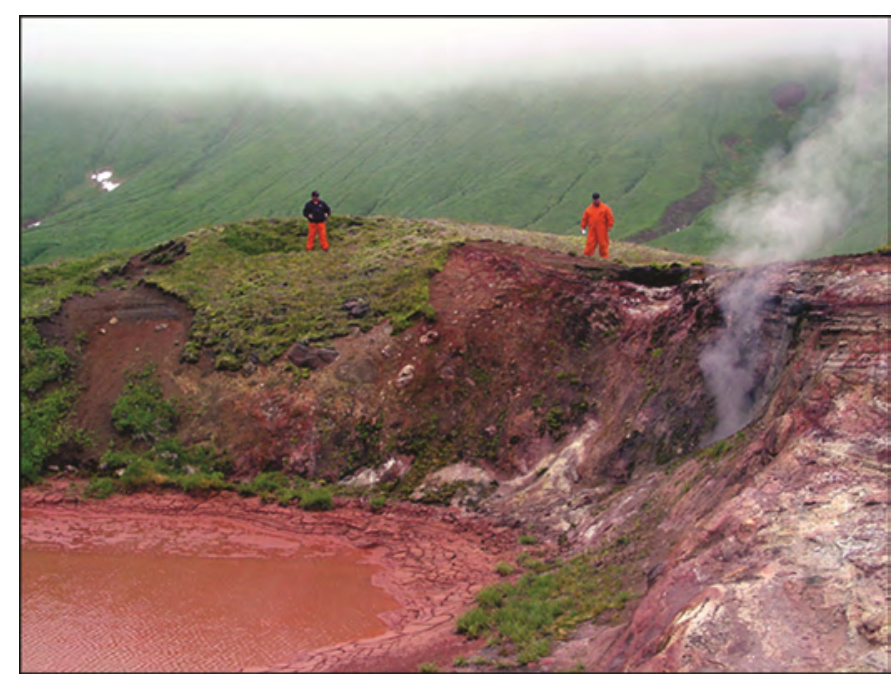

7.

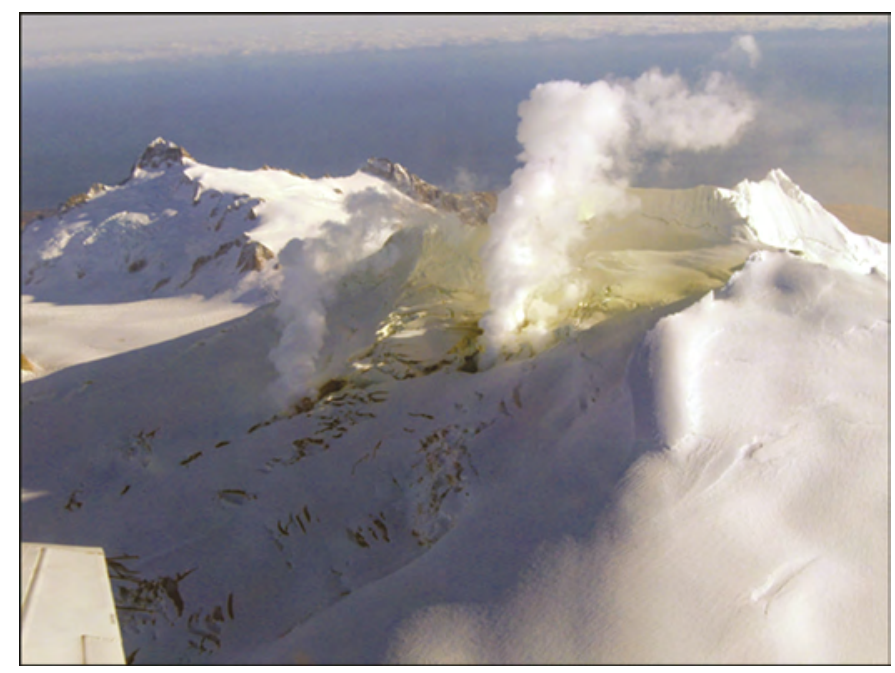

8. 


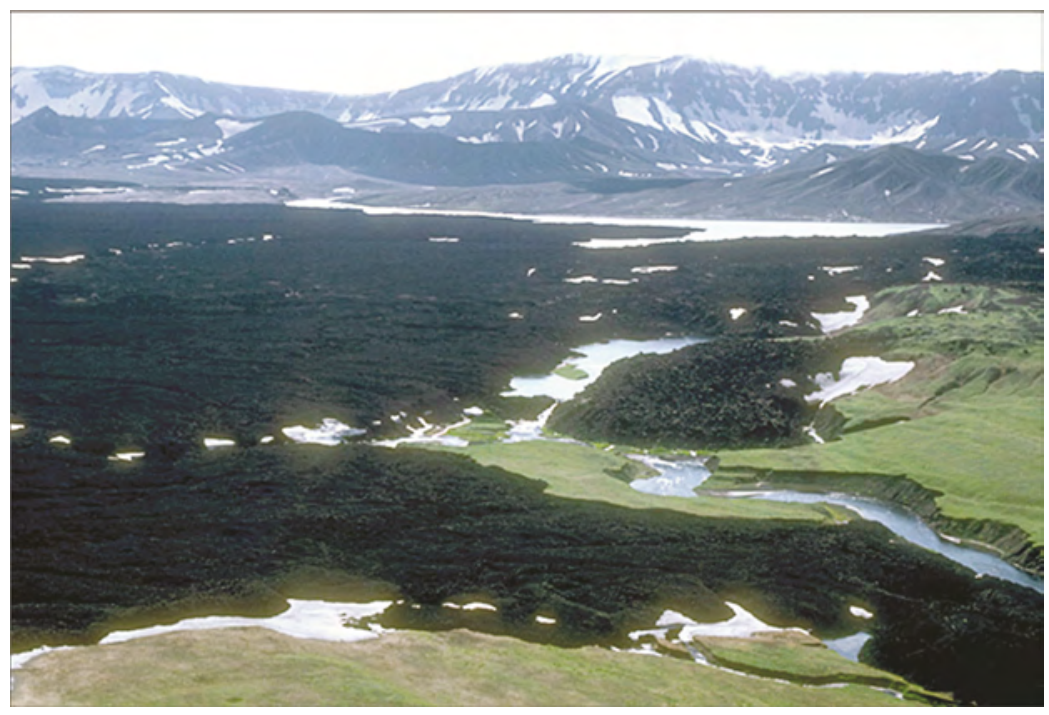

9.

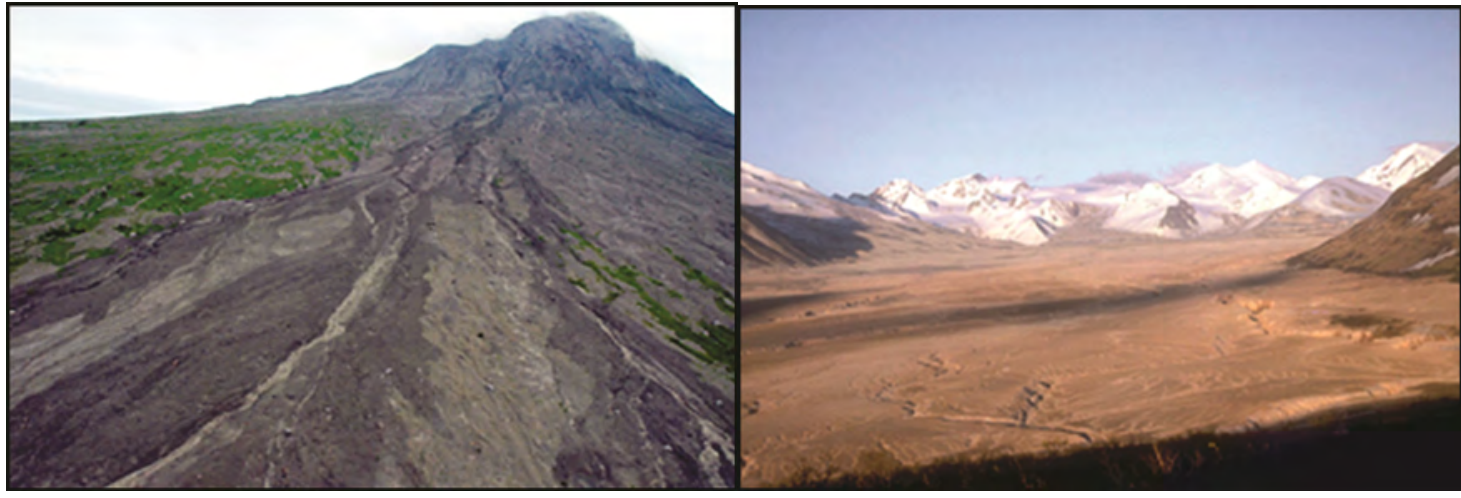

(A)

(B)

10. (A)

(B) 


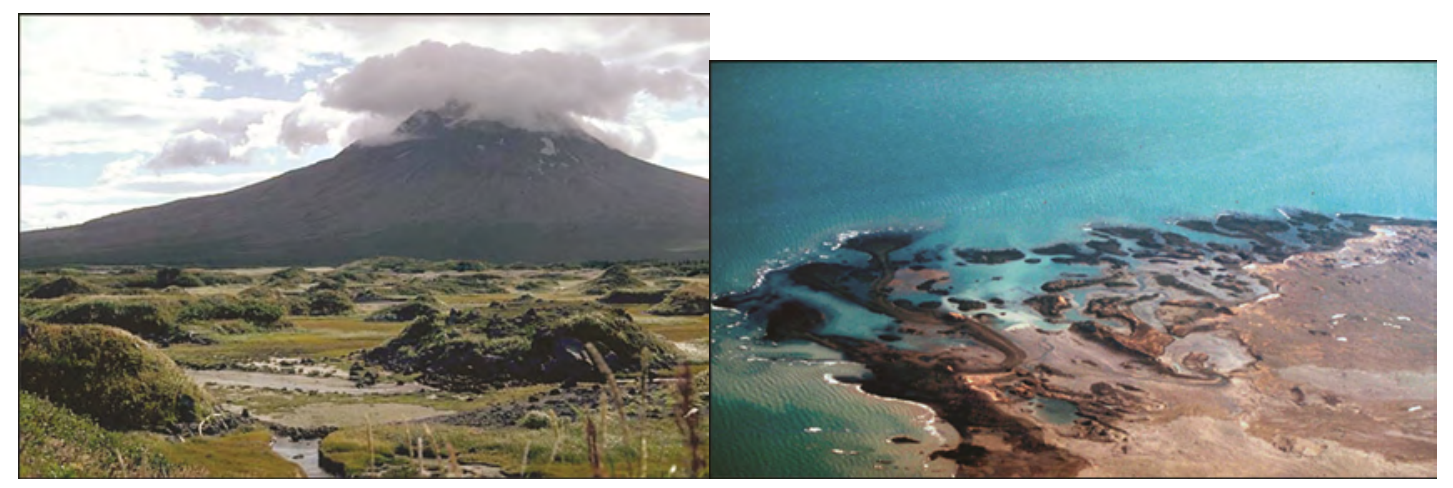

(A)

(B)

11. (A)

(B)

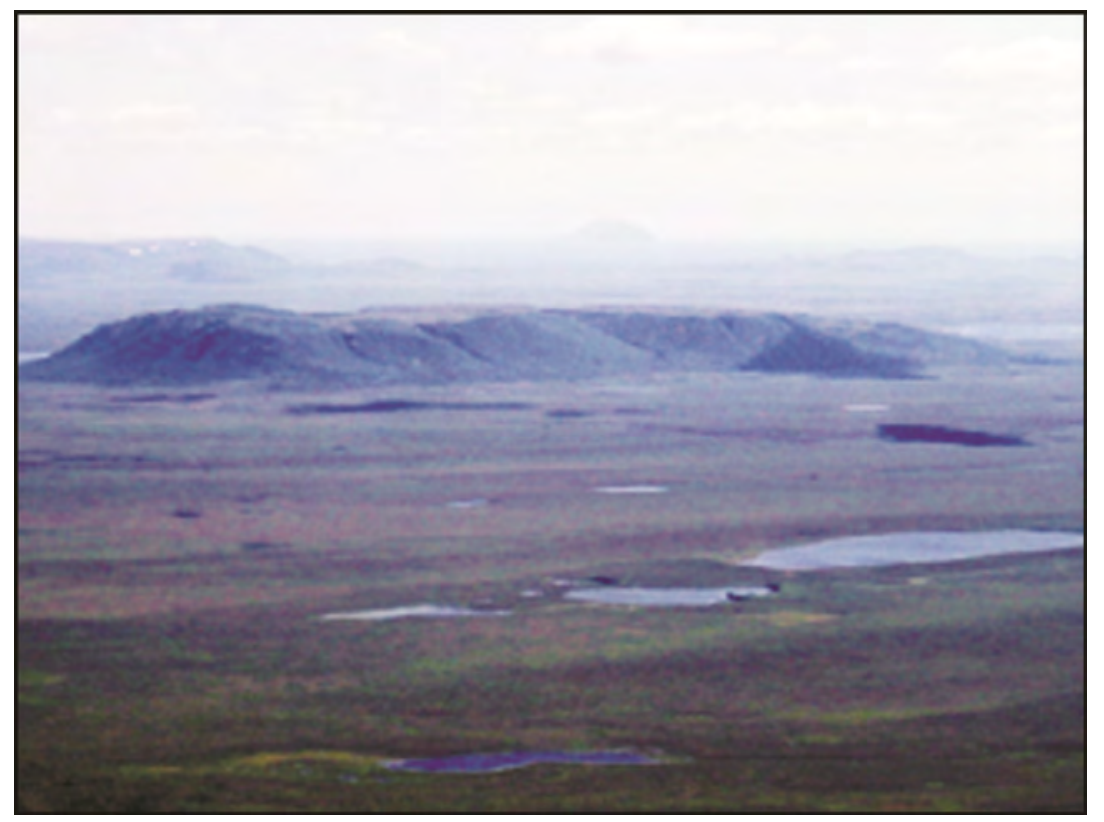

12. 


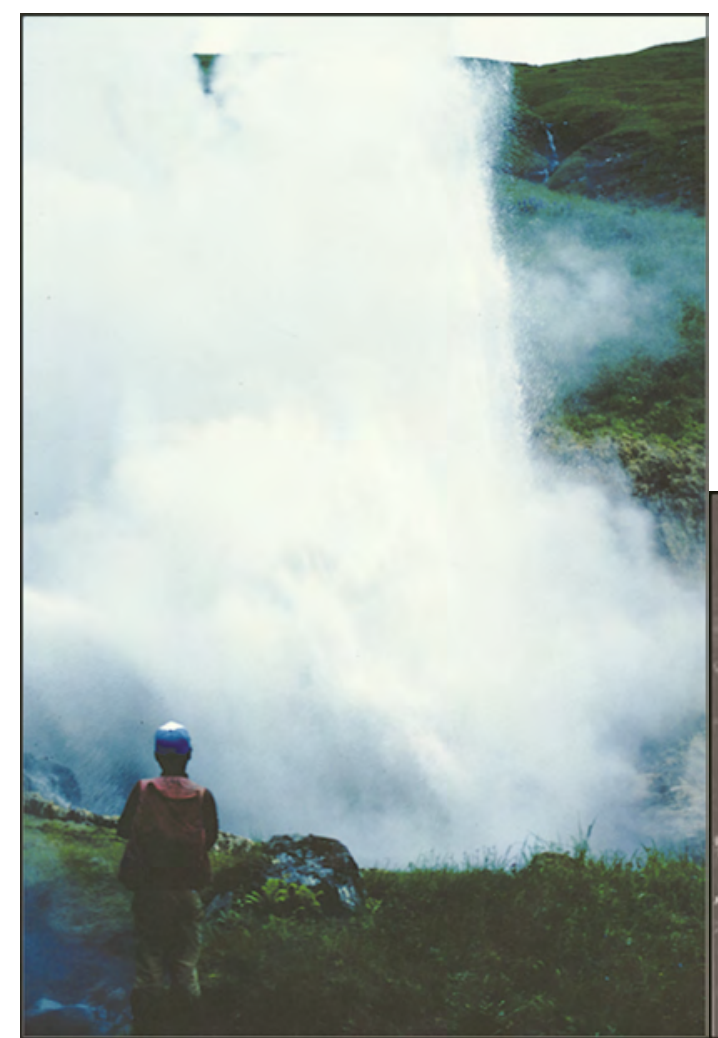

(A)

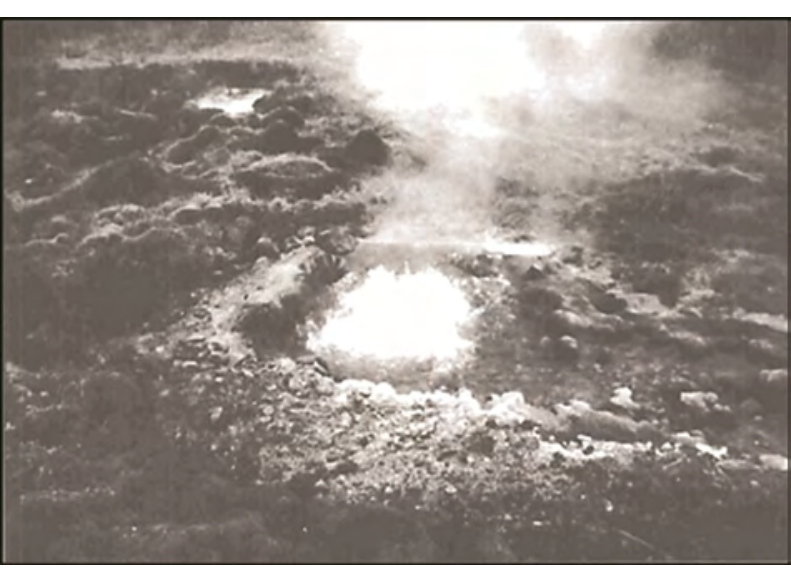

(B)

13. (A)

(B) 
Name

Date

Period

\section{Volcanic Landforms and Features Worksheet}

1. Which type of volcano often shows a layering of lava and pyroclastic flows?

2. Which type of volcano is the least explosive?

3. Which type of volcano has long periods of inactivity?

4. Which type of volcano has the steepest slopes?

5. Which type of volcano forms gentle slopes with low viscosity (resistance to flow) lava?

6. What causes the formation of maars?

7. Why do lava domes form close to a volcano’s vent?

8. Why are lava domes dangerous?

9. Describe the difference between a crater and a caldera.

10. Why are some calderas filled with water?

11. What causes the formation of a resurgent dome? 
12. Describe a fumarole.

13. Why are hot springs located along fault zones?

14. Give an example of a geyser and its location.

15. What are plateau basalts or flood basalts?

16. Draw and label your favorite volcanic landform. Would you expect to see it in Alaska? Why or why not? 


\section{Volcanic Landforms and Features Answer Key}

1. Which type of volcano often shows a layering of lava and pyroclastic flows?

Stratovolcano or composite cone or volcano

2. Which type of volcano is generally the least explosive?

Shield

3. Which type of volcano may have long periods of inactivity?

Stratovolcano or composite cone or volcano

4. Which type of volcano typically has the steepest slopes?

Tephra or cinder cones

5. Which type of volcano forms gentle slopes with low viscosity (resistance to flow) lava?

Shield

6. What causes the formation of maars?

Maars result from phreatic (or phreatomagmatic) activity wherein magma heats up water in the groundwater system, pressure builds as the water to turns to steam, and then the water and preexisting rock (if it includes new magma it is phreatomagmatic) are blasted out of the ground to form a tephra cone with gentle slopes.

7. Why do lava domes form close to a volcano's vent?

Because the viscosity of the type of lava that forms a dome is so high, the lava does not flow away from the vent, but instead piles up over the vent. Recall that viscosity is resistance to flow, so a high viscosity material would move very slowly resist flow. 
8. Why are lava domes dangerous?

Lava domes can be extremely dangerous because they form steep, unstable slopes that may collapse to expose gas-rich, viscous magma to atmospheric pressure. Lava domes often can cause a variety of dangerous hot, buoyant, and gas-rich volcanic surface flows such as a pyroclastic flow.

A pyroclastic flow is a ground-hugging avalanche of hot ash, pumice, rock fragments, and volcanic gas that rushes down the side of a volcano as fast as $100 \mathrm{~km} / \mathrm{hour}$ ( 60 $\mathrm{mi} /$ hour) or more. The temperature within a pyroclastic flow may be greater than $500^{\circ} \mathrm{C}\left(\sim 930^{\circ} \mathrm{F}\right)$, sufficient to burn and carbonize wood. Once deposited, the ash, pumice, and rock fragments may deform (flatten) and weld together because of the intense heat and the weight of the overlying material; the feature is then called a pyroclastic flow deposit.

9. Describe the difference between a crater and a caldera.

Craters are circular depressions, usually less than $1 \mathrm{~km}(\sim 0.6 \mathrm{mi})$ in diameter, that form as a result of explosions that emit gases and tephra. Calderas are much larger depressions, circular to elliptical in shape, with diameters ranging from $1 \mathrm{~km}$ to 50 $\mathrm{km}(0.6$ to $31 \mathrm{mi})$. Calderas form as a result of collapse of a volcanic structure. The collapse results from evacuation of the underlying magma chamber.

10. Why are some calderas filled with water?

Calderas are often enclosed depressions that can collect rainwater and snow melt, and lakes often form within them.

11. What causes the formation of a resurgent dome?

After the formation of a caldera by collapse, magma is sometimes re-injected into the area below the caldera. This can result in uplift of one or more areas within the caldera to form a resurgent dome.

12. Describe a fumarole.

A fumarole is vent where gases, either from a magma body at depth, or steam from heated groundwater, emerge at the ground surface.

13. Why are hot springs located along fault zones?

Hot springs are areas where hot water comes to the ground surface. A hot spring results if hot water can find its way back to the surface, usually along fault zones. 
14. Give an example of a geyser and its location.

A geyser results if a hot spring has a plumbing system cavern of chamber that allows for the accumulation of steam from local boiling water. When the steam pressure builds so that it is higher than the pressure of the overlying water in the system, the steam will move rapidly toward the surface, causing the eruption of the overlying water. Some geysers, like Old Faithful in Yellowstone National Park in Wyoming, and Calistoga's Old Faithful Geyser in California, erupt at regular intervals. The "Old Faithful" of the Geyser Bight geothermal resource area in Alaska had an eruption cycle of 12 minutes (Motkya and others, 1994). The time between eruptions is controlled by the time it takes for the steam pressure to build in the underlying plumbing system.

15. What are plateau basalts or flood basalts?

Plateau or flood basalts are extremely large volume outpourings of low viscosity basaltic magma from fissure vents. The basalts spread huge areas of relatively low slope and build up plateaus.

16. Draw and label your favorite volcanic landform. Would you expect to see it in Alaska? Why or why not?

Variable 


\section{Activity II. Topographic Profiles of Alaskan Volcanoes}

Grade Level 6-11

Setting Classroom

Time 45-90 minutes

Vocabulary (see Glossary)

caldera, cinder cone, shield volcano, stratovolcano (or composite cone), topographic map, topographic profile

Correlations to Alaska State Department of Education (2006) Performance Standards (Grade Level Expectations)

D1-Concepts of Earth Science

SD[6-11] Students develop an understanding of the concepts, processes, theories, models, evidence, and systems of earth and space sciences.

SD2[6-11] Students develop an understanding of the origins, ongoing processes, and forces that shape the structure, composition, and physical history of the Earth.

\section{Overview}

Students will produce topographic profiles from topographic maps of varying types of volcanoes in Alaska.

\section{Background}

- Jacaranda, 2005, Project j-How to draw a cross-section: John Wiley \& Sons Australia, Ltd website, accessed June 10, 2010, at http://www.jaconline.com.au/downloads/sose/2004-09-x-section.pdf.

- National Park Service, [n.d], WebRangers—Reading a Map: National Park Service webpage, accessed July 2, 2010, at http://www.webrangers.us/activities/readingmap/.

- Save the Bay's San Francisco Bay Watershed Curriculum, Three Ways to be 3-DUnderstanding Topographic Maps PDF http://www.savesfbay.org/sites/default/files/Three_Ways_to_be_3d.pdf.

- U.S. Geological Survey, 2007, What do maps show? Lesson 4-How to read a topographic map: U.S. Geological Survey webpage. (Available at http://egsc.usgs.gov/isb/pubs/teachers-packets/mapshow/lesson4.html.)

- U.S. Geological Survey, 2008, Topographic mapping-Online edition: U.S. Geological Survey website. (Available at http://erg.usgs.gov/isb/pubs/booklets/topo/topo.html.)

- Topographic Profile and Vertical Exaggeration information sheets provided 


\section{Objectives}

These activities will provide students with an understanding of the types of volcanoes in Alaska, and their different topographic features. Students will practice or learn new mapping skills.

\section{Materials}

— topographic and road maps of roughly the same location

- pencils

- drawing paper (lined, graph, or blank)

— ruler or straightedge (optional)

- Wrangell, Shishaldin, Okmok, and Tanaga Island worksheets

\section{Procedure}

\section{A. Different type of maps and Venn diagrams}

1. Show your students a topographic map and a road map of the same location. These maps do not need to include a volcanic region. The maps could show the community you teach in, a common vacation spot, or a distant location. The goal is to draw attention to different kinds of maps and give examples of how the same location can be illustrated differently.

2. Ask students to make a Venn diagram that shows how the topographic and roadmaps are similar and different. Venn diagrams are illustrations to show the relation between different groups of things (sets, typically as circles): where they (these circles) overlap and where they do not.

3. Discuss with your students how topographic maps are used and how they differ from road maps. For example, topographic maps illustrate changes in slope, uphill and down, and even the steepness or gentleness of the slope. In many cases, roadmaps do not illustrate changes in slope and may not be to scale. Both types of maps likely have a distance scale, labels for certain streets, community features, hospitals, and schools. See the Background section for reference materials to aid in leading discussion.

\section{B. Volcano Profiles and Topographic Profile Questions worksheets}

1. Hand out all profile worksheets and guide the students through the process of generating topographic profiles. Have the students answer the Topographic Profile Questions worksheet based on their profiles. Discuss their answers. 


\section{Extensions}

1. Driedger, C.L., Doherty, Anne, and Dixon, Cheryll, 2005, Living with a volcano in your backyard-An educator's guide with emphasis on Mount Rainier: U.S.

Geological Survey General Interest Product 19; produced in cooperation with the National Park service. (Available at

- Chapter 3: Don't be Scared-Be Prepared! Play Dough Topo!

http://vulcan.wr.usgs.gov/Outreach/Publications/GIP19/chapter_three_playdough topo.pdf.

2. U.S. Geological Survey, 1997 [2007], Volcanoes teacher's guide-Windows into the Earth-Why volcanoes occur: U.S. Geological Survey website. (Available at http://erg.usgs.gov/isb/pubs/teachers-packets/volcanoes/lesson1/lesson1.html.)

\section{References Cited}

Alaska State Department of Education and Early Development, 2006, Standards and grade level expectations, March 2006: State of Alaska website, accessed October 2009 at http://www.eed.state.ak.us/tls/assessment/GLEHome.html.

Motyka, R.J., Liss, S.A., Nye, C.J., and Moorman, M.A., 1994, Geothermal resources of the Aleutian arc: Alaska Division of Geological and Geophysical Surveys Professional Report 114, 17 p., 4 sheets, scale 1:1,000,000, accessed June 1, 2010, at http://www.dggs.dnr.state.ak.us./pubs/pubs?reqtype=citation\&ID=2314.

\section{Glossary}

Caldera - A caldera is a large, usually circular depression at the summit of a volcano formed when magma is withdrawn or erupted from a shallow underground magma reservoir. The removal of large volumes of magma may result in loss of structural support for the overlying rock, thereby leading to collapse of the ground and formation of a large depression. Calderas are different from craters, which are smaller, circular depressions created primarily by explosive excavation of rock during eruptions.

Cinder cone - A steep, conical hill of volcanic fragments that accumulate around and downwind from a vent.

Shield volcano - A volcano characterized by low angle slopes

Stratovolcano - A type of volcano (also called a composite cone), characterized by slope angles of as much as 35 degrees

Topographic map - A map showing topographic features of a land surface, commonly by means on contour lines.

Topographic profile - The outline produced where the plane of a vertical section intersects the surface of the ground 


\section{Source of Glossary Definitions}

Bates, R.K., and Jackson, J.A., eds., 1987, Glossary of Geology (3 ${ }^{\text {rd }}$ ed.): Falls Church, Va., American Geological Institute, 571 p.

U.S. Geological Survey, 2008, Cascades Volcano Observatory-Volcano Types : U.S. Geological Survey web page. (Available at

http://vulcan.wr.usgs.gov/Glossary/VolcanoTypes/volcano_types.html. 


\section{Topographic Profiles and Vertical Exaggeration}

\section{Topographic Profiles}

1. Draw a line the length of A-A on a separate piece of paper. Match up this line with A-A on the worksheet. Draw light or dashed lines from where the map A-A line crosses a contour line to your newly drawn line of the same length on your separate paper. On your separate paper note the contour value that A-A crossed. Repeat this process until you have reached the end of A-A .
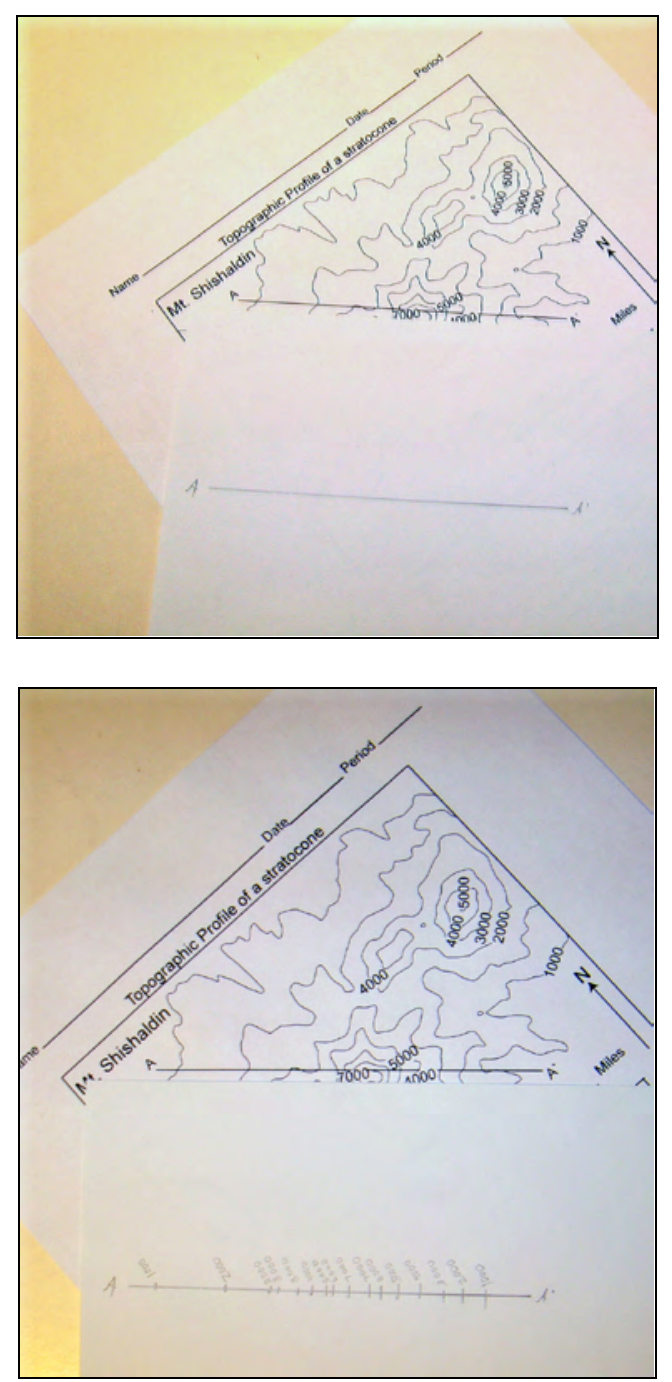
2. Match up your separate paper with A-A` and contour values with the horizontal line A-A ' on the plot area of your worksheet. Extend your light or dashed lines from the additional paper to the appropriate horizontal line for each noted contour value on your worksheet plot area and make a dot.

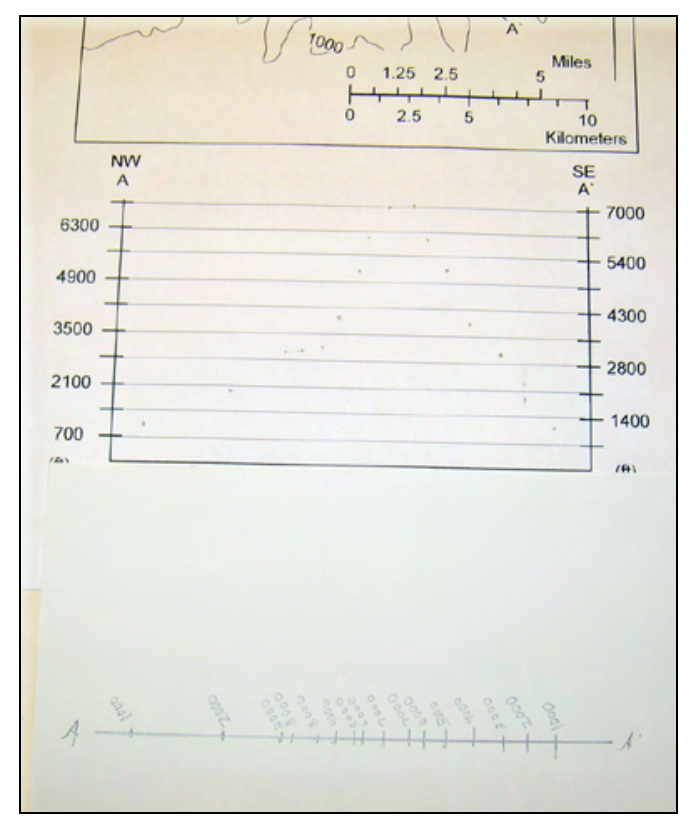

3. Connect the dots on the plot to complete.

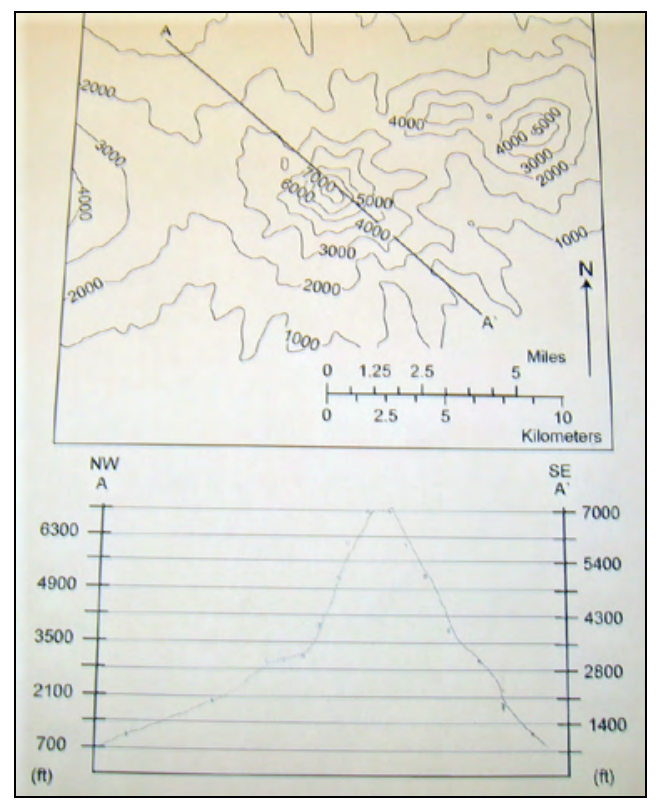




\section{Vertical Exaggeration}

Each map has a different vertical exaggeration noted near the region in which the profile will be drawn. The vertical exaggeration is the ratio between the vertical scale and the horizontal scale. If the two were the same, the ratio would be 1 and there would be no vertical exaggeration. However, because of the scale of most maps, the small amount of variation in elevation at map scale will mask most details of topography. Therefore, topographic profiles are typically generated with vertical exaggeration to emphasize the variations in topography.

One can figure out the vertical exaggeration in the following steps.

1. Determine the number of feet represented by 1 in. on the vertical axis of the topographic profile.

2. The horizontal scale of the profile is the same as the map.

3. The vertical exaggeration is determined by dividing the horizontal scale by the vertical scale. vertical exaggeration $=$ horizontal (map) scale/vertical scale

\section{Calculated Vertical Exaggerations for Worksheets Okmok Caldera}

Horizontal: $3.125 \mathrm{mi} / 1$ in. $=16,500 \mathrm{ft} / 1$ in.

Vertical: $1,254 \mathrm{ft} / 1$ in.

$16,500 / 1,254=13.16$ vertical exaggeration $(\sim 13 \mathrm{x})$

\section{Mt. Shishaldin}

Horizontal: $2.71 \mathrm{mi} / \mathrm{i}$ in. $=14,309 \mathrm{ft} / 1$ in.

Vertical: 2,800 ft / 1 in.

$14,309 / 2,800=5.11$ vertical exaggeration $(\sim 5 \mathrm{x})$

\section{Tanaga Island}

Horizontal: $3.75 \mathrm{mi} / \mathrm{i}$ in. $=19,800 \mathrm{ft} / 1$ in.

Vertical: $640 \mathrm{ft} / 1 \mathrm{in}$.

$19,800 / 640=30.94$ vertical exaggeration $(\sim 31 \mathrm{x})$

\section{Mt. Wrangell}

Horizontal: $4.1 \mathrm{mi} / 1$ in. $=21,648 \mathrm{ft} / 1 \mathrm{in}$.

Vertical: 7,000 ft / 1 in.

$27,648 / 7,000=3.09$ vertical exaggeration $(\sim 3 \mathrm{x})$ 


\section{Topographic Profile of a caldera}
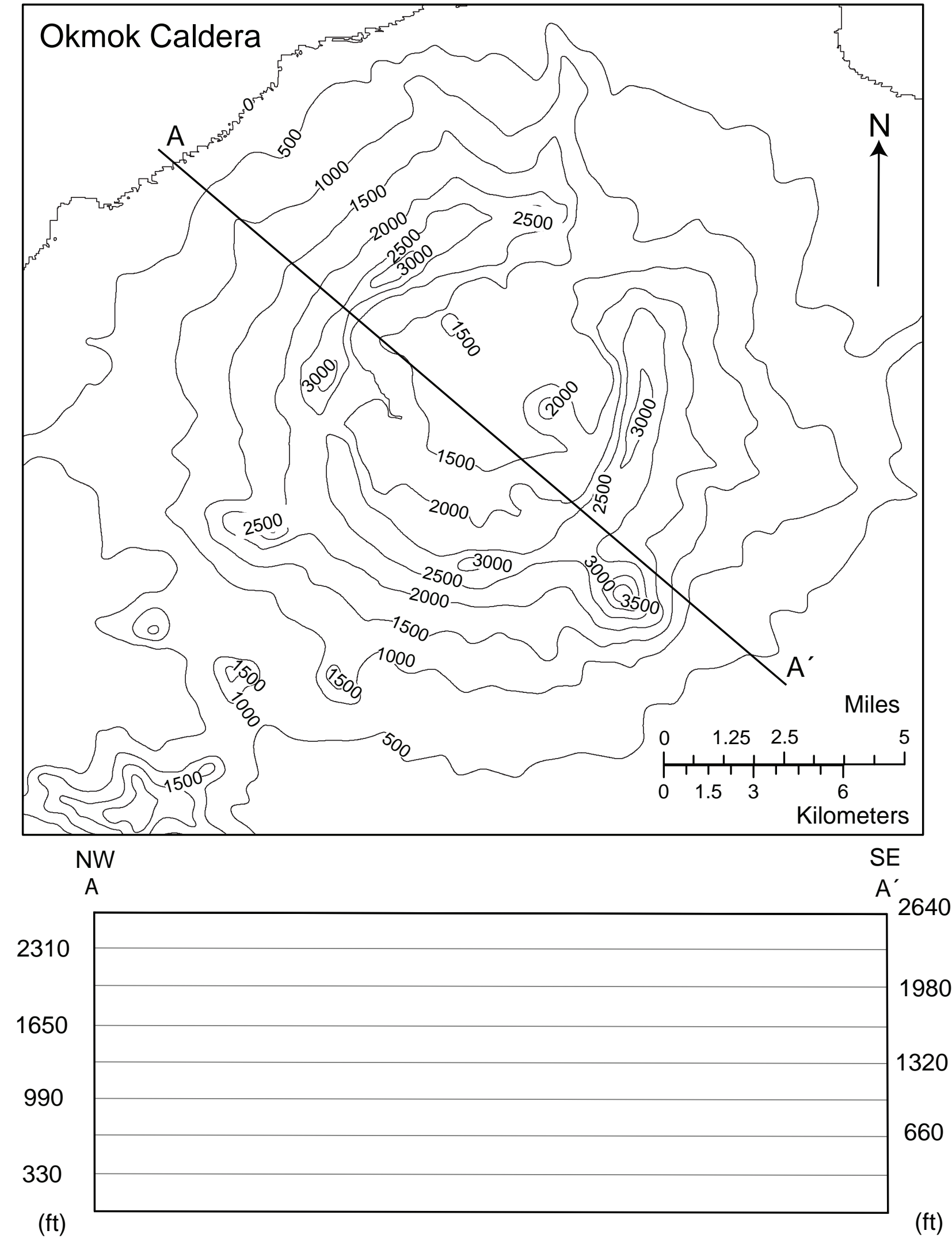
Topographic Profile of a caldera
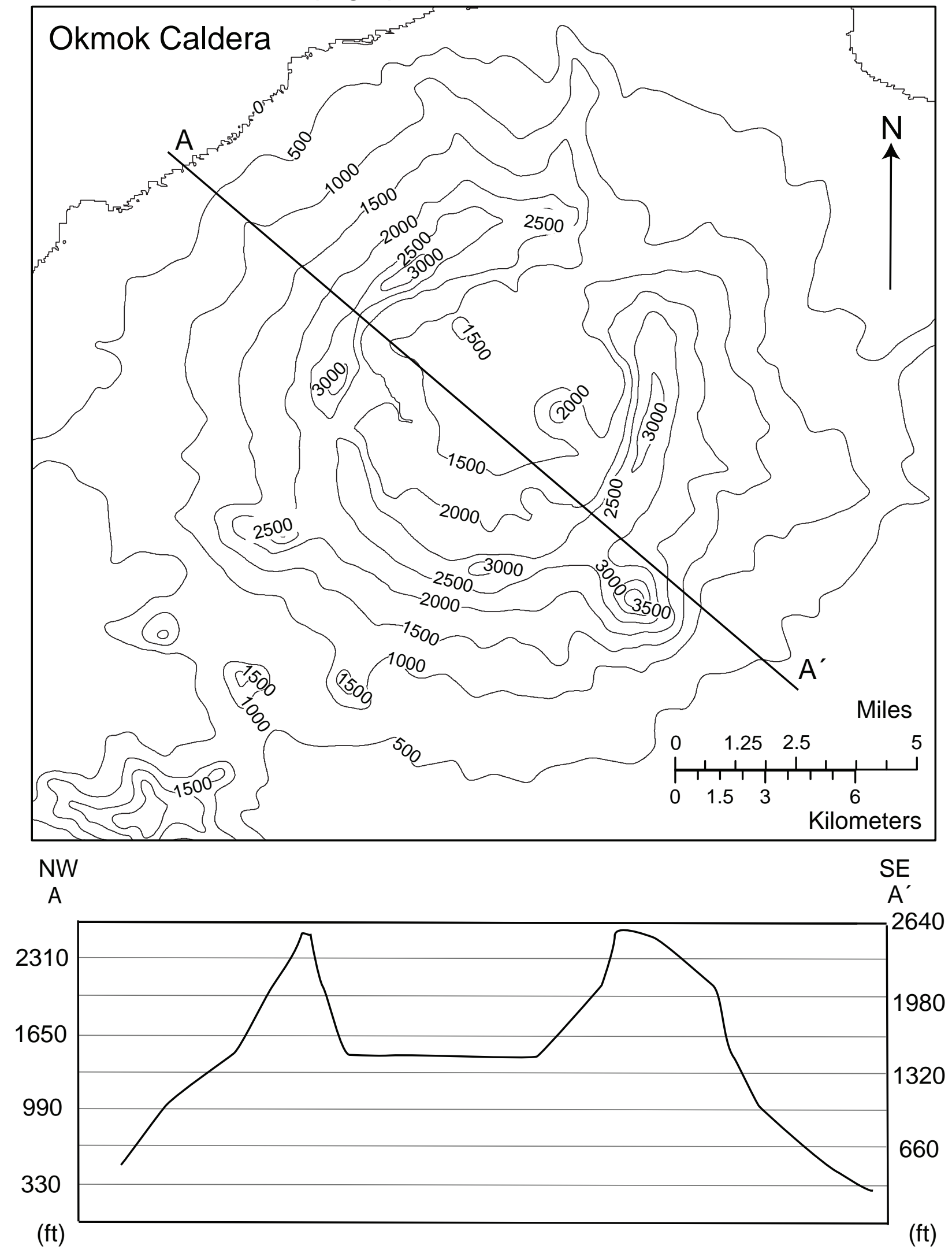

$13 \times$ vertical exageration 
Topographic Profile of a stratocone

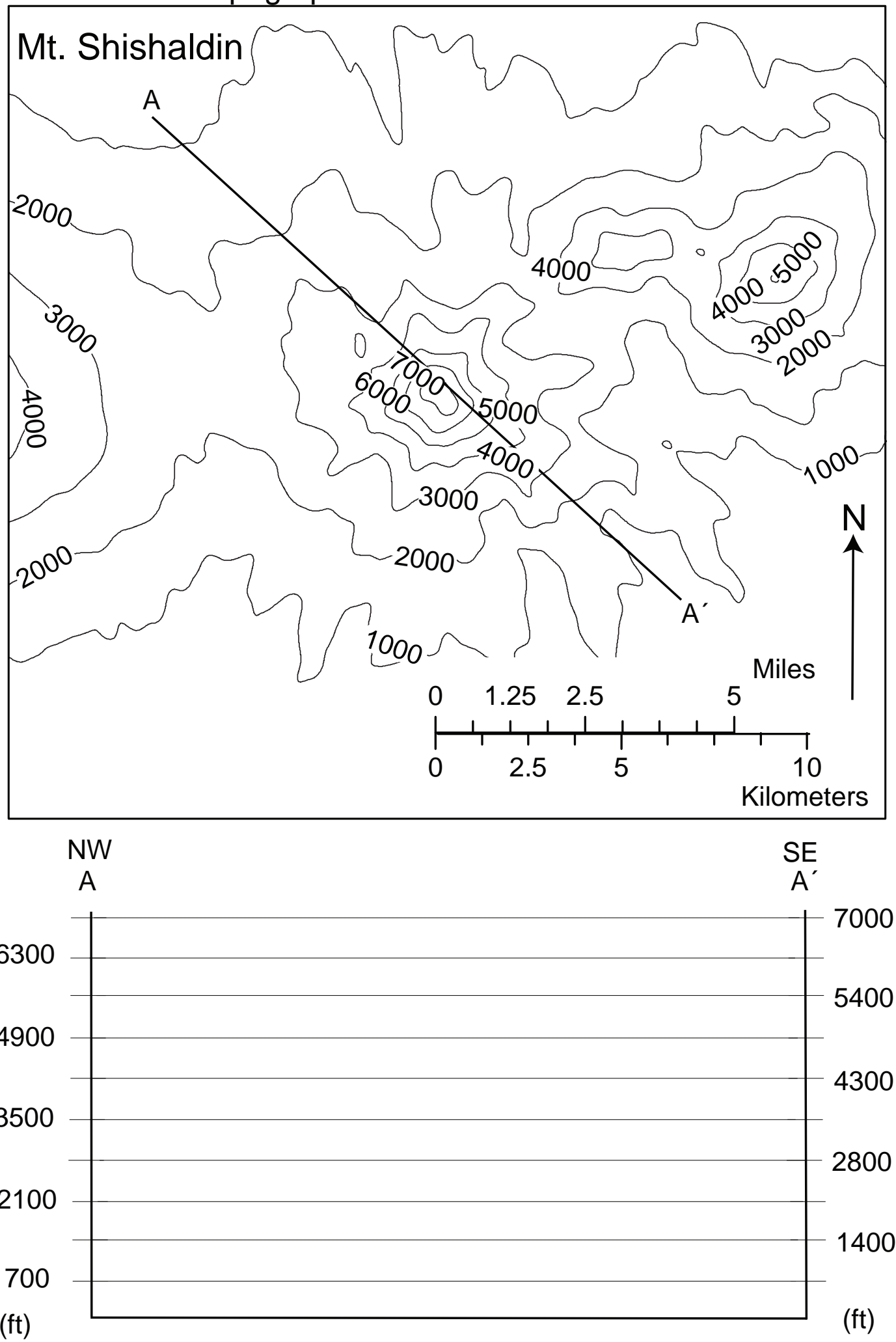

$5 x$ vertical exaggeration 
Topographic Profile of a Stratocone
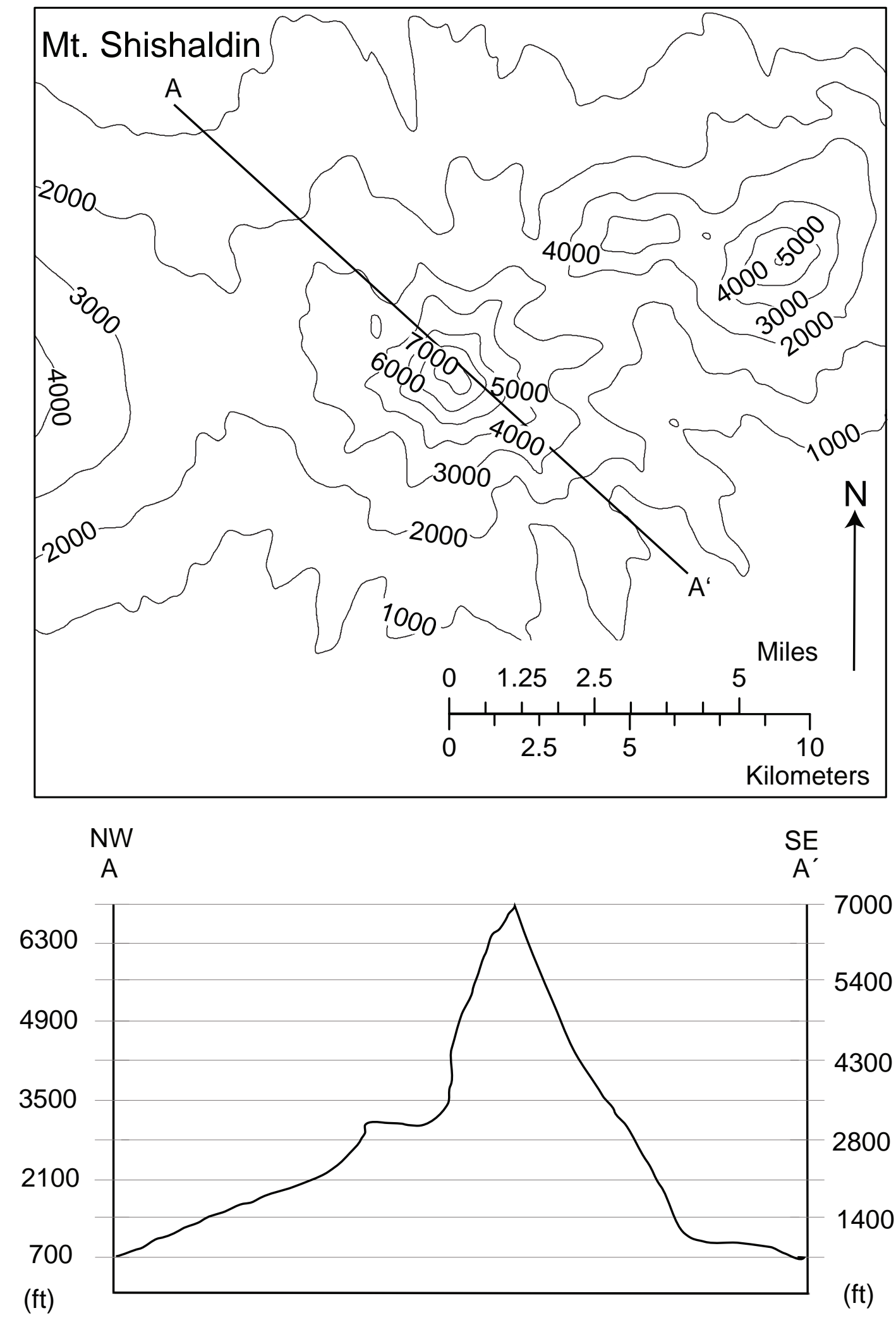

$5 x$ vertical exaggeration 
ио!ฺеләббехә јеว!นләл х

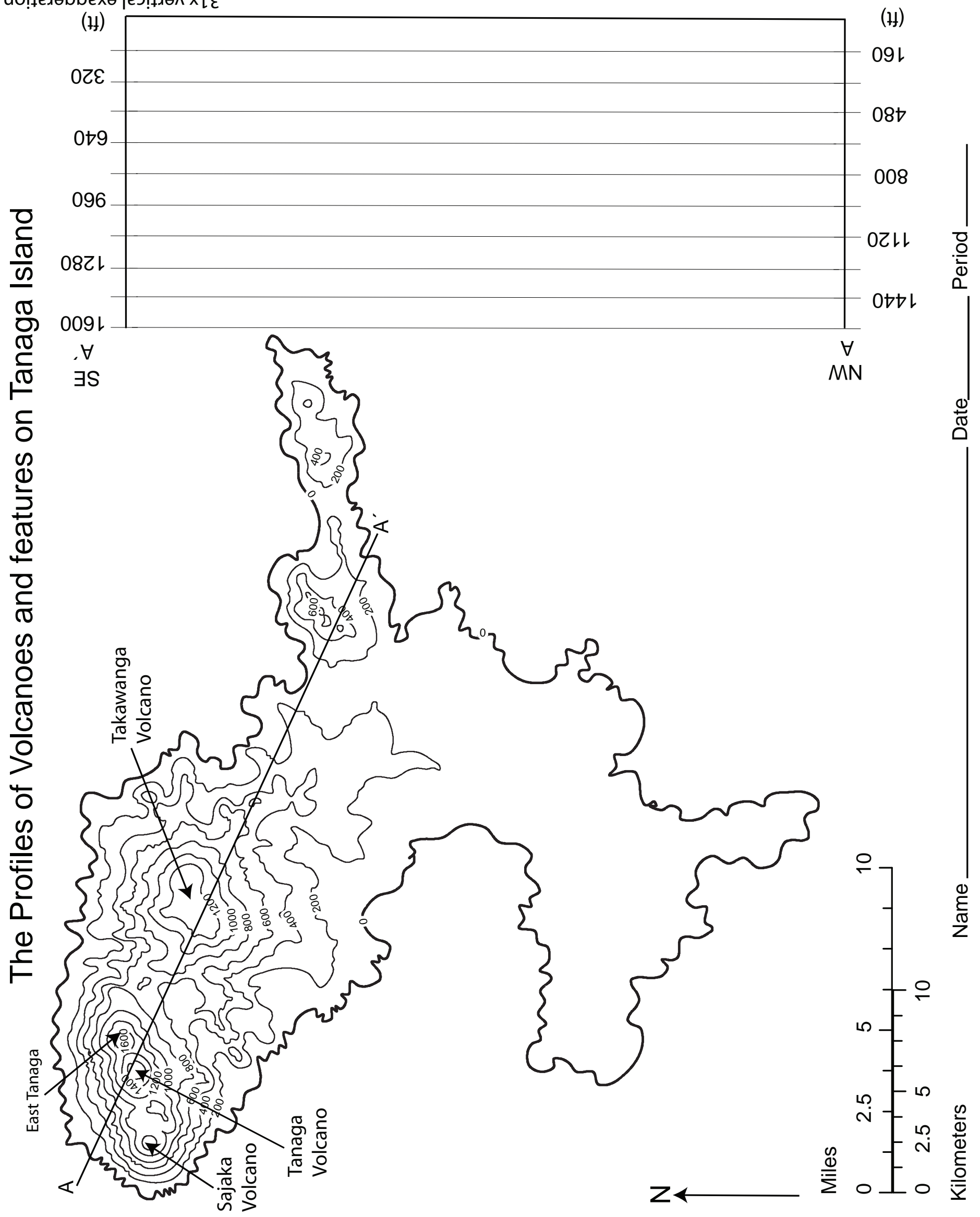




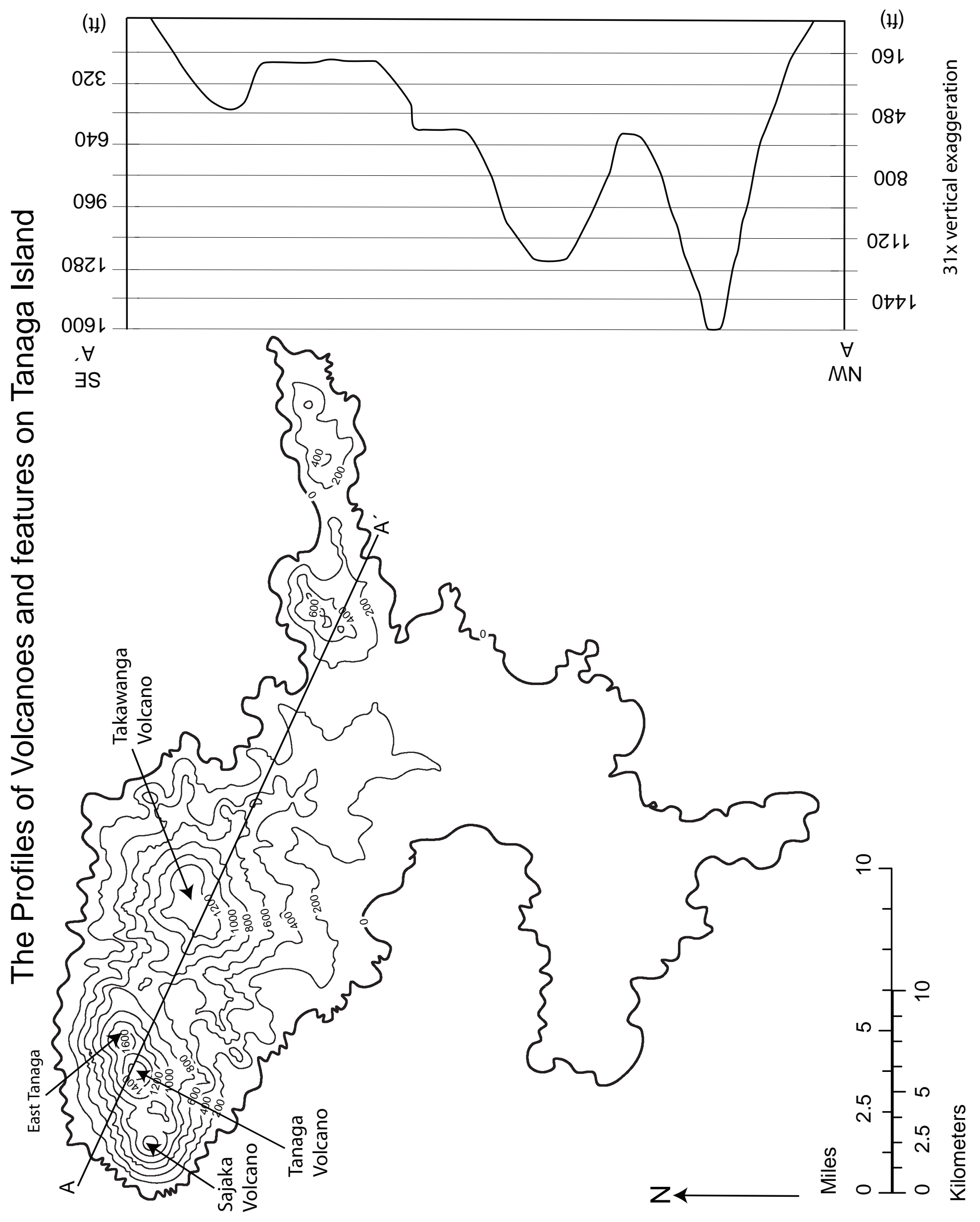


Topographic Profile of a shield

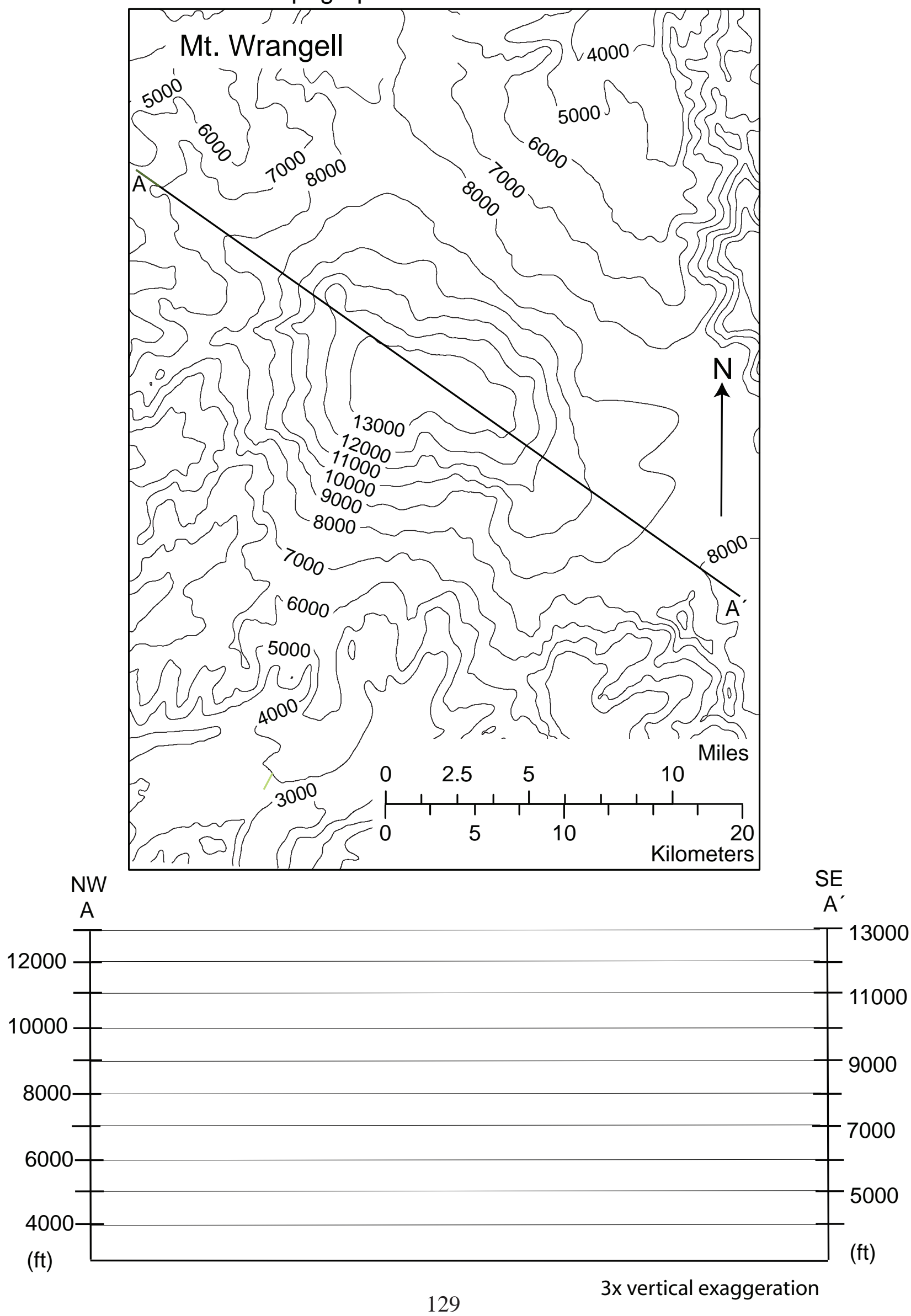


Topographic Profile of a Shield

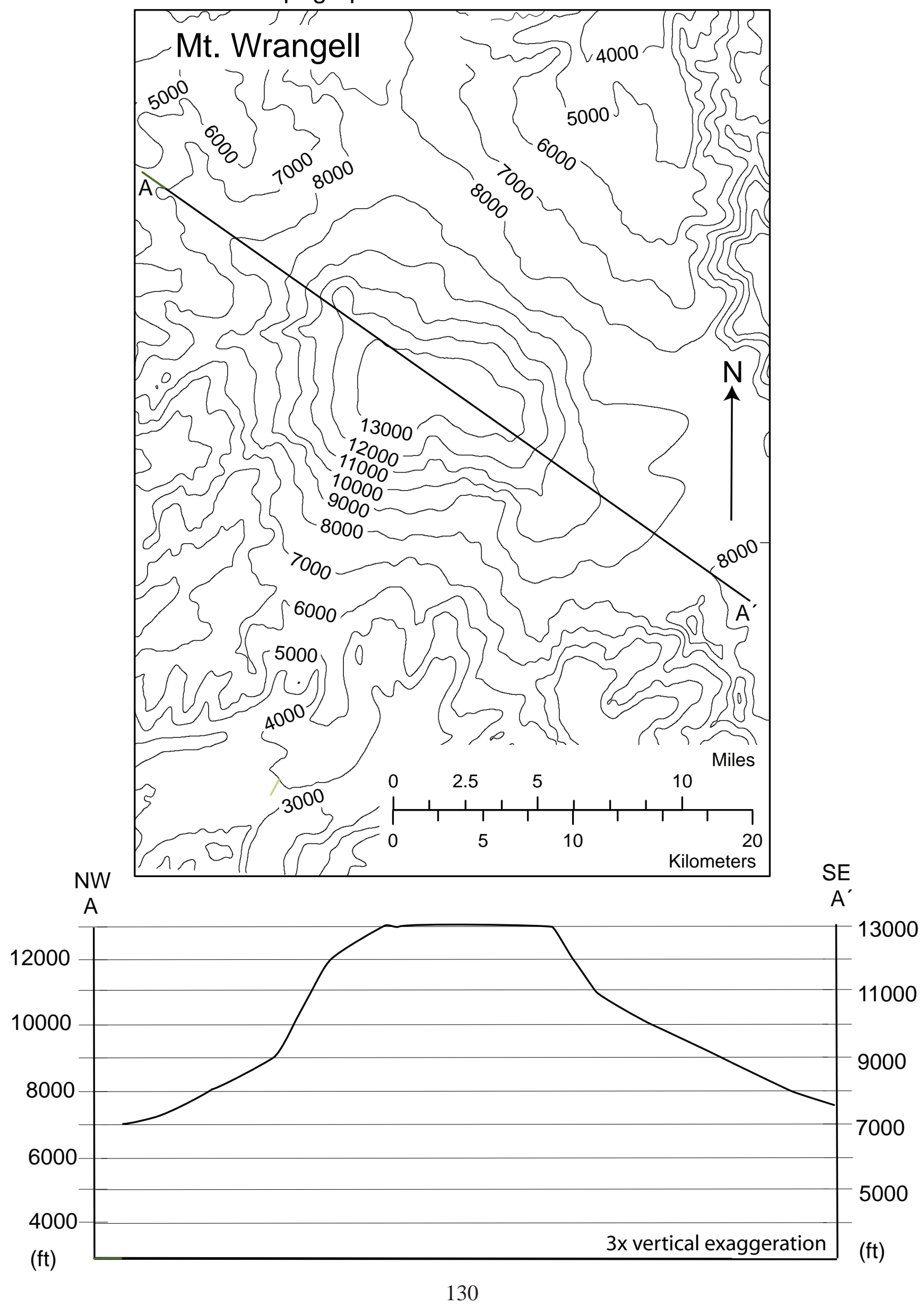


Name

Date

Period

\section{Topographic Profile Questions}

1. How do these topographic profiles compare to one another?

2. What type of volcano has the steepest slopes? The most gentle slopes? Why?

3. Can a single volcano have more than one peak? If yes, give an example from this activity.

4. Can a single volcanic island be composed of more than one volcano? If so, give an example from this activity.

5. Do topographic profiles illustrate the type of rock that comprises a volcano? Explain. 


\section{Topographic Profile Questions Key}

1. How do these topographic profiles compare to one another?

Mt. Shishaldin's topographic profile is steep and pointy...

Okmok Caldera has a rim (students may wrongly think two peaks) on either side of a low area...

Mt. Wrangell's profile is high and gently sloping with abroad flat appearing summit region...

Tanaga Island's profile has several features combined...

2. What type of volcano has the steepest slopes? The most gentle slopes? Why?

Shishaldin is steepest and is a stratovolcano. Wrangell is a shield volcano with the gentlest slopes. The viscosity of the lavas and deposits that form these volcanoes varies, contributing to the shape of volcanoes. The steeper the volcanic shape, the greater the likelihood of a higher viscosity of the lava.

3. Can a single volcano have more than one peak? If yes, give an example from this activity.

Yes (Tanaga is an example here). Students may think Okmok does, but what looks like two peaks in profile is really a rim.

4. Can a single volcanic island be composed of more than one volcano? If so, give an example from this activity.

Yes (Tanaga is the example here).

5. Do topographic profiles illustrate the type of rock that comprises a volcano is comprised? Explain.

In some cases, yes. The shape and slope angle of a shield volcano may relate to the viscosity and type of lava that formed the volcano. One example is the basaltic shield volcano Kilauea on the Big Island of Hawai'i. However, we have previously discussed that Wrangell volcano, also a shield volcano, is andesitic in composition and is made of more viscous lava than Kilauea. The shield shape of Wrangell is due to an eruption, which released a large volume of lava in a short amount of time. 


\section{Activity III. Alaska’s Volcanic Arc of Fame}

Grade Level 6-11

Setting Classroom

Time 30-90 minutes (or can be completed as a homework assignment)

\section{Vocabulary (see Glossary)}

acidic, altitude, amphitheater, ancestral, anoxic, ash plume, basal, caldera, cinder cone, composite volcano, crater, decapitated, diameter, dormance, edifice(s), elliptical, emergent, emission, ephemeral, erosion, explosive volcanic eruption, extinct, fissure, flank, fumarole, fumarole field, geothermal glaciation, hot springs, inadvertently, incandescence, intermittently, intracaldera, lahar(s), latitude, lava dome, longitude, maar, margin, marine terrace, olivine basalt, originating, parasitic, peak, phreatomagmatic, plateau, postcaldera, quadrangle, radiate, remnant, saddle, shield volcano, $\mathrm{SO}_{2}$, stratovolcano, submarine, submerged, sulfur, summit, symmetrical, truncated, vigorous, volcanic center, volcanic front, voluminous

\section{Correlations to Alaska State Department of Education (2006) Performance Standards (Grade Level Expectations) \\ D1-Concepts of Earth Science}

SD[6-11] Students develop an understanding of the concepts, processes, theories, models, evidence, and systems of earth and space sciences.

SD2[6-11] Students develop an understanding of the origins, ongoing processes, and forces that shape the structure, composition, and physical history of the Earth.

\section{Overview}

This activity will provide students with an overview of most of historically active volcanoes in Alaska.

\section{Background}

There are approximately 50 historically active volcanoes in Alaska. This activity will help familiarize students with the names, locations, and types of most of the historically active volcanoes in the state.

\section{Objectives}

Students will be able to identify several volcanoes in Alaska, their location, history of activity, and importance.

\section{Materials}

- pencils, pens or thin markers

- Alaska Map worksheet

- Alaska's Volcanic Arc of Fame worksheets

- scissors

- glue stick, glue for paper or tape 


\section{Procedure}

\section{A. Alaska Map worksheet}

1. Ask students to draw and label as many volcanoes on the Alaska Map worksheet as possible.

2. Through class discussion, or in a written form, have the students discuss why they might have heard of the specific volcanoes they were able to draw and label on the map (erupted recently, visited, saw on the news, in a documentary, and so on.)

3. Distribute the Alaskan Volcanic Arc of Fame handouts class-wide and have them complete the blanks using library, classroom, and on-line resources. It may be worthwhile to assign a page of two cards to each student as a homework assignment.

4. The cards were developed using the Alaska Volcano Observatory (AVO) website. Specifically, the information is available in the under the "Description" section on the corresponding AVO website webpage for each Alaskan volcano. The complete list of Alaskan volcanoes is available in map view and as an alphabetical list here: http://www.avo.alaska.edu/volcanoes/index.php. Move your computer mouse over the name of each volcano to see a list of options. Select "Description" for information about the selected volcano. In almost all cases, the text provided on the Alaska Volcanic Arc of Fame worksheets (each is two cards) also can be found here. The images used on the bulk of the cards are also are available at the AVO website.

5. Students can cut out and paste together the individual cards and swap, collect, and use them like collector cards. 


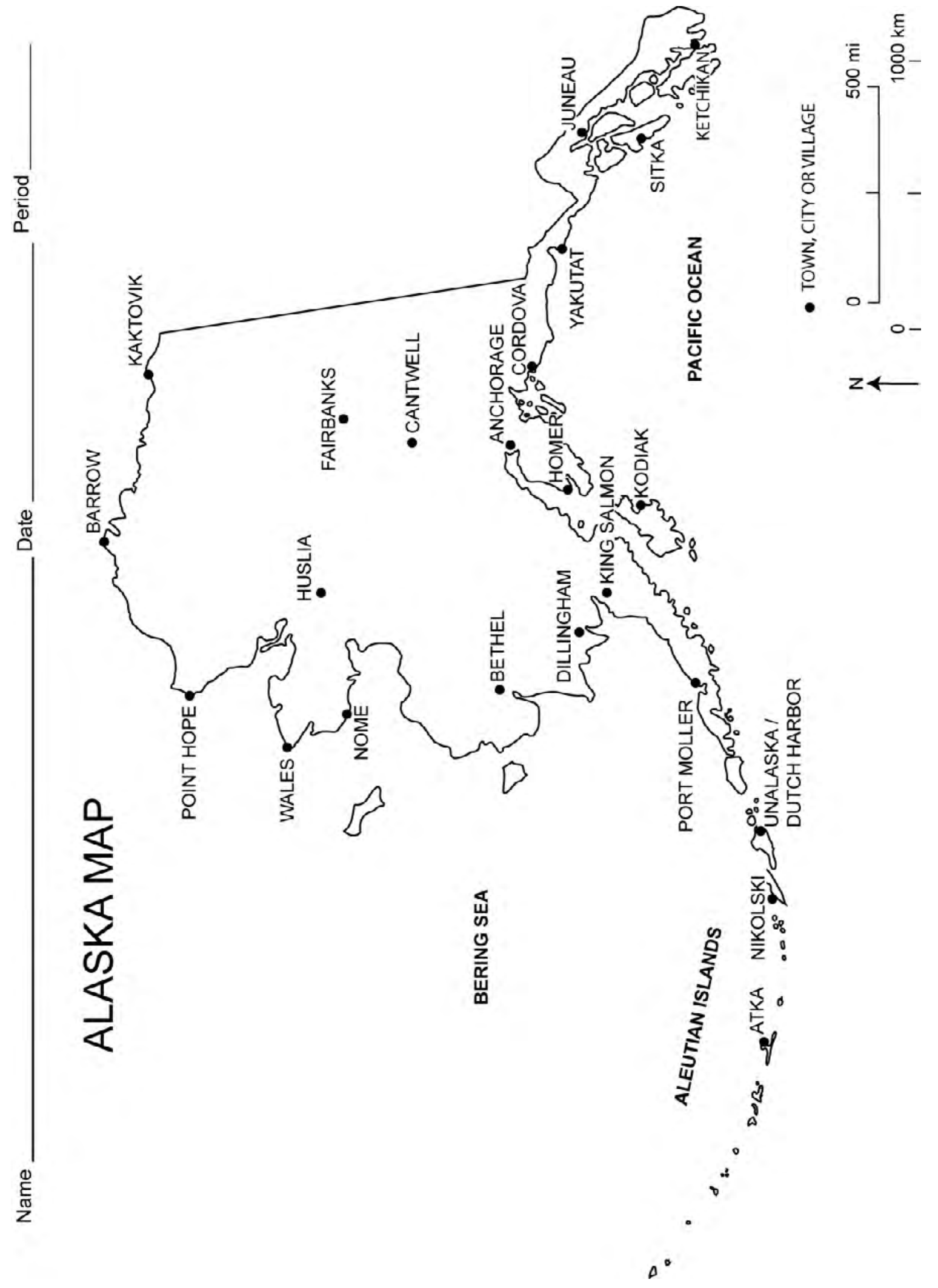




\section{Extensions}

1. Students can make these cards into a scaled mobile using a map of Alaska that notes the locations. Examples of these maps are:

- Nye, C.J., and others, 1998, Volcanoes of Alaska: Alaska Division of Geological and Geophysical Surveys Information Circular IC 0038, 1 sheet [2 sides], accessed June 1, 2010, at

- Front PDF (6.4 MB)

http://www.dggs.dnr.state.ak.us/webpubs/dggs/ic/oversized/ic038ed1998_sh0 01.PDF and

- Back PDF (6.6 MB) http://www.dggs.dnr.state.ak.us/webpubs/dggs/ic/oversized/ic038ed1998_sh0 02.PDF.

- Schaefer, J., and Nye, C. J., 2002, Historically active volcanoes of the Aleutian Arc: Alaska Division of Geological and Geophysical Surveys Miscellaneous Publication MP 0123, 1 sheet, accessed June 1, 2010, at Page size PDF http://www.avo.alaska.edu/pdfs/mp123_pagesize.pdf Poster size PDF http://www.avo.alaska.edu/pdfs/mp123.pdf (4.75 MB).

2. Have students develop game(s) using the cards and the information on them.

\section{Modified from}

Driedger, C.L., Doherty, Anne, and Dixon, Cheryll, 2005, Living with a volcano in your backyard-An educator's guide with emphasis on Mount Rainier: U.S. Geological Survey General Interest Product 19; produced in cooperation with the National Park Service, available at

- Chapter 1: What the past tells us-Activity: A string of volcanoes http://vulcan.wr.usgs.gov/Outreach/Publications/GIP19/chapter_one_string_of_vo lcanoes.pdf (6.9 MB)

\section{Reference Cited}

Alaska State Department of Education and Early Development, 2006, Standards and grade level expectations, March 2006: State of Alaska website, accessed October 2009 at http://www.eed.state.ak.us/tls/assessment/GLEHome.html. 
Glossary

Acidic - Having a pH of between 6 and 1.

Amphitheater - A concave landform, generally oval or circular in outline, nearly surrounded by steep slopes, and having a relatively flat floor.

Ancestral - Pertaining to ancestors. A person, object, idea, or style serving as the prototype, forerunner, or inspiration from which another has descended.

Anoxic - With little or no oxygen.

Ash plume -Volcanic ash-cloud eruption consisting of rock, mineral, and volcanic glass fragments smaller than $2 \mathrm{~mm}(0.1 \mathrm{in}$.) in diameter, which is slightly larger than the size of a pinhead. The ash is hard, does not dissolve in water, and can be extremely small—ash particles less than $0.025 \mathrm{~mm}(1 / 1,000$ th of an inch) in diameter are common.

Basal - The base of a feature.

Caldera - A large, usually circular depression at the summit of a volcano formed when magma is withdrawn or erupted from a shallow underground magma reservoir. The removal of large volumes of magma may result in loss of structural support for the overlying rock, thereby leading to collapse of the ground and formation of a large depression. Calderas are different from craters, which are smaller, circular depressions created primarily by explosive excavation of rock during eruptions.

Cinder cone - A steep, conical hill of volcanic fragments that accumulate around and downwind from a vent.

Composite volcano - Also called a stratovolcano.

Crater - Small circular depressions created primarily by explosive excavation of rock during eruptions.

Decapitated - The head (or top, or summit) has been removed, beheaded.

Diameter - A straight line passing through the center of a circle or sphere and meeting at each end the circumference or surface.

Dormance - A period of rest or inactivity.

Edifice(s) - A structural edge or face of a cliff.

Elevation - The height above sea level of a given point.

Elliptical - Oval in shape or orbit. 
Emergent - Still growing, becoming exposed to the surface or air.

Emission - Discharge.

Ephemeral - Something that lasts a very short time.

Erosion - Process by which the surface is worn away.

Explosive volcanic eruption - A volcanic eruption dominated by the violent fragmentation of magma.

Extinct - A volcano that is not currently erupting and is not likely to erupt in the future.

Fissure - A surface of fracture or a crack in rock along which there is distinct separation.

Flank - Side slope.

Fumarole - Vents from which volcanic gas escapes into the atmosphere. Fumaroles may occur along tiny cracks or long fissures, in chaotic clusters or fields, and on the surfaces of lava flows and thick deposits of pyroclastic flows. They may persist for decades or centuries if they are above a persistent heat source or disappear within weeks to months if they occur atop a fresh volcanic deposit that quickly cools.

Fumarole field - An area where a number of fumaroles may be located.

Geothermal - Pertaining to heat from the interior of the Earth.

Glaciation - The formation, movement, and recession or glaciers or ice sheets.

Hot springs - A thermal spring whose temperature is above that of the human body.

Incandescence (Incandescent) - The emission of light energy (visible radiation) by a body caused by its high temperature.

Intermittently - Occurring at intervals.

Intracaldera - Within a caldera.

Lahar(s) - An Indonesian word for a rapidly flowing mixture of rock debris and water that originates on the slopes of a volcano.

Latitude - The angular distance north or south from the equator of a point on the Earth's surface, measured on the meridian of the point. 
Lava dome - A roughly circular mound-shaped protrusion resulting from the slow eruption of felsic lava (usually rhyolite or dacite) from a volcano, or from multiple lava episodes of different magma types.

Longitude - The angular distance east or west on the Earth's surface measured by the angle contained between the meridian of a particular place and a prime meridian such as Greenwich, England.

Maar - A low-relief, broad volcanic crater formed by shallow explosive eruptions. The explosions are usually caused by the heating and boiling of groundwater when magma invades the groundwater table. Often fill with water to form a lake.

Margin - Border or edge.

Marine terrace - A narrow constructional coastal strip sloping gently seaward, veneered by marine deposit.

Olivine basalt - Basalt that contains olivine.

Originating - Beginning with.

Parasitic - Living off and taking resources from someone or something else.

Phreatomagmatic - A volcanic explosion that extrude steam and magmatic gases; it is caused by the contact of magma with shallow or surface water.

Plateau - A flattened landform, usually at higher altitude that surrounds areas.

Postcaldera - Occurring or forming after the formation of a caldera.

Quadrangle - A rectangular area bounded by parallels of latitude and meridians of longitude used as a unit in systematic mapping.

Radiate - Spreading outwards like rays from a center.

Remnant - A piece of a much larger formation or structure that remains.

Saddle - A low point in the crest line of a ridge. A broad, flat gap or pass sloping gently on both sides.

Shield volcano - A volcano characterized by low angle slopes.

$\mathbf{S O}_{2}-$ Sulfur dioxide.

Stratovolcano - Steep, conical volcano built by the eruption of viscous lava flows, tephra, and pyroclastic flows (also called a composite cone). 
Submarine - Under the surface of the ocean.

Submerged - Underneath either water or land.

Sulfur (S) - An element and mineral characterized by its yellow color and strong rotten egg smell.

Summit - The top or pinnacle.

Symmetrical - Of even shape, both sides are equal.

Volcanic Center - The middle of a volcano or system of multiple volcanoes.

Volcanic front - The edge of a system of volcanoes (more than one).

\section{Source of Glossary Definitions}

Bates, R.K., and Jackson, J.A., eds., 1987, Glossary of Geology ( $3^{\text {rd }}$ ed.): Falls Church, Va., American Geological Institute, 571 p.

Stein, Jess, ed., 1982, The Random House College Dictionary, revised edition: New York, Random House, Inc.

U.S. Geological Survey, 2008, Cascades Volcano Observatory—Volcano Types : U.S. Geological Survey web page. (Available at http://vulcan.wr.usgs.gov/Glossary/VolcanoTypes/volcano_types.html.

U.S. Geological Survey, 2010, Volcano Hazards Program-USGS photo glossary of volcanic terms: U.S. Geological Survey website. (Available at http://volcanoes.usgs.gov/images/pglossary/index.php.) 


\section{Alaska's Volcanic Arc of Fame}

A

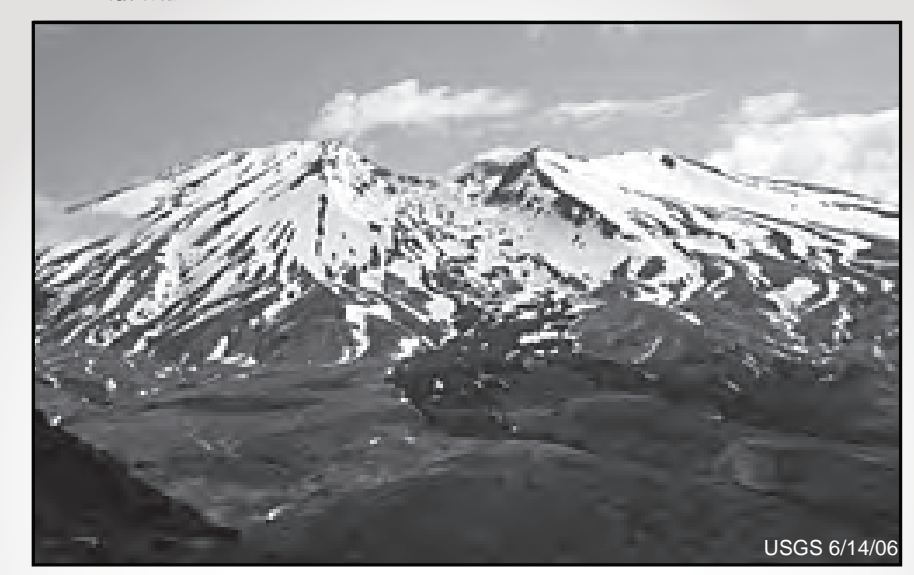

This volcano is a composite stratovolcano with a circular summit caldera about $2 \mathrm{~km}$ (1.2 mi) across and 60-365 m (197$1,198 \mathrm{ft})$ deep, and an active intracaldera cinder cone. There are active hot springs northeast of the caldera at the head of Hot Springs Bay valley and along the shore of Hot Springs Bay. The caldera rim reaches a maximum altitude of $1,303 \mathrm{~m}(4,275 \mathrm{ft})$.

\section{Alaska's Volcanic Arc of Fame}

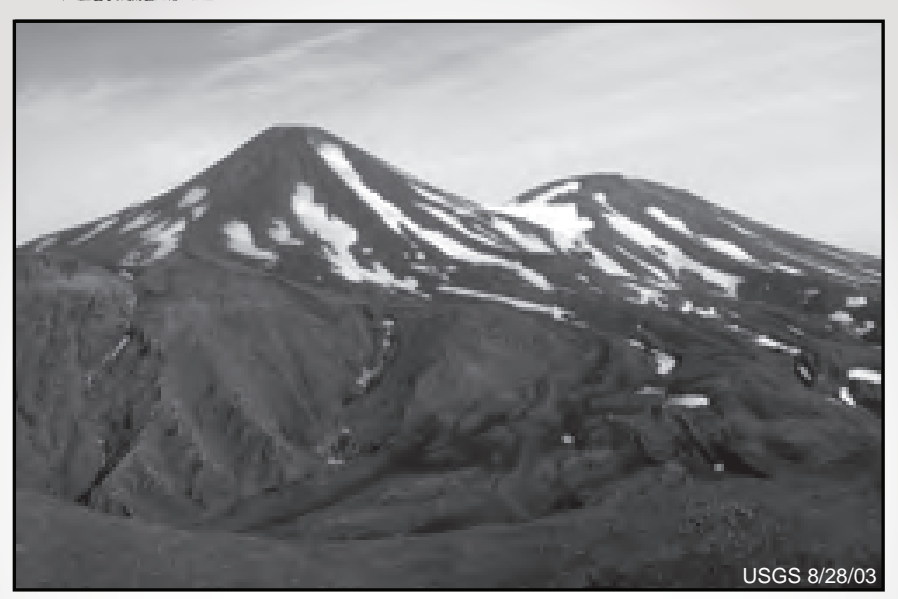

This volcano comprises three main volcanic edifices on the northern part of an island by the same name. The island lies in the Andreanof Islands $\sim 100 \mathrm{~km}(\sim 63 \mathrm{mi})$ west of the village of Adak in the Aleutians. Sajaka volcano lies west of this ediface and Takawangha lies east. No historical eruptions are known from Sajaka or Takawangha.

\section{Alaska's Volcanic Arc of Fame}

Name:

Type:

Most Recent Activity:

Elevation:

Latitude:

Longitude:

Quandrangle:

Cool Fact:
Alaska's Volcanic Arc of Fame

Name:

Type:

Most Recent Activity:

Elevation:

Latitude:

Longitude:

Quandrangle:

Cool Fact: 


\section{Alaska's Volcanic Arc of Fame}

A

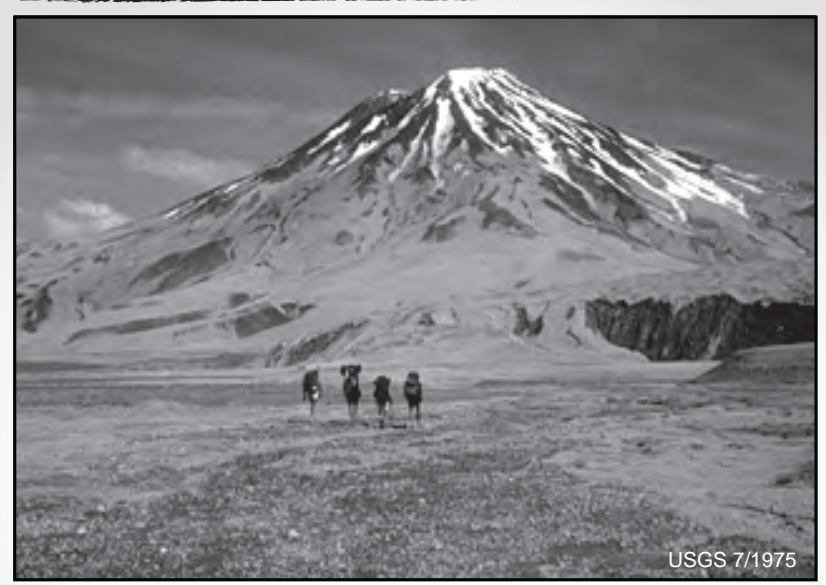

This volcano towers $1,700 \mathrm{~m}(5,577 \mathrm{ft})$ above the north margin of the Valley of Ten Thousand Smokes in Katmai National Park on the Alaska Peninsula. It lies northwest of the remarkably linear volcanic front defined by five other local volcanic centers of the Katmai cluster. It is formerly known as Knife Peak and was renamed for an early explorer of the area.

\section{Alaska's Volcanic Arc of Fame}

Name:

Type:

Most Recent Activity:

Elevation:

Latitude:

Longitude:

Quandrangle:

Cool Fact:

\section{Alaska's Volcanic Arc of Fame}

B

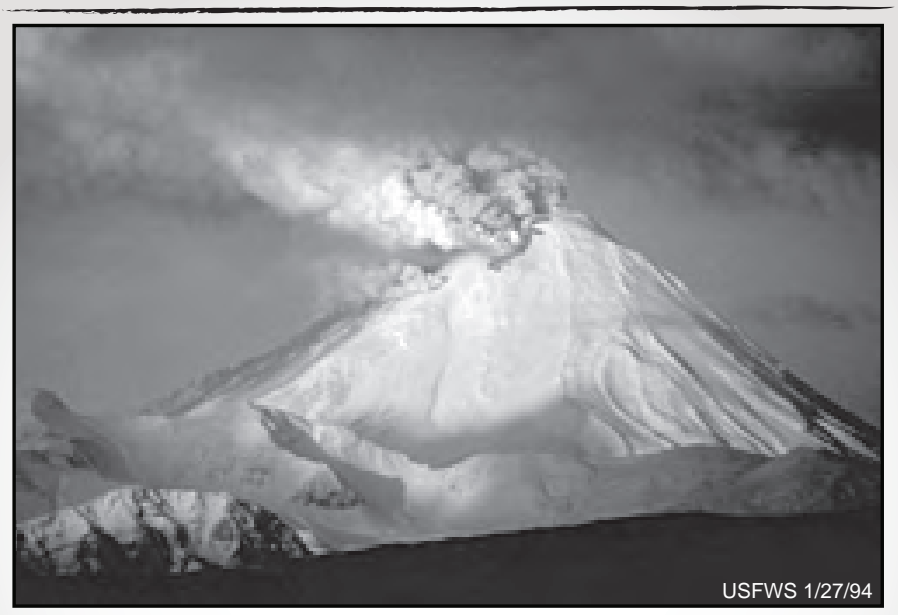

This symmetric composite cone is $1,307 \mathrm{~m}$ $(4,289 \mathrm{ft}) \mathrm{high}$ and $4.8 \mathrm{~km}$ (3 $\mathrm{mi})$ in diameter at sea level. This volcano occupies the northernmost corner of an island of the same name west of the U.S. Navy installation and port on Adak Island. The volcano erupted intermittently throughout 1994, dusting Adak with volcanic ash.

\section{Alaska's Volcanic Arc of Fame}

Name:

Type:

Most Recent Activity:

Elevation:

Latitude:

Longitude:

Quandrangle:

Cool Fact: 


\section{Alaska's Volcanic Arc of Fame}

A

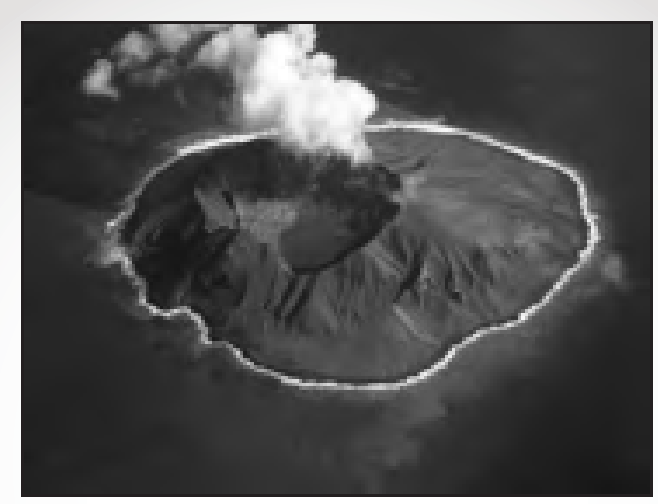

This $\sim 3 \mathrm{~km}(1.9 \mathrm{mi})$ diameter, $300 \mathrm{~m}(984 \mathrm{ft})$ high, island volcano in the central Aleutian Islands erupted violently on August 7, 2008 after an intense period of earthquake activity. The island is part of the Alaska Maritime National Wildlife Refuge and was occupied by two USFWS biologists when the precursory earthquakes began. A local fisherman safely evacuated the scientists less than 30 minutes prior to the eruption.

\section{Alaska's Volcanic Arc of Fame}

B

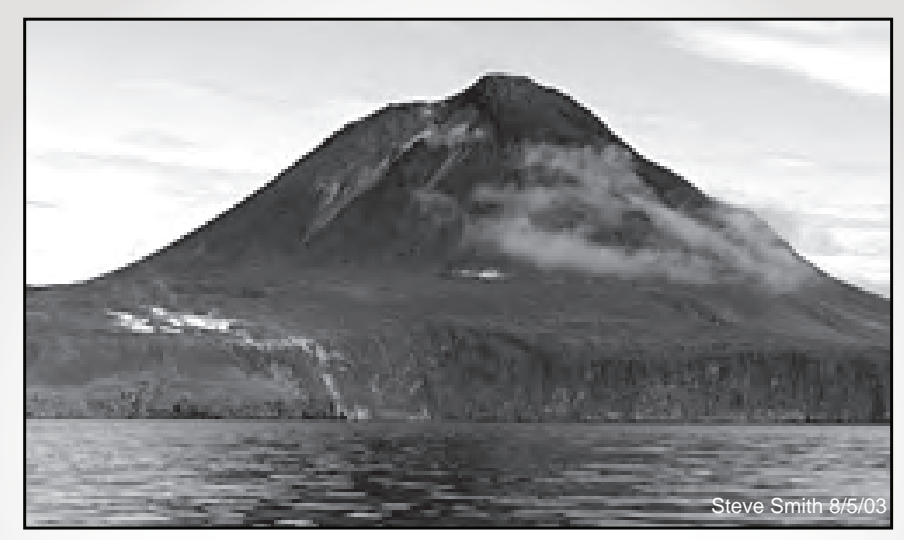

This volcano occupies most of the southern half of an island of the same name in the eastern Aleutian arc. The volcano consists of two cones and has an oval shape. The larger cone at the southeastern end of the volcano has an elevation of $893 \mathrm{~m}(2,930 \mathrm{ft})$; the cone at the northwestern end is about $610 \mathrm{~m}$ $(2,000 \mathrm{ft})$ high and appears to have two small summit craters.

\section{Alaska's Volcanic Arc of Fame}

Name:

Type:

Most Recent Activity:

Elevation:

Latitude:

Longitude:

Quandrangle:

Cool Fact:

\section{Alaska's Volcanic Arc of Fame}

Name:

Type:

Most Recent Activity:

Elevation:

Latitude:

Longitude:

Quandrangle:

Cool Fact: 


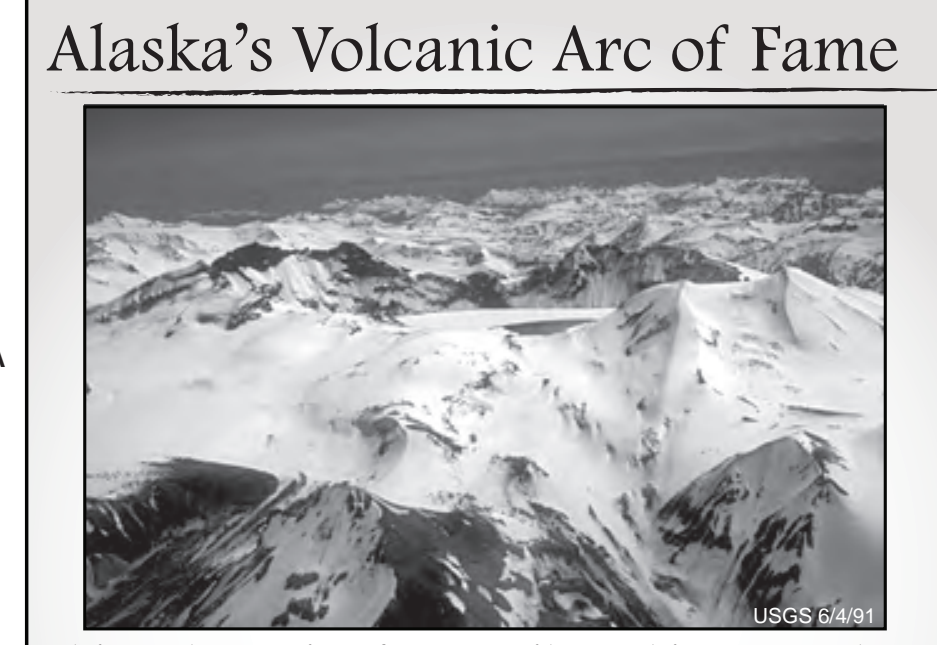

This volcano is often attributed incorrectly as the source of the voluminous pyroclastic flows erupted in 1912 forming the Valley of Ten Thousand Smokes in Katmai National Park. The correct source is Novarupta dome. Much of this volcano is mantled by snow and ice and several valley glaciers radiate out from the flanks. Three glaciers originating from the upper caldera walls descend into the crater to the lake.

\section{Alaska's Volcanic Arc of Fame}

B

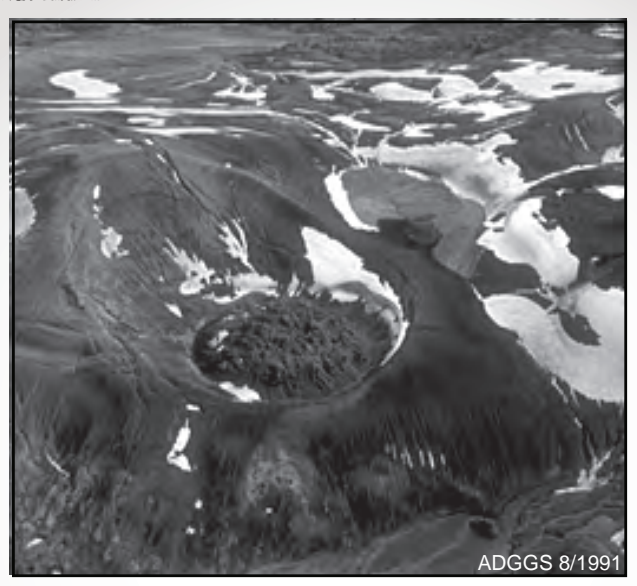

In 1916, a National Geographic Society expedition led by Robert Griggs visited the Katmai Valley. Among many other things, the expedition discovered this newly formed lava dome they named. This volcanic dome formed during the 1912 eruption that created the Valley of Ten Thousand Smokes in Katmai National Park. It is $\sim 400 \mathrm{~m}(1,312 \mathrm{ft})$ in diameter and $65 \mathrm{~m}(213 \mathrm{ft})$ high.

\section{Alaska's Volcanic Arc of Fame}

Name:

Type:

Most Recent Activity:

Elevation:

Latitude:

Longitude:

Quandrangle:

Cool Fact:

\section{Alaska's Volcanic Arc of Fame}

Name:

Type:

Most Recent Activity:

Elevation:

Latitude:

Longitude:

Quandrangle:

Cool Fact: 


\section{Alaska's Volcanic Arc of Fame}

A

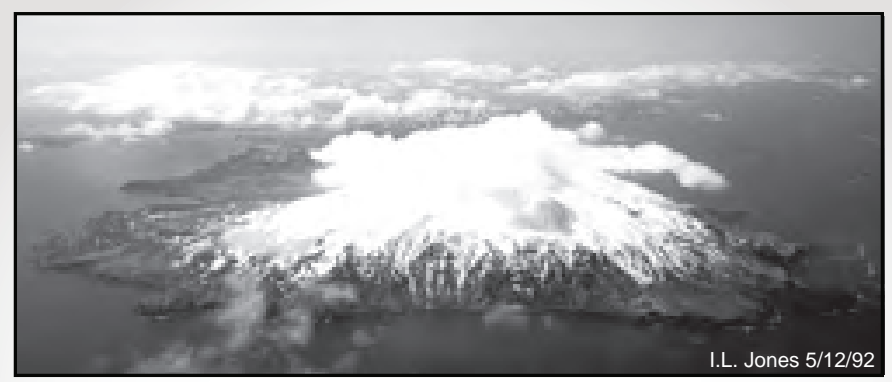

This stratovolcano is $1,221 \mathrm{~m}(4,006 \mathrm{ft})$ high. It is on the northern end of a western Aleutian island of the same name. Surface lava flows on this volcano are younger than the last major glaciation. Five of the youngest lava flows have been mapped and have steep fronts as much as $30 \mathrm{~m}(98 \mathrm{ft})$ high. On June 1, 1990, an observer on nearby Amchitka Island observed steam and minor ash emission from an upper flank vent of this volcano.

\section{Alaska's Volcanic Arc of Fame}

Name:

Type:

Most Recent Activity:

Elevation:

Latitude:

Longitude:

Quandrangle:

Cool Fact:

\section{Alaska's Volcanic Arc of Fame}

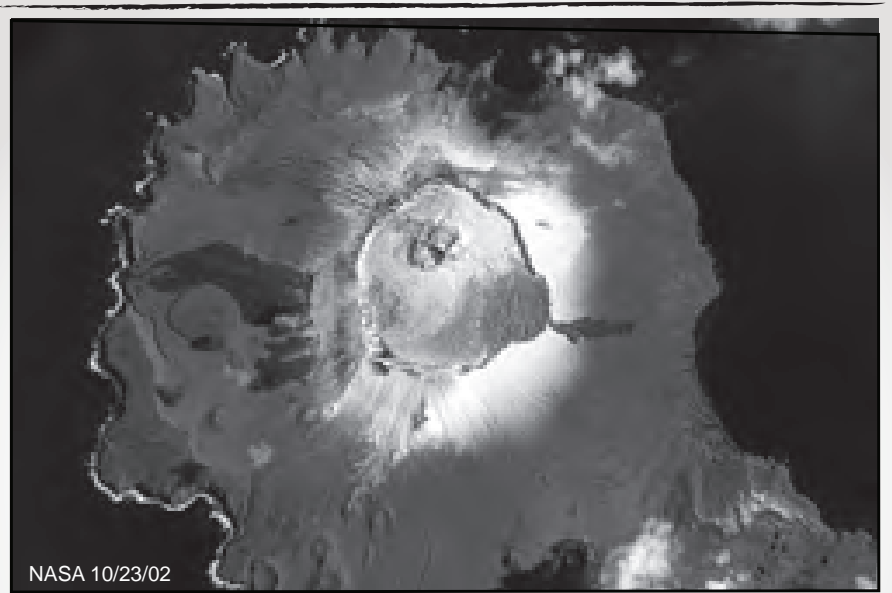

This is a stratovolcano on the northern end of an Aleutian island of the same name. It is 8.5 by $6.4 \mathrm{~km}$ in diameter at its base and $1,221 \mathrm{~m}$ high. A slightly elliptical crater occupies the summit. A parasitic 30 m high cinder cone, formed in 1962 near sea level, occurs at Sirius Point and an older parasitic cone, now leveled by marine erosion, occurs at sea level $5.6 \mathrm{~km}$ southwest of the volcano.

\section{Alaska's Volcanic Arc of Fame}

Name:

Type:

Most Recent Activity:

Elevation:

Latitude:

Longitude:

Quandrangle:

Cool Fact: 


\section{Alaska's Volcanic Arc of Fame}

A

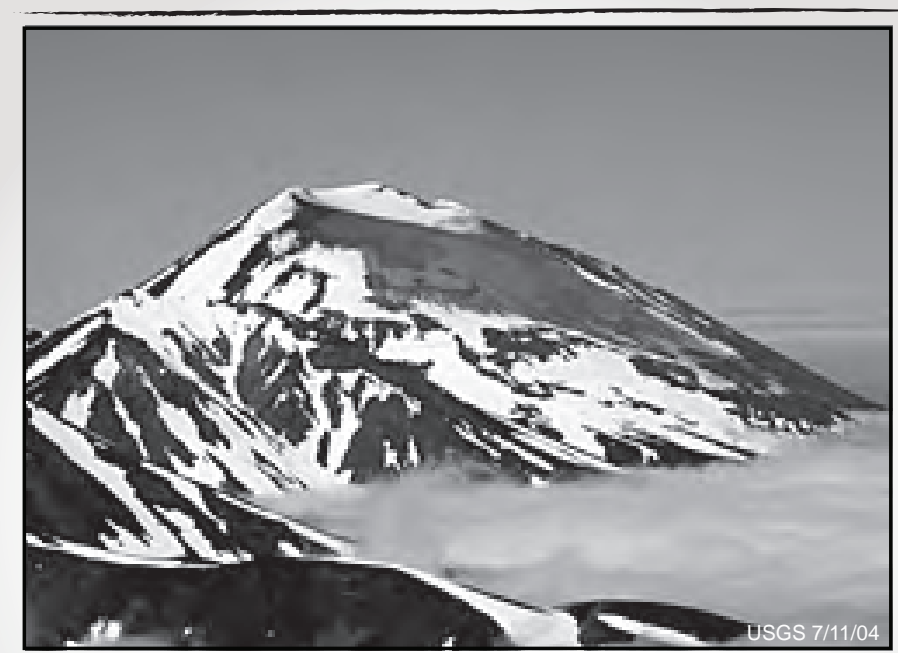

This is a stratovolcano, $1,533 \mathrm{~m}$ $(5,030 \mathrm{ft})$ high and almost $7 \mathrm{~km}(4.3 \mathrm{mi})$ in basal diameter. It has two summit vents. One summit vent is a symmetric cone with a small crater. The other summit vent is on the remnant of a cone with a steep walled crater, about $1 \mathrm{~km}(0.6 \mathrm{mi})$ wide at the rim and at least several hundred meters deep.
Alaska's Volcanic Arc of Fame

Name:

Type:

Most Recent Activity:

Elevation:

Latitude:

Longitude:

Quandrangle:

Cool Fact:

\section{Alaska's Volcanic Arc of Fame}

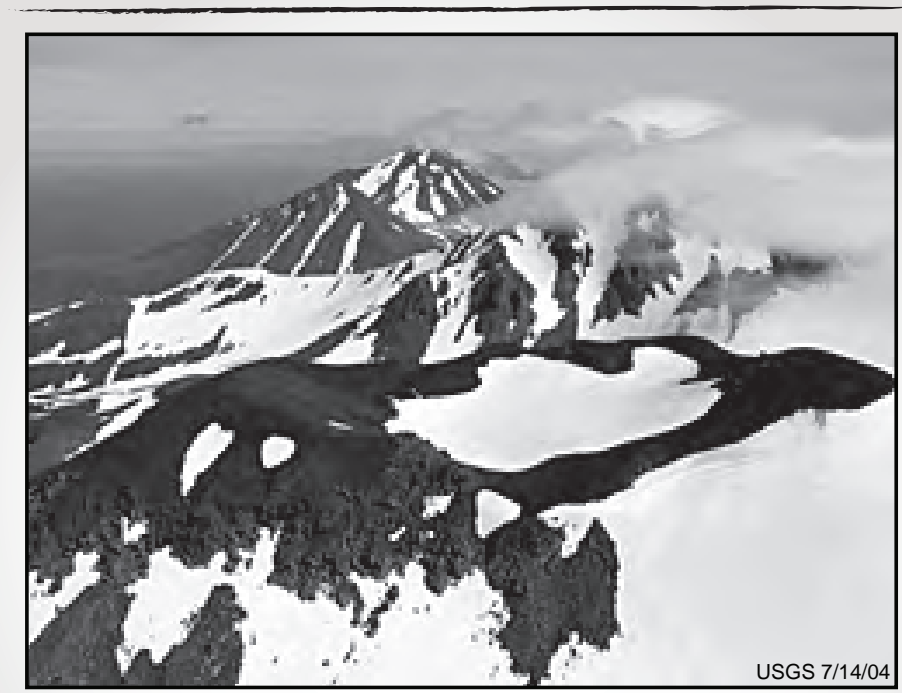

Above, you can see a young vent on the northeast shoulder of this volcano. Sarichef volcano is in the distance. This and other volcanoes are products of the latest stage of volcanic activity on Adak Island. Hot springs and fumaroles occur on the south and west flanks of this volcano.

\section{Alaska's Volcanic Arc of Fame}

Name:

Type:

Most Recent Activity:

Elevation:

Latitude:

Longitude:

Quandrangle:

Cool Fact: 


\section{Alaska's Volcanic Arc of Fame}

A

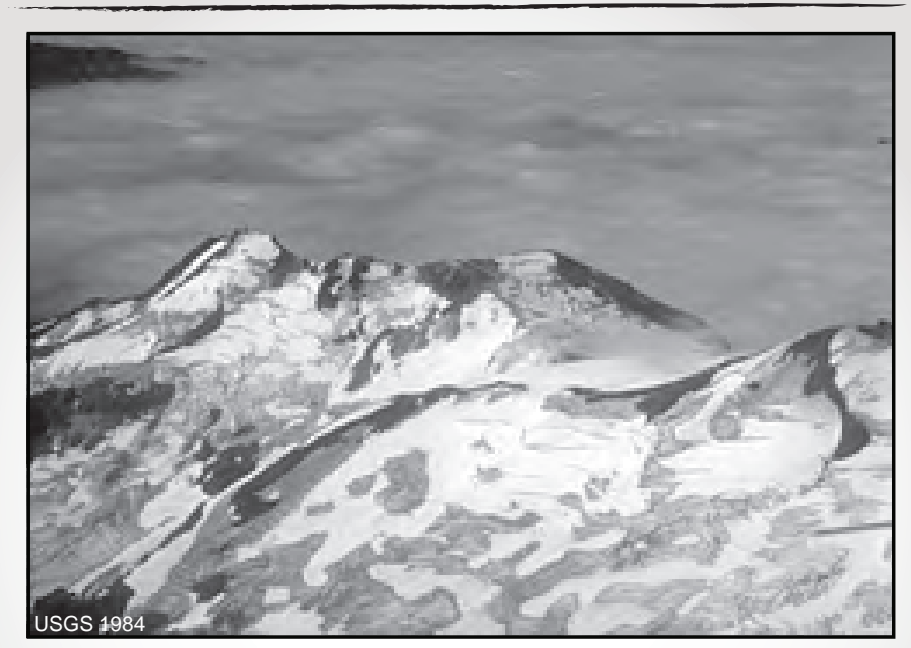

This is the largest and best known volcano of the Stepovak Bay chain of five volcanoes on the Alaska Peninsula. The Stepovak Bay chain includes the better known Veniaminof and Aniakchak calderas. This volcano is $1,895 \mathrm{~m}(2,217 \mathrm{ft})$ high and there is a fumarolic area marked by sulfur deposits at an elevation of $1,524 \mathrm{~m}(5,000 \mathrm{ft})$.

\section{Alaska's Volcanic Arc of Fame}

Name:

Type:

Most Recent Activity:

Elevation:

Lattitude:

Longitude:

Quandrangle:

Cool Fact:

\section{Alaska's Volcanic Arc of Fame}

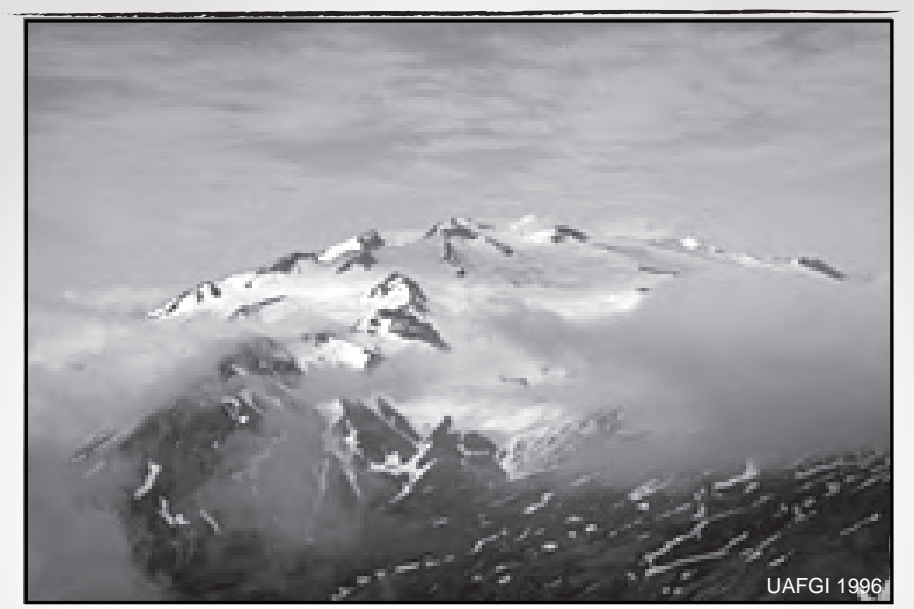

This volcano is a broad, stratovolcano. It is $6 \mathrm{~km}$ (1 mi) diameter at its base. It is on Unalaska Island in the Aleutians. Its summit caldera, $\sim 3 \mathrm{~km}(\sim 1.9 \mathrm{mi})$ across, contains a small cinder cone, remnants of other cones, and several fumaroles. The volcano is capped by an $\sim 40 \sim \mathrm{km}^{2}\left(\sim 15 \sim \mathrm{mi}^{2}\right)$ icefield. This volcano has also been called Cheerful Mountain.

\section{Alaska's Volcanic Arc of Fame}

Name:

Type:

Most Recent Activity:

Elevation:

Lattitude:

Longitude:

Quandrangle:

Cool Fact: 


\section{Alaska's Volcanic Arc of Fame}

A

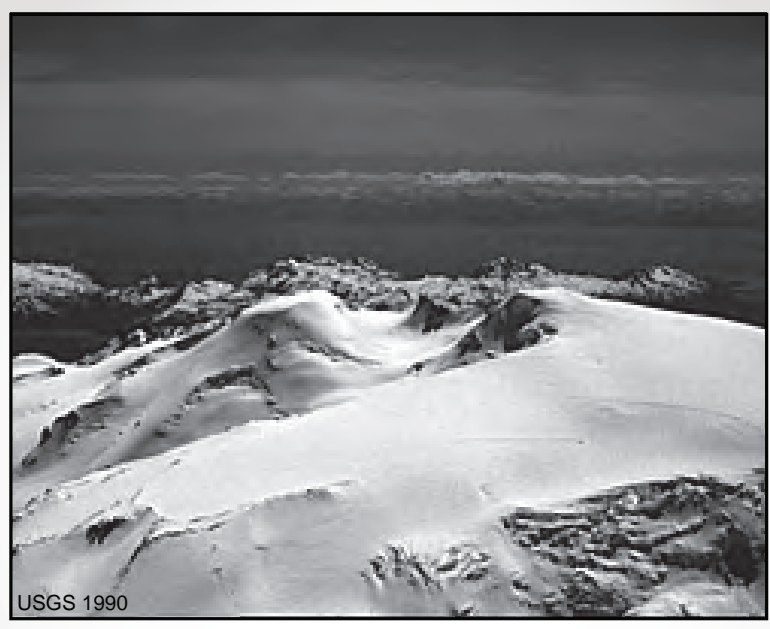

This almost completely ice covered volcano lies west of Hallo Bay in Katmai National Park. Unlike nearby Denison and Steller volcanoes, this volcano has a vigorous fumarole field. This volcano is $2,040 \mathrm{~m}$ $(6,693 \mathrm{ft})$ high.

\section{Alaska's Volcanic Arc of Fame}

Name:

Type:

Most Recent Activity:

Elevation:

Latitude:

Longitude:

Quandrangle:

Cool Fact:

\section{Alaska's Volcanic Arc of Fame}

B

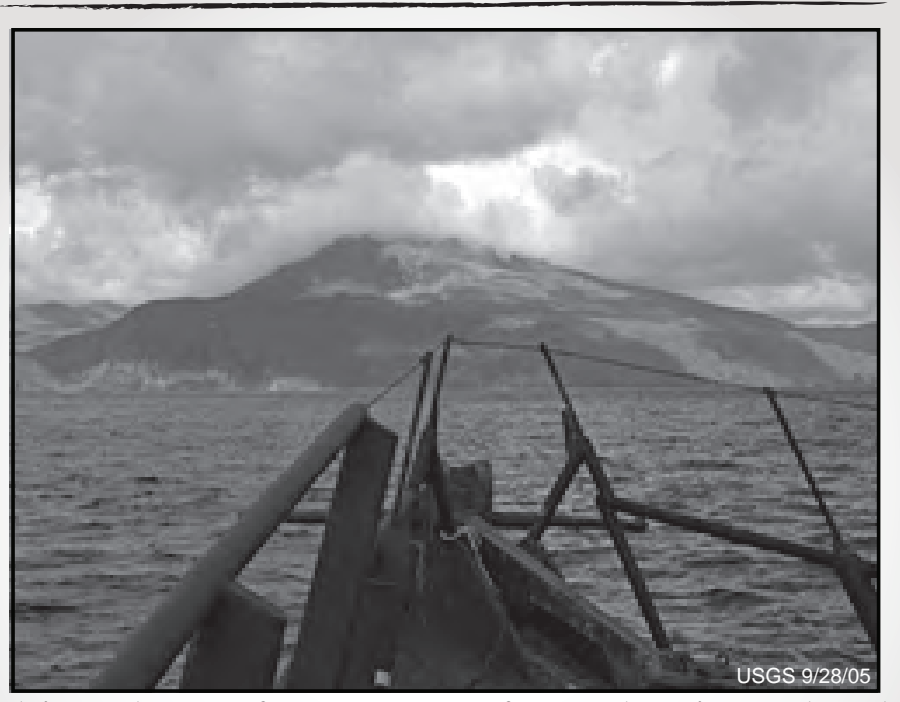

This volcano forms part of an Aleutian Island by the same name. It lies within the eroded remnants of a nested double caldera. There are fumaoles, hot springs, and inactive small mud volcanoes $\sim 10 \sim 20 \mathrm{~cm}(4 \sim 8 \mathrm{in}$.) high at this volcano inland of West Cove. This volcano lies near Kvostof and Davidof Islands.

\section{Alaska's Volcanic Arc of Fame}

Name:

Type:

Most Recent Activity:

Elevation:

Latitude:

Longitude:

Quandrangle:

Cool Fact: 


\section{Alaska's Volcanic Arc of Fame}

A

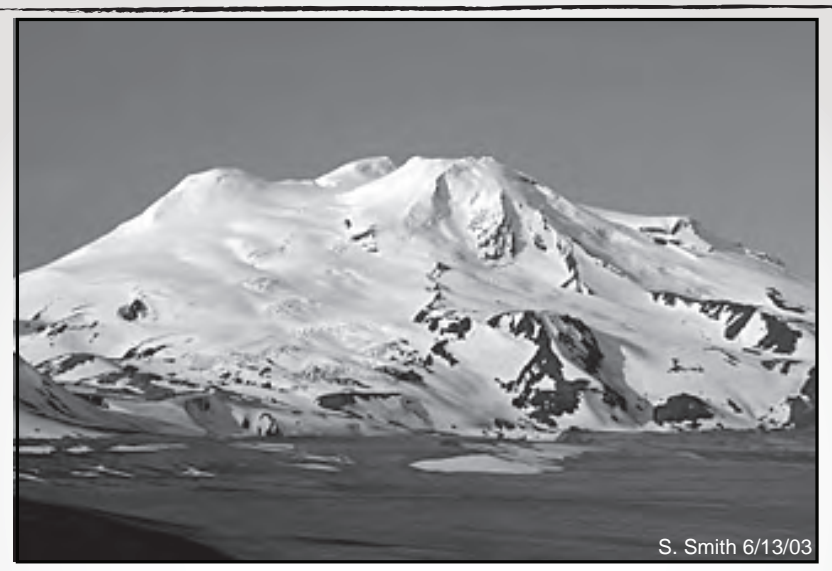

This volcano is within the Katmai Cluster of volcanoes in Katmai National Park's Valley of Ten Thousand Smokes. The ice covered summit area consists of one central high peak (elevation 2,165 $\mathrm{m}[7,100 \mathrm{ft}]$ ) and three small vent-cones. A small crater on the northeast side of the central peak contains a crater lake and supports vigorous fumarolic activity accompanied by sulfur deposition.

\section{Alaska's Volcanic Arc of Fame}

Name:

Type:

Most Recent Activity:

Elevation:

Latitude:

Longitude:

Quandrangle:

Cool Fact:

\section{Alaska's Volcanic Arc of Fame}

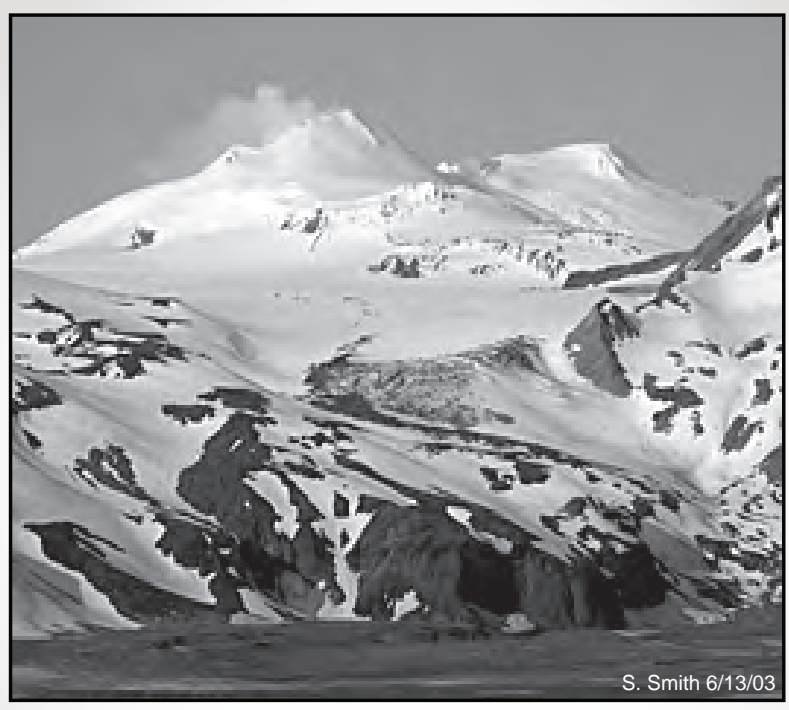

This volcano is within the Katmai Cluster of volcanoes in Katmai National Park's Valley of Ten Thousand Smokes. It's $300 \mathrm{~m}(984 \mathrm{ft})$ diameter summit crater is the site of intense fumarolic activity and steam emission, and contains an ephemeral crater lake.

\section{Alaska's Volcanic Arc of Fame}

Name:

Type:

Most Recent Activity:

Elevation:

Latitude:

Longitude:

Quandrangle:

Cool Fact: 


\section{Alaska's Volcanic Arc of Fame}

A

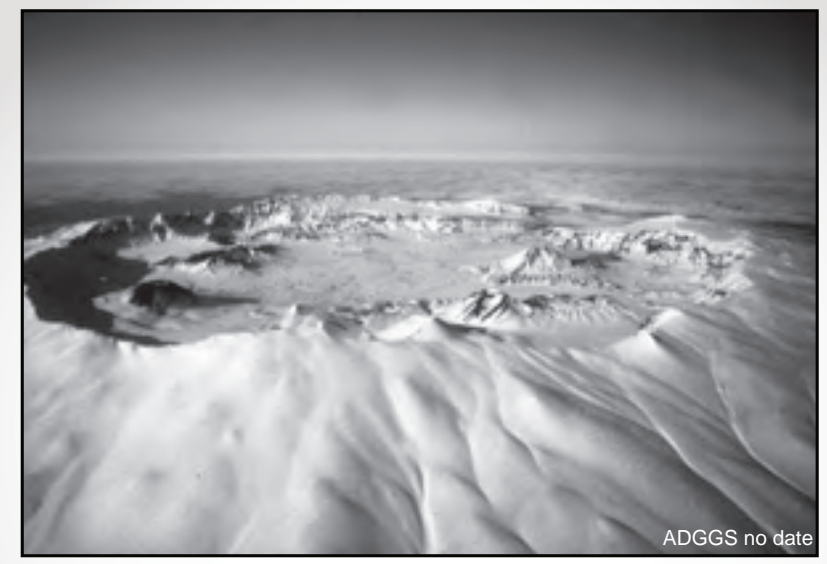

This volcano is an active caldera on the northeast end of Umnak Island, $\sim 100 \mathrm{~km}$ ( $\sim 62 \mathrm{mi}$ ) southwest of Dutch Harbor, Alaska. The caldera is $10 \mathrm{~km}(6 \mathrm{mi})$ in diameter and 500 800 m (1,640 2,625 ft) deep. Very large floods and lahars have accompanied past eruptions of this volcano.

\section{Alaska's Volcanic Arc of Fame}

Name:

Type:

Most Recent Activity:

Elevation:

Latitude:

Longitude:

Quandrangle:

Cool Fact:

\section{Alaska's Volcanic Arc of Fame}

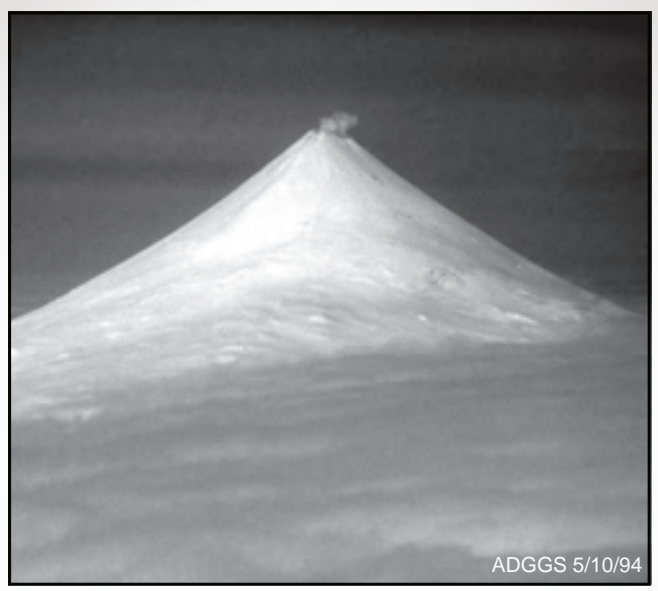

Beautifully symmetrical and one of the highest and most active volcanoes of the Aleutians, the 2,587 m $(8,488 \sim \mathrm{ft})$ high, glacier covered volcano is located in the eastern half of Unimak Island. The Aleuts named it Sisquk, meaning, "mountain which point the way I am lost." A steady steam plume rises from its small summit crater.

\section{Alaska's Volcanic Arc of Fame}

Name:

Type:

Most Recent Activity:

Elevation:

Latitude:

Longitude:

Quandrangle:

Cool Fact: 


\section{Alaska's Volcanic Arc of Fame}

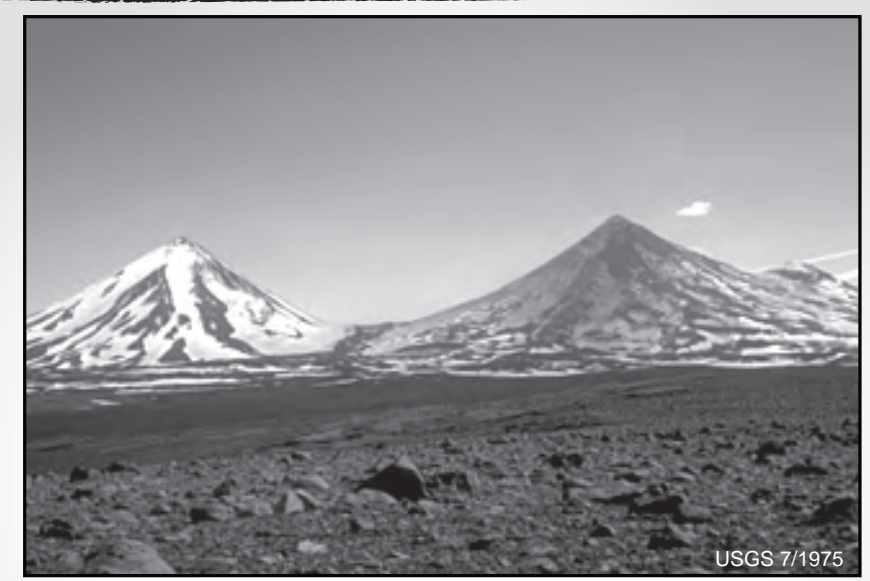

The volcano on the right, above is a largely snow covered, cone shaped mountain with a high ridge extending to the southwest toward the rim of Emmons Lake Caldera. This volcano is $\sim 7 \mathrm{~km}(\sim 4 \mathrm{mi})$ in diameter and has active vents on the north and east sides close to the summit. The volcano is one of the most active of Alaska's volcanoes. Pavlof Sister is the volcano on left, above.

\section{Alaska's Volcanic Arc of Fame}

Name:

Type:

Most Recent Activity:

Elevation:

Latitude:

Longitude:

Quandrangle:

Cool Fact:

\section{Alaska's Volcanic Arc of Fame}

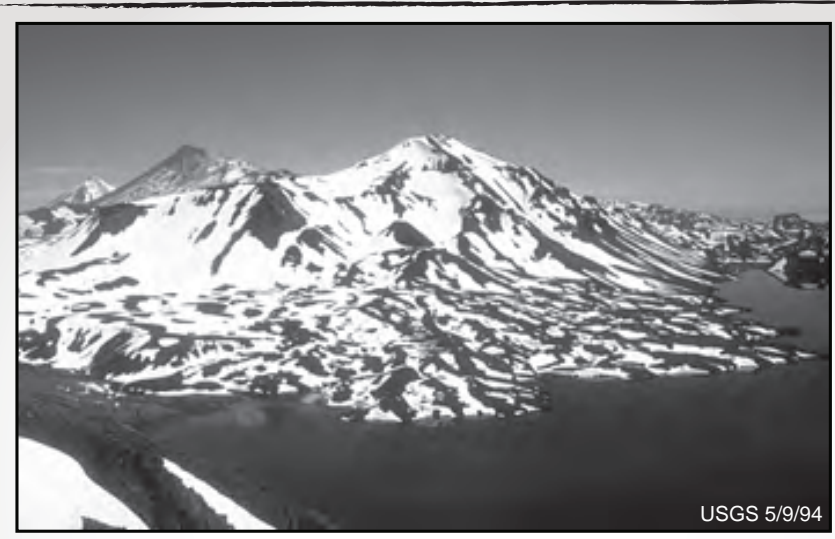

This volcanic center includes Pavlof, Little Pavlof, Double Crater, Mt. Hague, and this volcano. This volcano is a $1,436 \mathrm{~m}(4,711 \mathrm{ft})$ high postcaldera stratovolcano within a caldera of the same name on the Alaska Peninsula. The most recent of several caldera forming eruptions at Emmons Lake occurred more than 10,000 years ago. No historical eruptions have occurred here.

\section{Alaska's Volcanic Arc of Fame}

Name:

Type:

Most Recent Activity:

Elevation:

Latitude:

Longitude:

Quandrangle:

Cool Fact: 


\section{Alaska's Volcanic Arc of Fame}

A

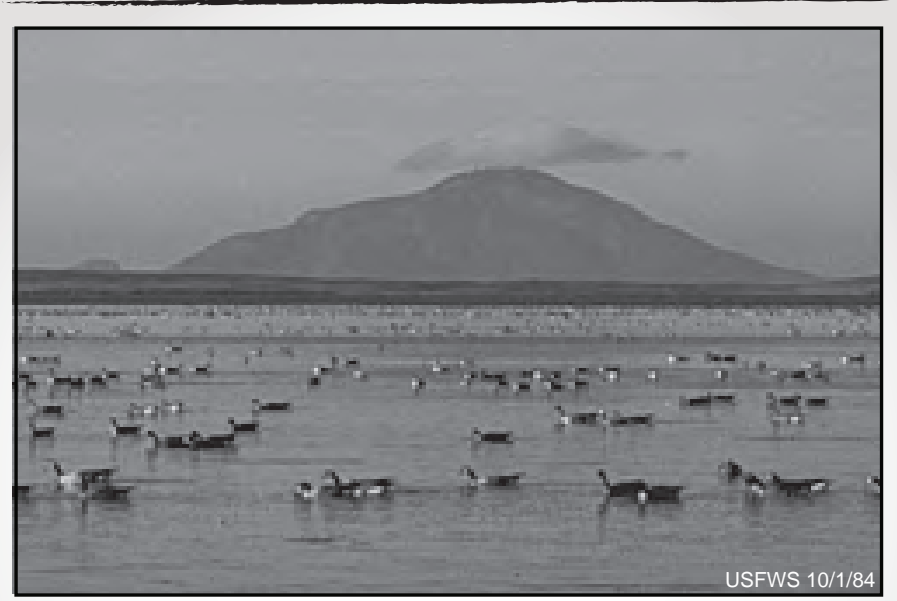

This small, young volcano encompasses an island in the Bering Sea $\sim 50 \mathrm{~km}(\sim 31 \mathrm{mi})$ north of Frosty Peak volcano at the western tip of the Alaska Peninsula. It is unusual in its position, which is significantly north of the main Aleutian volcanic front; Bogoslof is the only other such Aleutian volcano. This volcano is $995 \mathrm{~m}(3,264 \mathrm{ft})$ high.

\section{Alaska's Volcanic Arc of Fame}

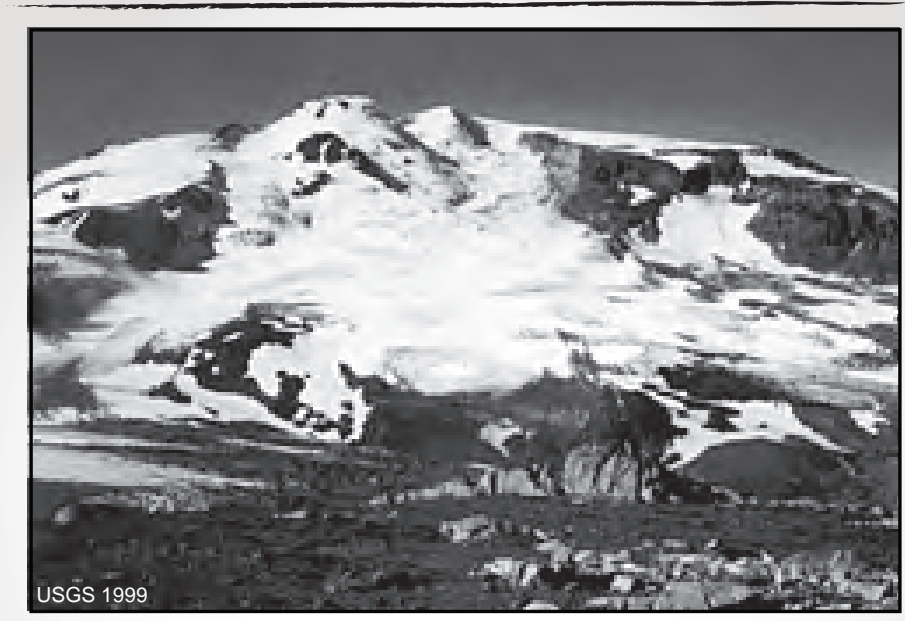

This complex volcanic center is almost entirely covered by the Serpant Tounge Glacier. It is within Katmai National Park. Three peaks extending above the ice along a northeast $\sim$ southwest trending ridge define the summit.There is an active fumarole field on the summit of the tallest peak. This volcano is $2,161 \mathrm{~m}(7,090 \mathrm{ft})$ high.

\section{Alaska's Volcanic Arc of Fame}

Name:

Type:

Most Recent Activity:

Elevation:

Latitude:

Longitude:

Quandrangle:

Cool Fact:

\section{Alaska's Volcanic Arc of Fame}

Name:

Type:

Most Recent Activity:

Elevation:

Latitude:

Longitude:

Quandrangle:

Cool Fact: 


\section{Alaska's Volcanic Arc of Fame}

A

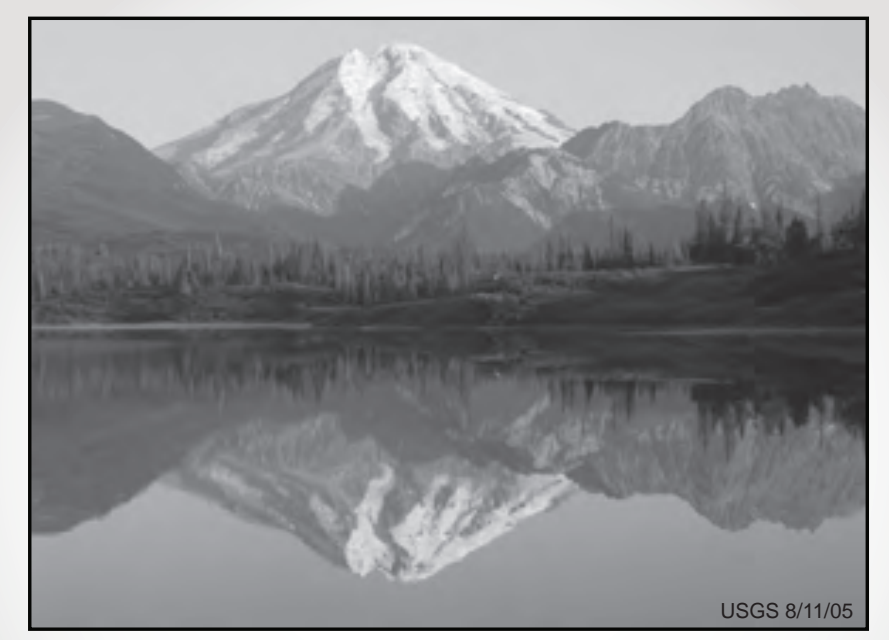

A brand new Boeing 747 encountered an ash cloud from an eruption of this volcano in 1989. All four of the plane's engines failed when the plane inadvertently flew through an ash cloud from this volcano. The crew successfully restarted a few of the engines and landed safely in Anchorage.

\section{Alaska's Volcanic Arc of Fame}

Name:

Type:

Most Recent Activity:

Elevation:

Latitude:

Longitude:

Quandrangle:

Cool Fact:

\section{Alaska's Volcanic Arc of Fame}

B

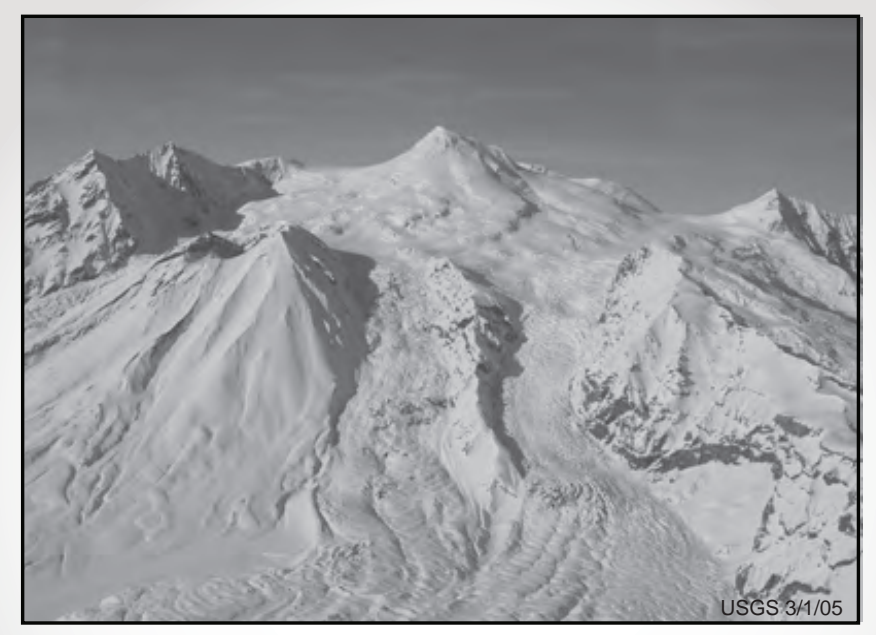

This volcano is close to Anchorage. Its 1992 eruption was from a satellite cone called Crater Peak. This eruption deposited $\sim 6 \mathrm{~mm}(\sim 1 / 4 \mathrm{in}$.) of volcanic ash in Anchorage, closed the airport, businesses, and schools. Air traffic as far away as Cleveland, Ohio, was disturbed.

\section{Alaska's Volcanic Arc of Fame}

Name:

Type:

Most Recent Activity:

Elevation:

Latitude:

Longitude:

Quandrangle:

Cool Fact: 


\section{Alaska's Volcanic Arc of Fame}

A

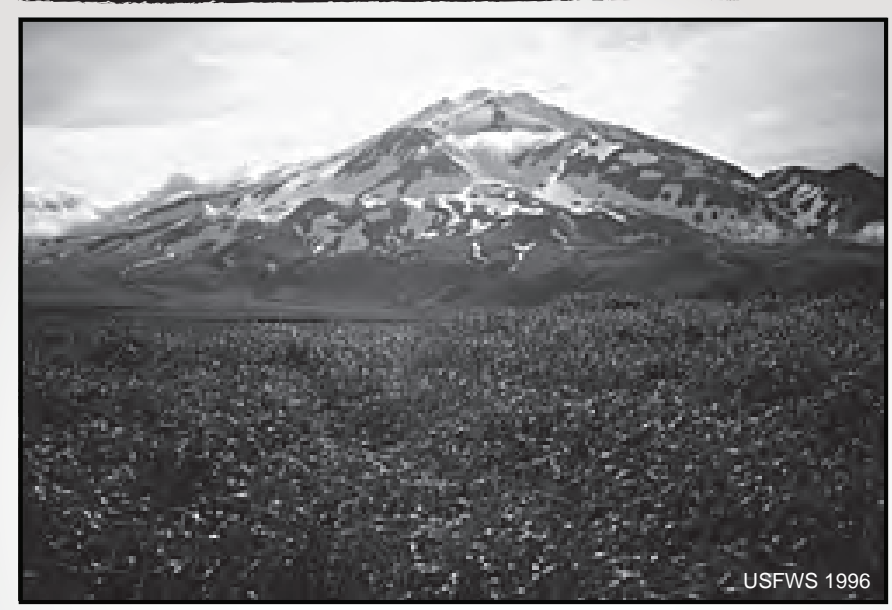

This volcano lies on an island of the same name between Amlia and Amukta Islands in the central Aleutians. This volcano is also referred to as Pyre Peak. Incandescent lava fountained from a fissure eruption near this volcano in March 1977. Explosive ash eruptions and a lava flow were reported by U.S. Coast Guard observers from July 31 to August 19, 1993.

\section{Alaska's Volcanic Arc of Fame}

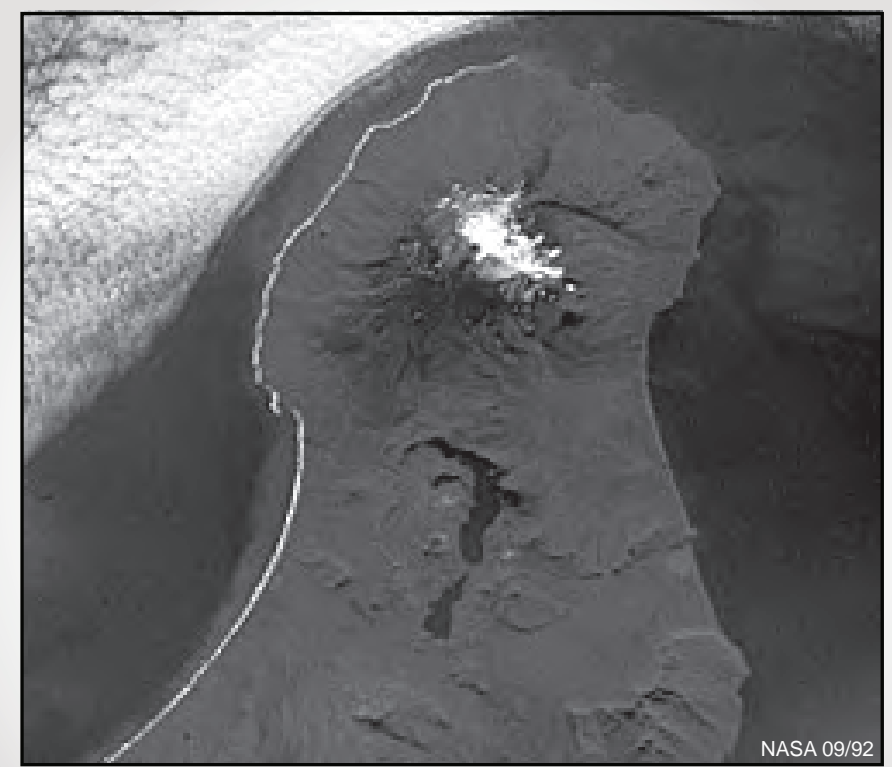

This caldera, one of the largest calderas in the Aleutian arc, is $11 \mathrm{~km}(6.8 \mathrm{mi})$ wide and $18 \mathrm{~km}(11 \mathrm{mi})$ long. It is one of at least three volcanoes on Unimak Island that have been active in historical time.

\section{Alaska's Volcanic Arc of Fame}

Name:

Type:

Most Recent Activity:

Elevation:

Latitude:

Longitude:

Quandrangle:

Cool Fact:
Name:

Type:

Most Recent Activity:

Elevation:

Latitude:

Longitude:

Quandrangle:

Cool Fact: 


\section{Alaska's Volcanic Arc of Fame}

A

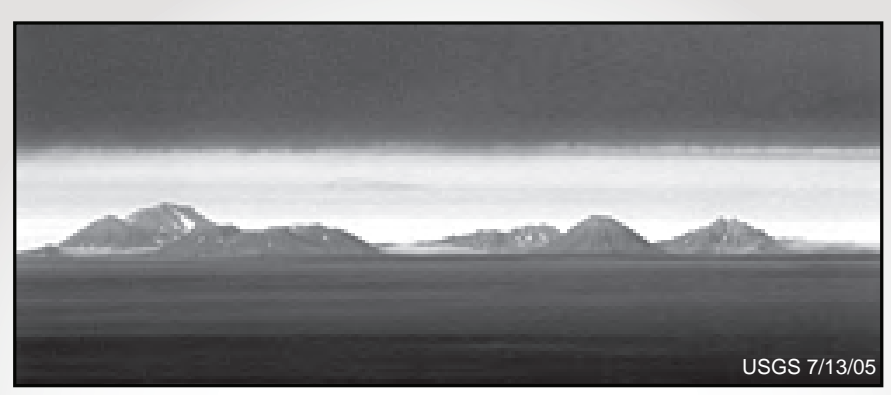

This volcano is the largest, young volcanic island in the western Aleutians. It boasts an 8 km (5 mi) wide caldera and small composite cones. One young composite cone (called Sugarloaf) has olivine basalt. This volcano is also on a small submarine ridge that extends northward as a part of the scorpion tail shaped Bower's Ridge. The latest reported activity occurred on April 13, 1987, when a plume extending $90 \mathrm{~km}$ (56 $\mathrm{mi}$ ) from the island was observed on satellite imagery.

\section{Alaska's Volcanic Arc of Fame}

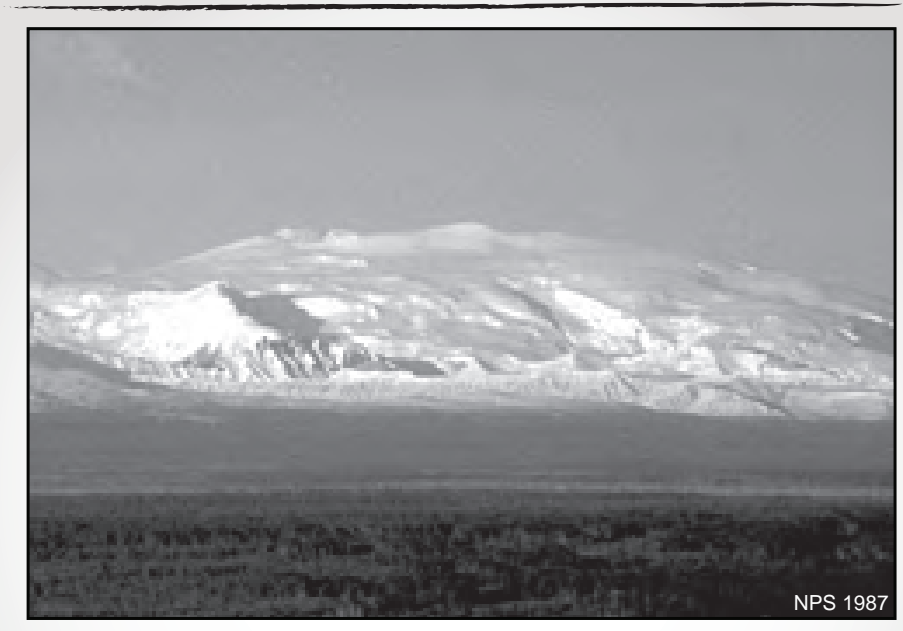

This a large shield volcano. It is capped by a 4 by $6 \mathrm{~km}$ ( 2.5 by $3.7 \mathrm{mi})$, ice filled summit caldera whose depth may exceed $1 \mathrm{~km}$ (0.6 mi). Mt. Zanetti, a large, steep sided cinder spatter cone is high on the northwest flank of the shield and may be the source of some lava flows.

\section{Alaska's Volcanic Arc of Fame}

Name:

Type:

Most Recent Activity:

Elevation:

Latitude:

Longitude:

Quandrangle:

Cool Fact:

\section{Alaska's Volcanic Arc of Fame}

Name:

Type:

Most Recent Activity:

Elevation:

Latitude:

Longitude:

Quandrangle:

Cool Fact: 


\section{Alaska's Volcanic Arc of Fame}

A

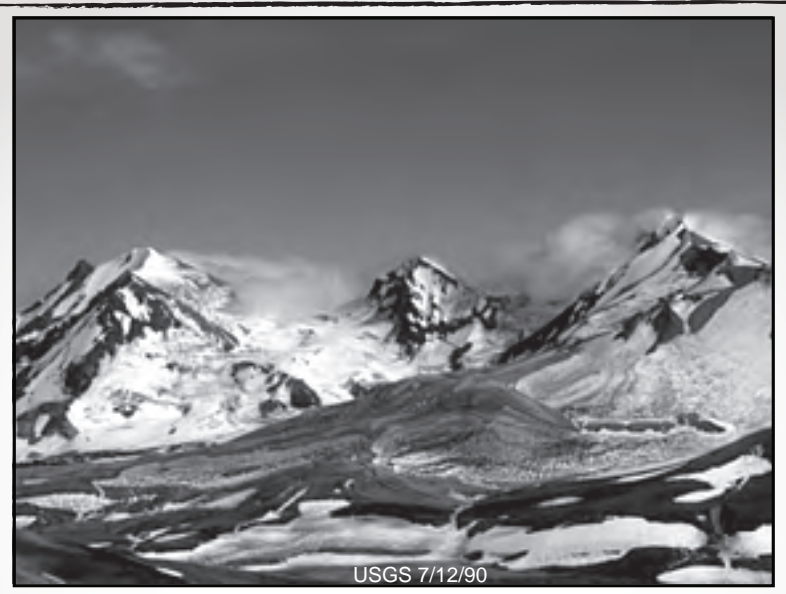

This is an eroded volcanic complex of three stratovolcanoes and numerous domes, as high as 1,864 $\mathrm{m}(6,115 \mathrm{ft})$ in elevation, on the Alaska Peninsula in Katmai National Park's Valley of Ten Thousand Smokes. A new fragmental cone was built from 1953 to 1974 to an altitude of $1,515 \mathrm{~m}(4,970 \mathrm{ft})$ in an amphitheater on the southwest flank of the southwest peak.

\section{Alaska's Volcanic Arc of Fame}

Name:

Type:

Most Recent Activity:

Elevation:

Latitude:

Longitude:

Quandrangle:

Cool Fact:

\section{Alaska's Volcanic Arc of Fame}

Name:

Type:

Most Recent Activity:

Elevation:

Latitude:

Longitude:

Quandrangle:

Cool Fact: 


\section{Alaska's Volcanic Arc of Fame}

A

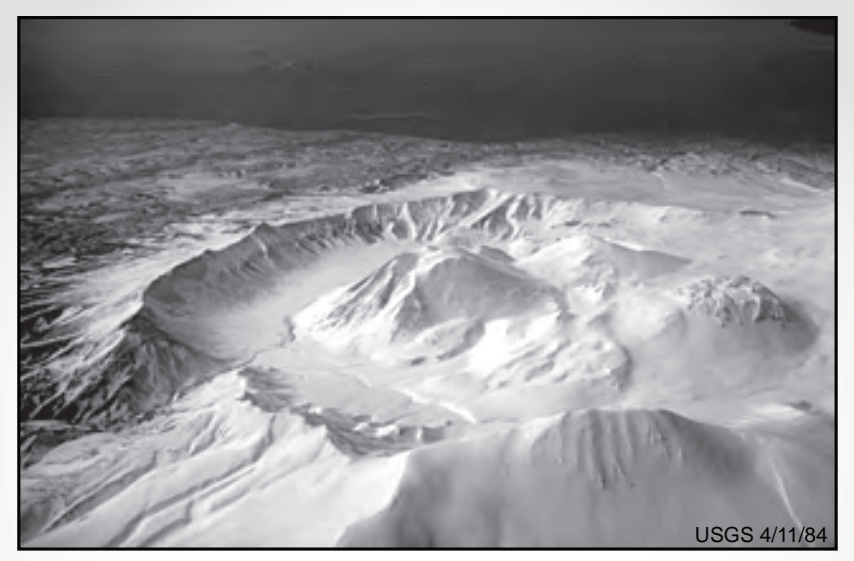

This caldera is $\sim 5 \mathrm{~km}(\sim 3 \mathrm{mi})$ in diameter and is south of Becharof Lake and east of Upper Ugashik Lake on the Alaska Peninsula. At least five lava domes (snow covered in this view) currently occupy the floor of the caldera. The peak of the caldera is $1,474 \mathrm{~m}$ $(4,836 \mathrm{ft})$ high.

\section{Alaska's Volcanic Arc of Fame}

Name:

Type:

Most Recent Activity:

Elevation:

Latitude:

Longitude:

Quandrangle:

Cool Fact:

\section{Alaska's Volcanic Arc of Fame}

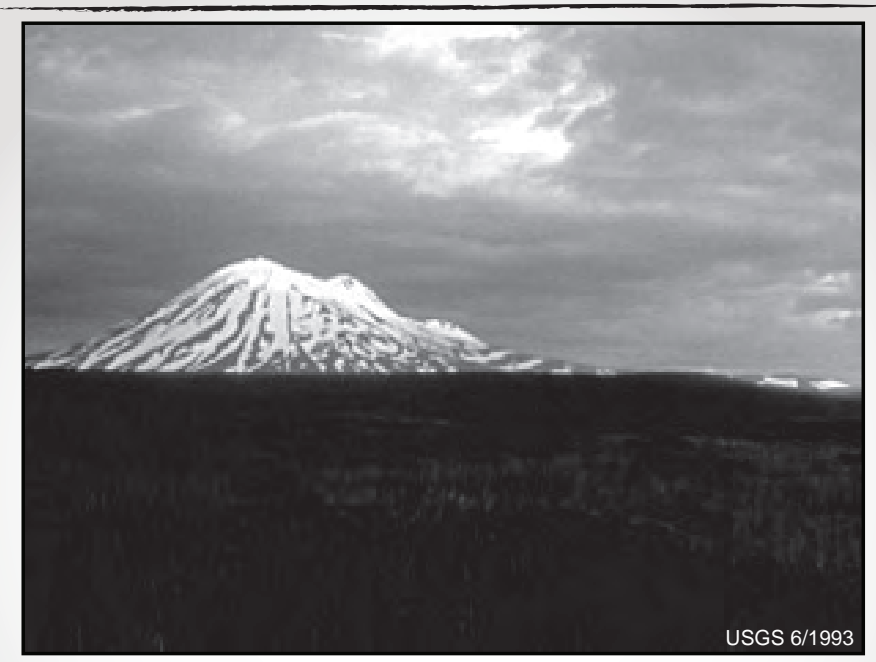

This volcano, a small truncated stratovolcano with a basal diameter of $\sim 10 \mathrm{~km},(\sim 6 \mathrm{mi})$ is near Becharof Lake on the Alaska

Peninsula. The volcano partially overlaps the north flank of Ugashik caldera. Flows from flank eruptions of this volcano cover $\sim 8 \mathrm{~km}^{2}$ $\left(3 \mathrm{mi}^{2}\right)$ north of the volcano extending as far as Becharof Lake.

\section{Alaska's Volcanic Arc of Fame}

Name:

Type:

Most Recent Activity:

Elevation:

Latitude:

Longitude:

Quandrangle:

Cool Fact: 


\section{Alaska’s Volcanic Arc of Fame}

A

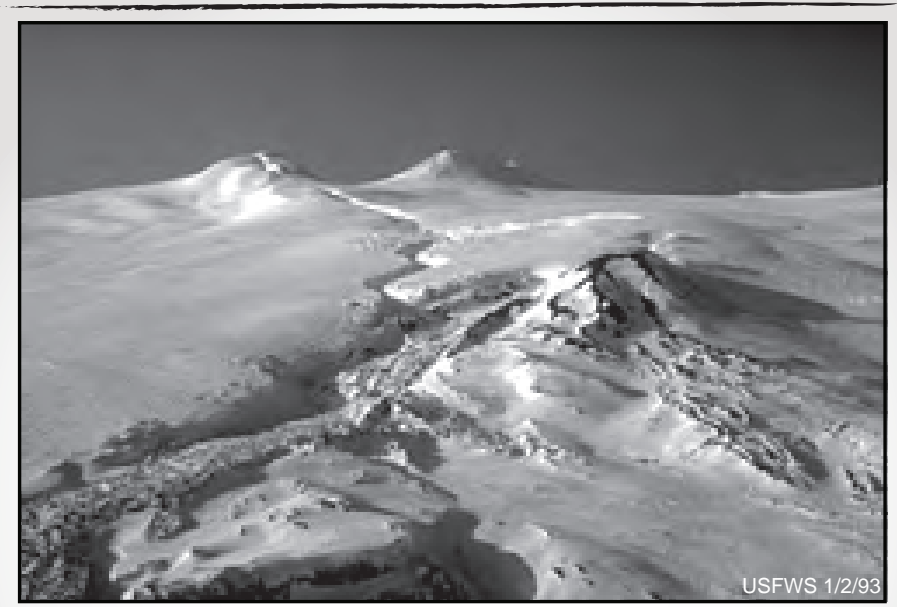

This peak, including nearby Faris Peak and Pogromni volcano, is located on a gently sloping plateau that may represent the surface of a truncated ancestral cone on Unimak Island in the eastern Aleutians. This volcano is $\sim 18 \mathrm{~km}$ (11 mi) in diameter at the base. On January 7, 2004, 90 earthquakes occurred over a period of 12 hours beneath this volcano.

\section{Alaska's Volcanic Arc of Fame}

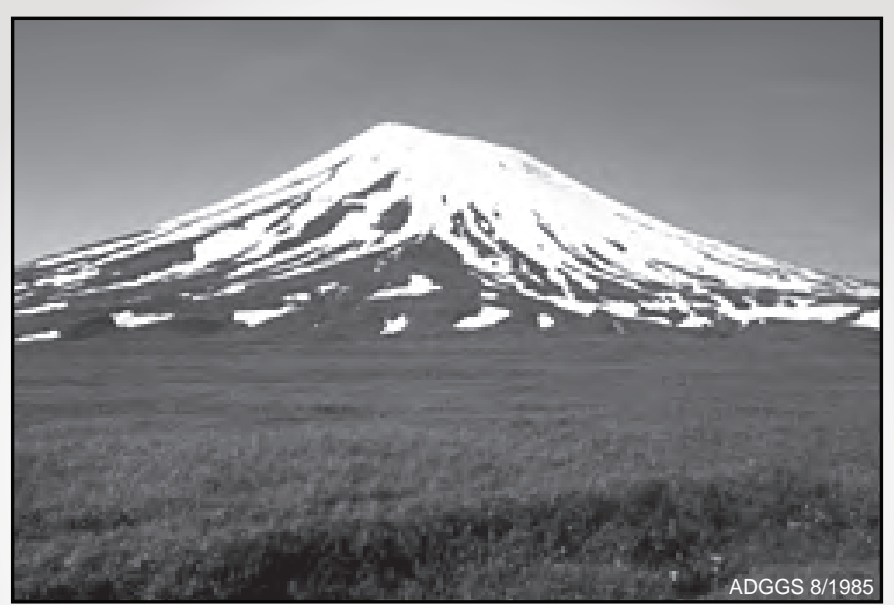

This volcano is a symmetrical stratovolcano near the southwest end of Umnak Island. It is $\sim 10 \mathrm{~km}(\sim 6 \mathrm{mi})$ wide at the base and steepens from 15 degrees at $300 \mathrm{~m}(984 \mathrm{ft})$ altitude to about 30 degrees near the summit. A crater occupies the summit. Glacial ice fills the crater and extends down the north and east flanks of the cone.

\section{Alaska's Volcanic Arc of Fame}

Name:

Type:

Most Recent Activity:

Elevation:

Latitude:

Longitude:

Quandrangle:

Cool Fact:

\section{Alaska’s Volcanic Arc of Fame}

Name:

Type:

Most Recent Activity:

Elevation:

Latitude:

Longitude:

Quandrangle:

Cool Fact: 


\section{Alaska's Volcanic Arc of Fame}

A

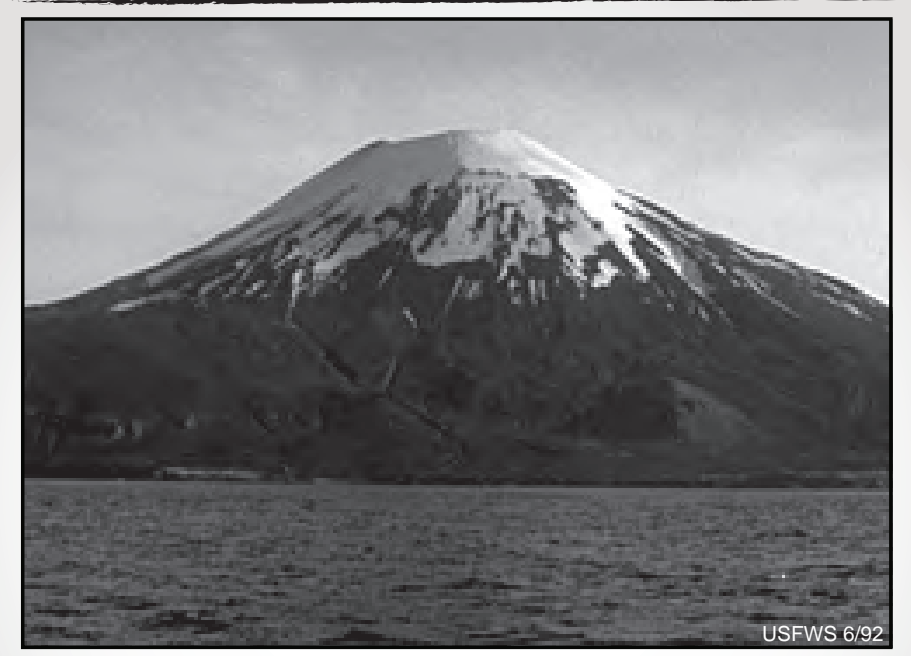

The most recent explosive eruption of this volcano occurred on Sept. 4, 1987, and was reported by a local pilot. The pilot observed a small dark ash plume rising at least $300 \mathrm{~m}$ (984 ft) above the summit of the volcano then drifting as much as $1 \mathrm{~km}(0.6 \mathrm{mi})$. The nearly circular volcanic cone is $1,066 \mathrm{~m}$ $(3,497 \mathrm{ft})$ high and is topped by a rater.

\section{Alaska's Volcanic Arc of Fame}

Name:

Type:

Most Recent Activity:

Elevation:

Latitude:

Longitude:

Quandrangle:

Cool Fact:

\section{Alaska's Volcanic Arc of Fame}

B

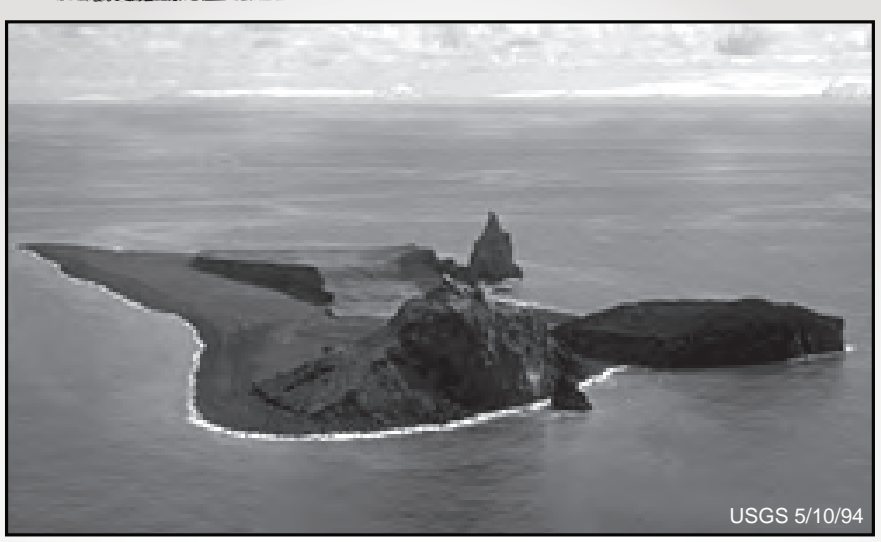

This is the largest of a cluster of small, low lying islands that comprise the summit of a large submarine stratovolcano that rises more than $1,500 \mathrm{~m}(4,921 \mathrm{ft})$ above the floor of the Bering Sea. It occurs north of the volcanic front of the main Aleutian arc. The island has undergone dramatic changes in size and shape during historical time, an evolution that has been well observed and recorded for such an isolated volcano.

\section{Alaska's Volcanic Arc of Fame}

Name:

Type:

Most Recent Activity:

Elevation:

Attitude:

Longitude:

Quandrangle:

Cool Fact: 


\section{Alaska's Volcanic Arc of Fame}

A

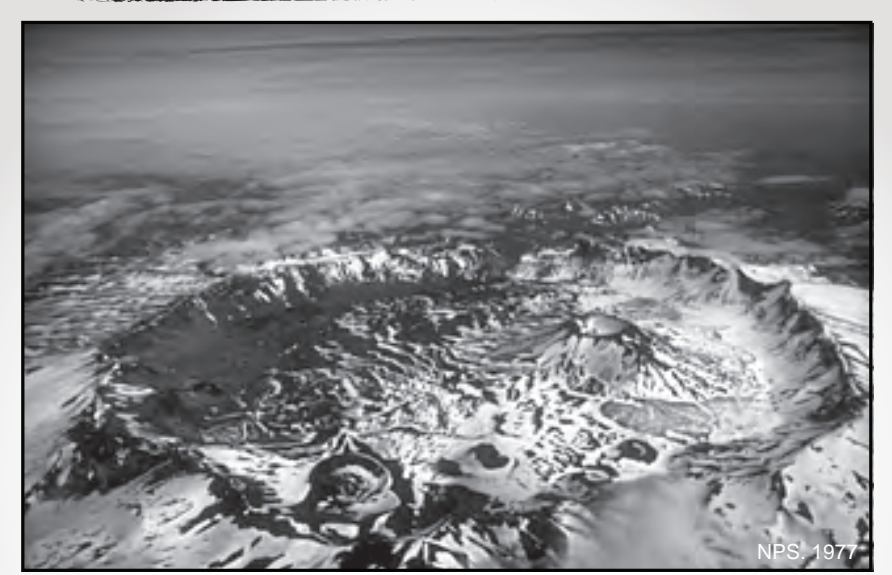

Ash flows from the caldera forming eruption of this volcano $\sim 3,400$ years ago reached both the Bering Sea and the Pacific Ocean. The caldera is $10 \mathrm{~km}(\sim 6.2 \mathrm{mi})$ across and $1 \mathrm{~km}(0.6 \mathrm{mi})$ deep at its deepest. The rim of the caldera varies from 610-1,341 m (2,000-4,400 ft). Within this caldera is $3.2-\mathrm{km}(2 \mathrm{mi})$ long lake at an elevation of $335 \mathrm{~m}(1,100 \mathrm{ft})$.

\section{Alaska's Volcanic Arc of Fame}

Name:

Type:

Most Recent Activity:

Elevation:

Latitude:

Longitude:

Quandrangle:

Cool Fact:

\section{Alaska's Volcanic Arc of Fame}

Name:

Type:

Most Recent Activity:

Elevation:

Latitude: plateau on the western side of the island
This volcano is located in a region called
Island of the Four Mountains in the central Aleutian Islands. This the symmetric cone is $1,524 \mathrm{~m}(5,000 \mathrm{ft})$ high and $\sim 6.5 \mathrm{~km}(4 \mathrm{mi})$ in diameter at sea level. Little is known about its structure or composition. There is some evidence of a $50 \mathrm{~m}(164 \mathrm{ft})$ high suggesting an emergent marine terrace.

\section{Alaska's Volcanic Arc of Fame}

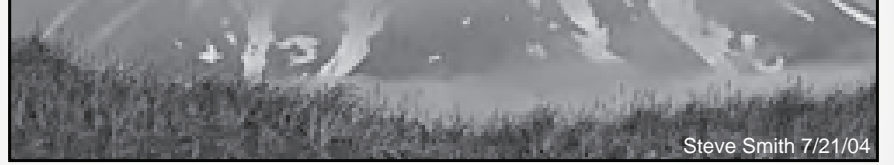
suggesting an emergent marine terrace. 


\section{Alaska's Volcanic Arc of Fame}

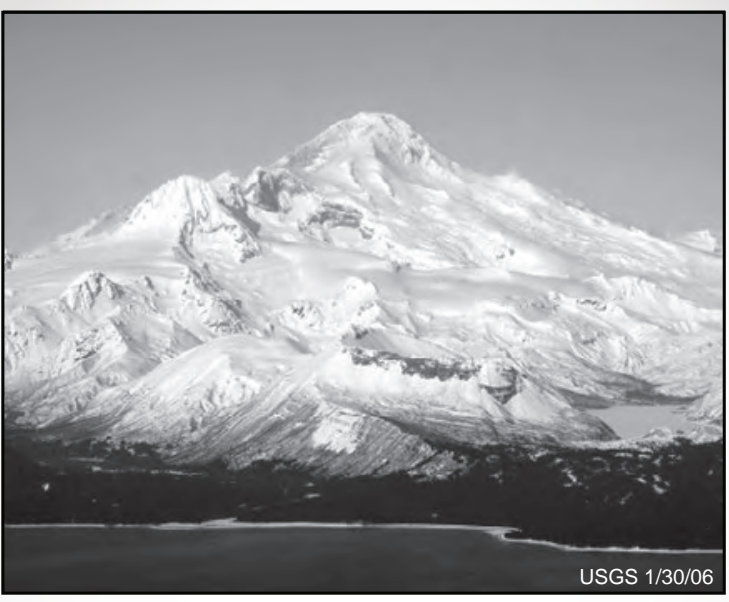

This volcano frequently is seen steaming from a fumarole and is often mistaken for eruptive activity. This volcano can be seen from several points on the Kenai Peninsula when looking southwest down Cook Inlet. Just south of the summit region of this volcano are a pair of peaks known as North Twin and South Twin.

\section{Alaska's Volcanic Arc of Fame}

Name:

Type:

Most Recent Activity:

Elevation:

Latitude:

Longitude:

Quandrangle:

Cool Fact:

\section{Alaska's Volcanic Arc of Fame}

B

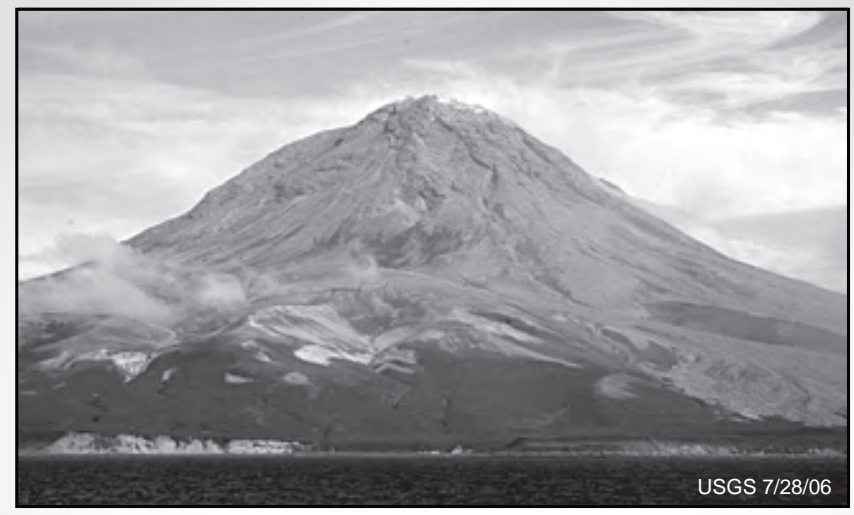

This is the most active and youngest volcano in the Cook Inlet. It erupted five times in the 20th century. The most recent eruption of this volcano began in the winter of 2006 and lasted throughout the spring and early summer. This is an island volcano and looks a lot like a pointy witch's hat with a wide, low brim close to shore and a pointy peak near the center.

\section{Alaska's Volcanic Arc of Fame}

Name:

Type:

Most Recent Activity:

Elevation:

Latitude:

Longitude:

Quandrangle:

Cool Fact: 


\section{Alaska's Volcanic Arc of Fame}

A

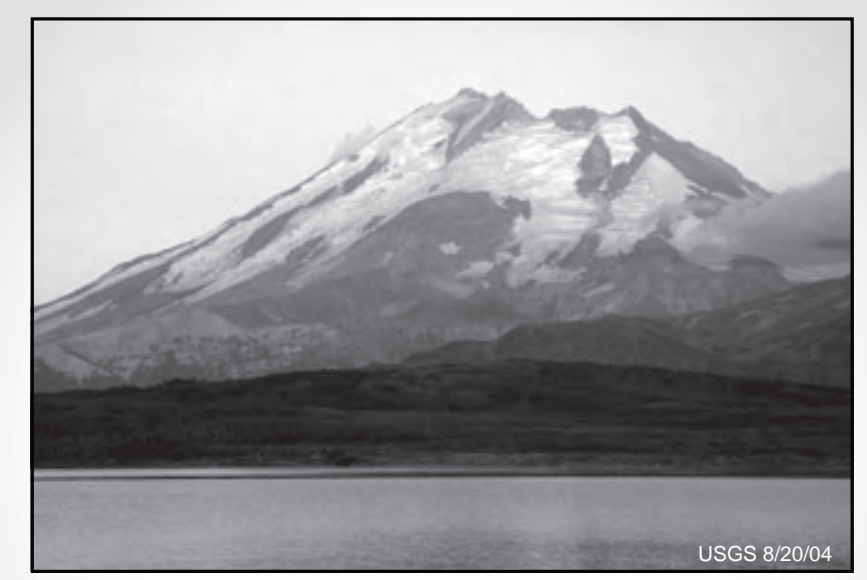

This volcano sits southwest of Mother Goose Lake in the Alaska Peninsula National Wildlife Refuge, Uagshik Unit. It is a 2,135 $\mathrm{m}(7,000 \sim \mathrm{ft})$ high symmetrical cone $\sim 8 \mathrm{~km}$ (5 mi) in diamemter. In 2004, a lake formed in the summit crater. In 2005, this acidic lake drained causing lahars, flooding, an anoxic lake, and acidic streams.

\section{Alaska's Volcanic Arc of Fame}

Name:

Type:

Most Recent Activity:

Elevation:

Latitude:

Longitude:

Quandrangle:

Cool Fact:
B

\section{Alaska's Volcanic Arc of Fame}

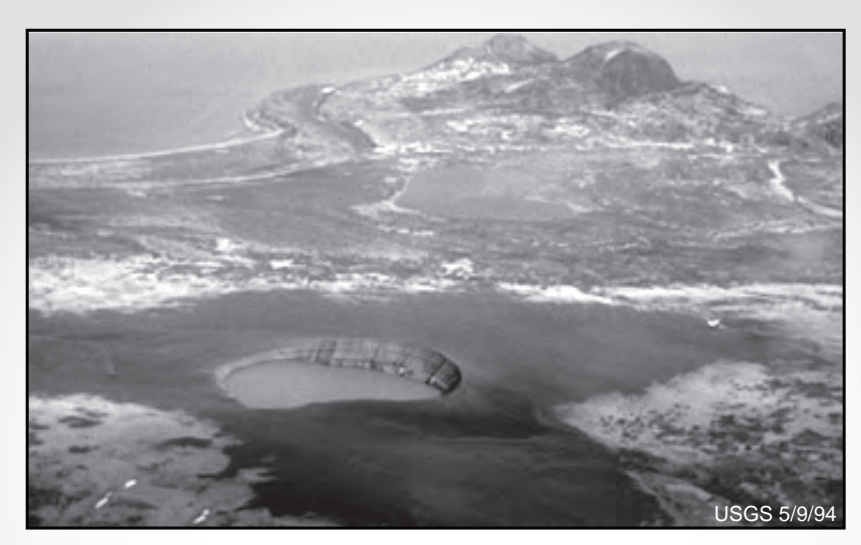

These maars were caused by phreato magmatic explosions (water flashing to steam due to the proximity of heat from nearby magma) in the spring of 1977 . The maars are south of Becharof Lake northwest of Peulik volcano and are $\sim 600 \mathrm{~m}(1,968 \mathrm{ft})$ apart. The East Maar is $300 \mathrm{~m}(984 \mathrm{ft})$ across, $70 \mathrm{~m}(230 \mathrm{ft})$ deep and has a submerged lava dome.

\section{Alaska's Volcanic Arc of Fame}

Name:

Type:

Most Recent Activity:

Elevation:

Latitude:

Longitude:

Quandrangle:

Cool Fact: 


\section{Alaska's Volcanic Arc of Fame}

A

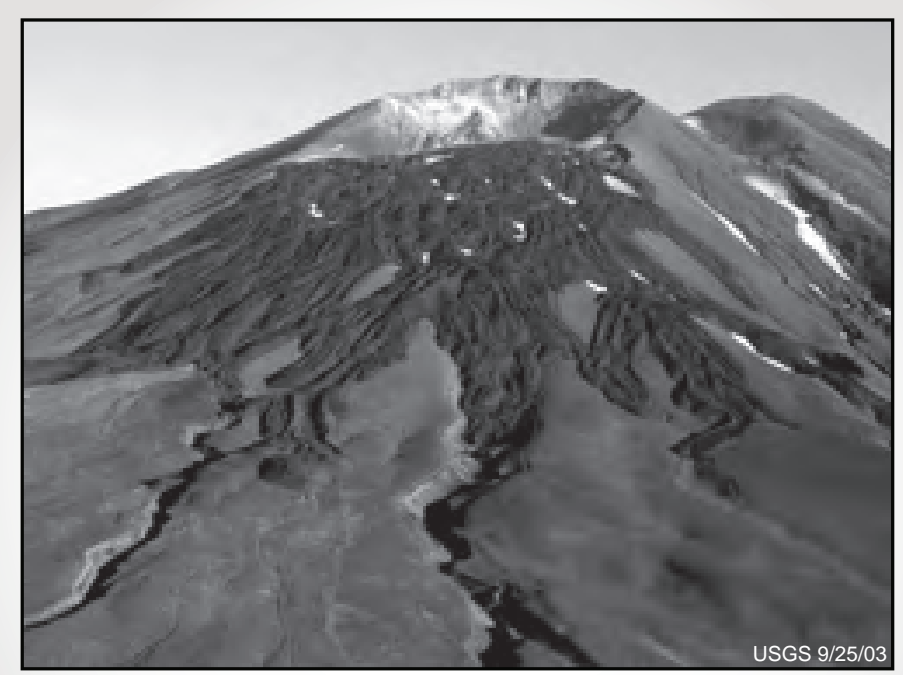

This volcano encompasses an island by the same name in the western Aleutians. It has two summits separated by a narrow saddle. Thirteen young craters are aligned along a south southeastward trending fissure on the southernmost peak and formed in 1929.

\section{Alaska's Volcanic Arc of Fame}

Name:

Type:

Most Recent Activity:

Elevation:

Latitude:

Longitude:

Quandrangle:

Cool Fact:

\section{Alaska's Volcanic Arc of Fame}

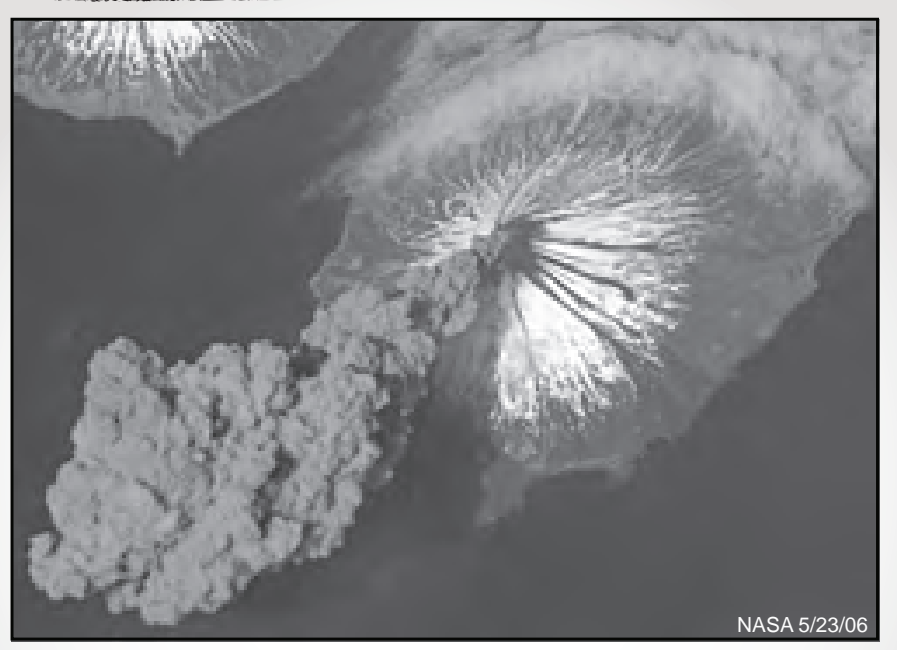

This volcano is in a region known as the Island of the Four Mountains in the central Aleutians. It makes up the western half of Chuginadak Island. It is $\sim 1,730 \mathrm{~m}$ ( 5,676 ft) high. On May 23, 2006, an astronaut aboard the International Space Station shot the image above and contacted the Alaska Volcano Observatory.

\section{Alaska's Volcanic Arc of Fame}

Name:

Type:

Most Recent Activity:

Elevation:

Latitude:

Longitude:

Quandrangle:

Cool Fact: 


\section{Alaska's Volcanic Arc of Fame}

A

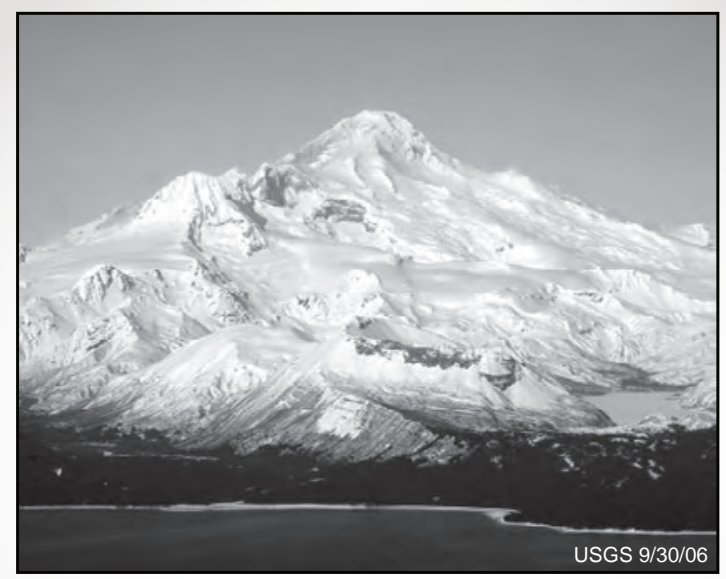

This volcano is in the northeasternmost part of Katmai National Park on the Alaska Peninsula, and is mostly covered by the Spotted Glacier. On the north side of the summit crater, there is an active fumarole field. There is no historical activity at this volcano, but the presence of a lake in the summit crater indicates recent activity.

\section{Alaska's Volcanic Arc of Fame}

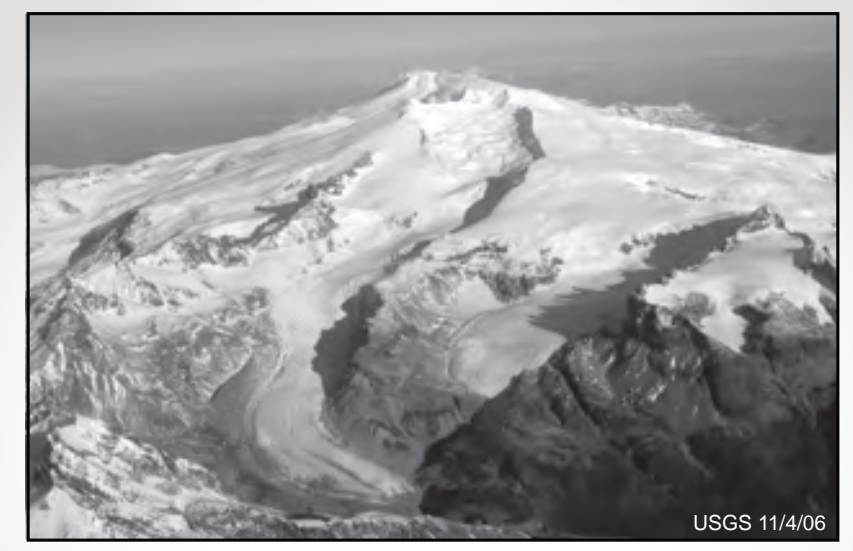

On Sept. 17, 2006, this volcano appeared to reawake from thousands of years of possible dormance. On that day, two steam plumes over this volcano were visible from Homer on the tip of the Kenai Peninsula. Satellite data showed that although these plumes did not contain significant amounts of volcanic ash, they did have high concentrations of magmatic $\mathrm{SO}_{2}$.

\section{Alaska's Volcanic Arc of Fame}

Name:

Type:

Most Recent Activity:

Elevation:

Latitude:

Longitude:

Quandrangle:

Cool Fact:

\section{Alaska's Volcanic Arc of Fame}

Name:

Type:

Most Recent Activity:

Elevation:

Latitude:

Longitude:

Quandrangle:

Cool Fact: 


\section{Alaska's Volcanic Arc of Fame}

A

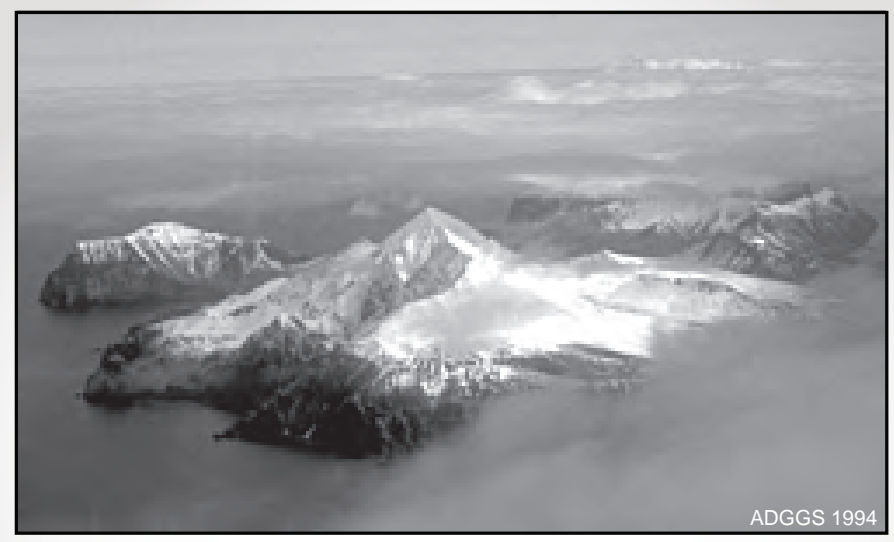

This is a small extinct volcano on the northernmost Akun Island. The summit has been completely eroded. Before 1948, active fumaroles in this area produced steam plumes visible as a distance. This activity has since stopped. Altered group northeast of the present summit There was an unsuccessful attempt to mine sulfur on the northeastern part of the volcano.

\section{Alaska's Volcanic Arc of Fame}

Name:

Type:

Most Recent Activity:

Elevation:

Latitude:

Longitude:

Quandrangle:

Cool Fact:

\section{Alaska's Volcanic Arc of Fame}

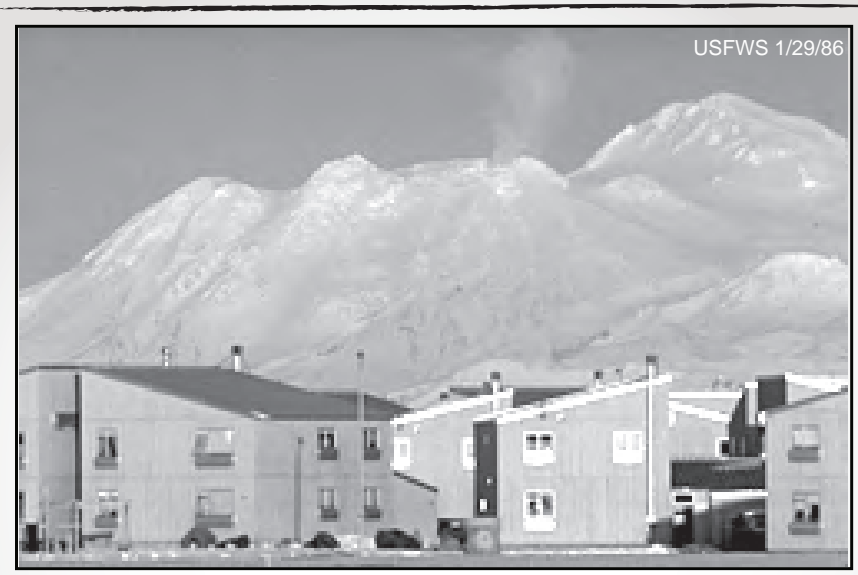

This volcano occupies the northern part of the island of the same name in the Andreanof Islands group of the central Aleutians. It is $1,740 \mathrm{~m}(5,709 \mathrm{ft})$ high. The volcano consists of the remains of an older, decapitated volcano and a younger parasitic cone that collapsed to form a small caldera on the west flank. This volcano looms over the town of Adak.

\section{Alaska's Volcanic Arc of Fame}

Name:

Type:

Most Recent Activity:

Elevation:

Latitude:

Longitude:

Quandrangle:

Cool Fact: 
p. \#

A. volcano

B. volcano

p. 141

A. Akutan

B. Tanaga

p. 142

A. Griggs

B. Kanaga

p. 143

A. Kasatochi

B. Kagamil

p. 144

A. Katmai

B. Novarupta

p. 145

A. Kiska

B. Yunaska

p. 146

A. Kluichef

B. Sarichef

p. 147

A. Kupreanof

B. Makushin

p. 148

A. Kukak

B. Little Sitkin p. 149

A. Mageik

B. Martin

p. 150

A. Okmok

B. Shishaldin

p. 151

A. Pavlov

B. Emmons

p. 152

A. Amak

B. Snowy

p. 153

A. Redoubt

B. Spurr

p. 154

A. Seguam

B. Fisher

p. 155

A. Semisopochnoi

B. Wrangell

p. 156

A. Trident

B. Veniaminof

p. 157

A. Ugashik

B. Peulik p. 158

A. Westdahl

B. Vsevidof

p. 159

A. AMutka

B. Bogoslof

p. 160

A. Aniakchak

B. Carlise

p. 161

A. Iliamna

B. Augustine

p. 162

A. Chiginigak

B. Ukinrek

p. 163

A. Gareloi

B. Cleveland

p. 164

A. Douglas

B. Fourpeaked

p. 165

A. Gilbert

B. Great Sitkin 


\section{Chapter 5 \\ Alaska's Volcanoes and You!}

\section{Resources}

- Alaska Volcano Observatory Preliminary Volcano Hazard Assessments http://www.avo.alaska.edu/downloads/classresults.php?pregen=haz .

- Begét, J.E., Larsen, J.F., Neal, C.A., Nye, C.J., and Schaefer, J.R., 2005, Preliminary volcano-hazard assessment for Okmok Volcano, Umnak Island, Alaska: Alaska Division of Geological and Geophysical Surveys Report of Investigations 2004-3, 32 p., 1 sheet, scale 1:150,000, accessed June 1, 2010, at http://www.avo.alaska.edu/downloads/classresults.php?citid=4029.

- Begét, J.E., Nye, C.J., and Bean, K.W., 2000, Preliminary volcano-hazard assessment for Makushin Volcano, Alaska: Alaska Division of Geological \& Geophysical Surveys Report of Investigations RI 2000-4, 22 p., 1 sheet, scale 1:100,000, accessed June 1, 2010, at http://www.avo.alaska.edu/downloads/classresults.php?citid=656.

- Begét, J.E., Nye, C.J., Schaefer, J.R., and Stelling, P.L., 2002, Preliminary volcano-hazard assessment for Shishaldin Volcano, Alaska: Alaska Division of Geological and Geophysical Surveys Report of Investigations 2002-4, 28 p., 1 sheet, scale 1:500,000, accessed June 1, 2010, at http://www.avo.alaska.edu/downloads/classresults.php?citid=3380.

- Coombs, M.L., McGimsey, R.G., and Browne, B.L., 2007, Preliminary volcanohazard assessment for the Tanaga Volcanic Cluster, Tanaga Island, Alaska: U.S. Geological Survey Scientific Investigations Report 2007-5094, 36 p., 1 sheet. (Also available at http://pubs.usgs.gov/sir/2007/5094/.)

- Coombs, M.L., McGimsey, R.G., and Browne, B.L., 2008, Preliminary volcanohazard assessment for Gareloi Volcano, Gareloi Island, Alaska: U.S. Geological Survey Scientific Investigations Report 2008-5159, 26 p., 1 sheet. (Also available at http://pubs.usgs.gov/sir/2008/5159/.)

- Fierstein, Judy, and Hildreth, Wes, 2001, Preliminary volcano-hazard assessment for the Katmai volcanic cluster, Alaska: U.S. Geological Survey Open-File Report 00-489, 50 p., 1 plate. (Also available at http://www.avo.alaska.edu/downloads/classresults.php?citid=660.)

- Neal, C.A., McGimsey, R.G., Miller, T.P., Riehle, J.R., and Waythomas, C.F., 2001, Preliminary volcano-hazard assessment for Aniakchak Volcano, Alaska: U.S. Geological Survey Open-File Report 00-519, 35 p., 1 plate. (Also available at http://www.avo.alaska.edu/downloads/classresults.php?citid=718.)

- Waythomas, C.F., Dorava, J.M., Miller, T.P., Neal, C.A., and McGimsey, R.G., 1998, Preliminary volcano-hazard assessment for Redoubt Volcano, Alaska: U.S. Geological Survey Open-File Report 97-857, 40 p., 1 plate, scale unknown. (Also available at http://www.avo.alaska.edu/downloads/classresults.php?citid=713.)

- Waythomas, C.F., and Miller, T.P., 1999, Preliminary volcano-hazard assessment for Iliamna Volcano, Alaska: U.S. Geological Survey Open-File Report 99-373, 31 p., 1 sheet, scale unknown. (Also available at http://www.avo.alaska.edu/downloads/classresults.php?citid=642.) 
- Waythomas, C.F., and Miller, T.P., 2002, Preliminary volcano-hazard assessment for Hayes Volcano, Alaska: U.S. Geological Survey Open-File Report 02-72, 33 p. (Also available at http://www.avo.alaska.edu/downloads/classresults.php?citid=2935.)

- Waythomas, C.F., Miller, T.P., and Mangan, M.T., 2006, Preliminary volcano hazard assessment for the Emmons Lake Volcanic Center, Alaska: Anchorage, Alaska: U.S. Geological Survey, Scientific Investigations Report 2006-5248, 33 p., 1 sheet. (Also available at http://www.avo.alaska.edu/downloads/classresults.php?citid=4180.)

- Waythomas, C.F., Miller, T.P., and Nye, C.J., 2002, Preliminary volcano-hazard assessment for Kanaga Volcano, Alaska: U.S. Geological Survey Open-File Report 02-397, 27 p., 1 sheet. (Also available at http://www.avo.alaska.edu/downloads/classresults.php?citid=3494.)

- Waythomas, C.F., Miller, T.P., and Nye, C.J., 2003, Preliminary volcano-hazard assessment for Great Sitkin Volcano, Alaska: U.S. Geological Survey Open-File Report 03-112, 25 p., 1 sheet. (Also available at http://www.avo.alaska.edu/downloads/classresults.php?citid=3493.)

- Waythomas, C.F., and Nye, C.J., 2002, Preliminary volcano-hazard assessment for Mount Spurr Volcano, Alaska: U.S. Geological Survey Open-File Report 01482, 46 p. (Also available at http://www.avo.alaska.edu/downloads/classresults.php?citid=2936.)

- Waythomas, C.F., Power, J.A., Richter, D.H., and McGimsey, R.G., 1998, Preliminary volcano-hazard assessment for Akutan Volcano east-central Aleutian Islands, Alaska: U.S. Geological Survey Open-File Report 98-360, 36 p., 1 plate, scale unknown. (Also available at http://www.avo.alaska.edu/downloads/classresults.php?citid=728.)

- Waythomas, C.F., and Waitt, R.B., 1998, Preliminary volcano-hazard assessment for Augustine Volcano, Alaska: U.S. Geological Survey Open-File Report 980106, 39 p., 1 plate, scale unknown. (Also available at http://www.avo.alaska.edu/downloads/classresults.php?citid=701.)

- U.S. Geological Survey Volcano Hazards Program Fact Sheets

- Brantley, S.R., McGimsey, R.G., and Neal, C.A., 2004 [2009], The Alaska Volcano Observatory-Expanded monitoring of volcanoes yields results: U.S. Geological Survey Fact Sheet 2004-3084, 2 p. (Also available at http://pubs.usgs.gov/fs/2004/3084/ and http://pubs.usgs.gov/fs/2004/3084/fs20043084_v1.1.pdf.)

- Fierstein, Judy, Hildreth, Wes, Hendley, J.W., and Stauffer, P.H., 1998, Can another great eruption happen in Alaska? U.S. Geological Survey Fact Sheet 07598, 2 p. (Also available at http://pubs.usgs.gov/fs/fs075-98/ and http://pubs.usgs.gov/fs/fs075-98/fs075-98.pdf.)

- Gardner C.A., and Guffanti, M.C., 2006, U.S. Geological Survey's alert notification system for volcanic activity: U.S. Geological Survey Fact Sheet 20063139, 4 p. (Also available at http://pubs.usgs.gov/fs/2006/3139/fs2006-3139.pdf.) 
- Kenedi, C.A., Brantley, S.R., Hendley, J.W., II, and Stauffer, P.H., 2000, Volcanic ash—A "hard rain" of abrasive particles: U.S. Geological Survey Fact Sheet 027-00, 2 p. (Also available at http://pubs.usgs.gov/fs/fs027-00/ and http://pubs.usgs.gov/fs/fs027-00/fs02700.pdf.)

- Myers, B., Brantley, S.R., Stauffer, P., and Hendley, J.W., II, 1997 [2004], What are volcano hazards: U.S. Geological Survey Fact Sheet 002-97, 2 p. (Also available at http://pubs.usgs.gov/fs/fs002-97/, http://pubs.usgs.gov/fs/fs00297/fs002-97.pdf, and Spanish PDF http://pubs.usgs.gov/fs/fs144-00/fs144-00.pdf.)

- Neal, C.A., Casadevall, T.J., Miller, T.P., Hendley, J.W., II, and Stauffer, P.H., 1997, Volcanic ash-Danger to aircraft in the north Pacific: U.S. Geological Survey Fact Sheet 030-97, 2 p. (Also available at http://pubs.usgs.gov/fs/fs03097/ and http://pubs.usgs.gov/fs/fs030-97/fs030-97.pdf.)

- Wallace, K.L., McGimsey, R.G., and Miller, T.P., 2000, Historically active volcanoes in Alaska-A quick reference: U.S. Geological Survey Fact Sheet 11800, 2 p. (Also available at http://pubs.usgs.gov/fs/2000/fs118-00/ and http://pubs.usgs.gov/fs/2000/fs118-00/fs118-00.pdf.)

- U.S. Geological Survey websites

- U.S. Geological Survey, 2003, Volcano and hydrologic hazards, features, and terminology: U.S. Geological Survey website. (Available at http://vulcan.wr.usgs.gov/Glossary/framework.html.)

- U.S. Geological Survey, 2009, Volcano Hazards Program-1989-90 eruption of Redoubt Volcano, Alaska, and the first test case of a USGS lahar-detection system: U.S. Geological Survey website. (Available at http://volcanoes.usgs.gov/activity/methods/hydrologic/afm_redoubt.php.)

- U.S. Geological Survey, 2009, Volcano Hazards Program-Types of Volcano Hazards: U.S. Geological Survey website. (Available at http://volcanoes.usgs.gov/hazards/.)

- U.S. Geological Survey and partners, 2010, Volcanic ash... what it can do and how to prevent damage: U.S. Geological Survey and partners website. (Available at http://volcanoes.usgs.gov/ash/.)

- U.S. Geological Survey, 2010, Volcano Hazards Program-USGS photo glossary of volcanic terms: U.S. Geological Survey website. (Available at http://volcanoes.usgs.gov/images/pglossary/index.php.)

- U.S. Geological Survey, 2009, Volcano Hazards Program-USGS volcanic activity alert-notification system: U.S. Geological Survey website. (Available at http://volcanoes.usgs.gov/activity/alertsystem/.)

- Municipality of Anchorage, [n.d.], Emergency Management-Volcanic Ash Preparedness: Municipality of Anchorage website, accessed June 1, 2010, at http://www.muni.org/Departments/OEM/Prepared/Pages/VolcanicAsh.aspx. 
- Federal Emergency Management Agency, 2010, Ready America: Federal Emergency Management Agency website, accessed June 1, 2010, at http://www.ready.gov/america/index.html.

- American Red Cross, [n.d.], Disaster preparedness for people with disabilities: American Red Cross booklet, 48 p., accessed June 1, 2010, at http://alaska.redcross.org/media/disability.pdf.

- American Red Cross, [n.d.], Public information-Volcanoes: American Red Cross web page, accessed June 1, 2010, at http://alaska.redcross.org/media/volcano.pdf.

- American Red Cross of Alaska, 2010, Be Red Cross ready (in English, Hmong, Russian and Spanish): American Red Cross of Alaska web page, accessed June 1, 2010, at http://alaska.redcross.org/index.php?pr=Safety_Tips.

- American Red Cross of Alaska, 2010, Volcanoes: American Red Cross of Alaska website, accessed June 1, 2010, at http://alaska.redcross.org/index.php?pr=Volcanoes.

- Department of Homeland Security, [n.d.], Preparing makes sense for people with disabilities and special needs: Department of Homeland Security web page, accessed June 1, 2010, at http://www.ready.gov/america/_downloads/disabilities.pdf.

- Federal Emergency Management Agency, [n.d.], Family emergency plan: Federal Emergency Management Agency website, accessed June 1, 2010, at http://www.ready.gov/america/_downloads/familyemergencyplan.pdf

- Federal Emergency Management Agency and American Red Cross, 1991, Your family disaster plan: Federal Emergency Management Agency and American Red cross pamphlet, , accessed June 1, 2010, at http://alaska.redcross.org/media/disasterplan.pdf.

- Federal Emergency Management Agency and American Red Cross, 2004, Preparing for disaster: Federal Emergency Management Agency and American Red Cross booklet, 14 p., accessed June 1, 2010, at http://www.redcross.org/images/pdfs/preparedness/A4600.pdf.

Federal Emergency Management Agency, 2009, Are you ready?_-Volcanoes: Federal Emergency Management Agency website, accessed June 1, 2010, at http://www.fema.gov/areyouready/volcanoes.shtm.

- International Volcanic Health Hazard Network (IVHHN), 2010, Durham University website, accessed June 1, 2010, at http://ivhhn.org/.

- The Health Hazards of Volcanic Ash-A guide for the public PDF http://www.ivhhn.org/index.php?option=com_content\&view=article\&id=55\&Ite $\underline{\text { mid }=61}$

- Guidelines on Preparedness Before, During and After an Ashfall PDF http://www.ivhhn.org/index.php?option=com_content\&view=article\&id=55\&Ite $\underline{\operatorname{mid}=61}$ 
- Washington Military Department, Emergency Management Division and U.S. Geological Survey, 1999, Volcanic ashfall—How to be prepared for an ashfall: Washington State Emergency Management Division pamphlet, accessed June 1, 2010, at http://emd.wa.gov/publications/pubed/volcanic_ash_english.pdf.

- Alaska Division of Emergency Services, [n.d.], Ash alert!: Alaska Division of Emergency Services website, accessed June 1, 2010, at http://www.ak-prepared.com/Poster_Contest_Files/Ash_Alert.pdf

\section{Activities}

Students will be introduced to several types of volcanic eruption products, all of which are potential hazards, likely to occur in Alaska at least once during their lifetime.

Students will generate their own volcanic activity notification systems and compare them to those used by the volcano observatories within the U.S. Students will study and generate safety and community planning documents, plans, and kits to help prepare for a volcanic eruption and will be able to watch as a community becomes affected by falling volcanic ash through hands-on experimentation. Students will synthesize the general background information about volcanoes in Alaska and apply this knowledge to planning and preparing for a volcanic eruption that may affect their own community.

Activity I. We need all the assistance you have...

Activity II. What is the Plan?

Activity III. Volcanic Ash Fall in Your Community 
Activity I. We Need All the Assistance You Have...

Grade Level 6-11

Setting Classroom

Time 45-90 minutes

Vocabulary (see Glossary)

acid rain, ash fall, bombs, debris avalanche, eruption cloud, eruption column, fumarole, lahar-volcanic mudflow-volcanic debris flow, landslide, lava flow, pyroclastic flow, tephra

Correlations to Alaska State Department of Education (2006) Performance Standards (Grade Level Expectations)

A1-Science as Inquiry and Process

SA3[6-11] Students develop an understanding that cultural, local knowledge, history, and interactions with the environment contribute to the development of scientific knowledge, and that local applications provide opportunity for understanding scientific concepts and global issues.

\section{D1-Concepts of Earth Science}

SD[6-11] Students develop an understanding of the concepts, processes, theories, models, evidence, and systems of earth and space sciences.

SD2[6-11] Students develop an understanding of the origins, ongoing processes, and forces that shape the structure, composition, and physical history of the Earth.

\section{E1-Science and Technology}

SE[6-11] Students develop an understanding of the relationship among science, technology, and society

SE1[6-11] Students develop an understanding of how scientific knowledge and technology are used in making decisions about issues, innovations, and responses to everyday events.

SE2[6-11] Students develop an understanding that solving problems involves different ways of thinking, perspectives, and curiosity that lead to the exploration of multiple paths that are analyzed using scientific, technological, and social merits. 


\section{Overview}

Students will be introduced to several types of volcanic eruption products, all of which are potential hazards, likely to occur in Alaska at least once during their lifetime. Students will also learn about the close encounter of a jet aircraft and a volcanic ash cloud from Redoubt volcano that took place in 1989. This activity will give students the opportunity to develop two systems to describe activity at a volcano and the likely hazards it may pose to local and distant communities and to regional air traffic. The documents prepared in this activity are used to explain likely volcanic eruption products, the hazards they may pose to Alaskans, and how scientists communicate that kind of information. Students will compare their system with the system current used at all U.S. volcano observatories including the Alaska Volcano Observatory.

\section{Background}

Alaska is home to about 140 volcanoes and volcanic regions, which have been active within the last 2 million years. Of these volcanoes, about 90 have been active within the last 10,000 years and more than 50 have been active within historical time (since about 1700, for Alaska).

- Alaska Volcano Observatory, [n.d.], About Alaska’s volcanoes: Alaska Volcano Observatory website. (Available at http://www.avo.alaska.edu/volcanoes/about.php.)

Several types of volcanic activity can endanger the lives of people and property at distances near to and far from the volcano. Most volcanic eruptions in Alaska include explosive ejection or the flow of rock fragments and molten rock in various combinations of hot or cold, wet or dry, fast or slow, and acidic or not. Some hazards are more severe than other hazards depending on the size and extent of the eruption that is taking place and whether people and (or) property are in the way. Although most volcano hazards are triggered directly by an eruption, some may occur even when a volcano is relatively quiet.

The Alaska Volcano Observatory (AVO) assesses the full range of potential hazards at volcanic regions of Alaska in support of planning for public land use, developing emergency response plans, and raising general public awareness about volcanic hazards. This requires researchers to study the style and frequency of past eruptions, and to assess potential effects of future activity. Scientific results are summarized in hazards assessments, and include descriptions of the eruptive history of a given volcano, explanations of likely eruption scenarios, and determinations of probable impact zones for the range of expected hazards. Ultimately, hazards assessments will be published for all seismically monitored volcanoes in Alaska. All of AVOs hazard assessments are posted on the AVO website (http://www.avo.alaska.edu/downloads/classresults.php?pregen=haz).

AVO uses an alert-notification system for describing the level of activity (including eruptions) at Alaskan volcanoes. The alert-notification system is useful to people on the ground and in the air. The system has two parts - a four-tiered Volcano Alert Level and a four-tiered Aviation Color Code. AVO scientists determine alert levels for a volcano by using monitoring data and their knowledge of the expected or ongoing hazardous activity and assign the appropriate attributes using this system. The information is then posted to 
AVOs website and is faxed and emailed to hundreds of organizations and agencies responsible for the safety of life and property on the ground and in the air. AVO also conducts a call-down to at least a dozen agencies and organizations that are involved in eruption response and have responsibilities to generate their own warning messages, for example air traffic closures, ash fall estimates, and community preparedness planning.

This volcano alert-notification system also is used by the Cascades Volcano Observatory, the Hawaiian Volcano Observatory, the Long Valley Observatory, and the Yellowstone Volcano Observatory.

Materials emphasizing the types of volcanoes and volcanic eruption products are in Chapter 3 of this guidebook.

\section{Objectives}

Students will understand the different types of volcanic eruption products and potential hazards in Alaska and the unique aspects of ground-based and aviation volcanic hazards. Students will become familiar with a real Alaskan eruption and the serious hazards posed in the air and on the ground during explosive activity. Students will learn about the difficulties of forming a consensus regarding volcanic activity notifications, specifically those in use by emergency managers. Students will compare their outcomes with notification schemes that are currently used by the U.S. Geological Survey (USGS).

\section{Materials}

- Potential Volcanic Hazards I, Potential Volcanic Hazards II, Potential Volcanic Hazards III, and Volcanic Activity Notifications worksheets

- KLM Flight 867, Boeing -747 Communications with Anchorage Center on December 15, 1989 handout

\section{Procedure}

\section{A. Potential Volcanic Hazards I worksheet}

1. Instruct students to label the correct type of potential volcanic hazards portrayed in the Potential Volcanic Hazards I worksheet. Suggested resources include

- U.S. Geological Survey

- Myers, Bobbie, Brantley, S.R., Stauffer, Peter, and Hendley, J.W., II, 1997 [2004], What are volcano hazards?: U.S. Geological Survey Fact Sheet 00297, 2 p. (Also available at http://pubs.usgs.gov/fs/fs002-97/, http://pubs.usgs.gov/fs/fs002-97/fs002-97.pdf, and (Spanish PDF) http://pubs.usgs.gov/fs/fs144-00/fs144-00.pdf.)

Note Roughly the worksheet provided in activity

- U.S. Geological Survey, 2003, Cascades Volcano Observatory-Volcano and hydrologic hazards, features, and terminology: U.S. Geological Survey web pages. (Available at http://vulcan.wr.usgs.gov/Glossary/framework.html.) 
- U.S. Geological Survey, 2009, Volcano Hazards Program-Types of volcano hazards: U.S. Geological Survey web pages. (Available at http://volcanoes.usgs.gov/hazards/.)

Note This web page includes a figure that is roughly equal to a figure on the worksheet provided in activity.

- U.S. Geological Survey, 2010, Volcano Hazards Program-USGS photo glossary of volcanic terms: U.S. Geological Survey website. (Available at http://volcanoes.usgs.gov/imagespglossary/index.php.)

\section{B. Potential Volcano Hazards II worksheet}

1. For each potential volcanic hazard instruct the student to fill in the name and year of a specific volcanic eruption in which the hazard was posed. Have students emphasize Alaskan volcanic eruptions whenever possible. There is space on the worksheet for students to include hazards not already identified in the worksheet. Suitable for this section:

- Alaska Volcano Observatory, [n.d.], Alaska Volcano Observatory website. (Available at http://www.avo.alaska.edu ).

- Alaska Volcano Obserbatory, [n.d.], Hazard assessments: Alaska Volcano Observatory web page. (Available at http://www.avo.alaska.edu/downloads/classresults.php?pregen=haz.)

The AVO website also has an "Impact" tab under the reported Activity timeline for each volcano with available published documentation of impacts. Thus, not all volcanoes or reported activity will have such a tab or information listed at the AVO website. For example:

- Alaska Volcano Observatory, [n.d.], Novarupta reported activity 1912_Impact: Alaska Volcano Observatory website. (Available at http://www2.avo.alaska.edu/volcanoes/volcact.php?volcname=Novarupta\&page= impact\&eruptionid=456.)

\section{Potential Volcano Hazards III worksheet}

1. Discuss with your class the need to categorize and report likely volcanic hazards for emergency planning purposes. Determine if your students can come up with the airborne ash hazard to aircraft. The resources listed in A. above are appropriate for this as well.

2. In discussion, and (or) using the Potential Volcanic Hazards I and II worksheets, have students segregate the illustrated possible volcanic hazards into two categories approximating proximal and distal (close to the vent and far away, on the flanks of the volcano, and in the air, and so on) and determine which hazards belong in which category. Many hazards may belong in both categories. Have them include any hazards they came up with that were not already on the worksheet. 


\section{KLM Flight 867 handout}

1. Have students read aloud the KLM Flight 867, Boeing -747 Communications with Anchorage Center on December 15, 1989 handout.

2. Ask students why volcanic ash is a danger to aircraft. Discuss if airborne ash is a threat only to jet aircraft or to general aviation, as well. Determine if airborne ash in the North Pacific is a problem only for Alaska aviation or if it affects air travel elsewhere. Suggested resources include

- U.S. Geological Survey Volcano Hazards Program Fact Sheets

- Brantley, S.R., McGimsey, R.G., and Neal, C.A., 2004 (rev. 2009), The Alaska Volcano Observatory—Expanded monitoring of volcanoes yields results: U.S. Geological Survey Fact Sheet 2004-3084, 2 p. (Also available at http://pubs.usgs.gov/fs/2004/3084/ and http://pubs.usgs.gov/fs/2004/3084/fs2004-3084_v1.1.pdf.)

- Fierstein, Judy, Hildreth, Wes, Hendley, J.W., II, and Stauffer, P.H., 1998, Can another great eruption happen in Alaska?: U.S. Geological Survey Fact Sheet 075-98, 2 p. (Also available at http://pubs.usgs.gov/fs/fs075-98/ and http://pubs.usgs.gov/fs/fs075-98/fs075-98.pdf.)

- Kenedi, C.A., Brantley, S.R., Hendley, J.W., II, and Stauffer, P.H., 2000, Volcanic ash—A "hard rain" of abrasive particles: U.S. Geological Survey Fact Sheet 027-00, 2 p. (Also available at http://pubs.usgs.gov/fs/fs027-00/ and http://pubs.usgs.gov/fs/fs027-00/fs027-00.pdf.)

- Kienle, J., 1994, Volcanic ash-aircraft incidents in Alaska prior to the Redoubt eruption on 15 December 1989, in Casadevall, T.J., ed., Volcanic ash and aviation safety—Proceedings of the First International Symposium on Volcanic Ash and Aviation Safety: U.S. Geological Survey Bulletin B 2047, p. 119-123. (Also available at http://www.avo.alaska.edu/downloads/classresults.php?citid=650.)

- Neal, C.A., Casadevall, T.J., Miller, T.P., Hendley, J.W., II, and Stauffer, P.H., 1997, Volcanic ash—Danger to aircraft in the north Pacific: U.S. Geological Survey Fact Sheet 030-97, 2 p. (Also available at http://pubs.usgs.gov/fs/fs030-97/ and http://pubs.usgs.gov/fs/fs030-97/fs030-97.pdf.)

3. Ask students what they have heard about the fate of this plane and its passengers. As a homework assignment, assign students to collect oral stories from relatives, friends, and other community members about this event and write a summary of their findings. An e-mail exchange will be all right instead of phone, radio, or in-person communication.

4. Discuss student findings in class. How many different accounts have the students assembled? Compare these summaries, memories of individuals who may have been there or heard of the incident, with the accounts conveyed in contemporary documents and periodicals. Stress the importance of contemporary documentation and its superiority to reliance on human memory. Recommended documents: 
- Casadevall, T.J., 1994, The 1989-1990 eruption of Redoubt Volcano, AlaskaImpacts on aircraft operations, in Miller, T.P., and Chouet, B.A., eds., The 19891990 eruptions of Redoubt Volcano, Alaska: Journal of Volcanology and Geothermal Research, v. 62, no. 1, p. 301-316.

- Dean, K.G., Whiting Lawrence, and Jiao, Haitao, 1994, An aircraft encounter with a Redoubt ash cloud (a satellite view), in Casadevall, T.J., ed., Volcanic ash and aviation safety-Proceedings of the First International Symposium on Volcanic Ash and Aviation Safety: U.S. Geological Survey Bulletin B 2047, p. 333-339. (Also available at http://www.avo.alaska.edu/pdfs/B2047_p333to339.pdf.)

- McGimsey, Game, 2001, Redoubt volcano and the Alaska Volcano Observatory, 10 years later, in Gough, L.P., and Wilson, F.H., eds., Geologic studies in Alaska by the U.S. Geological Survey, 1999: U.S. Geological Survey Professional Paper 1633, p. 5-12. (Also available at http://pubs.usgs.gov/pp/p1633/.)

- Miller, T.P., and Chouet, B.A., 1994, The 1989-1990 eruptions of Redoubt volcano-An introduction, in Miller, T.P., and Chouet, B.A., eds., The 19891990 eruptions of Redoubt Volcano, Alaska: Journal of Volcanology and Geothermal Research, v. 62, no. 1, p. 1-10.

5. The 1989-90 eruption of Redoubt Volcano generated lahars in the Drift River Valley. The lahars were caused by sudden melting of snow and ice from hot pyroclastic flows and dome collapses that swept down the volcano's north flank. Many of the lahars swept all the way to Cook Inlet (a distance of $\sim 35 \mathrm{~km},[\sim 22 \mathrm{mi}]$ ), and raised concern about the safety of an oil terminal facility built on the bank of Drift River. Discuss this event with your students. Have students conduct research about the response of the USGS. Resources include:

- Alaska Volcano Observatory, [n.d.], Redoubt reported activity—1989 eruption impact: Alaska Volcano Observatory website. Available at http://www.avo.alaska.edu/volcanoes/volcact.php?volcname=Redoubt\&page=imp act\&eruptionid $=442$.

- Dorava, J.M., and Meyer, D.F., 1994, Hydrologic hazards in the lower Drift River Basin associated with the 1989-1990 eruptions of Redoubt Volcano, Alaska, in Miller, T.P., and Chouet, B.A., eds., The 1989-1990 eruptions of Redoubt Volcano, Alaska: Journal of Volcanology and Geothermal Research, v. 62, no. 1, p. 387-407.

- Tuck, B.H., and Huskey, L., 1994, Economic disruptions by Redoubt volcano: assessment methodology and anecdotal empirical evidence, in Casadevall, T.J., ed., Volcanic ash and aviation safety—Proceedings of the First International Symposium on Volcanic Ash and Aviation Safety: U.S. Geological Survey Bulletin B 2047, p. 137-140. (Also available at http://www.avo.alaska.edu/pdfs/B2047_p137to140.pdf.)

- U.S. Geological Survey, 2009, Volcano Hazards Program-1989-1990 eruption of Redoubt Volcano, Alaska, and the first test case of a USGS lahar-detection system: U.S. Geological Survey website. (Available at http://volcanoes.usgs.gov/activity/methods/hydrologic/afm_recoubt.php.) 


\section{E. Volcanic Activity Notifications worksheets}

1. After completion of parts $A-D$, students should be able to recognize the distinct potential volcanic hazards facing infrastructure and people on the ground and in the air. Students will now develop a system that categorizes and ranks the level of volcanic activity and the possible hazards that it may pose to people and property.

2. On the Volcanic Activity Notifications worksheets, instruct students develop two, four-level activity notification schemes for use by emergency managers. Include one for ground-based hazards, and one for aviation hazards. Direct students to consider how scientists would move from one level of notification to another, "up" or "down." In other words, on what basis would scientists change the current level of activity to another? You may ignore the worksheet, and tell students to develop their own tables. This works well as a group activity or class activity, with results displayed on the classroom white board.

3. It may be worth showing or discussing examples of similar systems for relaying information about other kinds of natural hazards. A few examples are:

- National Oceanographic and Atmospheric Administration, 2009, National Weather Service Forecast Office— Baltimore/Washington—Definitions of Weather Watch, Warnings and Advisories: National Oceanic and Atmospheric Administration web page, accessed June 2, 2010, at http://www.erh.noaa.gov/lwx/Defined/index.htm.

- National Oceanographic and Atmospheric Administration, 2010, National Weather Service: National Oceanographic and Atmospheric Administration website, accessed June 2, 2010, at http://www.weather.gov/.

- National Oceanographic and Atmospheric Administration, 2010, National Weather Service Pacific Tsunami Warning Center Messages: National Oceanographic and Atmospheric Administration web page, accessed June 2, 2010, at http://www.prh.noaa.gov/ptwc/about_messages.php.

4. Have students compare their system to those in currently in use by AVO. You can use the current scheme provided in summary or use

- Gardner, C.A., and Guffanti, M.C., 2006, U.S. Geological Survey's alert notification system for volcanic activity: U.S. Geological Survey Fact Sheet 20063139. p. 2-3. (Also available at http://pubs.usgs.gov/fs/2006/3139/fs20063139.pdf.) [12.14 MB] 


\section{Extensions}

1. Have students study a particular Alaskan volcano or community and report the volcanic hazards the community faces or those that the volcano may produce in the event on an eruption.

2. Have students interview a relative, friend, or member of the community who can recall local ash fall, the KLM flight 867 Redoubt airborne ash encounter, or other volcanic activity affecting the community.

3. Have students study and report on the positive contributions of volcanic products to the landscape to agriculture, beauty, and so on.

\section{References Cited}

Alaska State Department of Education and Early Development, 2006, Standards and grade level expectations, March 2006: State of Alaska website, accessed October 2009 at http://www.eed.state.ak.us/tls/assessment/GLEHome.html.

Alaska Volcano Observatory, [n.d.], About Alaska’s volcanoes: Alaska Volcano

Observatory web page. (Available at http://www.avo.alaska.edu/volcanoes/about.php.)

Alaska Volcano Observatory, [n.d.], About AVO: Alaska Volcano Observatory web page. (Available at http://www.avo.alaska.edu/about/index.php.)

U.S. Geological Survey, 2009, Volcano Hazards Program-USGS volcanic activity alertnotification system: U.S. Geological Survey web page. (Available at http://volcanoes.usgs.gov/activity/alertsystem/.)

\section{Glossary}

Acid rain - The term "acid rain" is commonly used to mean the deposition of acidic components in rain, snow, fog, dew, or dry particles. The more accurate term is "acid precipitation." Distilled water, which contains no carbon dioxide, has a neutral pH of 7. Liquids with a pH less than 7 are acid, and those with a $\mathrm{pH}$ greater than 7 are alkaline (or basic). "Clean" or unpolluted rain has a slightly acidic $\mathrm{pH}$ of 5.6, because carbon dioxide and water in the air react together to form carbonic acid, a weak acid. Around Washington, D.C., however, the average rain $\mathrm{pH}$ is between 4.2 and 4.4.

Ash fall - Volcanic ash consists of fine fragments (less than $2 \mathrm{~mm}$ ( 8/100 of an inch) across) of lava or rock formed in an explosive volcanic eruption. When volcanic ash falls to the ground the deposit typically is called an ash fall (also ashfall) deposit and typically is referred to as an ash fall. Ash falls vary widely in intensity, size of the ash particles, and the degree to which light from the sun is obscured or blocked completely. Because of the unexpected darkness during daylight hours, loud thunder and lightning, and the sometimes-strong smell of sulfur during an ash fall, many people describe the experience as eerie and frightening, disorienting and confusing, or dreadful. In extreme ash fall, for example when ash thickness is more than 5-10 cm (2-4 in.), people may feel stunned and fearful of the conditions, and have difficult time breathing if a well-sealed shelter is not available. If caught outside during low visibility, people may become lost or extremely disoriented. 
Bombs - Volcanic bombs are lava fragments that were ejected while viscous (partially molten) and are larger than $64 \mathrm{~mm}$ in diameter. Many acquire rounded aerodynamic shapes during their travel through the air. Volcanic bombs include breadcrust bombs, ribbon bombs, spindle bombs (with twisted ends), spheroidal bombs, and "cow-dung” bombs.

Debris avalanche - Debris avalanches are moving masses of rock, soil, and snow that occur when the flank of a mountain or volcano collapses and slides downslope. As the moving debris rushes down a volcano and into river valleys, it incorporates water, snow, trees, bridges, buildings, and anything else in the way. Debris avalanches may travel several kilometers before coming to rest, or they may transform into more water-rich lahars, which travel many tens of kilometers downstream.

Eruption cloud - An eruption cloud is a cloud of tephra and gases that forms downwind of an erupting volcano. The vertical pillar of tephra and gases rising directly above a vent is known as an eruption column. Eruption clouds are often dark colored-brown to gray — but they also can be white, very similar to weather clouds. Eruption clouds may drift downwind for thousands of kilometers and often increasingly spread out over a large area with increasing distance from an erupting vent. Large eruption clouds can circle the Earth within days.

Eruption column - An explosive eruption blasts molten and solid rock fragments (tephra) into the air with tremendous force. The largest fragments (bombs) fall back to the ground near the vent, usually within $2 \mathrm{mi}$. The smallest rock fragments (ash) continue rising into the air, forming a huge, billowing eruption column. Eruption columns can be enormous in size and grow rapidly, reaching more than $12 \mathrm{mi}$ above a volcano in less than 30 minutes. Once in the air, the volcanic ash and gas form an eruption cloud. Large eruption clouds can travel hundreds of miles downwind from a volcano, resulting in ash fall over enormous areas.

Fumarole - Vents from which volcanic gas escapes into the atmosphere. Fumaroles may occur along tiny cracks or long fissures, in chaotic clusters or fields, and on the surfaces of lava flows and thick deposits of pyroclastic flows. They may persist for decades or centuries if they are above a persistent heat source or disappear within weeks to months if they occur atop a fresh volcanic deposit that quickly cools.

Lahar -Volcanic mudflow - Volcanic debris flow - Lahar is an Indonesian word for a rapidly flowing mixture of rock debris and water that originates on the slopes of a volcano. Lahars are also referred to as volcanic mudflows or debris flows. They form in various ways, chiefly by the rapid melting of snow and ice by pyroclastic flows, intense rainfall on loose volcanic rock deposits, breakout of a lake dammed by volcanic deposits, and as a consequence of debris avalanches.

Landslide - Describes a wide variety of processes that result in the downward and outward movement of slope-forming materials including rock, soil, artificial fill, or a combination of these materials. The materials may move by falling, toppling, sliding, spreading, or flowing. 
Lava flow - Streams of molten rock that pours or oozes from an erupting vent. Lava is erupted during either non-explosive activity or explosive lava fountains. Lava flows destroy everything in their path, but most move slowly enough that people can move out of the way. The speed at which lava moves across the ground depends on several factors, including (1) type of lava erupted and its viscosity; (2) steepness of the ground over which it travels; (3) whether the lava flows as a broad sheet, through a confined channel, or down a lava tube; and (4) rate of lava production at the vent.

Pyroclastic flow - A ground-hugging avalanche of hot ash, pumice, rock fragments, and volcanic gas that rushes down the side of a volcano as fast as $100 \mathrm{~km} / \mathrm{h}(\sim 60 \mathrm{mi} / \mathrm{h})$ or more. The temperature within a pyroclastic flow may be greater than $500^{\circ} \mathrm{C}\left(900^{\circ} \mathrm{F}\right)$, sufficient to burn and carbonize wood. Once deposited, the ash, pumice, and rock fragments may deform (flatten) and weld together because of the intense heat and the weight of the overlying material. The emplaced flow is called a deposit.

Tephra - A general term for fragments of volcanic rock and lava regardless of sizes that are blasted into the air by explosions or carried upward by hot gases in eruption columns or lava fountains. Tephra includes large dense blocks and bombs, and small light rock debris such as scoria, pumice, reticulite, and ash.

\section{Source of Glossary Definitions}

National Atlas of the United States, 2009, Landslide types and processes: National Atlas of the United States web page, accessed June 2, 2010, at http://www.nationalatlas.gov/articles/geology/a_landslide.html.

U.S. Geological Survey, 1997, What is acid rain?: U.S. Geological Survey web page. (Available at http://pubs.usgs.gov/gip/acidrain/2.html.)

U.S. Geological Survey, 2006, Cascades Volcano Observatory—Description-volcanic eruptions, blasts, plumes, ballistics, etc.: U.S. Geological Survey web page. (Available at http://vulcan.wr.usgs.gov/Glossary/VolcanicBlasts/description_volcanic_blasts.html.)

U.S. Geological Survey and partners, 2009, Volcanic ash—Effects and mitigation strategies-What's it like during an ash fall?: U.S. Geological Survey web page. (Available at http://volcanoes.usgs.gov/ash/ashfall.html.)

U.S. Geological Survey, 2010, Volcano Hazards Program-USGS photo glossary of volcanic terms: U.S. Geological Survey website. (Available at http://volcanoes.usgs.gov/images/pglossary/index.php.) 
Name

Date

Period

\section{Potential Volcanic Hazards I}

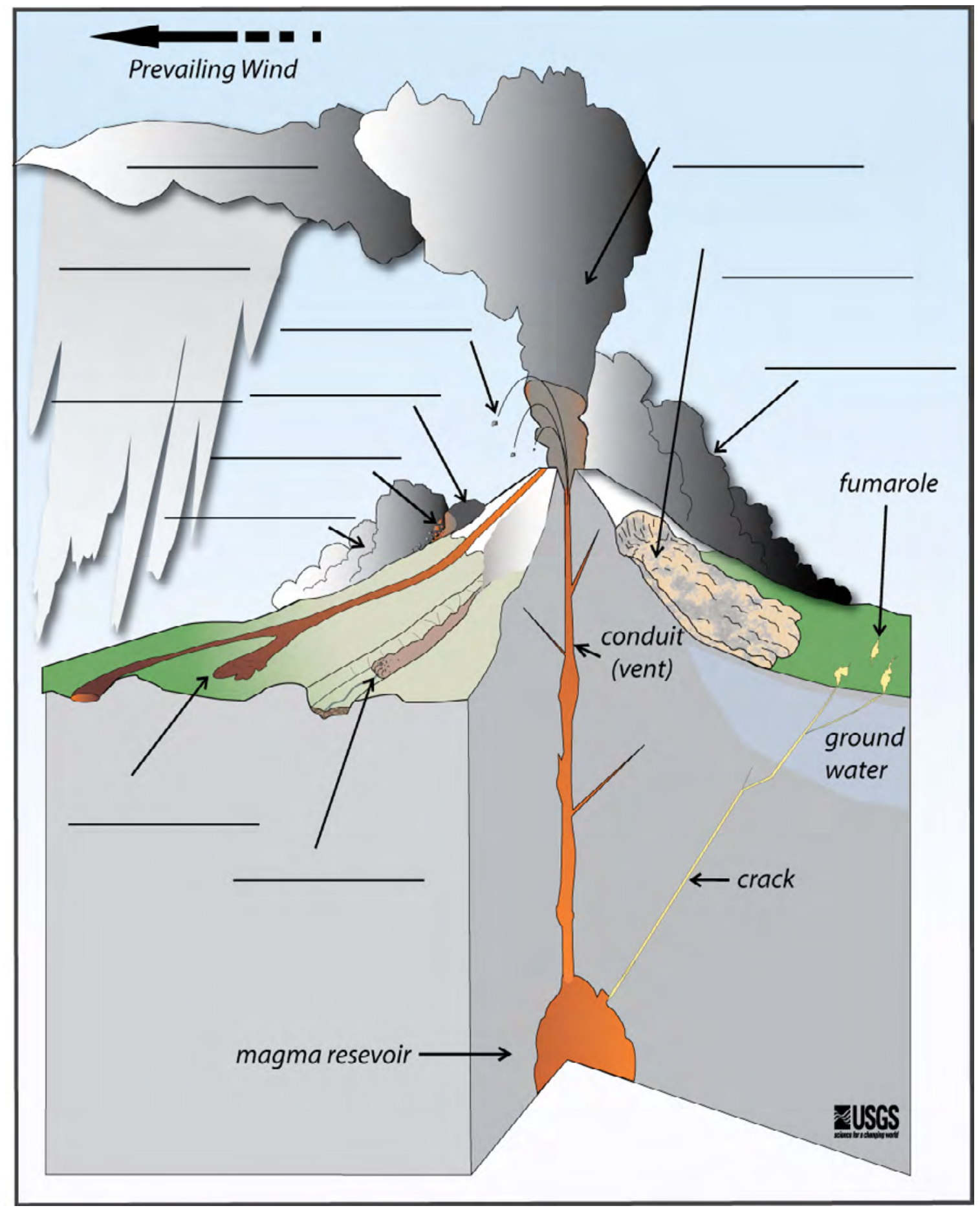




\section{Potential Volcanic Hazards I Key}

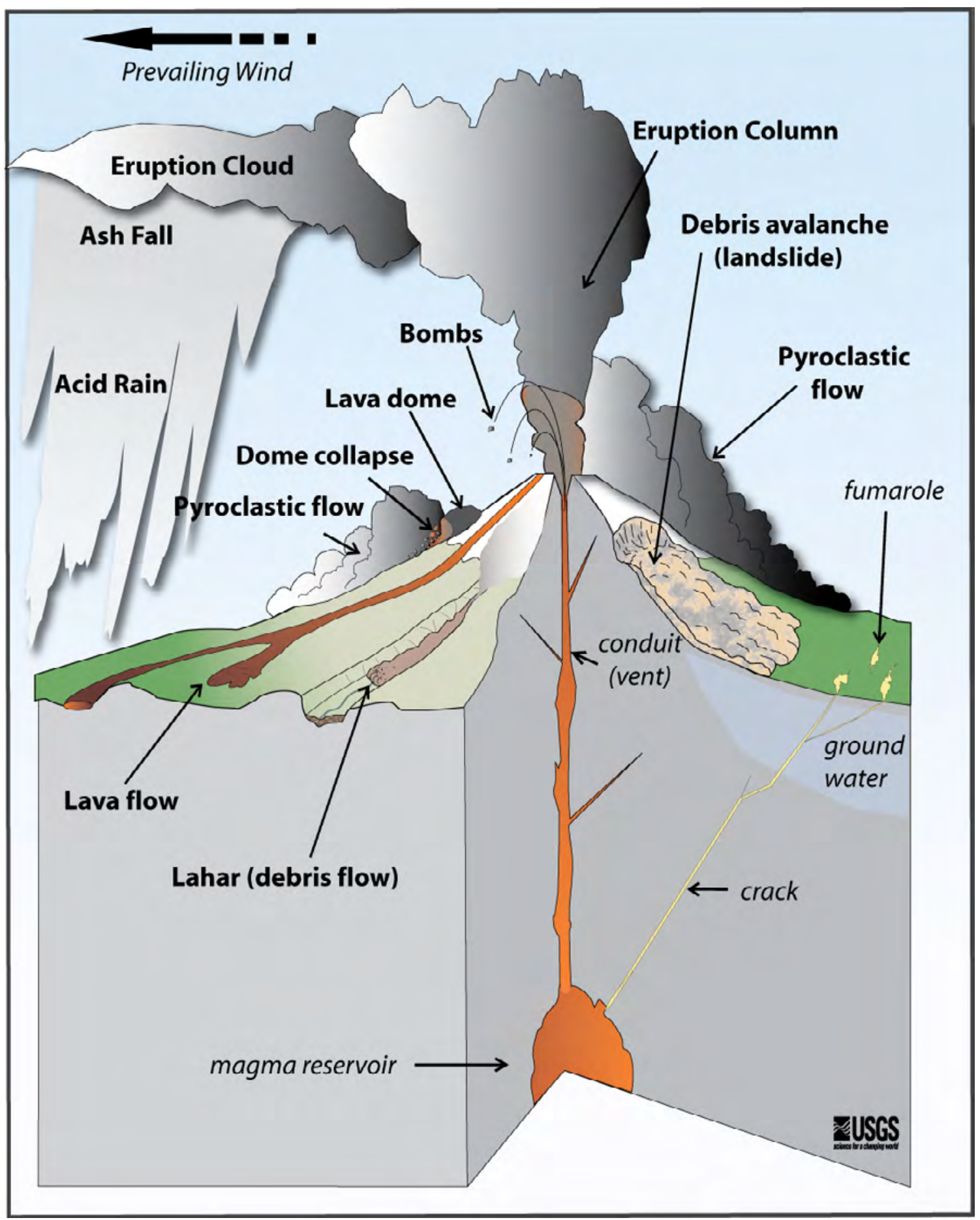


Name

Date

Period

\section{Potential Volcanic Hazards II}

Use the volcanic hazard terms below to fill in the blanks on the Volcanic Hazards I figure using your library, the internet, and other resources available to you. Under each term write an example of a volcano (try to find as many in Alaska as possible!) that has produced this type of hazard and the year of that eruption.

\section{Eruption cloud}

Volcano

Year

2. Pyroclastic flow

$\underline{\text { Volcano }}$

Year

\section{Bombs}

Volcano

Year

4. Lahar

Volcano

Year

5. Lava flow

Volcano

Year

6. Ash fall

Volcano

Year

7. Acid rain

Volcano

Year

8. Eruption column

Volcano

Year

9. Debris avalanche

Volcano

Year 
Name

Date

Period

10. Volcanic mudflow

Volcano

Year

11. Landslide

Volcano

Year

12. Eruption cloud

Volcano

Year

Bonus: What are additional hazards not noted on this figure? 


\section{Potential Volcanic Hazards II Answer Key}

Answers below are examples; there are several answers for each.

\section{Eruption cloud}

Volcano Redoubt (AK)

Year 1989-1990

2. Pyroclastic flow

Volcano Redoubt (AK)

Year 1989-1990

\section{Bombs}

Volcano Pavlof (AK)

Year 2007

4. Lahar

Volcano Redoubt (AK)

Year 1989-1990

5. Lava flow

Volcano Augustine (AK)

Year 2006

6. Ash fall

Volcano Mt. Spurr/ Crater Peak (AK)

Year 1992

7. Acid rain

Volcano Kilauea (HI)

Year 1983-

8. Eruption column

Volcano Augustine (AK)

Year 2006

9. Debris avalanche

Volcano Mt. St. Helen's (WA)

Year 1980

10. Volcanic mudflow

Volcano Redoubt (AK)

Year 1989-1990

\section{Landslide}

Volcano Mt. St. Helen's (WA)

Year 1980 


\section{Eruption cloud}

Volcano Mt. Spurr/ Crater Peak (AK)

Year 1992

Bonus: What additional hazards are not noted on this figure?

Earthquakes, tsunamis, lava-seawater explosions 
Name Date

Period

\section{Potential Volcanic Hazards III}

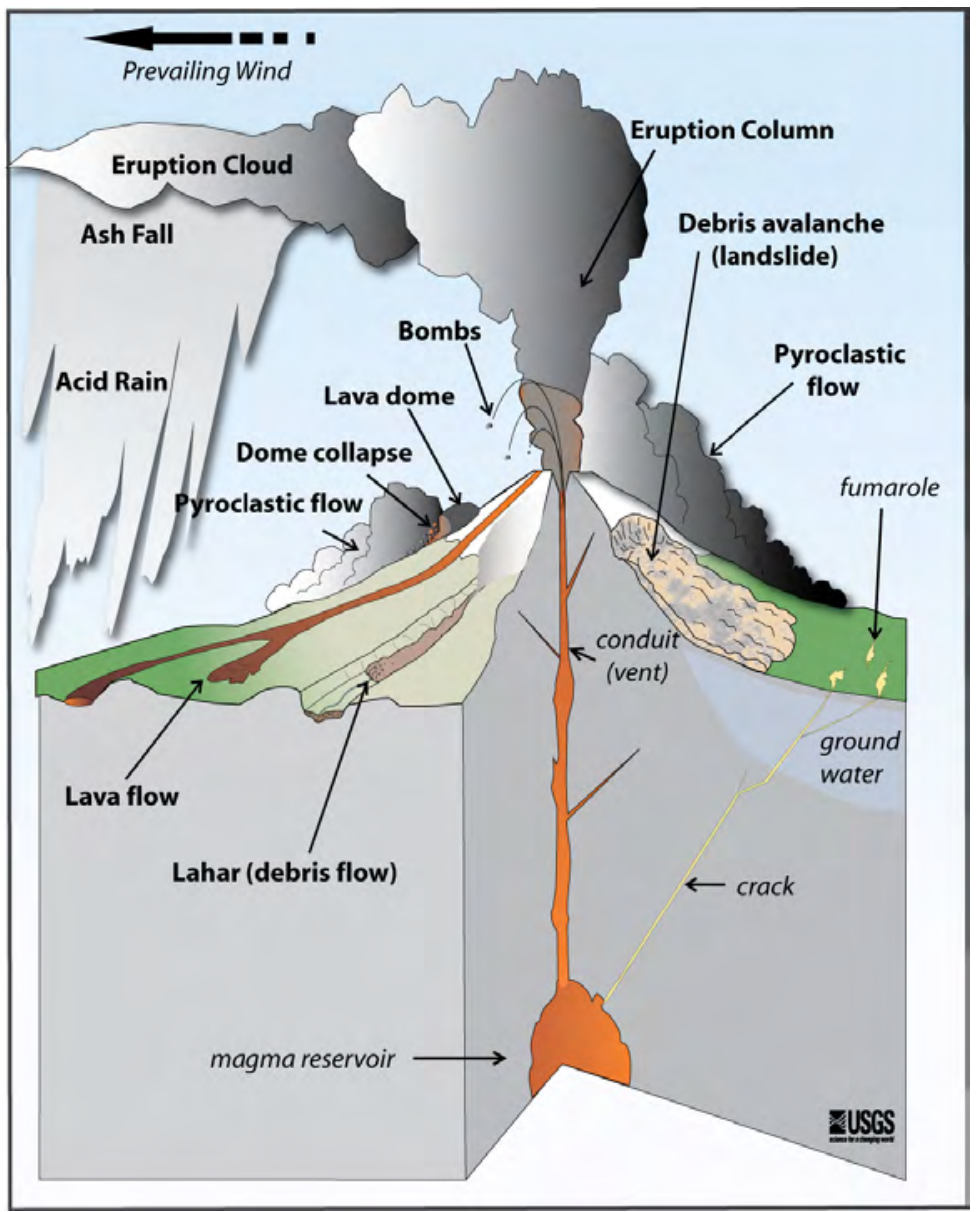

Scientists categorize volcanic hazards into two specific groups in order to generate appropriate response plans. What two groups would you select and which hazards belong in each group? Why? Be sure to include volcanic hazards that may not be in the figure.

1.

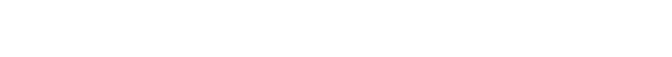

2.

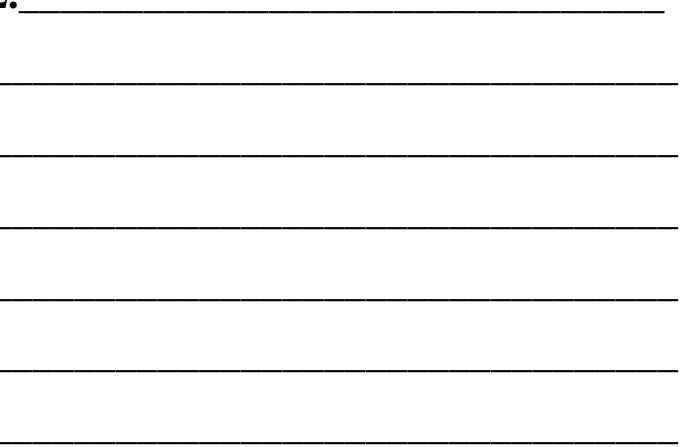




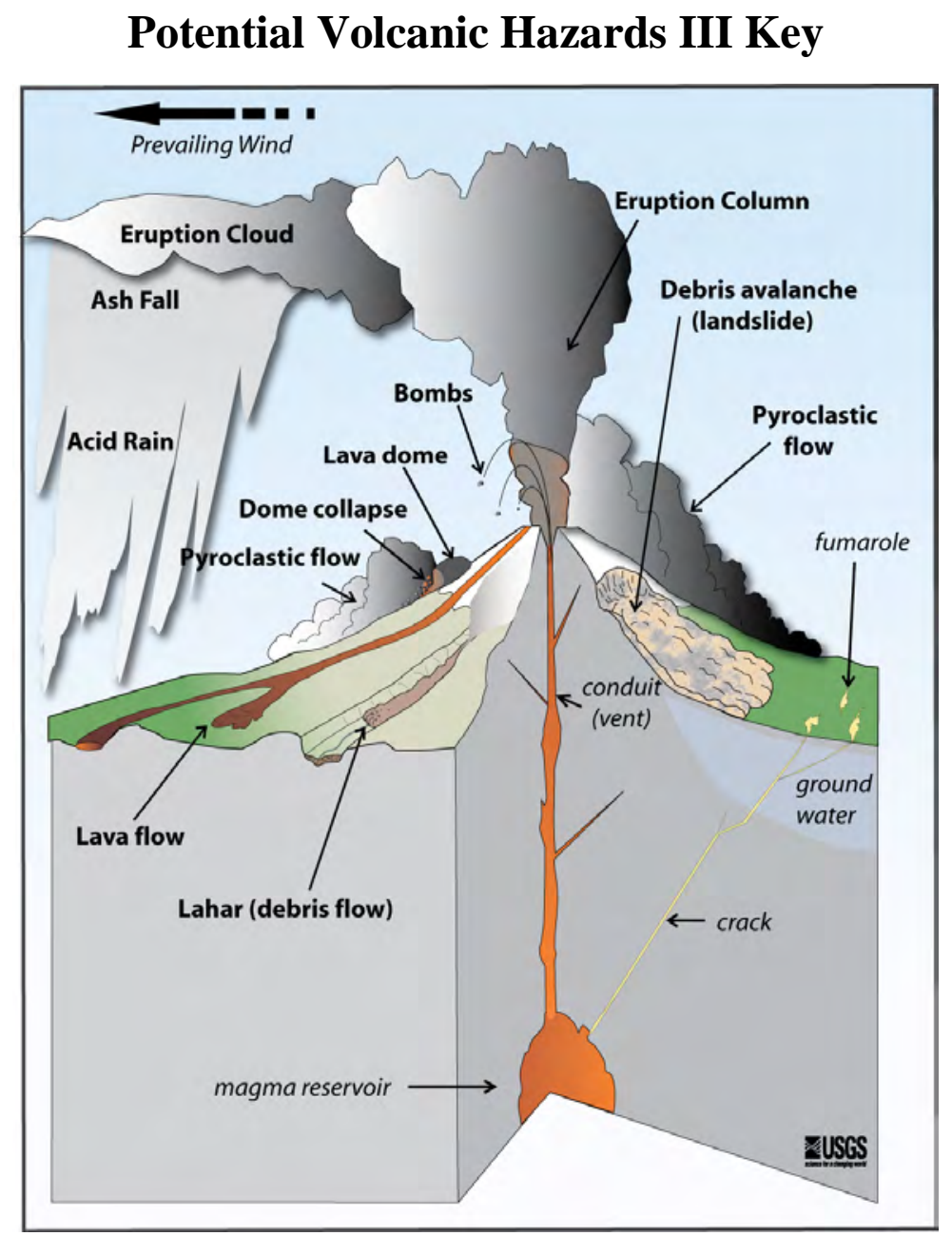

Scientists categorize volcanic hazards into two specific groups in order to generate appropriate response plans. What two groups would you select and which hazards belong in each group? Why? Be sure to include volcanic hazards that may not be in the figure.

1. Proximal (on flanks, close to...)

Eruption column and cloud, Lava flow

Lahar, ash fall, acid rain, gasses

Pyroclastic flow

\section{Dome collapse}

Bombs

Debris avalanche, volcanic mudflow

Landslide
2. Distal (airborne, far from...)

Eruption cloud

Acid rain

Ash fall

Eruption column and cloud

Volcanic gasses

Tsunami 
KLM Flight 867, Boeing-747 Communications with Anchorage Center on December 15, 1989

\section{Background:}

On December 14, 1989, at 9:47 AM, Redoubt Volcano began erupting with a major explosion. A Boeing-747 in route from Amsterdam flew into the ash cloud several hours after the eruption, and experienced complete engine failure. What follows is the communication between the pilot and the air traffic controller.

PILOT KLM B-747 - “KLM 867 HEAVY IS REACHING \{FLIGHT\} LEVEL 250” HEADING 140”

ANCHORAGE CENTER - "OKAY, DO YOU HAVE GOOD SIGHT ON THE ASH PLUME AT THIS TIME?”

PILOT KLM B-747 - “YEA, IT'S JUST CLOUDY IT COULD BE ASHES. IT'S JUST A LITTLE BROWNER THAN THE NORMAL CLOUD.”

PILOT KLM B-747 - “WE HAVE TO GO LEFT NOW... IT’S SMOKY IN THE COCKPIT AT THE MOMENT SIR.”

ANCHORAGE CENTER - “KLM 867 HEAVY, ROGER, LEFT AT YOUR DISCRETION.”

PILOT KLM B-747 - “CLIMBING TO \{FLIGHT\} LEVEL 390*, WE'RE IN A BLACK CLOUD, HEADING 130.”

PILOT KLM B-747 - “KLM 867 WE HAVE FLAME OUT ALL ENGINES AND WE ARE DESCENDING NOW!”

ANCHORAGE CENTER - “KLM 867 HEAVY ANCHORAGE?”

PILOT KLM B747 - “KLM 867 HEAVY WE ARE DESCENDING NOW ... WE ARE IN A FALL!”

PILOT KLM B-747 - “KLM 867 WE NEED ALL THE ASSISTANCE YOU HAVE SIR. GIVE US RADAR VECTORS PLEASE!”

${ }^{+} 250=25,000 \mathrm{ft}$ above sea level (asl)

$* 390=39,000 \mathrm{ft}$ asl

From: Statement of Captain Terry McVenes, Executive Chairman, Airline Pilots Association, International, Before the Committee on Commerce, Science, and Transportation Subcommittee on Disaster Prevention and Prediction, U.S. Senate March 16, 2006. Volcanic Hazards - Impacts on Aviation.

http://www.alpa.org/portals/alpa/pressroom/testimony/2006/TM_3-16-06.htm 
Name

Date

Period

\section{Volcanic Activity Notifications}

\begin{tabular}{|l|l|}
\hline $\begin{array}{c}\text { Aviation Hazard } \\
\text { Level }\end{array}$ & Description / Definition \\
\hline & \\
\hline & \\
\hline & \\
\hline & \\
\hline & \\
\hline
\end{tabular}

\begin{tabular}{|l|l|}
\hline $\begin{array}{c}\text { Ground-based Hazard } \\
\text { Level }\end{array}$ & Description / Definition \\
\hline & \\
\hline & \\
\hline & \\
\hline & \\
\hline
\end{tabular}




\section{USGS Volcano Hazards Alert-Notification System}

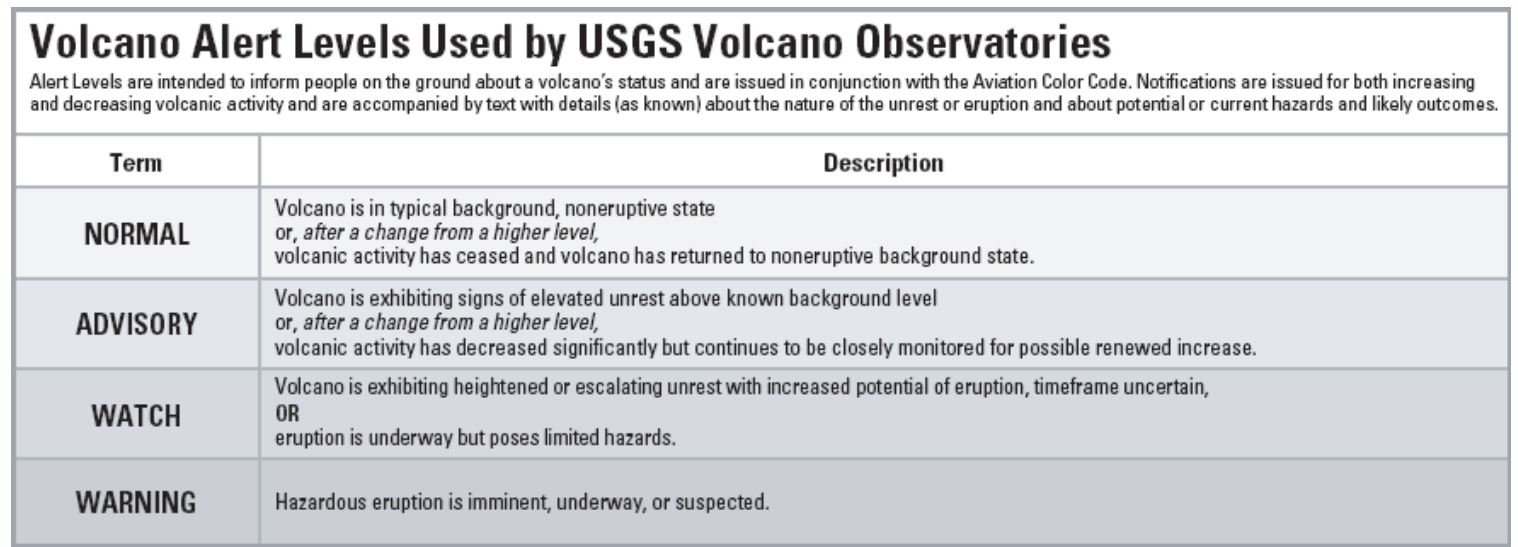

\begin{tabular}{|l|l|}
\hline $\begin{array}{l}\text { Aviation Color Code Used by USGS Volcano Observatories } \\
\text { Color codes, which are in accordance with recommended International Civil Aviation Organization (ICAO) procedures, are intended to inform the aviation sector about a volcano's status and } \\
\text { are issued in conjunction with an Alert Level. Notifications are issued for both increasing and decreasing volcanic activity and are accompanied by text with details (as known) about the } \\
\text { nature of the unrest or eruption, especially in regard to ash-plume information and likely outcomes. }\end{array}$ \\
\hline Color & \multicolumn{1}{|c|}{ Description } \\
\hline GREEN & $\begin{array}{l}\text { Volcano is in typical background, noneruptive state } \\
\text { or, after a change from a higher lievel, } \\
\text { volcanic activity has ceased and volcano has returned to noneruptive background state. }\end{array}$ \\
\hline YELLOW & $\begin{array}{l}\text { Volcano is exhibiting signs of elevated unrest above known background level } \\
\text { or, after a change from a higher level, } \\
\text { volcanic activity has decreased significantly but continues to be closely monitored for possible renewed increase. }\end{array}$ \\
\hline ORANGE & $\begin{array}{l}\text { Volcano is exhibiting heightened or escalating unrest with increased potential of eruption, timeframe uncertain, } \\
\text { OR } \\
\text { eruption is underway with no or minor volcanic-ash emissions [ash-plume height specified, if possible]. }\end{array}$ \\
\hline RED & $\begin{array}{l}\text { Eruption is imminent with significant emission of volcanic ash into the atmosphere likely } \\
\text { oR } \\
\text { eruption is underway or suspected with significant emission of volcanic ash into the atmosphere [ash-plume height specified, if possible]. }\end{array}$ \\
\hline
\end{tabular}




\section{Activity II. What is the Plan?}

Grade Level 6-11

Setting Classroom

Time 45-90 minutes

Correlations to Alaska State Department of Education (2006) Performance Standards (Grade Level Expectations)

A1-Science as Inquiry and Process

SA3[6-11] Students develop an understanding that cultural and local knowledge, history, and interactions with the environment contribute to the development of scientific knowledge, and that local applications provide opportunity for understanding scientific concepts and global issues.

\section{E1-Science and Technology}

SE[6-11] Students develop an understanding of the relationship among science, technology, and society.

SE1[6-11] Students develop an understanding of how scientific knowledge and technology are used in making decisions about issues, innovations, and responses to everyday events.

SE1.1[6] The student demonstrates understanding of how to integrate scientific knowledge and technology to address problems by recognizing that technology cannot always provide successful solutions for problems or fulfill every human need.

SE1.1[9] The student demonstrates an understating of how to integrate scientific knowledge and technology to address problems by recognizing that the value of any given technology may be different for different groups of people and at different points in time (e.g., different uses of snow machines in different regions of Alaska).

SE2[6-11] Students develop an understanding that solving problems involves different ways of thinking, perspectives, and curiosity that lead to the exploration of multiple paths that are analyzed using scientific, technological, and social merits.

SE2.1[6] The student demonstrates an understating that solving problems by involving different ways of thinking by identifying and designing a solution to a problem.

SE2.1[8] The student demonstrates an understanding that solving problems by identifying, designing, testing, and revising solutions to a local problem.

\section{Overview}

Students learn preparedness by planning for volcanic hazards, assembling a preparedness kit, learning how to protect their community, and assessing the likelihood of volcanic hazards, ash fall in particular, in their community. 


\section{Background}

Federal and state officials and preparedness organizations recommend that communities prepare to "shelter in place," meaning reliance on stored supplies of food, water, and medicine. Preparedness for volcanic hazards encompasses and instigates preparedness for other natural hazard emergencies as well.

\section{Objectives}

Students will describe recommended procedures to plan for volcanic hazards. Students will implement an emergency plan and plan a preparedness kit.

\section{Materials}

_ Examples of preparedness plans and kits, including those specific to ash

- Alaska Division of Emergency Services, [n.d.], Ash alert!: Alaska Division of Emergency Services website, accessed June 1, 2010, at http://www.ak-prepared.com/Poster_Contest_Files/Ash_Alert.pdf

- American Red Cross and Federal Emergency Management Agency (FEMA)

- American Red Cross, [n.d.], Disaster preparedness for people with disabilities: American Red Cross booklet, 48 p., accessed June 1, 2010, at http://alaska.redcross.org/media/disability.pdf.

- American Red Cross, [n.d.], Public information-Volcanoes: American Red Cross web page, accessed June 1, 2010, at http://alaska.redcross.org/media/volcano.pdf.

- American Red Cross of Alaska, 2010, Be Red Cross ready (in English, Hmong, Russian and Spanish): American Red Cross of Alaska web page, accessed June 1, 2010, at http://alaska.redcross.org/index.php?pr=Safety_Tips.

- American Red Cross of Alaska, 2010, Volcanoes: American Red Cross of Alaska website, accessed June 1, 2010, at http://alaska.redcross.org/index.php?pr=Volcanoes.

- Federal Emergency Management Agency and American Red Cross, 1991, Your family disaster plan: Federal Emergency Management Agency and American Red cross pamphlet, , accessed June 1, 2010, at http://alaska.redcross.org/media/disasterplan.pdf.

- Federal Emergency Management Agency and American Red Cross, 2004, Preparing for disaster: Federal Emergency Management Agency and American Red Cross booklet, 14 p., accessed June 1, 2010, at http://www.redcross.org/images/pdfs/preparedness/A4600.pdf.

- Federal Emergency Management Agency, 2009, Are you ready?_Volcanoes: Federal Emergency Management Agency website, accessed June 1, 2010, at http://www.fema.gov/areyouready/volcanoes.shtm 
- Federal Emergency Management Agency, 2010, Ready America: Federal Emergency Management Agency website, accessed June 1, 2010, at http://www.ready.gov/america/index.html.

- Federal Emergency Management Agency, [n.d.], Family emergency plan: Federal Emergency Management Agency website, accessed June 1, 2010, at http://www.ready.gov/america/_downloads/familyemergencyplan.pdf

- Department of Homeland Security, [n.d.], Preparing makes sense for people with disabilities and special needs: Department of Homeland Security web page, accessed June 1, 2010, at http://www.ready.gov/america/_downloads/disabilities.pdf.

- International Volcanic Health Hazard Network (IVHHN), 2010, Durham University website, accessed June 1, 2010, at http://ivhhn.org/.

- The Health Hazards of Volcanic Ash-A guide for the public PDF http://www.ivhhn.org/index.php?option=com_content\&view=article\&id=55\& itemid=61

- Guidelines on Preparedness Before, During and After an Ashfall PDF http://www.ivhhn.org/index.php?option=com_content\&view=article\&id=55\& itemid $=61$

- Municipality of Anchorage, [n.d.], Emergency Management-Volcanic Ash Preparedness: Municipality of Anchorage website, accessed June 1, 2010, at http://www.muni.org/Departments/OEM/Prepared/Pages/VolcanicAsh.aspx.

- U.S. Geological Survey and partners, 2010, Volcanic ash ...What it can do and how to prevent damage: U.S. Geological Survey website. (Available at http://volcanoes.usgs.gov/ash/.)

- Washington Military Department, Emergency Management Division and U.S. Geological Survey, 1999, Volcanic ashfall-How to be prepared for an ashfall: Washington State Emergency Management Division pamphlet, accessed June 1, 2010, at http://emd.wa.gov/publications/pubed/volcanic_ash_english.pdf.

\section{Procedure}

\section{A. Teacher set-up}

1. Download and print different preparedness plans and kit literature from the sites listed. Assemble enough preparedness plans and kit literature for your students to have a wide selection to view.

\section{B. Students review plan materials}

1. Give students time to examine the variety of different preparedness plans and kit literature that you made available. 
2. Have your class discuss the limitations on transportation into and out of their community and the possible difficulties with communications in the community during ash fall. In many rural communities, radios are used instead of telephones and air travel is very limited. Cell phone service could be hampered during an ash fall or any associated emergencies. Boat travel may be the only way to leave or approach certain marine communities. Some communities may receive emergency warning messages only by marine band radio due to poor or limited television broadcast services. Ask students to remember these concerns as they proceed through the activity.

C. Students generate plans

1. Using the examples as a guide, ask students to identify the necessary components of a preparedness plan for their community. Instruct students to generate an emergency plan for their family and to include all the identified necessary components. Students can incorporate any unique transportation and communications issues into their plans. Advise students to identify special situations that require additional thought and planning, such as care of people with disabilities, the elderly, and pets.

2. Suggest to your students that they carry out their plan as a training exercise with their family. Advise students to test the phone numbers (or radio messages) and other resources that they have gathered and put the phone numbers and other resources in their plans.

3. Using the examples as a guide, students can determine the necessary components of a preparedness kit.

\section{Extensions}

1. Have the students list all the available components of preparedness kit and gather all the needed supplies, if possible. One way to do this with limited financial impact is to purchases one item at a time during the family's standard shopping trip or order. Here is an example using this concept:

- Alaska Division of Homeland Security and Emergency Management, [n.d.], Homeland security and emergency preparedness 7 day survival kit: Alaska Division of Homeland Security and Emergency Management brochure, 4 p., accessed June 2, 2010, at http://ready.alaska.gov/outreach/DHSEM\%207\%20Day\%20Survival\%20Kit. pdf.

2. Instruct students to develop a plan and kit for their classroom, school and (or) workplace.

3. Have students develop a plan and kit for someone in the community, a business or a local organization. 
4. Have students explore opportunities to assist their community's emergency responders in the event of an emergency. Resources include

- Citizen Corps, [n.d.], About Citizen Corps: Federal Emergency Management Administration website, accessed June 2, 2010, at http://www.citizencorps.gov/.

- Learning for Life, 2005, Exploring (age 14 and completed $8^{\text {th }}$ grade through 20 years old): Learning for Life website, accessed June 2, 2010, at http://www.learning-for-life.org/exploring/index.html.

\section{Reference Cited}

Alaska State Department of Education and Early Development, 2006, Standards and grade level expectations, March 2006: State of Alaska website, accessed October 2009 at http://www.eed.state.ak.us/tls/assessment/GLEHome.html.

\section{Modified from}

Driedger, C.L., Doherty, Anne, and Dixon, Cheryll, 2005, Living with a volcano in your backyard-An educator's guide with emphasis on Mount Rainier: U.S. Geological Survey General Interest Product 19; produced in cooperation with the National Park service. (Available at http://vulcan.wr.usgs.gov/Outreach/Publications/GIP19/.)

- Chapter 3: Don’t be scared-Be prepared! http://vulcan.wr.usgs.gov/Outreach/Publications/GIP19/chapter_three_dont_be_ scared.pdf. 


\section{Activity III. Volcanic Ash Fall in Your Community}

Grade Level 6-11

Setting Large (non-carpeted) classroom, gym, or outside

Time 90-150 minutes

Correlations to Alaska State Department of Education (2006) Performance Standards (Grade Level Expectations)

D1-Concepts of Earth Science

SD[6-11] Students develop an understanding of the concepts, processes, theories, models, evidence, and systems of earth and space sciences.

SD2[6-11] Students develop an understanding of the origins, ongoing processes, and forces that shape the structure, composition, and physical history of the Earth.

SD2.3[6] The student demonstrates an understanding of the forces that shape Earth by describing how the surface can change rapidly as a result of geological activity (e.g., earthquakes, tsunamis, volcanoes, floods, landslides, avalanches).

\section{E1-Science and Technology}

SE[6-11] Students develop an understanding of the relationships among science, technology, and society.

SE1[6-11] Students develop an understanding of how scientific knowledge and technology are used in making decisions about issues, innovations, and responses to problems and everyday events.

\section{Overview}

By simulating an ash-rich volcanic eruption on a model community of their own design, students will learn firsthand about the affects of volcanic ash fall on a community, and how preparedness and planning by a community may lessen the affects of ash fall.

\section{Background}

The most common and widespread hazard in the event of a volcanic eruption in Alaska is volcanic ash fall. Volcanic ash is electrically conductive, corrosive, abrasive, and heavy, especially when wet. Airborne volcanic ash can travel hundreds of miles before falling to the ground. Two sources of information are:

- U.S. Geological Survey and partners, 2010, Volcanic ash ... what it can do and how to prevent damage: U.S. Geological Survey and partners website. (Available at

- Ash properties \& dispersal by wind http://volcanoes.usgs.gov/ash/properties.html and

- What's it like during and ash fall? http://volcanoes.usgs.gov/ash/ashfall.html.) 


\section{Objectives}

Students will construct a model community and subject it to an ash fall. Students will observe the relation between particle size and distance traveled. Students will evaluate their community and determine changes that should be made when considering the ash fall scenario.

\section{Materials}

\section{_ Volcanic Ash Fall in Your Community worksheets}

Simulated ash fall (enough for multiple groups)

_ soil, sand, dirt, rice, flour, dry oatmeal-roughly 4 cups ( 950 mL) each of four types of dry goods (preferably varying in color and particle size)

_ 1/8 of a cup ( $\sim 30 \mathrm{~mL})$ measuring cups

_ fans and (or) blow dryers

- brush or broom, dust pan and brush

_ meter sticks or tape measures

Community building (not all materials are necessary, but a good variety is beneficial)

— table cloths, butcher paper, easel paper, or tarps, at least 1.5 x $1.5 \mathrm{~m} \mathrm{(} \mathrm{5} \mathrm{x} 5 \mathrm{ft})$ to serve as base

_ colored markers or paints (and associated brushes and water containers for rinsing)

- newspaper

_ shallow plastic bowls

_ masking or duct tape

- thimbles

_ small measuring cups (like for liquid medicine)

— board game pieces

- spray bottles with water

— board game objects

_ tooth pick, popsicle stick or cardboard structures

\section{Procedure}

\section{A. Constructing a model community}

1. Divide students into manageable groups. Each group will create an Alaskan community using the materials provided. Students must draw a 2.5 x $2.5 \mathrm{~cm}(1 \times 1$ in.) grid on their base (or use a checkered picnic/table cloth. Each square represents 1 $\mathrm{km}^{2}\left(0.4 \mathrm{mi}^{2}\right)$ in the simulation and calculations.

2. Students need to have a "volcano" on the perimeter of their region, designated by a $15 \mathrm{~cm}$ ( 6 in.) radius semicircle on one side (if the base is not square, the volcano should be on one of the two shorter sides).

3. Students can consider making topography (mountains and basins) using wadded up newspaper, plastic bowls (convex or concave), thimbles, or other supplies available. These may be placed on top of or underneath the base for the desired effect. 
4. Make sure the base material and structures (tarp, butcher paper, and so on) are taped down (or adhered any other way) to the surface. The goal is for the structures to be affected by the ash fall, not blown away the wind!

5. Students can draw a map view (from the perspective of looking straight down) of their community in the space provided on the Volcanic Ash Fall in Your Community worksheet

\section{B. Eruption! and Ash Fall in Your Community worksheet}

1. Each group can gather their worksheet, wind sources (fan, blow dryer, or other device), markers, meter stick (or tape measure), 1/8 cup ( $30 \mathrm{~mL}$ ) measuring cup, and $\sim 1$ cup $(\sim 240 \mathrm{~mL})$ each of the four types of dry goods or soil-like substances as ash simulators.

2. Have students place or hold the wind sources at the edge of the "volcano." Box fans can stand on the ground. Shorter fans or blow dryers should be held at roughly waist level.

3. Have students turn the wind source on, using the lowest setting. Have another student gently sprinkle 1/8 cup ( $\sim 30 \mathrm{~mL})$ of one ash simulator in front of source of wind to release it into the wind. Make sure students begin with the smallest particle-size ash simulator, then the next smallest, until the last sample used is the one with the largest particle size. Note Students need to turn the fan off between the releases of each ingredient. Measurements of each "ash” fall are made while the fan is off. Students can relocate their hand to the same position relative to the fan each time.

4. Students will use a marker to outline the concentrated area of the deposit where most of the "ash" fell.

5. Students will measure the furthest distance traveled by each ingredient. Remind students that the side of each square equals $1 \mathrm{~km}$ and to record the results in the space provided on the worksheet.

6. Students will count the number of squares that are covered by each ingredient, determine the area covered, and record the results in the space provided on the Volcanic Ash Fall in Your Community worksheet.

7. Have students repeat the steps until all ash simulators have been tried.

8. When students finish the experiment, ask each group to look at the other groups' communities and answer the questions on the Volcanic Ash Fall in Your Community worksheet before clean up.

9. Reassemble the class and review the answers to the questions. 


\section{Extensions}

1. Have students use AVO's Ash Collection Instructions by simulating ash fall using soil, sand, dirt, rice, flour, and (or) dry oatmeal. If you are using a human food item, please do not so this activity outside because the remaining food items left will become an attractant for wildlife.

- Alaska Volcano Observatory, [n.d.], Procedures for collecting and returning ash samples from modern volcanic eruptions: Alaska Volcano Observatory web page. (Available at http://www.avo.alaska.edu/ashfall.php.)

2. Change the wind direction by setting the fan at an angle to the paper.

3. Add wind shear by using multiple wind sources at different heights above the volcano. Be sure the "ash" falls in front of both sources of wind.

\section{Reference Cited}

Alaska State Department of Education and Early Development, 2006, Standards and grade level expectations, March 2006: State of Alaska website, accessed October 2009 at http://www.eed.state.ak.us/tls/assessment/GLEHome.html.

\section{Modified from}

Driedger, C.L., Doherty, Anne, and Dixon, Cheryll, 2005, Living with a volcano in your backyard-An educator's guide with emphasis on Mount Rainier: U.S. Geological Survey General Interest Product 19; produced in cooperation with the National Park service. (Available at http://vulcan.wr.usgs.gov/Outreach/Publications/GIP19/.)

- Chapter 2: Today’s Discoveries Unlock the Past-Volcano Fan Club http://vulcan.wr.usgs.gov/Outreach/Publications/GIP19/chapter_two_volcano_fan club.pdf. 
Name

Date

Period

\section{Volcanic Ash Fall in Your Community}

\section{Build Your Community}

1. Create an Alaskan community using the materials provided.

2. Draw a $2.5 \times 2.5 \mathrm{~cm}$ ( 1 x 1 in.) grid on your base. Each square represents $1 \mathrm{~km}^{2}(0.4$ $\mathrm{mi}^{2}$ ) in the simulation and calculations.

3. Include a volcano on the perimeter of your community. Designate the volcano by drawing a $15 \mathrm{~cm}$ ( $\sim$ in.) radius semicircle on one side of your base. If your base is not square, draw the volcano on one of the shorter sides of your base.

4. Make topography (mountains and basins) using wadded up newspaper, plastic bowls (convex or concave), thimbles, or other supplies under or on top of your base. These may be placed on top of or underneath the base for the desired effect.

5. Make sure the base material and all structures are taped or adhered to the surface.

6. Draw a map-view of your community below. 
Name

Date

Period

\section{Volcanic Ash Fall in Your Community}

\section{Volcanic Ash Fall}

1. Gather your wind sources (fan, blow dryer...), markers, meter stick (or tape measure), 1/8 cup ( $\sim 30 \mathrm{~mL})$ measuring cup and $\sim 1$ cup $(\sim 240 \mathrm{~mL})$ each of the four types of dry goods or soil-like substances for ash simulators.

2. Place or hold your wind sources at the edge of the "volcano." Box fans can stand on the ground. Shorter fans or blow dryers should be held at roughly waist level.

3. Turn on the wind source to low. Gently sprinkle 1/8 cup ( $30 \mathrm{~mL})$ of one ash sample in front of source of wind to release it into the wind towards your community. Begin with the smallest particle size sample, then the next smallest, until the last sample used is the one with the largest particle size. Turn off the fan and make the designated measurements between the releases of each ash sample.

4. Use a marker to outline the concentrated area of the deposit where most of the ash fell.

5. Measure the farthest distance traveled by each ash. Remember the side of each square equals $1 \mathrm{~km}$. Record the results in the table below.

6. Count the total number of squares that are covered by each ingredient, determine the area covered, and record in the table below.

7. Relocate your hand to the same position relative to the fan each time. Repeat until all ash samples have been tried.

8. Look at the other groups' communities before clean up.

\begin{tabular}{|c|c|c|c|}
\hline $\begin{array}{c}\text { Ash } \\
\text { sample }\end{array}$ & $\begin{array}{c}\text { Farthest distance } \\
\text { traveled km (mi) }\end{array}$ & $\begin{array}{c}\text { Number of squares covered or } \\
\text { mostly covered by deposit }\end{array}$ & $\begin{array}{c}\text { Area covered by } \\
\text { deposit } \mathbf{k m}^{\mathbf{2}} \mathbf{( \mathbf { m i } ^ { 2 } )}\end{array}$ \\
\hline & & & \\
\hline & & & \\
\hline & & & \\
\hline & & & \\
\hline
\end{tabular}


Name Date Period

\section{Volcanic Ash Fall in Your Community}

1. What were the similarities and differences in each group's results?

2. Were there structures that survived best? Why or why not?

3. Were there basins filled with ash? Were they close to or far from the volcano?

4. Did ash gather at the base of slopes? On which side of the slope, relative to the volcano did the ash gather?

5. Having seen these results, would you have designed your community differently? How? 


\section{Chapter 6 Climate and Volcanic Eruptions}

\section{Resources}

- U.S. Geological Survey

- Mastin, L.G., 1993, Can rain cause volcanic eruptions?: U.S. Geological Survey Open-File Report 93-445, 2 p. (Available at http://vulcan.wr.usgs.gov/Projects/Mastin/Publications/OFR93-445/OFR93-445.html.)

- McGee. K.A., and Gerlach, T.M., 1995, Volcanic gas: U.S. Geological Survey Open-File Report 95-85, 2 p. (Also available at http://vulcan.wr.usgs.gov/Glossary/Emissions/Publications/OFR95-85/OFR95-85.pdf.)

- McGee, K.A., Doukas, M.P., Kessler, R., and Gerlach, T.M., 1997, Impacts of volcanic gases on climate, the environment, and people: U.S. Geological Survey Open-File Report 97-262. (Available at http://pubs.usgs.gov/of/1997/of97262/of97-262.html.)

- U.S. Geological Survey, 1998, Volcano watch-Greenhouse gases in our backyard: U.S. Geological Survey website. (Available at http://hvo.wr.usgs.gov/volcanowatch/1998/98_10_22.html.)

- U.S. Geological Survey, 2005, Cascades Volcano Observatory-DescriptionVolcanoes and the weather: U.S. Geological Survey website. (Available at http://vulcan.wr.usgs.gov/Glossary/VolcWeather/description_volcanoes_and_wea ther.html.)

- U.S. Geological Survey, 2007, Volcano watch-Which produces more $\mathrm{CO}_{2}$, volcanic or human activity?: U.S. Geological Survey website. (Available at http://hvo.wr.usgs.gov/volcanowatch/2007/07_02_15.html.)

- U.S. Geological Survey, 2008, Volcano Hazards Program-Direct gas sampling and laboratory analysis: U.S. Geological Survey website. (Available at http://volcanoes.usgs.gov/activity/methods/gas/sample.php.)

- U.S. Geological Survey, 2008, Volcano Hazards Program-Volcanic sulfur aerosols affect climate and the Earth's ozone layer: U.S. Geological Survey website. (Available at http://volcanoes.usgs.gov/hazards/gas/s02aerosols.php.)

- U.S. Geological Survey, 2009, Long Valley Observatory-Carbon dioxide and helium discharge from Mammoth Mountain, Long Valley caldera, California: U.S. Geological Survey website. (Available at http://lvo.wr.usgs.gov/CO2.html.)

- U.S. Geological Survey, 2009, Volcano Hazards Program-Measuring volcanic gases-Continuous on-site gas monitoring: U.S. Geological Survey website. (Available at http://volcanoes.usgs.gov/activity/methods/gas/continuous.php.)

- U.S. Geological Survey, 2009, Volcano Hazards Program-Measuring volcanic gases_-Emission rates of sulfur dioxide and carbon dioxide in volcanic plumes: U.S. Geological Survey website. (Available at http://volcanoes.usgs.gov/activity/methods/gas/plumes.php.)

- U.S. Geological Survey, 2009, Volcano Hazards Program-Measuring volcanic gases_-Soil efflux: U.S. Geological Survey website. (Available at http://volcanoes.usgs.gov/activity/methods/gas/soil.php.) 
- U.S. Geological Survey, 2010, Volcano Hazards Program-Volcanic gases and their effects: U.S. Geological Survey website. (Available at http://volcanoes.usgs.gov/hazards/gas/index.php.)

- National Aeronautics and Space Administration

- National Aeronatics and Space Administration, [n.d.], Lesson 28A-Volcanic outgassing: National Aeronautics and Space Administration website, accessed July 2, 2010, at http://education.gsfc.nasa.gov/ess/Units/Unit4/U4L28A.html.

- National Aeronautics and Space Administration, 2005, Students On-Line Atmosphere Research (SOLAR)—Aerosols, what are they and why are they so important?: National Aeronautics and Space Administration webpage, accessed June 7, 2010, at http://asd-www.larc.nasa.gov/SOLAR/learning-aerosol.html.

- Shindell, D., January 2004, Science briefs-The Sun vs. the volcano-Drivers of regional climate change: Goddard Institute for Space Studies webpage, accessed June 7, 2010, at http://www.giss.nasa.gov/research/briefs/shindell_07/.

- Wolfe, Jason, 2000, NASA Earth observatory-Volcanoes and climate change: National Aeronautics and Space Administration webpage, accessed June 7, 2010, at http://earthobservatory.nasa.gov/Study/Volcano/.

- Camp, Dr. Vic, 2000, Climate effects of volcanic eruptions: San Diego State University, web page, accessed June 7, 2010, at http://www.geology.sdsu.edu/how_volcanoes_work/climate_effects.html.

- Energy Information Administration, 2008, Greenhouse gases, climate change, and energy: U.S. Energy Information Administration Brochure DOE/EIA-X012, 2 p., accessed June 7, 2010, at http://www.eia.doe.gov/bookshelf/brochures/greenhouse/Chapter1.htm.

- International Volcanic Health Hazard Network (IVHHN), 2010, Guidelines and databases-International Volcanic Health Hazard Network webpage, accessed July 2, 2010, at http://www.ivhhn.org/guidelines.html.

- Oppenheimer, C., 2003, Volcanic degassing, in Turekian, K.K., and Holland, H.D., eds., Treatise on Geochemistry, v. 3, chap. 6: Elsevier, p. 123-166.

- Public Broadcasting Service, 2006, NOVA, Mystery of the megavolcano-Why Toba matters: Public Broadcasting Service webpage, accessed June 7, 2010, at http://www.pbs.org/wgbh/nova/megavolcano/shindell.html.

- Schmincke, H., 2004, Volcanism: New York, Springer.

- Chapter 3: Magma, p. 21-34

- Chapter 14: Volcanoes and Climate, p. 259-271.

- Scientific American, 2009, Are volcanoes or humans harder on the atmosphere?: Scientific American, EarthTalk webpage, accessed June 7, 2010, at http://www.sciam.com/article.cfm?id=earthtalks-volcanoes-or-humans.

- University of Cambridge Department of Geography, 2006, Effects of volcanoes in the atmosphere: University of Cambridge web page, accessed June 7, 2010, at http://www.geog.cam.ac.uk/research/projects/volcanoeffects/. 


\section{Activities}

The material covered in this chapter builds on background information students have gained through the guidebook and emphasizes big picture and long-term contributions made by volcanism to the Earth's atmosphere.

These activities will allow students to understand the source and behavior of magmatic $\mathrm{SO}_{2}$ and $\mathrm{CO}_{2}$ and their contributions to atmospheric changes. By comparing a volcanic system to shaken soda bottles, students will understand that dissolved gases under pressure escape slowly over time at some volcanoes, and quickly during volcanic eruptions. Students will also identify Alaskan sources of volcanic gases and volcanic features associated with volcanic gases. Through a graphing exercise, students will observe that volcanic eruptions that eject large volumes of gases and ash into Earth's atmosphere can affect global climate for periods lasting from 1 to 3 years. The phenomena can be visualized using graphs that display changes in global average temperature following major volcanic eruptions. Students will compare the relative amounts of $\mathrm{CO}_{2}$ contributed on an annual basis to the atmosphere through the burning of fossil fuels and by the emissions of volcanoes into the atmosphere by graphing values of each and interpreting their results. Students will learn that the amount of $\mathrm{CO}_{2}$ contributed by the burning of fossil is orders of magnitude greater than the amount contributed by volcanoes.

Activity I. The Gas They Pass

Activity II. What Goes Up Must Come Down

Activity III. Globally Averaged Temperature and Volcanic Eruptions

Activity IV. An Order of Magnitude 


\section{Activity I. The Gas They Pass}

Grade Level 6-11

\section{Setting Classroom}

Time 45 minutes

\section{Vocabulary (see Glossary)}

amphibole, anthropogenic, $\mathrm{CO}_{2}$, composition, crust, crustal melting zone, dolomite, exsolve and exsolution, geothermal, $\mathrm{H}_{2} \mathrm{O}$, hydrothermal, magma, mantle, mica, phase, precipitate, $\mathrm{SO}_{2}$, subduction zone, volcanogenic

\section{Correlations to Alaska State Department of Education (2006) Performance Standards (Grade Level Expectations) \\ D1-Concepts of Earth Science \\ SD[6-11] Students develop an understanding of the concepts, processes, theories, models, evidence, and systems of earth and space sciences.}

SD1[6-11] Students develop and understanding of earth's geochemical cycles.

SD2[6-11] Students develop an understanding of the origins, ongoing processes, and forces that shape the structure, composition, and physical history of the Earth.

\section{Overview}

Prior to a discussion concerning the possible affects of volcanic gases on climate change, it is important to identify the sources and types of the gases emitted by volcanoes.

\section{Background}

The area of melting within the Earth's crust (called the crustal melting zone) is an area of high pressures and temperatures tens of kilometers (miles to tens of miles) below the ground surface and is the boundary between the mantle and the overlying continental crust. In this zone, rocks melt to form magma — a mixture of three phases: liquid rock, which is the host of mineral crystals and dissolved gases. The proportions of these three phases correspond to the temperatures and pressures of the magma storage region and relate to the composition of the magma. The addition (by melting) of overlying rock (also known as host rock) to the magma, as well as the contribution of marine sediments in the case of a subduction zone (like that which forms the Aleutians), contributes to the types of gases that eventually escape from the magma. These gases, often called magmatic or volcanic gases, can come out passively (through continuous or long-term degassing) or rapidly during an eruption.

Gases exsolve from magma during the early stages of melting and include water $\left(\mathrm{H}_{2} \mathrm{O}\right)$, carbon dioxide $\left(\mathrm{CO}_{2}\right)$, and sulfur dioxide $\left(\mathrm{SO}_{2}\right)$ available from the melting of the minerals amphibole, dolomite, and mica. These gases are important because their expansion during magma ascent provides the energy that propels magma to Earth's surface and outward during an explosive volcanic eruption. Minerals and free-floating chemical elements in the liquid rock arrange and re-arrange as pressure, temperature, and composition change. 
As an ascending body of magma approaches the surface of the crust, magmatic gases separate from the magma, grow into bubbles that coalesce, and are expelled during explosive volcanic eruptions. Volcanic gases can also escape passively through local hydrothermal systems and fractures nearly at the surface of the earth.

During large explosive eruptions, gases can rise tens of kilometers (miles to tens of miles) into Earth's atmosphere. Once these gases are airborne, the prevailing winds carry the eruption cloud hundreds to thousands of kilometers (hundreds of miles) downwind from the volcano. These gases spread as an eruption cloud, primarily as acid sulfate aerosols (tiny acid droplets), compounds attached to tephra particles, and microscopic salt particles.

The wide body and narrow neck of a soda bottle roughly resemble the shape of a magma storage region and the ascending path of magma within and finally out of a volcano. The pressurized soda water represents gas-rich magma that is under pressure from overlying rocks. Carbonated beverages include dissolved $\mathrm{CO}_{2}$. When the bottle is capped, carbon dioxide dissolves within the soda from the pressure exerted on it. It also occupies the void between the surface of the liquid and the cap. Shaking the bottle adds energy and causes gas in the soda water to separate, forming tiny bubbles throughout the liquid. Formation of the bubbles creates pressure inside the bottle. Quickly removing the cap releases this pressure and the bubbles immediately expand and coalesce. Forced up the narrow neck, the fluid and bubbles burst from the high-pressure environment of the bottle to the lower pressure of the atmosphere. Bubbles of water vapor, carbon dioxide, sulfur dioxide, and other gases within magma undergo a similar progression. The gasses initially are dissolved in magma and depressurization in the magma chamber frees the bubbles from the magma in a process called exsolution. The bubbles then rise to the top of the magma chamber. Pressure from the gas bubbles propels the magma and gas up the conduit. The gas bubbles rapidly expand to thousands of times their original volume when escaping up the conduit to the top of the erupting volcano.

\section{Objectives}

This activity will allow students to understand that magma includes a component of dissolved gases, which escape slowly over time at some volcanoes and quickly during volcanic eruptions. Students will also identify Alaskan sources of volcanic gas and volcanic features associated with volcanic gases.

\section{Materials}

_ 2 or more full, sealed bottles of soda, best if less than 1 liter

- Data Table worksheet 


\section{Procedure}

\section{A. Discuss the concept of phase change}

1. Initiate a classroom discussion about items within students' homes that change phase with a change in temperature. Here are some examples:

- Ice cube - Solid when frozen, turns into a liquid when heated, and eventually into a gas with continued heat.

- Brownies - Liquid mixture, changes to a "solid" state when baked, and baking releases gases - the aroma smelled throughout. Note to students that walnuts or some other additions may not change phase at the temperature needed to bake the brownies. Also note that the temperatures needed to achieve a phase change varies from one material to another.

\section{B. Soda Bottle Eruption}

1. Use a soda bottle eruption (real, or hypothetical) to illustrate an increase in pressure and the visual build up of gas bubbles at the top of a new, full, sealed, and shaken soda bottle. If you go through with a soda bottle eruption, note that when uncapped there is a sudden release of gases (and sticky liquid) into the air and onto everything nearby.

- Shake one of the bottles of soda. Pass both bottles around the room and have students squeeze them (the shaken bottle may have to be re-shaken as it is passed around). Remind students that shaking the one bottle adds energy to it, causing the liquid and dissolved $\mathrm{CO}_{2}$ gas to separate. Students should observe that the shaken bottle is firmer (more pressurized), relative to the unshaken bottle and point out that a foam (vat of connected bubbles) has formed at the top of the shaken bottle.

- Develop a theory with the class about why one bottle is firmer than the other bottle and what will happen when you uncap both bottles. You may test the theory by uncapping both bottles. The sudden decrease in pressure due to uncapping, and constraint exerted by the narrow neck of the bottle, will force the foam and bubbles in the shaken bottle to escape rapidly.

\section{Do volcanoes smell?}

1. Have students recall and (or) research if volcanoes are smelly - if volcanoes have associated precipitates (and of what; sulfur is one common example) or other evidence of gas emissions (either while erupting or not; steam plumes are a common example). Ask students to recall local Alaskan eruptions and if any associated smells (rotten egg or match strike smells) or precipitates (yellowing at vents, cracks, and hydrothermal features) were reported. A quick web search should produce reports of sulfur smell (rotten egg and match strike odors) at several volcanoes in Alaska, including the recent activity at Augustine and Redoubt volcanoes in Cook Inlet, and at volcanoes in the Aleutians.

2. Use the included Visible Degassing at Alaskan Volcanoes handout and presentation as a resource to discuss your student's findings. 


\section{Extensions}

1. This extension will introduce a solid component - to represent the mineral crystal component in magma. Partially freeze the bottle of soda used in this activity. Ask students to theorize about, or experiment with the varying proportion of solid material (based on the amount of time that the bottle remains in the freezer) and the possible differences in "eruption" style that results when the bottle is uncapped.

2. Have students explore

- Annenberg Media Multimedia Collection, 2010, Interactives-Volcanoes-Can we predict volcanic eruptions-Melting rocks: Annenberg Media web page, accessed June 7, 2010, at http://www.learner.org/interactives/volcanoes/activty1/tempmain.html.

3. Review the Rock Cycle

- U.S. Geological Survey, 2003, Overview of geologic fundamentals: U.S. Geological Survey web page. (Available at http://3dparks.wr.usgs.gov/nyc/common/geologicbasics.htm.)

4. Have students study how volcanologists measure volcanic gases using chemical analysis, hand-held and airborne instrumentation, and satellite image analysis. Have students study the use of spectrometry. Resources include:

- OMI Sulfur Dioxide Group, 2008, Top stories: Joint Center for Earth Systems Technology at the University of Maryland Baltimore County (UMBC) and NASA Goddard Space Flight Center website, accessed June 7, 2010, at http://so2.umbc.edu/omi/

- U.S. Geological Survey, 2005, Cascades Volcano Observatory-DescriptionMount St. Helens volcanic gases: U.S. Geological Survey website. Available at http://vulcan.wr.usgs.gov/Volcanoes/MSH/Emissions/description_msh_gases.html.)

- U.S. Geological Survey, 2007, Cascades Volcano Observatory-Volcanic gas and emissions: U.S. Geological Survey website. (Available at http://vulcan.wr.usgs.gov/Glossary/Emissions/framework.html.)

- U.S. Geological Survey, 2009, Volcano Hazards Program-Monitoring volcanic gases: U.S. Geological Survey website. (Available at http://volcanoes.usgs.gov/activity/methods/gas.php.)

5. Perform "Soda Bottle Volcano" from

Driedger, C.L., Doherty, Anne, and Dixon, Cheryll, 2005, Living with a volcano in your backyard—An educator's guide with emphasis on Mount Rainier, Chap. 1: U.S. Geological Survey General Interest Product 19; produced in cooperation with the National Park Service. (Available at http://vulcan.wr.usgs.gov/Outreach/Publications/GIP19/chapter_one_soda_bottle_volca no.pdf.) 


\section{References Cited}

Alaska State Department of Education and Early Development, 2006, Standards and grade level expectations, March 2006: State of Alaska website, accessed October 2009 at http://www.eed.state.ak.us/tls/assessment/GLEHome.html.

Driedger, C.L., Doherty, Anne, and Dixon, Cheryll, 2005, Living with a volcano in your backyard-An educator's guide with emphasis on Mount Rainier, Chap. 1: U.S. Geological Survey General Interest Product 19; produced in cooperation with the National Park Service. (Available at

- Riding the Magma Elevator http://vulcan.wr.usgs.gov/Outreach/Publications/GIP19/chapter_one_magma_el evator.pdf and

- Soda Bottle Volcano http://vulcan.wr.usgs.gov/Outreach/Publications/GIP19/chapter_one_soda_bottl e_volcano.pdf.)

\section{Glossary}

Amphibole - Amphiboles are an important group of generally dark-colored rockforming silicate minerals that include iron and magnesium in their compositions.

Anthropogenic - Caused by human activity

$\mathbf{C O}_{2}$ - Carbon dioxide

Composition - The amounts and types of minerals and (or) elements a rock is comprised of (or a mineral is comprised of)

Crust - The outermost layer of the Earth. The crust is rigid and very thin compared with the other layers.

Crustal melting zone - An area of high pressures and temperatures tens of kilometers below the ground surface that is the boundary between the mantle and the overlying continental crust. In this zone, rocks melt to form magma-a mixture of three phases: liquid rock, mineral crystals, and magmatic gases.

Dolomite - A light colored rock-forming, carbonate mineral consisting of calcium magnesium carbonate.

Exsolve (and exsolution) - To separate from one another at a critical point in temperature; dissolved gases forming gas bubbles

Geothermal - Heat energy extracted from reservoirs in the Earth's interior

$\mathbf{H}_{2} \mathbf{O}$ - Water

Hydrothermal - Water heated by magma or in association with magma. 
Magma - Magma is molten or partially molten rock beneath the Earth's surface. When magma erupts onto the surface, it is called lava. Magma typically consists of (1) a liquid part (often referred to as the melt); (2) a solid part made of minerals that crystallized directly from the melt; (3) solid rocks incorporated into the magma from along the conduit or reservoir, called xenoliths or inclusions; and (4) dissolved gases.

Mantle - The mantle is a dense, hot layer of semi-solid rock that is approximately 2,900 km thick. The mantle, which contains more iron, magnesium, and calcium than the crust, is hotter and denser because temperature and pressure inside the Earth increase with depth.

Mica - Hydrous silicates of aluminum or potassium that crystallize in forms that allow perfect cleavage

Phase - A state: solid, liquid, or gas that is homogeneous in its structure and atomic arrangement.

Precipitate - Solid substances in suspension, or settling, or filtering out of a fluid

$\mathbf{S O}_{2}-$ Sulfur dioxide

Subduction Zone - The zone of convergence of two tectonic plates, one of which usually overrides the subducting plate

Volcanogenic - Having a volcanic source

\section{Source of Glossary Definitions}

Bates, R.K., and Jackson, J.A., eds., 1987, Glossary of Geology ( $3^{\text {rd }}$ ed.): Falls Church, Va., American Geological Institute, 571 p.

Kious, W.J., and Tilling, R.I., 1996, This dynamic Earth-The story of plate tectonics [online edition]: Reston, Va., U.S. Geological Survey website. (Available at http://pubs.usgs.gov/gip/dynamic/dynamic.html.)

U.S. Geological Survey, 2010, Volcano Hazards Program-USGS photo glossary of volcanic terms: U.S. Geological Survey website: (Available at http://volcanoes.usgs.gov/images/pglossary/index.php.)

U.S. Geological Survey, 2010, Volcano Hazards Program-Volcanic gases and their effects: U.S. Geological Survey website. (Available at http://volcanoes.usgs.gov/hazards/gas/index.php.) 
Name Date Period

Visible Degassing at Alaskan Volcanoes Handout

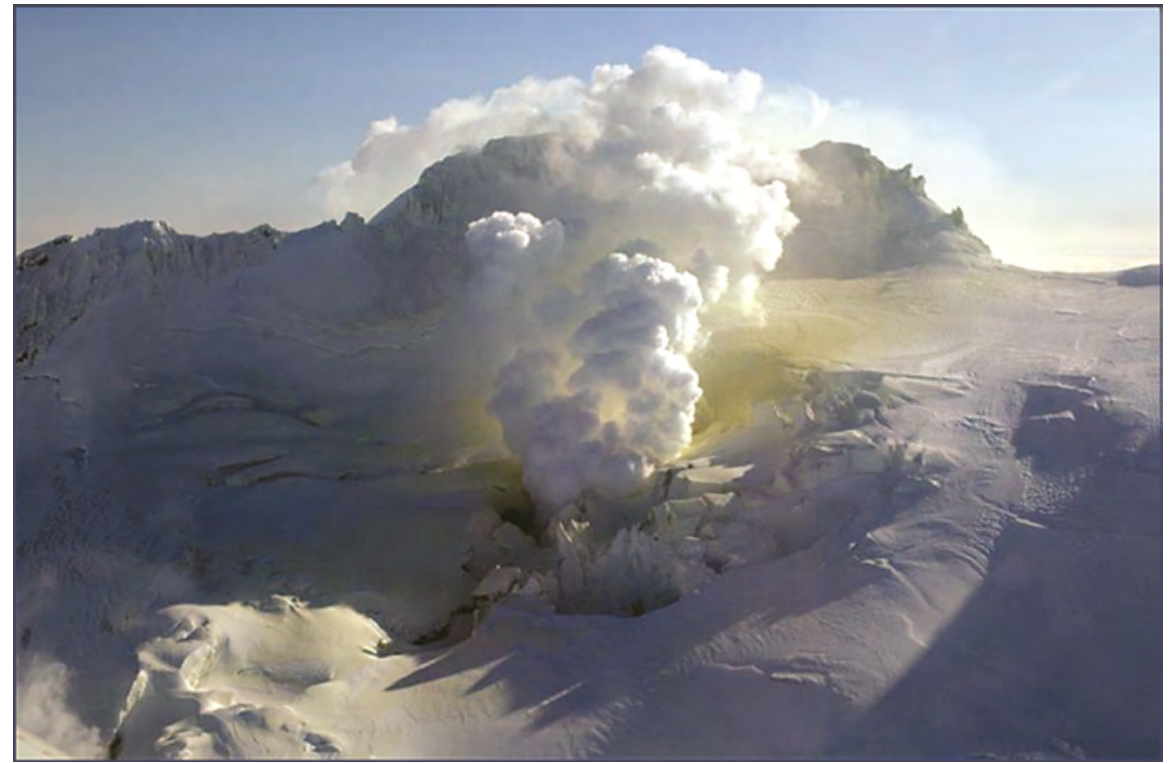

1. Fumarole on northwest side of Fourpeaked Mountain. Yellow staining on the snow is the result of sulfur emission from the vent. Photograph taken by C. Read, U.S. Geological Survey, February 22, 2007.

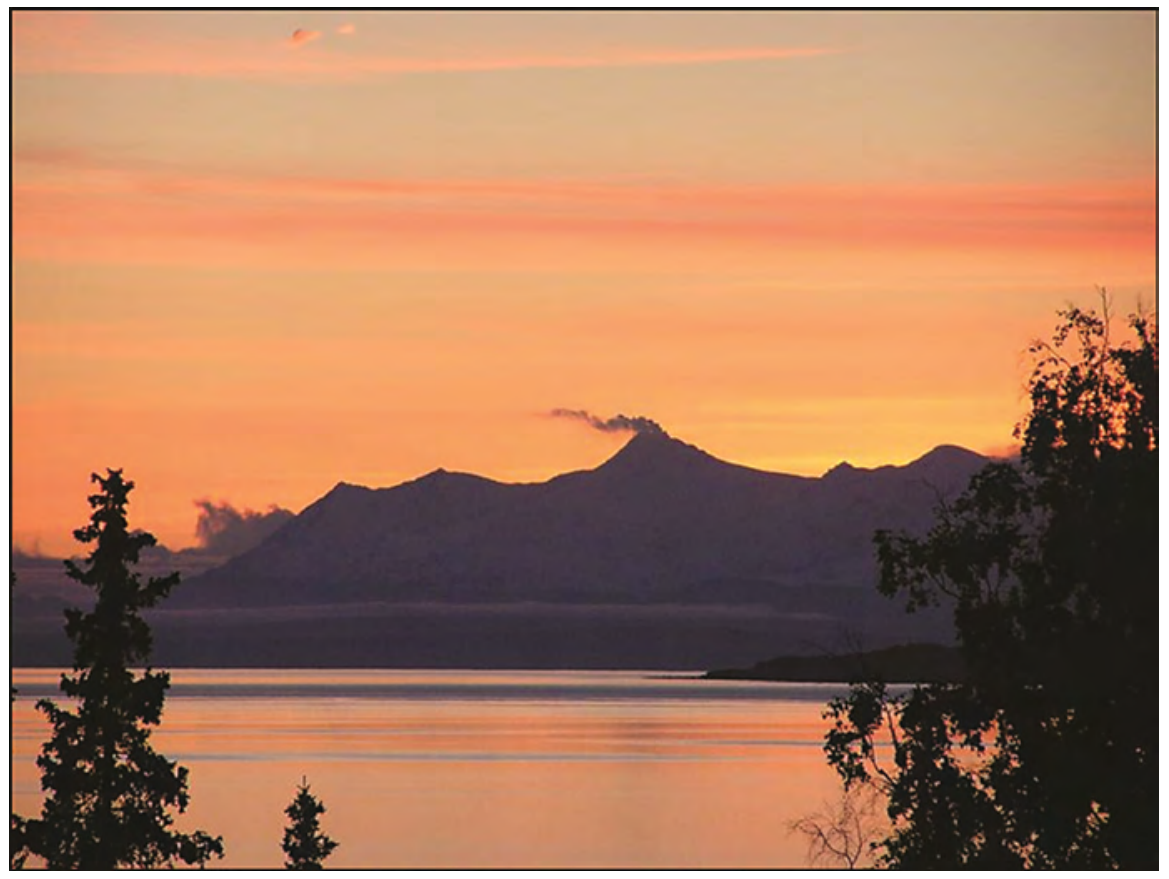

2. Steam plume emanating from the summit ice cauldron of Mt. Spurr. Photograph taken September 10, 2006, courtesy of J. Copen. Used with permission. 


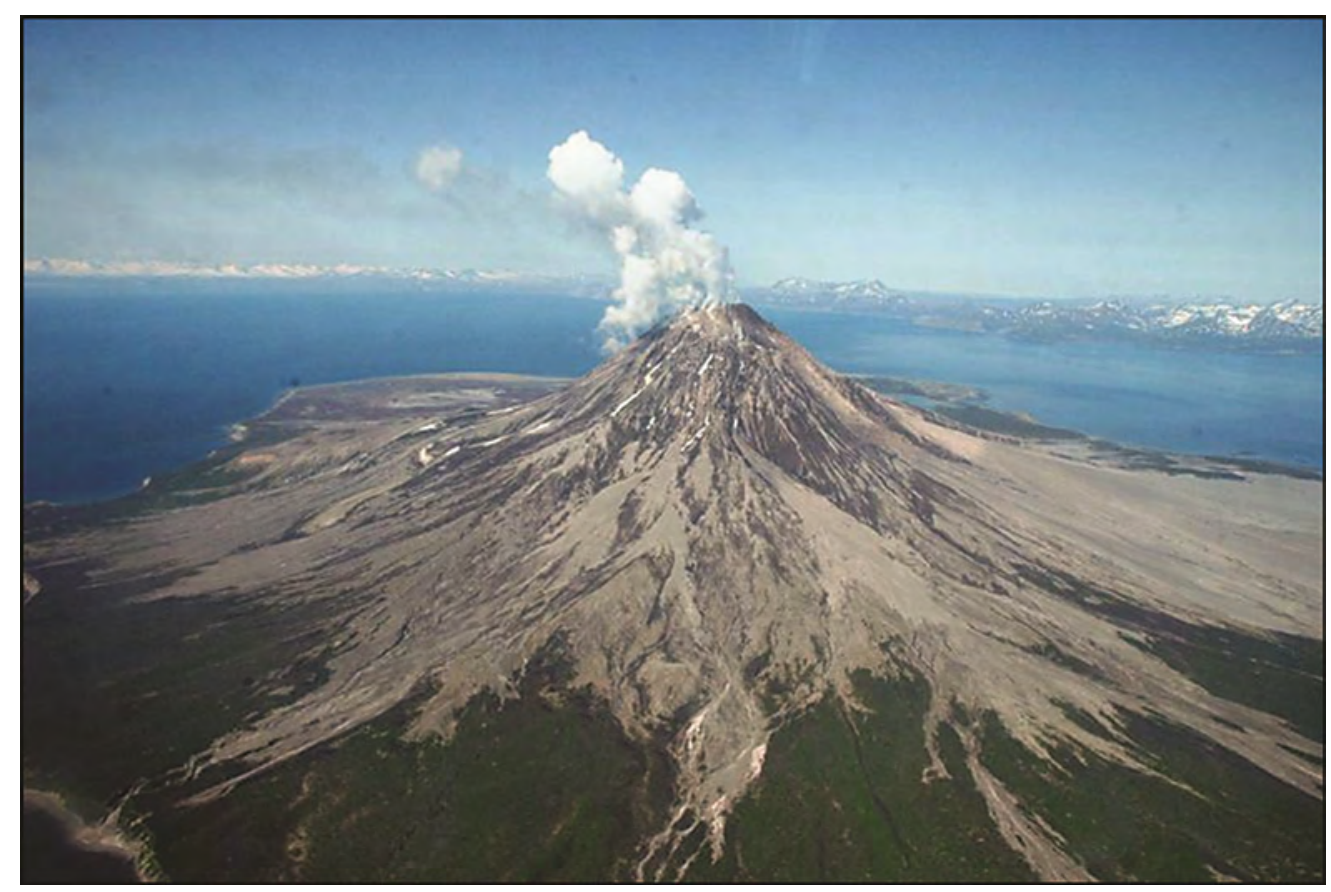

3. View of the east-southeast flanks of Augustine Volcano and steaming summit. Photograph taken by G. McGimsey, U.S. Geological Survey, June 2, 2006.

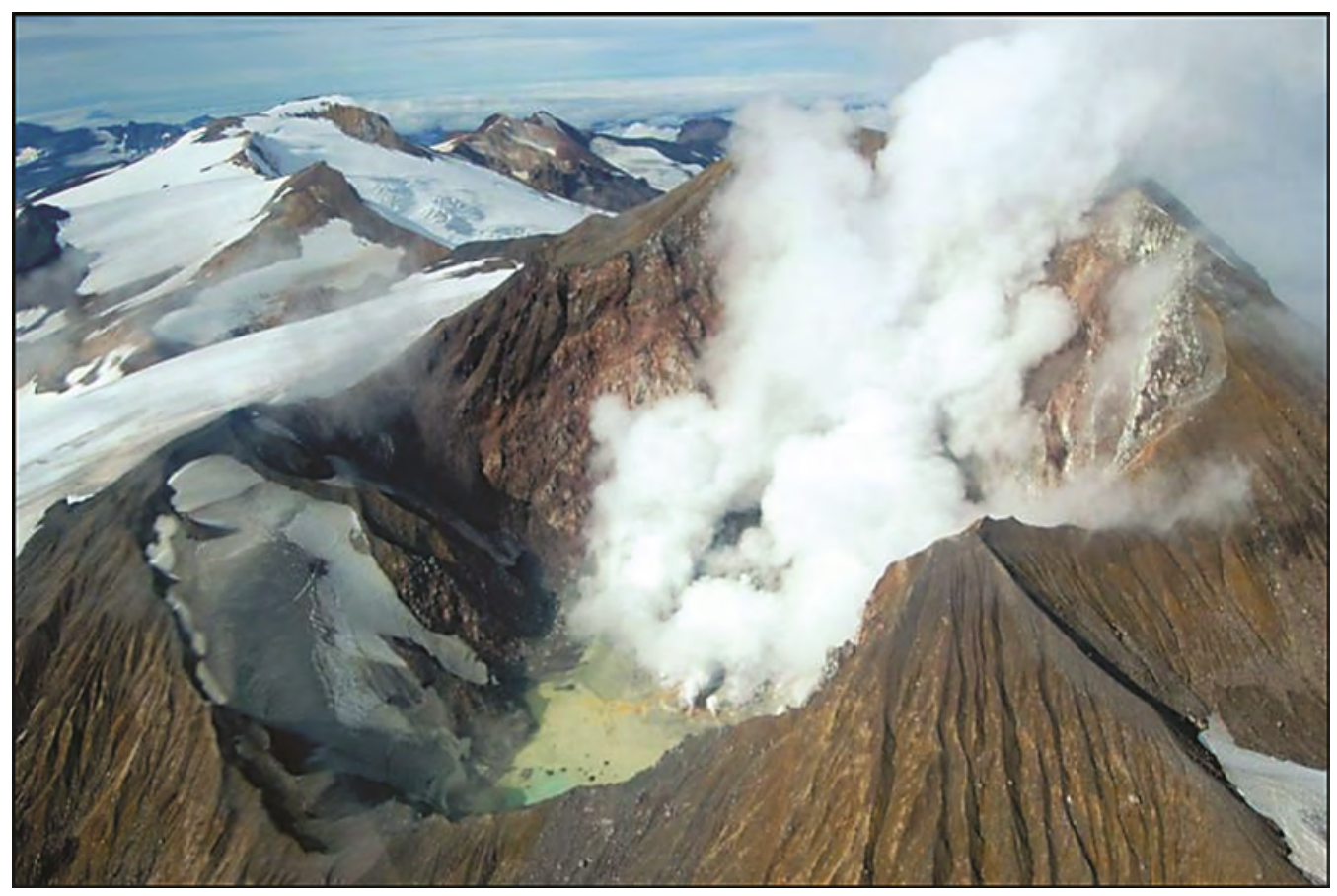

4. Martin summit crater in Katmai National Park. The vigorous fumaroles at Martin and nearby Mageik often have been mistaken for volcanic eruptions. Photograph taken by C. Read, U.S. Geological Survey, August 26, 2006. 


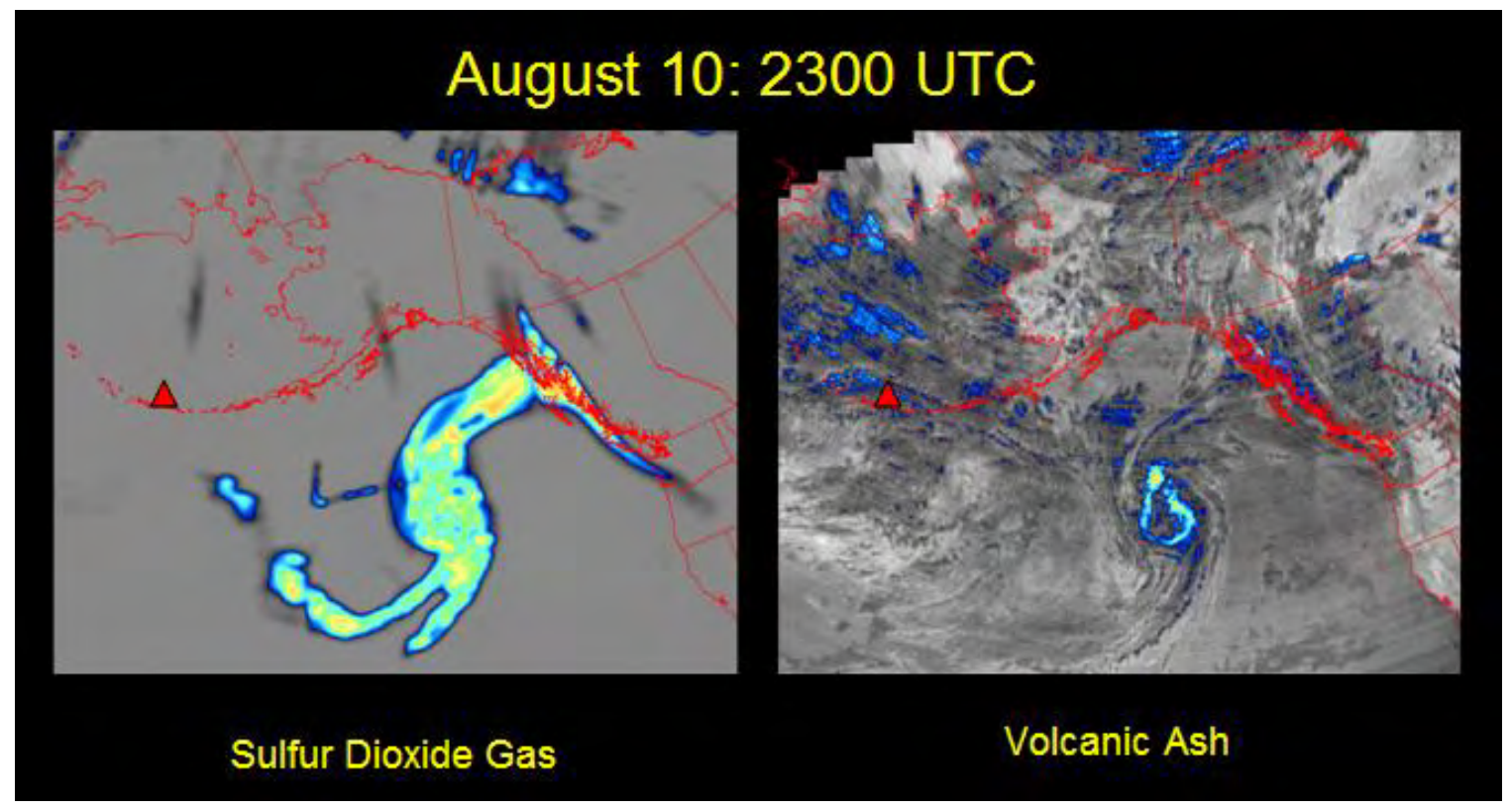

5. Kasatochi volcanic cloud as observed at 2300 UTC on August 10, 2008, approximately 3 days after the start and 2 days after end of the eruption. The image on the left shows $\mathrm{SO}_{2}$ gas detected by the OMI sensor and the image on the right shows a smaller region of volcanic ash as indicated by a GOES thermal infrared brightness temperature difference image. The colors are related to the total column abundance (mass per area) of $\mathrm{SO}_{2}$ and volcanic ash, with warmer colors indicating greater amounts of gas and ash. These data are from NASA's EOS-Aurasatellite and Ozone Monitoring Instrument (OMI), courtesy of Dr. Simon Carn, University of Maryland, Baltimore County. Graphic prepared by Dave Schneider, image courtesy of Alaska Volcano Observatory and U.S. Geological Survey. 


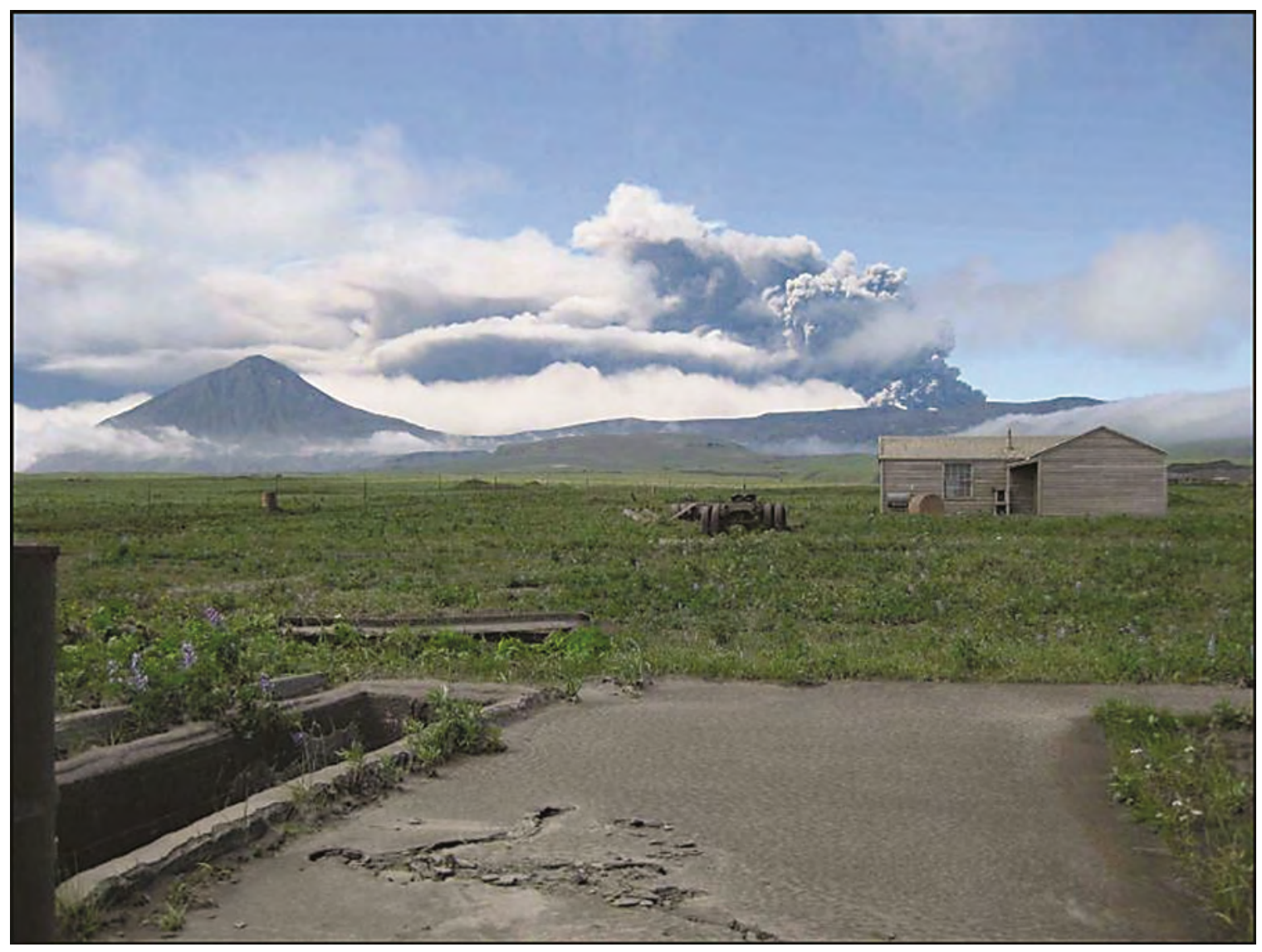

6. View of the Okmok caldera's eruption plume viewed from Fort Glenn (ranch building in foreground) on August 3, 2008. The small peak to the left is Tulik, a stratocone outside of the caldera. Photograph taken by J. Larson, University of Alaska Fairbanks Geophysical Institute, August 3, 2008. 


\section{Activity II. What Goes Up Must Come Down}

Grade Level 6-11

Setting Classroom

Time 20 minutes

Vocabulary (see Glossary)

aerosol, chlorine monoxide (ClO), chlorofluorocarbon (CFC), eruption cloud, greenhouse effect, ozone $\left(\mathrm{O}_{3}\right)$, pollution, radiation, reflection, stratosphere, sulfate, volcanic ash, volcanic (or magmatic) gases

Correlations to Alaska State Department of Education (2006) Performance Standards (Grade Level Expectations)

B1-Concepts of Physical Science

SB[6-11] Students develop an understanding of the concepts, models, theories, universal principles, and facts that explain the physical world.

SB1[6-11] Students develop an understanding of the characteristic properties of matter and the relationship of these properties to their structure and behavior.

\section{D1-Concepts of Earth Science}

SD[6-11] Students develop an understanding of the concepts, processes, theories, models, evidence, and systems of earth and space sciences.

SD1[6-11] Students develop an understanding of Earth's geochemical cycles.

SD2[6-11] Students develop an understanding of the origins, ongoing processes, and forces that shape the structure, composition, and physical history of the Earth.

\section{Overview}

Scientists considered three historical, explosive volcanic eruptions in Indonesia: Tambora (1815), Krakatau (1883), and Agung (1963). They noted decreases in temperatures $\left(0.18-1.3^{\circ} \mathrm{C},\left[\sim 2^{\circ} \mathrm{F}\right]\right)$ close to the ground surface after these eruptions, which were similar magnitudes. The overall amount of material injected during each eruption was different. Comparing the estimated amount of ash and sulfur with the amount of sulfur erupted into the stratosphere by each eruption, suggested that, in the long term, sulfate aerosols $\left(\mathrm{SO}_{4}{ }^{-2}\right)$ formed in the atmosphere with the volcanogenic sulfur, not with the volcanic ash (which falls out within a few months of an eruption). Volcanogenic sulfur, therefore, is the ultimate controlling factor in decreasing temperatures on the Earth's surface following a large, explosive volcanic eruption. 


\section{Background}

Studies of the eruption of El Chichon, Mexico, in 1982 conclusively demonstrated that it is the amount of sulfur in the erupting magma that contributes to the decreases in temperature measured on the Earth's surface following substantial, gas rich volcanic eruptions (not airborne volcanic ash!). The explosive eruption of El Chichon injected at least 8 million metric tons (MT) of sulfur into the atmosphere, and was followed by a measureable cooling of parts of the Earth's surface and a warming of the upper atmosphere. A similar-sized eruption at Mount St. Helens in 1980, however, injected only about $1 \mathrm{MT}$ of sulfur aerosols into the stratosphere. The eruption of Mount St. Helens injected much less sulfur into the atmosphere and it did not result in a noticeable cooling of the earth's surface. The Total Ozone Mapping Spectrometer (TOMS) satellite launched in 1978 made it possible to measure these differences in the eruption clouds. Direct satellite measurements of the eruption clouds combined with surface temperatures make it possible to study the correlation between volcanic sulfur aerosols and temporary changes in the world's climate after some volcanic eruptions.

\section{Objectives}

Student will use a simple laboratory exercise to model minimally suspended volcanic ash and long term suspended airborne volcanogenic sulfate aerosols associated with an explosive volcanic eruption. Students will learn about the effects of a significant sulfur input into the atmosphere.

\section{Materials}

For a single demonstration (duplicate sets of materials for the number of students or groups to perform)

_ large, clear plastic or glass beaker or other wide-mounted container

- $\quad$ source of water

_ $\quad$ 1/2 cup of breadcrumbs with herbs (homemade or store bought) or

_ $\quad$ any other mixture of materials in which one will float (herbs) and one will sink (breadcrumbs)

\section{Procedure}

\section{A. Set up}

1. Set up as a demonstration or for an individual or group activity.

2. Fill a large clear container $\sim 2 / 3$ full of tap water (represents the atmosphere). Prepare as many containers with water in them as there are individuals or groups performing this activity.

3. Mix $\sim 1 / 2$ cup of breadcrumbs with herbs; make as many $1 / 2$-cup mixtures as you have individuals or groups performing the activity. 


\section{B. Float or sink}

1. Inform students that the water represents Earth's atmosphere and the dry materials represent ash and sulfate aerosols formed in the atmosphere from a large, explosive volcanic eruption. The bottom of the container represents Earth's surface. Note You could start with the next step and ask the students to draw this analogy from the activity.

2. Gently pour (and/or have students gently pour) all of the dry mixture onto the surface of the water in the container.

3. Have students observe and record the settling of the materials, including observations of how fast and which material(s) settle to the bottom of the container, and in what order (if there is more than one kind of materials that does so). Let the materials settle in the container overnight if necessary. You and your students should see that the breadcrumbs rapidly sink to the bottom while the herbs will float at the surface.

4. Initiate a discussion about how the settled materials represent volcanic ash, and how it stays aloft briefly (afloat in this experiment) and then settles to the bottom of the container. The material(s) that remain floating the longest represents airborne sulfur expelled during an explosive volcanic eruption.

5. Review with your students the conversion of sulfur to sulfate aerosol. When sulfur dioxide $\left(\mathrm{SO}_{2}\right)$ gas is released, it reacts chemically with sunlight, oxygen, dust particles, and water in the air to form a mixture of sulfate aerosols $\left(\mathrm{SO}_{4}{ }^{-2}\right)$ (tiny particles and droplets), sulfuric acid $\left(\mathrm{H}_{2} \mathrm{SO}_{4}\right)$, and other oxidized sulfur species. Note For discussion about aerosols: students might not know about these colorless invisible substances, so you could provide some direct comparison to hairsprays, and so on.

6. Discuss with your students-Because sulfate aerosols stay aloft longer than ash in Earth's atmosphere (like the breadcrumb herbs), they have the most substantial effect in blocking heat and keeping solar radiation from reaching the Earth's surface. The airborne material that remains aloft also keeps heat radiating from the Earth from reaching the upper atmosphere.

C. Volcanic Gas

1. Using the Volcanic Gas figure to introduce or review the various materials, tephra, and gases produced by a volcanic eruption and the ways in which they react to modify Earth's atmosphere. This will also come in handy when proceeding to Activity IV. An Order of Magnitude.

- $\mathrm{SO}_{2}$

- The conversion of $\mathrm{SO}_{2}$ to sulfuric acid $\left(\mathrm{H}_{2} \mathrm{SO}_{4}\right)$ condenses rapidly in the stratosphere to form fine sulfate aerosols. The aerosols increase the reflection of radiation from the Sun back into space and cool the Earth's lower atmosphere or troposphere; however, they also absorb heat radiated up from the Earth, thereby warming the stratosphere. 
- The sulfate aerosols also promote complex chemical reactions on their surfaces that alter chlorine and nitrogen chemical species in the stratosphere. This effect, together with increased stratospheric chlorine levels from chlorofluorocarbon (CFC) pollution, generates chlorine monoxide (ClO), which destroys ozone $\left(\mathrm{O}_{3}\right)$.

- $\mathrm{CO}_{2}$

- Volcanoes release hundreds of millions metric tons of $\mathrm{CO}_{2}$ into the atmosphere every year. This colorless, odorless gas usually does not pose a direct hazard to life because it typically becomes diluted to low concentrations quickly whether it is released continuously from the ground or during episodic eruptions. In certain circumstances, however, $\mathrm{CO}_{2}$ may become concentrated at levels lethal to people and animals. Carbon dioxide gas is heavier than air and the gas can flow into low-lying areas; breathing air with more than 30 percent $\mathrm{CO}_{2}$ can quickly induce unconsciousness and cause death. In volcanic or other areas where $\mathrm{CO}_{2}$ emissions occur, it is important to avoid small depressions and low areas that might be $\mathrm{CO}_{2}$ traps. The boundary between air and lethal gas can be extremely sharp; even a single step upslope may be adequate to escape death.

- Volcanic eruptions can enhance global warming by adding $\mathrm{CO}_{2}$ to the atmosphere; however, the amount of $\mathrm{CO}_{2}$ from volcanoes is dwarfed by anthropogenic sources. This relation will be emphasized in Activity IV. An Order of Magnitude.

- Volcanic Ash

On a short time frame, airborne volcanic ash can block out the earth's sunlight, reduce solar radiation and lower the mean global temperatures. This can generate red sunsets because of the scattering of red wavelengths by submicron-size particles in the stratosphere and upper troposphere.

\section{Extensions}

1. Ask students if there are positive contributions of volcanic gases. Have students conduct research projects to determine how volcanoes have been an important agent in the development of Earth's atmosphere.

2. Elaborate on the concepts of photochemistry (reactions requiring energy from sunlight), albedo (the ability of a material to reflect sunlight), cirrus clouds (high, thin, wispy clouds), condensation, coagulation, dispersion, using the figure.

- Use an animated version of a similar figure available at:

National Aeronautics and Space Administration, 2005, Students On-Line Atmosphere Research (SOLAR)-Aerosols, what are they and why are they so important?: National Aeronautics and Space Administration webpage, accessed June 7, 2010 webpage, accessed June 7, 2010, at http://asdwww.larc.nasa.gov/SOLAR/learning-aerosol.html.

3. National Aeronautics and Space Administration, 2009, Total Ozone mapping Spectrometer (TOMS) Resource Materials for Science Educators: National Aeronautics and Space Administration website, accessed June 1, 2010, at http://toms.gsfc.nasa.gov/teacher/teacher.html. 


\section{References Cited}

Alaska State Department of Education and Early Development, 2006, Standards and grade level expectations, March 2006: State of Alaska website, accessed October 2009 at http://www.eed.state.ak.us/tls/assessment/GLEHome.html.

Camp, Vic, [n.d.], Climate effects of volcanic eruptions: San Diego State University, Department of Geological Sciences website, accessed June 7, 2010, at http://www.geology.sdsu.edu/how_volcanoes_work/climate_effects.html.

National Aeronautics and Space Administration, 2009, Earth observatory-Sulfur dioxide cloud from Aleutians' Kasatochi Volcano: National Aeronautics and Space Administration web page, accessed June 7, 2010, at http://earthobservatory.nasa.gov/IOTD/view.php?id=8998.

U.S. Geological Survey, 2010, Volcano Hazards Program-Volcanic gases and their effects: U.S. Geological Survey web page. (Available at http://volcanoes.usgs.gov/hazards/gas/index.php.)

U.S. Geological Survey, 2009, Volcano Hazards Program-Volcanic sulfur aerosols affect climate and the Earth's ozone layer-Volcanic ash vs. sulfur aerosols: U.S. Geological Survey web page. (Available at http://volcanoes.usgs.gov/hazards/gas/s02aerosols.php.)

\section{Glossary}

Aerosol - Fine liquid or solid particles suspended in the atmosphere. When sulfur dioxide $\left(\mathrm{SO}_{2}\right)$ gas is released, it reacts chemically with sunlight, oxygen, dust particles, and water in the air to form a mixture of sulfate $\left(\mathrm{SO}_{4}{ }^{-2}\right)$ aerosols (tiny particles and droplets), sulfuric acid $\left(\mathrm{H}_{2} \mathrm{SO}_{4}\right)$, and other oxidized sulfur species.

Chlorine monoxide (CIO) - Atmospheric gas that destroys ozone.

Chlorofluorocarbon (CFC) - Manufactured substances used as coolants and computerchip cleaners. When these products break down they destroy stratospheric ozone, creating the Antarctic Ozone Hole in the Southern Hemisphere in spring (Northern Hemisphere in autumn). Although no longer in use, their long lifetime will lead to a slow removal from the atmosphere.

Eruption cloud - A cloud of tephra and gases that forms downwind of an erupting volcano. The vertical pillar of tephra and gases rising directly above a vent is an eruption column. Eruption clouds often are dark colored - brown to gray_-but they also can be white, similar to weather clouds. Eruption clouds may drift downwind for thousands of kilometers, often spreading out over a large area as distance increases from an erupting vent. Large eruption clouds can encircle the Earth within days.

Greenhouse effect - The heating of the Earth's surface because out-going longwavelength terrestrial radiation is absorbed and re-emitted by the carbon dioxide and water vapor in the lower atmosphere and eventually returned to the surface.

Ozone $\left(\mathbf{O}_{3}\right)$ - Ozone is a molecule consisting of three oxygen atoms that is formed by a reaction of oxygen and ultraviolet radiation. In the stratosphere, ozone has beneficial 
properties because it forms an ozone shield that prevents dangerous radiation from reaching the Earth's surface. Closer to the planet's surface, ozone is considered an air pollutant that adversely affects humans, plants, and animals, as well as a greenhouse gas.

Pollution - Pollution is the introduction of contaminants into an environment that causes instability, disorder, or harm to systems and (or) organisms.

Radiation - Energy from the Earth emitted from its surface toward the atmosphere and beyond.

Reflection - The change in the direction of sunlight heading toward the earth to be bounced back towards the sun.

Stratosphere - The stratosphere is the region of the atmosphere that extends from the top of the troposphere to the base of the mesosphere; an important area for monitoring stratospheric ozone.

Sulfate $\left(\mathrm{SO}_{4}\right)$ - Salt of sulfuric acid $\left(\mathrm{H}_{2} \mathrm{SO}_{4}\right)$

Volcanic ash - Rock, mineral, and volcanic glass fragments smaller than $2 \mathrm{~mm}$ (0.1 in.) in diameter, which is slightly larger than the size of a pinhead. Volcanic ash is not the same as the soft fluffy ash that results from burning wood, leaves, or paper. It is hard, does not dissolve in water, and can be extremely small—ash particles less than $0.025 \mathrm{~mm}$ $(1 / 1,000$ th of an inch) in diameter are common. Ash is extremely abrasive, similar to finely crushed window glass, mildly corrosive, and electrically conductive, especially when wet. Volcanic ash is created during explosive eruptions by the shattering of solid rocks and violent separation of magma (molten rock) into tiny pieces. Explosive eruptions are generated when groundwater is heated by magma and abruptly converted to steam and also when magma reaches the surface so that volcanic gases dissolved in the molten rock expand and escape (explode) into the air extremely rapidly. After being blasted into the air by expanding steam and other volcanic gases, the hot ash and gas rise quickly to form a towering eruption column directly above the volcano.

Volcanic (or magmatic) gases - Magma contains dissolved gases that are released into the atmosphere during eruptions. Gases also are released from magma that either remains below ground (for example, as an intrusion) or is rising toward the surface. The most abundant gas typically released into the atmosphere from volcanic systems is water vapor $\left(\mathrm{H}_{2} \mathrm{O}\right)$, followed by carbon dioxide $\left(\mathrm{CO}_{2}\right)$, and sulfur dioxide $\left(\mathrm{SO}_{2}\right)$. Volcanoes also release smaller amounts of others gases, including hydrogen sulfide $\left(\mathrm{H}_{2} \mathrm{~S}\right)$, hydrogen $\left(\mathrm{H}_{2}\right)$, carbon monoxide (CO), hydrogen chloride (HCL), hydrogen fluoride (HF), and helium (He). 


\section{Source of Glossary Definitions}

Energy Information Administration, 2008, Greenhouse gases, climate change, and energy: U.S. Department of Energy Brochure DOE/EIA-X012, accessed June 7, 2010, at http://www.eia.doe.gov/bookshelf/brochures/greenhouse/Chapter1.htm.

National Weather Service, 2010, Climate prediction center-Climate glossary: National Oceanic and Atmospheric Administration web page, accessed June 9, 2010, at http://www.cpc.noaa.gov/products/outreach/glossary.shtml.

U.S. Geological Survey, 2009, Volcano Hazards Program-Volcanic gases and their effects: U.S. Geological Survey website. (Available at http://volcanoes.usgs.gov/hazards/gas/index.php.)

U.S. Geological Survey, 2010, Volcano Hazards Program-USGS photo glossary of volcanic terms: U.S. Geological Survey website. (Available at http://volcanoes.usgs.gov/images/pglossary/index.php.)

U.S. Geological Survey, 2010, Volcano Hazards Program-Volcanic air pollution, Kilauea Volcano, Hawai i-Long-lasting eruption of Kilauea Volcano, Hawai i leads to volcanic-air pollution: U.S. Geological Survey web page. (Available at http://volcanoes.usgs.gov/hazards/gas/volgaspollution.php.) 


\section{Volcanic Gas}

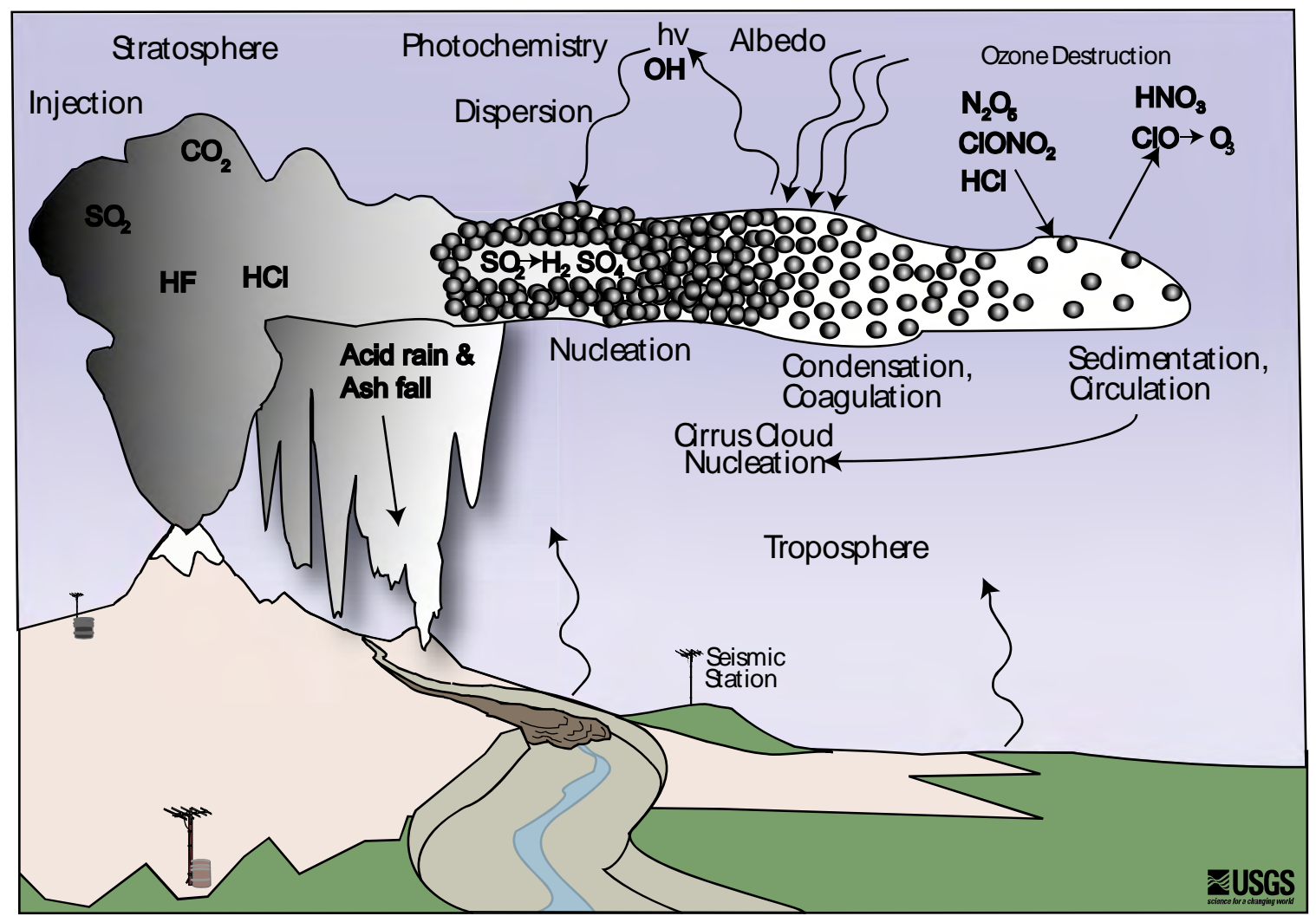

Large volcanic eruptions inject water vapor $\left(\mathrm{H}_{2} \mathrm{O}\right)$, carbon dioxide $\left(\mathrm{CO}_{2}\right)$, sulfur dioxide $\left(\mathrm{SO}_{2}\right)$, hydrochloric acid ( $\mathrm{HCl})$, hydrofluoric acid (HF), and ash into the stratosphere (10-20 mi above the Earth's surface).

- $\mathrm{CO}_{2}$ is a greenhouse gas and contributes to global warming.

- $\mathrm{HCl}$ and $\mathrm{HF}$ can dissolve in water and fall to the Earth as acid rain.

- The most significant impact is when $\mathrm{SO}_{2}$ is converted to sulfuric acid $\left(\mathrm{H}_{2} \mathrm{SO}_{4}\right)$, which condenses into a mist of fine particles (sulfate aerosols). These aerosols reflect radiation from the sun, cooling the troposphere; they also absorb the Earth's heat, warming the stratosphere. The aerosols, together with increased stratospheric chlorine levels from chlorofluorocarbon pollution, also promote ozone destruction by altering chlorine and nitrogen chemical species in the stratosphere. As the aerosols settle down into the upper troposphere, they can serve as nuclei for cirrus clouds, further affecting the Earth's radiation balance.

- Carbon dioxide allows short wavelength radiation from the sun to penetrate through the lower atmosphere to the Earth's surface and absorbs long wavelength radiation, which is the energy the earth reradiates back into space. The trapping of this infrared heat energy by these greenhouse gases results in warming.

- Most of the $\mathrm{HCl}$ and $\mathrm{HF}$ are dissolved in water droplets in the eruption cloud and fall to the quickly ground as acid rain. The injected ash also falls rapidly from the stratosphere; most of it is removed within several days to a few weeks.

Figure modified from Richard Turco, 1992, Volcanism and climate change: American Geophysical Union Special Report, May 1992. 


\section{Activity III. Globally Averaged Temperature and Volcanic Eruptions}

Grade Level 8-12

Setting Classroom or computer lab

Time 60 minutes

Vocabulary (see Glossary)

anthropogenic, decadal, Volcano Explosivity Index (VEI)

Correlations to Alaska State Department of Education (2006) Performance Standards (Grade Level Expectations)

A1-Science as Inquiry and Process

SA1[6-11] Students will develop an understanding of the processes and applications of scientific inquiry.

\section{E1-Science and Technology}

SE1[6-11]Students develop an understanding of the relationships among science, technology, and society.

\section{Overview}

Scientists have observed that volcanic eruptions, which eject large volumes of gases and ash into Earth's atmosphere, can affect global climate for periods lasting from 1 to 3 years. This has been recognized by analysis of globally averaged temperature prior to and following volcanic eruptions. The general effect seen is a short-term cooling trend of one degree Celsius more or less for the subsequent $1-2$ years. The phenomena can be visualized by using graphs that display changes in global average temperature following significant volcanic eruptions.

\section{Background}

When sulfur dioxide $\left(\mathrm{SO}_{2}\right)$ gas is released during a volcanic eruption, it reacts chemically with sunlight, oxygen, dust particles, and water in the air to form a mixture of sulfate $\left(\mathrm{SO}_{4}^{-2}\right)$ aerosols (tiny particles and droplets), sulfuric acid $\left(\mathrm{H}_{2} \mathrm{SO}_{4}\right)$, and other oxidized sulfur species. Once formed, sulfate aerosols stay in the stratosphere for about 2 years; however, remnants of the layer can remain in the atmosphere longer. This limits the amount of time the temperature measured at the ground surface can be affected by volcanically erupted $\mathrm{SO}_{2}$.

\section{Objective}

Students will quantify how global average temperatures have changed over the past 150+ years by plotting annual average temperatures over time. Students will identify temperature trends before and after major volcanic eruptions worldwide with an emphasis on Alaskan eruptions. Students will be able to correlate the size of one volcanic eruption to another using the Volcanic Explosivity Index (VEI). 


\section{Materials}

To graph by hand

- graph paper

- colored pencils

_ $\quad$ data table of temperatures during the last 150 years

To graph using a computer spreadsheet program

_ computer with spreadsheet or graphing program

\section{Procedure}

\section{A. Decadal-to-Century Variability and Trends worksheet}

1. Use Table 1: Ave. Global temp in ${ }^{\circ} \mathrm{C}$ and ${ }^{\circ} \mathrm{F}$ from $1880-2005$ - in the section of handouts associated with this activity.

- Students should make a scatter plot of annual temperature and time for the years 1880-1920 and then answer questions on the Decadal-to-Century Variability and Trends worksheet or in a group discussion.

- Students then can make a scatter plot of the same data, but for the period 1921-65, and answer questions on the same worksheet or in a group discussion.

- Finally, students should make a scatter plot for the period 1966-2005, and answer questions on the worksheet or in a group discussion.

\section{B. Inter-annual Variability worksheet}

1. Students will use the table of major volcanic eruptions 1883-2005 on the worksheet.

- Using Table 1: Ave. Global temp in ${ }^{\circ} \mathrm{C}$ and ${ }^{\circ} \mathrm{F}$ from 1880-2005, have students make a scatter plot of annual temperature and time for the periods designated in the worksheet and answer the associated questions.

- Have students indicate these eruptions on their plots. Make sure students distinguish the Alaska eruptions from the others. The easiest way to do this may be to use colored straight, vertical lines through each year when there is an eruption and to label the lines. Students could identify all Alaskan eruptions using the same color for the designating line.

Note The Volcanic Explosivity Index (VEI) is way to describe the relative size or magnitude of explosive volcanic eruptions. It is a 0-to-8 index of increasing explosivity. Each increase in number represents an increase about a factor of ten. The VEI uses several factors to assign a number, including volume of erupted pyroclastic material (for example, ashfall, pyroclastic flows, and other ejecta), height of eruption column, duration in hours, and qualitative descriptive terms. See http://volcanoes.usgs.gov/images/pglossary/vei.php for more information. 
C.

1. Have students view and discuss the plots of comparison between global mean surface temperature anomalies $\left({ }^{\circ} \mathrm{C}\right)$ from observations and simulations forced with (a) anthropogenic (man made) and natural forcings (solar and volcanic) and (b) natural forcings only.
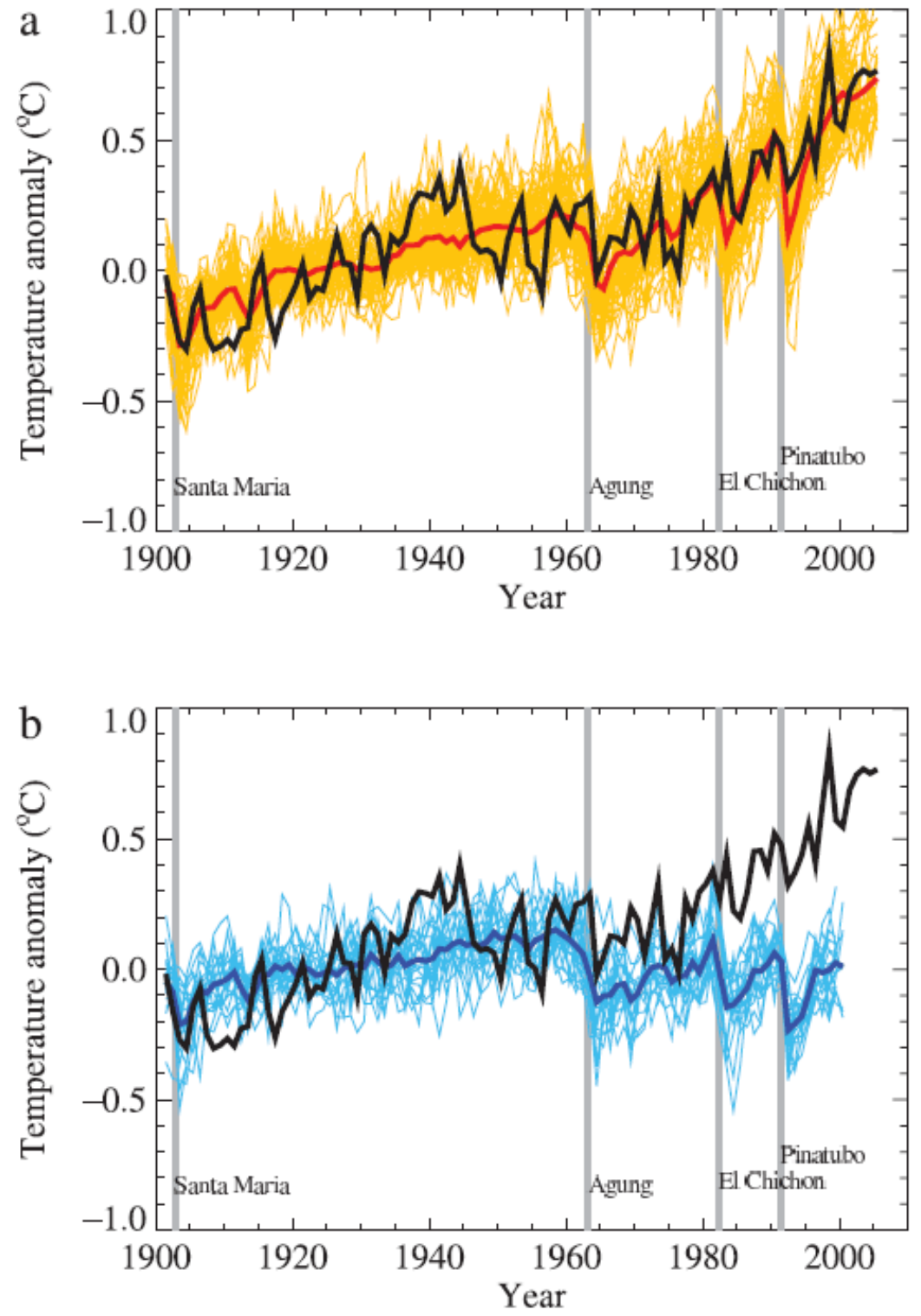

Comparison between global mean surface temperature anomalies $\left({ }^{\circ} \mathrm{C}\right)$ from observations (black) and simulations (computer model outputs) forced with (a) anthropogenic and natural forcings (solar and volcanogenic) and (b) natural forcings only.

(a) Global mean surface temperatures $\left({ }^{\circ} \mathrm{C}\right)$ from observations (black) and simulations (multiple runs of multiple computer models with different variables - the average of which is shown by the red line) with anthropogenic and natural forcings. 
(b) Global mean surface temperatures $\left({ }^{\circ} \mathrm{C}\right)$ from observations (black) and simulations (multiple runs of multiple computer models with different variables - the average of which is shown by the dark blue line) with natural forcings (solar and volcanogenic) only.

On (a) and (b) the vertical grey lines indicate the timing of major volcanic events.

In essence, graph (a) shows computer model calculations that include anthropogenic and natural (volcanic and solar) inputs and the direct measurement of average global temperature match. Graph (b) also shows the direct measurement of average global temperature in black, increasing over time, but computer model calculations using only natural (volcanic and solar) inputs show a steady average global temperature. One could conclude from this figure that the anthropogenic sources or inputs are the cause of increasing average global temperatures. Graph (b) also illustrates that immediately following the noted volcanic eruptions there is a decrease in globally averaged temperatures for the next 2,3 , or 4 years, but the average achieved over a much longer time scale is attained within a few years.

Intergovernmental Panel on Climate Change (IPCC), 2007. http://www.ipcc.ch/publications_and_data/publications_ipcc_fourth_assessment_repo rt_wg1_report the physical_science basis.htm (download PDFs)

- $\quad$ FAQ 8.1, Figure 1, Chapter 8 Climate Models and their Evaluation

- Figure is 9.5, Chapter 9, Understanding and Attributing Climate Change, Fourth Assessment Report Climate Change

\section{Modified from}

Columbia University, 2007, The climate system-EESC 2100, Fall 2007: Columbia University webpage, accessed July 2, 2010, at http://eesc.ldeo.columbia.edu/courses/ees/climate/labs/globaltemp.

\section{References Cited}

Alaska State Department of Education and Early Development, 2006, Standards and grade level expectations, March 2006: State of Alaska website, accessed October 2009 at http://www.eed.state.ak.us/tls/assessment/GLEHome.html.

Intergovernmental Panel on Climate Change (IPCC), 2007, Fourth Assessment Report Climate Change-The Physical Science Basis, Working Group I contribution to the Fourth Assessment Report of the Intergovernmental Panel on Climate Change, Chapters 8 and 9, FAQ 8.1, figure 1; Figure 9.5: New York, Cambridge University Press, accessed December 14, 2009, at http://www.ipcc.ch/ipccreports/ar4-wg1.htm.

National Aeronautics and Space Administration, 1996, Facts online, atmospheric aerosols - What are they, and why are they so important?: National Aeronautics and Space Administration Fact Sheet FS-1996-08-11-LaRC, accessed June 1, 2010, at http://oea.larc.nasa.gov/PAIS/Aerosols.html.

The Climate System, 2007, EESC 2100V Fall 2007: Columbia University web page, accessed June 10, 2010, at http://eesc.ldeo.columbia.edu/courses/ees/climate/labs/globaltemp/. 
Smithsonian Institution, [n.d.], Global volcanism program: Volcanic Explosivity Index (VEI): Smithsonian Institution database, accessed June 1, 2010, at http://www.volcano.si.edu/world/largeeruptions.cfm?sortorder=desc.

\section{Glossary \\ Anthropogenic - Derived from human activities}

Decadal - Pertaining to ten; consisting of tens.

Volcano Explosivity Index (VEI) - Proposed in 1982 as a way to describe the relative size or magnitude of explosive volcanic eruptions. It is a 0 -to-8 index of increasing explosivity. Each increase in number represents an increase around a factor of ten. The VEI uses several factors to assign a number, including volume of erupted pyroclastic material (for example, ashfall, pyroclastic flows, and other ejecta), height of eruption column, duration in hours, and qualitative descriptive terms.

\section{Source of Glossary Definitions}

U.S. Geological Survey, 2010, Volcano Hazards Program-USGS photo glossary of volcanic terms: U.S. Geological Survey website. (Available at http://volcanoes.usgs.gov/images/pglossary/index.php.) 
Name

Date

Period

\section{Decadal-to-Century Variability and Trends}

1. Using Table 1: Ave. Global temp in ${ }^{\circ} \mathrm{C}$ and ${ }^{\circ} \mathrm{F}$ from $1880-2005$ make a scatter plot of annual temperature and time for the period 1880-1920 only. Then answer the questions.

- How would you describe the general appearance of this curve? Imagine you are a scientist in 1921 predicting the future by extrapolating this trend.

- What would you predict the current global temperature in 2005 to be?

- Describe the major features of the global temperature time series in words so that a person not seeing the graph can qualitatively construct it on a sheet of paper based on your description.

2. Now make a scatter plot of the same data but for the period 1921-65. Then answer the questions.

- How would you describe your plot's appearance? Imagine you are a scientist in 1966 predicting the future by extrapolating this trend.

- $\quad$ Based on this trend, what would you predict the temperature to be in 2005?

- In 1966, would you have been more worried about global warming or a return to another Ice Age? 
3. Now make a scatter plot for the period 1966-2005. Then answer the questions.

- Based on the trend, what would you predict the temperature to be in 2006?

- In 2005, would you have been more worried about global warming or a return to another Ice Age?

- What are the five warmest years in the record?

- The five coldest?

- Have we come anywhere close to having one of the coldest years in the record during your lifetime?

- How long a record is needed to see clear evidence of global warming? 
Table 1: Ave. Global temp in ${ }^{\circ} \mathrm{C}$ and ${ }^{\circ} \mathrm{F}$ from 1880 - 2005, The Climate System, Columbia Univ. http://eesc.ldeo.columbia.edu/courses/ees/climate/labs/globaltemp

\begin{tabular}{|c|c|c|}
\hline Year & $\begin{array}{c}\text { Ave. } \\
\text { Global } \\
\text { Temp. } \\
\left({ }^{\circ} \mathrm{C}\right)\end{array}$ & $\begin{array}{c}\text { Ave. } \\
\text { Global } \\
\text { Temp. } \\
\left({ }^{\circ} \mathrm{F}\right)\end{array}$ \\
\hline 1880 & 13.75 & 56.75 \\
\hline 1881 & 13.8 & 56.84 \\
\hline 1882 & 13.77 & 56.79 \\
\hline 1883 & 13.76 & 56.77 \\
\hline 1884 & 13.7 & 56.66 \\
\hline 1885 & 13.7 & 56.66 \\
\hline 1886 & 13.75 & 56.75 \\
\hline 1887 & 13.65 & 56.57 \\
\hline 1888 & 13.74 & 56.73 \\
\hline 1889 & 13.85 & 56.93 \\
\hline 1890 & 13.63 & 56.53 \\
\hline 1891 & 13.72 & 56.70 \\
\hline 1892 & 13.68 & 56.62 \\
\hline 1893 & 13.68 & 56.62 \\
\hline 1894 & 13.67 & 56.61 \\
\hline 1895 & 13.73 & 56.71 \\
\hline 1896 & 13.83 & 56.89 \\
\hline 1897 & 13.88 & 56.98 \\
\hline 1898 & 13.75 & 56.75 \\
\hline 1899 & 13.83 & 56.89 \\
\hline 1900 & 13.9 & 57.02 \\
\hline 1901 & 13.84 & 56.91 \\
\hline 1902 & 3.73 & 56.71 \\
\hline 1903 & 13.69 & 56.64 \\
\hline 1904 & 13.66 & 56.59 \\
\hline 1905 & 13.75 & 56.75 \\
\hline 1906 & 13.8 & 56.84 \\
\hline 1907 & 13.61 & 56.50 \\
\hline 1908 & 13.66 & 56.59 \\
\hline 1909 & 13.65 & 56.57 \\
\hline 1910 & 13.67 & 56.61 \\
\hline 1911 & 13.66 & 56.59 \\
\hline 1912 & 13.66 & 56.59 \\
\hline 1913 & 13.68 & 56.62 \\
\hline 1914 & 13.85 & 56.93 \\
\hline 1915 & 13.91 & 57.04 \\
\hline 1916 & 13.7 & 56.66 \\
\hline 1917 & 13.6 & 56.48 \\
\hline 1918 & 13.68 & 56.62 \\
\hline 1919 & 13.8 & 56.84 \\
\hline 1920 & 13.81 & 56.86 \\
\hline 1921 & 13.87 & 56.97 \\
\hline
\end{tabular}

\begin{tabular}{r|r|r}
\hline & $\begin{array}{c}\text { Ave. } \\
\text { Global } \\
\text { Temp. } \\
\text { ('C) }\end{array}$ & $\begin{array}{c}\text { Ave. } \\
\text { Global } \\
\text { Temp. } \\
\text { ( }{ }^{\circ} \text { F) }\end{array}$ \\
\hline 1922 & 13.76 & 56.77 \\
\hline 1923 & 13.8 & 56.84 \\
\hline 1924 & 13.79 & 56.82 \\
\hline 1925 & 13.84 & 56.91 \\
\hline 1926 & 13.99 & 57.18 \\
\hline 1927 & 13.87 & 56.97 \\
\hline 1928 & 13.89 & 57.00 \\
\hline 1929 & 13.75 & 56.75 \\
\hline 1930 & 13.93 & 57.07 \\
\hline 1931 & 13.99 & 57.18 \\
\hline 1932 & 13.94 & 57.09 \\
\hline 1933 & 13.83 & 56.89 \\
\hline 1934 & 13.95 & 57.11 \\
\hline 1935 & 13.89 & 57.00 \\
1936 & 13.96 & 57.13 \\
\hline 1937 & 14.08 & 57.34 \\
\hline 1938 & 14.11 & 57.40 \\
\hline 1939 & 14.03 & 57.25 \\
\hline 1940 & 14.05 & 57.29 \\
\hline 1941 & 14.11 & 57.40 \\
\hline 1942 & 14.03 & 57.25 \\
\hline 1943 & 14.1 & 57.38 \\
\hline 1944 & 14.2 & 57.56 \\
\hline 1945 & 14.07 & 57.33 \\
\hline 1946 & 13.96 & 57.13 \\
\hline 1947 & 14.01 & 57.22 \\
\hline 1948 & 13.96 & 57.13 \\
\hline 1949 & 13.94 & 57.09 \\
\hline 1950 & 13.85 & 56.93 \\
\hline 1951 & 13.96 & 57.13 \\
\hline 1952 & 14.03 & 57.25 \\
\hline 1953 & 14.11 & 57.40 \\
\hline 1954 & 13.9 & 57.02 \\
\hline 1955 & 13.9 & 57.02 \\
\hline 1956 & 13.83 & 56.89 \\
\hline 1957 & 14.08 & 57.34 \\
\hline 1958 & 14.08 & 57.34 \\
\hline 1959 & 14.06 & 57.31 \\
\hline 1960 & 13.99 & 57.18 \\
\hline 1961 & 14.08 & 57.34 \\
\hline 1962 & 14.04 & 57.27 \\
\hline & 14.08 & 57.34 \\
\hline
\end{tabular}

\begin{tabular}{r|r|r}
\hline & \multicolumn{1}{c}{$\begin{array}{c}\text { Ave. } \\
\text { Global } \\
\text { Temp. }\end{array}$} & $\begin{array}{c}\text { Ave. } \\
\text { Global } \\
\text { Temp. } \\
\text { Year }{ }^{\circ} \text { C) }\end{array}$ \\
\hline 1964 & 13.79 & 56.82 \\
\hline 1965 & 13.89 & 57.00 \\
\hline 1966 & 13.97 & 57.15 \\
\hline 1967 & 14 & 57.20 \\
\hline 1968 & 13.96 & 57.13 \\
\hline 1969 & 14.08 & 57.34 \\
\hline 1970 & 14.03 & 57.25 \\
\hline 1971 & 13.9 & 57.02 \\
\hline 1972 & 14 & 57.20 \\
\hline 1973 & 14.14 & 57.45 \\
\hline 1974 & 13.92 & 57.06 \\
\hline 1975 & 13.95 & 57.11 \\
\hline 1976 & 13.84 & 56.91 \\
\hline 1977 & 14.13 & 57.43 \\
\hline 1978 & 14.02 & 57.24 \\
\hline 1979 & 14.09 & 57.36 \\
\hline 1980 & 14.18 & 57.52 \\
\hline 1981 & 14.27 & 57.69 \\
\hline 1982 & 14.05 & 57.29 \\
\hline 1983 & 14.26 & 57.67 \\
\hline 1984 & 14.09 & 57.36 \\
\hline 1985 & 14.06 & 57.31 \\
\hline 1986 & 14.13 & 57.43 \\
\hline 1987 & 14.27 & 57.69 \\
\hline 1988 & 14.31 & 57.76 \\
\hline 1989 & 14.19 & 57.54 \\
\hline 1990 & 14.38 & 57.88 \\
\hline 1991 & 14.35 & 57.83 \\
\hline 1992 & 14.13 & 57.43 \\
\hline 1993 & 14.14 & 57.45 \\
\hline 1994 & 14.24 & 57.63 \\
\hline 1995 & 14.38 & 57.88 \\
\hline 1996 & 14.3 & 57.74 \\
\hline 1997 & 14.4 & 57.92 \\
\hline 1998 & 14.57 & 58.23 \\
\hline 1999 & 14.33 & 57.79 \\
\hline 2000 & 14.33 & 57.79 \\
\hline 2001 & 14.48 & 58.06 \\
\hline 2002 & 14.56 & 58.21 \\
\hline 2003 & 14.55 & 58.19 \\
\hline 2005 & 14.49 & 58.08 \\
\hline & 14.63 & 58.33 \\
\hline
\end{tabular}


Name

Date

Period

\section{Inter-annual Variability}

Using Table 1: Ave. Global temp in ${ }^{\circ} \mathrm{C}$ and ${ }^{\circ} \mathrm{F}$ from $1880-2005$ make a scatter plot of annual temperature and time for the entire period 1880 - 2005. Below is a list of major volcanic eruptions since 1883, their Volcanic Explosivity Index (VEI), location, and the year that each eruption occurred. Identify them on your plot. Distinguish the eruptions that took place in Alaska from the others.

\begin{tabular}{llcc} 
Volcano & Location & VEI* & Year \\
\hline Krakatau & Indonesia & 6 & 1883 \\
\hline Colima & México & 4 & 1890 \\
\hline Soufriere / Santa Maria & West Indies / Guatemala & $4 / 6$ & 1902 \\
\hline Novarupta & Alaska (USA) & 6 & 1912 \\
\hline Aniakchak & Alaska (USA) & 4 & 1931 \\
\hline Agung & Lesser Sunda Islands (Indonesia) & 5 & 1963 \\
\hline Fernandina Island & Galápagos Islands & 4 & 1968 \\
\hline Mt. St. Helens & Washington (USA) & 5 & 1980 \\
\hline Augustine & Alaska (USA) & 4 & 1986 \\
\hline Pinatubo & Luzon (Philippines) & 6 & 1991 \\
\hline Spurr & Alaska (USA) & 4 & 1992 \\
\hline
\end{tabular}

*The Volcanic Explosivity Index (VEI) is way to describe the relative size or magnitude of explosive volcanic eruptions. See http://volcanoes.usgs.gov/images/pglossary/vei.php for more information.

Using your plot, develop an Average Global Temperatures table. For all the above eruptions, note the average annual global temperature for the year in which the eruption occurred, the year before the eruption, the year after the eruption, 2 years after the eruption, and 3 years after the eruption. Note: Be sure to identify the temperature scale because the Ave. Global Temp. is recorded in ${ }^{\circ} \mathrm{F}$ or ${ }^{\circ} \mathrm{C}$. Answer the following questions based on your plot and table.

- What is the typical magnitude and direction (warming or cooling) of the effect of volcanoes on global climate?

- How long does it take the climate to return to normal after a major eruption? 
Name

Date

Period

\section{Mean Surface Temperature $\left({ }^{\circ} \mathrm{C}\right)$ Anomalies Handout}

Comparison between global mean surface temperature anomalies $\left({ }^{\circ} \mathrm{C}\right)$ from observations (black) and simulations (computer model outputs) forced with (a) anthropogenic and natural forcings (solar and volcanogenic) and (b) natural forcings only.

(a) Global mean surface temperatures $\left({ }^{\circ} \mathrm{C}\right)$ from observations (black) and simulations (multiple runs of multiple computer models with different variables - the average

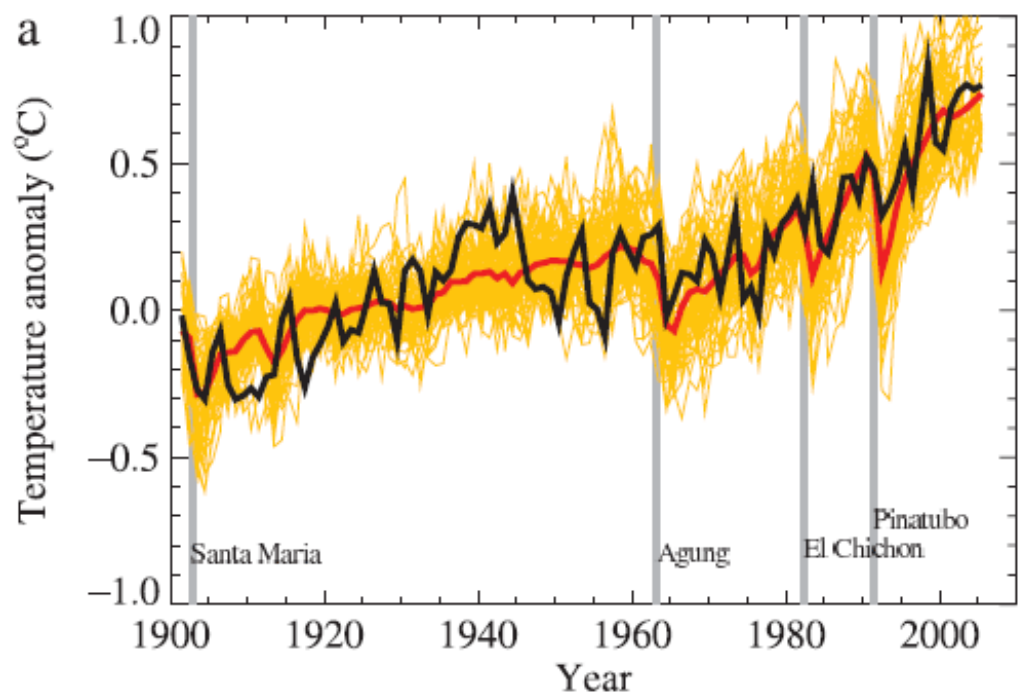
is shown by the red line) with anthropogenic and natural.

(b) Global mean surface temperatures $\left({ }^{\circ} \mathrm{C}\right)$ from observations (black) and simulations (multiple runs of multiple computer models with different variables - the average is shown by the dark blue line) of natural forcings (solar and volcanogenic) only.

On (a) and (b) the vertical grey lines indicate the timing of major volcanic events.

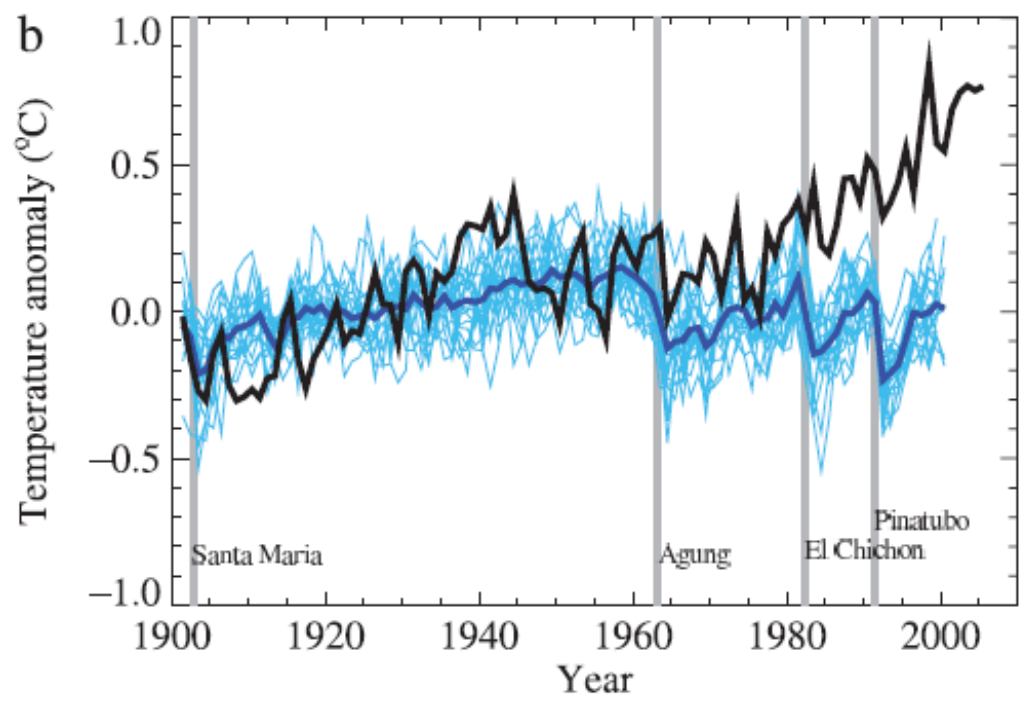

This is figure 9.5 from

Intergovernmental Panel on Climate Change (IPCC), 2007, Fourth Assessment Report

Climate Change - The Physical Science Basis, Working Group I contribution to the

Fourth Assessment Report of the Intergovernmental Panel on Climate Change,

Chapters 8 and 9, FAQ 8.1, figure 1; Figure 9.5: New York, Cambridge University

Press, accessed December 14, 2009, at http://www.ipcc.ch/ipccreports/ar4-wg1.htm.

- Graph (a): FAQ 8.1, Figure 1, Chapter 8 Climate Models and their Evaluation;

- Graph (b): Figure is 9.5, Chapter 9, Understanding and Attributing Climate Change, Fourth Assessment Report Climate Change. 


\section{Decadal-to-Century Variability and Trends Key}

1. Using Table 1: Ave. Global temp in ${ }^{\circ} \mathrm{C}$ and ${ }^{\circ} \mathrm{F}$ from 1880 to 2005 create a scatter plot of annual temperature and time for 1880-1920 only. Then answer the questions.

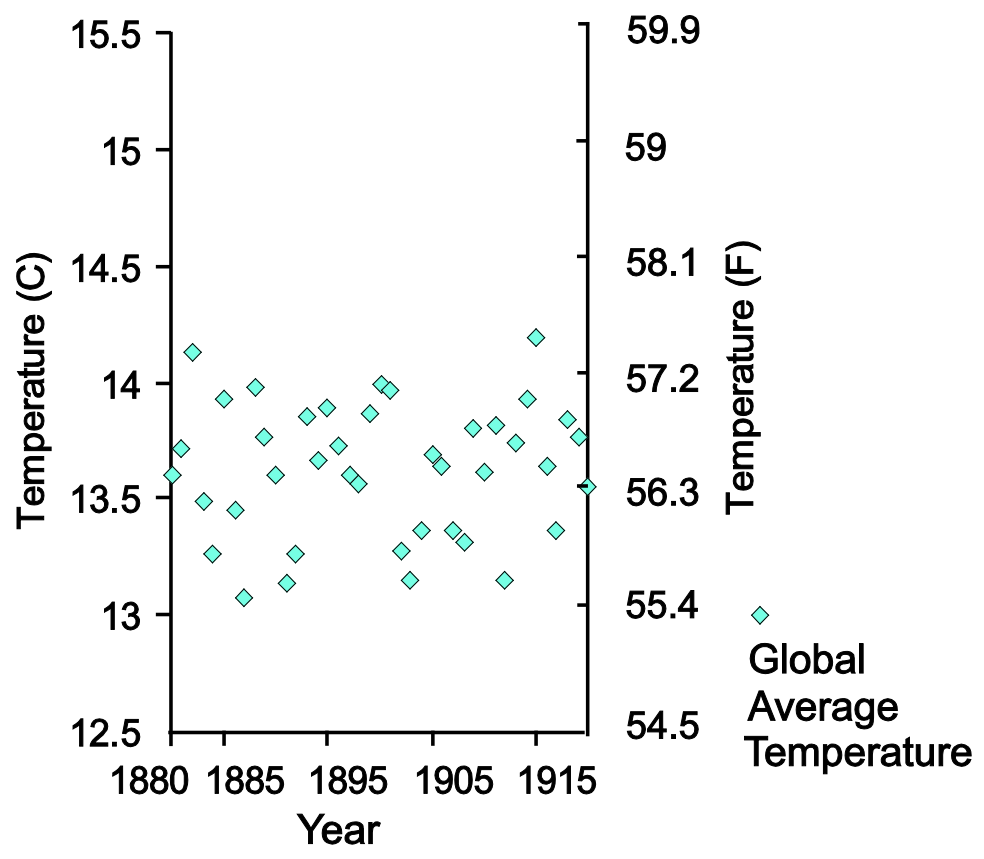

- How would you describe the general appearance of this curve? Imagine you are a scientist in 1921 predicting the future by extrapolating this trend.

Curve? It appears fairly flat. It is punctuated early on and towards the end, but overall the trend is flat and steady.

- What would you predict the current global temperature in 2005 to be?

I imagine it will continue to be flat at the same temperature observed here.

- Describe the major features of the global temperature time series in words so that a person not seeing the graph can qualitatively construct it on a sheet of paper based on your description.

The annual temperature between 1880 and 1920 varies from $\sim 13.1$ to $14.2^{\circ} \mathrm{C}$ $\left(55.5-57.7^{\circ} \mathrm{F}\right)$. The lowest temperature was in 1887 and the highest temperature was in 1915, although no overall increase in temperature was recorded between those two dates. 
2. Now make a scatter plot of the same data but for the period 1921-1965 instead. Then answer the questions.

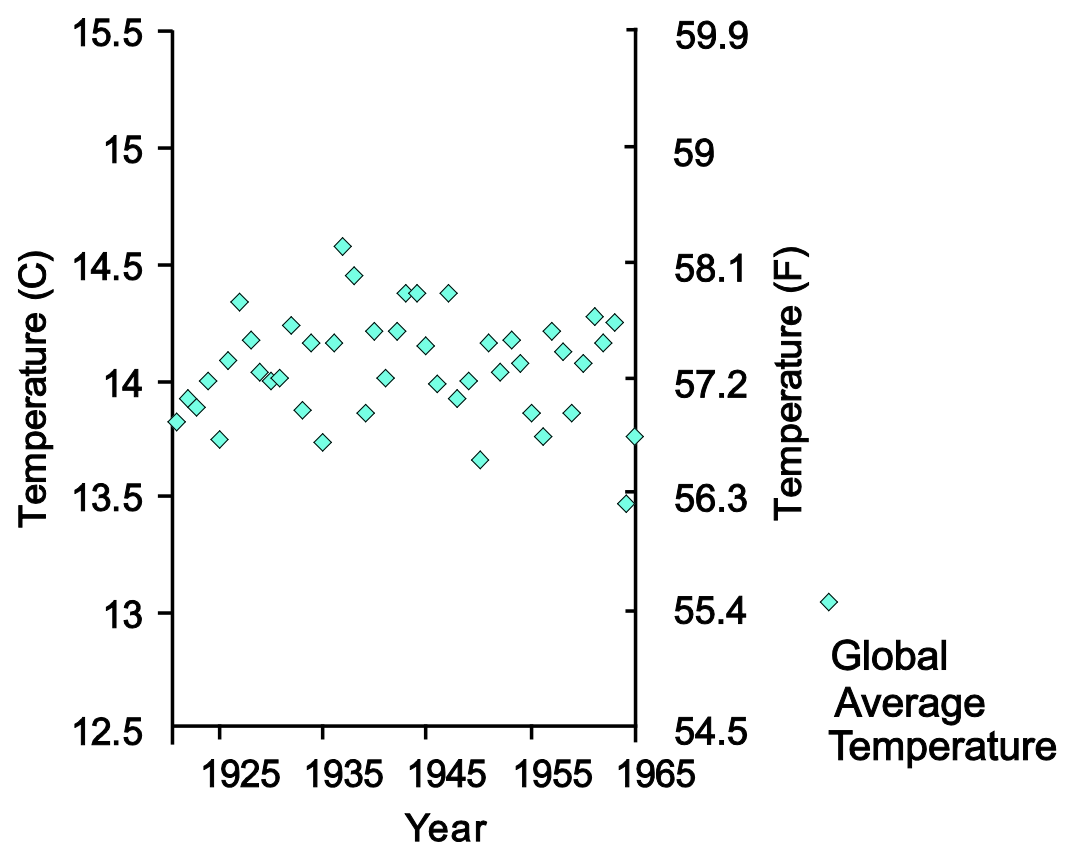

- How would you describe its appearance? Imagine you are a scientist in 1966 predicting the future by extrapolating this trend.

The data almost appear to arc, with a few highest temperatures between 1937 and 1947 of $14.3-14.6^{\circ} \mathrm{C}\left(57.8-58.1^{\circ} \mathrm{F}\right)$, but temperatures come back down to temperatures measured before 1937 .

- $\quad$ Based on this trend, what would you predict the temperature to be in 2005 ?

Although there may be more variance than there was in the previous data, I would imagine the data would maintain a flattish trend and remain steady between the previous described temperatures.

- In 1966, would you have been more worried about global warming or a return to another Ice Age?

Nope. 
3. Now make a scatter plot for the period 1966-2005. Then answer the questions.

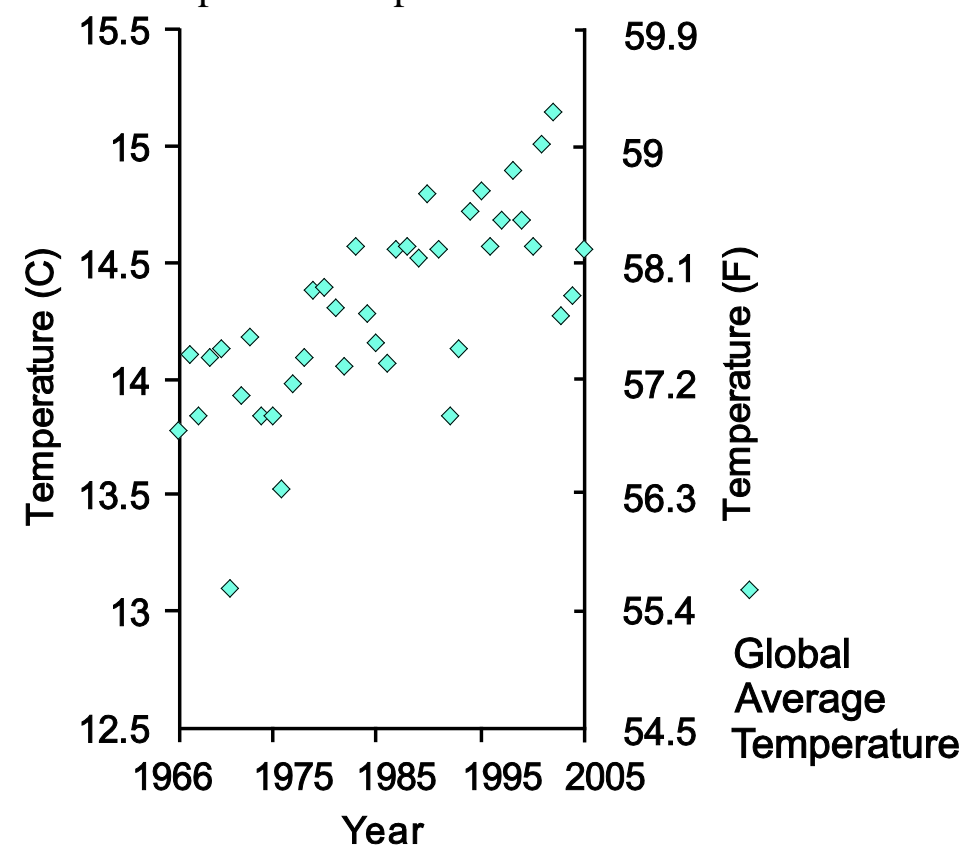

- Based on the trend, what would you predict the temperature to be in 2006?

There is a substantial increase in temperature each year. I would imagine that the 2006 temperature would be higher than the 3 years prior, but not the highest seen yet.

- In 2005, would you have been more worried about global warming or a return to another Ice Age?

Global warming!

- What are the five warmest years in the record?

2002, 2001, 1997, 1994, and 1993

- The five coldest?

1968, 1971, 1974, 1975, and 1976

- Have we come anywhere close to having one of the coldest years in the record during your lifetime?

No, but I am 31-likely not for your students either!

- How long a record is needed to see clear evidence of global warming?

It seems to depend on the period of record observed, but the trend seen here is evident between 1966 and 1975, so maybe not very long. 


\section{Inter-annual Variability Key}

Generate a scatter plot of annual temperature and time for 1880-2005. Identify the volcanic eruptions from the table provided (see question below) on your plot.

Using your plot, develop an Average Global Temperatures Table. For all of the above eruptions, note the average annual global temperature for the year in which the eruption occurred, the year before the eruption, the year after the eruption, 2 years after the eruption, and 3 years after the eruption. Note: Be sure to identify if the Ave. Global Temp. is recorded in ${ }^{\circ} \mathrm{F}$ or ${ }^{\circ} \mathrm{C}$. Answer the following questions based on your plot and table.

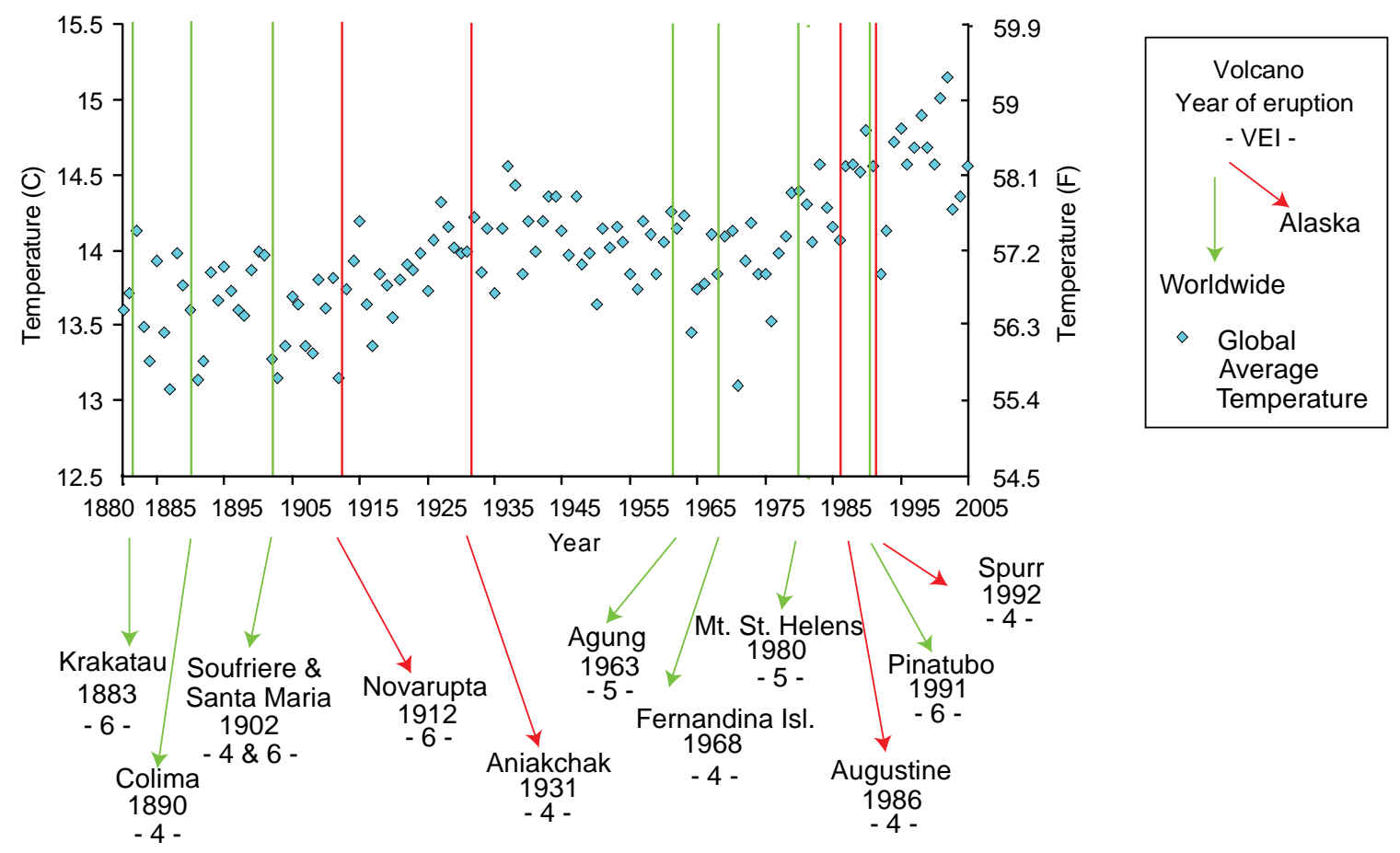




\section{Average Global Temperatures Key (temperatures are ${ }^{\circ} \mathrm{F}$ )}

\begin{tabular}{|c|c|c|c|c|c|c|c|c|c|c|}
\hline Volcano & $\begin{array}{c}\text { Erupt. } \\
\text { Year }\end{array}$ & $\begin{array}{c}\text { Ave. } \\
\text { Global } \\
\text { Temp. }\end{array}$ & $\begin{array}{l}\text { Erupt. } \\
\text { Year -1 } \\
\end{array}$ & $\begin{array}{l}\text { Ave. } \\
\text { Global } \\
\text { Temp. }\end{array}$ & $\begin{array}{c}\text { Erupt. Y } \\
+1 \\
\end{array}$ & $\begin{array}{c}\text { Ave. } \\
\text { Global } \\
\text { Temp. }\end{array}$ & $\begin{array}{c}\text { Erupt. } \\
\text { Yr +2 } \\
\end{array}$ & $\begin{array}{c}\text { Ave. } \\
\text { Global } \\
\text { Temp. }\end{array}$ & $\begin{array}{l}\text { Erupt. } \\
\text { Yr +3 } \\
\end{array}$ & $\begin{array}{c}\text { Ave. } \\
\text { Global } \\
\text { Temp. }\end{array}$ \\
\hline Krakatau & 1883 & 56.77 & 1882 & 56.79 & 1884 & 56.66 & 1885 & 56.66 & 1886 & 56.75 \\
\hline Colima & 1890 & 56.53 & 1889 & 56.93 & 1891 & 56.7 & 1892 & 56.62 & 1893 & 56.62 \\
\hline $\begin{array}{c}\text { Soufriere / } \\
\text { Santa Maria }\end{array}$ & 1902 & 56.71 & 1901 & 56.91 & 1903 & 56.64 & 1904 & 56.59 & 1905 & 56.75 \\
\hline Novarupta & 1912 & 56.59 & 1911 & 56.59 & 1913 & 56.62 & 1914 & 56.93 & 1915 & 57.04 \\
\hline Aniakchak & 1931 & 57.18 & 1930 & 57.07 & 1932 & 57.09 & 1933 & 56.89 & 1934 & 57.11 \\
\hline Agung & 1963 & 57.34 & 1962 & 57.27 & 1964 & 56.82 & 1965 & 57.00 & 1966 & 57.15 \\
\hline $\begin{array}{l}\text { Fernandina } \\
\text { Island } \\
\end{array}$ & 1968 & 57.13 & 1967 & 57.2 & 1969 & 57.34 & 1970 & 57.25 & 1971 & 57.02 \\
\hline Mt. St. Helens & 1980 & 57.52 & 1979 & 57.36 & 1981 & 57.69 & 1982 & 57.29 & 1983 & 57.67 \\
\hline Augustine & 1986 & 57.43 & 1985 & 57.31 & 1987 & 57.69 & 1988 & 57.76 & 1989 & 57.54 \\
\hline Pinatubo & 1991 & 57.83 & 1990 & 57.88 & 1992 & 57.43 & 1993 & 57.45 & 1994 & 57.63 \\
\hline Spurr & 1992 & 57.43 & 1991 & 57.83 & 1993 & 57.45 & 1994 & 57.63 & 1995 & 57.88 \\
\hline
\end{tabular}


- What is the typical magnitude and direction (warming or cooling) of the effect of volcanoes on global climate?

In many cases there is a tenth or hundredth of one degree increase in temperature within 1 year following the eruption, if anything at all. Relative to Activity 2, this seems much less clear-do volcanic eruptions increase or decrease average global temperature? There are many variables, and each eruption is different. Although some of the eruptions noted were followed by an increase in temperature, others were not. Other variables also can alter the global average temperature for any given year; however, these variables are not accounted for in this exercise. This plot indicates that regardless of the volcanic eruptions, the average mean temperature over time is increasing-illustrating no correlation between volcanic eruptions and longer-term (century long) changes in globally averaged annual mean temperatures.

- How long does it take climate to return to normal after a major eruption?

Just a few years. 


\section{Activity IV. An Order of Magnitude}

Grade Level 6-11

Setting Classroom, computer lab

Time 50 minutes

Vocabulary (see Glossary)

anthropogenic, atmosphere, $\mathrm{CO}_{2}$, fossil fuels, greenhouse gas, order of magnitude, volcanogenic

Correlations to Alaska State Department of Education (2006) Performance Standards (Grade Level Expectations)

A1-Science as Inquiry and Process

SA2[6-11] Students develop an understanding that the processes of science require integrity, logical reasoning, skepticism, openness, communication, and peer review.

SA2.1[6] The student demonstrates an understanding of the attitudes and approaches to scientific inquiry by identifying and differentiating fact from opinion.

SA2.1[7] The student demonstrates an understanding of the attitudes and approaches to scientific inquiry by identifying and evaluating the sources used to support scientific statements.

SA2.1[8] The student demonstrates an understanding of the attitudes and approaches to scientific inquiry by recognizing and analyzing differing scientific explanations and models.

SA2.1[9] The student demonstrates an understanding of the attitudes and approaches to scientific inquiry by formulating conclusions that are logical and supported by evidence.

SA2.1[10] The student demonstrates an understanding of the attitudes and approaches to scientific inquiry by examining methodology and conclusions to identify bias and determining if evidence logically supports the conclusion.

SA2.1[11] The student will demonstrate and understanding of the attitudes and approaches to scientific inquiry by evaluating the credibility of cited sources when conducting the student's own scientific investigation.

\section{D1-Concepts of Earth Science}

SD[6-11] Students develop an understanding of the concepts, processes, theories, models, evidence, and systems of earth and space sciences.

SD1[6-11] Students develop an understanding of Earth's geochemical cycles. 


\section{E1-Science and Technology}

SE[6-11] Students develop an understanding of the relationships among science, technology, and society.

SE2[6-11] Students develop an understanding that solving problems involves different ways of thinking, perspectives, and curiosity that lead to the exploration of multiple paths that are analyzed using scientific, technological, and social merits.

\section{G1-History and Nature of Science}

SG[6-11] Students develop an understanding of the history and nature of science.

SG1[6-11] Students develop an understanding that historical perspectives of scientific explanations demonstrate that scientific knowledge changes over time, building on prior knowledge.

SG2[6-11] Students develop an understanding that the advancement of scientific knowledge embraces innovation and requires empirical evidence, repeatable investigations, logical arguments, and critical review in striving for the best possible explanations of the natural world.

SG3[6-11] Students develop an understanding that scientific knowledge is ongoing and subject to change as new evidence becomes available through experimental and/or observational confirmation(s).

\section{Overview}

Students will learn about the relative amounts of $\mathrm{CO}_{2}$ contributed on an annual basis to the atmosphere through the burning of fossil fuels and by the emissions of volcanoes into the atmosphere by graphing values of each and interpreting their results. Students will learn that the amount of $\mathrm{CO}_{2}$ contributed by the burning of fossil is orders of magnitude greater than the amount contributed by volcanoes.

\section{Background}

Rising concentrations of greenhouse gases, including $\mathrm{CO}_{2}$, produce an increase in the average surface temperature of the earth over time. Rising temperatures can produce changes in precipitation patterns, storm severity, and sea level collectively referred to as climate change. The Intergovernmental Panel on Climate Change (IPCC) suggests that the Earth's climate has warmed between 0.6 and $0.9^{\circ} \mathrm{C}\left(33.1\right.$ and $\left.33.6^{\circ} \mathrm{F}\right)$. Energy-related $\mathrm{CO}_{2}$ emissions, resulting from the burning of fossil fuels represented 82 percent of total U.S. anthropogenic greenhouse gas emissions in 2006.

Volcanoes release hundreds of millions of tons of $\mathrm{CO}_{2}$ into the atmosphere every year. Through the burning of fossil fuels, humans emit tens to hundreds of thousands of millions of $\mathrm{CO}_{2}$ into the atmosphere every year. For comparison, 110 tons (0.04 million tons) of $\mathrm{CO}_{2}$ gas would fill approximately 1 million bottles of champagne, so millions of tons would fill billions of champagne bottles. 
Volcanic $\mathrm{CO}_{2}$ is difficult to measure and scientists do not have a steadfast, single value for the global volcanic contribution of $\mathrm{CO}_{2}$ into Earth's atmosphere. Volcanic $\mathrm{CO}_{2}$ is measured several different ways, and it is difficult to completely combine, compare, or assess values obtained from the various different measurement types and sources. Below are some resources explaining many of the ways volcanic $\mathrm{CO}_{2}$ is measured.

\section{U.S. Geological Survey}

- U.S. Geological Survey, 2009, Volcano Hazards Program-Direct gas sampling and laboratory analysis: U.S. Geological Survey website. (Available at http://volcanoes.usgs.gov/activity/methods/gas/sample.php.)

- U.S. Geological Survey, 2009, Volcano Hazards Program-Measuring volcanic gases-Continuous on-site gas monitoring: U.S. Geological Survey website. (Available at http://volcanoes.usgs.gov/activity/methods/gas/continuous.php.)

- U.S. Geological Survey, 2009, Volcano Hazards Program-Measuring volcanic gases-Emission rates of sulfur dioxide and carbon dioxide in volcanic plume: U.S. Geological Survey website. (Available at http://volcanoes.usgs.gov/activity/methods/gas/plumes.php.)

- U.S. Geological Survey, 2009, Volcano Hazards Program-Measuring volcanic gases-Soil efflux: U.S. Geological Survey website. (Available at http://volcanoes.usgs.gov/activity/methods/gas/soil.php.)

Oregon State University, [n.d.], VolcanoWorld-Measuring volcanic gases-Remote sensing: Oregon State University website, accessed June 1, 2010, at http://volcano.oregonstate.edu/education/gases/remote.html

- Direct Sampling http://volcano.oregonstate.edu/education/gases/direct.html

- Estimates from Rocks, Minerals, and Inclusions http://volcano.oregonstate.edu/education/gases/estimates.html

- NASA Jet Propulsion Laboratory-Orbiting Carbon Observatory http://oco.jpl.nasa.gov/.

$\mathrm{CO}_{2}$ contributions to the atmosphere at hydrothermal systems at volcanoes are rarely measured or considered in compilations and the estimates are riddled with uncertainties. The published values of contributions of $\mathrm{CO}_{2}$ emissions by volcanoes globally are based on very few measurements, typically only at active volcanoes, and very few measurements have been made at volcanoes near the poles (Arctic and Antarctic). Many of the figures are calculated through inference by measuring other more easily and (or) more often measured volcanic gases and these inferences may not necessarily be correct. Until many more measurements are made, this is about as good as it gets, or in other words - it is an order of magnitude. That is to say that in all cases where a reasonable comparison is made between volcanogenic $\mathrm{CO}_{2}$ and anthropogenic (burning of fossil fuels) $\mathrm{CO}_{2}$, the anthropogenic values are orders of magnitude higher than volcanogenic values. 


\section{Objectives}

Through independent reading and class discussion students will learn about greenhouse gases, $\mathrm{CO}_{2}$, and climate change. Students will understand the varying amounts of volcanic and anthropogenic $\mathrm{CO}_{2}$ contributed into the Earth's atmosphere over time and the significantly greater amount steadily contributed to the atmosphere by the burning of fossil fuels.

\section{Procedure}

\section{A. Climate Change and Greenhouse Gas- $-\mathrm{CO}_{2}$}

1. Assign students the task of researching climate change and greenhouse gases, $\mathrm{CO}_{2}$ in particular, for a homework or classroom, library or on-line internet search exercise. In addition to the resources listed at the beginning of this chapter, additional suggested on-line sources include:

- U.S. Geological Survey

- Ager, Tom, 2010, Ecosystem and climate history of Alaska: U.S. Geological Survey Earth Surface Process Team web page. (Available at http://esp.cr.usgs.gov/research/alaska/.)

- U.S. Geological Survey, 2010, Climate Change Science-Exchanges of greenhouse gases, water vapor, and heat at the Earth's surface: U.S. Geological Survey web page. (Available at http://geochange.er.usgs.gov/carbon/ghg/.)

- USGS Microbiology Climate Change, Permafrost Monitoring http://microbiology.usgs.gov/climate_permafrost.html

- Ager, Thomas, 1997, How does climate change influence Alaska's vegetation? Insight from the fossil record: U.S. Geological Survey Fact Sheet 071-97. (Available at http://pubs.usgs.gov/fs/fs-0071-97/.)

- U.S. Geological Survey, DATE, CoreCast climate change-Interview with Tom Armstrong, Senior Advisor to the Director on Climate Change: U.S. Geological Survey webcast. (Available at http://gallery.usgs.gov/audios/2.)

- United States Global Change Research Program: Alaska http://www.globalchange.gov/publications/reports/scientific-assessments/usimpacts/regional-climate-change-impacts/alaska

- Environmental Protection Agency, Climate Change-Greenhouse Gas Emissions: Carbon Dioxide webpage http://www.epa.gov/climatechange/emissions/co2.html

- The Nature Conservancy—Carbon Footprint Calculator: What's My Carbon Footprint? http://www.nature.org/initiatives/climatechange/calculator/ 


\section{B. Volcanogenic vs. Anthropogenic $\mathrm{CO}_{2}$}

1. Using the table provided, have students graph by hand or use a computer graphic program to make two graphs, one using the volcanogenic $\mathrm{CO}_{2}$ and a second using the anthropogenic $\mathrm{CO}_{2}$ values. Bar graphs will suffice.

Table 1. Emissions from specific volcanic regions, volcanoes, burning of fossil fuels, and anthropogenic sources

\begin{tabular}{|c|c|}
\hline $\begin{array}{c}\text { Estimates of annual volcanic } \mathrm{CO}_{2} \\
\text { emissions }\end{array}$ & $\begin{array}{c}\begin{array}{c}\text { Millions of } \\
\text { tons/year } \mathrm{CO}_{2}\end{array} \\
\end{array}$ \\
\hline $\begin{array}{l}\text { Global estimate for submarine and } \\
\text { subaerial volcanoes }^{1}\end{array}$ & 416 \\
\hline I. Global $\mathrm{CO}_{2}$ emissions by volcanoes ${ }^{2}$ & 308 \\
\hline II. Global $\mathrm{CO}_{2}$ emissions by volcanoes ${ }^{3}$ & 200 \\
\hline III. Global $\mathrm{CO}_{2}$ emissions by volcanoes ${ }^{4}$ & 130 \\
\hline $\begin{array}{l}\text { Estimates of annual anthropogenic } \\
\mathrm{CO}_{2} \text { emissions }\end{array}$ & $\begin{array}{c}\text { Millions of } \\
\text { tons/year } \mathrm{CO}_{2}\end{array}$ \\
\hline Anthropogenic $\mathrm{CO}_{2}$ in $2003^{5}$ & 26,800 \\
\hline $\begin{array}{l}\text { Global } \mathrm{CO}_{2} \text { emissions from the burning } \\
\text { of fossil fuels } 2006^{6}\end{array}$ & 83,800 \\
\hline
\end{tabular}

\section{Sources}

${ }^{1}$ Arthur, M.A. 2000, Volcanic contributions to the carbon and sulfur geochemical cycles and global change, in Sigurdsson, H. and others, eds., Encyclopedia of Volcanoes: Academic Press, p. 1047.

${ }^{2}$ Brantley, S.L., and Koepenick, K.W., 1995, Measured carbon dioxide emissions from Oldoinyo Lengai, and the skewed distribution of passive volcanic fluxes: Geology, v. 23, no. 10, p. 933-936.

${ }^{3}$ Gerlach, T.M., 1991, Present-day $\mathrm{CO}_{2}$ emissions from volcanoes: Transactions of the American Geophysical Union (EOS), v. 72, p. 249, and 254-255.

${ }^{4}$ U.S. Geological Survey, 2009, Volcano Hazards Program—Volcanic gases and their effects-Carbon dioxide: U.S. Geological Survey website. (Available at http://volcanoes.usgs.gov/hazards/gas/index.php\#CO2.)

${ }^{5}$ Compiled by Earth Policy Institute from G. Marland, T. A. Boden, and R. J. Andres, 2007, Global, regional, and National $\mathrm{CO}_{2}$ emissions, Trends-A compendium of data on global change: Oak Ridge, Tenn., Carbon Dioxide Information Analysis Center, London, BP, Statistical Review of World Energy website, accessed June 1, 2010, at http://www.earthpolicy.org/Indicators/CO2/2008_data.htm\#fig3.

${ }^{6}$ Moore, F.C., 2008, Carbon emissions_-Carbon dioxide emissions accelerating rapidly: Earth Policy Institute, Eco-Economy Indicators webpage, accessed June 1, 2010, at http://www.earthpolicy.org/Indicators/CO2/2008.htm.

2. Students may mention that they have come across figures that vary from those in the table. Discuss the difficulties mentioned in the Background section in establishing a clear, single set of values to use for a comparison such as this. 
3. Discuss the concept of an order of magnitude with your students using the graphs as examples. For every multiple of 10, an order of magnitude is accounted for. The volcanogenic values are measured in the hundreds of millions of tons, and the anthropogenic and fossil fuel values are in the tens of thousands of millions of tons. The anthropogenic/fossil fuel values are two orders of magnitude greater than the volcanic values.

\section{Extensions}

1. Ask students if they think that volcanic eruptions in Alaska can alter the flow of the Niger River in Africa or if rain can cause volcanic eruptions. Review and use:

- Mastin, L.G., 1993, Can rain cause volcanic eruptions?: U.S. Geological Survey Open-File Report 93-445. (Available at http://vulcan.wr.usgs.gov/Projects/Mastin/Publications/OFR93-445/OFR93445.html.)

- National Aeronautics and Space Administration, 2006, Goddard Space Flight Center-Historic volcanic eruption shrunk the mighty Nile River: National Aeronautics and Space Administration web page, accessed June 1, 2010, at http://www.nasa.gov/centers/goddard/news/topstory/2006/volcano_nile.html.

2. Use the DLESE Teaching Boxes-Ways of wind-Lesson sequence http://www.teachingboxes.org/jsp/teachingboxes/weatherEssentials/wind/index.jsp

\section{References Cited}

Alaska State Department of Education and Early Development, 2006, Standards and grade level expectations, March 2006: State of Alaska website, accessed October 2009 at http://www.eed.state.ak.us/tls/assessment/GLEHome.html.

Arthur, M.A., 2000, Volcanic contributions to the carbon and sulfur geochemical cycles and global change in H.S. Sigurdsson and others, eds., Encyclopedia of Volcanoes: San Diego, Calif., Academic Press, p. 1045-1056.

Brantley, S.L., and Koepenick, K.W., 1995, Measured carbon dioxide emissions from Oldoinyo Lengai and the skewed distribution of passive volcanic fluxes: Geology, v. 23, no. 10, p. 933-936.

Energy Information Administration, 2008, Greenhouse gases, climate change, and energy: U.S. Department of Energy Brochure DOE/EIA-X012, accessed June 7, 2010, at http://www.eia.doe.gov/bookshelf/brochures/greenhouse/Chapter1.htm.

Hilton, D.R., Fischer, T.P., and Bernard, M., 2002, Noble gases and volatile recycling at subduction zones: Reviews in Mineralogy and Geochemistry, v. 47, p. 319-370.

Oppenheimer, C., 2003, Volcanic degassing, in K.K. Turekian, and Holland, H.D., eds., Treatise on Geochemistry, Chap. 6: Elsevier, v. 3.

U.S. Geological Survey, 2007, Hawaiian Volcano Observatory: U.S. Geological Survey Hawaiian Volcano Observatory Volcano Watch,web pages. (Available at

- February 15, 2007-Which produces more $\mathrm{CO}_{2}$, volcanic or human activity? http://hvo.wr.usgs.gov/volcanowatch/2007/07_02_15.html and

- October 22, 1998-Greenhouse gases in our backyard http://hvo.wr.usgs.gov/volcanowatch/1998/98_10_22.html.) 
U.S. Geological Survey, 2009, Volcano Hazards Program—Volcanic gasses and their effects: U.S. Geological Survey web page. (Available at http://volcanoes.usgs.gov/hazards/gas/index.php.)

U.S. Geological Survey, 2009, Volcano Hazards Program-Measuring volcanic gassesemission rates of sulfur dioxide and carbon dioxide in volcanic plumes: U.S. Geological Survey web page. (Available at http://volcanoes.usgs.gov/activity/methods/gas/plumes.php.)

U.S. Geological Survey, 2009, Long Valley Observatory-Carbon dioxide and helium discharge from Mammoth Mountain: U.S. Geological Survey website. (Available at http://lvo.wr.usgs.gov/CO2.html.)

Werner, C., and Brantley, S., 2003, $\mathrm{CO}_{2}$ emissions from the Yellowstone volcanic system: Geochemistry Geophysics Geosystems, v. 4, iss. 7, p, 1061, doi:10.1029/2002GC000473.

\section{Glossary}

Anthropogenic-Derived from human activities

Atmosphere - A layer of gases surrounding the Earth that is retained by gravity and that varies with altitude.

$\mathbf{C O}_{2}$ - Carbon dioxide

Fossil fuels - Fuels derived from hydrocarbon deposits such as coal, petroleum, natural gas, and to some extent, peat.

Greenhouse gas - Specific gases in the atmosphere-water vapor, carbon dioxide, nitrous oxide, and methane, for example, that can trap energy from the sun and warm the surface of the Earth.

Order of magnitude - The difference between two values by a factor of 10

Volcanogenic - Generated by or stemming from a volcano or volcanic processes

\section{Source of Glossary Definitions}

Energy Information Administration, 2008, Greenhouse gases, climate change, and energy: U.S. Department of Energy Brochure DOE/EIA-X012, accessed June 7, 2010, at http://www.eia.doe.gov/bookshelf/brochures/greenhouse/Chapter1.htm. 


\section{Millions of Tons of $\mathrm{CO}_{2}$ Emissions from Volcanic, Anthropogenic, and Burning of Fossil Fuels Sources}

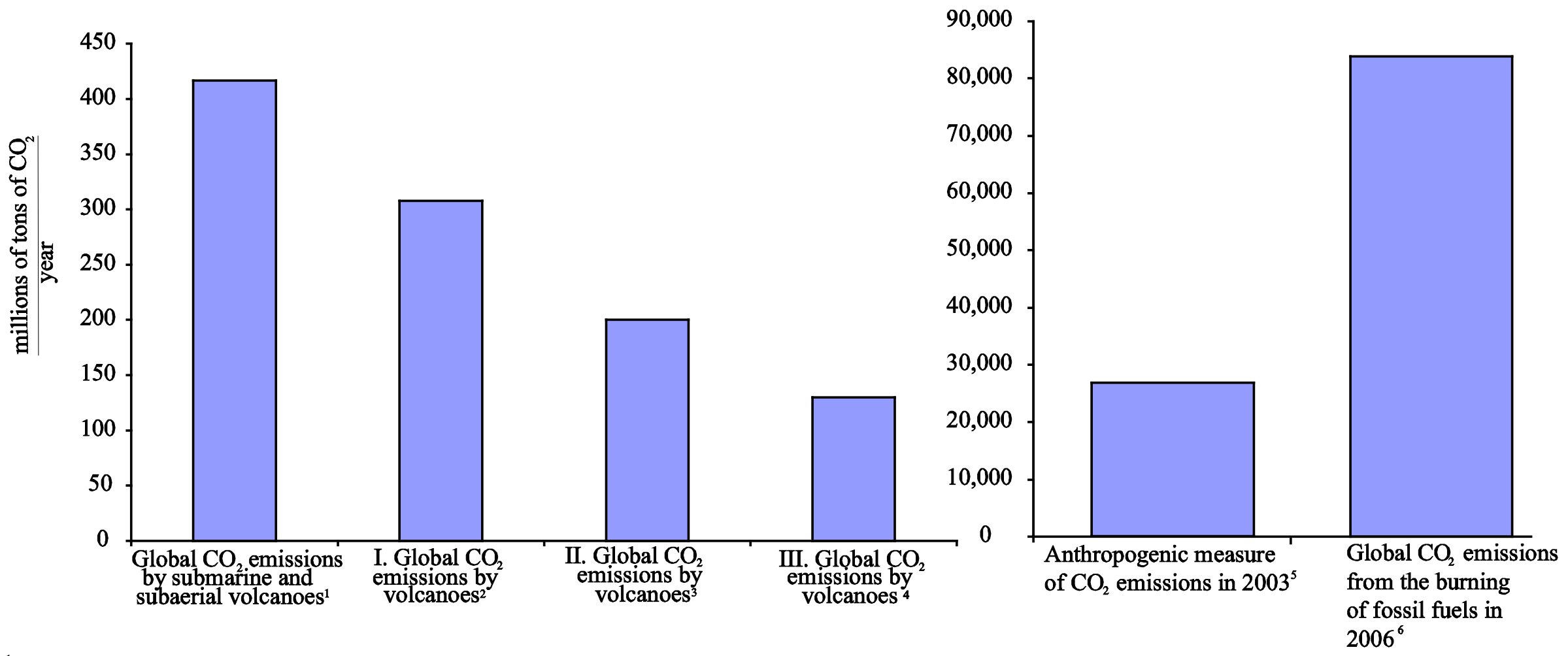

${ }^{1}$ Arthur, M.A. 2000, Volcanic contributions to the carbon and sulfur geochemical cycles and global change in H. Sigurdsson, and others, eds., Encyclopedia of volcanoes: Academic Press, p 1047.

${ }^{2}$ Brantley, S.L., and Koepenick, K.W., 1995, Measured carbon dioxide emissions from Oldoinyo Lengai, and the skewed distribution of passive volcanic fluxes: Geology, v. 23, no. 10, p. 933-936.

${ }^{3}$ Gerlach, T.M., 1991, Present-day $\mathrm{CO}_{2}$ emissions from volcanoes: Transactions of the American Geophysical Union (EOS), v. 72, p. 249 , and $254-255$.

${ }^{4}$ U.S. Geological Survey, 2009, Volcano Hazards Program-Volcanic gases and their effects—Carbon dioxide: U.S. Geological Survey website. (Available at

http://volcanoes.usgs.gov/hazards/gas/index.php\#CO2.)

${ }^{5}$ Compiled by Earth Policy Institute from Marland, G., Boden, T.A., and Andres, R.J., 2007, Global, regional, and national CO ${ }_{2}$ emissions—Trends—A compendium of data on global change: Oak Ridge, Tenn., Carbon Dioxide Information Analysis Center; London, BP, Statistical Review of World Energy,

http://www.earthpolicy.org/Indicators/CO2/2008 data.htm\#fig3.

${ }^{6}$ Moore, F.C., 2008, Carbon emissions-Carbon dioxide emissions accelerating rapidly: Earth Policy Institute, Eco-Economy Indicators webpage http://www.earthpolicy.org/Indicators/CO2/2008.htm. 


\section{Chapter 7 \\ Volcano Monitoring, Research, and Careers}

\section{Resources}

- Alaska Public Radio show about volcanoes in Alaska from November 19, 2005. (Available at http://akradio.org/archive/olderprograms.html.)

- Spice, B., Sci. Ed., 2000, Volcanologist was caught off-guard by eruption: PostGazette, Sunday, August 27, 2000. http://www.post-gazette.com/healthscience/20000827volcano1.asp

- Spice, B., Sci. Ed., 2000, Study of volcanoes a high-risk venture: Post-Gazette, Sunday, August 27, 2000.

http://www.post-gazette.com/healthscience/20000827volcanoside9.asp

- AVO website

- Operations

http://www.avo.alaska.edu/about/operations.php

- Fields of Study

o Geology

http://www.avo.alaska.edu/about/geology.php

o Seismology

http://www.avo.alaska.edu/about/seismology.php

o Remote Sensing http://www.avo.alaska.edu/about/remote.php

o Deformation http://www.avo.alaska.edu/about/deformation.php

- Twentieth Anniversary

o Schaefer, J.R., and Nye, Chris, 2008, The Alaska Volcano Observatory-20 years of volcano research, monitoring, and eruption response: Alaska Division of Geological \& Geophysical Surveys, Alaska GeoSurvey News, NL 2008001, v. 11, n. 1, p. 1-9.

PDF http://www.avo.alaska.edu/pdfs/cit4443.pdf

o University of Alaska Fairbanks Geophysical Institute, 2008, 20th anniversary of the Alaska Volcano Observatory: University of Alaska Geophysical Institute pamphlet, 2 p.

PDF http://www.avo.alaska.edu/pdfs/cit4450.pdf

- University of Alaska, Fairbanks (UAF) Volcanology Group website http://kiska.giseis.alaska.edu/volgrp/

- U.S. Geological Survey

- Adleman, J.N., Cameron, C.E., Snedigar, S.F., Neal, C.A., and Wallace, K.L., 2010, Public outreach and communications of the Alaska Volcano Observatory during the 2005-2006 eruption of Augustine Volcano, chapter 27 of Power, J.A., Coombs, M.L., and Freymueller, J.T., eds., The 2006 eruption of Augustine Volcano, Alaska: U.S. Geological Survey Professional Paper 1769, p. 631-644. (Available at http://pubs.usgs.gov/pp/1769/chapters/p1769_chapter27.pdf. 
- Neal, C.A. Murray, T.L., Power, J.A., Adleman, J.N., Whitmore, P.M., and Osiensky, J.M., 2010, Hazard information management, interagency coordination, and impacts of the 2005-2006 eruption of Augustine Volcano, chapter 28 of Power, J.A., Coombs, M.L., and Freymueller, J.T., eds., The 2006 eruption of Augustine Volcano, Alaska: U.S. Geological Survey Professional Paper 1769, p. 645-667. (Available at http://pubs.usgs.gov/pp/1769/chapters/p1769_chapter28.pdf.

- U.S. Geological Survey, 2007, Hawaiian Volcano Observatory-What does it take to become a volcanologist?: U.S. Geological Survey Volcano Watch website. (Available at http://hvo.wr.usgs.gov/volcanowatch/2007/07_08_09.html.) U.S. Geological Survey, 2009, Cascade Volcano Observatory-Information for future volcanologists: U.S. Geological Survey website. (Available at http://vulcan.wr.usgs.gov/Outreach/StudyVolcanoes/framework.html.)

- U.S. Geological Survey, 2009, Volcano Hazards Program-Frequently Asked Questions (FAQs) about studying and working on volcanoes: U.S. Geological Survey website. (Available at http://volcanoes.usgs.gov/about/faq/faqstudying.php.)

- U.S. Geological Survey, 2010, Yellowstone Volcano Observatory: U.S. Geological Survey websites. (Available at http://volcanoes.usgs.gov/yvo/.)

o Frequently Asked Questions (FAQs) http://volcanoes.usgs.gov/yvo/about/faq/index.php.

o Brantley, S.R., and others, 2004, Tracking changes in Yellowstone's restless volcanic system: U.S. Geological Survey Fact Sheet 100-03, 4 p. http://pubs.usgs.gov/fs/fs100-03/.

o Christiansen, R.L., Lowenstern, J.B>, Smith, R.B., Heasler, Henry, Morgan, L.A., Nathenson, Manuel, Mastin, L.G., Muffler, L.J.P., and Robinson, J.E., 2007, Preliminary assessment of volcanic and hydrothermal hazards in Yellowstone National Park and vicinity: U.S. Geological Survey Open-File Report 2007-1071, 98 p.

o Lowenstern, J.B., Christiansen, R.L., Smith, R.B., Morgan, L.A., and Heasler, Henry, 2005, Steam explosions, earthquakes, and volcanic eruptions-What's in Yellowstone's future?: U.S. Geological Survey Fact Sheet 2005-3024, 6 p. http://pubs.usgs.gov/fs/2005/3024/.

0 Website Introductory Page http://pubs.usgs.gov/of/2007/1071/. Report http://pubs.usgs.gov/of/2007/1071/of2007-1071.pdf (8.26 MB).

o Yellowstone Volcano Observatory, 2006, Volcano and earthquake monitoring plan for the Yellowstone Volcano Observatory, 2006-2015: U.S. Geological Survey Scientific Investigations Report 2006-5276, 17 p. Website Introductory Page http://pubs.usgs.gov/sir/2006/5276/. Report http://pubs.usgs.gov/sir/2006/5276/sir2006-5276.pdf.

- U.S. Geological Survey, 2010, CoreFacts episodes for volcanoes: U.S. Geological Survey podcasts (examples below). (Available at http://www.usgs.gov/podcasts/corefacts/?tag=volcanoes).

0 Is it dangerous to work on volcanoes, and what precautions do scientists take? http://gallery.usgs.gov/audios/173.

o What kind of school training do you need to become a volcanologist? http://gallery.usgs.gov/audios/169. 
- Batish, Sapna, and Reynolds, Jennifer, 2004, Voyage to the Aleutian IslandsUnderstanding Alaska's deep sea frontiers: National Oceanic and Atmospheric Administration web page. (Available at http://www.research.noaa.gov/spotlite/archive/spot_aleutian.html.)

- Bruce, V., 2001, No apparent danger-The true story of volcanic disaster at Galeras and Nevado Del Ruiz: Harper Collins, 272 p.

- EarthSky, 2008, Michael Ramsey on watching volcanoes from space: EarthSky extended podcast, October 27, 2008. (Available at http://www.earthsky.org/interviewpost/earth/michael-ramsey-on-watching-volcanosfrom-space .)

- Feidt, Annie, 2006, Alaska volcano's activity propels researchers: National Public Radio (NPR) October 15, 2006, web page, accessed June 1, 2010, at http://www.npr.org/templates/story/story.php?storyId=6270835.

- Firestone, M., 2005, Volcanologist-Weird careers in science: Chelsea House Publications, $77 \mathrm{p}$.

- Hayhurst, C., 2002, Volcanologists-Life exploring volcanoes, extreme careers: Rosen Publishing Group, 64 p.

- Oregon State University, [n.d.], VolcanoWorld: Oregon State University websites, accessed June 1, 2010, at

- Do you want to become a volcanologist? http://volcano.oregonstate.edu/volcanologist/how_to.html.

- Interviews: Sonia Calvari, Volcanologist http://volcanoworld.wordpress.com/2008/06/19/interviews-sonia-calvari/.

- Natural Resources Canada-How to become a Volcanologist webpage http://gsc.nrcan.gc.ca/volcanoes/volcanologist_e.php.

- National Science Teachers Association (NSTA), The High School Classroom-An Interview with Volcanologist Jeff Byrnes, September 2003, webpage http://www3.nsta.org/main/news/stories/science_teacher.php?news_story_ID=48554.

- McLaughlin, L., 2005, Volcanologist uses local mountain range as geological laboratory: University of California Fullerton News and Information article http://campusapps.fullerton.edu/news/2005/browne.htm.

- Nettleton, L., 2007, Augustine eruption leads to updated model: Fairbanks, University of Alaska Newsroom, Arctic Region Supercomputing Center. http://www.uaf.edu/news/featured/07/augustine/.

- Schmitt, Harrison H., [n.d.], Former NASA astronaut, biographical data: National Aeronautic and Space Administration website. (Available at http://www.jsc.nasa.gov/Bios/htmlbios/schmitt-hh.html.)

- Thompson, D., 2002. Volcano cowboys-The rocky evolution of a dangerous science: St. Martin's Griffin; 336 p.

- Tyson, P., 2005, Volcano under the city boom or bust: Public Broadcasting Service, NOVA Inquiry: Public Broadcasting Service website. (Available at http://www.pbs.org/wgbh/nova/volcanocity/boom.html.)

- Williams, S., and Montaigne, F., 2001, Surviving Galeras: Houghton Mifflin, 320 p. 


\section{Activities}

These activities focus on career opportunities in the Earth sciences and include an overall assessment of the student's knowledge of the field of volcanology in Alaska. Through literature review students will learn about career opportunities in volcanology in Alaska, Hawaii, the lower-48 states, and abroad. Students also will be given an opportunity to discuss the reality of docudrama and Hollywood's portrayals of volcanologists and volcanic eruptions. By conducting a culminating role playing activity and possible eruption scenario students will also understand what observatory staff do and be able to exhibit their knowledge of the study of Alaskan volcanism. This chapter ends with a series of pointers and suggestions on specific guidebook activities and resources available during heightened volcanic activity and eruptions in Alaska.

Activity I. So, you say you are a volcanologist...

Activity II. Hooray for Hollywood: Dante's Peak and Supervolcano

Activity III. A Day in the Life of a Volcano Observatory

Activity IV. Consider before, during, or after a volcanic eruption 
Activity I. So, You Say You Are a Volcanologist...

Grade Level 7-11

Setting Classroom

Time 50 minutes

Correlations to Alaska State Department of Education (2006) Science Performance Standards (Grade Level Expectations)

A1-Science as Inquiry and Process

SA2[6-11] Students develop an understanding that the processes of science require integrity, logical reasoning, skepticism, openness, communication, and peer review.

SA3[6-11] Students develop an understanding that culture, local knowledge, history, and interaction with the environment contribute to the development of scientific knowledge, and local applications provide opportunity for understanding scientific concepts and global issues.

\section{E1-Science and Technology}

SE[6-11] Students develop an understanding of the relationships among science, technology, and society.

SE2[6-11] Students develop an understanding that solving problems involves different ways of thinking, perspectives, and curiosity that lead to the exploration of multiple paths that are analyzed using scientific, technological, and social merits.

SE3[6-11] Students develop an understanding of how scientific discoveries and technological innovations affect and are affected by our lives and cultures.

\section{F1-Cultural, Social, Personal Perspectives, and Science}

SF[6-11] Students develop an understanding of the dynamic relationships among scientific, cultural, social, and personal perspectives.

SF1[6-11] Students develop an understanding of the interrelationships among individuals, cultures, societies, science, and technology.

SF2[6-11] Students develop an understanding that some individuals, cultures, and societies use other beliefs and methods in addition to scientific methods to describe and understand the world.

SF3 [6-11] Students develop an understanding of the importance of recording and validating cultural knowledge.

\section{Overview}

Through literature research and review students will learn about career opportunities in volcanology in Alaska, Hawaii, the lower-48 states, and abroad. 


\section{Background}

Volcanology is an uncommon profession, but it is a very important, exciting, and interesting career. Volcanology, the study of volcanoes, is accomplished by a wide subset of Earth scientists, few of whom hold the actual title "Volcanologist." More commonly, the people who study volcanoes in an observatory are geologists and geophysicists and they rely heavily on technology experts (satellites, mapping, field instrumentation, radio telemetry, data storage and transfer, software developers, etc.). Professionals in Alaska face many challenges not faced by those who study volcanoes elsewhere within the United States, or even worldwide. Working in Alaska means dealing with poor weather, cloud cover, challenging access to remote locations, low sun angle, and high snow levels in winter, and working on Federal, state and private land with varying degrees of restriction.

Professional volcanologists, geophysicists and geologists are prolific throughout the sciences, and may be found hard at work at academic and government entities including colleges and universities, research laboratories, in the classroom, and among Federal state and local land management and educational organizations. There are volcanologists who study volcanism on other planets and who study the volcanism on the Earth's sea floor. A thorough discussion of career opportunities available to students interested in pursuing degrees and experiences in the geosciences and volcanology in particular is incomplete as only an observatory setting is discussed.

\section{Objective}

By learning about volcanologists, including those in Alaska, students will gain a perspective on the wide variety of careers and job duties preformed by this select and dedicated group of individuals.

\section{Materials}

- access to volcanologist narratives, media, texts, articles, podcasts, and radio programs through library, on-line, and classroom resources

\section{Procedure}

\section{A. Literature research and review: Volcanologists}

1. Assign students to complete a paper, poster, podcast, or digital presentation about the jobs of volcanologists. Make sure students do not focus solely on scientists at volcano observatories.

\section{Extension}

1. Encourage students to write fictional stories about volcanic research they would conduct if they were a volcanologist.

2. Give students time to work in groups to illustrate, present, or write about how they would work as a team to solve a specific mystery at an Alaskan volcano.

\section{Reference Cited}

Alaska State Department of Education and Early Development, 2006, Standards and grade level expectations, March 2006: State of Alaska website, accessed October 2009 at http://www.eed.state.ak.us/tls/assessment/GLEHome.html. 
Activity II. Hooray for Hollywood: Dante’s Peak and Supervolcano

Grade Level PG-13+

Setting Classroom, auditorium

Time 4-5 hours

Vocabulary (see Glossary)

andesite, basalt, basaltic andesite, block and ash flow, caldera, dacite, Electronic Distance Meters (EDM), frequency content, fumarole, leachate, leveling survey, long-period or volcanic earthquake, phreatomagmatic, pyroclastic flow, rhyolite, strainmeter, tiltmeter, volcano-tectonic-type earthquake, waveform

\section{Correlations to Alaska State Department of Education (2006) Science Performance Standards (Grade Level Expectations)}

A1-Science as Inquiry and Process

SA[6-11] Students develop an understanding of the processes and applications of scientific inquiry.

SA1[6-11] Students develop an understanding of the processes of science used to investigate problems, design, and conduct repeatable scientific investigations, and defend scientific arguments.

SA2[6-11] Students develop an understanding that the processes of science require integrity, logical reasoning, skepticism, openness, communication, and peer review.

SA3[6-11] Students develop an understanding that culture, local knowledge, history, and interaction with the environment contribute to the development of scientific knowledge, and local applications provide opportunity for understanding scientific concepts and global issues.

\section{E1-Science and Technology}

SE[6-11] Students develop an understanding of the relationships among science, technology, and society.

SE1[6-11] Students develop an understanding of how scientific knowledge and technology are used in making decisions about issues, innovations, and responses to problems and everyday events.

SE2[6-11] Students develop an understanding that solving problems involves different ways of thinking, perspectives, and curiosity that lead to the exploration of multiple paths that are analyzed using scientific, technological, and social merits.

SE3[6-11] Students develop an understanding of how scientific discoveries and technological innovations affect and are affected by our lives and cultures. 


\section{F1-Cultural, Social, Personal Perspectives, and Science}

SF[6-11] Students develop an understanding of the dynamic relationships among scientific, cultural, social, and personal perspectives.

SF1[6-11] Students develop an understanding of the interrelationships among individuals, cultures, societies, science, and technology.

SF2[6-11] Students develop an understanding that some individuals, cultures, and societies use other beliefs and methods in addition to scientific methods to describe and understand the world.

SF3[6-11] Students develop an understanding of the importance of recording and validating cultural knowledge.

\section{Overview}

Nothing beats watching someone carry out dramatic job responsibilities quite like in a movie! Through dramatizations, special effects, and actual eruption footage, a wellprepared movie script can demystify the roles of volcanologists and provide insights about common responses of communities in peril.

\section{Background}

The BBC and Discovery docudrama Supervolcano explores the effect of a large calderaforming eruption at Yellowstone volcano in Wyoming. The movie realistically depicts what could happen if an eruption of this magnitude were to occur again. Although the drama is set in the future, it does an acceptable job of addressing some of the issues that scientists grapple with today.

Dante's Peak is a volcano-disaster thriller from Universal Studios. This movie dramatizes some real-world concerns faced by communities located near active volcanoes in the United States. Set in the northern Cascade Range of Washington State, the movie portrays the roles of USGS scientists and public officials during the re-awakening and eruption of a fictional volcano-one that resembles dozens of real volcanoes in Alaska, British Columbia, Washington, Oregon, and northern California. Keep in mind that both the volcano and the town portrayed in this movie are named Dante's Peak.

\section{Objective}

Students should recognize that the "science" in these two movies has roots in reality, but not everything portrayed is thoroughly explained or realistic. Students should learn to appreciate that volcanologists, no matter what their specialty, have an exciting, sometimes stressful, and crucial job to do. Students will be able to assess fact and fiction using the included question (and answer) worksheets to help separate fact from fiction in these two popular, mainstream movies.

\section{Materials}

— BBC and Discovery Docudrama Supervolcano, 120 minutes (in two parts)

- Universal Studios Dante's Peak, PG-13, 109 minutes

- Dante's Peak FAQ's and Supervolcano worksheets 


\section{Procedure}

A.

1. You may choose to use one or both of the movies and associated worksheets.

- Dante's Peak

- Watch movie as a class

- You may hand out the Dante's Peak FAQ's worksheet and have the students fill them out or at least take notes during the movie.

- Students will likely need to research many of the questions using additional resources and you may consider completion of the worksheet as a homework assignment.

- Review the questions and answers with the students when they are completed.

- Supervolcano

- Watch movie as a class

- You may hand out the Supervolcano worksheet and have the students fill them out or at least take notes during the movie.

- Students will likely need to review additional materials from the Yellowstone Volcano Observatory (YVO) website and other resources. You may consider completion of the worksheet as a homework assignment.

- Review the questions and answers with the students when they are completed.

\section{Extensions}

1. Have students develop their own questions and use the included answer sheets to assist in answering them.

2. Have the students generate their own questions associated with additional volcano movies and research the answers. Review those questions and answers as class discussion.

3. Watch additional volcano movies and use available teaching materials associated with them. Movies with teaching materials include:

- Mystery of the Megavolcano http://www.pbs.org/wgbh/nova/teachers/programs/3312_megavolc.html

- Volcano Above the Clouds http://www.pbs.org/wgbh/nova/teachers/programs/3017_kilimanj.html

- Volcano Under the City http://www.pbs.org/wgbh/nova/teachers/programs/3215_volcanoc.html

- Volcano's Deadly Warning http://www.pbs.org/wgbh/nova/teachers/programs/2913_volcano.html

- Volcanoes of the Deep http://www.pbs.org/wgbh/nova/teachers/programs/2609_abyss.html

- Buried in Ash http://www.pbs.org/wgbh/nova/teachers/programs/2117_ash.html

- Deadly Shadow of Vesuvius http://www.pbs.org/wgbh/nova/teachers/programs/2515_vesuvius.html

- Hawaii Born of Fire http://www.pbs.org/wgbh/nova/teachers/programs/2211_hawaii.html

- In the Path of a Killer Volcano http://shop.wgbh.org/product/show/7832 


\section{References Cited}

Alaska State Department of Education and Early Development, 2006, Standards and grade level expectations, March 2006: State of Alaska website, accessed October 2009 at http://www.eed.state.ak.us/tls/assessment/GLEHome.html.

U.S. Geological Survey, 2008a, Living with volcanoes, Dante's Peak FAQ's (frequently asked questions): U.S. Geological Survey webpage. (Available at http://vulcan.wr.usgs.gov/LivingWith/PopCulture/DantesPeak/dantes_peak.html.)

U.S. Geological Survey, 2008b, Yellowstone Volcano Observatory scientists answer questions about Supervolcanoes, Volcanic Hazards, and Yellowstone: U.S. Geological Survey webpage. (Available at http://volcanoes.usgs.gov/yvo/publications/2005/docudrama.php.)

\section{Glossary}

Andesite - A gray to black volcanic rock with between about 52 and 63 weight percent silica $\left(\mathrm{SiO}_{2}\right)$. The low-end silica value rock is also known as basaltic andesite.

Basalt - Basalt is a hard, black volcanic rock with less than about 52 weight percent silica $\left(\mathrm{SiO}_{2}\right)$.

Block and ash flow - A flow consisting of blocks from the collapse of an active volcanic dome, volcanic gases, and volcanic ash.

Caldera - A caldera is a large, usually circular depression at the summit of a volcano formed when magma is withdrawn or erupted from a shallow underground magma reservoir. The removal of large volumes of magma may result in loss of structural support for the overlying rock, thereby leading to collapse of the ground and formation of a large depression. Calderas are different from craters, which are smaller, circular depressions created primarily by explosive excavation of rock during eruptions.

Dacite - A rock that is often light gray to dark gray or black that consists of about 63 to 68 percent silica dioxide $\left(\mathrm{SiO}_{2}\right)$.

Electronic Distance Meters (EDM) - The EDM is an ultra-precise distance-measuring instrument used to measure crustal deformation along faults and near volcanoes.

Frequency content - A concept similar to the musical pitch of sound. Just as vocal range is classified in terms of bass, baritone, and tenor, the frequency content of a seismic signal can be classified as very long period (VLP), long period (LP), and high frequency.

Fumarole - Vents from which volcanic gas escapes into the atmosphere. Fumaroles may occur along tiny cracks or long fissures, in chaotic clusters or fields, and on the surfaces of lava flows and thick deposits of pyroclastic flows. They may persist for decades or centuries if they are above a persistent heat source or disappear within weeks to months if they occur atop a fresh volcanic deposit that quickly cools. 
Leachate - Potentially harmful water-soluble substances (mainly acids and salts), which cling to glass and crystals particles

Leveling survey - A type of surveying used to establish a baseline and re-survey a leveling line typically for benchmarks that were.

Long-period or volcanic earthquake - A type of earthquake occurring in a volcanic system resulting from fluid motion in a confined cavity, conduit, or crack. Long-period earthquakes and volcanic tremor are often grouped together in the general category of "long-period seismicity."

Phreatomagmatic - A volcanic explosion that extrudes steam and magmatic gases; it is caused by the contact of magma with shallow or surface water.

Pyroclastic flow -A ground-hugging avalanche of hot ash, pumice, rock fragments, and volcanic gas that rushes down the side of a volcano as fast as $100 \mathrm{~km} / \mathrm{h}(\sim 60 \mathrm{mi} . / \mathrm{h})$ or more. The temperature within a pyroclastic flow may be greater than $500^{\circ} \mathrm{C}\left(900^{\circ} \mathrm{F}\right)$, sufficient to burn and carbonize wood. Once deposited, the ash, pumice, and rock fragments may deform (flatten) and weld together because of the intense heat and the weight of the overlying material. The emplaced flow is called a deposit.

Rhyolite - A light-colored rock with silica $\left(\mathrm{SiO}_{2}\right)$ content greater than about 68 weight percent. Sodium and potassium oxides can reach about 5 weight percent.

Strainmeter - An instrument placed in the ground that detects small changes in length and volume associated with deformation of the earth by tectonic stresses or by the passage of seismic waves.

Tiltmeter - An instrument placed in the ground designed to measure very small changes from the horizontal level, either on the ground or in structures.

Volcano-tectonic-type earthquake - This type of earthquake occurs in a volcanic system that is smaller in magnitude, but otherwise indistinguishable from common tectonic earthquakes. These earthquakes are associated with shear slip along a preexisting or newly formed fault plane.

Waveform - The different types of patterns appearing on a time series of recorded ground motion, or seismogram. A waveform is usually a small part or subset of a seismogram linked to a particular phenomenon (for example, an earthquake). For instance, if two earthquakes occur close to each other at almost the same time, their waveforms, as recorded on a seismogram, are said to overlap. 


\section{Source of Glossary Definitions}

Bates, R.K., and Jackson, J.A., eds., 1987, Glossary of Geology, third edition: Falls Church, Va., American Geological Institute.

Volcano Hazards Program-USGS Photo Glossary of volcanic terms website http://volcanoes.usgs.gov/images/pglossary/index.php

USGS Earthquake Program Two-color EDM

http://quake.usgs.gov/research/deformation/twocolor/twocolor.html

Dr. Matthew Haney, U.S. Geological Survey, Research Geophysicist, oral commun., 2009

USGS Hawaiian Volcano Observatory-State-of-the-Art Volcano-Monitoring Instruments Installed on Mauna Loa and Kilauea volcanoes http://hvo.wr.usgs.gov/howwork/strain/

USGS Cascades Volcano Observatory: Description: Tiltmeters and Tilt Measurements http://vulcan.wr.usgs.gov/Monitoring/Descriptions/description_tilt.html 
Name

Date

Period

\section{Dante’s Peak FAQ's}

Dante's Peak (1997) is a volcano-disaster thriller from Universal Studios. It dramatizes some real-world concerns faced by communities located near active volcanoes in the United States. Set in the northern Cascade Range of Washington State, the movie portrays the roles of U.S. Geological Survey (USGS) scientists and local officials during the re-awakening and eruption of a fictional volcano- one that resembles dozens of real volcanoes in Alaska, British Columbia, Washington, Oregon, and northern California.

\section{General Questions}

1. Can scientists really forecast volcanic eruptions? If so, how?

2. Are specific predictions of an eruption's time, place, and character possible?

3. Is there really a U.S. Geological Survey (USGS) and does it provide eruption warnings?

4. If so, how do the USGS and its partners provide eruption warnings?

5. How many active volcanoes are there in the United States and its territories? In Alaska?

6. How many active volcanoes are there on Earth?

7. What are the names of historically active volcanoes in the Alaska?

8. Which Alaskan volcano will erupt next and why do you think so? 


\section{Volcanic Eruptions}

1. Is the eruption depicted in Dante's Peak realistic? Why or why not?

2. Can eruptions really threaten helicopters, as in the movie, and other aircraft? If so, how?

3. Can the temperature of hot springs near a restless volcano change quickly enough to injure bathers? Why or why not?

4. Do earthquakes large enough to collapse buildings and roads accompany most volcanic eruptions? Why or why not?

5. Can a town's water supply become contaminated when a volcano is restless? If so, how?

6. Do scientists drive across moving lava flows? If so, where and when?

7. Can carbon dioxide $\left(\mathrm{CO}_{2}\right)$ gas from volcanoes kill trees and wildlife? If so, how?

8. Can volcanoes suddenly become restless and erupt within 1 day of the first signs of activity? Why or why not?

9. Are robots used to monitor volcanoes? If so, how?

10. Can volcanoes produce large explosive eruptions and rivers of fluid lava at the same time? If so, how?

11. Can lakes near volcanoes become acidic enough to be dangerous to people? If so, how? 


\section{Eruption precursors}

1. What kinds of unusual activity might be noticed before an eruption?

2. What is volcanic tremor, and how does it differ from earthquakes?

3. Do volcanoes produce different kinds of earthquakes, and if so, what are they and how do they differ?

4. What kind of gases escape from volcanoes?

5. Are there any volcanoes exhibiting heightened volcanic activity in the U.S. and its territories today? 


\section{Volcano Monitoring}

1. Does the USGS have a team of volcanologists that can respond to volcanic unrest on short notice? If so, can you describe the team?

2. Does the USGS have a team for rapid response to volcano emergencies in other countries? If so, can you describe the team?

3. How does the USGS monitor volcanoes in the United States and its territories?

4. How are earthquakes monitored?

5. How are ground movements measured?

6. How are volcanic gases measured?

7. Can mudflows be monitored? If so, how?

8. What else do scientists measure at volcanoes? 


\section{Volcanic Hazards}

1. What kinds of hazards were depicted in the movie, and what part have they played in real volcanic eruptions? Are they realistic?

2. Can volcanoes be dangerous even when they do not erupt? If so, how?

3. How can residents who live near volcanoes prepare for future eruptions? 


\section{Dante's Peak FAQ's Key}

(based on

http://vulcan.wr.usgs.gov/LivingWith/PopCulture/DantesPeak/dantes_peak.html)

Dante's Peak (1997), a volcano-disaster thriller from Universal Studios, dramatizes some real-world concerns faced by communities located near active volcanoes in the United States. Set in the northern Cascade Range of Washington State, the movie portrays the roles of U.S. Geological Survey (USGS) scientists and local officials during the reawakening and eruption of a fictional volcano — one that resembles dozens of real volcanoes in Alaska, British Columbia, Washington, Oregon, and northern California.

\section{General Questions}

1. Can scientists really forecast volcanic eruptions? If so, how?

Yes, in many cases, but most reliably only for volcanoes that have been studied geologically. By studying and determining the age of deposits of rock and ash formed by past events, volcanologists can re-construct the history of a volcano in considerable detail. This allows them to make general forecasts about future activity, because the past often is, although not always, a good guide to the future. For example, Alaska Volcano Observatory (AVO) scientists who studied Augustine volcano during its eruptions throughout the 1900s recognized that, for thousands of years, it had been the most frequently active volcano in the Cook Inlet region of Alaska. When seismic and other data began to indicate a renewal in activity in the summer and autumn 2005, AVO scientists forecasted that Augustine volcano might be the next Cook Inlet volcano to erupt. The eruption began on January 11, 2006. This eruption lasted several months.

2. Are specific predictions of an eruption's time, place, and character possible?

Yes, in some cases, but specific predictions require more and different kinds of information. Using seismometers and other sensitive monitoring instruments on-site a local volcanoes, AVO scientists are keeping an eye on more than 30 volcanoes in Alaska. Additional monitoring by satellite allows AVO scientists to view activity at all Alaska's potentially active volcanoes as weather and data acquisition allows. At the first sign of trouble, they will intensify their monitoring efforts, as depicted in the movie. Taking the pulse of a restless volcano in this way allows scientists to refine their assessment of hazards and make increasingly specific statements about future activity, including the time, location, and type of activity expected.

For example, in 1991, an accurate prediction of the largest eruption on Earth in almost 80 years saved thousands of lives and millions of dollars worth of property near Mount Pinatubo in the Philippines. 
3. Is there really a U.S. Geological Survey (USGS) and does it provide eruption warnings?

Yes, the USGS was established by Congress in 1879. The USGS provides biologic, geologic, hydrologic, and topographic information to the Nation. The USGS is mandated by Congress to provide timely warnings about geologic hazards, including volcano hazards, to U.S. citizens and public officials. This mission is accomplished mainly through the USGS Volcano Hazards Program, which operates volcano observatories in Washington, Alaska, Hawaii, Yellowstone, and California, and supports research on volcanoes and volcanic processes at other locations in the U.S such as the Northern Marianas Islands.

The Alaska Volcano Observatory (AVO) is a joint program of the United States Geological Survey (USGS), the Geophysical Institute of the University of Alaska Fairbanks (UAFGI), and the State of Alaska Division of Geological and Geophysical Surveys (ADGGS). The Alaskan-USGS based operations are at the USGS Alaska Science Center in Anchorage.

- Alaska Volcano Observatory website http://www.avo.alaska.edu/

- USGS Alaska Science Center website http://alaska.usgs.gov/

- USGS Alaska Science Center, 2007, Alaska Science Center-Providing timely, relevant, and impartial study of the landscape, natural resources, and natural hazards for Alaska an our Nation: U.S. Geological Survey Fact Sheet 2007-3019, 4 p.

Website http://pubs.usgs.gov/fs/2007/3019/ PDF http://pubs.usgs.gov/fs/2007/3019/pdf/fs20073019.pdf

4. If so, how do the USGS and its partners provide eruption warnings?

The USGS warning system varies depending on the nature and proximity of volcanic hazards to surrounding communities or aircraft. Before a crisis starts, the USGS prepares volcano hazard-zonation maps, preliminary hazard assessments and other information about the frequency of eruptions and extent of specific hazards for use by the public, public officials, land-use planners, and emergency-management agencies. When a volcano becomes restless, USGS volcano observatories and their partners use various instrumental data and direct observations by people, cameras, and satellites to track activity and issue frequent statements about the volcano's activity and hazards. For the aviation sector, the USGS works with the Federal Aviation Administration and National Weather Service (and other state and local officials) to provide airline pilots with timely information about hazardous volcanic ash clouds.

When communities are at risk, scientists give hazards information directly to public officials to help them make decisions about land-use or evacuations. Unlike the movie, warnings are delivered only after a thorough analysis of all existing information and careful consultation among members of the USGS response team and other experts that may be needed. The goal is always to keep natural processes from becoming natural disasters. 
5. How many active volcanoes are there in the United States and its territories? In Alaska?

According to the USGS Cascades Volcano Observatory FAQ's on-line, about 170 volcanoes in the U.S. have been active in the past 10,000 years. Scientists consider these the most likely to erupt again in the future. Most of these are located in Alaska, where eruptions occur virtually every year. Many others are located in the Cascade Range (Washington, Oregon, northern California), or in Hawaii on the islands of Hawaii and Maui.

Alaska contains more than 140 volcanoes and volcanic fields, which have been active within the last 2 million years. Of these volcanoes, about 90 have been active within the last 10,000 years, and more than 50 have been active within historical time (since about 1760 , for Alaska).

- AVO webpage concerning historically active volcanoes in Alaska. http://www.avo.alaska.edu/volcanoes/about.php

6. How many active volcanoes are there on Earth?

According to the Smithsonian Institute Global Volcanism Program, there are about 1,500 potentially active volcanoes worldwide. About 87 percent of these erupted in the Holocene (past 10,000 years) and about 550 of these have had documented eruptions. Many of these volcanoes are located along the Pacific Rim in what is known as the "Ring of Fire." In the U.S., volcanoes in the Cascade Range and Alaska (including Cook Inlet and the Aleutian volcanic chain) are part of the Ring; however, Hawaiian volcanoes form over a "hot spot" near the center of the Ring. These values do not include the more or less continuous belt of volcanoes atop oceanic spreading centers deep below the surfaces of the Atlantic and Pacific oceans.

- Smithsonian Institution Global Volcanism Program webpage http://www.volcano.si.edu/faq/index.cfm?faq $=03$

7. What are the names of historically active volcanoes in the Alaska?

- AVO website (Bold, black font on this webpage indicates a volcano is historically active). http://www.avo.alaska.edu/volcanoes/index.php

- Wallace, K.L., McGimsey, R.G., and Miller, T.P., 2000, Historically active volcanoes in Alaska-A quick reference: U.S. Geological Survey Fact Sheet 118-00, 2 p.

Website http://pubs.usgs.gov/fs/2000/fs118-00/ PDF http://www.avo.alaska.edu/pdfs/usgsfs118-00.pdf

- Schaefer, J. and Nye, C.J., 2002, Historically active volcanoes of the Aleutian Arc: Alaska Division of Geological \& Geophysical Surveys Miscellaneous Publication MP 0123.

Page Size http://www.avo.alaska.edu/pdfs/mp123_pagesize.pdf Poster Size http://www.avo.alaska.edu/pdfs/mp123.pdf 
- Nye, C.J., and others, 1998, Volcanoes of Alaska: Alaska Division of Geological \& Geophysical Surveys Information Circular 38.

- PDF Front http://www.dggs.dnr.state.ak.us/webpubs/dggs/ic/oversized/ic038ed1998_sh0 01.PDF and

- PDF Back http://www.dggs.dnr.state.ak.us/webpubs/dggs/ic/oversized/ic038ed1998_sh0 $\underline{\text { 02.PDF }}$

8. Which Alaskan volcano will erupt next and why do you think so?

No one knows for sure, but the volcanoes that have been most active since 1700 could be the next to erupt.

- AVO About Alaska's Volcanoes webpage http://www2.avo.alaska.edu/volcanoes/about.php

\section{Volcanic Eruptions}

1. Is the eruption depicted in Dante's Peak realistic? Why or why not?

In many, but not all respects, the movie's depiction of eruptive hazards hits close to the mark. The move accurately conveys the enormous power unleashed during an explosive eruption. Stratovolcanoes in the Cascade Range and Alaska-like the one in the movie-often erupt explosively and produce pyroclastic flows, clouds of volcanic ash, and debris flows (also known as mud flows and lahars) that behave much as shown in the movie. Lava flows at these volcanoes, though, are usually thick and slow moving, unlike the fluid, rapidly flowing lava flows in the movie. Fastmoving flows of basalt lava are common in Hawaii, though. Real eruptions may be considerably larger or smaller, and affect larger or smaller areas, than those shown in the film.

2. Can eruptions really threaten helicopters, as in the movie, and other aircraft? If so, how?

Yes. Encounters between aircraft and clouds of volcanic ash are a serious concern. Jet engines and other aircraft components are vulnerable to damage by fine, abrasive volcanic ash, which can drift in dangerous concentrations hundreds of miles downwind from an erupting volcano.

From 1973 to 2008 (inclusive) 121 jet aircraft encountered volcanic ash plumes and in 10 of those cases, 1 or more engines temporarily lost power. In the past 20 years (1989-2008, inclusive), 78 aircraft have accidently encountered volcanic ash clouds and in 6 of those cases the aircraft experienced temporary engine power loss (M. Guffanti, oral commun., 2009). An international consortium of government agencies, including the USGS, Federal Aviation Administration, and National Weather Service, is working cooperatively with the International Civil Aviation Organization (ICAO), the Air Line Pilots Association (ALPA), and other aviation government and industry organizations to make sure that aircraft receive ample warning of potentially dangerous ash clouds and other eruptive phenomena. 
3. Can the temperature of hot springs near a restless volcano change quickly enough to injure bathers? Why or why not?

Temperature changes can and do occur, but usually more slowly than shown in the movie. In fact, the temperature of hot springs may increase, decrease, or stay the same during volcanic unrest. Increases in water temperature, when they do occur, usually take days or weeks to develop, rather than a few seconds as shown in the movie. That being said, earthquakes can suddenly disrupt a volcano's hot groundwater system, changing its temperature and flow characteristics. In rare cases, changes in the flow of water from hot springs has caused the onset of geyser-like activity that could threaten bathers and such changes may occur without felt earthquakes (B. Evans, written commun., 2009).

- $\quad$ Farrar, C.D., Evans, W.C., Venezky, D.Y, Hurwitz, Shaul, and Oliver, L.K., 2007, Boiling water at Hot Creek-The dangerous and dynamic thermal springs in California’s Long Valley Caldera: U.S. Geological Survey Fact Sheet 20073045, 4 p.

PDF http://pubs.usgs.gov/fs/2007/3045/fs2007-3045.pdf

4. Do earthquakes large enough to collapse buildings and roads accompany most volcanic eruptions? Why or why not?

Not usually. Earthquakes associated with most eruptions rarely exceed magnitude 5 and these moderate earthquakes are probably not big enough to destroy the kinds of buildings, houses, and roads that were demolished in the movie. The largest earthquakes at Mount St. Helens in 1980 were magnitude 5, large enough to sway trees and damage buildings, but not destroy them. During the huge eruption of Mount Pinatubo in the Philippines in 1991, several hundred thousand people felt dozens of light to moderate earthquakes (magnitude 3 to 5). Many houses collapsed, but not primarily because of the shaking. Heavy, wet ash from the eruption and a hurricane accumulated on roofs and crushed them.

Stronger earthquakes sometimes occur near volcanoes as a result of tectonic faulting. For example, four magnitude 6 earthquakes struck Long Valley caldera, California, in 1980, and a magnitude 7.2 earthquake struck Kilauea Volcano, Hawaii, in 1975. Both volcanoes were quiet at the time. The Hawaii earthquake triggered a small eruption at the summit of Kilauea. No eruption has yet occurred at Long Valley, but the area has been restless since the 1980 earthquakes.

Earthquakes associated with caldera forming eruptions, however, may reach higher magnitudes. The 1912 eruption of Novarupta volcano on the Alaska Peninsula and the associated collapse of Mt. Katmai (creating the Katmai caldera) generated 14 earthquakes of magnitude 6-7 during the 60-hour-long eruption (see link below). This eruption is also the largest volcanic eruption in the world in the Twentieth century. The eruption of the remote volcano and associated earthquakes, hundreds of miles from the nearest significant buildings, houses, and roads, did not destroy any infrastructure. Nearby villages with semi-subterranean housing constructed by nomadic populations, however, were buried in volcanic ash fall deposits. 
- Fierstein, Judy, Hildreth, Wes, Hendley, J.W., II, and Stauffer, P.H., 1998, Can another great volcanic eruption happen in Alaska?: U.S. Geological Survey Fact Sheet 0075-98, 2 p.

Website http://pubs.usgs.gov/fs/fs075-98/

PDF http://pubs.usgs.gov/fs/fs075-98/fs075-98.pdf

5. Can a town's water supply become contaminated when a volcano is restless? If so, how?

Yes, but probably not as quickly as shown in the movie. If a town's water supply originates directly from a volcano's groundwater system or from a stream that has been covered with volcanic ash, the water could become contaminated with foulsmelling gases or fine ash and other sediment. Some volcanic gases such as sulfur dioxide dissolve in groundwater, making the water acidic. The most common sulfurous odors, however, are caused by hydrogen sulfide gas, which smells like rotten eggs.

Potentially harmful substances in some volcanic ash are the water-soluble materials called leachates, mostly acids and salts, which cling to the particles of glass and crystals. Rarely, volcanic eruptions produce ash that is high in Flourine. Excess fluorine is recognized as the most hazardous leachate in water supplies. The main concern of fluorine poisoning is for livestock, which graze on ash-contaminated grass and feed (see link below).

- Volcanic Ash-Effects and mitigation strategies-What it can do and how to prevent damage: U.S. Geological Survey Water Supply website http://volcanoes.usgs.gov/ash/water/index.html

6. Do scientists drive across moving lava flows? If so, where and when?

No. Any attempt to drive across an active lava flow, even one that has partly solidified to form a thin crust, is likely to lead to disaster. With a temperature of $2,000^{\circ} \mathrm{F}\left(1,100^{\circ} \mathrm{C}\right)$ or higher, fresh lava will quickly melt rubber tires and ignite gas tanks. If a vehicle is stuck in moving lava, well, you know the rest of the story. Furthermore, road access to Alaska's volcanoes is scarce and AVO does not have an off road vehicle like that portrayed in the movie. Volcanoes in Alaska are on Federal, state, and private land with varying degrees of restriction as well.

7. Can carbon dioxide $\left(\mathrm{CO}_{2}\right)$ gas from volcanoes kill trees and wildlife? If so, how?

Yes. At several volcanoes around the world, carbon dioxide gas released from magma has accumulated in the soil in sufficient concentrations to kill vegetation or has collected in low areas and suffocated animals. This colorless, odorless gas usually does not pose a direct hazard to life because it typically becomes diluted to low concentrations quickly whether it is released continuously from the ground or during episodic eruptions. In certain circumstances, however, $\mathrm{CO}_{2}$ may become concentrated at levels lethal to people and animals. At Mammoth Mountain in California, carbon dioxide has killed about 100 acres of trees since 1989, and visitors to this area occasionally have suffered symptoms of asphyxiation when entering cabins or belowground excavations. In 2003, three members of the Mammoth Ski Patrol were killed 
when they fell through an unstable snow roof over a well-known geologic feature called the Mammoth Mountain fumarole, a vent that releases water vapor and carbon dioxide. The snow roof had acted as a cap over the fumarole and a high level of $\mathrm{CO}_{2}$ collected within the capped vent. USGS scientists have concluded that the gas is escaping from a magma body beneath Mammoth Mountain. The magma itself is not currently moving toward the surface, but the USGS is monitoring the situation carefully.

- Sorey, M.L., and others, 1996, Invisible $\mathrm{CO}_{2}$ gas killing trees at Mammoth

Mountain, California: U.S. Geological Survey Fact Sheet 172-96, 2 p.

Website http://pubs.usgs.gov/fs/fs172-96/

PDF http://pubs.usgs.gov/fs/fs172-96/fs172-96.pdf

8. Can volcanoes suddenly become restless and erupt within 1 day of the first signs of activity? Why or why not?

Yes. The initial major phreatomagmatic, vent-clearing explosion of Redoubt volcano in Cook Inlet, Alaska occurred at 9:47 AM on December 14, 1989, and was preceded by only 1 day of intense earthquake activity. Three more ash-rich explosions occurred the following day, December 15, 1989. Okmok Volcano erupted explosively, with virtually no warning, starting July 12, 2008, sending ash to 50,000 feet. Other volcanoes, and even other eruptions at Okmok and Redoubt volcanoes in Alaska, have been restless for months or years before an eruption occurred, and sometimes a period of unrest does not produce an eruption at all.

- AVO website

- Redoubt reported activity-1989 http://www.avo.alaska.edu/volcanoes/volcact.php?volcname=Redoubt\&erupti onid=442\&page $=$ basics

- Okmok reported activity-2008 http://www.avo.alaska.edu/volcanoes/volcact.php?volcname=Okmok\&eruptio nid=604\&page=basics

9. Are robots used to monitor volcanoes? If so, how?

Presently the USGS relies on observations and measurements made by experienced scientists and on critical data sent by radio or satellite relay from monitoring instruments installed around a volcano. These instruments include seismometers, tiltmeters, Global Positioning System (GPS) receivers, gas sensors, mudflow (lahar or debris flow) sensors, temperature probes, active satellite radar, thermal imaging, ground-based ash radar, and additional satellite techniques.

Robotic vehicles have been used to explore undersea volcanoes and the volcanic landscapes on the surface of Mars. A group of European scientists also investigated the use of robots in studying active volcanoes through a project called Robovolc.

In the U.S., NASA has tested a robot named Dante at Mount Erebus volcano in Antarctica and Mount Spurr volcano in Alaska following the 1992 eruption of Crater Peak. More information on the NASA robot Dante II at Alaska's Mt. Spurr in 1994 is available from various media sources on-line, such as the New York Times website. 
10. Can volcanoes produce large explosive eruptions and rivers of fluid lava at the same time? If so, how?

Not usually. During a single eruption, a volcano can produce lava flows and ash, sometimes simultaneously. The red, glowing lava fountains and lava flows in Dante's Peak (including the active flow across which Harry Dalton drives) are characteristic of a fluid magma, called basalt. In contrast, explosive gray ash columns and pyroclastic flows shown in other scenes are characteristic of viscous magmas, called andesite, dacite, or rhyolite. It is uncommon for a volcano to erupt magmas of widely different composition at the same time, but over the course of a lengthy eruption the eruptive products of an intermediate magma composition (like basaltic andesite) can transition from explosive (ash plume generation) to effusive (lava flow generation).

Following precursory heightened volcanic activity that began in November 2005, Augustine Volcano in Alaska's Cook Inlet erupted in January 2006. The eruption lasted several months and consisted of multiple phases of eruption activity. The eruption began with an explosive phase, which lasted from January 11 to January 28, 2006. These explosions produced ash plumes, reported by the U.S. National Weather Service to have reached heights greater than $9 \mathrm{~km}$ (5.6 mi.) above sea level.

The volcano then entered a period of more continuous eruptive activity that began on January 28 and lasted until February 2. The phase began with four explosive eruptions that generated ash plumes to heights of $9 \mathrm{~km}(5.6 \mathrm{mi})$ above sea level. These explosions generated substantial pyroclastic, block, and ash flows that destroyed scientific monitoring equipment on the west and north flanks of the volcano.

Augustine then entered an effusive phase, which lasted from February 2 through March 6. During this period, the eruption lava was extruded at the summit and two blocky lava flows moved down the north and northeastern flanks. The effusion of lava stopped in late March 2006.

- $\quad$ AVO website - Augustine reported activity - 2005

http://www.avo.alaska.edu/volcanoes/volcact.php?volcname=Augustine\&eruption $\underline{\mathrm{id}=547 \& \text { page }=\text { basics }}$

11. Can lakes near volcanoes become acidic enough to be dangerous to people? If so, how?

Yes. Crater lakes atop volcanoes typically are the most acidic, with $\mathrm{pH}$ values as low as 0.1 (very strong acid). Normal lake waters, in contrast, have relatively neutral $\mathrm{pH}$ values near 7.0. The crater lake at El Chichon volcano in Mexico had a pH of 0.5 in 1983 and Mount Pinatubo's crater lake had a pH of 1.9 in 1992. The acid waters of these lakes are capable of burning skin, but are unlikely to dissolve metal quickly. Gases from magma that dissolve in lake water to form such acidic brews include carbon dioxide, sulfur dioxide, hydrogen sulfide, hydrogen chloride, and hydrogen fluoride. However, the movie's rapidly formed acidic lake capable of dissolving an aluminum boat in a matter of minutes is unrealistic. 
In 2005, AVO received news of activity of Chiginigak volcano on the Alaska Peninsula from the owner of a nearby fishing lodge. It was later determined that between November 2004 and early May 2005, a flux of heat to the summit area caused melting of ice and snow filling the summit crater of Chiginagak, resulting in a cauldron containing an acidified lake. In early May 2005, a catastrophic release of sulfurous, clay-rich debris and acidic water from the lake, with an accompanying acidic aerosol component, traveled $27 \mathrm{~km}(\sim 17 \mathrm{mi})$ downstream and flowed into the Mother Goose Lake, headwaters of the King Salmon River. Extensive vegetation damage occurred along the flood route and Mother Goose Lake was acidified (pH of 2.9-3.1), killing all aquatic life and preventing the annual salmon run. For more information on this acidic lake drainage in Alaska, see:

- AVO website Chiginigak reported activity - 2005 http://www.avo.alaska.edu/volcanoes/volcact.php?volcname=Chiginagak\&eruptio nid=535\&page=basic

\section{Eruption Precursors}

Before a volcano erupts, magma must force its way upward through solid rock beneath a restless volcano. This process causes the ground above to heave and shake as rock is shoved aside or broken. At the same time, gases are released from the magma as it rises to shallower levels where the pressure is lower. These phenomena-ground movements, earthquakes, and changes in volcanic gases-provide the clues that scientists use to recognize a restless volcano and anticipate what might happen next.

1. What kinds of unusual activity might be noticed before an eruption?

Common symptoms of volcanic unrest include an increase in the frequency or intensity of earthquakes beneath a volcano; the occurrence of volcanic tremor; swelling, subsiding, or cracking of the ground; increased steam emission or small steam explosions; melting snow or ice; changes in existing fumaroles or hot springs, or the appearance of new ones; and increased discharge of magmatic gases. Volcanologists assess the significance of volcanic unrest partly by monitoring the pace and intensity of such activity.

2. What is volcanic tremor, and how does it differ from earthquakes?

Tremor is a seismic vibration, similar to a volcanic earthquake, but of longer duration and more continuous than earthquakes of the same amplitude. Volcanic tremor can last from minutes to days. It may be caused by magma moving through narrow cracks, boiling and pulsation of pressurized fluids within the volcano, or escape of pressurized steam and gases from fumaroles. 
3. Do volcanoes produce different kinds of earthquakes, and if so, what are they and how do they differ?

Yes. A variety of earthquake types can occur at a volcano that is getting ready to erupt. These include earthquakes caused by rocks breaking along faults or fractures (volcano-tectonic-type earthquakes). Another common type is called a long-period or volcanic earthquake. These can occur when bubble-filled magma is on the move beneath a volcano. In Dante's Peak, Harry Dalton states in one scene that he has felt some volcanic earthquakes. In fact, the differences between tectonic-type and longperiod earthquakes are so subtle that they can be distinguished only by using seismometers and looking carefully at the waveforms and frequency content.

4. What kind of gases escape from volcanoes?

The fumes escaping from a volcano consist mostly of water vapor (steam). Steam may be emitted from the hot interiors of volcanoes even when they are dormant. Steaming usually increases dramatically as magma intrudes and heats groundwater beneath a volcano. Magma gives off carbon dioxide $\left(\mathrm{CO}_{2}\right)$ and hydrogen sulfide $\left(\mathrm{H}_{2} \mathrm{~S}\right.$, rotten egg gas) that do not totally dissolve in groundwater and can therefore show up at the surface. As water inside the volcano boils away, other more watersoluble volcanic gases can reach the surface, signaling an increasing likelihood of eruption. These gases include sulfur dioxide $\left(\mathrm{SO}_{2}\right)$ and common halogen gases such as hydrogen chloride ( $\mathrm{HCl})$, and hydrogen fluoride (HF).

5. Are there any volcanoes exhibiting heightened volcanic activity in the U.S. and its territories today? In Alaska?

- Latest U.S. Volcano Alerts and Updates webpage http://volcanoes.usgs.gov/

\section{Volcano Monitoring}

To anticipate the awakening or reawakening of a volcano, volcanologists watch for changes caused by moving or pressurizing of magma and any associated changes in the hydrothermal system surrounding the magma. Much as depicted in Dante's Peak, magma moving toward the surface can cause swarms of earthquakes; swelling of the volcano, subsidence, or cracking of the volcano's flanks; and changes in the amount or types of gases emitted. The USGS continuously monitors many volcanoes in the states of Washington, Oregon, California, Hawaii, Alaska, Wyoming (Yellowstone) and the Northern Marianas Islands to detect unusual activity.

1. Does the USGS have a team of volcanologists that can respond to volcanic unrest on short notice? If so, can you describe the team?

Yes. The USGS Volcano Hazards Team includes experts in all aspects of volcano hazard assessment, monitoring, information dissemination, and volcano- emergency response. As depicted in the movie, a group of USGS scientists will respond to any potentially hazardous volcanic activity in the United States. 
2. Does the USGS have a team for rapid response to volcano emergencies in other countries? If so, can you describe the team?

Yes. Such a team is operated by the USGS as part of the Volcano Disaster Assistance Program (VDAP). The team was formed in cooperation with the U.S. Office of Foreign Disaster Assistance (OFDA) of the U.S. Agency for International Development following the 1985 eruption of Nevado del Ruiz Volcano, Colombia, in which more than 23,000 people lost their lives. At the request of host countries and working through OFDA, VDAP scientists work with local scientists to quickly determine the nature of volcanic unrest and assess its possible consequences. VDAP has responded to volcano emergencies in more than a dozen countries during the past decade.

In addition to helping people in other countries to get out of harm's way, VDAP's international work directly benefits volcano-hazard mitigation in the United States. Through VDAP, the USGS gains experience at active volcanoes that will help during future crises in the western United States, and collects important scientific data on eruption precursors that are used to understand better, how volcanoes work.

3. How does the USGS monitor volcanoes in the United States and its territories?

One of the earliest signs of an impending eruption is often a subtle change in seismic or earthquake activity beneath a volcano. In cooperation with universities and state agencies, the USGS monitors seismic activity near volcanoes using networks of seismometers. When unusual activity is detected, a response team may install more seismometers and other instruments to track the location and depth of the earthquakes and determine if an eruption is likely. Scientists also monitor the amount and types of gases released at volcanoes, shrinking and swelling of volcanic edifices, changes in ground and hydrothermal temperatures at volcanoes, and several other monitoring streams to watch for changes indicative of magma movement.

- About AVO webpage http://www.avo.alaska.edu/about/index.php

4. How are earthquakes monitored?

By installing seismometers, which send information continuously by radio to a central recording site (observatory), scientists can determine the sizes and locations of earthquakes near a volcano. Scientists look for specific types of earthquakes that are often associated with volcanic activity. An increase in the number or size or shallow earthquakes below a volcano usually means that an eruption is likely. Anyone with internet access can view incoming real-time seismic data from dozens of seismometers placed at Alaskan volcanoes.

- AVOs webicorders webpage http://www.avo.alaska.edu/webicorders/ 
5. How are ground movements measured? (number dropped off?)

Ground deformation (swelling, subsidence, or cracking) is measured in situ using various techniques, including Electronic Distance Meters (EDM), the Global Positioning System (GPS), precise leveling surveys, strainmeters, and tiltmeters. EDMs use lasers to accurately measure changes in distance between reflectors installed at benchmarks (fixed points) with repeated measurements. GPS makes use of satellites orbiting the Earth to determine and track the locations of points. Strainmeters and tiltmeters are used to monitor subtle changes in shape of the ground surface.

Scientists also rely on satellite-based images that illustrate ground movement over time. These images are generated by using active radar satellite data of the same area at two different points in time and subtracting one data set from the other. Changes in elevation will become apparent through this process, including whether an area has inflated or subsided. This technique is call Interferometric Synthetic Aperture Radar (InSAR) and the images produced using this technique of data subtraction are called interferograms. One suggested paper illustrating the use of InSAR in Alaska is:

- Lu, Zhong, and others, 2003, Interferometric synthetic aperture radar studies of Alaska volcanoes: Earth Observation Magazine, v. 12, no. 3, p. 8-10. PDF http://quake.usgs.gov/research/deformation/modeling/papers/2003/lu_et_all_2003 .pdf

6. How are volcanic gases measured?

Instruments to measure volcanic gases can be mounted in aircraft or used on the ground on a tripod. Typically, scientists measure a concentration of a particular gas in a plume and then use the wind speed and width of the plume to determine the quantity of gas being emitted on a daily basis. In Dante's Peak, a correlation spectrometer (COSPEC) was mounted in a helicopter to monitor sulfur dioxide emissions from the volcano. The instrument that detects carbon dioxide can be used from an aircraft and also installed on a volcano and configured to send data continuously by radio to an observatory. Sulfur dioxide in volcanic clouds also can be measured from space with instruments aboard satellites.

Volcanic gases also may be dissolved within the regional hydrothermal waters. Direct and repeat sampling of local waterways can be used to detect possible trends in the amount and types of dissolved gases with a volcanoes watershed. Scientists can be observed collecting water samples from glacial drainages of the Drift Glacier on redoubt volcano during heightened volcanic activity in 2009.

- AVO movie: Measuring water temperature at the outflow of Drift Glacier, Redoubt Volcano webpage http://www.avo.alaska.edu/image.php?id=16552 
Scientists are continuously improvising the ability of using satellite imagery to monitor volcanic gas plumes erupted from volcanoes. On August 7, 2008, Kasatochi volcano in the central Aleutian Islands erupted explosively. The cumulative volcanic cloud from the eruption of Kasatochi contained a large amount of sulfur dioxide gas that was detected by the Ozone Monitoring Instrument on NASA's EOS-Aura satellite for more than a week after the eruption as the cloud circled the globe.

- AVO News - Small Volcano, Big Eruption, Scientists Rescued Just in Time http://www.avo.alaska.edu/activity/Kasatochi08/Kasatochi2008PLW.php

7. Can mudflows be monitored? If so, how?

The torrents of mud, rocks, logs, and other debris depicted in Dante's Peak are collectively called mudflows, debris flows, or lahars, an Indonesian term for volcanic mudflows. An instrument called an acoustic flow monitor can be installed near river valleys leading away from a volcano to help provide warnings of approaching flows. The system senses vibrations caused by the mudflows and sends alerts by radio to the volcano observatory or another official emergency office.

- USGS Volcano Hazards Program, 1989-90 Eruption of Redoubt Volcano, Alaska, and the First Test Case of a USGS Lahar-Detection System, webpage http://volcanoes.usgs.gov/activity/methods/hydrologic/afm_redoubt.php

8. What else do scientists measure at volcanoes?

Field observations by experienced volcanologists go hand in hand with more sophisticated equipment and techniques to form a complete system for monitoring volcanoes. Field observations may include water temperature and $\mathrm{pH}$ (acidity) measurements, as shown in Dante's Peak, or observations of ground cracking, new areas of avalanching rocks, and so on. An experienced observer can integrate many types of data on the spot and design simple measurements to assess further the significance of volcanic unrest. There is no substitute for well-trained, experienced observers when trying to determine how a volcano will behave. Additionally, understanding past eruption history serves as the key framework for evaluating current and future unrest and the most likely eruption scenarios.

\section{Volcanic Hazards}

In Dante's Peak, a restless volcano endangers nearby residents with clouds of ash, falling blocks of rock, pyroclastic flows or ash hurricanes, lava flows, and floods of debris or lahars. These hazards are typical of snow- and ice-covered stratovolcanoes like those in the Cascade Range and Alaska. Since 1980, volcanic activity has killed more than 29,000 people worldwide, mainly due to roof collapses under the weight of ash fall deposits and widespread disease from unsanitary conditions following a volcanic eruption. Most of the deaths were caused by lahars and pyroclastic flows; a few hundred people were killed by ash falls, which collapsed the roofs of buildings. Lists are available that rank the world's deadliest volcanic eruptions. 
- Pacific Disaster Center-Deadliest Eruptions webpage http://www.pdc.org/iweb/volcano_deadliest.jsp

1. What kinds of hazards were depicted in the movie, and what part have they played in real volcanic eruptions? Are they realistic?

Debris flows, or lahars, are slurries of muddy debris and water like the one that carried away Paul Dreyfuss in Dante's Peak. They are caused by mixing of volcanic debris and local soil and rocks with water, melted snow, or ice. Lahars destroyed houses, bridges, and logging trucks during the May 1980 eruption of Mount St. Helens, and have inundated other valleys around Cascade volcanoes during prehistoric eruptions. Lahars at Nevado del Ruiz volcano, Colombia, in 1985, killed more than 23,000 people. At Mount Rainier, major landslides that apparently were neither triggered nor accompanied by eruptive activity have produced lahars. Lahars can travel many tens of miles in a period of hours, destroying everything in their paths. Mudflows have occurred during eruptions at Alaska's volcanoes-most notably those of Redoubt volcano in the Cook Inlet.

Tephra (ash and coarser debris), like that which buried the town of Dante's Peak, is composed of fragments of magma or rock blown apart by gas expansion during an explosive eruption. Tephra accumulation is heavy, especially when wet, and can cause roofs to collapse, respiratory problems, and damage to machinery and infrastructure. Tephra can also severely damage aircraft in flight and short out power lines hundreds of miles downwind of eruptions. Explosions may also throw large rocks a few miles. As depicted in Dante's Peak, falling blocks killed people at Galeras Volcano in Colombia in 1992, and at Mount Etna, Italy, in 1979.

Pyroclastic flows and surges are lumped together and called "pyroclastic clouds" by Harry Dalton in Dante's Peak. These two phenomena are related but slightly different; pyroclastic surges are hot, turbulent clouds of tephra that can surmount ridges and topography easily; pyroclastic flows are dense, turbulent mixtures of tephra and gas that are funneled downslope and in valley bottoms. Pyroclastic flows and surges can travel more than a hundred miles per hour and incinerate or crush most objects in their path. Although most extend only a few miles, a pyroclastic surge at Mount St. Helens in 1980 extended $18 \mathrm{mi}(28 \mathrm{~km})$ and killed 57 people. Pyroclastic surges at El Chichon Volcano in Mexico in 1982 killed 2000 people, and pyroclastic flows and surges at Mount Unzen, Japan, in June 1991, killed 43 people. Contrary to the movie, it is unlikely that speeding vehicles could outrun a pyroclastic flow or surge if it is nearby. The pyroclastic flow deposit from the 1912 eruption of Novarupta now within Katmai National Park and Preserve on the Alaska Peninsula formed the famed Valley of Ten Thousand Smokes.

Lava flows erupted at stratovolcanoes like those in the Pacific Northwest and Alaska are typically slow-moving, thick, blocky, viscous flows. Shield volcanoes that produce basalt like Kilauea Volcano on the island of Hawaii has produced thin, fluid lava flows like those depicted in Dante's Peak throughout its history, and almost continuously since 1983. Lava flows destroyed a visitor center at Kilauea in 1989 and overran the village of Kalapana on the volcano's southeast flank in 1991. 
2. Can volcanoes be dangerous even when they do not erupt? If so, how?

Definitely. Many stratovolcanoes have a plumbing system of hot acid water that progressively breaks down hard rock to soft, clay-rich material. As the volcano gradually weakens, large parts may suddenly fail. Resulting water-rich landslides are especially dangerous because they can occur without any volcanic or seismic warning.

Steam explosions, rock falls, acid hot springs, and significant $\mathrm{CO}_{2}$ emissions are also possible non-eruptive hazards.

3. In the U.S. and its territories, how can residents who live near volcanoes prepare for future eruptions?

Residents can obtain copies of USGS volcano-hazard reports and preliminary hazard assessments to determine whether they live or work in areas at risk from volcanic activity and what kinds of hazards they face. Everyone should plan how they and their family will respond to a natural disaster, including unrest or eruptive activity at nearby volcanoes. Preparation might include knowing where to go when family members are separated, where to go for emergency housing, what emergency supplies to keep on hand, and how to be self sufficient for several days, as recommended by local emergency management agencies. Residents who live within $160 \mathrm{~km}$ (100 mi) of a volcano should also find out what their local officials are doing to prepare their community for the possibility of renewed volcanic activity. Lastly, enjoy the scenic, recreational, and inspirational benefits of living near an active volcano! 
Name

Date

Period

\section{Supervolcano}

The docudrama Supervolcano dramatically explores the effect of a large caldera-forming eruption at Yellowstone National Park in Wyoming. Answer the questions below and shed light on issues related to volcanism at Yellowstone.

1. What is the chance of another catastrophic volcanic eruption at Yellowstone?

2. What is a "supervolcano"?

3. What would happen if a "supervolcano" eruption occurred again at Yellowstone?

4. Is Yellowstone monitored for volcanic activity and if so, why?

5. Do scientists know if a catastrophic eruption is imminent at Yellowstone? If so, how?

6. How far in advance could scientists predict an eruption of the Yellowstone volcano?

7. Can some of the pressure at Yellowstone be released by drilling into the volcano? If so, how?

8. Could the Yellowstone volcano have an eruption that is not catastrophic? Is so, when? Can you describe it?

9. Because Yellowstone is so geologically active, are there other potential geologic hazards in Yellowstone? If so, what are they? 


\section{Supervolcano Key \\ (based on http://volcanoes.usgs.gov/yvo/2005/docudrama.html)}

The docudrama Supervolcano dramatically explores the effect of a large caldera-forming eruption at Yellowstone National Park in Wyoming. The scale of the portrayed eruption is similar to the eruption of the Huckleberry Ridge Tuff at Yellowstone 2.1 million years ago. The movie is realistic insofar as depicting what could happen if an eruption of this magnitude were to occur again. Although the drama is set in the future, it does an acceptable job of addressing some of the issues scientists would grapple with if Yellowstone showed signs of an impending eruption. The questions and answers below shed light on issues related to volcanism at Yellowstone.

1. What is the chance of another catastrophic volcanic eruption at Yellowstone?

Although it is possible, scientists conclude that the probability of another catastrophic eruption at Yellowstone is extremely small. Given Yellowstone's history, the annual probability of another caldera-forming eruption could be calculated as 1 in 730,000 or 0.00014 percent. However, this number is based simply on averaging the two intervals between the three major past eruptions at Yellowstone - hardly enough information to make a defensible statistical forecast. This probability is roughly similar to that of a large (1 km [ 3,280 ft]) asteroid hitting the Earth. In summary, although it is possible, it is highly unlikely.

2. What is a "supervolcano"?

The term "supervolcano" refers to a volcanic system capable an eruption of magnitude 8 on the Volcano Explosivity Index, meaning that more than 1,000 km $\left(240 \mathrm{mi}^{3}\right)$ of magma (partially molten rock with crystals, dissolved gases, and liquid rock) are erupted. The most recent such event on Earth occurred 74,000 years ago at the Toba Caldera in Sumatra, Indonesia.

3. What would happen if a "supervolcano" eruption occurred again at Yellowstone?

Such a giant eruption would devastate everything within hundreds to thousands of miles. It would have widespread regional effects from falling ash, volcanic gas, and aerosol clouds causing disruption of lives and communities throughout the United States. The ash and gas cloud would circle the globe causing changes in global climate for years to decades. The surrounding states of Montana, Idaho, and Wyoming would be affected, as well as other places in the U.S. and the world. Such eruptions usually form calderas, broad volcanic depressions created as the ground surface collapses because of withdrawal of partially molten rock (magma) below. Fortunately, the chances of this sort of eruption at Yellowstone are exceedingly small in the next few thousands of years. 
4. Is Yellowstone monitored for volcanic activity?

Yes. The Yellowstone Volcano Observatory (YVO), a partnership between the U.S. Geological Survey (USGS), Yellowstone National Park, and the University of Utah, closely monitors volcanic activity at Yellowstone. The YVO website features realtime data for earthquakes, ground deformation, streamflow, and selected stream temperatures. Additionally, YVO scientists collaborate with scientists from around the world to study the Yellowstone volcano and better understand how it works.

5. Do scientists know if a catastrophic eruption is imminent at Yellowstone? If so, how?

There is no evidence that a catastrophic eruption at Yellowstone is imminent, and such events are unlikely to occur in the next few centuries. Scientists have also determined no indication of an imminent smaller eruption of lava.

6. How far in advance could scientists predict an eruption of the Yellowstone volcano?

The science of forecasting a volcanic eruption has significantly advanced over the past 25 years. Most scientists think that the buildup preceding a catastrophic eruption would be detectable for weeks and perhaps months to years. Precursors to volcanic eruptions include strong earthquake swarms and rapid ground deformation and typically take place days to weeks before an actual eruption. Earthquake activity can sometimes begin to rise subtly many months prior to an eruption. Scientists at YVO closely monitor the Yellowstone region for such precursors. They expect that the buildup to larger eruptions would include intense precursory activity far exceeding those that have been typically observed at multiple spots within the Yellowstone volcano. As at many caldera systems around the world, small earthquakes, ground uplift and subsidence, and gas releases at Yellowstone are commonplace events that do not lead to eruptions. Smaller eruptions or steam explosions may have no precursory signals at all.

7. Can you release some of the pressure at Yellowstone by drilling into the volcano? If so, how?

No. Scientists agree that drilling into a volcano would be of questionable usefulness. Notwithstanding the enormous expense and technological difficulties in drilling through hot, mushy rock, drilling is not likely to have much effect. At near magmatic temperatures and pressures, minerals crystallizing from the natural fluids that are present at those depths would rapidly seal any hole.

8. Could the Yellowstone volcano have an eruption that is not catastrophic? Is so, when? Can you describe it?

Yes. Over the past 640,000 years since the last giant eruption at Yellowstone, approximately 80 relatively non-explosive, lava-flow eruptions have occurred. This would be the most likely kind of future eruption. If such an event were to occur today, activities would be disrupted in Yellowstone National Park, but few lives would be threatened. The most recent volcanic eruption at Yellowstone, a lava flow on the Pitchstone Plateau, occurred 70,000 years ago. 
9. Because Yellowstone is so geologically active, are there other potential geologic hazards in Yellowstone? If so, what are they?

The heat and geologic forces fueling the massive Yellowstone volcano affect the park in many ways. Yellowstone's many geysers, hotsprings, steam vents, and mudpots are evidence of the heat given off by magma many miles beneath the surface. These hydrothermal (hot water) features are mostly benign, but rarely can be the sites of a type of eruption (phreatic or steam explosions driven by the flash of water to steam in a pressured environment) and pose a hydrothermal hazard. Earthquakes, another example of active geologic forces, are quite common in Yellowstone, with 1,000-3,000 occurring annually. Most of these are quite small, although significant earthquakes have shaken Yellowstone, such as the 1959 magnitude 7.5 Hebgen Lake earthquake, the largest historical earthquake in the intermountain region, and the 1975 magnitude 6.1 earthquake near Norris Geyser Basin. The many earthquakes and gas and steam explosions in the past 10,000 years at Yellowstone have not led to volcanic eruptions. 


\section{Activity III. A Day in the Life of a Volcano Observatory}

\section{Grade Level 7-11}

Setting Two classrooms or one large room

Time 2-3 hours

Depending on the number of students in the class and the length of a class period, it may take as much as 4 hours to complete this activity. The activity can be broken down into different days; it need not be continuous until complete.

\section{Vocabulary (see Glossary)}

andesite, basaltic andesite, geologist, geology, geophysicist, glaciology, hydrology, incandescence, incandescent, phreatic, plume, proglacial lake, radar, volcanic (or magmatic) gases, volcanologist

Correlations to Alaska State Department of Education (2006) Science Performance Standards (Grade Level Expectations)

A1-Science as Inquiry and Process

SA[6-11] Students develop an understanding of the processes and applications of scientific inquiry.

SA1[6-11] Students develop an understanding of the processes of science used to investigate problems, design and conduct repeatable scientific investigations, and defend scientific arguments.

SA2[6-11] Students develop an understanding that the processes of science require integrity, logical reasoning, skepticism, openness, communication, and peer review.

SA3[6-11] Students develop an understanding that culture, local knowledge, history, and interaction with the environment contribute to the development of scientific knowledge, and local applications provide opportunity for understanding scientific concepts and global issues.

\section{E1-Science and Technology}

SE[6-11] Students develop an understanding of the relationships among science, technology, and society.

SE1[6-11] Students develop an understanding of how scientific knowledge and technology are used in making decisions about issues, innovations, and responses to problems and everyday events.

SE2[6-11] Students develop an understanding that solving problems involves different ways of thinking, perspectives, and curiosity that lead to the exploration of multiple paths that are analyzed using scientific, technological, and social merits.

SE3[6-11] Students develop an understanding of how scientific discoveries and technological innovations affect and are affected by our lives and cultures. 


\section{F1-Cultural, Social, Personal Perspectives, and Science}

SF[6-11] Students develop an understanding of the dynamic relationships among scientific, cultural, social, and personal perspectives.

SF1[6-11] Students develop an understanding of the interrelationships among individuals, cultures, societies, science, and technology.

SF2[6-11] Students develop an understanding that some individuals, cultures, and societies use other beliefs and methods in addition to scientific methods to describe and understand the world.

SF3[6-11] Students develop an understanding of the importance of recording and validating cultural knowledge.

\section{Overview}

Through this "table top” volcanic activity scenario and exercise, students will learn how the Alaska Volcano Observatory (AVO) functions when there is an increase in volcanic activity at an Alaskan volcano. Students will play the roles of managers and scientists at AVO, interagency partners, the media, and the public during a volcanic event. A guided discussion will follow the exercise and allow students the chance to discuss how they functioned as a group and fulfilled their individual duties.

\section{Background}

AVO is a joint program of the U.S. Geological Survey (USGS), the Geophysical Institute of the University of Alaska Fairbanks (UAFGI), and the State of Alaska Division of Geological and Geophysical Surveys (ADGGS). AVO was formed in 1988, and uses Federal, State, and university resources to monitor and study Alaska's hazardous volcanoes, to predict and record eruptive activity, and to mitigate volcanic hazards to life and property.

AVO offices are in Anchorage and Fairbanks, Alaska. The Anchorage office is at the USGS, and is the primary point of information dissemination during crises. Fairbanks offices are concentrated at the UAFGI, which serves as the data collection point for most seismic and satellite data. AVO is staffed by the equivalent of a few dozen full-time scientists, technicians, and administrators and supports several graduate students. Managerial responsibility for AVO rests with the Scientist-in-Charge, a USGS employee in Anchorage, and the Coordinating Scientist in Fairbanks, a UAFGI or ADGGS employee.

AVO has three primary objectives:

- To conduct monitoring and other scientific investigations in order to assess the nature, timing, and likelihood of volcanic activity

- To assess volcanic hazards associated with anticipated activity, including kinds of events, their effects, and areas at risk

- To provide timely and accurate information on volcanic hazards, and warnings of impending dangerous activity, to local, state, and Federal officials and the public 
An important component of AVO's program is to conduct research into how volcanoes work. The scope of this research includes:

- Basic geological mapping to determine eruptive histories of active volcanoes

- Geochemical characterization and modeling of diverse magmatic systems

- Investigation of hydrologic hazards associated with eruptions of snow and ice-clad volcanoes

- Documentation and analysis of eruptive processes

- Geophysical exploration of the interiors of volcanoes and mechanisms of eruption

- Development of new instrumentation to aid in prediction and interpretation of volcanic unrest

Results of these studies contribute significantly to the quality of volcanic hazards assessments and to the continual improvement of AVO's monitoring and forecasting capabilities.

For more information see:

- About AVO webpage http://www.avo.alaska.edu/about/

Also for detailed information about AVO specific interagency response during volcanic activity, specifically episodes including ash fall, see pages 6-17 in:

- Madden, John, Murray, T.L., Carle, W.J., Cirillo, M.A., Furgione, L.K., Trimpert, M.T., and Hartig, Larry (signatories), 2008, Alaska interagency operating plan for volcanic ash episodes, $52 \mathrm{p}$.

PDF http://www.avo.alaska.edu/pdfs/cit3996_2008.pdf

The scenario used in this activity reflects the sequence of events in autumn 2006 described below.

As autumn arrived in Alaska in 2006, a phreatic eruption from a volcano not considered active in the Holocene (last 10,000 years) surprised AVO and residents of south-central Alaska. In September, AVO received several citizen telephone reports of a dark plume, fed by what appeared to be two sources, rising from the area near Cape Douglas in lower Cook Inlet. Satellite analysis indicated the source of the plumes to be roughly between closely spaced Douglas and Fourpeaked volcanoes. Subsequent data analysis concluded that Fourpeaked, within the northeast corner of Katmai National Park and Preserve on the Alaska Peninsula, $7.5 \mathrm{mi}(12 \mathrm{~km})$ southwest of Mount Douglas was the source of the plume. The drifting cloud produced by these rising plumes persisted throughout the night, reaching a minimum altitude of $6,100 \mathrm{~m}(20,000 \mathrm{ft})$ based on radar data, but drifting only $20 \mathrm{~km}$ (12 mi) downwind in an unusually calm and clear atmosphere over south-central Alaska. The sizes and styles of past eruptions are not well constrained, however, past eruptions of andesite and dacite indicate that eruptions of Fourpeaked can be explosive, possibly producing plumes that reach in excess of $10 \mathrm{~km}(33,000 \mathrm{ft})$ above sea level and local ash fall. For the next several weeks, AVO was involved in a significant response to this activity. 
For a complete description of AVOs response and activity at the volcano see:

- Neal, C.A, McGimsey, R.G., Dixon, J.P., Manevich, Alexander, and Rybin, Alexander, 2009, 2006 volcanic activity in Alaska, Kamchatka, and the Kurile Islands-Summary of events and response of the Alaska Volcano Observatory: U.S. Geological Survey Scientific Investigations Report 2008-5214, 102 p. PDF http://pubs.usgs.gov/sir/2008/5214/pdf/sir20085214.pdf

\section{Objectives}

By playing roles in a volcanic activity scenario students will understand what Observatory staff do, as well as how and why. For one or more class periods, one or more students will be assigned to, or choose to, play the roles of Observatory geophysicists, geologists, and the Scientist-in-Charge (which may also be the role of the instructor). Additional students will play the roles of emergency managers, the public, and the media. In these roles, students will work through an Observatory exercise concerning reported activity of a volcano on the Alaska Peninsula. The scenario presented in this exercise closely matches the order of events that took place in autumn of 2006 when Fourpeaked volcano had a phreatic eruption (an explosion involving water flashing to steam at depth), which caused a significant plume observed by individuals in Homer on the Kenai Peninsula.

Students will answer a series of questions the worksheet provided. These questions aim to have students describe their roles, and how well (or poorly) their tasks were carried out. The worksheet also may be used to generate class discussion instead of written response. Students will be able to identify the roles of individual specialists within the Observatory and additionally identify career paths for students who would like to study volcanoes.

\section{Materials}

- The Finer Points worksheet

- Briefing and Discussion information handouts

- chalk or dry erase board (optional)

— digital projector, laptop(s) or other computers with internet access (optional) available

\section{Procedure}

\section{Set up}

1. To conduct this exercise you may need an additional, supervised classroom area. Students playing different roles will be having simultaneous conversations, which should take place in different locations. The use of the internet, a digital overhead projector and computer, and chalk or dry erase board will be useful in both classrooms.

2. For simplicity in this scenario, staff from the Federal Aviation Administration (FAA) and National Weather Service (NWS) will not be included. They are AVOs closest, and in many respects, most crucial interagency partners. Be sure to include the involvement of these two agencies in the discussion following the scenario as mentioned in The Finer Points post scenario discussion guide / worksheet.

3. For the sake of simplicity, there is no Coordinating Scientist role in this scenario. 
4. There are many unit measurements in this exercise. In some cases, conversions are provided, in other cases they are not. This reflects the complexity of information gathered and used by AVO.

5. Although the Observatory releases their information products to emergency managers, the media, public, and land managers at the same time, it is rare that representatives from all these agencies would be present for a Briefing at one time (as in the scenario portrayed here).

6. This scenario uses a now old aviation color code. For information about the new code and development of the new code please see:

- Gardner, C.A., and Guffanti, M.C., 2006, U.S. Geological Survey's alert notification system for volcanic activity: U.S. Geological Survey Fact Sheet 20063139, 4 p.

PDF http://pubs.usgs.gov/fs/2006/3139/fs2006-3139.pdf (12.14 MB)

\section{Assign Roles}

1. Assign a student or small groups of students each of the following roles:

One person each

- Observatory Scientist-in-Charge (SIC) (may be played by instructor)

- Observatory Information Manager (may be played by instructor)

— National Park Superintendent

One or more people each

- Geophysicists (geodesists, seismologists, and satellite remote sensors)

- Geologists (geochemists, petrologists, hydrologists, and glaciologists)

- Emergency Managers (includes Homeland Security, Borough Emergency Managers, and Village Public Safety Officers)

- Members of the public

- Media (TV, print, web-based, and radio)

Note It may be best to assign or let students choose their roles and distribute the first set of materials (Discussion 1 only) the day before you plan to start the scenario.

Additionally, class discussion and (or) the completion of the worksheet may best take place after the scenario has been completed. It may take up to 4 hours to complete this activity in full, but it does not need to be carried out in one continuous session.

2. The materials presented here are broken into four discussion periods. The teacher or designee will begin the scenario by reading Discussion 1 and sharing the materials (as an overhead, handout, or digital presentation) in the Volcano Activity Narrative.

3. Everyone receives a page (or more) of specific and guiding information about their assigned/chosen role. The Observatory staff should receive updates from the teacher (distribute the appropriate information to the right character at the allotted time) prior to the next Discussion held. Students will have to incorporate this information into a series of Discussions, which should last no longer than 15 minutes. During these Discussions, the Observatory staff should develop an Activity Statement-a brief description of the activity at the volcano for a general audience. In essence, each 
Discussion period will serve as a way for the Scientist-in-Charge (SIC) to hear from all his or her staff to develop this statement, have it reviewed, and approved. The Activity Statement must include the use of the aviation level of concern color code.

\begin{tabular}{|c|l|}
\hline Green & No eruption anticipated. Volcano is in quiet, "dormant" state. \\
\hline Yellow & $\begin{array}{l}\text { An eruption is possible in the next few weeks and may occur } \\
\text { with little or no additional warning. Small earthquakes detected } \\
\text { locally and (or) increased levels if volcanic gas emissions. }\end{array}$ \\
\hline Orange & $\begin{array}{l}\text { Explosive eruption is possible within a few days and may occur } \\
\text { with little or no warning. Ash plume(s) bot expected to reach } \\
\text { 25,000 feet above sea level. Increased numbers of local } \\
\text { earthquakes. Extrusion of lava dome or lava flows (non-explosive } \\
\text { eruption) may be occurring. }\end{array}$ \\
\hline Red & $\begin{array}{l}\text { Major explosive eruption expected within } 24 \text { hours. Large ash } \\
\text { plume(s) expected to reach at least 25,000 feet above sea level. } \\
\text { Strong earthquake activity detected even at distant monitoring } \\
\text { stations. Explosive eruption may be in progress. }\end{array}$ \\
\hline
\end{tabular}

Aviation Level of Concern Color Code

4. The Observatory SIC and the Information Manager are responsible for the generation and distribution of this Activity Statement to the media, emergency managers, and the Park Superintendent during Briefings. Each Briefing is designed so the media, emergency managers, and the Park Superintendent receive the Activity Statement from the Information Manager and ask questions about the contents of the statement. It is up to individual staff or the SIC whether or not the Observatory staff needs to be present, in whole or individually, at Briefings.

5. While Discussions are occurring, non-Observatory staff should NOT be present, and while Briefings are occurring, the Observatory Information Manager should try to limit the time the media, emergency managers and the Park Superintendent are at the "Observatory” and contact with the SIC and Observatory staff.

6. Media will be tasked with writing articles (or producing radio or TV broadcasts, etc.) for the public-likely, in a room they will share with the members of the public and other non-Observatory staff. It may be best for each group to have their own section of this room in which to work. The media will need to develop and disseminate (or show) their products while the Observatory is having their Discussions. The Media can print and distribute a news story, hold a press conference for the public, or have a mock news briefing with the public watching or a similar event. 
7. The students should advance through their assignments with 15-minute long Discussions (Observatory only) including Activity Statement development, and 5 minutes for Briefings (some Observatory and non-Observatory staff with limitations described previously).

8. If the teacher/educator is not a member of the "cast":

- Try to participate in the Discussion and Briefings as little as possible. The students' characters and their attachment to their position may become more pronounced. You may serve as a moderator in the event that no student or students take this lead.

- During Discussions and Briefings allow and encourage the students to draw and show figures and graphs to illustrate their points and, if necessary, get attached, concerned, worried, or downright frustrated in their roles!

9. Upon completion of the last Briefings, lead a class discussion, using The Finer Points worksheet as a guide and have the students focus on what did and did not work, and how they felt as the professional trying to accomplishing their job, etc. A big test is to determine if the public received accurate information about the activity at each point an Activity Statement was generated. Having the public describe to the Observatory what they thought was going on could be eye opening!

\section{Extensions}

1. Have students discuss how the new Aviation Color Code and Volcanic Alert Level would be used in this scenario. A description of this newer system can be used.

- Gardner, C.A., and Guffanti, M.C., 2006, U.S. Geological Survey's alert notification system for volcanic activity: U.S. Geological Survey Fact Sheet 20063139, 4 p.

PDF http://www.avo.alaska.edu/pdfs/fs2006-3139.pdf (12.14 MB)

2. Instead of a discussion, have the students individually or within their identified groups answer the discussion points in a report, poster, or presentation.

\section{References Cited}

Alaska State Department of Education and Early Development, 2006, Standards and grade level expectations, March 2006: State of Alaska website, accessed October 2009 at http://www.eed.state.ak.us/tls/assessment/GLEHome.html.

Neal, C.A, McGimsey, R.G., Dixon, J.P., Manevich, Alexander, and Rybin, Alexander, 2009, 2006 volcanic activity in Alaska, Kamchatka, and the Kurile Islands-Summary of events and response of the Alaska Volcano Observatory: U.S. Geological Survey Scientific Investigations Report 2008-5214, 102 p. (Available at http://pubs.usgs.gov/sir/2008/5214/pdf/sir20085214.pdf.)

\section{AVO website references in order of appearance in the exercise}

Cape Douglas from Main Street, Homer, Alaska, September 17, 2006. Photograph taken by Lanny Simpson, Alaska High Mountain Images, used with permission.

http://avo.alaska.edu/images/image.php?id=11078. 
Location map of Fourpeaked and Douglas volcanoes, Image created by Seth Snedigar and J.R. Schaefer, Alaska Volcano Observatory/Alaska Division of Geological \& Geophysical Surveys, dated September 18, 2006. http://www.avo.alaska.edu/image.php?id=11079.

Image from the King Salmon NEXRAD weather radar showing the volcanic cloud at Fourpeaked Mountain volcano on September 17, 2006, at 12:40 ADT (20:40 UTC). Image dated September 19, 2006. This image was produced by David Schneider, U.S. Geological Survey/Alaska Volcano Observatory, using data and software provided by the NOAA National Climatic Data Center. http://www.avo.alaska.edu/image.php?id=11086.

Image showing the total amount of sulfur dioxide in the atmosphere over Fourpeaked Mountain volcano on September 17, 2006, as measured by the Ozone Monitoring Instrument (OMI) on NASA's Aura satellite. Image created by the volcanic emissions group at the University of Maryland Baltimore County, Baltimore, Md., USA, dated September 19, 2006 (S.A. Carn, N.A. Krotkov, A.J. Krueger, and K. Yang). OMI was built by a Dutch/Finnish collaboration and managed by KNMI and NIVR in the Netherlands. http://www.avo.alaska.edu/image.php?id=11085.

Image from Puff volcanic ash dispersion model showing the predicted position of the volcanic cloud at 15:00 ADT (23:00 UTC) from Fourpeaked Mountain volcano on September 17, 2006. Image taken by Peter Webley, Alaska Volcano

Observatory/University of Alaska Fairbanks, Geophysical Institute, dated September 20, 2006. http://www.avo.alaska.edu/image.php?id=11087.

Terminus of Fourpeaked Glacier. Notice the dark-colored sediment issuing from an elongate tunnel in the ice that is distinctly different than the color of the proglacial lake. Photograph taken by K. Wallace, U.S. Geological Survey/Alaska Volcano Observatory, September 20, 2006. http://avo.alaska.edu/images/image.php?id=11102.

Photograph taken during the helicopter observation flight between 19:40 and 20:30 local time, looking NNW. SE Ridge in the foreground, top of the "headwall" at the extreme right of the photograph and both plumes in the background. Photograph taken by Guy Tytgat, Alasak Volcano Observatory/University of Alaska Fairbanks, Geophysical Institute, September 20, 2006. http://avo.alaska.edu/images/image.php?id=11132.

Headwall of Fourpeaked Glacier NE of the summit of Fourpeaked volcano. Waterfalls were issuing from beneath the ice at the top of the headwall at an elevation of 5,000 $\mathrm{ft}$ (1,900 ft below the summit). A convective vapor plume was rising above the cloud deck between the summit (obscured by clouds) and the headwall region. Photograph taken by K.L., Wallace, Alaska Volcano Observatory/U.S. Geological Survey, September 20, 2006. http://avo.alaska.edu/images/image.php?id=11099.

Newly installed temporary broadband seismometer (bottom) and time-lapse camera (top) located about 6 km (4 mi) NW of Fourpeaked summit. Photograph taken by Rick Wessels, U.S. Geological Survey/Alaska Volcano Observatory, September 25, 2006. http://avo.alaska.edu/images/image.php?id=11429. 
Steaming on the uppermost section of the northern flank of Fourpeaked volcano. Photograph taken by Jennifer Adleman, U.S. Geological Survey/Alaska Volcano Observatory, November 4, 2006. http://avo.alaska.edu/images/image.php?id=12359.

Thermal image of chain of vents at Fourpeaked summit from $6.4 \mathrm{~km}$ (4 mi) NNW of summit. Black arrows on inset map show approximate field of view. FLIR image created by Rick Wessels, U.S. Geological Survey/Alaska Volcano Observatory, September 24, 2006. http://avo.alaska.edu/images/image.php?id=11462.

Terminus of Fourpeaked Glacier. Notice the dark-colored sediment issuing from an elongate tunnel in the ice that is distinctly different than the color of the proglacial lake. Photograph taken by K. Wallace, U.S. Geological Survey/Alaska Volcano Observatory, September 20, 2006. http://avo.alaska.edu/images/image.php?id=11102.

Fumaroles on west side of Fourpeak Volcano. Photograph taken by Cyrus Read, Alaska Volcano Observatory/U.S. Geological Survey, September 24, 2006. http://avo.alaska.edu/images/image.php?id=11205.

Photograph of flowage deposit of ice and debris on the NW flank of Fourpeaked volcano. The debris/ice flow originated from a glacial outbreak flood caused by melting of summit glacial ice by volcanic processes on September 17, 2006. View is looking to the west, down slope. Rick Wessels, Alaska Volcano Observatory (AVO), points to large ice block in the flowage deposit. Photograph taken by K.L. Wallace, Alaska Volcano Observatory/U.S. Geological Survey, dated, September 25, 2006. http://avo.alaska.edu/images/image.php?id=11677.

AVO staff member getting ready to sample the thin debris flow deposit on the surface of the ice field north of Fourpeaked volcano. The debris flow originated from a glacial outbreak flood caused by melting of summit glacial ice by volcanic processes on September 17, 2006. View is looking to the east, southeast. Photograph taken by K.L. Wallace, U.S. Geological Survey/Alaska Volcano Observatory, dated September 25, 2006. http://avo.alaska.edu/images/image.php?id=11659.

USGS Aviation Color Code and Volcanic Alert Level, 2006. http://www.avo.alaska.edu/color_codes.php.

\section{Glossary}

Andesite - A gray to black volcanic rock with between about 52 and 63 weight percent silica $\left(\mathrm{SiO}_{2}\right)$. The low-end silica value rock is also known as basaltic andesite.

Geologist - One who is trained in and works in any of the geological sciences.

Geology - The study of the planet Earth - the materials of which it is made, the processes that act on these materials, the products formed, and the history of the planet and its life forms since its origin.

Geophysicist - One who studies the geophysical properties of the Earth, or applies physical measurement to geological problems. 
Glaciology - The study of all aspects of snow and ice; the science that treats quantitatively the whole range of processes associated with all forms of solid water. Glaciology is the study of existing glaciers and ice sheets, and of their physical properties.

Hydrology - The science that deals with global water (both liquid and solid), its properties, circulation, and distribution on and under the Earth's surface and in the atmosphere, from the moment of its precipitation until it is returned to the atmosphere through evapotranspiration or is discharged into the ocean.

Incandescence - The emission of visible light by a body caused by its high temperature.

Incandescent - Produced by incandescence.

Phreatic - A volcanic explosion of steam, mud, or other material that is not incandescent; it is caused by the heating and consequent expansion of groundwater due to an underlying igneous heat source.

Plume - A volcanic plume is a mixture of particles and gas emitted by an eruption. Plumes may reach heights of several thousand meters (tens of thousands of feet) during large eruptions.

Proglacial lake - A lake formed just beyond the frontal margin of an advancing or retreating glacier or ice sheet, generally at or near its lower end.

Radar (radio detection and ranging) - An electronic detection device or active system for locating or tracking a distant object by measuring elapsed circuit time of travel of ultrahigh frequency radio waves of known propagation velocity emitted from a transmitter and reflected back by the object to or near the point of transmission in such a way that range, bearing, height, and other characteristics of the object may be determined.

Volcanic (or magmatic) gases - Magma contains dissolved gases that are released into the atmosphere during eruptions. Gases also are released from magma that either remains below ground (for example, as an intrusion) or rises toward the surface. The most abundant gas typically released into the atmosphere from volcanic systems is water vapor $\left(\mathrm{H}_{2} \mathrm{O}\right)$, followed by carbon dioxide $\left(\mathrm{CO}_{2}\right)$ and sulfur dioxide $\left(\mathrm{SO}_{2}\right)$. Volcanoes also release smaller amounts of others gases, including hydrogen sulfide $\left(\mathrm{H}_{2} \mathrm{~S}\right)$, hydrogen $\left(\mathrm{H}_{2}\right)$, carbon monoxide (CO), hydrogen chloride (HCL), hydrogen fluoride (HF), and helium (He).

Volcanologist - A volcanologist is a person who studies volcanoes, lava, magma, and related geological and geophysical phenomena.

\section{Source of Glossary Definitions}

Bates, R.K., and Jackson, J.A., eds., 1987, Glossary of Geology, (3 ${ }^{\text {rd }}$ ed.): Falls Church, Va., American Geological Institute, 571 p.

U.S. Geological Survey, 2010, Volcano Hazards Program-USGS photo glossary of volcanic terms: U.S. Geological Survey website. (Available at http://volcanoes.usgs.gov/images/pglossarys/index.php.) 
Stein, Jess, ed., 1982, The Random House College Dictionary, revised edition: New York, Random House, Inc.

U.S. Geological Survey, 2010, Volcano Hazards Program-Volcanic gases and their effects: U.S. Geological Survey website. (Available at http://volcanoes.usgs.gov/hazards/gas/index.php.) 


\section{Volcano Activity Narrative}

It is September 17, a fine, crisp Sunday evening, and beginning at 8:15 PM and over the next several hours, AVO received reports of two discrete plumes (seen in the image) rising from the Cape Douglas area on the Alaska Peninsula within Katmai National Park and Preserve. Based on photo comparisons, the plume reached approximately 20,000 ft above sea level.

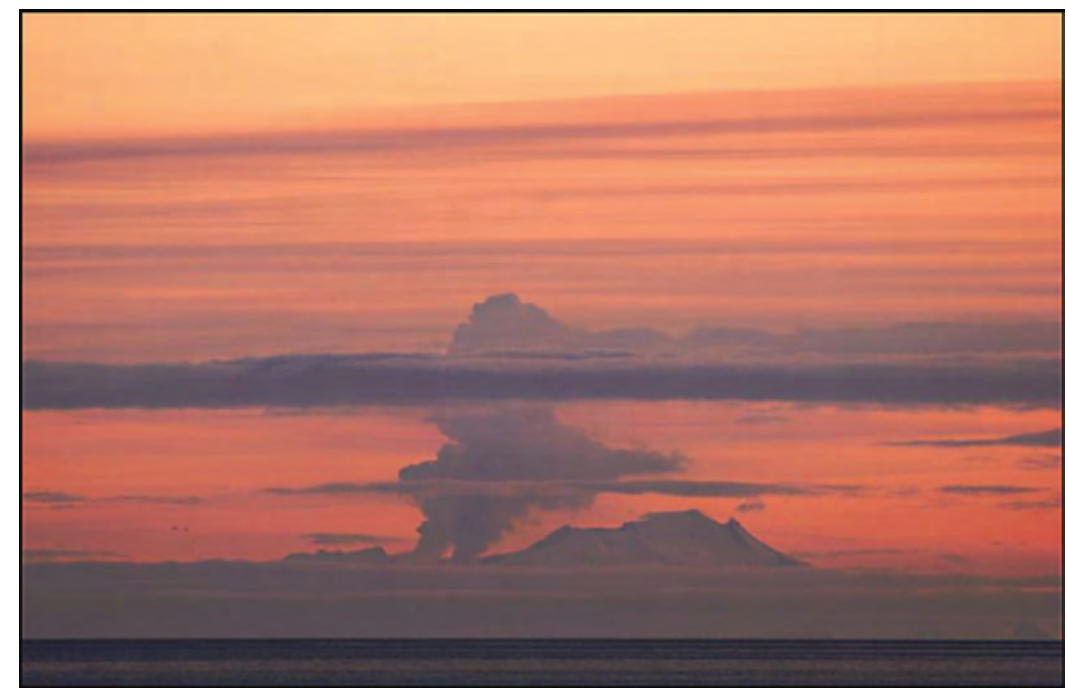

Cape Douglas from Main Street, Homer, Alaska, September 17, 2006. Photograph by Lanny Simpson, Alaska High Mountain Images, used with permission.

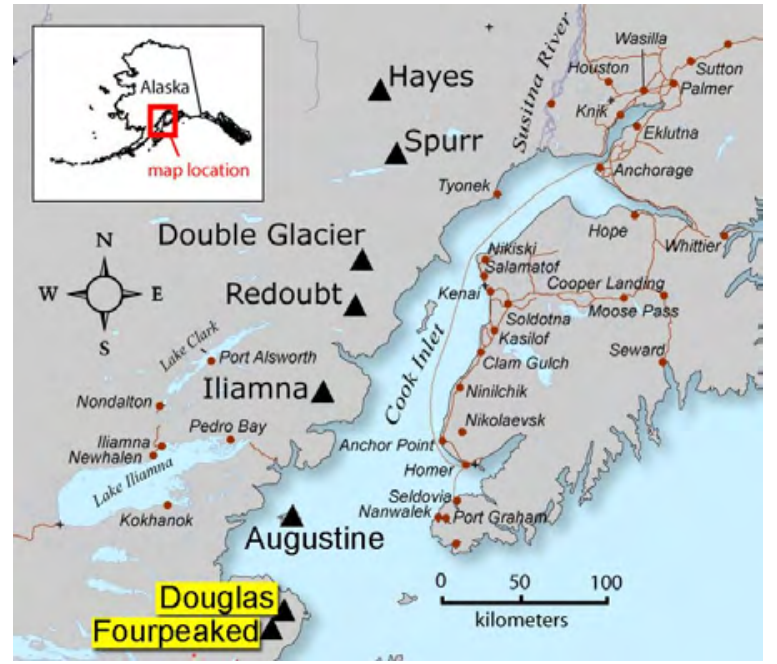

Location map of Cape Douglas emphasizing Fourpeaked and Douglas volcanoes (AVO website). 
Name

Date

Period

\section{Scientist-in-Charge (SIC)}

You are The Boss, the ultimate decision maker in the Observatory. You must manage your staff, take into consideration all data, activities, and assessments, and plan how to use your resources efficiently. You are directly responsible for the performance of the Observatory and for the accuracy, relevance, and timeliness of the information produced by the Observatory through a system of Activity Statements - a brief description of the activity at the volcano for a general audience and must include use of the Level of Concern Color Code.

\begin{tabular}{|c|l|}
\hline Green & No eruption anticipated. Volcano is in quiet, "dormant" state. \\
\hline Yellow & $\begin{array}{l}\text { An eruption is possible in the next few weeks and may occur } \\
\text { with little or no additional warning. Small earthquakes detected } \\
\text { locally and (or) increased levels if volcanic gas emissions. }\end{array}$ \\
\hline Orange & $\begin{array}{l}\text { Explosive eruption is possible within a few days and may occur } \\
\text { with little or no warning. Ash plume(s) bot expected to reach } \\
25,000 \text { feet above sea level. Increased numbers of local } \\
\text { earthquakes. Extrusion of lava dome or lava flows (non-explosive } \\
\text { eruption) may be occurring. }\end{array}$ \\
\hline Red & $\begin{array}{l}\text { Major explosive eruption expected within } 24 \text { hours. Large ash } \\
\text { plume(s) expected to reach at least 25,000 feet above sea level. } \\
\text { Strong earthquake activity detected even at distant monitoring } \\
\text { stations. Explosive eruption may be in progress. }\end{array}$ \\
\hline
\end{tabular}

Level of Concern Color Code

To deal with the reporting of volcanic activity you will lead Observatory staff in 15minute Discussions during which you must asses the situation and complete a wellwritten and brief Activity Statement with which your staff will concur. You must make sure that the Activity Statement gets to:

- Observatory staff

- Emergency Managers (includes Homeland Security, Borough Emergency Managers, and Village Safety Officers)

- Park Superintendent

- Media (TV, print, web-based news, and radio) 
To accomplish this, each Discussion is followed by a 5-minute Briefing. During this Briefing the non-Observatory staff will be invited into the Observatory and the Observatory Information Manager will convey your Activity Statement to them in the manner you see fit (print, digital presentation, orally, poster). The Observatory Information Manager will try to limit the access non-Observatory staff has to the Observatory scientists and yourself. It is up to you to decide if your staff must be present at the Briefing.

Remember you are in charge. You are the responsible party in the event the Activity Statement does not go out, or is flawed. You can and may assign the task to another individual, but you must see and approve the statement before it goes out.

You periodically will be given information pertaining to the time you will coordinate the next Activity Statement. 


\section{SIC}

\section{Discussion 1 (September 17-19)}

1 This Activity Statement needs to include all that you know right now without causing panic. Your information product needs to include the Observatory plans for dealing with this activity in the future. People who need the information you are generating likely do not know anything about Fourpeaked or Douglas volcanoes, not even where they are!

2 You also need permission from the Park Superintendent to conduct any fieldwork at Fourpeaked or Douglas volcanoes and you should notify him or her of increased volcanic activity!

\section{Discussion 2 (September 20-23)}

\section{SIC}

1 Today, September 21, you spoke with the Park Superintendent. You explained to the Park Superintendent the fieldwork you needed to do immediately. To access remote areas of the region, your staff will need to travel in small aircraft.

2 You also offered to get someone from the Observatory to the Park headquarters next week to provide a briefing to their staff.

3 You want your staff to inform the Park Superintendent the day before you fly, where you intend to fly, with whom, and what you intend to do. Eventually you may not need to do so, but for the first flights, you think it is best to do so. This gives the Park Superintendent an opportunity to note any sensitive areas and demonstrates that you respect their mission too.

4 In this Activity Statement, show what you have learned since the last statement. Continue to discuss a course of future action. \&

\section{Discussion 3 (September 24 - 26)}

\section{SIC}

1. Continue to re-evaluate the information you receive, and determine how you can describe it best to your audience. Describe what the Observatory and the volcano have done and what the Observatory will do. S

\section{Discussion 4 (September 27-)}

\section{SIC}

1. Develop a scenario or a set of scenarios describing the timing and likelihood of an eruption and the course of action (or plan) the Observatory is taking to continue to refine that list. Logically fit this into your Activity Statement. 
Name

Date

Period

\section{Information Manager}

You work closely with the boss, the Scientist-in-Charge (SIC), the ultimate decision maker in the Observatory. You and the SIC must cooperatively develop a series of Activity Statements during 15-minuute long Observatory Discussions. Activity Statements are a brief description of the activity at the volcano for a general audience and must include use of the Level of Concern Color Code. Following each Discussion is a 5minute Briefing. During the Briefing, the non-Observatory staff will be invited in by you.

- Emergency managers (includes Homeland Security, Borough Emergency Managers, and Village Safety Officers)

- Park Superintendent

- Media (TV, print, web-based, and radio)

You will convey the Activity Statement to them in the manner you and the SIC agree upon (print, digital presentation, orally, poster). You will try to limit the access nonObservatory staff has to the Observatory scientists and yourself.

You must make sure the Activity Statement is factual, well written, spoken and (or) illustrated, brief, and to the point. You must answer questions about it from the Briefing attendees. If you do not know the answer you should find it out and get back to the person who asked you the question during the next break or earlier.

\begin{tabular}{|c|l|}
\hline Green & No eruption anticipated. Volcano is in quiet, "dormant" state. \\
\hline Yellow & $\begin{array}{l}\text { An eruption is possible in the next few weeks and may occur } \\
\text { with little or no additional warning. Small earthquakes detected } \\
\text { locally and (or) increased levels if volcanic gas emissions. }\end{array}$ \\
\hline Orange & $\begin{array}{l}\text { Explosive eruption is possible within a few days and may occur } \\
\text { with little or no warning. Ash plume(s) bot expected to reach } \\
25,000 \text { feet above sea level. Increased numbers of local } \\
\text { earthquakes. Extrusion of lava dome or lava flows (non-explosive } \\
\text { eruption) may be occurring. }\end{array}$ \\
\hline Red & $\begin{array}{l}\text { Major explosive eruption expected within } 24 \text { hours. Large ash } \\
\text { plume(s) expected to reach at least 25,000 feet above sea level. } \\
\text { Strong earthquake activity detected even at distant monitoring } \\
\text { stations. Explosive eruption may be in progress. }\end{array}$ \\
\hline
\end{tabular}

Level of Concern Color Code 
You should know what kind of graphic tools (maps, diagrams, photographs, or video) are available in the event one of the groups you distribute the Activity Statement to wants to generate an article, website, or news story about it. You should stress the facts and not let your audience generate a panic situation in nearby communities.

Remember, your boss, the SIC, is the responsible party in the event the Activity Statement is not released or it is done poorly, but he or she can and may assign this task to another individual. However, he or she must see and approve the statement before it goes out.

You will be given guiding questions and information for you to use during each 15minute long Observatory Discussion.

\section{Information Manager}

\section{Discussion 1 (September 17 - 19)}

1 This Activity Statement needs to include all that you know right now without causing panic and it needs to include the plans the Observatory has for dealing with this activity in the future. People who need the information you are generating likely do not know anything about Fourpeaked or Douglas volcanoes, not even where they are!

2 On September 18

- Two pilots reported smelling sulfur while flying at an altitude of 11,000-12,000 ft above sea level, 200 mi west of Anchorage

- A heavy sulfuric smell and ash in the air were reported from two lodges in the Park

- One of your staff was able to collect a sample of ash fall on top of the glacier at Fourpeaked

3 On September 19, another lodge in the Park reported ash fall. \&

\section{Information Manager}

\section{Discussion 2 (September 20-23)}

1 Show progress in this Activity Statement, both in volcano activity and new information learned since the last statement. Include information on earthquake, other geophysical, satellite, or any other information, if available.

2 On September 20, residents in a nearby community reported ash fall.

3 On September 21, you received reports from a nearby community of a "mushroom cloud" like formation near Fourpeaked. 


\section{Information Manager}

\section{Discussion 3 (September 24-26)}

1. You received a call on September 25, from a pilot in a community near Fourpeaked. They wanted AVO to know that the waterfalls at the headwall of Fourpeaked Glacier and the sediment flowing into the lake at the foot of the glacier are normal occurrences that they have seen many times over their tens of years of flying in the area.

2. Continue to re-evaluate the information you are receiving and determine how you can best describe it to your audience. Describe what the Observatory and the volcano have done and what the Observatory will do.

\&

\section{Information Manager}

\section{Discussion 4 (September 27-)}

1 Develop a scenario or a set of scenarios describing the timing and likelihood of an eruption, or if an eruption has occurred, and the course of action (or plan) the Observatory is taking to continue to monitor the volcano. Logically fit this into your Activity Statement. 
Name

Date

Period

\section{Media}

This could be the story that makes or breaks your career! You are a budding new journalist and this kind of "killer" volcanic eruption could jettison you career into stardom! CNN, BBC, NPR, FOX, they will all be seeking you out if you get this one right! You could do a radio show, a blog, an on-line news report, or an actual printed newspaper article... the possibilities seem endless.

It is not likely that you will have loads of time to spend at the Observatory; they generally do not want you hanging out, no matter how much you would just love to be a fly on the wall. Periodically, throughout the eruption you will receive brief statements that you hope describe what is going on. You will have an opportunity to question the Observatory staff. Make the most of it, and be pushy, you want this story!

1. Do the Activity Statements you are given answer all your questions? Those questions that you think the public has?

2. Are there informative and exciting photographs, graphs, plots, figures that you can see or use?

3. Can you snag an interview with a scientist, how about the Scientist-in-Charge?

4. What about emergency managers and Park officials, what are they doing to plan?

5. How many people died? Were any planes downed by the eruption? What are the dangers that the current activity poses to people?

You are also tasked with writing articles (or producing radio or television broadcasts or presentations) for the public. You will need to develop and disseminate your products while the Observatory is developing those brief statements for you. You could try to have the public available for a Q\&A with you, write and distribute a story you hope they will read (catchy title!), or have a news-like segment with your adoring fans watching.

You will be given some leading questions to consider during each Briefing. 


\section{Media}

\section{Briefing 1}

1. Was there an eruption? If not, then what happened?

2. What does the Observatory know about this volcano specifically?

3. What kinds of fieldwork are scientists at the Observatory conducting? Do they have pictures of the volcano or of Observatory staff at work?

4. What is the color code level and why? \&

\section{Media}

\section{Briefing 2}

1. Did the plume(s) have ash in them? What kinds of gases were in the plumes?

2. Were there any earthquakes when those plume(s) formed?

3. Are there any pictures of the holes these plumes are coming from?

4. Was anyone hurt? Did this plume affect air traffic?

5. What is the color code and why, and what are the associated hazards to people on the ground and in the air?

\section{Media}

\section{Briefing 3}

1. Was there ash fall and if so, where?

2. What were those plume(s) made of?

3. Are there any pictures of the holes these plumes are coming from?

4. Was anyone hurt? Did this plume affect air traffic?

5. What is the color code and why, and what are the associated hazards to people on the ground and in the air? \&

\section{Media}

\section{Briefing 4}

1. So what is likely to happen at the volcano, what are staff at the Observatory doing?

2. Can we expect another event such as this one, and if so, when?

3. Are there any pictures of the holes these plumes are coming from or other features of this volcano?

4. Were flights cancelled or diverted due to the eruption?

5. What is the color code and why, and what are the associated hazards to people? 
Name

Date

Period

\section{Geophysicists}

You study earthquakes, satellite imagery, ground deformation, and other phenomena that could indicate how a volcano may be behaving physically and what it could do in the future. Almost all of your studies require some kind of instrument be in place on the ground at a volcano so you can assess its activity or some satellite image to show a particular feature that indicates activity.

This is an odd event for you to respond to because of the complete lack of instruments on the ground at this volcano! In all likelihood, you really want be asked at some point to come up with plans to install some geophysical devices on the volcano. In order to further your needs, you must design this network taking into consideration the phenomena that can be measured or visualized from other sources of data and determine how to build the best network possible under seasonal constraints. This area is covered with glacial ice and the only bare rock tends to make difficult spots to land a helicopter. Once winter sets in, you will not be able to access the volcano easily.

The Scientist-in-Charge (SIC) of the Observatory, your boss, will lead a series of 15minute long Discussions where he or she is gathering information to generate an Activity Statement - a brief description of the activity at the volcano for a general audience and must include use of the Level of Concern Color Code.

\begin{tabular}{|c|l|}
\hline Green & No eruption anticipated. Volcano is in quiet, "dormant" state. \\
\hline Yellow & $\begin{array}{l}\text { An eruption is possible in the next few weeks and may occur } \\
\text { with little or no additional warning. Small earthquakes detected } \\
\text { locally and (or) increased levels if volcanic gas emissions. }\end{array}$ \\
\hline Orange & $\begin{array}{l}\text { Explosive eruption is possible within a few days and may occur } \\
\text { with little or no warning. Ash plume(s) bot expected to reach } \\
\text { 25,000 feet above sea level. Increased numbers of local } \\
\text { earthquakes. Extrusion of lava dome or lava flows (non-explosive } \\
\text { eruption) may be occurring. }\end{array}$ \\
\hline Red & $\begin{array}{l}\text { Major explosive eruption expected within } 24 \text { hours. Large ash } \\
\text { plume(s) expected to reach at least 25,000 feet above sea level. } \\
\text { Strong earthquake activity detected even at distant monitoring } \\
\text { stations. Explosive eruption may be in progress. }\end{array}$ \\
\hline
\end{tabular}

Level of Concern Color Code

This is your opportunity to present new data and to lay out your network plans and image interpretations. Each Discussion is followed by a Break. During a Break, the Observatory Information Manager will present the Activity Statement to a group of people who need to know what is going on. 
Discussion 1 (September 17-19)

\section{Geophysicists}

1. Satellite images from the evening of September 17 show a cloud originating near Fourpeaked and Douglas volcanoes and persisting throughout the night. Satellite imagery does not indicate any ash in the cloud, which traveled as far as $12 \mathrm{mi}$ to the northeast. No thermal anomalies or areas on the ground that appear unusually warm or hot, were detected.

2. On September 18, you notice that the anomalies and plume reported are more likely from Fourpeaked than from Douglas. \&

Discussion 2 (September 20-23)

\section{Geophysicists}

You have some data to add during Discussions at specific points in time. These data sets are as follows and should be shared during the noted Discussion period.

On September 20, while working on seismic stations at Augustine volcano, you were able to take the helicopter to Fourpeaked

1. You obtained an ash sample

2. You also observed two steam plumes above Fourpeaked. The two steam plumes appeared, vigorous, similar in size, white (no evidence of ash), and were rising to $\sim 11,000 \mathrm{ft}$. Shown in photograph below (photograph taken by Guy Tytgat, Alaska Volcano Observatory/University of Alaska Fairbanks Geophysical Institute, September 20, 2006).

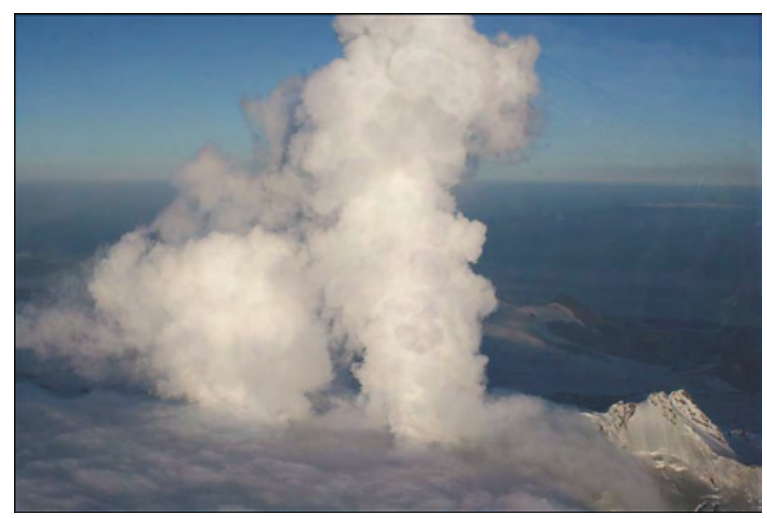

3. You detected a strong smell of rotten eggs as you approached Fourpeaked from the north. There is discoloration (gray) of the snow around the vent(s) from possible ash fall near the volcano in different direction, but the darkest snow (most ash deposits) was on the northwest side of the volcano. 
4. You also observed flow on the surface of the glacial ice on the northwest side of the mountain. The flow looked like mud coming out of the glacial crevasses and extending for quite a distance down the glacier. Shown in photograph below (photograph taken by Guy Tytgat, Alaska Volcano Observatory/University of Alaska Fairbanks Geophysical Institute, September 20, 2006).

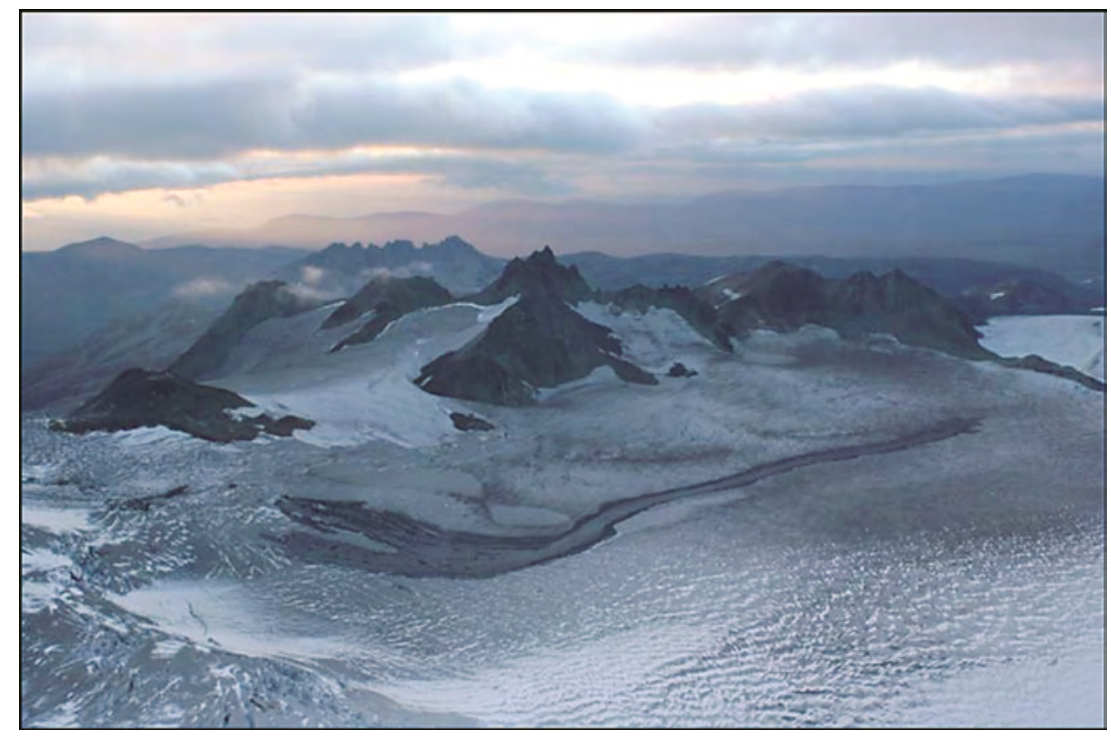

5. On September 20, you received an image from the closest weather radar station showing the volcanic cloud at Fourpeaked volcano on September 17 at 12:40 PM local time.

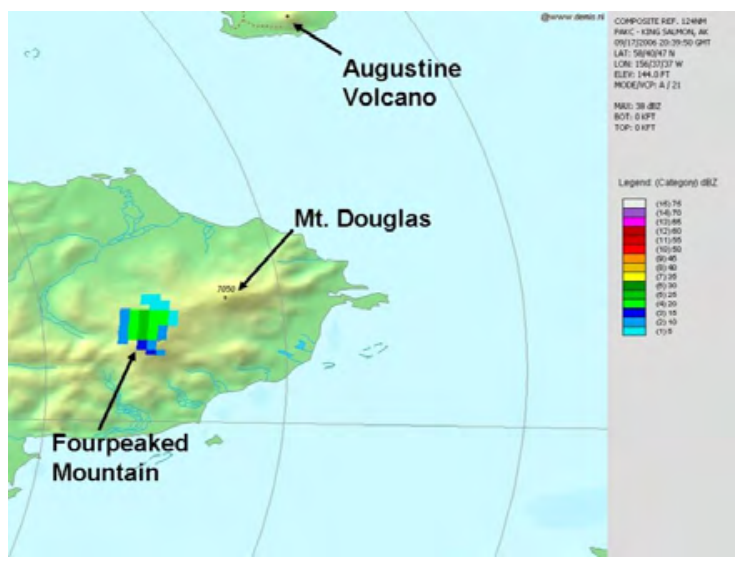

The color scheme shows a scale of radar reflectivity (from light blue-low, to dark green-moderate), which corresponds to greater numbers and (or) sizes of particles in the atmosphere. The figure shows retrospective analysis of radar data showing a signal above Fourpeaked volcano beginning at 12:00 noon on September 17. The cloud stayed over or near the vent for the entire time (that is, it was not observed drifting away). Remind your colleagues that the radar detects reflectors and cannot determine the cloud composition. This means that it can see, but not distinguish between large water droplets, ice particles, or coarse ash (like mm size [0.04 in.] [AVO website]). 
Also on September 20, colleagues emailed you an image showing the amount of sulfur dioxide in the atmosphere over Fourpeaked volcano at 3 PM on September 17.

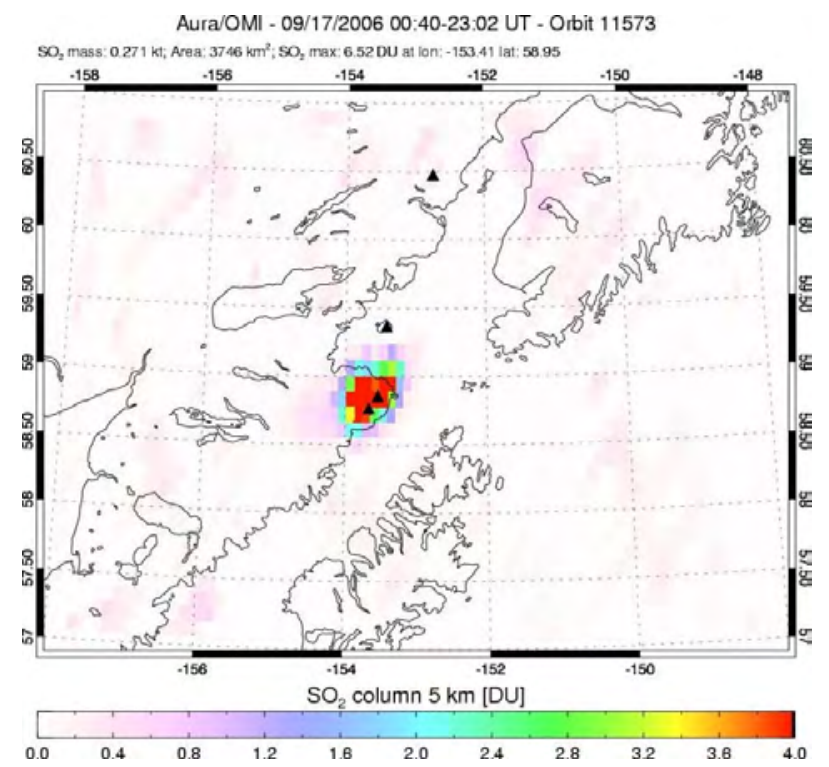

This image was created using data from the Ozone Monitoring Instrument (OMI) on NASA's EOS Aura satellite. This image confirms that the plume was volcanic! Nothing else you know of could produce approximately 300 tons of sulfur dioxide into the atmosphere except a volcano (AVO website).

6. Based on the satellite and weather radar data you now have, you ran the Puff volcanic ash dispersion model for the same time as the $\mathrm{SO}_{2} \mathrm{OMI}$ image you got from your colleagues in Maryland.

The Puff-generated image shows the predicted position of a volcanic cloud at 3 PM local time from Fourpeaked volcano on September 17. The Puff prediction showed the ash cloud to be 5 to $6 \mathrm{~km}$ above sea level (asl). The color scheme at the bottom of the image shows the altitude scale (asl) for the ash cloud from $0 \mathrm{~km}$ (purple) to $8 \mathrm{~km}$ (red) (AVO website).
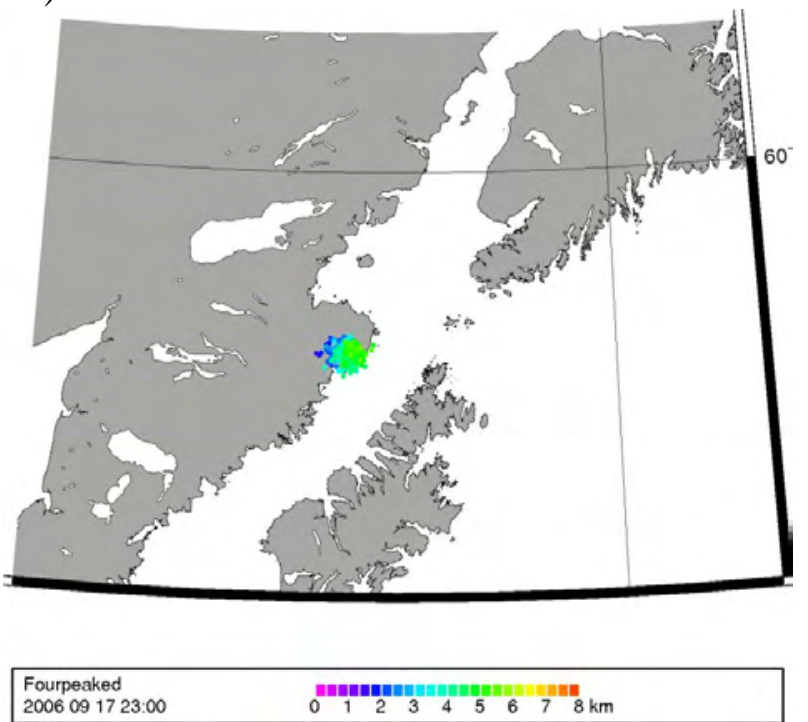
7. On September 21, you notice that a small swarm of earthquakes was detected on the regional seismic network from 11:48 AM to 3:50 PM on September 17.

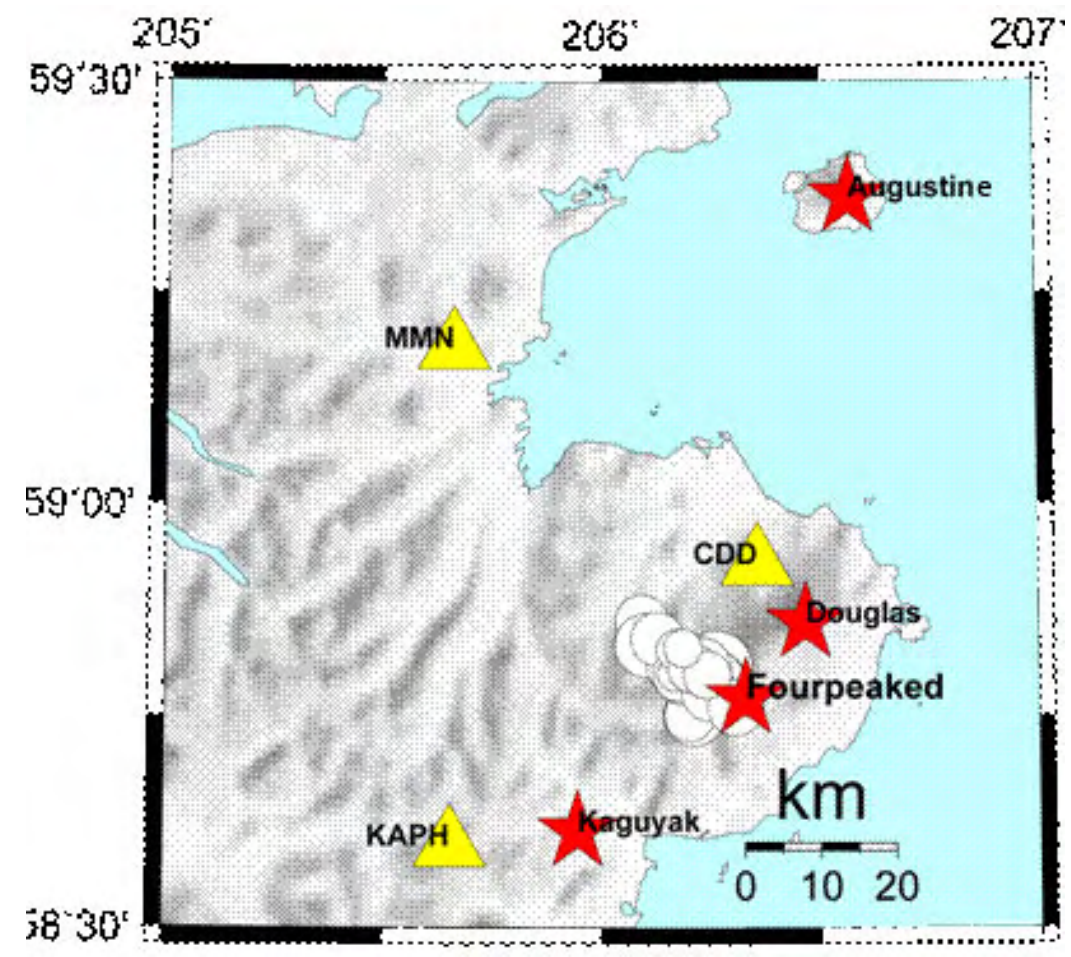

Sixteen of the earthquakes (white circles) were large enough to show up on stations in nearby Katmai, Oil Point, Augustine (yellow triangles), and in Kodiak (not pictured). The earthquake magnitudes were between 0.8 and 1.8 and were clustered to the northwest of the Fourpeaked summit. The red stars are volcanoes (AVO website). 
8. On September 23, you went on a gas flight (a small airplane flight to make observations and use equipment to determine the types and amount of volcanic gases coming from the volcano). You saw a linear series of vents to the north and just below the summit of Fourpeaked. Gas was abundant. You measured carbon dioxide $\left(\mathrm{CO}_{2}\right)$, and you measured and could smell sulfur dioxide (rotten egg smell- $\mathrm{SO}_{2}$ ), and hydrogen sulfide (striking a match smell $-\mathrm{H}_{2} \mathrm{~S}$ ). Shown in photograph below (Photograph taken by P. Cervelli, U.S. Geological Survey/Alaska Volcano Observatory, September 23, 2006).

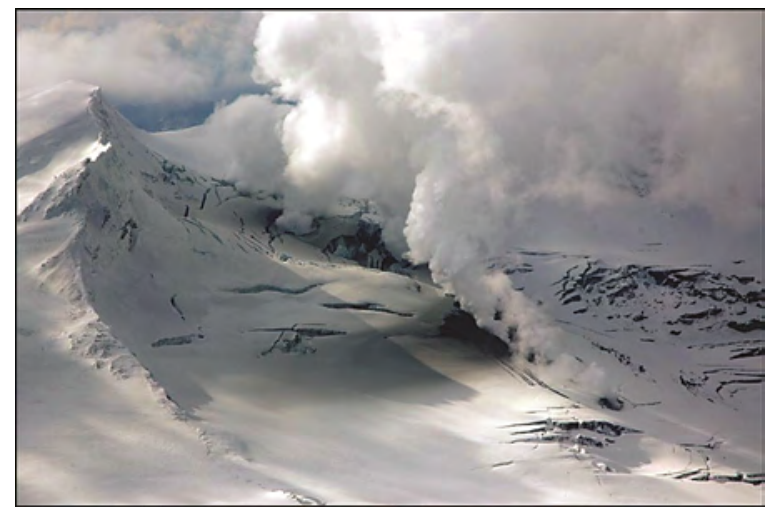




\section{Geophysicists}

\section{Discussion 3 (September 24 - 26)}

1. On Monday and Tuesday, September 24-25 you were one of the AVO staff in a helicopter visiting the Fourpeaked area and have the following to report:

- The nearest, but inoperable, seismometer (used to detect earthquakes) was repaired and a new station was installed 7 mi east of the volcano. Both instruments are now sending data to AVO.

- A campaign (non-telemetered) seismometer was installed 4 mi northwest of the summit (shown in the photograph below). This station recorded earthquake information on-site but could not automatically relay it to AVO facilities. Scientists would have to travel back to this site to retrieve the digital data storage card to view the data. (Photograph taken by R. Wessels, U.S. Geological Survey/Alaska Volcano Observatory, September 25, 2006.)

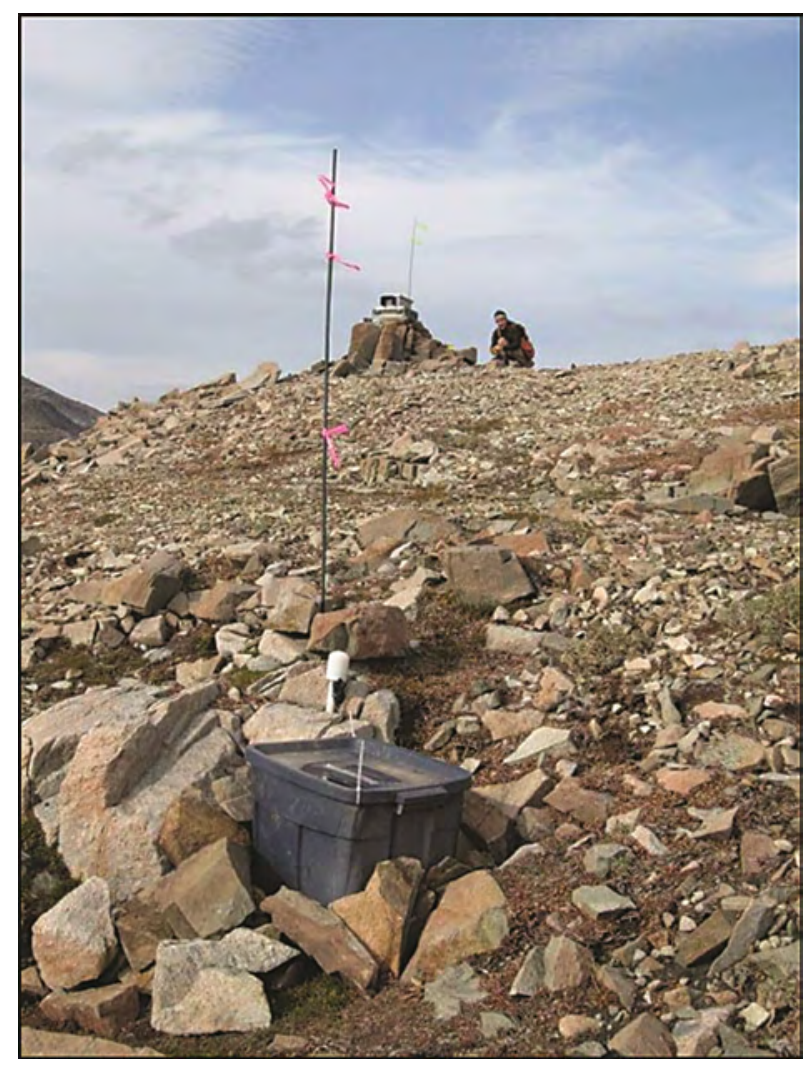

- Using a hand-held gas detection instrument you determined that gases emanating from a source of magma beneath the volcano were all present. 
- Along the $1 \mathrm{~km}$ long crack on the side of the summit glacier discrete vents are emitting gas. Using your Forward Looking Infrared Radiometer (FLIR), you determined these are the hottest surface areas along the crack and they reach temperatures $\sim 12^{\circ} \mathrm{C}\left(54^{\circ} \mathrm{F}\right)$. The color of the feature in the photograph corresponds to the color on the temperature scale shown in the FLIR images. The FLIR produces an image whose color scale correlates to the surface temperatures within the shot Dark purple to black features generally are the coldest and white to yellow features are the hottest. (Photograph taken by J. Adleman, November 4, 2006 (top) and FLIR by R. Wessels, September 24, 2006 (bottom), both of U.S. Geological Survey/Alaska Volcano Observatory).
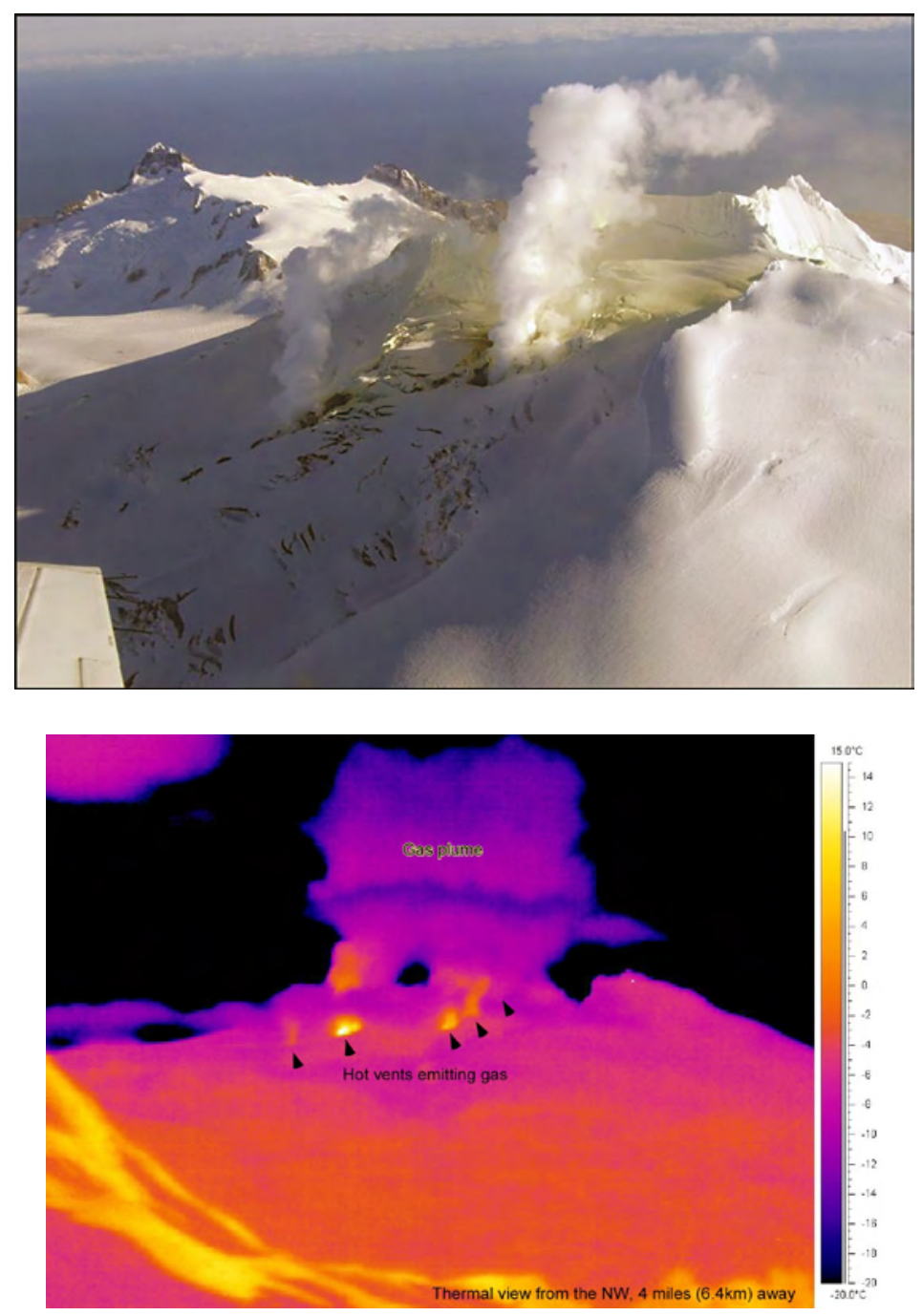
- Additionally, you used the FLIR to look at the water draining from inside a lobe of glacial ice (of the Fourpeaked Glacier), which drains into a proglacial lake and the end of the lobe. The geologists thought that the water might have been warm and anomalous. You determined that it was cool. Note the cool purple imaged water emanating from the glacier; seen below in the FLIR (R. Wessels, U.S. Geological Survey/Alaska Volcano Observatory, September 24, 2006) and visible photograph below (R. Wessels, U.S. Geological Survey/Alaska Volcano Observatory, September 20, 2006).
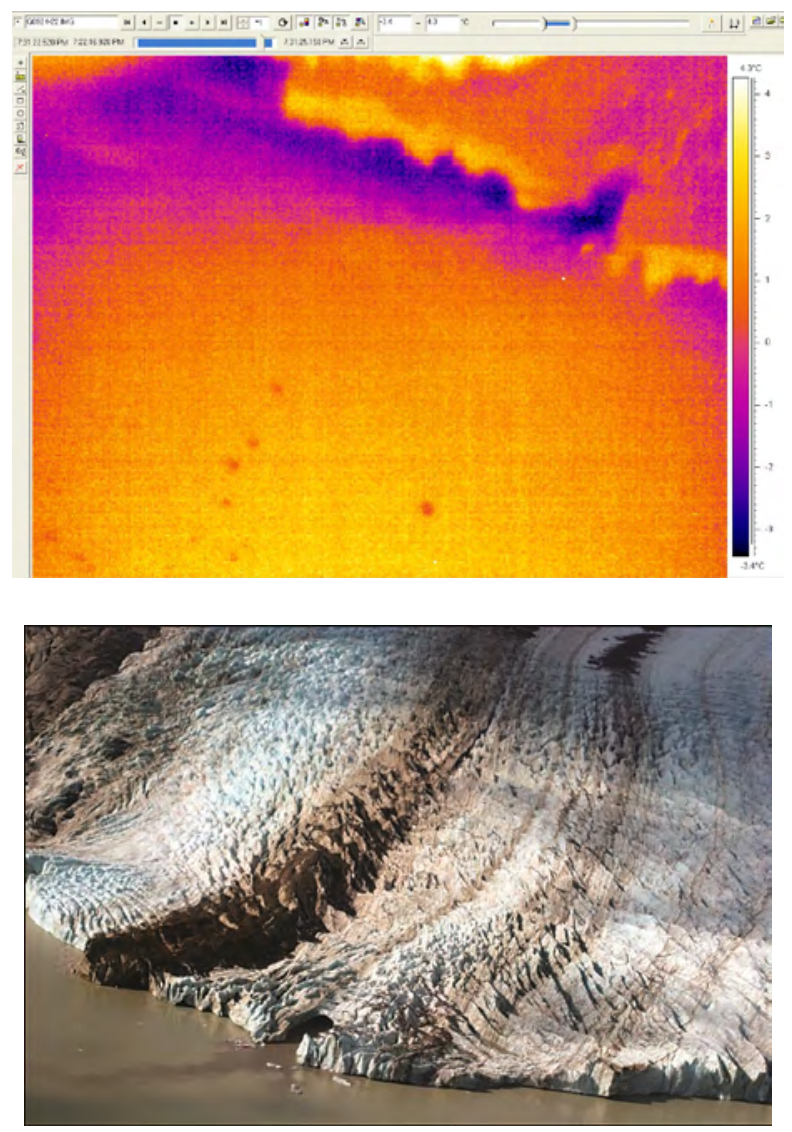
\&

\section{Discussion 4 (September 27 - )}

\section{Geophysicists}

1 Develop a scenario or a set of scenarios describing the timing and likelihood of an eruption (if you believe it was an eruption) or similar explosion or event and the course of action (or plan) the Observatory is taking to continue to refine that list. Logically fit this into your Activity Statement. 


\section{Geologists}

You study rocks, the products of current and previous volcanic eruptions, and the processes by which magma moves, erupts, and changes landforms at the Earth's surface. Working with you are volcanic gas, hydrology, and glaciology specialists. You also usually wind up flying in small planes to make visual observations and magmatic gas measurements. Your studies also require mapping, access to the ground (usually by helicopter), laboratory analysis, and assessment of any studies previously completed on the volcano in question.

This is an odd volcano to you because it has been poorly studied and there is no evidence of historic activity. In all likelihood, you will be asked to come up with plans to visit the volcano and look for evidence of historic or prehistoric eruptions. To plan your fieldwork, and the appropriate laboratory work to undertake, you must take into consideration information gathered by geophysicists and satellite remote sensors. This volcano is covered by glacial ice and the only bare rock tends to make difficult spots to land a helicopter to install instruments on the ground. Once winter sets in, you will not be able to access the volcano easily and geologic evidence will be buried by snow.

The Scientist-in-Charge (SIC) of the Observatory, your boss, will lead a series of 15minute long Discussions where he or she is gathering information in order to generate an Activity Statement - a brief description of the activity at the volcano for a general audience and must include use of the Level of Concern Color Code.

\begin{tabular}{|c|l|}
\hline Green & No eruption anticipated. Volcano is in quiet, "dormant" state. \\
\hline Yellow & $\begin{array}{l}\text { An eruption is possible in the next few weeks and may occur } \\
\text { with little or no additional warning. Small earthquakes detected } \\
\text { locally and (or) increased levels if volcanic gas emissions. }\end{array}$ \\
\hline Orange & $\begin{array}{l}\text { Explosive eruption is possible within a few days and may occur } \\
\text { with little or no warning. Ash plume(s) bot expected to reach } \\
25,000 \text { feet above sea level. Increased numbers of local } \\
\text { earthquakes. Extrusion of lava dome or lava flows (non-explosive } \\
\text { eruption) may be occurring. }\end{array}$ \\
\hline Red & $\begin{array}{l}\text { Major explosive eruption expected within } 24 \text { hours. Large ash } \\
\text { plume(s) expected to reach at least 25,000 feet above sea level. } \\
\text { Strong earthquake activity detected even at distant monitoring } \\
\text { stations. Explosive eruption may be in progress. }\end{array}$ \\
\hline
\end{tabular}

Level of Concern Color Code 
This is your opportunity to present new data and to lay out your plans and interpretations. Each Discussion is followed by a Briefing. During a Briefing, the Observatory Information Manager will be presenting the Activity Statement to a group of people who need to know what is going on.

You have some data to add during Discussions at specific points in time. These data sets should be shared during Discussion periods. 


\section{Geologists}

\section{Discussion 1 (September 17-19)}

Upon learning of the observed and possibly volcanic cloud, you and colleagues began to gather all the known information about Fourpeaked and Douglas volcanoes - those volcanoes are located closest to the plume observed and reported by people in Homer on the Kenai Peninsula in southcentral Alaska. From Wood and Kienle (1990) you learned that:

Fourpeaked Mountain consists of small isolated volcanic exposures surrounded by the Fourpeaked Glacier. The exposures are along ridge crests and cliff faces on the sides of ridges that radiate out from the icecovered summit. Lava flows are interlayered with volcanic agglomerate in the isolated exposures.

Orientation of lava flows suggests the present summit of Fourpeaked is probably the vent for Fourpeaked volcano. Extensive hydrothermal alteration of rocks in this area is consistent with this vent location.

Fourpeaked is known only from limited reconnaissance studies. The lavas are porphyritic andesite.

and

Mount Douglas is a dissected stratovolcano covered by ice of the Spotted Glacier. The summit of the volcano is marked by a crater with a small (160-m wide) crater lake. An active fumarole field on the north side of the crater keeps the area free of ice. A black scum floating on the lake in 1980 was probably sulfide minerals of some sort (consistent with a lake temperature of $25^{\circ} \mathrm{C}\left[77^{\circ} \mathrm{F}\right.$ ] [and a pH of 1 measured in 1982]).

Much of the volcano has been subjected to glacial erosion, but a ramp of lava flows on the northwest flank is relatively uneroded. Most of the volcano is icecovered, but isolated outcrops of lava flows (high-silica andesite) are in the ice. Reconnaissance geologic surveys suggest that the lavas extend to elevations lower than glacier's, but this has not been confirmed on the ground.

No historic activity has been reported for Mount Douglas; however, the presence of unglaciated lava flows and the active fumaroles indicate recent activity.

\section{Reference Cited}

Wood, C.A., and Kienle, Jürgen, eds., 1990, Volcanoes of North America-United States and Canada: Cambridge University Press, p.77-78, Contribution by S.E. Swanson. 
You also know:

Andesite is a volcanic rock with 56-64 weight percent silica and consists of large-grained crystals in a fine-grained groundmass.

Porphyritic texture displays minerals in two distinct size populations.

Agglomerate is a volcanic rock consisting of rounded and angular fragments fused together.

Fourpeaked and Douglas volcanoes are not monitored seismically. There are seismometers around the Katmai group of volcanoes, about $50 \mathrm{mi}(80 \mathrm{~km})$ to the southwest, and around Augustine volcano, $40 \mathrm{mi}(64 \mathrm{~km})$ to the north. 
$\&$

\section{Geologists}

\section{Discussion 2 (September 20-23)}

On September 20, you and other AVO staff were in a small plane visiting the Fourpeaked area and have the following to report:

1. At the terminus of Fourpeaked Glacier, dark-colored sediment is issuing from an elongate tunnel in the ice, shown in photograph below (photograph taken by $\mathrm{K}$ Wallace, U.S. Geological Survey/Alaska Volcano Observatory, September 20, 2006).

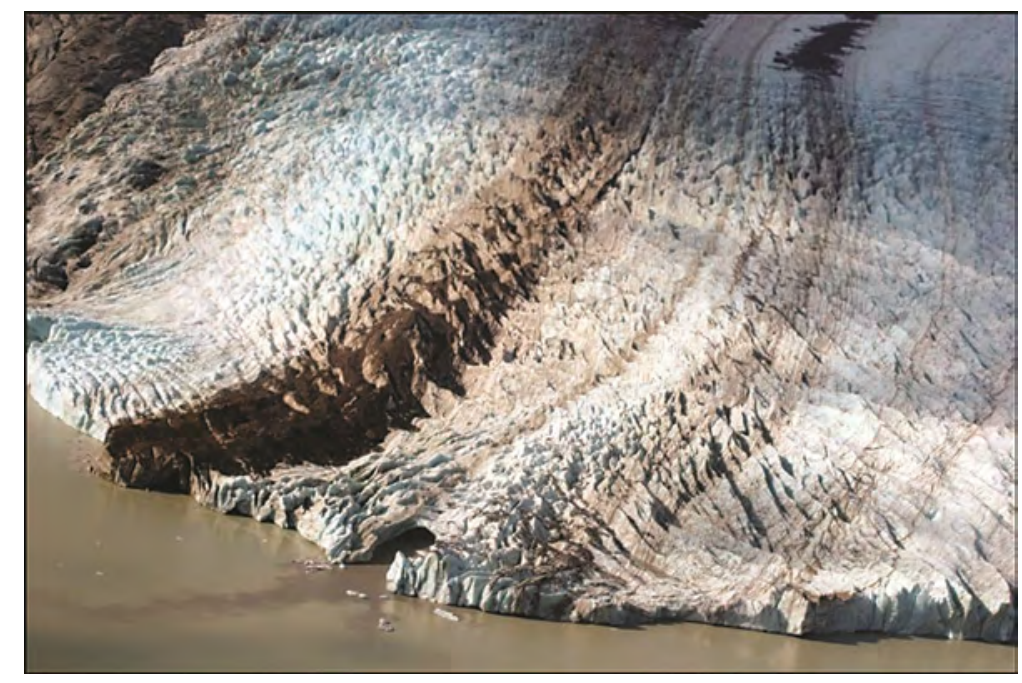

2. Looking toward the north-northwest, the southeast ridge of Fourpeaked volcano has distinct, white steam plumes, shown in photograph below (photograph taken by Guy Tytgat, U.S. Geological Survey/Alaska Volcano Observatory, September 20, 2009).

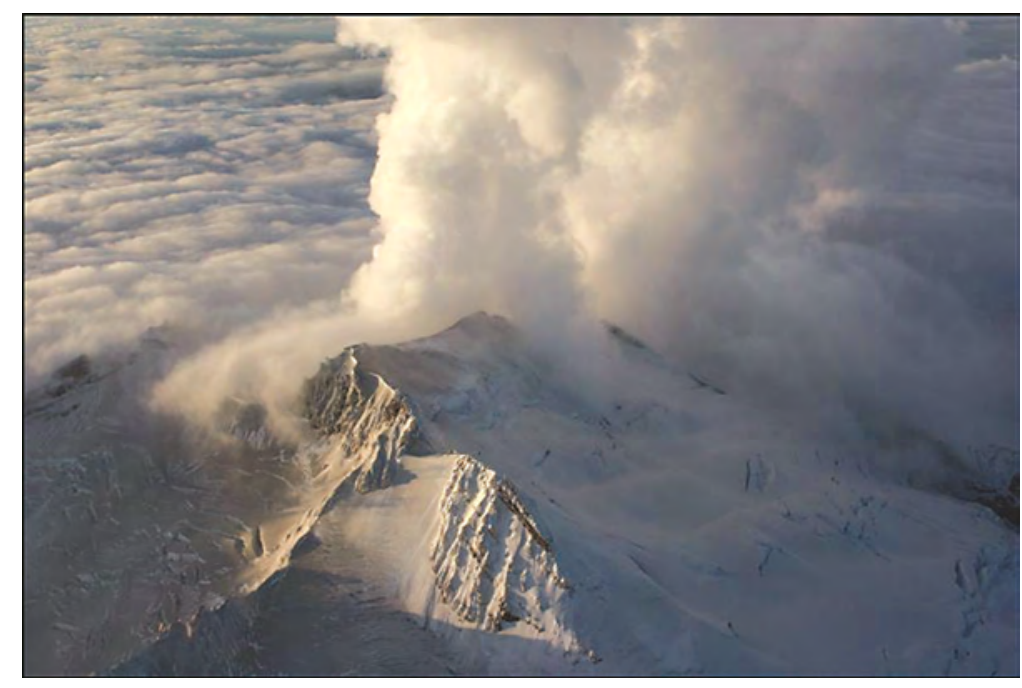

3. Looking due west at the flanks of Fourpeaked volcano, there are deposits of dirty, lobe-shaped flows and what is probably ash fall on top of the glacial ice. 
4. You observed the headwall of Fourpeaked Glacier just northeast of the summit of Fourpeaked volcano. Waterfalls were issuing from beneath the ice at the top of the headwall at an elevation of 5,000 ft (1,900 ft below the summit), shown in photograph below (taken by K. Wallace, U.S. Geological Survey/Alaska Volcano Observatory, September 20, 2009).

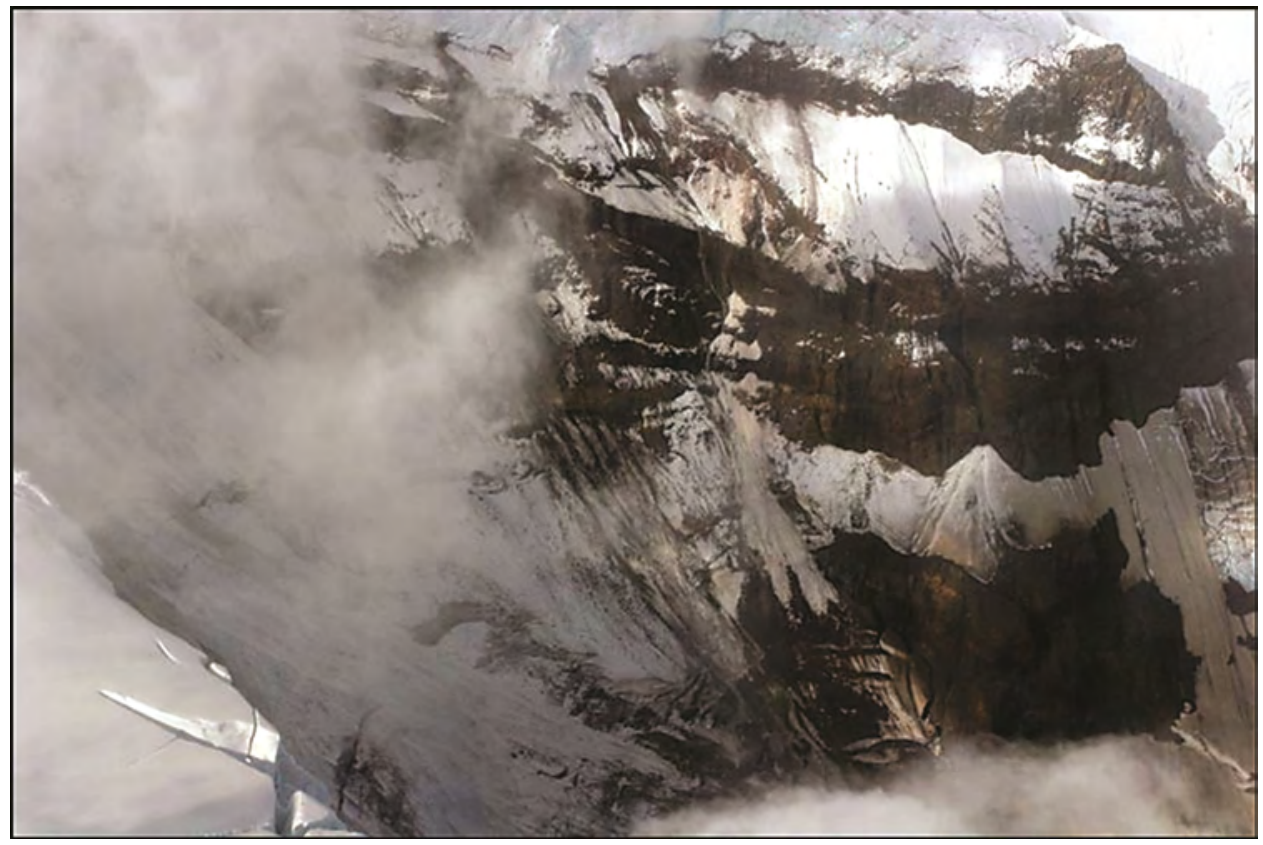

5. There is a strong sulfuric smell just east-southeast of the summit of Fourpeaked at $6,500 \mathrm{ft}$ above sea level.

6. A glaciologist on your staff calculated the elevation difference between a topographic map from 1951 and elevation data from satellite imagery from 2000 for Fourpeaked. The total ice loss (the most likely reason for the difference in elevation) on the volcano is $\sim 10.8 \mathrm{~km}^{3}\left(2.6 \mathrm{mi}^{3}\right)$ between the years.

7. These are your preliminary observations of the sample retrieved from Fourpeaked by your geophysicist colleague on September 20.

- The sample consists of coarse material and crystal fragments

- The coarse material appears to be primarily crystal fragments, some altered rock, and possibly some dark rock or glassy material.

- The crystal fragments look sharp and broken, rather than rounded or smooth.

- You did not see anything that looks obviously like glassy, bubble-filled ash in the coarse material.

- You did see a lot of pyrite (very metallic, gold colored, cubic, and striated facesalthough the grains are very tiny.)

- You warn that these observations are preliminary! 
\&

\section{Geologists}

Discussion 3 (September 24-26)

AVO geologists and other staff were on a gas measuring and observation flight on September 24. You crisscrossed the plume 20 times!

1. You had good views of the entire line of vents in the ice. You noted that the lower two pits were circular, the middle segment was elongate or maybe multiple, now coalesced vents, and it had multiple, vigorous steam sources and a fresh ring of ash around it. The upper region had at least three steam sources offset from the linear trend. There was no incandescence, although an outcrop of orange altered rock gave you a scare! Shown in the photograph below (taken by C. Read, U.S. Geological Survey/Alaska Volcano Observatory, September 24, 2009).

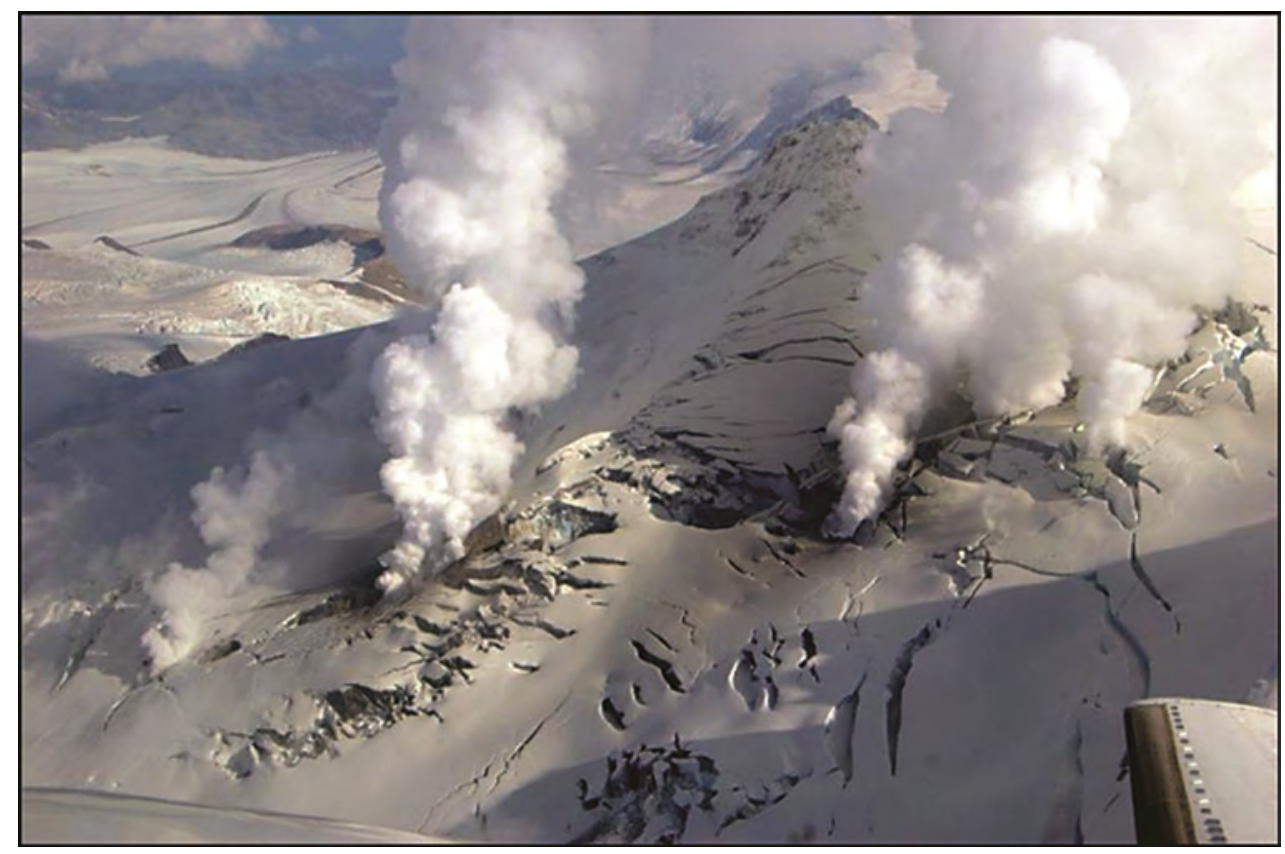

2. You also noted fresh snow since the September 20.

On Monday and Tuesday, September 24-25, geologists and other AVO staff were in a helicopter visiting the Fourpeaked area and have the following to report:

1. You were able to land on Fourpeaked glacier and you sampled the lobe shaped flows noticed on an earlier trip; shown in the photographs below (taken by K. Wallace U.S. Geological Survey/Alaska Volcano Observatory, September 25, 2006). 

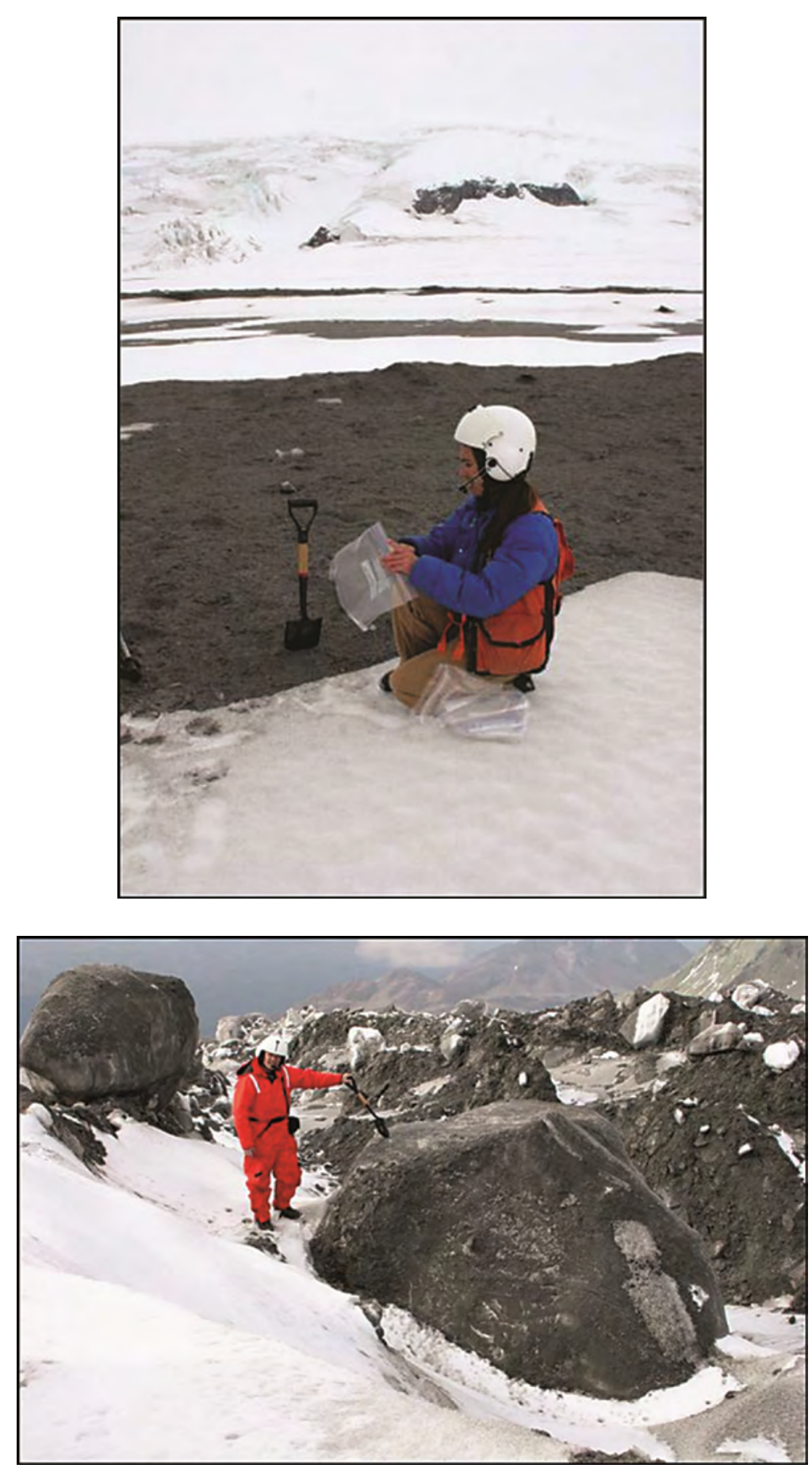

You collected samples from the lobate muddy surface flow and observed giant chunks of the glacier that may have been ripped up during the formation of these flows.

You were able to look at the riverbanks along the Douglas River and did not see any deposits corresponding to volcanic eruptive activity in the last few thousand years anywhere nearby. 


\section{Geologists}

Discussion 4 (September 27-)

1. Describe the timing and likelihood of an eruption, explosion, or event based on your findings from the last observations. Use historical and local information to make your report. Describe the timing and focus of the next set of observations/data collections that will be performed. 
Name

Date

Period

\section{Emergency Managers \\ (Homeland Security, Borough Emergency Managers, Village Public Safety Officers)}

You have the responsibility for communicating and implementing procedures, precautions and instructions, to the public in the event of a natural disaster or other emergency situation. This includes any volcanic activity within the state.

You must obtain accurate information regarding all volcanic activity before, during, and after a volcanic eruption. Your most likely source, but not your only source, for this information is the Alaska Volcano Observatory (AVO). You are also concerned with any information the media is releasing to the public. Information may be inaccurate, and you must be prepared to handle the questions and concerns the public. You may need to communicate with Federal, State, or local land managers in the event the activity affects regions within these land management units.

You will not have loads of time to spend at the Observatory learning every detail of the eruption or activity at hand. Periodically, throughout the eruption you will receive brief statements describing the volcanic activity. This may include information including forecasts of what activity is expected. You will periodically have an opportunity to question the Observatory staff. You have certain issues that must be dealt with.

1. What, exactly, is happening now, what will happen in the near future (when?) and what will the effects be?

2. What is the Observatory doing to mitigate the situation?

3. Will you need to order an evacuation, prepare residents for ash fall, mud flows, loss of communications, and transportation systems? Will there be power outages?

4. Is the volcano in a National Park? If so, what is the Park Superintendent doing about the local concerns?

You are tasked with providing guidance to the public. You will need to develop and disseminate your products while the Observatory is developing those brief statements for you. You could try to have the public available for a Q\&A with you. Write and distribute a set of instructions you hope they will read, or have a press conference.

You will be given some leading questions to consider during each Briefing. 


\section{Emergency Managers}

\section{Briefing 1}

1. Was there an eruption, explosion or other type or volcanic event?

2. What are the hazards to ground and air populations based on the activity that has already occurred?

3. What does the Observatory staff think will happen in the immediate future, how about in the long term?

4. What are staff of the Observatory doing to study this event and project what will happen next?

\&

\section{Emergency Managers}

\section{Briefing 2}

1. Did the plume(s) have volcanic ash and (or) magmatic gases in them?

2. Were there any earthquakes when those plume(s) formed?

\&

\section{Emergency Managers}

\section{Briefing 3}

1. Did ash fall anywhere nearby or distant from the volcano?

2. What were those plume(s) made of — steam, magmatic gases, rock shards?

\section{Emergency Managers}

\section{Briefing 4}

1. So what is likely to happen at the volcano, what is the Observatory doing?

2. What can we expect to be our main concerns for the next days, to weeks, or months? 
Name Date Period

\section{Park Superintendent}

You are the head of the National Park in which there are several active volcanoes. You keep in close communication with the Alaska Volcano Observatory (AVO) for two reasons. One is to hear about any volcanic activity that may lead to an eruption from a volcano within the lands you manage. The other reason is that the Observatory must have your permission to work within the Park.

You have the responsibility for communicating and implementing procedures, precautions, and instructions to Park staff and visitors in the event of a natural disaster or other emergency. This includes any volcanic activity within the Park. You and your staff also have an interpretive responsibility if the activity becomes a visitor attraction!

You must obtain consistently and quickly thorough and accurate information regarding all volcanic activity before, during, and after a volcanic eruption and any related work the Observatory may do within the Park. Your most likely source, but not your only source, for this information is the Alaska Volcano Observatory (AVO). You are also concerned with any information the media is releasing to the public. Even if it is inaccurate, you must be prepared to handle the questions and concerns this information will generate from the public. You may need to communicate with Federal, State, or local emergency managers in the event the activity affects communities within the Park.

You will not have loads of time to spend at the Observatory learning every detail of the eruption or activity at hand. Periodically, throughout the eruption you will receive brief statements describing the volcanic activity. This may include information including forecasts of what activity is expected. You will periodically have an opportunity to question the Observatory staff. You have certain issues that must be dealt with.

1. What, exactly, is happening now, what will happen in the near future (when?) and what will the affects be?

2. What is the Observatory doing to mitigate the situation?

3. Will you need to order an evacuation of staff? Will you need to order an evacuation of visitors? Will you need to prepare staff/visitors for ash fall, mudflows, loss of communications and transportation systems? Will there be power outages?

4. Is the volcano going to affect communities within or near the Park? What are emergency managers' concerns?

You will be given some leading questions and information to consider during each Briefing. 


\section{Park Superintendent}

\section{Briefing 1}

1. Was there an eruption, explosion, or other type or volcanic event?

2. What are the hazards to ground and air populations based on the activity that has already occurred?

3. What does the Observatory staff think will happen in the immediate future, how about in the long term?

4. What are staff of the Observatory doing to study this event and project what will happen next?

\section{Park Superintendent}

\section{Briefing 2}

1. Did the plume(s) have ash in them? Were there any earthquakes when those plume(s) formed?

2. Today, September 21, you spoke with the Observatory Scientist-in-Charge (SIC) about the fieldwork your staff needs to do to research the activity that occurred. The SIC also offered to get someone from the Observatory down here next week to provide a briefing to your staff.

\&

\section{Park Superintendent}

\section{Briefing 3}

1. Did ash fall anywhere nearby or distant from the volcano?

2. What were those plume(s) made of—-steam, magmatic gases, rock shards?

\&

\section{Park Superintendent}

\section{Briefing 4}

1. What is likely to happen at the volcano, what is the Observatory doing?

2. What can we expect to be our main concerns for the next days, weeks, or months? 
Name

Date

Period

\section{The Public}

What on Earth is going on? A volcanic eruption? In Alaska? Where? What should you do? Is it going to affect you, your daily routine? Do you need to prepare, plan, leave? You consider what resources are available to you: an observatory, the media, and government. You want to know what happened, what is likely to happen in the near future, and when, and what to do. You listen for any kind of public meetings, reports from friends and neighbors about what they heard, and what they say on the news.

At the very least, you would like to keep a journal about the experience! Maybe someday someone would want to read it. Photographs would not hurt either. So, you will make this your task-write down what you learn about this possible volcanic eruption practically in your own backyard! 
Name

Date

Period

\section{The Finer Points}

1. How did you feel information from each Alaska Volcano Observatory (AVO) subgroup (Scientist-in-Charge [SIC], Information Manager, Geologists, Geophysicists) was used to develop Activity Statements?

2. Was there equal value placed on each data set, or were some more important than others? Were there individuals or subgroups of AVO staff that were better at making themselves heard?

3. Did the media get all the information they wanted? Did their story reflect the statements made by the Observatory?

4. Did the emergency managers get the information they needed and wanted in a timely manner? Were their directions to the public a true reflection of what needed to happen?

5. Did the Park Superintendent get the information he or she needed and wanted in a timely manner? Was their permission sought for work done at the volcano? Were their directions to staff and visitors a true reflection of what needed to happen? 
6. Who spoke with whom? Did the media, emergency managers or Park Superintendent get to talk with anyone at the Observatory other than the Information Manager? Should they have?

7. This activity has few rules. Did the media, emergency managers, or Park Superintendent manage to get "into" the Observatory during discussions, and when they were there, did they manage to talk with anyone?

8. How did each person feel throughout the process: ignored, worried, angry, frustrated, or excited? Did your feelings have an effect on how you completed your job or a specific task?

9. In the end, did the public have the correct information in a timely and appropriate manner?

10. How could things have been improved? 
11. Imagine if this volcanic activity continued for weeks or months, or maybe even years. What kinds of changes do you imagine may take place in your procedures if you have to maintain them 24/7 indefinitely? What sorts of issues would a long explosive eruption in this part of Alaska raise for residents, businesses, and others?

12. The three AVO products shown below reflect the activity at Fourpekaed for the period you handled in the activity. AVO has several types of reports:

- Weekly Update-Issued on Fridays, reports on all Alaskan volcanoes

- Information Release or Statement-Issued on significant changes at an Alaskan volcano

- Status Report-Issued daily, reports on restless Alaskan volcanoes

AVO also uses two products when there is a change in color code at a volcano. One product is a Volcanic Activity Notice (VAN) and the other is a Volcano Observatory Notice to Aviation (VONA).

The included Weekly Updates and Status Reports have been abbreviated to show only Fourpeaked information. Complete reports included information for Cleveland and Veniaminof volcanoes, also at elevated levels of activity.

Additionally, a volcano can only be listed as GREEN in the Level of Concern Color Code if it is seismically monitored. Fourpeaked was not previously seismically monitored and therefore the Level of Concern Color Code was Not Assigned.

How do the four reports made by your Observatory scenario compare to those made by AVO? 


\section{ALASKA VOLCANO OBSERVATORY Information Release Monday, September 18, 2006 2:20 PM AKDT (2220 UTC)}

DOUGLAS VOLCANO (CAVW\#1102-27-)

5851'18" N153³2'31" W, Summit Elevation 7021 ft (2140 m)

Current Level of Concern Color Code: Not Assigned

FOURPEAKED VOLCANO (CAVW\#1102-26-)

5846'12" N15340'19" W, Summit Elevation 6903 ft (2104 m)

Current Level of Concern Color Code: Not Assigned

On Sunday, September 17, AVO received several reports of two discrete plumes rising from the Cape Douglas area, about 200 miles (320 km) southwest of Anchorage, beginning at approximately 8:15 PM AKDT (0415 UTC, September 18) and continuing until darkness. Analysis of satellite images shows that the plumes originated in the area of Fourpeaked Glacier, located between Fourpeaked and Douglas volcanoes. Photographs of the plumes show that they reached up to approximately $20,000 \mathrm{ft}(6,000 \mathrm{~m})$ above sea level.

Satellite images show a cloud originating from Fourpeaked glacier area and persisting throughout the night. The cloud does not show an ash signature. The cloud traveled up to 12 miles $(20 \mathrm{~km})$ to the northeast.

Fourpeaked and Douglas volcanoes are not monitored seismically. Seismometers around the Katmai group of volcanoes, about 50 miles $(80 \mathrm{~km})$ to the southwest, and around Augustine volcano, 40 miles $(64 \mathrm{~km})$ to the north, did not record any unusual seismic activity. Based on the absence of an ash signature in the cloud in satellite data, a significant volcanic eruption did not occur. The origin of the two plumes is still unknown.

Poor weather in the area today prevents further visual observations. AVO will continue to monitor the area via satellite and local pilot reports. AVO will attempt an overflight of the area later this week.

Mount Douglas, a 2,140 m (7,020 ft) high stratovolcano, is located on the northern tip of the Alaska Peninsula, $320 \mathrm{~km}$ (200 mi) southwest of Anchorage. The summit of Mount Douglas has a small lake-filled crater, and an active fumarole field on the northeast crater wall. In 1982, the crater lake had a temperature of 25 degrees $\mathrm{C}$ (77 degrees F) and a pH of 1. Although Mount Douglas is dissected and eroded, lava flows on the northwest flank are relatively uneroded. Douglas has not experienced eruptive activity within historical times; the most recent eruption was in the early Holocene. 
Fourpeaked Mountain lies within the northeast corner of Katmai National Park and Preserve on the Alaska Peninsula, 7.5 miles $(12 \mathrm{~km})$ southwest of Mount Douglas. It is the likely vent for Fourpeaked volcano, a stratovolcano that is mostly surrounded (and covered) by Fourpeaked Glacier. Small isolated volcanic exposures along ridge crests and cliff faces radiate out from the ice-covered summit. The last volcanic activity at Fourpeaked was probably greater than 10,000 years ago. No recent volcanic or hydrothermal activity has been identified.
ABBREVIATED COLOR CODE KEY (contact AVO for complete description):
GREEN volcano is dormant; normal seismicity and fumarolic activity occurring YELLOW volcano is restless; eruption may occur
ORANGE volcano is in eruption or eruption may occur at any time
RED significant eruption is occurring or explosive eruption expected at any time 


\title{
ALASKA VOLCANO OBSERVATORY Information Release Wednesday, September 20, 2006 2:25 PM AKDT (2225 UTC)
}

\author{
FOURPEAKED VOLCANO (CAVW\#1102-26-) \\ 5846'12" N15340'19" W, Summit Elevation 6903 ft (2104 m) \\ Current Level of Concern Color Code: YELLOW
}

On Sunday evening, September 17, AVO received numerous reports of a large unusual cloud rising to heights of 20,000 ft (6,000 m) above sea level from the Cape Douglas area, about 200 miles (320 km) southwest of Anchorage and about 80 miles (140 km) northwest of Kodiak. Since our Monday, September 18 Information Release, additional data and observations of the September 17 event have been compiled from several new sources. These data confirm that the source of the large cloud observed Sunday evening was volcanic. Thus, AVO is increasing the Level of Concern Color Code for Fourpeaked volcano from "Not Assigned" to YELLOW

The exact location of the source is still unknown. Satellite and radar data suggest a source low on the flank of Fourpeaked volcano and we are assigning this activity to Fourpeaked based on this data. However, this location has not yet been confirmed by visual observations.

New details of Sunday's event have been added since Monday afternoon:

Retrospective analysis of data from the NEXRAD Doppler radar in King Salmon show an unusual cloud starting at 12:00 PM AKDT (2000 UTC) on September 17. The maximum cloud height determined by radar during the first hour of the event was 20,000 $\mathrm{ft}(6,000 \mathrm{~m})$. The radar return from the cloud continued until at least 9:45PM AKDT (0545 UTC).

A cloud of sulfur dioxide gas released during the eruption was observed by colleagues at the University of Maryland Baltimore County over Cape Douglas/Fourpeaked region on September 17, 2006 at 3:00PM AKDT (2300 UTC) using data collected by the Ozone Monitoring Instrument (OMI) on NASA's Aura satellite.

Puff particle dispersion modeling showed that the cloud would have spread west to east as it moved northwards over the subsequent day. This is consistent with pilot reports received by AVO on the afternoon of Monday, September 18, that described a strong sulfur smell in the Stony River Valley, 300 km (180 miles) northwest of the Fourpeaked area, and from additional OMI sulfur dioxide observations of the cloud.

Although satellite data did not detect ash during this event, AVO received reports of a trace of ashfall at Nonvianuk Lake outlet $(110 \mathrm{~km}$, about 70 miles, west-northwest of the volcano) and near Homer (about 95 miles northeast of the volcano). 
Although poor weather in the area has prevented visual observations, NEXRAD data over the past two days have not detected any further emissions. AVO staff will attempt both fixed-winged and helicopter overflights this afternoon to locate the possible vent areas and document any changes. AVO continues to monitor satellite data for further signs of activity.

Fourpeaked Mountain lies within the northeast corner of Katmai National Park and Preserve on the Alaska Peninsula, 7.5 miles $(12 \mathrm{~km})$ southwest of Mount Douglas. It is the likely vent for Fourpeaked volcano, a stratovolcano that is mostly surrounded (and covered) by Fourpeaked Glacier. Small isolated volcanic exposures along ridge crests and cliff faces radiate out from the ice-covered summit. The last volcanic activity at Fourpeaked was probably greater than 10,000 years ago. No recent volcanic or hydrothermal activity has been identified.

ABBREVIATED COLOR CODE KEY (contact AVO for complete description): GREEN volcano is dormant; normal seismicity and fumarolic activity occurring YELLOW volcano is restless; eruption may occur ORANGE volcano is in eruption or eruption may occur at any time RED significant eruption is occurring or explosive eruption expected at any time 


\title{
ALASKA VOLCANO OBSERVATORY \\ Current Status Report \\ Thursday, September 21, 2006 12:45 PM AKDT (2045 UTC)
}

\author{
FOURPEAKED VOLCANO (CAVW\#1102-26-) \\ 5846'12" N15340'19" W, Summit Elevation 6903 ft (2104 m) \\ Current Level of Concern Color Code: YELLOW
}

AVO staff conducted both fixed-wing and helicopter overflights in the Cape Douglas area Wednesday afternoon and confirmed the source of volcanic activity reported on Sunday, September 17 to be Fourpeaked volcano.

Weather clouds partly obscured the summits of Douglas and Fourpeaked volcanoes yesterday, however a strong sulfur smell was noted immediately downwind (east) of Fourpeaked volcano and two white vapor plumes rose through the cloud deck as high as 2000 feet $(610 \mathrm{~m})$ above the approximate summit of the volcano (6903 ft, $2100 \mathrm{~m})$.

Analysis of photographs and other data is ongoing. AVO continues to monitor Fourpeaked using satellite images. There is currently no real-time seismic network on the volcano and AVO is unable to track local earthquake activity that may indicate volcanic unrest.

\section{ALASKA VOLCANO OBSERVATORY \\ Current Status Report \\ Friday, September 22, 2006 12:10 PM AKDT (2010 UTC)}

\section{FOURPEAKED VOLCANO (CAVW\#1102-26-) \\ 5846'12" N15340'19" W, Summit Elevation 6903 ft (2104 m) \\ Current Level of Concern Color Code: YELLOW}

Satellite images of Fourpeaked volcano have been obscured by clouds over the past day.

AVO continues to monitor Fourpeaked using satellite images. There is currently no realtime seismic network on the volcano and AVO is unable to track local earthquake activity that may indicate volcanic unrest. 


\title{
ALASKA VOLCANO OBSERVATORY \\ Weekly Update \\ Friday, September 22, 2006 12:45 PM AKDT (2045 UTC)
}

\author{
FOURPEAKED VOLCANO (CAVW\#1102-26-) \\ 5846'12" N15340'19" W, Summit Elevation 6903 ft (2104 m) \\ Current Level of Concern Color Code: YELLOW
}

AVO raised the Level of Concern Color Code for Fourpeaked volcano from "Not Assigned" to YELLOW on Wednesday, September 20. A large steam explosion near the summit of Fourpeaked volcano occurred on Sunday, September 17 beginning at approximately 12:00 noon AKDT (2000 UTC, September 18). Photographs and NEXRAD weather radar show that the plume reached up to approximately 20,000 ft $(6,000 \mathrm{~m})$ above sea level. Satellite images showed a cloud originating from Fourpeaked volcano, and persisting throughout the night. No ash or thermal anomalies have been detected in satellite images. The plume was visible on NEXRAD until 9:45 PM AKDT September 17 (0545 September 18 UTC). AVO staff conducted both fixed-wing and helicopter overflights in the Cape Douglas area September 20 and confirmed the source of volcanic activity to be Fourpeaked volcano.

A small but distinct SO2 cloud over the area was detected by researchers from the Univ. of Maryland-Baltimore County using a new NASA satellite-based UV sensor (the Ozone Mapping Instrument, or OMI) at 3:00 PM AKDT (2300 UTC) September 17. Puff windfield modeling showed that the plume would have spread west and then moved north over the next day or so. This is consistent with pilot reports received by AVO on September 18 that described a strong sulfur smell in the Stony River Valley, 200 miles west of Anchorage. Subsequent passes of the OMI have also shown an SO2 cloud whose position is consistent with Puff modeling. AVO has received several accounts of very light ashfall, in Homer and near Nonvianuk Lake in Katmai National Park, that are also consistent with Puff modeling.

There is currently no real-time local seismic network on the volcano. The closest seismometer is 40 miles $(64 \mathrm{~km})$ to the north. A small swarm of tectonic earthquakes was detected on the regional seismic network from 11:48 AM to 3:50 PM AKDT (19:48 to 23:50 UTC) September 17. No explosion signals were detected seismically, but the infrasound array at the University of Alaska-Fairbanks picked up a signal from the Fourpeaked area with an origin time consistent with the other data.

There have been no known historical eruptions of Fourpeaked and no known geologic evidence for activity in the last 10,000 years. These factors and the lack of close-in seismic monitoring limit AVO's ability to forecast likely future activity. A helicopter flight is scheduled for this weekend to make geologic observations, collect samples, and install telemetered seismometers. AVO continues to monitor Fourpeaked using satellite images. 


\title{
ALASKA VOLCANO OBSERVATORY \\ Current Status Report \\ Saturday, September 23, 2006 12:55 PM AKDT (2055 UTC)
}

\author{
FOURPEAKED VOLCANO (CAVW\#1102-26-) \\ 5846'12" N15340'19" W, Summit Elevation 6903 ft (2104 m) \\ Current Level of Concern Color Code: YELLOW
}

Satellite images of Fourpeaked volcano have been obscured by clouds over the past day. A fixed-wing mission to sample gases at Fourpeaked and Cook Inlet volcanoes is in progress.

AVO continues to monitor Fourpeaked using satellite images. There is currently no realtime seismic network on the volcano and AVO is unable to track local earthquake activity that may indicate volcanic unrest.

\section{ALASKA VOLCANO OBSERVATORY \\ Current Status Report \\ Sunday, September 24, 2006 12:30 PM AKDT (2030 UTC)}

FOURPEAKED VOLCANO (CAVW\#1102-26-)

5846'12" N15340'19" W, Summit Elevation 6903 ft (2104 m)

Current Level of Concern Color Code: YELLOW

On Saturday, September 23, AVO flew an observation flight over Fourpeaked volcano. Relatively good weather permitted the first look at the volcano's summit since the event of September 17. Observers saw a linear series of vents running north from the summit for about $1 \mathrm{~km}$. Most of these vents were vigorously emitting steam and other volcanic gases. In the immediate vicinity of the vents, the glacier had been disrupted. Gas measurements indicated abundant quantities of sulfur dioxide, hydrogren sulfide, and carbon dioxide. The sulfur species could be smelled easily by the observers on the flight at distances of up to $50 \mathrm{~km}$ from the Fourpeaked summit.

There are three field missions in progress at Fourpeaked today: (1) the installation of seismic instrumentation; (2) geologic observations; and (3) airborne thermal and gas measurements.

AVO continues to monitor Fourpeaked using satellite images. There is currently no realtime seismic network on the volcano and AVO is unable to track local earthquake activity that may indicate volcanic unrest. 


\section{ALASKA VOLCANO OBSERVATORY \\ Current Status Report \\ Monday, September 25, 2006 1:30 PM AKDT (2130 UTC)}

FOURPEAKED VOLCANO (CAVW\#1102-26-)

5846'12" N15340'19" W, Summit Elevation 6903 ft (2104 m)

Current Level of Concern Color Code: YELLOW

Aerial observations over the weekend indicate that unrest continues at Fourpeaked volcano. A series of pits and elongate openings through glacial ice high on the north flank of the volcano are emitting significant amounts of volcanic gas and steam. Channels and debris fans on the ice field indicate that outbursts of water have occurred. A helicopter is in the area today to make additional geologic and thermal observations and to install a time-lapse camera and one or two seismic stations near the volcano. 


\title{
ALASKA VOLCANO OBSERVATORY Information Release Monday, September 25, 2006 3:35 PM AKDT (2335 UTC)
}

\author{
FOURPEAKED VOLCANO (CAVW\#1102-26-) \\ 5846'12" N15340'19" W, Summit Elevation 6903 ft (2104 m) \\ Current Level of Concern Color Code: YELLOW
}

On September 17, an explosion of ash, gas, and steam from Fourpeaked Mountain 320 km (200 mi) SW of Anchorage on the Alaska Peninsula marked the onset of unrest at this long-dormant, ice-clad volcano. AVO elevated the level of concern color code to YELLOW on September 20. Since then, AVO has gathered aerial and ground-based information and also initiated installation of geophysical instrumentation to better track activity at Fourpeaked. Based on our observations and limited geologic understanding of the volcano, it is possible that significant eruptive activity could occur in the coming days to weeks.

Over the weekend and continuing today, AVO flew a variety of missions to Fourpeaked volcano. The main findings are as follows: (1) Observers saw a linear series of vents running north from the summit for about $1 \mathrm{~km}(0.6 \mathrm{mi})$. Most of these vents were vigorously emitting steam and other volcanic gases. In the immediate vicinity of the vents, the glacier had been disrupted and showed signs of subsidence. (2) Gas measurements reveal that emission rates of sulfur dioxide, hydrogren sulfide, and carbon dioxide were all high. The sulfur dioxide emission rate was roughly equivalent to that measured at Augustine before its January 2006 eruptions. A distinct sulfur smell was evident up to $50 \mathrm{~km}$ (30 mi) from Fourpeaked's summit. (3) Marked scouring of a glacier flowing west from the summit indicates flooding, probably from the September 17th event. (4) Thermal measurements of 60 degrees C (140 degrees F) where recorded at the vents, though the abundant steam was likely obscuring hotter areas.

All evidence, including the ash emission of September 17th, the abundant volcanic gases, the presence of new vents at the summit, and the disruption and floods occurring at and below the summit glaciers, suggest the presence of new magma at shallow levels beneath the volcano. Because AVO has had no instrumentation network on Fourpeaked, we do not have the geophysical measurements necessary to provide independent evidence for the presence of new magma.

Fourpeaked volcano is not known to have erupted in the last 10,000 years, though geological investigations have been limited and ice covers much of the area. Because of this, the range of sizes and styles of past eruptions is not well-constrained. However, the composition of the volcano indicates that eruptions of Fourpeaked can be explosive, possibly producing plumes that reach in excess of $10 \mathrm{~km}(33,000 \mathrm{ft})$ above sea level and local ashfall. 
Based on all currently available evidence, AVO believes that an eruption from Fourpeaked in the next days to weeks is possible. Given below are some possible future scenarios for the current unrest at Fourpeaked, listed in order, with the most likely scenario listed first:

1. A small to moderate eruption will occur, which may produce ash plumes exceeding $10 \mathrm{~km}(33,000 \mathrm{ft})$ above sea level. Lava flows may also occur.

2. No eruption occurs. Unrest gradually subsides to background levels.

3. A large eruption will occur, which would produce ash plumes exceeding $10 \mathrm{~km}$ $(33,000 \mathrm{ft})$ above sea level, and possible widespread ash fall.

Even minor volcanic activity can result in floods, debris flows, and lahars (volcanic mud flows) into the nearby drainages. These can occur without obvious signs of volcanic activity like ash plumes or loud explosions. Thus, the local area is considered especially hazardous.

AVO has begun constructing a network of geophysical monitoring instruments at Fourpeaked. Over the last two days, two seismometers were installed between 10 and 20 $\mathrm{km}$ (6 -12 mi) from the summit. These instruments give AVO volcanic earthquake detection capability, but do not provide enough information for short-term forecasts of volcanic eruptions. Additional seismometers will be installed in the coming days. If conditions permit, these instruments will be closer to the summit and should provide better forecasting capability. AVO also plans the installation of web cameras and instruments for measuring ground deformation.

AVO will continue to monitor the volcano with satellite data, observation flights, and new geophysical data streams as they become available. 


\title{
ALASKA VOLCANO OBSERVATORY \\ Current Status Report
}

Tuesday, September 26, 2006 12:45 PM AKDT (2045 UTC)

\author{
FOURPEAKED VOLCANO (CAVW\#1102-26-) \\ 5846'12" N15340'19" W, Summit Elevation 6903 ft (2104 m) \\ Current Level of Concern Color Code: YELLOW
}

Aerial and ground observations yesterday indicate that volcanic unrest continues. A series of pits and elongate openings through glacial ice high on the north flank of the volcano are vigorously emitting volcanic gas and steam. Channels and debris fans on the ice field indicate that outbursts of water have occurred.

Limited seismic data from the area of Fourpeaked volcano are now being received at AVO. As weather allows, AVO will install additional instrumentation and conduct further geologic investigations near the volcano.

\section{ALASKA VOLCANO OBSERVATORY Current Status Report Wednesday, September 27, 2006 12:25 PM AKDT (2025 UTC)}

\section{FOURPEAKED VOLCANO (CAVW\#1102-26-)}

5846'12" N15340'19" W, Summit Elevation 6903 ft (2104 m)

Current Level of Concern Color Code: YELLOW

Cloudy and rainy conditions have prevented any new visual or satellite observations of Fourpeaked. The limited seismic data now being received at AVO do not indicate significant volcanic activity.

As weather allows, AVO will install additional instrumentation and conduct further geologic investigations near the volcano. 


\section{Activity IV. Activities to Consider Before, During, or After a Volcanic Eruption}

\section{Grade Level 6-11}

Setting varies

Time varies

\section{Correlation to Alaska State Science Standards varies}

\section{Overview}

Several of the activities within this guidebook may be prioritized in the event of increased volcanic activity or current volcanic eruption(s) in Alaska. Additional, dynamic resources also are available on-line and in print in the event of a forecasted or actual volcanic eruption in Alaska or elsewhere.

\section{Background}

During volcanic eruptions in Alaska, the Alaska Volcano Observatory (AVO) has developed activity web pages that are updated every few hours to reflect the ongoing or forecasted activity at one or more of Alaska's volcanoes. AVO also posts associated satellite, seismic and other monitoring data, images from staff and the public, and other pertinent information that can be useful for activities and classroom discussion, as well and safety and emergency planning.

In addition, AVO staff conducts media interviews and press conferences during periods of heightened activity and volcanic eruption(s). There is typically an increase in the amount of media coverage (blogs, documentaries, news reports and articles, radio spots etc.) related AVO and the heightened activity or erupting volcano during this time.

AVO's interagency partners such as the NOAA National Weather Service, Federal Aviation Administration, and Alaska State Department of Homeland Security and Emergency Services, among others, also post pertinent information, and monitoring data and tools on-line and conduct media interviews. These tools and media documentation can augment activities in this guidebook and Earth science curriculum.

A list of Common Websites Used During Volcanic Episodes in Alaska is included. This is a general list and additional websites and sources for current information will be included - so stayed tuned for additional postings on the AVO website and other agency websites, and media references for additional resources. AVO places links associated with the activity of a specific volcano on the AVO website activity web page under the heading, "Links." This website is a great resource for you and your students and all of your colleagues and families, as well.

Additionally, many of Alaska’s active volcanoes are on public land managed by a Federal, State or local agencies. These land managers often place pertinent information on their own websites. The boroughs and city municipalities in which these volcanoes and nearby communities reside place pertinent information on their websites. 


\section{Objective}

By learning about a current or forecasted volcanic eruption(s) in Alaska and elsewhere, students will gain perspective on the wide variety of data, interagency organization, and personal responsibility and preparedness needed to remain safe and to learn from these dynamic, and rather frequent, volcano events.

\section{Materials}

- access to on-line, print, and radio media, and podcasts and on-line resources such as the AVO website and those of its interagency partners

— materials specific to prioritized guidebook activities mentioned below

\section{Suggested Procedures}

\section{A. Research, Present, and Review}

1. Assign students to complete a paper, poster, podcast, or digital presentation about the ongoing activity. You can assign or students can select a different topic to research and discuss during daily or weekly classroom periods. Students can also discuss how their individual family is preparing for the event of an ash fall.

\section{B. Prioritized Activities}

1. It may be worthwhile to prioritize some of the activities in the guidebook to inform students about possible volcanic hazards and preparedness planning that may be most pertinent in the event the community is affected by the heightened activity or eruption(s). Suggested, prioritized activities are listed in order of appearance in the guidebook. The activities in Chapter 5 Alaska's Volcanoes and You! may be the most valuable for communities that may be directly affected by heightened activity or eruption(s).

\section{Chapter 1 Alaska Plate Tectonics}

Activity II Plate Tectonics Mapping

\section{Chapter 2 Alaska's Igneous Rocks}

Activity III Comparison of Hawaiian, Cascade, and Alaskan Volcanic Rocks

\section{Chapter 3 Eruption!}

Activity I Eruption 1, 2, 3

\section{Chapter 4 Alaska's Volcanic Landforms and Features}

Activity I Volcanic Landforms and Features Information Search

\section{Chapter 5 Alaska's Volcanoes and You!}

Activity I We need all the assistance you have...

Activity II What is the Plan?

Activity III Volcanic Ash Fall in Your Community

\section{Chapter 6 Climate and Volcanic Eruptions}

Activity III Globally Averaged Temperature and Volcanic Eruptions 


\section{Ash fall deposit collection}

1. AVO has thorough ash fall collection instructions posted on its website. It may be a great outside activity for students to complete after an ash fall. Be sure that all other medial, emergency, and safety needs and precautions are met prior to conducting this activity.

- AVO Procedures for Collecting and Returning Ash Samples from Modern Volcanic Eruptions http://www.avo.alaska.edu/ashfall.php

2. You can use the ash-deposit collection instructions to collect your own "ash" by using a household granular substance in place of volcanic ash when a real ash fall is unavailable, or to practice with practice during heightened activity, but before a likely ash fall occurs. If you decide to use a human food item such as corn meal or flour in place of real ash, be sure not to conduct your collection experiment outside where the remaining food items may be an attractant for wildlife.

\section{Extension 1}

1. Encourage students to write fictional or non-fiction stories about volcanic eruptions, and describe what they would do if they were a volcanologist studying this eruption.

2. Give students time to work in groups to illustrate, present, or write about how they would work as a team to solve a specific mystery at an Alaskan volcano. 


\title{
Websites Commonly Used During Volcanic Episodes in Alaska
}

GENERAL PREPARDNESS

Alaska Homeland Security and Emergency Management: http://www.ak-prepared.com/

USGS Volcanic Ash-What it can do and how to prevent damage http://volcanoes.usgs.gov/ash/

\section{ASHFALL WARNINGS, MARINE ADVISORIES}

NOAA National Weather Service (NWS) Alaska Aviation Weather Unit (AAWU):

- PIREPS (Pilot Reports) http://aawu.arh.noaa.gov/pireps/webPirep.htm

- Ashfall and Marine Advisories http://www.arh.noaa.gov/ and through the

Center Weather Service Unit (CWSU) http://cwsu.arh.noaa.gov/

\section{WIND TRAJECTORIES}

NOAA Air Resource Laboratory: HYSPLIT

http://www.arl.noaa.gov/ready/traj_alaska.html

\section{RADAR}

NOAA National Doppler Radar Sites http://radar.weather.gov/

\section{AIRBORNE VOLCNAIC ASH}

Volcanic Ash Advisory Centers (VAAC) http://www.ssd.noaa.gov/VAAC/vaac.html

- Alaska VAAC - http://aawu.arh.noaa.gov/

- Oakland VAAC - http://www.wrh.noaa.gov/zoa/oceanSIG.php

- Washington VAAC http://www.ssd.noaa.gov/VAAC/messages.html

\section{HEALTH - ASH IMPACTS}

Alaska Department of Environmental Conservations-Division of Air Quality: Air Quality Advisories \& Alerts http://www.dec.state.ak.us/air/am/aq_sr.htm

Alaska State Health and Social Services

- Public Health http://www.hss.state.ak.us/dph/

- Epidemiology: Volcano Facts http://www.epi.hss.state.ak.us/volcanoes/default.htm

\author{
AIR TRAFFIC CLOSURES \\ Federal Aviation Administration (FAA)—Flight Restrictions http://tfr.faa.gov/tfr2/list.jsp \\ MARINE SAFETY \\ U.S. Coast Guard (USCG): http://www.uscg.mil/d17/
}


This page intentionally left blank. 
Publishing support provided by the U.S. Geological Survey Publishing Network, Tacoma Publishing Service Center

For more information concerning the research in this report, contact the Alaska Volcano Observatory

Volcano Science Center

U.S. Geological Survey

4200 University Drive

Anchorage, AK 99508

http://www.avo.alaska.edu/ 


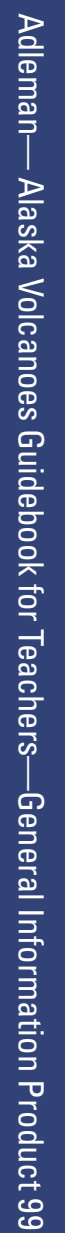

ISBN $978-1-4113-3047-4$

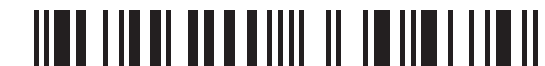

